INTERNATIONAL HUMANITARIAN UNIVERSITY

DEPARTMENT OF MANAGEMENT

\title{
THE VISEGRÁD FOUR - UKRAINIAN DIMENSION. INTEGRATION - STEP BY STEP
}

Collective monograph under the editorship of $T$. Derkach, Doctor of of Economic Sciences, Associate Professor 


\section{Reviewers:}

Lutsyshyn Z.O. - Doctor of Economic Sciences, Professor, Honoured Worker of Education of Ukraine, Professor at Department of World Economy and International Economic Relations, Institute of International Relations, Taras Shevchenko National University of Kyiv. Sokhatska O.M. - Doctor of Economic Sciences, Professor, Head of Department of International Economic Relations, Ternopil National Economic University.

\section{Scientific Board:}

Saveliev Ye.V. - Doctor of Economic Sciences, Professor, Head of Department of International Economics, Ternopil National Economic University.

Kuryliak V.Ye. - Doctor of Economic Sciences, Professor, Professor at Department of International Economics, Ternopil National Economic University.

Kyrylenko O.P. - Doctor of Economic Sciences, Professor, Head of Department of Finance named after S.I. Yurii, Ternopil National Economic University.

Movchan V. - Academic Director, Institute for Economic Research and Policy Consulting, Kyiv.

Yakubovskyi S.O. - Doctor of Economic Sciences, Professor, Head of Department of World Economy and International Economic Relations, Odessa I.I. Mechnikov National University.

Derkach T.V. - Doctor of Economic Sciences, Head of Department of Management, International Humanitarian University.

Editorship: T.V. Derkach, Doctor of Economic Sciences, Head of Department of Management, International Humanitarian University.

\section{Recommended for printing by the Academic Council of International Humanitarian University Protocol № 3 on 28.11.2017}

The authors of articles usually express their own opinion, which is not always comply with the editorial Board's opinion. The content of the articles is the responsibility of their authors.

The presented collective monograph is the result of the round table "Countries of the Visegrád Group: Results of Economic Interaction and Lessons for Ukraine" held within the framework of International Scientific-Practical Conference "Modern Global Regionalistics and Economic Entities: Directions of Influence" devoted to the $26^{\text {th }}$ anniversary of the foundation of the Visegrád Group, as well as result of work of a group of authors united by a common idea to present the results of their research.

The Visegrád Four - Ukrainian dimension. Integration - step by step: Collective monograph / under the editorship of T. Derkach, Doctor of of Economic Sciences, Associate Professor. Riga, Latvia: Izdevnieciba "Baltija Publishing”, 2017. 308 p. 


\section{INTRODUCTION}

The presented monograph is the result of a roundtable on "Countries of the Visegrád Group: Results of Economic Cooperation and Lessons for Ukraine" held on February 16, 2017.

In recent years, international economists' attention was drawn to the jubilees of the Visegrád Four: the decade of membership in the EU and the $25^{\text {th }}$ anniversary of the creation of the Visegrád Group. Many scientific works and researches have been devoted to this regional association. However, there are not so many monographs that would affect a whole range of scientific areas and this is one of the few books in Ukraine devoted to the problems of social and economic development of the countries of the Visegrád Four (B4). Problems and prospects of the European integration of B4 countries are being actively discussed both in the EU countries and outside it. Proceeding from this, a multi-authored monograph is prepared that reflects issues of socio-economic processes both in the region as a whole and in individual countries.

Today's vector of development of our country calls for research and understanding of the development trajectories of countries ahead of Ukraine in the processes of economic transformation. That is why books, to a greater or lesser degree, offering their answers to contemporary Ukrainian questions, become so noticeable in this situation. The publication that you hold in your hands just touches on the issues of the future development strategy of Ukraine. To date, this is one of the large-scale goals, which is quite difficult both in research and in achieving results.

In general, the book is a scientific study that significantly expands the view of the Visegrád group as a region of dynamic transformations in the EU. The monograph is intended for a wide range of readers. It will be interesting for international economists, academic and teaching staff of Ukrainian universities, postgraduates and students, specialists of ministries and departments involved in the foreign economic activity.

Points of view and evaluations of the authors of the monograph "The Visegrád Four - Ukrainian dimension. Integration - step by step" do not always coincide; however, they are all important for understanding the processes taking place in Eastern Europe for the Ukrainian reader. 



\section{CONTENTS}

\section{26 YEARS OF VISEGRÁD COOPERATION: ECONOMIC ASPECTS OF FUNCTIONING}

Grabchuk I.F., Bugaichuk V.V., Razumna K.A.

PRODUCT QUALITY: METHODOLOGY AND PRAXIS

Козюк В.В., Гайда Ю.І., Шиманська О.П.

ГЛОБАЛЬНІ МІСТА: ПИТАННЯ ТЕОРІЇ, ЗВ' ЯЗОК 3 ВІДРИТІСТЮ КРАЇН,

ЕКОЛОГІЧНИЙ ВИМІР 14

\section{THE PLACE OF VISEGRÁD GROUP IN THE EU REAL SECTOR}

Деркач T.B.

КРАЇНИ ВИШЕГРАДСЬКОЇ ГРУПИ - СУБРЕГІОН ЄВРОПЕЙСЬКОЇ ІНТЕГРАЦІЇ. 30

Якубовський С.О., Журавльов О.В.

ЕКОНОМІЧНИЙ РОЗВИТОК КРАЇН ВИШЕГРАДСЬКОЇ ГРУПИ

В УМОВАХ СВРОІНТЕГРАЦІЇ.

\section{ECONOMIC BENEFITS AND RISKS OF COUNTRIES}

OF THE VISEGRÁD FOUR FROM THE EU MEMBERSHIP

Ліщинський I.O., Лизун М.В.

ТРАНСФОРМАЦЙНИЙ ПРОЦЕС ТЕРИТОРІАЛЬНОГО УСТРОЮ

КРАЇН ВИШЕГРАДСЬКОЇ ЧЕТВІРКИ: ВІД ДОІНТЕГРАЦІЙНОГО ПЕРІОДУ

ДО ПАН'ЄВРОПЕЙСЬКИХ ІНІЦІАТИВ

Шедяков В.Є.

РЕФЛЕКСИВНІ ОРГАНІЗАЦІЯ ТА УПРАВЛІННЯ ПРАЦЕЮ

ЯК РИСИ ПОСТСУЧАСНОЇ МОДЕРНІЗАЦІЇ

\section{REGIONAL IDENTITY OF MEMBERS OF THE VISEGRÁD FOUR}

Zborovska O.M., Markov B.M.

STRUCTURAL CHARACTERISTICS OF THE ECONOMY OF UKRAINE

IN THE CONTEXT OF INTERNATIONAL COMPARISON

Malakhovskyi Y.V., Nabulsi H.N., Savitska I.M.

FEATURES OF FINANCING OF THE INNOVATIVE-ORIENTED STRUCTURES

USING MECHANISMS OF THE PUBLIC-PRIVATE PARTNERSHIP .... 106

\section{PARTICIPATION OF COUNTRIES OF THE VISEGRÁD FOUR IN THE IMPLEMENTATION OF PROVISIONS \\ OF THE ENERGY CHARTER TREATY}

Chichulina K.V.

UKRAINE AND THE VISEGRÁD FOUR: THE EXPERIENCE OF ESCO MARKET

\section{UKRAINE AND THE VISEGRÁD EUROPE - USING THE POTENTIAL OF ECONOMIC INTERACTION}

\section{Ganski U.A.}

THE CULTURAL HERITAGE OF VISEGRÁD GROUP COUNTRIES

AS A RESOURCE FOR LOCAL DEVELOPMENT

Гегедош К.В.

ВДОСКОНАЛЕННЯ МЕХАНІЗМУ ВЗАСМОДІЇ УКРАЇНИ ТА КРАЇН

ВИШЕГРАДСЬКОЇ ГРУПИ В РАМКАХ КАРПАТСЬКОГО ЄВРОРЕГІОНУ

НА ЗАСАДАХ ІНТЕРАКТИВНОГО МАРКЕТИНГУ 
Грубінка I.I., Верзун А.А.

ВИШЕГРАДСЬКА ЧЕТВІРКА Й УКРАЇНА: СТАН РОЗВИТКУ ЕКОНОМІЧНОЇ

СИСТЕМИ І ДЕРЖАВНОЇ ПІДТРИМКИ СІЛЬСЬКОГО ГОСПОДАРСТВА

Karkovska V.Ya., Yaremko I.I., Blynda Y.O.

DEVELOPMENT MANAGEMENT OF THE NATIONAL ECONOMY BASED

ON THE RESEARCH ON THE IMPACT OF SAVINGS AT THE LEVEL

OF GROSS DOMESTIC PRODUCT.

Rybina L.O., Samoshkina I.D., Mikulina M.O.

WAYS TO INCREASE THE COMPETITIVENESS OF UKRAINE ON THE BASIS

OF THE VISEGRÁD EXPERIENCE

Савельєв Є.В., Куриляк В.С., Куриляк С.Ю., Куриляк М.Ю.

РОЗВИТОК ПРОМИСЛОВИХ КЛАСТЕРІВ В КРАЇНАХ ВИШЕГРАДСЬКОЇ ЧЕТВІРКИ:

ДОСВІД ДЛЯ УКРАЇНИ

Solodovnik G.V., Venhrina O.S.

THE DETERMINATION OF THE RATIONAL SIZE OF THE DEVELOPMENT FUND

OF A MANUFACTURING ENTERPRISE

\section{INTEGRATION OF BUSINESS STRUCTURES OF COUNTRIES OF THE VISEGRÁD GROUP AND UKRAINE}

Германюк Н.В.

ТРУДОВІ РЕСУРСИ АГРОСФЕРИ В УМОВАХ ІНТЕГРАЦІЙНОГО РОЗВИТКУ

Zhylenko K.M.

MODERN DETERMINANTS OF INVESTING AND PRODUCTION-FINANCIAL

TNCS' ACTIVITIES

Kovalenko S.I.

GAINING MESO-COMPETITIVE ADVANTAGES BASED ON NETWORK FORMS

OF INTERNATIONAL QUASI-INTEGRATION

Krutova A.S., Tarasova T.O., Yanchev A.V.

ACCOUNTING SYSTEM AS A BASIS FOR UKRAINIAN BUSINESS INTEGRATION

IN THE EUROPEAN ECONOMIC ENVIRONMENT

Prymostka O.O.

UKRAINE PARTNERSHIP OF THE VISEGRÁD GROUP IN THE GLOBAL WORLD .289 


\section{26 YEARS OF VISEGRÁD COOPERATION: ECONOMIC ASPECTS OF FUNCTIONING}

Grabchuk I.F.

Candidate of Economic Sciences, Senior Lecturer at Department of Economics and Entrepreneurship, Zhytomyr National Agroecological University

Bugaichuk V.V.

Candidate of Economic Sciences, Senior Instructor at Department of Economics and Entrepreneurship, Zhytomyr National Agroecological University

Razumna K.A. Senior Instructor at Department of Foreign Languages, Zhytomyr National Agroecological University

\section{PRODUCT QUALITY: METHODOLOGY AND PRAXIS}

Summary. The research reveals the theoretical essence of product quality and presents the economic mechanism of product quality management at an enterprise. It is established that under the conditions of voluntary certification, a share of domestic producers who submit product samples for the test on compliance with the established standards is insignificant. However, about $17.0 \%$ out of the total number of samples submitted for tests on product quality to the State Enterprise "Zhytomyrstandartmetrologiia" during 2014-2016 are condemned as defective. The largest share of samples condemned as defective was found in products, which constitute the main diet of the population, namely: dairy products, vegetables, meat, fish products. The methodological recommendations concerning the improvement of the quality of dairy products as a direct factor for increasing the efficiency of its production and profitability of the operation of an enterprise are substantiated. It was established that the level of product quality forms the requirements for the quality of raw materials and advanced production technologies, biological means of production, personnel work, and management methods.

Introduction. Ukrainian experience in social and economic development indicates (prep) unfavourable tendencies in the field of providing product quality and this is characteristics of the great majority of enterprises. First and foremost, such problems are manifested in the irrational usage of various kinds of resources, significantly lower quality of domestic products if compared to their analogues of economically developed countries and, eventually, in the shortfall of a significant part of the income of commodity producers and, consequently, low efficiency of their functioning.

Modern transformations taking place in the national economy under the influence of internationalization and globalization processes are accompanied by the emergence of new requirements for the quality of products manufactured by enterprises and for 
product competitiveness. Improving product quality is closely connected to structural changes. The quality level forms the requirements for the quality of materials and advanced manufacturing technologies, biological means of production, personnel work, and management methods. That is why the tasks as to substantiating strategic directions to improve the outlined situation need an in-depth scientific study.

Improvement of quality management of products belongs to the scientific directions that are studied rather actively. The fundamental work in the field of economics and product quality management includes the works of such foreign scholars as E. Deming, J. Juran, P. Crosby, A. Robertson, Feigenbaum, M. Hammer, M. Minor, I. Muto, S. Shing, etc. Recently, these problems have been actively investigated in Ukraine in the works of Yu. Harachuk, V. Heiets, O. Borodin, M. Kuchera, D. Leheza, O. Momot, M. Shapoval and others.

Nevertheless, a number of problematic issues still do not have a final scientific solution. First of all, this concerns the economic and organizational aspects of the growth of the quality level of products as an indispensable element of the management process at an enterprise and the impact of product quality on the efficiency of an enterprise. The foregoing is relevant both for the sphere of production and for the activities of domestic enterprises, which led to the choice of research direction.

In order to solve existing problems in improving the product quality, first of all, it is necessary to focus on the adaptation and harmonization of the legislative and normative base according to European norms; and it is also crucial to develop a measure of economic incentives for enterprises that implement quality management systems.

\section{Theoretical basics of product quality}

One of the strategic objectives of the national economy is the production of quality food products. The feasibility of practical actions in this direction is conditioned by the objective need of a civilized approach to the organization of environmentally safe agricultural and industrial production, preservation of the health and gene pool of the nation, formation of response measures of the state on the integration of environmental constraints into the legal basis of international foreign trade relations.

The study of the problem of improving the product quality requires the epistemology of the subject of research. In several scientific works, the concept of "quality" is distinguished as a separate philosophical aspect, which is based on the fact that objective reality is a set of processes, in which objects constantly appear, change, and wear off, and it does not consist of finished, completed objects $[1 ; 2 ; 3]$. In the context of such a philosophical definition, quality expresses the objectively existing integral characteristic of the functional unity of the properties of the object, which adds relative stability to it and determines its distinction from other objects or similarities to them. However, the division into primary and secondary qualities according to the degree of their objectivity was formed. The objective properties of material bodies were recognized as primary ones and the subjective feelings that differ from the properties of external objects were defined as secondary ones [4, p. 134]. This aspect further led to a long-standing scientific discussion on defining the term "quality", which continues to this day.

According to O. Borodina, V. Heiets, A. Hutorov, "quality" is the properties of products (or services) that can be measured and that meet specific technical 
requirements [5]. U. Deming identified quality with the presence of product characteristics, set by established technical requirements, which can be measured [6]. Therefore, according to one point of view, an attention is focused on the importance of evaluating the effectiveness of quality management, and according to another, an attention should be paid to the fact that quality is the property of a product that does not depend on quantitative characteristics and is directly determined by the degree of satisfaction of the consumer's needs. Thus, a significant importance was given to the property of products to meet the consumer's needs. Hence, the quality can only be determined by a specific person, and, at the same, time it is a multidimensional and multi-stage category. J. Juran and K. Ishikawa stated that the quality lies in those properties of products that meet the consumer's needs and, therefore, ensure their satisfaction with this product, and, consequently, the quality is the absence of inconsistencies [7, 8]. It is emphasized that in the narrow sense quality is the quality of products, but in the broad sense, quality means the quality of work, information, process, labour, etc., that is, all functional components of the enterprise without exception.

Other researchers define "quality" as a measure of constructive and operational perfection, which is manifested in the useful properties of the product, the totality and significance of which reflect the needs (requests) of society, formed for a certain time [9, p. 7]. Quality is also considered from the standpoint of "... the complex characteristics of a product, reflecting the degree of its technical and aesthetic and ergonomic excellence, provided with a set of properties designed to meet the conditioned or predicted needs for a given period of time with the full safety of use" [10, p. 56].

That is while assessing the product quality, it is expedient to check its main properties: a compliance with technological, biological, hygienic, and physiological norms; reliability; economic efficiency, environmental friendliness; aesthetics, patent law, etc. (Fig. 1.1).

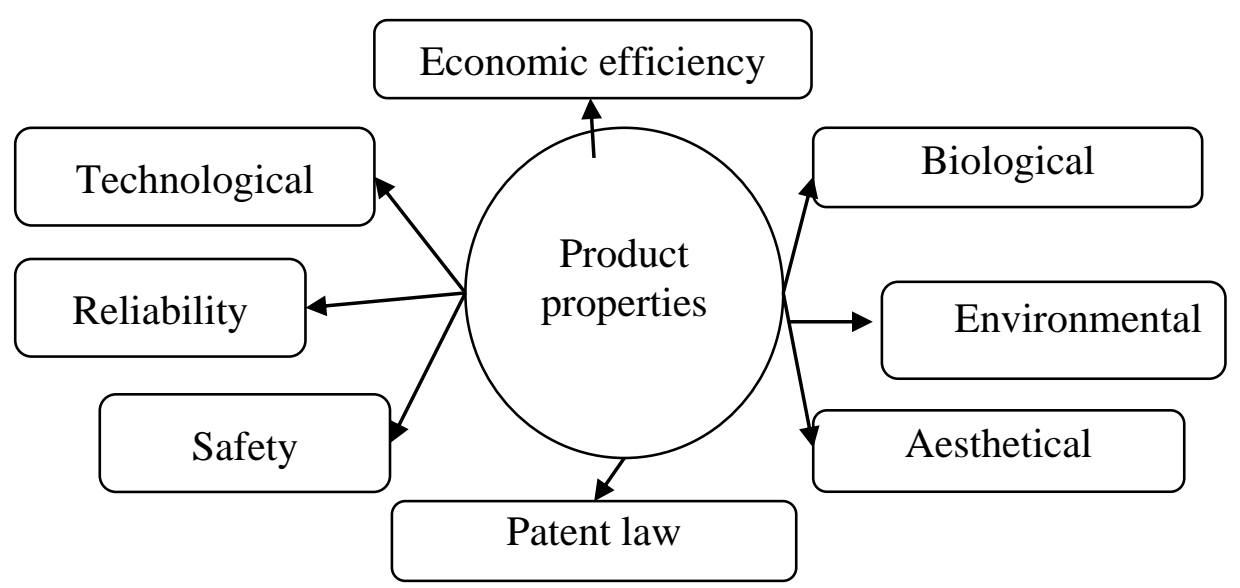

\section{Fig. 1.1. Main product properties that are defined in the process of evaluating quality}

Source: the author's research

However, it seems necessary to clarify the approach to the concept of quality at the level of an individual enterprise and the corresponding set of production processes. Consequently, the full range of economic and social and economic aspects of this 
concept can be taken into account when considering the product quality as an object of management, where quantitative and statistical characteristics of individual products are clearly specified.

The methodology of quality management was substantiated in the works of E. Deming [11], J. Juran [12], P. Crosby [13], A. Feigenbaum [14], V. Shukhart [15] et al. It specifies that management of enterprise includes three elements: the subject of management (the personnel of an enterprise), the object of management (production process), the management mechanism, which is carried out through the implementation of a set of management functions with their correction according to goals and objectives in the quality policy.

Accordingly, a productive and effective process of quality management should cover all stages of production and activity of an enterprise as a whole, that is, it is of a complex nature. The basis of modern production of quality products is the following system: "initial raw materials - semi-finished products - components and additives used - finished product". Within the framework of this scheme, quality management is recommended as a set of actions and measures that allow establishing, providing, maintaining, controlling, and stimulating receiving of quality raw materials and food (Fig. 1.2).

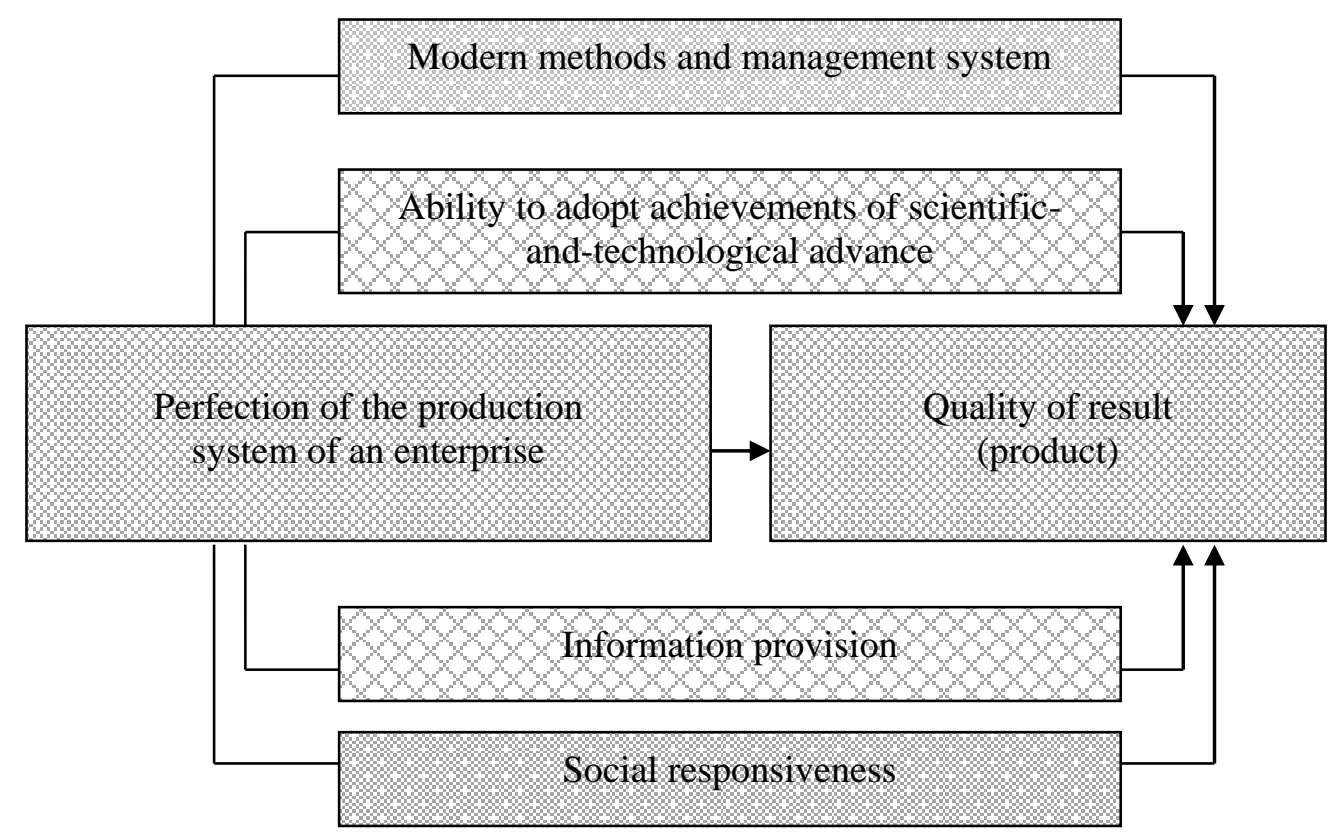

\section{Fig. 1.2. The principle of operability of the production activity of an enterprise concerning product quality}

Source: adapted [16, p. 99-102]

Assurance of product quality at an enterprise requires multi-elemental focusing of enterprise management, covering requirements for management activities, production systems, organizational structure, processes, operations and production methods, etc. $[17,18]$. Quality is a complex concept that characterizes the effectiveness of all aspects of the activity: development of strategy, an organization of production, marketing, etc.

The essence of the effect of "quality" at the microeconomic level is to achieve positive dynamics of profitability of an enterprise. It can be achieved through obtaining benefits from improving the product quality; the latter involves both 
reducing the losses from shortages and imperfect products, and obtaining direct benefits from marketing better and more expensive products. At the same time, it is suggested to consider both macro- and meso-economic aspects of the effect of implementing an effective mechanism of quality management (Fig. 1.3). Since the beginning of the 2000s, the substantiation of the benefit of the transition of postSoviet management to the principles of international standards and quality systems, as well as the key benefits of a reasonable increase in the expenses for the quality have been substantiated in a large number of scientific and applied works of domestic researchers $[19,20]$. The recommendations of the scientific and applied plan regarding the introduction of quality management or its individual elements were suggested [21, 22].

The product quality is essential for Ukraine's integration into the world economy. International standards of ISO 9000 series concerning the creation of systems of quality control have become widespread and for several decades they have been a common demonstration of reliability, stability of quality and competitive ability of products all over the world. [23, p. 3].

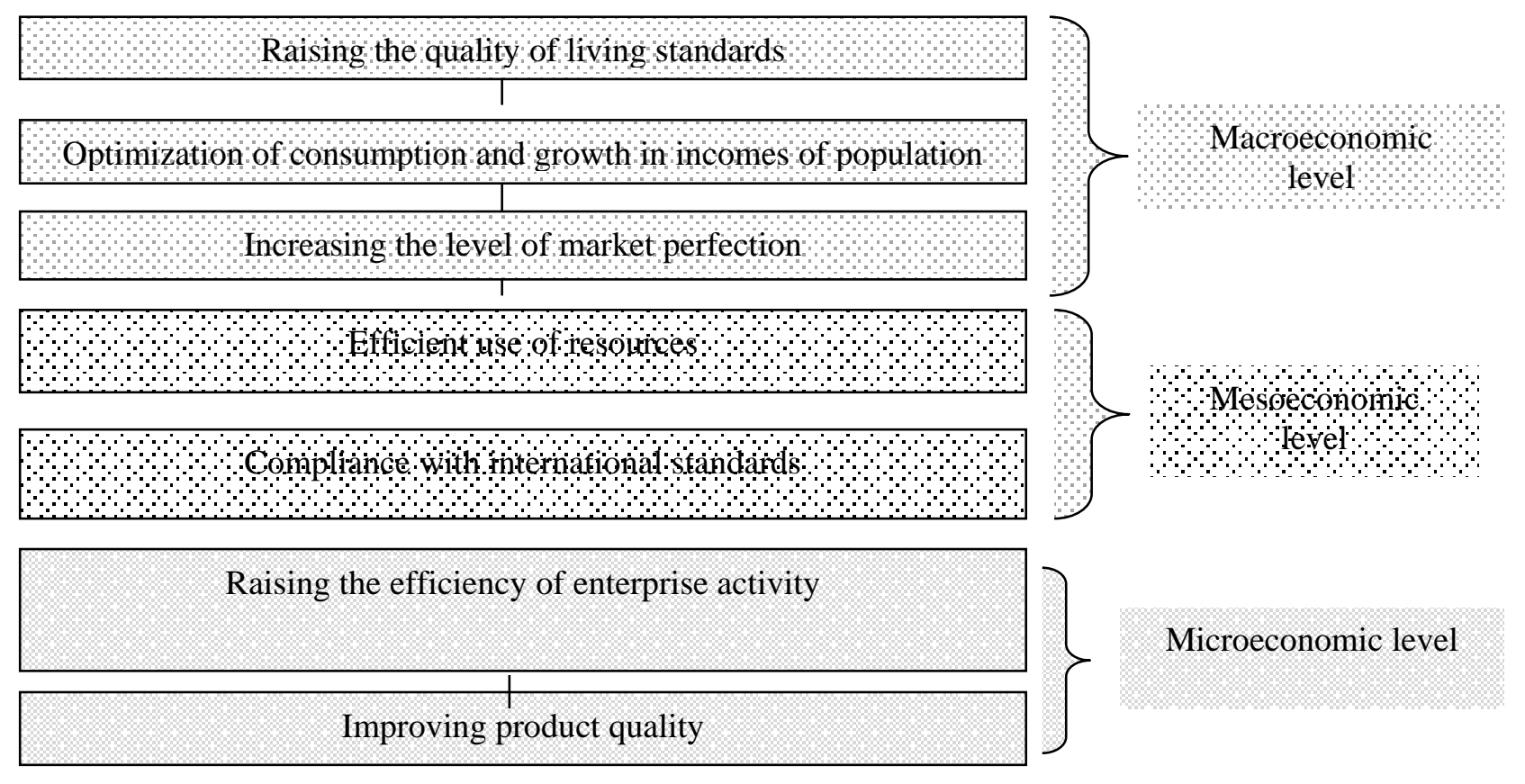

Fig. 1.3. Milestones for the implementation of the economic mechanism of managing product quality at an enterprise

Source: the author's research

Consequently, in the general scientific sense, quality is a category that reflects the important aspects of objective reality. It is a synthetic indicator, which reflects the manifestation of many factors, namely: the dynamics and development of the national economy to the ability to organize and manage the process of forming quality within a separate economic entity. World experience of management shows that it is the product quality, which is one of the main factors of successful activity of enterprises in a market economy. 


\section{The contemporary state of product quality and strategic directions of its improvement}

The quality control of food products is one of the most important links in the long chain of healthy eating. A significant extension of the range of food products on the consumer market does not happen without the manufacturer's attempts to release undisguised copycats or products of low quality in the guise of well-known brands. Falsification of food products has become widespread, that is, their falsification by means of food and non-food additives, which are used to improve organoleptic characteristics, or the replacement of a higher grade product by a lower one.

However, since 2017, according to the requirements of the Law of Ukraine "On Basic Principles and Requirements for the Safety and Quality of Food Products", the mandatory condition for carrying out production activities at food enterprises is the introduction of permanent procedures based on the principles of the system Hazard Analysis and Control at Critical Points (HACCP). In addition, the "Blue Guide" of the EU sets the regulatory regime that exists in the EU for all types of products. At present, a number of legislative acts were adopted in Ukraine; they are harmonized with relevant acts of the legislation of the European Union, the EFTA and associated countries. Based on 27 acts of European sectoral legislation, 24 technical regulations were adopted in Ukraine, 21 of which are already mandatory. The Ministry of Economic Development developed and adopted 2313 national normative documents, 1998 of which are harmonized with international and European ones [24]. European experts also notice success, but they urge not to focus only on numbers. They admit that the process is not easy. A lot depends on the manufacturers themselves; they must understand the new rules and use them effectively.

It should be noted that responsible manufacturers looking into the future not only introduce such systems but also certify them. That is, it is documented that this system is evaluated and recognized by a third party, an accredited certification body.

In 2014-2016, the Testing laboratory of the Zhytomyr Scientific and Production Center for Standardization, Metrology and Certification, which, according to the results of comparative laboratory tests, is among the top ten in Ukraine, tested on average 1695 samples of food products (289 samples of which were condemned as defective, 210 of them according to microbiological indicators and 79 according to physical and chemical indicators) and 1406 samples of industrial products, no violations were detected in proven samples.

The dynamics of the tests carried out for certain types of products are shown in Fig. 2.1.

Under the conditions of voluntary product certification, the majority of tests to establish product quality were carried out on samples of bakery - 115, vegetables 96 , dairy -87 , fish -78 , meat -63 . These are the products which form the basis of the diet of the population. However, leader products in determining the product quality are tea, phytotea, and herbs. This situation is explained by the presence of the TOV (LCC) "Liktravy" in Zhytomyr. The population of Zhytomyr region and other adjoining regions carries out the harvesting of medicinal and phyto-plants for this enterprise. Apart from tea, phytotea, and herbs, the majority of samples that the DP (State Enterprise) "Zhytomyrstandartmetrologiia" received for quality testing were dairy products -269 and bakery -115 pcs. 


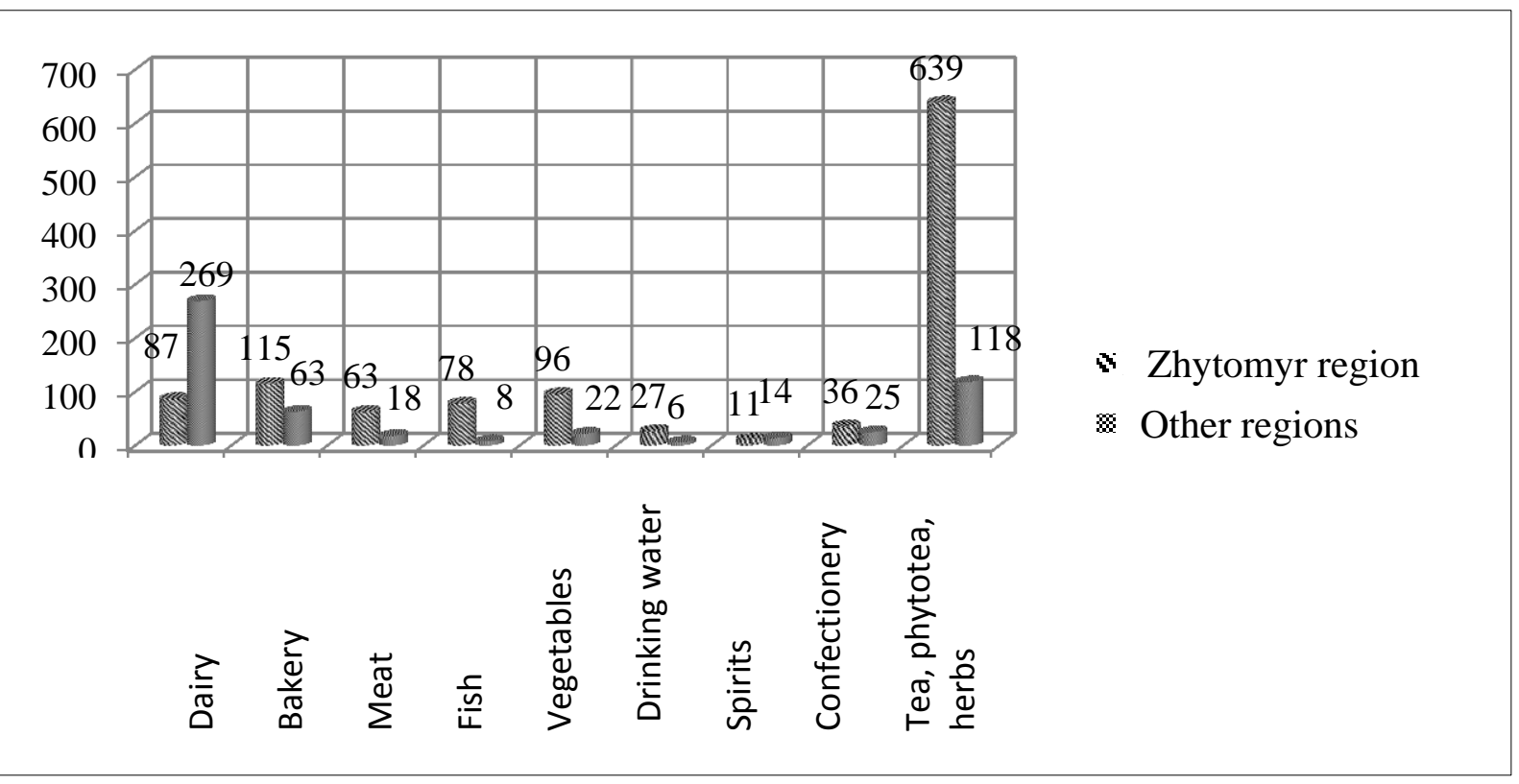

Fig. 2.1. Carrying out tests for product quality in DP (State Enterprise) "Zhytomyrstandartmetrologiia" on average during 2014-2016, pes.

Source: built according to the data of Zhytomyr Scientific and Production Center for Standardization, Metrology and Certification

Of the total number of samples submitted for testing on product quality in the DP (State Enterprise) "Zhytomyrstandartmetrologiia" during 2014-2016, about 17.0\% were condemned as defective (Table 2.1).

Table 2.1

The share of product samples condemned as defective in the total number of samples submitted for testing to DP (State Enterprise) "Zhytomyrstandartmetrologiia" on average during 2014-2016.

\begin{tabular}{|l|c|c|c|}
\hline Types of products & $\begin{array}{c}\text { Total number } \\
\text { of submitted } \\
\text { samples, pcs }\end{array}$ & $\begin{array}{c}\text { Number of } \\
\text { samples } \\
\text { condemned as } \\
\text { defective, pcs }\end{array}$ & $\begin{array}{c}\text { Share of samples } \\
\text { condemned as } \\
\text { defective in the total } \\
\text { number of samples, \% }\end{array}$ \\
\hline dairy & 356 & 116 & 32,6 \\
\hline bakery & 178 & 25 & 14,0 \\
\hline meat & 81 & 24 & 29,6 \\
\hline fish & 118 & 19 & 22,1 \\
\hline vegetables & 33 & 50 & 42,4 \\
\hline drinking water & 25 & 6 & 12,1 \\
\hline spirits & 61 & 14 & 24,0 \\
\hline confectionery & 757 & 31 & 23,0 \\
\hline tea, phytotea, herbs & 1695 & 289 & 4,1 \\
\hline Total & & & 17,0 \\
\hline
\end{tabular}

Source: built according to the data of Zhytomyr Scientific and Production Center for Standardization, Metrology and Certification 
The largest share of samples condemned as defective was found for vegetable products $-42.4 \%$, dairy products $-32.6 \%$, meat $-29.6 \%$, spirits $-24 \%$ and confectionery products $-23.0 \%$.

In particular, $11.4 \%$ of the total number of product samples submitted for testing in Zhytomyr region and $29.1 \%$ of samples from other regions did not meet the standards (Table 2.2).

Table 2.2

\section{Noncompliance of product samples with the established quality requirements} in Zhytomyr region and other areas

\begin{tabular}{|c|c|c|c|c|c|}
\hline \multirow[b]{3}{*}{$\begin{array}{l}\text { Types of } \\
\text { products }\end{array}$} & \multirow[b]{3}{*}{$\begin{array}{l}\text { Indicators of } \\
\text { product quality, } \\
\text { according to } \\
\text { which } \\
\text { noncompliance } \\
\text { was established }\end{array}$} & \multicolumn{4}{|c|}{$\begin{array}{c}\text { Noncompliance of samples with the established quality } \\
\text { requirements }\end{array}$} \\
\hline & & \multicolumn{2}{|c|}{ Zhytomyr region } & \multicolumn{2}{|c|}{ Other areas } \\
\hline & & $\begin{array}{c}\text { number of } \\
\text { samples } \\
\text { condemned } \\
\text { as defective, } \\
\text { pcs }\end{array}$ & $\begin{array}{c}\text { share of } \\
\text { samples } \\
\text { condemned } \\
\text { as defective } \\
\text { in the total } \\
\text { number of } \\
\text { submitted } \\
\text { samples, \% }\end{array}$ & $\begin{array}{l}\text { number of } \\
\text { samples } \\
\text { condemned } \\
\text { as } \\
\text { defective, } \\
\text { pcs }\end{array}$ & $\begin{array}{c}\text { share of } \\
\text { samples } \\
\text { condemned } \\
\text { as defective } \\
\text { in the total } \\
\text { number of } \\
\text { submitted } \\
\text { samples, \% }\end{array}$ \\
\hline dairy & \begin{tabular}{|l|} 
nondairy fats \\
(butter, milk)
\end{tabular} & 21 & 24,1 & 95 & 35,3 \\
\hline bakery & $\begin{array}{l}\text { microbiological } \\
\text { indicators, } \\
\text { preserving agents }\end{array}$ & 14 & 12,2 & 11 & 17,5 \\
\hline meat & $\begin{array}{l}\text { hormonelike } \\
\text { materials, } \\
\text { nitrosamines, } \\
\text { pesticides, } \\
\text { radionuclides and } \\
\text { antibiotics } \\
\end{array}$ & 18 & 28,6 & 6 & 33,3 \\
\hline fish & $\begin{array}{l}\text { microbiological } \\
\text { indicators, } \\
\text { preserving agents }\end{array}$ & 15 & 19,2 & 4 & 50,0 \\
\hline vegetables & $\begin{array}{l}\text { nitrates, nitrites, } \\
\text { heavy metals }\end{array}$ & 32 & 33,3 & 18 & 81,9 \\
\hline $\begin{array}{l}\text { drinking } \\
\text { water }\end{array}$ & $\begin{array}{l}\text { microbiological } \\
\text { indicators }\end{array}$ & 3 & 11,1 & 1 & 67,0 \\
\hline spirits & $\begin{array}{l}\text { microbiological } \\
\text { indicators }\end{array}$ & 2 & 18,2 & 4 & 28,6 \\
\hline confectionery & $\begin{array}{l}\text { microbiological } \\
\text { indicators }\end{array}$ & 8 & 22,2 & 6 & 24,0 \\
\hline $\begin{array}{l}\text { tea, phytotea, } \\
\text { herbs }\end{array}$ & radionuclides & 18 & 2,8 & 13 & 11,0 \\
\hline Total & & 131 & 11,4 & 158 & 29,1 \\
\hline
\end{tabular}

Source: built according to the data of Zhytomyr Scientific and Production Center for Standardization, Metrology and Certification 
The dairy products that passed the test showed noncompliance with the indicator of the content of non-dairy fats. Drinking milk, curd products, buttermilk, sour cream, canned milk, and other products from this group do not meet the quality requirements. Standards on storage terms, technical specifications for dairy products procurement, including baby food, methods of fat determination, water purity, microbiological analysis, and others are not followed [25, p. 175]. As for meat and meat products, the noncompliance with the requirements for safety indicators is even greater, with respect to the content of mercury, lead, copper, zinc, cadmium, arsenic, mycotoxins, hormonelike materials, nitrosamines, pesticides, the activity of radionuclides and antibiotics.

In recent years, there has been a clear tendency to increase the production of vegetable products with higher nitrate content. In general, in Ukraine, more than $30 \%$ of agricultural products have a nitrate content that exceeds the permissible level. The problem is that nitrates are the main source of nitrogen feed, and the excess of these compounds leads to severe environmental consequences that affect human health.

Under the conditions of saturation of the world market with food products, standards are the model and quality benchmark that commodity producers must aim for in order to withstand the expansion of more experienced competitors from market players. This is a requirement not only of the current legislation but also of time. Modern production of safe food products should necessarily have, if not a complete food safety management system (HACCP), then at least introduce its basic elements. It is clear that the use of HACCP procedures at production requires both time and money, that is why the legislation determines a transitional period for their mandatory implementation. In particular, for enterprises that carry out activities with food products, which include raw ingredients of animal origin (except small enterprises) - from September 20, 2017. This category includes all dairy plants, slaughterhouses, etc. For enterprises that carry out activities with food products, which contain no raw ingredients of animal origin (except small enterprises) - from September 20, 2018 (these are producers of juices and sweets, etc.); for small enterprises - from September 20, 2019.

Transition periods enable market operators to reorient themselves to new requirements and bring food production in line with the provisions of the new legislation. After September 20, this year, the State Committee for Supervision of Civil Service conducts inspections to check compliance with the requirements of the above-mentioned Law of Ukraine. If market operators fail to fulfil the obligation to implement the HACCP system, fairly significant penalties will be imposed. For legal entities, for example, the amount of fines will be from 30 to 75 minimum wages, which in the monetary equivalent amounts to 36-91 thousand UAH.

Despite the rather significant transition period provided by the legislation, the vast majority of food producers in the Zhytomyr region did not wait for the critical deadlines for introducing HACCP systems. This concerns both large and small enterprises. Moreover, honest manufacturers, which still had enough time to get started, began work in this direction among the first; and they were awarded certificates for the quality management system according to DSTU ISO 9001: 2009 and food safety management system for compliance with DSTU ISO 22000: 2007. The producers who took this way are: PAT (PJSC) "Zhytomyr Butter Plant", TOV (LLC) "Berdychevpyvo", PAT (PJSC) "Novograd-Volynsky Bread Factory", TOV (LLC) "Brusyliv-Meat", TOV (LLC) "Marian", TOV (LLC) "Ovrutsky Milk-canning Plant" and a well-known regional producer of functional and special dietary foods 
based on innovative technologies, the Scientific and Production Limited Liability Company "Zhytomyrbioproduct".

Since 2016, 19 Ukrainian enterprises producing dairy products, 11 producers of meat products, 3 enterprises producing fish products, and 2 producers of eggs and egg products have received permission to export products to the EU market. In the final decision, published by the European Commission on the inclusion of our dairy and milk processing companies and enterprises processing dairy, meat and fish products, the official list of approved exporters in the EU includes: PrAT (PJSC) "Yagotinsky Dairy Plant" (Kyiv region), PrAT (PJSC) "Zhytomyr Butter Plant" (Zhytomyr region), PrAT (PJSC) "Zolotonisky Maslorobny Kombinat" (Cherkasy region), branch "Poultry Factory "Avis" and PrAT (PJSC) Poultry Farm "Chervony Prapor" (Khmelnytsky region), TOV (LLC) "Imperovo Foods" (Ivano-Frankivsk region), TOV (LLC) "Tulchyn Miaso" and TOV (LLC) "Litynsky Meat Processing Plant" (Vinnytsia region), TOV (LLC) "Zagotzbut" (Ternopil region), TOV (LLC) "More 2007" (Dnipropetrovsk region), TOV (LLC) "Pyriatynsky Delicacy" and PrAT (PJSC) "Kremenchuk City Milk Plant" (Poltava region), PrAT (PJSC) "Bogoduhivsky Meat-Packing Plant" and PJSC "Complex Bezlyudovsky MeatPacking Plant" (Kharkiv region) and others.

During this time, these enterprises significantly changed their infrastructure and considerably increased the level of competence and responsibility of production personnel. Of course, every manufacturer went their own way, but the goal was the same: to upgrade production capacities so that they meet the requirements of international standards. And for this purpose, it was necessary to take into account the state of the infrastructure and maintain it at a level that could provide consumers with the production of safe products. That is, during production, strict control of the internal environment of production should be carried out; and only such technological operations, which exclude any possible contamination of raw materials and end products, should be performed.

It should be noted that the introduction of an effective management system of food safety is not a matter of one month; this process can take from a few months to a year or even more. Moreover, after the completion of the entire complex of planned work on the implementation of the HACCP system, many manufacturers decided to certify it. And that was not a spontaneous step since among the mandatory requirements of a number of Ukrainian retail chains and demands for the export of products is the presence of a certified HACCP system.

It is worth highlighting that the requirements for management systems of food safety established by the international standard DSTU ISO 22000: 2007 are common and suitable for use by all organizations of the food chain, regardless of their size and complexity. These include not only food manufacturers, but also many other organizations, one way or another involved in one or more parts of the food chain. In particular, these are: feed producers, harvesters, farmers, manufacturers of ingredients, retailers, food outlets, product suppliers and even organizations that provide cleaning and disinfection services for transport. In the same range, there are suppliers of equipment, washing and disinfectants, packaging materials and other materials that are in contact with food. This is how the well-known chain "from the field to the table" should be built up. 
The formation of a promising strategy for enterprises at the present stage requires a clear description of the causal relationships and patterns between the determinants that influence the product quality.

The general analytical model for describing the role of the quality control factor in the activities of enterprises is emphasized on the determining role of the two main system elements, such as biological and technological level of quality:

$$
\mathrm{AL}_{\mathrm{q}}=\mathrm{BL}_{\mathrm{q}}+\mathrm{TL}_{\mathrm{q}}
$$

where: $A L_{q}$ stands for the achieved level of quality;

$B L_{q}$ stands for the biological level of quality;

$T L_{q}$ stands for the technological level of quality.

The biological level of quality is achieved in the production of products at the expense of natural, soil, and climatic conditions and with the minimum use of technological costs in the process of processing raw materials.

It is expedient to determine the relationship between the level of profitability of manufacturing products and the level of profitability of the operation of an enterprise and the dynamics of indicators of its quality. In this context, the product quality index was used.

To measure the quantitative relationship of qualitative parameters of production of dairy products and resulting indicators, a multi-factor regression model was used for 4 enterprises of Zhytomyr region: PAT (PJSC) "Zhytomyr Butter Plant", TOV (LLC) "Galiivsky Butter Plant", TOV (LLC) "Nash Molochnyk", TOV (LLC) "Andrushivsky Maslosyrzavod" (Table 2.3).

The investigated enterprises should invest extra resources in improving the quality of dairy products as a direct factor in increasing the efficiency of their production and profitability of the operation of enterprises. Since the profit for $1 \mathrm{UAH}$ of the sold products will grow from $18 \%$ to $46 \%$, and the level of profitability of the operation of an enterprise from $6 \%$ to $16 \%$.

Conclusions. Thus, the current trends in the social and economic development of society require the introduction of effective measures to improve the product quality as one of the main and non-alternative factors of modern micro- and macroeconomic growth. The trend of gradual growth of the quality of domestic products in the last decade has an objective character, which is conditioned by the effect of increasing the technological and scientific and technical support of production. However, taking into account the potential of Ukraine and the global trends concerning food security, this dynamics is clearly insufficient.

The study showed that under the conditions of voluntary certification, the share of domestic producers that submit samples of products to the test for compliance with established standards is insignificant. However, about $17.0 \%$ out of the total number of samples submitted for tests on product quality to the State Enterprise "Zhytomyrstandartmetrologiia" during 2014-2016 are condemned as defective. The largest share of samples condemned as defective was found in vegetable products $-42.4 \%$, dairy products $-32.6 \%$, meat products $-29.6 \%$, spirits $-24 \%$, and confectionery $-23.0 \%$.

All tested products showed the discrepancy in the content of many components. Dairy products showed incompliance in terms of non-dairy fats; bakery in terms of microbiological indicators and preserving agents; meat - hormonal preparations, nitro substitutes, pesticides, radionuclides, and antibiotics; fish - microbiological 
indicators; vegetables in terms of nitrates, nitrites, heavy metals; drinking water, spirits, and confectionery products in terms of microbiological indicators, tea, phytotea - radionuclides.

Table 2.3

Calculating predicted values for enterprises under investigation

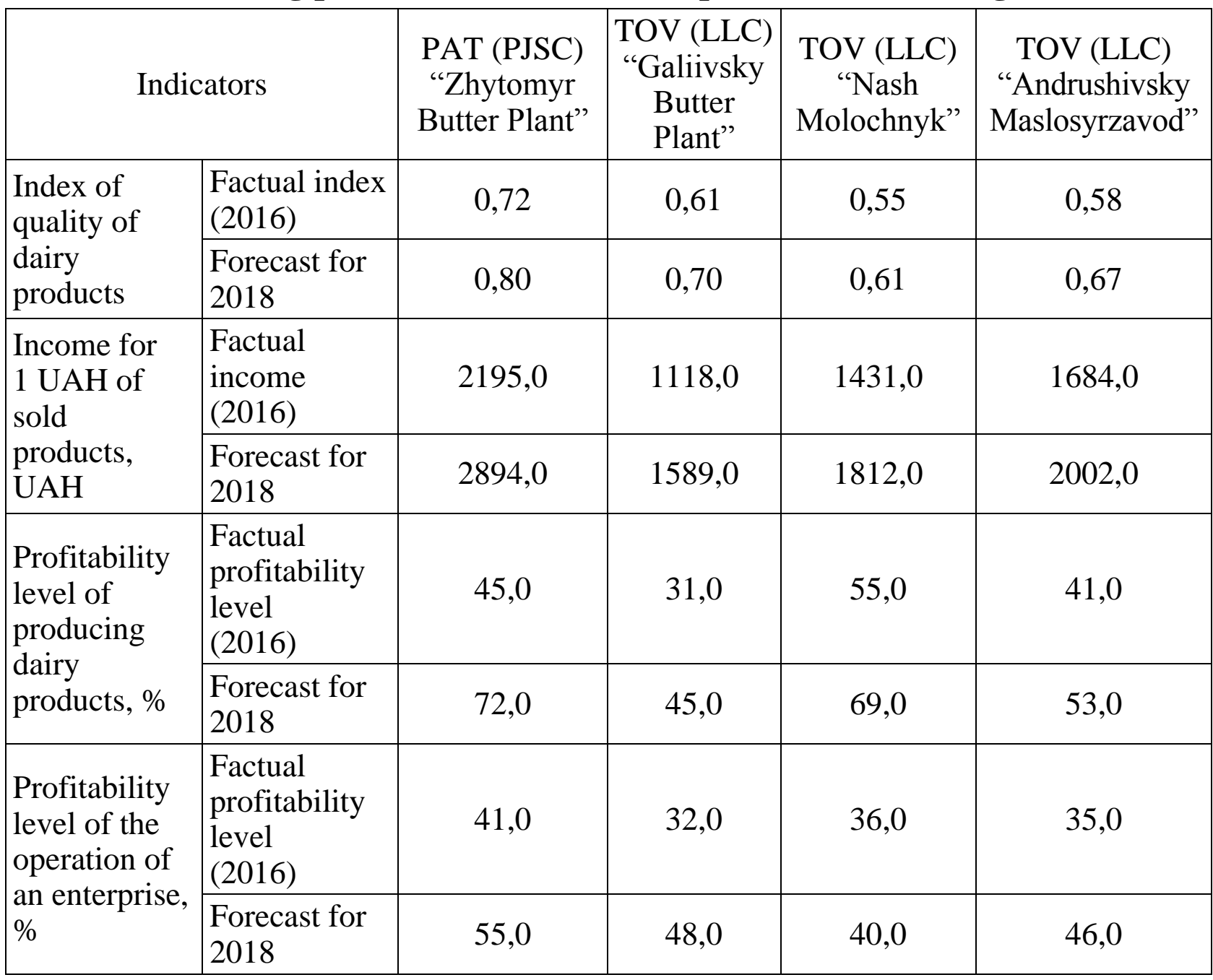

Source: calculating using the data from financial statements of PAT (PJSC) "Zhytomyr Butter Plant", TOV (LLC) "Galiivsky Butter Plant", TOV (LLC) "Nash Molochnyk", TOV (LLC) "Andrushivsky Maslosyrzavod".

The results of research on the example of 4 enterprises of Zhytomyr region (PAT (PJSC) "Zhytomyr Butter Plant", TOV (LLC) "Galievsky Butter Plant", TOV (LLC) "Nash Molochnyk", TOV (LLC) "Andrushivsky Maslosyrzavod") showed that the synergy of the growth of the quality of dairy products was accompanied by the effect of increased profitability of the operation of enterprises (from 18\% to 46\%).

In turn, the determining factors of increasing the effectiveness of product quality management are: 1) the development and implementation of an effective and appropriately focused business development strategy; 2) the level of corporate culture from the standpoint of the role of motives concerning sustainable growth of quality; 3 ) the organization of production processes, which also includes technical and technological aspects of solving the problem. These are the aspects, which determine the direction of further research. 


\section{References:}

1. Momot O. Investigating the notion of "quality" and its peculiarities in Ukraine / O. Momot // Collection of research papers of Cherkasy State Technological University. Series: economic science. - Issue 17. - Cherkasy: CHDTU, 2007. - P. 236-240.

2. Harachuk $\mathrm{Yu}$. Increasing the efficiency of enterprise activity by means of managing competitive ability / Yu. Harachuk // Current issues of economics. - 2008. - No 2 (80). - P. 60-65.

3. Leheza D. Issues of quality and competitive ability of fruit products / D. Leheza // Economy of agro-industrial complex. - No 4. - 2002. - P. 50-52.

4. Kucher M., Shevchenko V. Ensuring quality of grain products in Canada / M. Kucher, V. Shevchenko // Economy of agro-industrial complex. - No 5. - 2003. - P. 133-135.

5. Ukrainian pattern of agricultural development and its social and economical retargeting: scientific paper / [O. Borodina, V. Heiets, A. Hutorov et al.]; under the editorship of V. Heiets, O. Borodina, I. Prokopa; NASU, Institute for economics and forecasting. - K., 2012. - 56 p.

6. Deming W.E. Tributes to Walter A. Shewhart / W.E. Deming // - Industrial Quality Control. - 1967. - Vol. 24(02), August. - 56 p.

7. Hutkevych S. Efficiency of functioning of quality management system at an enterprise from the standpoint of process-oriented approach / S. Hutkevych, O. Kravchenko // Current issues of economics. - 2006. - No 3. - P. 75-84.

8. Aronov I. TQM as a Tailor's management system / I. Aronov // Standards and quality. 2001. - No 12. - P. 94-98.

9. Kaplan R. Strategic map. Transformation of intangible assets into deliverables / R. Kaplan. D. Norton; translation from English. - M.: "Olimp-Business", 2005. - P. 12-68.

10. Tailor F. Principles of scientific management / F. Tailor [translation from English by A. Zak]; with the foreword and under the editorship of E. Kochergina. - M.: Magazine "Controlling", 1991. - 104 p.

11. Buriak R. Contemporary approaches to product quality management of poultry products / R. Buriak // Scientific reporter of NAU. - 2002. - Issue 56. - P. 317-319.

12. Versan V. Merits and flaws of new version of ISO standards of 9000 series: strategy and implementation / V. Versan // Standards and quality. - 2001. - No 12. - P. 56-61.

13. Drobot V. Technology of breadmaking production / V. Drobot. - K.: Lotos, 2005. -365 p.

14. Ferapontov A. New approach to assessing product quality / A. Ferapontov // Standards and quality. - 1993. - No 10.

15. Ford G. My life, my achievements / G. Ford [translation from English]; under the editorship of E. Kochergin. - M.: Finance and statistics, 1989. - 206 p.

16. Hammer M. Business in the $21^{\text {st }}$ century: the agenda. What every company needs to do to become a market leader in current decade / M. Hammer. - M.: Dobraia kniga. - 2005. - 336 p.

17. Kots G. Modelling the expenses in the management system of ensuring product quality / G. Kots // Sci-tech collected volume. Series: Economic science. - K.: Technics, 2001. - Issue 28. P. 39-42.

18. Crosby Philip B. Quality and I. Life of a businessman in America / Philip B. Crosby; [translation from English by A. Denysova and O. Zamiatina]. - M.: RIA "Standards and quality", 2003. - 264 p.

19. Bibik Yu. Problems of evaluating the efficiency of product certification in compliance with international standards // Collection volume of scientific works "Economics: problems of theory and praxis". Issue 147. - Dnipropetrovsk: DNU, 2002. - P. 9-14.

20. Bilukha M. Basics of scientific research: textbook for students of economical speciality of higher educational establishments / M. Bilukha. - K: Vyscha shkola, 1997. - $271 \mathrm{p}$.

21. Veblen T. Theory of leisure class / T. Veblen; under the editorship of V. Motyliov; translation from English by S. Sorokyn. - М. : Прогресc, 1984. - 348 c.

22. Vitkin L. Ukraine's place in the world and European quality / L. Vitkin // Standardization, certification, quality. -2002 - No 3. - P. 5-7.

23. Ganaba M. Quality as a main criterion for producing products able to meet competition / M. Ganaba // Economy of agro-industrial complex. - No 9. - 2006. - P. 108-112.

24. Official website of the Ministry of Economic Development and Trade of Ukraine http://www.kmu.gov.ua/control/uk/publish/article. 
25. Grabchuk I. Quality of milk and meat of agricultural enterprises in Zhytomyr region in the context of European integration requirements / I. Grabchuk // Scientific reporter of Volyn National University named after Lesia Ukrainka. - Lutsk: Publishing house "Vezha" VNU, 2008. - Vol. 7 P. 168-177.

Козюк В.В. доктор економічних наук, професор, завідувач кафедри економічної теорії Тернопільського національного економічного університету

Гайда Ю.І. доктор сільськогосподарських наук, професор, професор кафедри економічної теоріі Тернопільського національного економічного університету Шиманська О.П. кандидат економічних наук, доцент, дочент кафедра економічної теорії Тернопільського національного економічного університету

\section{ГЛОБАЛЬНІ МІСТА: ПИТАННЯ ТЕОРЇ̈, ЗВ’ЯЗОК З ВІДРИТІСТЮ КРАЇН, ЕКОЛОГІЧНИЙ ВИМІР}

\section{1. Актуалізація дослідження ролі глобальних міст у світовій економіці}

Поглиблення зв'язків і взаємозалежностей на світових ринках, яке зумовлене, насамперед, прискореним розвитком технологій, провокує зростання мобільності населення, розширення можливостей для ведення бізнесу, посилюючи тим самим вплив конкурентного середовища на національні економіки. За таких умов зростає роль міст, які стають ключовими центрами глобального економічного та політичного простору. «Архітектура» глобальної економіки в ії просторовому вимірі дедалі більшою мірою формується завдяки виокремленню міських агломерацій у вузли перетину мереж потоків капіталів, благ, інформації. Значення міст цілком очевидно стає першочерговим у просторовій алокації сучасних транскордонних операцій, формуючи теоретичне розуміння того, чому ефекти агломерації перетворюють міста на домінуючих глобальних «гравців».

Широкий набір факторів опосередковано засвідчує наявність конкретних переважаючих форм ролі міст над роллю країни. Зокрема глобальний бізнес починає планувати свою стратегію та перспективи розвитку з міста, а не країни. Аналітична інформація у сфері глобальних фінансів щодо тенденцій та кон'юнктури ринку активів подається здебільшого в розрізі міст. В різного роду аналітичних звітах про «стан багатства» (так звані Wealth Reports) порівняння розподілу доходів та активів також здійснюється з урахуванням особливостей сучасних міст. Глобальний ринок нерухомості сегментований з точки зору того, як приплив глобальних капіталів впливає на вартість нерухомості та оренди саме в міських агломераціях (наприклад, Case-Shiller Index автохтонно 
розраховується саме для міст, і вже згодом почав обраховуватись для країн). Водночас феномен «гламурних міст» засвідчує, що нематеріальні фактори впливу на алокацію глобальних капіталів та вектор руху виробничих ресурсів (особливо знань та інформації) стають дедалі більш важливими детермінантами позиціонування та атракційності у глобальному соціо-економічному просторі. Враховуючи швидке зростання і розвиток багатьох міст, особливо 3 ринками, що виникають, зокрема в Китаї, Індії, конкуренція між ними щодо ведення бізнесу, залучення інвестицій, таланту та інтелекту постійно загострюється $[1$, c. 52]. У зв'язку з цим у наукових колах актуалізуються дослідження щодо глобальної ваги міст в сучасному світовому просторі.

Вагомий внесок у дослідження ролі міст у світовій економіці належить: П. Геддесу [2], Ф. Броделю, П. Холлу [3], С. Сассен [4; 5], М. Кастельсу [9; 10; 11], Дж. Фридману [12] та іншим.

Науковий дискурс стосовно глобальних/світових міст розпочався на початку $\mathrm{XX}$ століття. Обговорюючи торговельні та міжнародні ринкові зв'язки, вчені обгрунтовували зміни в містах специфікою існуючих міжнародних та національних політичних умов [2]. Свропейський історик Ф. Бродель свого часу назвав міста «логістичними центрами», до яких тяжіє світова економіка, наголошуючи на все більш тісній «вмонтованості» міст у межі національних економічних систем та їх підпорядкованості політичній владі відповідних держав. Британський вчений П. Холл сконцентрував увагу на ролі світових міст, як «центрів національної та міжнародної політичної влади, урядових центрів, центрів національної та міжнародної торгівлі, банківської і страхової справи, центрів концентрації найкваліфікованіших фахівців, а також збору та передачі інформації за допомогою видавничої справи, мас-медіа, центрів мистецтва і культури [3]. П. Холлу належить ідея «світового міста», в якому «сконцентрована непропорційно велика частка найважливішого світового бізнесу» [3].

Авторство терміну «глобальне місто» належить американському соціологу та економісту С. Сассен (1991р.), яка ототожнила його зі «стратегічним центром концентрації господарської діяльності, управління транскордонними фінансовими потоками та надання певних високотехнологічних послуг для існуючих всередині нього мультинаціональних компаній» [4]. На ï думку, саме великі, технологічно розвинені міські агломерації, зокрема такі як Токіо, Лондон, Нью-Йорк, виконуючи роль рушіїв світової економіки, визначають характер сучасного світу. На думку С. Сассен, у ньому відбувається звуження значення національної економіки на користь тих місць, в яких по-особливому поєднуються політичні та економічні можливості. С. Сассен акцентує увагу на тому, що стрімке зростання глобальних міст обумовлене вимогами транснаціонального капіталу, який циркулює у банківській сфері, аудиті, рекламі, фінансовому менеджменті, консалтингу тощо. Глобальний контроль за капіталом уможливлюється лише за наявності особливих агломеративних територіальних утворень - «глобальних міст», які водночас $є: 1)$ базами для глобальних операцій ТНК; 2) місцями виробництва і ринками; 3) лідерами в ієрархії міст, яка формується, виходячи 3 їх відмінних ролей у світовій економіці. У міру того як регіони, в яких розміщуються глобальні міста, перевершують територіальну економіку держави, множаться нові форми нерівномірності розвитку - в глобальному, національному та регіональних 
масштабах. На противагу винятковій ролі глобальних міст низка інших, на думку С. Сассен, об’ єктивно виявляється позбавленою «статусу» «глобальних економічних гравців». До них відносяться міста та регіони, яким не вдалося успішно подолати наслідки де-урбанізації, або ж так звана «глобальна периферія», в якій зосереджена більшість населення світу. У ході дослідження С. Сассен виокремила 7 основних характеристик глобальних міст: 1) розосередження діяльності компаній в різних країнах, що призводить до збільшення масштабів і складності координації їх діяльності; 2) залучення компаніями ззовні «третіх осіб» (outsourcing), які спеціалізуються на менеджменті, правових аспектах фінансової діяльності, консалтингу; 3) залежність глобальних компаній від «агломеративних економік» - не у сенсі усталеного розуміння економічного злиття центрального міста та прилеглих до нього, а - властивої для того чи іншого глобального міста особливої концентрації висококваліфікованого персоналу і надання спеціалізованих послуг, які сконцентровані в єдиному «інформаційному центрі», що забезпечує можливість оперативнішого та ефективнішого вирішення завдань; 4) переміщення штаб-квартир глобальних компаній внаслідок відсутності потреби у безпосередній близькості як до тих, хто їх обслуговує, так і до постачальників; 5) розширення спеціалізованого сервісу (використання послуг однієї спеціалізованої компанії для обслуговування іншої), яке призводить до створення «транснаціональних міських систем», внаслідок чого окремі міста стають економічно незалежними або від регіонів, в яких розташовані, або ж від національних економік в цілому; 6) рішення щодо розміщення глобальних компаній приймаються з урахуванням можливостей доступу до джерел отримання низькокваліфікованої праці (поза конкуренцією перебувають міста-столиці з постійним припливом іммігрантів); 7) космополітизм глобальних міст супроводжується розривом у доходах населення.

Стосовно теоретичних підходів досліджуваної проблеми вагомою $є$ нова економічна географія та сітьова доктрина. Пояснення торгівлі на основі ефекту масштабу, який релевантний ефекту агломерації, віддзеркалює те, чому алокація капіталів, найбільш продуктивних ідей та технологій концентрується у містах. Незважаючи на те, що в рамках підходу нової економічної географії П. Кругмана $[6,7,8]$ безпосередньо не йдеться про виокремлення глобальних міст, логіка його наукових розвідок відкриває шлях для розуміння утворення економічних центрів та їх відриву від периферії навіть в межах окремої національної економіки. Глобалізація посилює цей ефект, завдяки чому ефекти агломерації підпадають під дію глобального резонансу.

В рамках такого підходу розвинув концепцію глобальних міст відомий американський соціолог М. Кастельс, визначивши глобальне місто «домінантною формою просторової організації людської діяльності». У цьому контексті виняткова роль глобальних міст пов'язується 3 концентрацією, ущільненням вузлів виробництва інформації та управління інформаційними потоками в глобальному мережевому просторі. Сітьовий підхід М. Кастельса вказує на те, що міста є вузлами перетину мереж різного типологічного характеру, взаємодія між якими має низку синергічних ефектів, які дозволяють отримувати переваги доступу одразу до усіх мереж завдяки виконанню агломераціями вузлових функцій $[10 ; 11]$. Попри те, що сітьове суспільство може функціонувати на достатньо децентралізованому рівні, саме пошуки глобальних ефектів 
масштабу виробництва спонукають до концентрації різних роззосереджених агентів в центрах ухвалення рішень та координації, а також локалізації виробництва та створення нових технологій. Саме мегаполіси, забезпечуючи перетин інформаційних потоків та фінансових ресурсів, стають зручними центрами прийняття управлінських рішень внаслідок концентрації адміністративних, управлінських та політичних функцій, реалізація яких породжує ресурсні потоки [9]. Емпіричні дані з розвитку міст, зростання їх площі та кількості населення підтверджують тезу М. Кастельса про домінуючий статус глобальних міст в економічному і соціальному просторі [13].

Вищезгадані теоретичні підходи безумовно підтверджують домінуюче значення міст в архітектурі глобальної економіки, однак потребують поглиблення розуміння цієї проблеми крізь призму аналізу методик оцінки ваги міст, зокрема в екстраполяції на порівняння зі ступенем глобалізації країн, що й спонукає до подальших наукових досліджень.

\section{2. Проблема взаємозв'язку між вагою глобальних міст і мірою глобалізації країн}

У сфері аналітики глобальна вага міст оцінюється за допомогою низки кількісних індикаторів. Зокрема, Індекс глобальних міст (The Global Cities Index / A.T. Kearney - GCI / A.T. Kearney), побудований за методологією Міжнародної консалтингової компанії (США), призначений для визначення рейтингу глобальних міст світу і включає в себе супутній індекс - Emerging Cities Outlook (ECO), який вимірює потенціал міст на найближчу перспективу [14]. Ступінь глобалізації міст, а відтак й відповідних країн, за цим індексом оцінюється у 5-ти вимірах: «ділова активність», «людський капітал», «інформаційний обмін», «культурний досвід» і «політична активність». «Ділова активність» передбачає врахування наявності штаб-квартир найбільших світових корпорацій, місцезнаходження фірм, які надають кращі бізнеспослуги, вагомості (ємності?) ринків капіталу міста, кількості проведених міжнародних конференцій, потоку товарів тощо. «Людський капітал» оцінює здатність міста приваблювати таланти, враховуючи чисельність населення іноземного походження, якість університетів, кількість міжнародних шкіл, іноземних студентів, резидентів 3 вищою освітою. «Обмін інформацією» відображає активність циркуляції новин та інформації всередині та за межами міста, базуючись на доступі до основних каналів телевізійних новин та наявності мережі Internet, свободу вираження думок. «Культурні досягнення» визначають широкий спектр атракцій, включаючи кількість музеїв, мистецьких центрів, іноземних туристів, зв'язки 3 містами-побратимами. «Політична активність» оцінює впливовість міста у глобальному політичному діалозі й вимірюється кількістю посольств і консульств, міжнародних організацій та місцевих установ міжнародного масштабу, чисельністю проведення конференцій за участю політиків. У сукупності Global Cities Index i Global Cities Outlook, розраховані зокрема у 2015 та 2016 pp., презентують оцінку 125 найбільших i найвпливовіших міст у світі. Ці індикатори не лише відображають рейтинг ключових поточних «гравців», а й забезпечують можливість 3'ясувати, які міста в майбутньому можуть стати генераторами змін у глобальному економічному просторі (табл. 1). 
Toп-25 міст за Global Cities Index тa Global Cities Outlook

\begin{tabular}{|c|c|c|c|c|c|}
\hline \multicolumn{3}{|c|}{ Global Cities Index } & \multicolumn{3}{|c|}{ Global Cities Outlook } \\
\hline \multirow{2}{*}{ Місто } & \multicolumn{2}{|c|}{ Рейтинг } & \multirow{2}{*}{ Мicto } & \multicolumn{2}{|c|}{ Рейтинг } \\
\hline & 2015 p. & 2016 p. & & 2015 p. & 2016 p. \\
\hline Лондон & 2 & 1 & Сан-Франциско & 1 & 1 \\
\hline Нью-Йорк & 1 & 2 & Нью-Йорк & 4 & 2 \\
\hline Париж & 3 & 3 & Бостон & 3 & 3 \\
\hline Токіо & 4 & 4 & Лондон & 2 & 4 \\
\hline Гонконг & 5 & 5 & X'юстон & 6 & 5 \\
\hline Сан-Франциско & 6 & 6 & Атланта & 16 & 6 \\
\hline Чикаго & 7 & 7 & Стокгольм & 8 & 7 \\
\hline Сінгапур & 8 & 8 & Амстердам & 9 & 8 \\
\hline Пекін & 9 & 9 & Мюнхен & 7 & 9 \\
\hline Вашингтон & 10 & 10 & Цюріх & 5 & 10 \\
\hline Сеул & 11 & 11 & Чикаго & 17 & 11 \\
\hline Брюссель & 12 & 12 & Сідней & 11 & 12 \\
\hline Мадрид & 16 & 13 & Париж & 19 & 13 \\
\hline Сідней & 15 & 14 & Берлін & 13 & 14 \\
\hline Мельбурн & 19 & 15 & Мельбурн & 15 & 15 \\
\hline Берлін & 17 & 16 & Женева & 12 & 16 \\
\hline Торонто & 13 & 17 & Сінгапур & 14 & 17 \\
\hline Москва & 14 & 18 & Торонто & 20 & 18 \\
\hline Відень & 18 & 19 & Токіо & 18 & 19 \\
\hline Шанхай & 21 & 20 & Даллас & 29 & 20 \\
\hline Буенос-Айрес & 20 & 21 & Лос-Анджелес & 21 & 21 \\
\hline Амстердам & 25 & 22 & Брюссель & 24 & 22 \\
\hline Сан-Франциско & 22 & 23 & Тайбей & 28 & 23 \\
\hline Бостон & 23 & 24 & Копенгаген & 23 & 24 \\
\hline Стамбул & 29 & 25 & Ванкувер & 27 & 25 \\
\hline
\end{tabular}

Джерело: [14]

Компанія А.T. Kearney за рейтингом топ- 25 визначила низку міст, які класифікуються як «глобальна еліта». У 2016 р. їх виявилось 15 (табл. 2), усі вони не лише загальновідомі центри культури та політики, а й глобальні економічні центри із загальною чисельністю населення близько 8,8 млн. осіб і створеним ВВП у обсязі в 7,3 трлн. дол. США. Висока продуктивність цих міст i їх потужний потенціал засвідчують про зростання їх глобального впливу у майбутньому.

Статус «глобальної еліти», як і раніше, продовжують утримувати Лондон і Нью-Йорк. Однак, незважаючи на їх силу, вони не «заблоковані» глобальним лідерством. Вісімнадцять різних міст лідирують 3-поміж тих чи інших із 27 показників за Global Cities Index і 20 міст демонструють повне або часткове лідерство за 13 показниками, передбаченими Global Cities Outlook, що засвідчує зіткнення «еліти» з серйозними проявами конкуренції з боку різних міст у всіх основних регіонах світу. 
«Глобальна еліта» за Global Cities Index i Global Cities Outlook, 2016 p.

\begin{tabular}{|c|c|c|c|}
\hline \multirow[b]{2}{*}{ Регіон } & \multirow[b]{2}{*}{ Мicта } & \multicolumn{2}{|c|}{ Рейтинг } \\
\hline & & $\begin{array}{l}\text { Global Cities } \\
\text { Index }\end{array}$ & $\begin{array}{c}\text { Global Cities } \\
\text { Outlook }\end{array}$ \\
\hline \multirow{6}{*}{ США } & Нью-Йорк & 2 & 2 \\
\hline & Лос-Анджелес & 6 & 21 \\
\hline & Чикаго & 7 & 11 \\
\hline & Торонто & 17 & 18 \\
\hline & Сан-Франциско & 23 & 1 \\
\hline & Бостон & 24 & 3 \\
\hline \multirow{5}{*}{ Свропа } & Лондон & 1 & 4 \\
\hline & Париж & 3 & 13 \\
\hline & Брюссель & 12 & 22 \\
\hline & Берлін & 16 & 14 \\
\hline & Амстердам & 22 & 8 \\
\hline \multirow{4}{*}{$\begin{array}{c}\text { Азійсько- } \\
\text { Тихоокеанський } \\
\text { регіон }\end{array}$} & Токіо & 4 & 19 \\
\hline & Сінгапур & 8 & 17 \\
\hline & Сідней & 14 & 12 \\
\hline & Мельбурн & 15 & 15 \\
\hline
\end{tabular}

Джерело: [14]

Ще один показник для визначення рейтингу глобальних міст, який запропонований фахівцями міжнародної консалтингової компанії Knight Frank (The Global Cities Index / Knight Frank), грунтується на врахуванні чотирьох чинників: «економічної діяльності», «якості життя», «знань» та «впливу політичної влади». У табл. 3 відображений рейтинг топ-10 глобальних міст, які визначені Knight Frank у 2014 р. (у порівнянні з 2013 р.), а також їх прогнозний рейтинг на 2024 p.

Таблиця 3

Рейтинг 10-ти глобальних міст за оцінками Knight Frank

\begin{tabular}{|c|c|c|c|}
\hline Місце & $\mathbf{2 0 1 4} \mathbf{p .}$ & $\mathbf{2 0 1 3} \mathbf{~ p .}$ & $\mathbf{2 0 2 4} \mathbf{p .}$ \\
\hline 1 & Лондон & Лондон & Нью-Йрк \\
\hline 2 & Нью-Йорк & Нью-Йорк & Лондон \\
\hline 3 & Сінгапур & Сінгапур & Гонконг \\
\hline 4 & Гонконг & Гонконг & Сінгапур \\
\hline 5 & Женева & Женева & Шанхай \\
\hline 6 & Шанхай & Шанхай & Пекін \\
\hline 7 & Дубай & Майамі & Дубай \\
\hline 8 & Майамі & Дубай & Майамі \\
\hline 9 & Париж & Пекін & Женева \\
\hline 10 & Пекін & Париж & Мумбай \\
\hline
\end{tabular}

Джерело: складено за [15] 
На думку аналітиків Knight Frank, глобальні міста сьогодні внаслідок зростання ступеня сконцентрованості працівників розумової праці, знаходяться на етапі «переформатування» в аспекті розміщення і призначення сучасних офісів, розважальних центрів, які знаходяться поруч одні від одних, пошуку 3 боку інвесторів можливостей для забезпечення вищої прибутковості капіталовкладень, що призводить до об'єднання капіталів задля фінансування розвитку міст у майбутньому. Згадані тенденції в глобальних містах сприймаються як необхідна умова забезпечення пристосованості нових працівників і фірм до очікуваних змін [15]. На перший погляд видається доволі специфічним той факт, що міста розширюються, перевершуючи економіки країн, в яких вони розміщені, однак працівники глобальних міст $є$ одними 3 найпродуктивніших у світі, що, зазвичай, позначається на рівні розвитку країн. Фахівці Knight Frank прогнозують у найближчій перспективі нову хвилю піднесення міст з ринками, що виникають. Незважаючи на те, що в країнах Азії, Африки, Південної Америки, пропозиції для інвесторів можуть ускладнюватися через низку причин, зокрема політичну нестабільність, коливання валютних курсів, низьку прозорість ринку, все ж спостерігається тенденція націленості інвесторів на цілком розвинуті ринки в Кенії, Південній Африці, Ботсвані та Нігерії. Значення Найробі, зокрема, в якості бази для функціонування панафриканського бізнесу в Східній Африці, швидко зростає внаслідок наявності нафтових родовищ, зростання телекомунікаційної індустрії та появи багатьох світових фірм. Кейптаун, Йоганнесбург і Лагос також розглядаються як стратегічні центри поширення ділової активності. Дубай забезпечує обслуговування зростаючого потоку африканського інвестиційного капіталу [15].

В якості сучасного вимірника рівня розвитку національної та глобальної економік сьогодні також широко застосовується Індекс глобальної потужності міст (The Global Power City Index - GPCI) Токійського Інституту Меморіального фонду міських стратегій (The Mori Memorial Foundation's Institute for Urban Strategies), який оцінює і визначає рейтинг найбільших міст світу відповідно до їх «магнетизму» - всеохоплюючої влади, яка сприяє залученню творчих особистостей та бізнесу з усіх континентів задля мобілізації активів 3 метою забезпечення економічного, соціального та екологічного розвитку [16]. За даними GPCI-16, Лондон впродовж останніх п’яти років зберігає своє місце у верхній частині загального рейтингу, й надалі демонструючи тенденцію до поглиблення розриву з Нью-Йорком.

Аналіз провідних світових економік, здійснений зокрема у 2014 р. Чиказькою радою з глобальної політики (Chicago Council on Global Affairs) за даними Світового банку (The World Bank) i Brookings Institution, уможливив визначення рейтингу міст, грунтуючись на порівнянні світової економіки 3 власне національними економіками. На перший погляд очевидними $є$ кілька особливостей: велика концентрація економічно впливових міст в Китаї і США, концентрація економічно впливових міст в прибережних районах, які значно вразливіші до зміни кліматичних умов, здатність столичних економік генерувати частку загальнонаціонального ВВП, яка істотно перевищує частку населення їх країн, а також значне представництво не столичних міст [17]. У ході аналізу було виявлено, що лише у двох містах в топ- 25 економік - Токіо (14-е місце) і Нью-Йорк (19-е) міський ВВП перевищує 1 трлн. дол. США. 3 огляду на аналогічні обсяги інших національних економік, Токіо знаходиться 
попереду Саудівської Аравії, Канади, Іспанії та Туреччини, тоді як Нью-Йорк випереджує Іран, Австралію, Таїланд та Нігерію (табл. 4).

Таблиця 4

Порівняльні групи міст

\begin{tabular}{|c|c|c|c|c|}
\hline Група & Міста & $\begin{array}{l}\text { Середній обсяг } \\
\text { міського ВВП, } \\
\text { млрд. дол. США }\end{array}$ & $\begin{array}{c}\text { Вибірка } \\
\text { «однотипних» } \\
\text { країн } \\
\text { (рейтинг) }\end{array}$ & $\begin{array}{c}\text { Середнс } \\
\text { значення ВВП } \\
\text { «однотипних» } \\
\text { країн, } \\
\text { млрд. дол. США }\end{array}$ \\
\hline $\begin{array}{l}\mathrm{I} \\
(1-25)\end{array}$ & $\begin{array}{l}\text { Токіо (14), } \\
\text { Нью-Йорк (19) }\end{array}$ & $1,435.6$ & $\begin{array}{l}\text { Канада (16), } \\
\text { Іспанія (17), } \\
\text { Туреччина (18) }\end{array}$ & $1,477.1$ \\
\hline \begin{tabular}{|l|} 
II \\
$(26-50)$
\end{tabular} & $\begin{array}{l}\text { Лос-Анджелес (27), } \\
\text { Сеул-Інчхон (28), } \\
\text { Лондон (29), } \\
\text { Париж (32), } \\
\text { Осака-Кобе (35), } \\
\text { Шанхай (38), } \\
\text { Чикаго (39), } \\
\text { Москва (41), } \\
\text { Пекін (45), } \\
\text { Кельн-Дюссельдорф (47), } \\
\text { Х'юстон (48) }\end{array}$ & 614.8 & $\begin{array}{l}\text { Філіппіни (34), } \\
\text { Колумбія (36), } \\
\text { ОАЕ (37) }\end{array}$ & 617.8 \\
\hline \begin{tabular}{|l} 
III \\
$(51-75)$
\end{tabular} & $\begin{array}{l}\text { Вашингтон, } \\
\text { ок. Колумбія (56), } \\
\text { Сан-Паулу (57), } \\
\text { Гонконг (58), } \\
\text { Даллас (59), } \\
\text { Мехіко (61), } \\
\text { Гуанчжоу (65), } \\
\text { Тяньцзінь (69), } \\
\text { Сінгапур (70), } \\
\text { Нагоя (71), } \\
\text { Шеньчжень (72), } \\
\text { Бостон (73), } \\
\text { Стамбул (74) }\end{array}$ & 369.1 & $\begin{array}{l}\text { Румунія (62), } \\
\text { Австрія (63), } \\
\text { Перу (67) }\end{array}$ & 370.1 \\
\hline $\begin{array}{l}\text { IV } \\
(76-100)\end{array}$ & $\begin{array}{l}\text { Філадельфія (76), } \\
\text { Сучжоу (77), } \\
\text { Сан-Франциско (78), } \\
\text { Тайбей (80), } \\
\text { Джакарта (81), } \\
\text { Роттердам-Амстердам (81), } \\
\text { Буенос-Айрес (84), } \\
\text { чунцин (85), } \\
\text { Мілан (86), } \\
\text { Бангкок (88), } \\
\text { Пусан-Ульсан (89), } \\
\text { Атланта (90), } \\
\text { Нью-Делі (91), } \\
\text { Торонто (94), } \\
\text { Сіетл (97), } \\
\text { Маямі (98), } \\
\text { Мадрид (99) }\end{array}$ & 290.2 & $\begin{array}{l}\text { Чехія (83), } \\
\text { Катар (87), } \\
\text { Португалія (92) }\end{array}$ & 288.7 \\
\hline
\end{tabular}

Джерело: [17, p. 5] 
У другій групі міст, які охоплюють рейтингові позиції з 26-ї до 50-ї (3-поміж 100 найбільших економік), їх кількість різко зростає - до 11-ти (з обсягами ВВП від 459 до 818 млрд. дол. США і з середнім значенням міського ВВП близько 615 млрд. дол. США). Середнє значення обсягу міського ВВП ставить міста другої групи в один рівень 3 такими країнами, як Філіппіни (659 млрд. дол. США), Колумбія (608 млрд. дол.) і Об’єднані Арабські Емірати (587 млрд. дол.). У третій групі кількість міст зросла до 12-ти 3 середнім міським ВВП, який становить 369 млрд. дол., тоді як у четвертій групі їх - 17 з середньою величиною ВВП у 290 млрд. дол. США [17].

Територіально високо презентативні міські економіки здебільшого розташовані в Північній Америці та Азії, 3 найбільшою їх концентрацією в США та Китаї. Зі 100 найбільших світових економік 14 - це північноамериканські міські агломерації, 12 з яких розміщені виключно в США. Серед 100 найбільших світових економік представлені лише 6 міст Західної Свропи 3 відомими європейськими столицями - Берліном, Римом, Стокгольмом, Віднем. Така різка розбіжність дозволяє висловити припущення, що державна влада i культурний вплив реалізуються одночасно $з$ економічною потужністю. Окрім цього жодне 3 африканських чи австралійських міст не потрапило до зазначеного переліку. Хоча Африка є найменш урбанізованим континентом 3поміж усіх інших, однак демонструє найвищі темпи урбанізації. Зокрема, у містах в країнах Африки, які знаходяться на південь від Сахари, спостерігаються щорічні темпи зростання населення від 3 до 6 \%. Аналітики прогнозують, що цей континент до 2050 р. стане місцем проживання для близько 1,3 млрд. міських жителів. За прогнозами фахівців, упродовж найближчих 25 років на Африканському континенті очікується подвоєння кількості міського населення [18]. На відміну від цього, Свропа і Північна Америка, демонструватимуть зростання міського населення менш ніж на 1 \% на рік до 2050 року, досягнувши загальної чисельності міського населення у 580 i 390 млн. відповідно [19]. У той час як багатство і урбанізація корелюють, збільшення обсягів виробництва не $\epsilon$ неминучим результатом зростаючого міського населення. Іншими словами, ні чисельність населення, ні темпи урбанізації не є особливо надійними індикаторами поточного чи майбутнього економічного впливу в глобальному масштабі. Поточна картина $є$ такою, що велика частина Африки і деякі частини Південної Азії відображають зростання чисельності населення, яке супроводжується економічним розвитком і різким розширенням можливостей працевлаштування для міського населення.

В світлі проблеми виокремлення міст в якості провідних глобальних гравців та економічних передумов для більш високої факторної віддачі в них (порівняно 3 країнами) виникає питання, як співвідноситься між собою глобальне позиціонування міст та ступінь глобалізованості країн. Ймовірно між ними повинна існувати пряма залежність, оскільки глобальна вага міст, у випадку їх домінування, повинна впливати на загальний рівень залучення країни в процеси глобалізації. Водночас, можна припустити, що якщо агломерації утворюють «центр-периферійну» конфігурацію навіть у власній країні, зв'язок між глобальною вагою міст і рівнем глобалізованості країни може не відповідати теоретично передбачуваному. Окрім цього можна припустити, що масштаб країни та особливості просторової алокації 
виробничих факторів у ній впливатимуть на викривлення взаємозв'язків між глобальним значенням їі міст та рівнем іiі глобалізованості.

Як видно з рис. 1, на емпіричному рівні підтверджуються одразу обидві гіпотези. Він також відображає лінійну залежність між субіндексом «економічної глобалізації» KOF-індексу глобалізації країн i Індексом глобальної потужності міст, яка характеризується слабкою щільністю взаємозв'язку $(\mathrm{R} 2=0,0734)$, але прямою залежністю. Це можна характеризувати як те, що міста насправді впливають на рівень глобалізованості країн, але при цьому такий вплив не є суттєвим. Тобто інші фактори економічної відкритості країни визначають масштаб іï залучення у процеси глобалізації. Також можна припустити, що слабка щільність зв'язку пов'язана з неоднорідністю вибірки, у яку увійшло 40 міст з 29 країн. Для уточнення результатів емпіричного аналізу варто скористатись аналітичним групуванням країн за принципом їх поділу на великі і малі економіки 3 міркувань того, що останні $є$ більш відкриті, спеціалізовані і менш диференційовані, завдяки чому теоретично повинні мати вищий рівень відкритості, отже глобальної залученості, а також за принципом поділу на розвинуті країни та країни з ринками, що виникають, оскільки останні в силу технологічного відставання та вищої вразливості до зовнішніх шоків можуть виявитись менш глобально інтегрованими, ніж розвинуті, навіть попри вищий формальний рівень відкритості по каналах торгівлі чи руху капіталу.

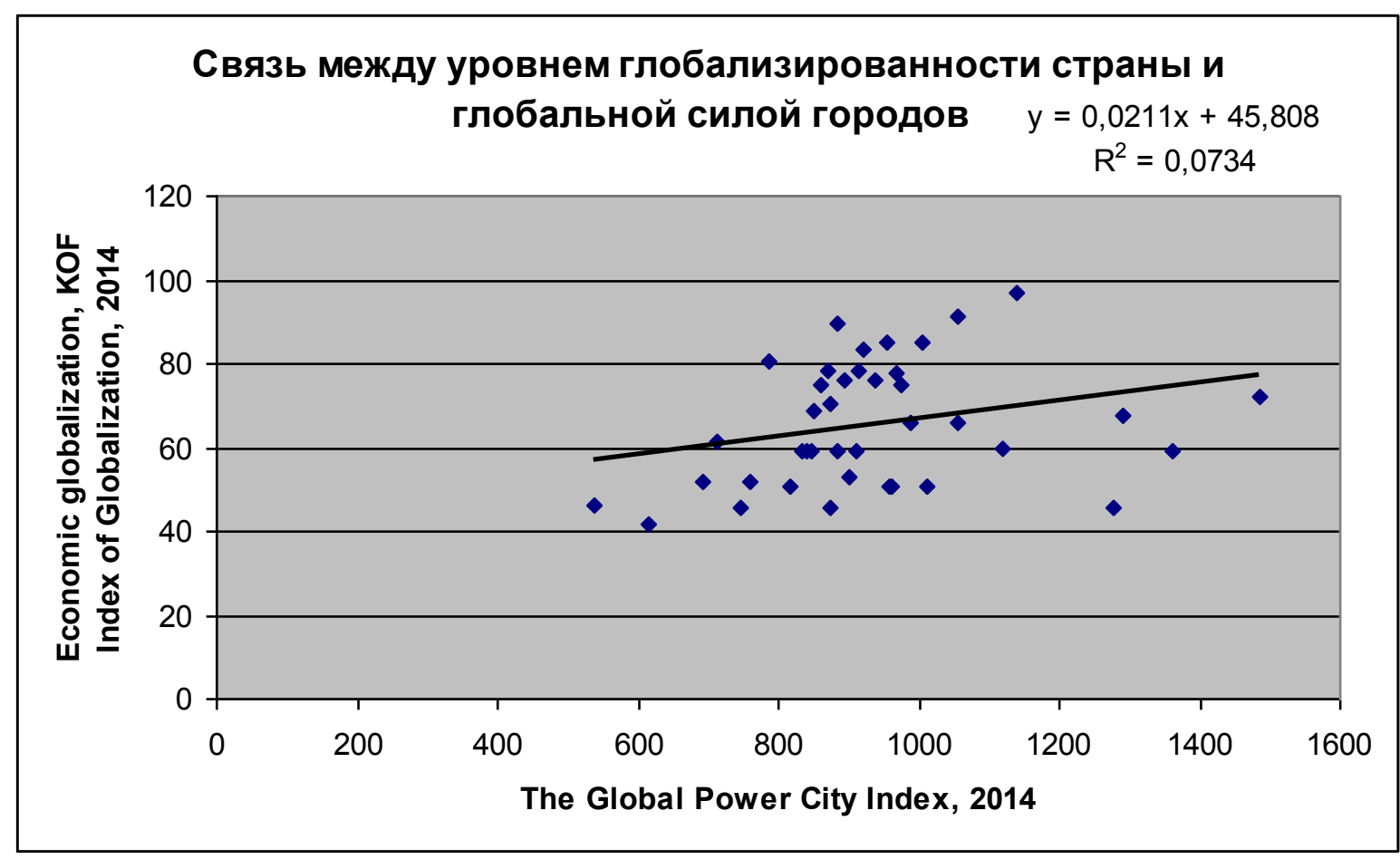

Рис. 1. Зв'язок між рівнем глобалізації країни і глобальною потужністю міст [складено за 20, 21]

Так, у розрізі трьох груп країн, середнє значення рівня глобалізації великих розвинутих економік $(61,6) €$ значно нижчим, ніж відповідне значення даного індексу для малих розвинутих економік $(83,3)$. Середнє ж значення даного індексу стосовно країн $з$ ринками, що виникають, становить 55,9. Це повністю відповідає припущенню про те, що найбільш глобалізованими є розвинуті малі 
відкриті економіки, а найменш - країни з ринками, що виникають. Для Індексу глобальної потужності міст відстежується логічна закономірність у його значеннях: найвищий показник характерний для великих розвинутих економік $(1006,4)$, дещо нижчий - для малих $(958,7)$, найменше значення даного індексу демонструють країни з ринками, що виникають $(827,5)$. Це є свідченням того, що ефекти агломерації для великих розвинутих країн значно чіткіше виражені, ніж для решти світу, а економічна потужність їхніх міст є визначальною в структурі глобальної просторової економіки. Найнижчі міжгрупові значення цього показника для країн з ринками, що виникають, також вказують на те, що попри тенденцію до виділення глобально значимих агломерацій, їхнє значення залишається не таким репрезентативним, як у випадку розвинутих країн.

Стосовно залежності між середніми значеннями індексів глобальної потужності міст і субіндексом «економічної глобалізації» КОF-індексу глобалізації всередині груп країн, варто зауважити, що для малих розвинутих економік рівень глобальної потужності міст значною мірою впливає на рівень глобалізації країни, що не властиво для великих розвинутих економік. В останніх, незважаючи на значний рівень глобальної потужності міст, рівень глобалізації країни є значно нижчим, ніж в малих розвинутих економіках. В країнах з ринками, що виникають, рівень глобальної потужності міст серед визначених груп $\epsilon$ найнижчим, що в свою чергу позначилося й на рівні глобалізації країни. 3 цього можна зробити певні аналітичні висновки:

- найбільша глобальна потужність міст може не корелювати 3 рівнем глобалізованості країни, що вказує на дію ефектів агломерації, коли саме лідерство міст є основним каналом комутації великої країни 3 глобальною економікою. При цьому, саме така потужність визначає профіль глобалізованості великих країн. По-суті, вона «локалізована» в глобально значимих агломераціях;

- найбільш глобалізовані країни є малими, завдяки чому ефекти агломерації можуть не відігравати в них настільки великої ролі як у великих країнах. Такі ефекти обмежені малим фізичним простором таких країн. Але при цьому достатньо високий рівень глобальної значимості міст в таких країнах вказує на те, що такі країни глобально інтегровані як на рівні агломерацій, так і на рівні «периферії»;

- відкритість має агломераційне зміщення в великих країнах, але, швидше, не має в малих, завдяки чому перші можуть в цілому бути значно менш глобально інтегровані, ніж другі;

- рівень розвитку залишається суттєвим драйвером як рівня глобалізованості, так і рівня глобальної значимості міст;

- подальший розвиток країн з ринками, що виникають, однозначно призведе до того, що швидка експансія їхніх міст-лідерів посилюватиме дію ефектів агломерації аналогічно до того, як вони діють у великих та малих розвинутих країнах. Це означає, що в подальших дослідженнях поділ країн з ринками, що виникають, на малі та великі вбачається актуальним.

Таким чином, належну глибину аналізу процесів глобалізації можливо забезпечити лише через застосування нової системи кількісних індикаторів, яка логічно й структурно доповнює існуючі статистичні моделі і долає однобічне розуміння стану та якісних параметрів розвитку глобальної економіки. 


\section{3. Глобальні міста та екологічний вимір держави добробуту: проблема взасмозв'язку}

Сучасні тенденції поглиблення розвитку глобальних міст актуалізують ще одну важливу проблему - співвідношення урбанізму та екологізму, обумовлюючи зміщення фокусу дослідження з аналізу екологічної складової добробуту держави на екологічну складову добробуту міст. Незважаючи на те, що традиційний еко-корелят держави добробуту (вагоме екологічне оподаткування, жорсткі регуляторні норми), зазвичай, є прерогативою міжкраїнного аналізу, особливо несприятливий антропогенний вплив на довкілля сьогодні чинять найбільш урбанізовані центри світу - мегаполіси [22]. Варто зауважити, що класичними вимірниками держави добробуту вважаються величини соціальних трансфертів та обсяги надання соціальних послуг, насамперед, - частка соціальних витрат у ВВП [23], а також показники, які характеризують стан ринку праці, зокрема, рівень зайнятості [24]. Кількісні ж та якісні показники стану навколишнього середовища, зазвичай, не використовувалися для ідентифікації держави добробуту. Загалом традиційні підходи щодо трактування «держави добробуту» не враховували складову екологічного добробуту (комфорту) населення, в тому числі у великих містах, які в більшості національних економік відіграють домінуючу роль у їх економічному, соціальному та екологічному розвитку. 3 огляду на це актуалізується проблема виявлення зв'язку між рівнем добробуту міст та індикаторами екологічної ситуації в них.

Аналіз ранжування найбільших міст світу за індексом GPCI у 2016 році засвідчив, що за критерієм «навколишнє середовище» перші п'ять місць займають відповідно Франкфурт-на-Майні, Цюріх, Женева, Сінгапур та Відень, а останні - Стамбул, Шанхай, Каїр, Пекін і Москва [16]. Узагальнена оцінка стану довкілля міст коливається від 73,5 до 201,9 балів (коефіцієнт варіації $\mathrm{CV}=21,1 \%$ ) при середньому значенні $152,6 \pm 4,98$. Варіативний ряд оцінок екологічного стану 42 міст за розподілом близький до нормального (рис. 2) 3 незначною правосторонньою асиметрією (As $=-0,643)$ і дуже слабким ексцесом $(\mathrm{Ex}=-0,080)$.

Як бачимо, найбільша частка міст (29 із 42 отримали оцінку від 140 до 200). Показово, що усі міста західноєвропейських країн, в яких екологічні аспекти відіграють домінуючу роль у їх внутрішній і зовнішній політиці, за винятком Барселони, знаходяться у верхній половині ранжованого списку (їх оцінки $\epsilon$ вищими за середне арифметичне значення критерію «навколишнє середовище»). 3 іншого боку, правостороннє зміщення кривої розподілу вказує на значимість екологічного фактора розвитку міст і це $\epsilon$ глобальним трендом.

Однофакторний дисперсійний аналіз, у якому в якості предиктора використано критерій «частина світу, в якій розташоване місто», виявив його достовірний вплив на стан довкілля досліджуваних міст (рис. 3). Найкращий стан навколишнього середовища спостерігається у Європейських містах та містах Австралії, найгірший - Азії та Африки. При цьому варто зазначити, що задля отримання більш статистично значущих результатів під час проведення подальших досліджень необхідно враховувати більшу вибірку міст Австралії, Африки та Південної Америки. Такий характер розподілу найімовірніше зможе підтвердити пануючу тривалий час гіпотезу, що для формування попиту на 
екологічні блага потрібен певний мінімум рівня розвитку. Саме це опосередковано підтвердив проведений аналіз на рівні міських агломерацій.

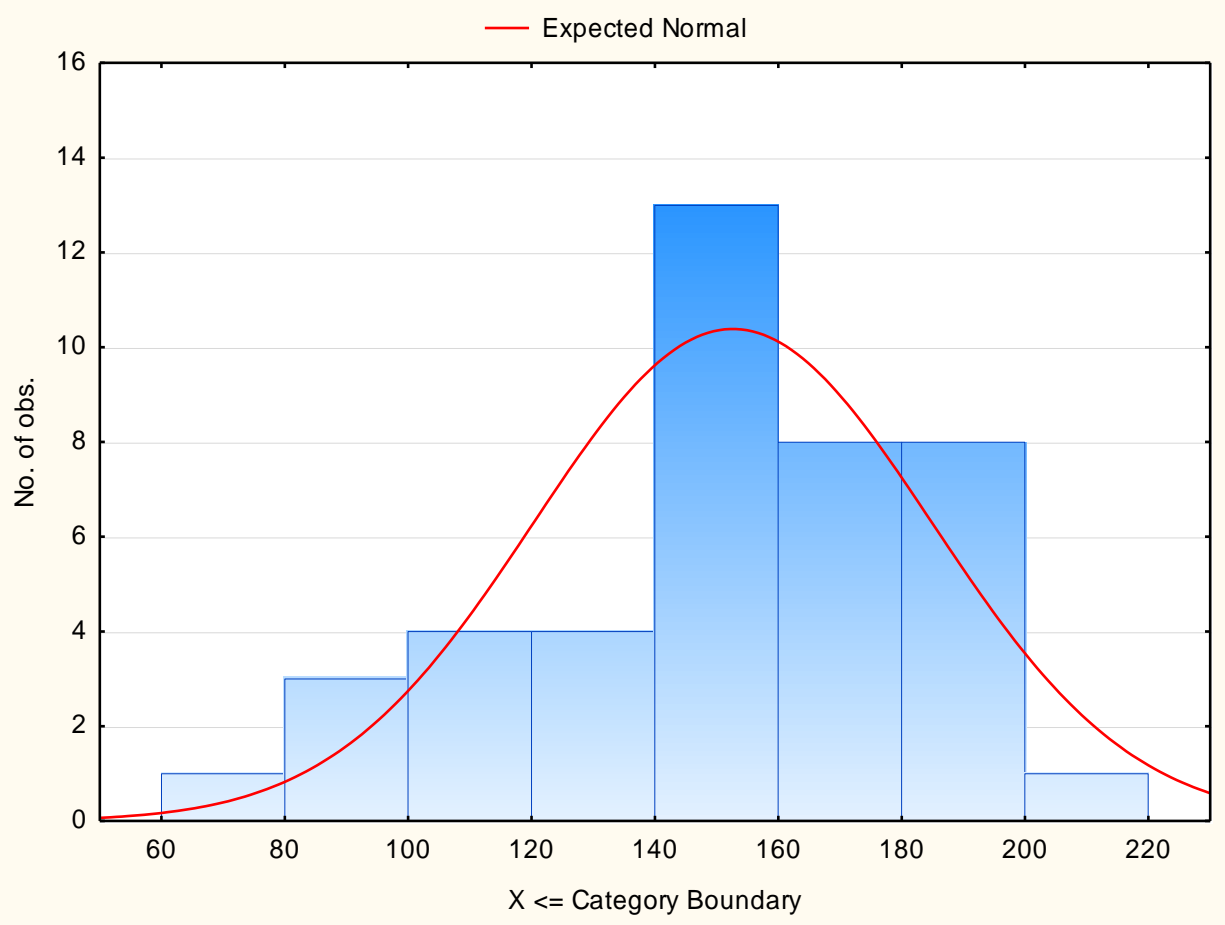

Рис. 2. Гістограма розподілу кількості міст за оцінкою стану їх навколишнього середовища

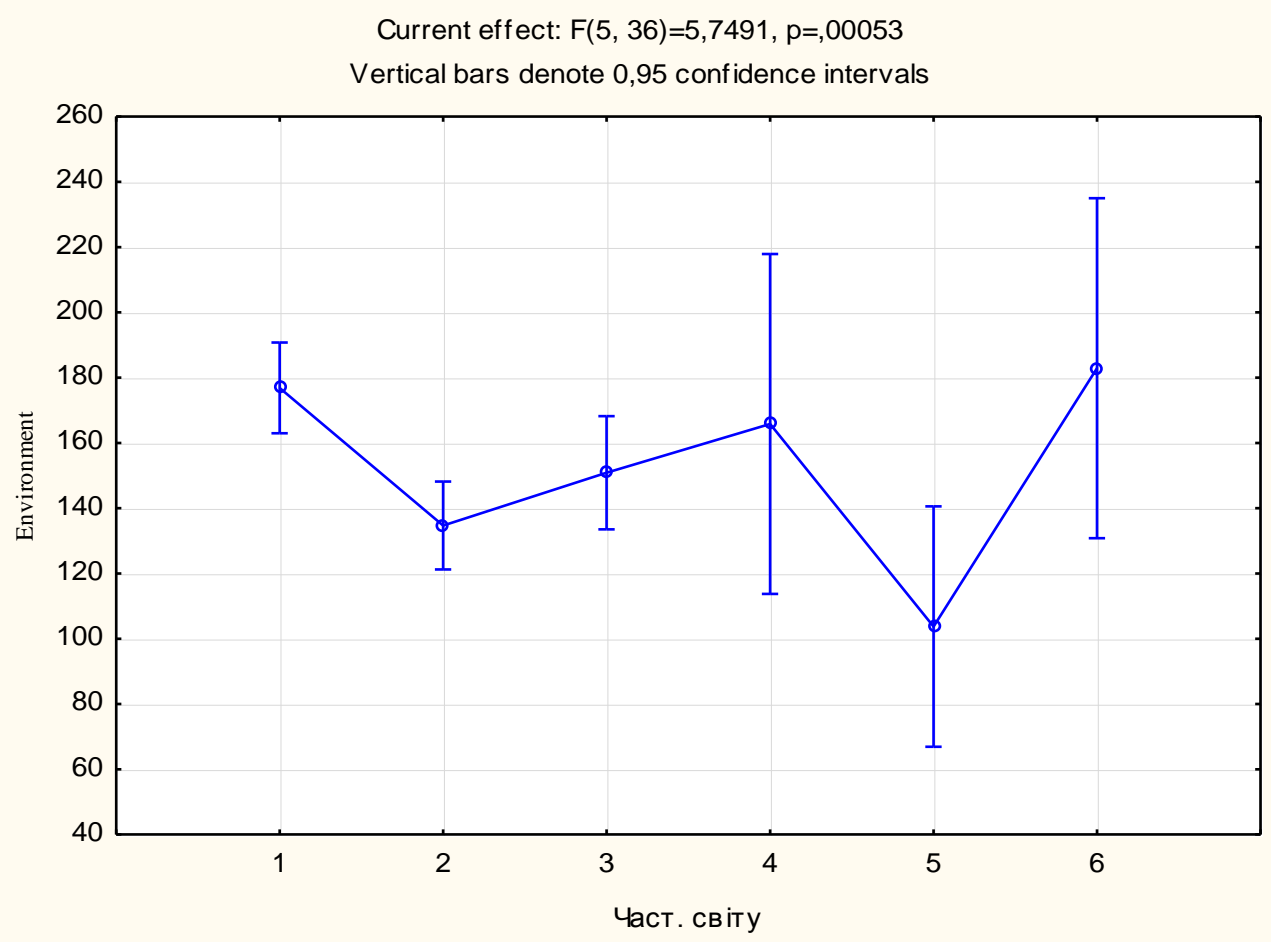

Рис. 3. Середні значення оцінок стану навколишнього середовища міст у розрізі частин світу: 1 - Свропа, 2 - Азія, 3 - Північна Америка, 4 - Південна Америка, 5 - Африка, 6 - Австралія 
Порівняння рангів міст за критерієм стану навколишнього середовища та за GPCI загалом свідчить про наявність помірної кореляції між ними (коефіцієнт кореляції Спірмена $\mathrm{r}_{\mathrm{S}}=0,440$, при $\mathrm{r}_{\mathrm{st}}=0,396$ для $\left.\mathrm{p}<0,01\right)$. Це підкреслює доволі вагому роль стану довкілля міст у прояві їх глобального «магнетизму».

На думку окремих дослідників, рівень екологізації країни, регіону чи міста перманентно залежить від рівня добробуту населення відповідної територіальної одиниці [25]. Однак ця залежність не $є$ однозначною: дані табл. 5 підтверджують відсутність значущої лінійної залежності між показниками стану навколишнього середовища міст та рівнем їх економічного розвитку.

Таблиця 5

Кореляційна матриця категорій (функцій)

індексу глобальної потужності міст (GPCI)

\begin{tabular}{|c|c|c|c|c|c|c|}
\hline & 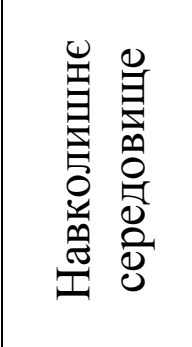 & 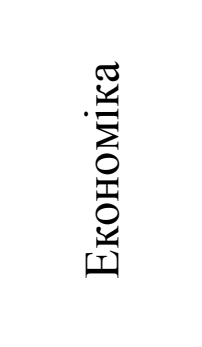 & 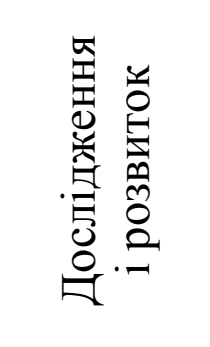 & 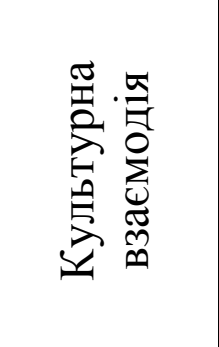 & 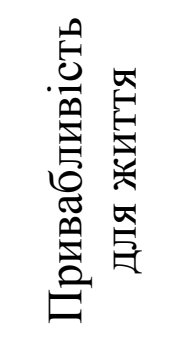 & 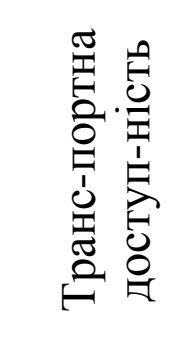 \\
\hline $\begin{array}{l}\text { Навколишнє } \\
\text { середовище }\end{array}$ & 1,000 & 0,297 & 0,192 & 0,115 & $0,463 * *$ & 0,127 \\
\hline Економіка & 0,297 & 1,000 & $0,718 * * *$ & $\mathbf{0 , 5 8 6} * * *$ & $\mathbf{0 , 3 4 2 *}$ & $0,601 * *$ \\
\hline \begin{tabular}{|l|} 
Дослідження і \\
розвиток
\end{tabular} & 0,192 & $0,718 * * *$ & 1,000 & $0,687 * * *$ & 0,215 & $0,543 * * *$ \\
\hline $\begin{array}{l}\text { Культурна } \\
\text { взаємодія }\end{array}$ & 0,115 & $0,586 * * *$ & $0,687 * * *$ & 1,000 & 0,151 & $0,716 * * *$ \\
\hline $\begin{array}{l}\text { Привабливість } \\
\text { для життя }\end{array}$ & $0,463 * *$ & $0,342 *$ & 0,215 & 0,151 & 1,000 & $0,305^{*}$ \\
\hline $\begin{array}{l}\text { Tранспортна } \\
\text { доступність }\end{array}$ & 0,127 & $0,601 * * *$ & $\mathbf{0 , 5 4 3 * *}$ & $0,716 * * *$ & $\mathbf{0 , 3 0 5} *$ & 1,000 \\
\hline
\end{tabular}

Примітка: коефіцієнт кореляції значущий для:

$*-\mathrm{p}<0,05 ; * *-\mathrm{p}<0,01 ; * * *-\mathrm{p}<0,001$.

Разом 3 тим використання нелінійного регресійного аналізу забезпечило можливість побудови низки репрезентативних однофакторних нелінійних моделей із незалежною змінною, яка комплексно характеризує економічний розвиток міста та залежною, яка представлена узагальненим показником стану довкілля (табл. 6).

У моделях 1-3 залежність між Y та Х означає, що при збільшенні значення X (покращенні стану економіки міста) монотонно, хоча й зі спадним темпом, покращується Y (стан навколишнього середовища). Модель 4, яка $є$ поліномом другого ступеня, також демонструє зростання (зі спадним темпом) значення загального показника екологічного стану міста при покращенні його економічних показників. 
Однофакторні нелінійні регресійні моделі

\begin{tabular}{|c|c|c|c|c|c|c|}
\hline \multirow[b]{2}{*}{$\begin{array}{l}\cdot \\
0 \\
0 \\
0 \\
2 \\
2 \\
0 \\
2\end{array}$} & \multirow[b]{2}{*}{ Статистична модель } & \multicolumn{5}{|c|}{ Характеристики моделі } \\
\hline & & $\mathrm{R}^{2}$ & 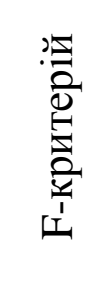 & 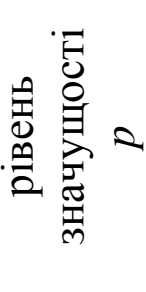 & 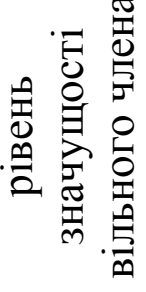 & 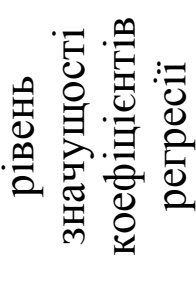 \\
\hline 1 & $Y=-961,44-1,11 X+584,81 \operatorname{Lg} X$ & 0,230 & 5,83 & 0,006 & 0,022 & $\begin{array}{c}0,029 \\
0,011\end{array}$ \\
\hline 2 & $Y=-961,44-1,11 X+253,98 \operatorname{Ln} X$ & 0,230 & 5,83 & 0,006 & 0,022 & $\begin{array}{l}0,029 ; \\
0,011\end{array}$ \\
\hline 3 & $Y=-407,40-2,49 X+75,49 X^{1 / 2}$ & 0,232 & 5,89 & 0,006 & 0,043 & $\begin{array}{l}0,016 ; \\
0,010\end{array}$ \\
\hline 4 & $Y=-26,87+1,65 X-0,0035 X^{2}$ & 0,234 & 5,96 & 0,005 & 0,631 & $\begin{array}{l}0,004 \\
0,010\end{array}$ \\
\hline
\end{tabular}

Примітка: регресант (Y) - показник стану навколишнього середовища міста, регресор $(\mathrm{X})$ - показник розвитку економіки міста.

Таким чином, враховуючи, що урбанізація відображає сучасний тренд глобального розвитку, при формуванні нової парадигми держави добробуту необхідно враховувати екологічну та/або урбоекологічну іiі компоненту, розробляти нові теоретичні та методичні підходи для іiї оцінювання. Зокрема отримані нелінійні регресійні залежності між економічними та екологічними характеристиками найбільших міст світу можуть слугувати певною емпіричною базою процесу корекції таксономічних ознак держави добробуту (міст добробуту) через їх розширення за рахунок екологічних індикаторів.

\section{Список використаних джерел:}

1. Сучасні вимірники рівня розвитку структурних та інституціональних характеристик національної та глобальної економік: навч.-метод. посіб. / В. В. Козюк [та ін.]; за ред. В. В. Козюка. - 2-ге вид., випр. і доп. - Тернопіль : Вектор, 2015. - 248 с.

2. Geddes, P. Cities in evolution an introduction to the town planning movement and to the study of civics / Patrick Geddes. - London : Villiams \& Norgate, 1915. - 409 p.

3. Peter Hall. The Global City // International Social Science Journal. - 1996. - Vol. 48. - P. 15-23.

4. Saskia Sassen. The Global City: New York, London, Tokyo. Princeton University Press, Princeton, New Jersey, 1991. - 397 p.

5. Sassen, S. The Global City: New York, London, Tokyo. Princeton, NJ : Princeton University Press. -2001.

6. Krugman P. Increasing Returns, Monopolistic Competition and International Trade // Journal of International Economics. - 1979. - Vol. 9. - No. 4. - P. 469-479.

7. Krugman P. Scale Economies, Product Differentiation, and the Pattern of Trade // American Economic Review. - 1980. - Vol. 70. - No. 5. - P. 950-959.

8. Krugman P. Increasing Returns and Economic Geography // Journal of Political Economy. 1991. - Vol. 99. - No. 3. - P. 483-499.

9. Кастельс, М. Информационная епоха: экономика, общество и культура / М. Кастельс. М. : М. : ГУ-ВШЕ, 2000. - С. 338-340. 
10. Кастельс М. Становление общества сетевых структур / М. Кастельс // Новая постиндустриальная волна на Западе. Антология / под ред. В.Л. Иноземцева. - М. : Academia, 1999. - C. 494-505.

11. Castells, M. The information Age. The Rise of the Network Society / M.Castells. - Vol. 1. London : Blackwell, 1996. - 556 pp.

12. Friedmann, J. The World City Hypothesis / John Friedmann // Development and Change. January. - 1986. - Vol. 17. - Issue 1. - P. 69-83.

13. Історія економіки та економічної думки : підруч. / В. В. Козюк, Л. А. Родіонова, О. В. Длугопольський [та ін.] ; за ред. В. В. Козюка, Л. А. Родіонової. - Тернопіль : ТНЕУ, 2015. - C. 338-340.

14. ATKearney. Global Cities 2016. Which global cities are performing best today, which have the best long-term potential, and what makes a "smart city"? [Електронний ресурс]. - Режим доступу: https://www.atkearney.com/documents/10192/8178456/Global+Cities+2016.pdf/8139cd44-c7604a93-ad7d-11c5d347451a

15. Knight Frank. Global Cities: the 2015 report [Електронний ресурс]. - Режим доступу: http://www.knightfrank.com/global-cities-index-2015

16. Global Power City Index 2016 [Електронний ресурс]. - Режим доступу: http://mori-mfoundation.or.jp/pdf/GPCI2016_en.pdf

17. 100 Top Economie: Urban Influence and the Position of Cities in an Evolving World Order [Електронний ресурс]. - Режим доступу: https://www.thechicagocouncil.org/publication/100top-economies-urban-influence-and-position-cities-evolving-world-order

18. EdeIjjasz-Vasquez, «Making Urbanization Work for Africa» (video), World Bank Blog, September 15, 2015 [Електронний ресурс]. - Режим доступу: http://blogs.worldbank.org/ sustainablecities/making-urbanization-work-africa-0.

19. World Urbanization Prospects: The 2014 Revision, United Nations, 2014 [Електронний pecypc]. - Режим доступу: http://esa.un.org/unpd/wup/Publications/Files/WUP2014-Report.pdf.

20. Global Power City Index 2014 [Електронний ресурс]. - Режим доступу: http://www.mori-m-foundation.or.jp/gpci/pdf/GPCI14_E_Web.pdf

21. KOF Index of Globalization 2014 [Електронний ресурс]. - Режим доступу: http://globalization.kof.ethz.ch/media/filer_public/2014/04/15/rankings_2014.pdf

22. Kraas, F. et al. (ed.). Megacities: our global urban future. - Springer Science \& Business Media, 2013.

23. Starke, P. The politics of welfare state retrenchment: A literature review // Social Policy \& Administration. - 2006. - T. 40. - №. 1. - C. 104-120.

24. Korpi, W. Welfare-state regress in Western Europe: politics, institutions, globalization, and Europeanization //Annual Review of Sociology. - 2003. - T. 29. - №. 1. - C. 589-609.

25. Hsu, A. et al. (2016). 2016 Environmental Performance Index. New Haven, CT : Yale University [Електронний ресурс]. - Режим доступу: www.epi.yale.edu. 


\section{THE PLACE OF VISEGRÁD GROUP \\ IN THE EU REAL SECTOR}

Деркач T.B.

доктор економічних наук, дочент, завідувач кафедри менеджменту Міжнародного гуманітарного університету, м. Одеса

\section{КРАЇНИ ВИШЕГРАДСЬКОЇ ГРУПИ - СУБРЕГІОН ЄВРОПЕЙСЬКОЇ ІНТЕГРАЦЇ̈}

\section{Вступ}

Найбільш розвинені країни Центрально-Східної Свропи створили регіональне угрупування - «Вишеградська Група» у відповідь на потужні геополітичні та геоекономічні виклики на початку 90-х років та безальтернативність ходи до європейської інтеграції.

Топологічне сусідство зумовило тісни зв'язки на певному історичному підгрунті, своєрідну регіональну логіку розвитку суспільства та спільні риси бачення майбутнього.

5 лютого 1991 p. в угорському місті Вишеград лідери Угорщини, Чехословаччини і Польщі підписали декларацію про створення «Європейської трійки» (Вишеградської групи). Основними цілями, оголошеними в декларації, були регіональна інтеграція, об'єднання спільних зусиль для інтеграції цих країн до західних структур: НАТО і СС. Також вони домовилися співпрацювати в галузі економіки, транспорту, захисту навколишнього середовища i в науковій галузі. Одним з перших значущих досягнень учасників Вишеградської групи був заключення Центрально-європейської угоди вільної торгівлі (CEFTA) з метою зняття бар'єрів у взаємних торговельних зв'язках і створення зони вільної торгівлі.

Лідерами країн була знайдена «своя легенда $\ldots$ для логічного i культурологічного обгрунтування виділення Угорщини, Чехословаччини i Польщі в регіональний союз, який об'єднав частину Східної Європи.

Легенда свідчить, що в 1335 р. Вишеград ... 3'їхалися королі Угорщини, Богемії та Польщі, щоб, кажучи сучасною мовою, вирішити «питання регіональної безпеки» ... «Вишеградський саміт» став важливою віхою у встановленні нових мирних дипломатичних принципів i в обмеженні військових конфліктів в регіоні ... Зустрічі цього рівня 3 тих пір стали періодично повторюватися, що часто підноситься як свідчення встановлення регіонального діалогу на тривалу перспективу» [3, с. 77].

Вишеградська група $\epsilon$ об'єднанням, позбавленим інституційної бази. Співпраця грунтується на принципі ротаційного головування країн-учасниць. В теорії регіоналізму існують два основні підходи до регіональної інтеграції. Перший - раціоналістичний - припускає участь держав в інтеграційному процесі з метою отримання більшої безпеки і підвищення рівня добробуту. 
Відповідно до другого підходу, який можна охарактеризувати як ідейний, регіональна інтеграція розглядається як похідна від регіональної ідентичності [1, с. 32]. 3 цих позицій в Європейському Союзі можна виділити кілька субрегіональних угруповань, які часто транслюють на наднаціональний рівень узгоджені заздалегідь позиції, які згодом значно впливають на вироблення рішень $\mathrm{CC}$, поза прийняття політичних рішень, так і для узгодження технічних питань. Чим більше країн входить в ЄС, тим вище диференціація інтересів в питаннях внутрішньої і зовнішньої політики. Одночасно ускладняється процес узгодження законодавчих актів і рішень в $\mathrm{CC}$, збільшуються різночитання при їх імплементації [1, с. 32].

\section{1. Геополітичне позиціонування Вишеградської групи: регіон в регіоні}

Після ліквідація соціалістичних структур, які на той час об'єднували весь регіон Східної Свропи від Адріатики до Балтики, він розділився на дві частини: Південно-Східну (Балканську) Європу і Східно-Центральну (Вишеградську). Зміцненню цієї тенденції сприяв одномоментний прийом Угорщини, Польщі, Словаччини та Чехії спочатку в НАТО, а незабаром і в Свропейський Союз. Однак, межи субрегіонів не є досить визначеними. Так, до Вишеградського регіону, наприклад, тяжіють Словенія, Україна ... Вишеградська Європа, 3 точки зору формування нового субрегіону Свропи, можливо, ще не досягла своєї цілісності $[8$, с. 8].

По-друге, цей регіон, пройшовши крізь століття і непрості випробування, які підступали до нього, то з Заходу, то зі Сходу, дійсно, виробив неповторну своєрідність, що виразилося, 3 одного боку, в синтезі їх цивілізаційних характеристик, з іншого - в особливому ставленні до своєї власної ідентичності.

Результатом став загострений критичний настрій, що переходить в скепсис, як тільки мова заходить про далекосяжних європейських інтеграційних ініціативах. Ці країни об'єднує прагнення слідувати за передовими технологіями i політичними віяннями i, одночасно, надзвичайно дбайливе ставлення до своїх власних вікових традицій, мови та культури $[8$, с. 8].

По-третє, це найбільш динамічний регіон Східної Європи, який вже не одне десятиліття намагається заявити про себе в самих різних, переважно реформаторських якостях, що дуже нагадує болісно шуканий людством в XX столітті «третій шлях», чомусь в разі Східної Свропи охрещений недоброзичливцями як «наздоганяючий розвиток» [8, с. 9].

Так, країни В4 разом з Німецькою Демократичною Республікою були найбільш розвинутими країнами Ради Економічної Взаємодопомоги (РЕВ), а саме 70\% експорту $Є С$ до країн Східної Європи і 68\% імпорту звідти доводилося саме на три країни регіону - Польщу, Чехію та Угорщину. За такими показниками, як вартість (складність) виробництва однієї тони експорту, Угорщина майже в шість разів перевершувала Латвію. Це посилювало відрив країн Вишеградської Групи від їх сусідів по Східній Свропі і колишніх республік Прибалтики [8, с. 9].

Створення Вишеградської групи за часом збіглося зі створенням Європейського союзу і тим самим стало складовою частиною складного геополітичного процесу, що взяв старт в останньому десятилітті XX століття. [8, с. 11].

Отже, Вишеградська група, або, як іiі тоді ще назвали - Вишеградська трійка - утворилася в 1991 році, в період, коли вже була визначена доля РЕВ, 
відбулося возз'єднання двох Німеччин, але ще не було чіткого бачення перспектив інтеграції з СС і НАТО. Не варто випускати і того факту, що виникла вона на тлі висловлювання голови Комісії у закордонних справах конгресу США, Л. Иглбергером про намір США залишитися в Свропі в якості гаранта іï стабільності. А також того, що Декларація про співпрацю Чехословацької Федеративної Республіки, Республіки Польщі та Угорської Республіки була активно підтримана офіційним Вашингтоном, на відміну від Центральноєвропейської ініціативи. Це дуже важливий факт для становлення подібної структури, тому що як сказав Збігнєв Бжезинський, східноєвропейська «трійка» повинна була вже в той час взяти на себе функції буферної зони, що обгороджує ядро «розвиненої Європи» від нестабільності на території колишнього СРСР [8, с. 14].

Основні завдання цієї організації, зафіксовані в декларації, також носять скоріше декларативний, політичний характер, більш покликаний окреслити нову внутрішню i зовнішньополітичну орієнтацію цих країн, ніж якісь конкретні механізми співпраці:

- зміцнення на новій основі державного суверенітету, демократії та свободи;

- знищення всіх залишків тоталітаризму в соціальній, економічній і духовній сферах життя суспільства;

- побудова парламентської демократії, сучасної правової держави і повагу прав людини основних свобод;

- повне включення країн-учасниць в систему європейської політики, економіки, права та безпеки [8, с. 16]

Після тривалого застою в історії цієї організації 21 жовтня 1998 року, напередодні вступу Угорщини, Чехії та Польщі в НАТО, в Будапешті прем'єрміністри Угорщини, Чехії та Польщі прийняли заяву про відновлення Вишеградського співробітництва. Були виголошені промови про нові серйозні наміри. У той же час, як відзначає Андраш Деак, залишилося багато питань по суті: «У чому відмінність між сьогоднішньою співпрацею «другого покоління» і попереднім? [8, с. 20].

Якщо позицію Польщі при розподілі місць в структурах розширеного СС Вишеградські країни в цілому не підтримали, то вони стали активніше діяти, ставши членами спільноти. Їх перший спільний виступ відбулося вже влітку 2004 року. Тоді вішеградци вирішили виступити єдиним фронтом проти дискримінаційних положень у прийнятому бюджеті, що стосується розподілу 3 фондів ЄС. У спільній заяві прем'єр-міністрів чотирьох країн за підсумками року в зв'язку 3 цією обставиною пропонувалося «підготувати умови для досягнення» [8, с. 26].

Це був перший спільний виступ країн Вишеградської групи, в якому вони проявили рішучість до взаємодії у відстоюванні спільних інтересів. Тривалі спільні зусилля «четвірки», кілька зустрічей з прем'єр-міністрами Бенілюксу, головою Сврокомісії Ж. М. Баррозу і з прем'єр-міністром Великобританії Тоні Блером, який був головою 3 другої половини 2005 року в $\mathrm{CC,} \mathrm{принесли} \mathrm{свої}$ результати. Прийняті країни отримали доступ до коштів 3 бюджету $\mathrm{CC}$ не тільки на рівних, але в ряді випадків і на особливо сприятливих умовах. Навіть, не знадобився резервний сценарій, що пропонувався країнами Вишеградської групи про те, щоб прийняти бюджет СС не на сім років, а на найближчі два-три 
роки. Це нібито могло б допомогти уникнути паніки і надати час для вирішення найбільш гострих бюджетних протиріч [8, с. 27].

Цю подію, без перебільшення, можна вважати першою великою перемогою країн Вишеградської четвірки та їх хрещення в якості дієздатного регіону $\mathrm{CC}$, a також в якості локомотива східноєвропейської інтеграції в цю структуру. Важко сказати якою мірою, але очевидно, що спільні політичні битви за рівність, мала ефективність рекомендацій $\mathrm{CC}$, а також недостатня підготовленість до вступу, зіграли свою роль в незадоволеності країн Вишеградської групи від підсумків перших років перебування в західній інтеграції.

Розчарування населення в стабілізуючий ролі $Є С$ вилилося не тільки в масові протести сільськогосподарських робітників в Угорщині або зайнятих в реструктуризації сталеливарної та вугільної галузях робочих Польщі. Прямим результатом можна розглядати прихід до влади в країнах Вишеградської групи на перших же після вступу в СС виборах національно-консервативних сил. До влади в Чехії, Польщі та Словаччини прийшли партії, що не заперечують курсу на зміцнення своїх позицій в $\mathrm{EC}$, але виступають за розумний баланс між національними та загальноєвропейськими інтересами $[8$, с. 2].

Безліч чинників різного порядку свідчить про те, що протиріччя між вишеградськими країнами в ряді випадків є досить серйозною перешкодою для сприйняття їх як регіональної одиниці.

За останні роки це проявилося у ставленні вішеградцев до косовського питання і основоположного Договору Росія - СС. Так, Словаччина не визнала незалежність Косово, в той час як три інші країни ВГ зробили це досить швидко. Польща блокувала підписання нового договору між Росією і СС, а потім разом 3 Чехією схвалила американські плани зведення в їх країнах американських ПРО, не радячись з Угорщиною і Словаччиною. Ну і, звичайно ж, обставину, що Словаччина 31 січня 2009 року увійшла в зону євро, що значно звузило можливості вішеградцев виступати єдиним фронтом в СС у відстоюванні регіональних економічних інтересів, що вважалося головним досягненням ЦЕФТА. Тепер інші три країни домагаються права сидіти за тим же столом в Брюсселі на переговорах країн єврозони по виходу з кризи [8, с. 29].

Також країнам В4 необхідно було для повного інтегрування в європейські структури зміцнити демократію і унеможливити повернення до тоталітаризму, що було була можлива тільки при тісній співпраці.

Щоб уявити загальний огляд історії Вишеградського співробітництва, можна виділити шість періодів, що мали різну протяжність:

1) «Протовішеградскій період» (до 1990р.)

2) Від координації до співпраці (1990-1991);

3) Інші досягнення і початок серйозних проблем (1991-1993);

4) Чи існує Вишеградська група чи ні (1993-1998);

5) Відродження і «криза ідентичності» (1998-2004);

6) Вишеградська четвірка як реальність (2004 до сьогоднішнього дня) [9, с. 37].

У Декларації визначалися «п'ять основних цілей майбутньої співпраці: повне відновлення державної незалежності, демократії і свободи, знищення всіх рудиментів тоталітаризму в соціально-економічному i духовному житті, створення парламентської демократії, сучасної правової держави, повага прав і свобод людини, перехід до сучасної ринкової економіки, повна інтеграція в 
європейську політичну та економічну систему, а також систему безпеки i законодавства» [10].

Другий прийнятий документ - Вишеградська спільна заява - був історичним документом, який створював перший постійний інститут Вишеградської групи, тобто, Міжнародний Вишеградський фонд (МВФ), офіційно заснований 9 червня 2000 року на саміті прем'єр-міністрів в Чеській Республіці. Штабквартира МВФ перебувала в столиці Словаччини Братиславі - факт, знову підтверджує, що позиції Словаччини знову зміцнилися [9, с. 42].

У ситуації з Вишеградської країнами результат виходить неоднозначний. Принаймні, десятиліття членства країн Східної Свропи в ЄС не виразилося в одностайну позитивну оцінку наслідків цього кроку. До того ж відповідь про успішність членства дуже сильно залежить від того, хто іiі дає: якщо погляд зі сходу (зокрема, 3 боку російських дослідників), то переважає досить песимістична версія; якщо оцінку дають самі країни НЧСС, то, як правило, домінує оптимістична версія. Західні дослідники намагаються дотримуватися збалансованої версії, але все одно найчастіше схиляються в сторону позитивних висновків [2, с. 51].

Символом перших 15 років співпраці був акцент на євроатлантичної інтеграції регіону, а також на внутрішніх соціально-економічних трансформаціях. Наступний етап розвитку групи, на якому були прийняті важливі документи, свідчив про значний поворот до зовнішнього світу і суттєвою ступеню визначався зовнішньою політикою групи. Однак пріоритетним моментом залишалося внутрішня єдність групи [9, с. 43].

Якщо підводити підсумок, то можна стверджувати, що Вишеградська група організація, яку всі країни групи вважають корисною і цікавою і за відсутністю іншої постійної структури, таким чином, бути достатньою для подальшого співробітництва. Реалізація цих двох чинників також може бути достатньою для того, щоб захистити групу від можливого скептичного ставлення політичних еліт, які можуть прийти до влади в країнах Вишеградської «четвірки» [9, с. 46].

Вишеградська група збереже два основних вектори: перший - зміцнення внутрішньої єдності в Центральній Європі, і другий -- зовнішній - потенціал країн «четвірки» ділитися унікальним досвідом, накопиченим з різних аспектів трансформації, з суміжними країнами [9, с. 47].

В області зовнішньої політики країни ЦСС слабо зацікавлені у вирішенні традиційно важливих для Свропейського Союзу проблем середземноморського i африканського регіонів. Невелика їх участь в політиці розвитку і допомоги найбіднішим країнам світу. 3 іншого боку, країни ЦСС мають досить специфічні відносини з Росією і США, що часто накладає відбиток на позицію ЄС в цілому [1, с. 33].

За чверть століття в усіх країнах регіону встановилася повноцінна багатопартійна система, устоялися прозорі демократичні вибори. Якщо на перших виборах ще були пропозиції вибирати між «старим» i «новим», то за два 3 половиною десятиліття партії, які представляли комуністичний вибір, в основному пішли в минуле. Винятком є комуністична партія Чехії, до сих пір присутня в парламенті, але, мабуть, тут заслуга Чехії, як країни 3 найбільш стабільними демократичними традиціями, так само, як i вміння чеських комуністів слідувати за мінливими вимогами дня [4, с. 18]. 


\section{2. Соціально-економічний розвиток країн Вишеградської четвірки}

На сьогоднішній день за розміром економіки згадані країни займають дуже скромне місце, їх частка в створенні світового ВВП трохи більше $1 \%$. Найбільшим господарством в регіоні володіє Польща, яка створює більше половини (55\%) регіонального ВВП в рамках Вишеградської групи [3, с. 78].

Напередодні вступу в ЄС однією з характерних рис країн ВГ був нижчий рівень доходів населення, ніж в країнах СС-15. Середній показник країн ВГ ВВП на душу населення становив близько 55\% від рівня ЄС-15. У 2004-2010 pp. наступило скорочення розриву в рівнях доходів населення держав ВГ і країн ЄC-15, але, незважаючи на це, в 2010 році середній показник ВВП на душу населення країн ВГ становив 64\% від рівня країн СС-15.

Незважаючи на формальне переміщення в групу розвинених держав, економікам країн ВГ був на той час притаманний ряд проблем, серед яких необхідно відзначити низький рівень доходів, відносно високий рівень безробіття, а також наявність диспропорцій у формуванні ВВП окремими галузями економіки в порівнянні з країнами $\mathrm{CC}-15$. Так як підготовка країнами ВГ до вступу в СС почалася задовго до 2004 року, тому, буде доречним називати 2000-2010 рр. «Інтеграційним десятиліттям» (integration decade) для країн ЦСЄ» за словами Анджея Габарта [11].

Однією 3 характерних рис країн ВГ напередодні вступу в $С С$ був нижчий рівень доходів населення, ніж в країнах СС-15. Середній показник країн ВГ ВВП на душу населення становив близько 55\% від рівня СС-15. У 2004-2010 pp. наступило скорочення розриву в рівнях доходів населення держав ВГ і країн ЄC-15, але, незважаючи на це, в 2010 році середній показник ВВП на душу населення країн ВГ становив 64\% від рівня країн СС-15 [11].

Структура формування ВВП країн ВГ також відрізняється від показників розвинених країн. Так, питома вага сфери послуг у формування ВВП досить мала у порівнянні з країнами $\mathrm{CC}-15$, де в середньому по даному регіону становила $64 \%$. Висока частка промисловості (бл. 33\%) свідчить про незавершеність стадії переходу їх економік до постіндустріального суспільства [11].

Структура зайнятості в країнах ВГ також відрізнялась від країн СС-15. Середній показник зайнятості в сільському господарстві серед країн ВГ становить близько $6 \%$ зайнятого населення, причому найвищий показник в Польщі - 13\%. У промисловості країн ВГ трудиться близько $31 \%$ населення цих країн, найвищий показник відзначений в Чехії - 39\%. У сфері послуг зайнято $62 \%$. Найвищий показник зайнятих в цій галузі в Словаччині - $69 \%$. Диспропорції між внеском окремих галузей економіки в створення ВВП і рівнем зайнятості в них говорить про недостатню ефективність економік країн ВГ [11].

У «інтеграційний період» нові країни СС (СС-10), до яких відносяться держави ВГ, зайняли перше місце за обсягом залучених прямих іноземних інвестицій (ПЗІ) на душу населення і друге, після країн Східної Азії, за сукупним обсягом залучених прямих закордонних інвестицій (524 трлн. дол. США [1]). Приплив капіталу в 2000-2009 рр. в 5,5 разів перевищив показники 1990-1999 pp. [11].

Характерною рисою країн ВГ протягом «інтеграційного періоду» був високий обсяг дефіциту платіжного балансу, що фінансується за рахунок припливу іноземного капіталу. Іншою відмінною рисою вищезазначених країн, був високий показник співвідношення частки залученого іноземного капіталу до 
ВВП, а також дефіциту платіжного балансу до ВВП. Завдяки притоку іноземного капіталу, країни ВГ змогли збільшити рівень кредитування національних економік, а також фінансувати зростаючі витрати домашніх господарств. Починаючи з 2004 p, спостерігається зростання товарообігу країн ВГ в рамках інтеграційного об'єднання. Варто зауважити, що у багатьох, незважаючи на стрімке зростання рівня експорту, торгове сальдо було негативним [11].

До факторів, що стимулюють економічне зростання країн ВГ, можна зарахувати зняття обмежень між країнами ВГ і СС на вільне пересування товарів, послуг, капіталу, факторів виробництва і робочої сили (з деякими застереженнями). Інтеграція країн ВГ в рамках СС відбувається досить швидко, чому сприяло зростання внутрішньорегіонального експорту, а також приплив іноземного капіталу [11].

До факторів зростання економік країн ВГ в «інтеграційному десятилітті» можна віднести наявність, з одного боку, кваліфікованої, а з іншого, дешевої робочої сили, географічна близькість до ринків збуту $\mathrm{CC}$, а також низьке податкове навантаження [11].

Іншими факторами, що сприяють зростанню ВВП після 2004 року були макроекономічна стабільність економік країн ВГ та прогнозованість їх економічних політик.

Внаслідок відставання економік країн ВГ за багатьма показниками від розвинених країн виникли нові проблеми для сталого розвитку. У багатьох країн ЦСС напередодні кризи 2008-2009 рр. дефіцит рахунку поточних операцій досягав 10\% ВВП, основними джерелами фінансування яких, був приплив іноземного капіталу в банківський сектор, а також боргове фінансування. Вищеописані чинники зробили економіки країн ЦСС уразливими на рахунок зовнішніх чинників, а також раптовий відтік капіталу. Іншим негативним явищем стало різке зростання рівня заборгованості домашніх господарств напередодні 2008 р. [11].

Економічна криза 2008-2009 pр. справила значний вплив на економіку країн ВГ. За винятком Польщі, яка була єдиною країною, де був відзначено економічне зростання, у всіх інших країнах $€ C$, в тому числі в країнах ВГ, був відзначений спад ВВП, причому темпи падіння ВВП в країнах ВГ були вище, ніж в інших країнах ЄС-15. У 2009 р. був відзначений негативний приріст ВВП для країн ВГ (-3,5\% ВВП) [11].

Джерелом зростання економік країн ВГ було підвищення попиту на експортні товари з боку традиційних партнерів ВГ, при одночасному зменшенні величини імпорту [11]. Темпи зростання товарообігу країн ЦСЄ після приєднання до ЄС перевищили показники попереднього періоду, причому обсяг торгівлі 3 третіми країнами зростав швидшими темпами, ніж 3 партнерами по інтеграційного об'єднання [11].

Вступ країн ЦСЄ в ЄС сприяло подальшої інтеграції їх економік у світове господарство, а також імплементації політики спільного ринку.

Після 2004 р. підвищився рівень відкритості економіки. Величина експортної та імпортної квоти значно зросла. Якщо порівнювати країни Вишеградської групи з СС-15 за показником відкритості економіки, який відображає ступінь залучення країни в міжнародний поділ праці через участь в міжнародній торгівлі, то він спочатку (2004 р.) був на високому рівні - 112\%, через 10 років він виріс до $147 \%$ [3, с. 79]. 
Одним з основних драйверів економічного зростання і соціально економічних перетворень після вступу країн Вишеградської групи в СС став приплив до них прямих іноземних інвестицій (ПІІ). середній обсяг припливу ПІІ в 1993-2013 рр. становив близько 6,6 млрд. дол. США на рік, причому найвищі показники в групі були у Польщі - 9,7 млрд і Угорщини - 9,4 млрд. [3, с. 79].

Таблиця 1

\section{Інвестиційна привабливість країн ВГ}

\begin{tabular}{|c|c|}
\hline \multirow[t]{2}{*}{ Польща } & $\begin{array}{l}\text { Фіскальні пільги: звільнення від податку на прибуток у СЕЗ (із } \\
\text { врахуванням витрат інвестора на робочу силу та інвестиції), } \\
\text { звільнення від податку на нерухомість у СЕЗ (залежно від } \\
\text { регіону), зменшення оподаткування при придбанні нових } \\
\text { технологій, фінансуванні науково-дослідних центрів }\end{array}$ \\
\hline & $\begin{array}{l}\text { Фінансові пільги надаються через: } \\
\text { - структурні фонди ЕС - переважно на розвиток науки, } \\
\text { технологій, інновацій і підтримку підприємництва, а також } \\
\text { низьковуглецевої економіки; } \\
\text { - «Національну програму підтримки інвестицій», яка спрямована } \\
\text { на підтримку створення нових робочих місць і нових інвестицій }\end{array}$ \\
\hline \multirow[t]{2}{*}{ Словаччина } & $\begin{array}{l}\text { Фіскальні пільги: звільнення від податку на прибуток строком на } \\
10 \text { років. }\end{array}$ \\
\hline & $\begin{array}{l}\text { Фінансові пільги надаються через: } \\
- \text { структурні фонди ЄС - на вирівнювання регіональних } \\
\text { диспропорцій, розвиток технологічних і наукових парків, } \\
\text { інформаційних технологій, підвищення частки «зеленої» } \\
\text { енергетики у загальному енергоспоживанні; } \\
\text { - фінансову підтримку при створенні нових робочих місць у } \\
\text { регіонах, де рівень безробіття вищий за середній по країні; } \\
\text { - здешевлення для інвестора отримуваного державного/ } \\
\text { муніципального майна; } \\
\text { - відшкодування витрат у частині придбання земельної ділянки, } \\
\text { технічного обладнання, устаткування, нематеріальних активів - } \\
\text { ліцензій, ноу-хау тощо }\end{array}$ \\
\hline \multirow[t]{2}{*}{ Угорщина } & $\begin{array}{l}\text { Фіскальні пільги: зниження до } 80 \text { \% податку на прибуток на } \\
\text { період до } 10 \text { років після вкладення інвестицій. }\end{array}$ \\
\hline & $\begin{array}{l}\text { Фінансові пільги надаються через: } \\
\text { - структурні фонди ЄС - на підвищення рівня зайнятості, } \\
\text { конкуренції та міжнародної активності бізнес-середовища, } \\
\text { заохочення НДДКР, підвищення енергетичної ефективності; } \\
\text { - субсидії - спрямовані на заохочення співпраці бізнесу } 3 \\
\text { університетами та дослідними інститутами; - державні «VIP } \\
\text { субсидії»: } \\
\text { - за інвестиції (інвестування не менше } € 10 \text { млн); } \\
\text { - на створення нових робочих місць (не менше } 250 \text { - у } \\
\text { депресивних регіонах, або не менше } 150 \text { - у мікро-регіонах } \\
\text { країни); } \\
\text { - на освіту, підвищення рівня кваліфікації тощо }\end{array}$ \\
\hline
\end{tabular}


Продовження таблиці 1

\begin{tabular}{|c|c|}
\hline Чехія & 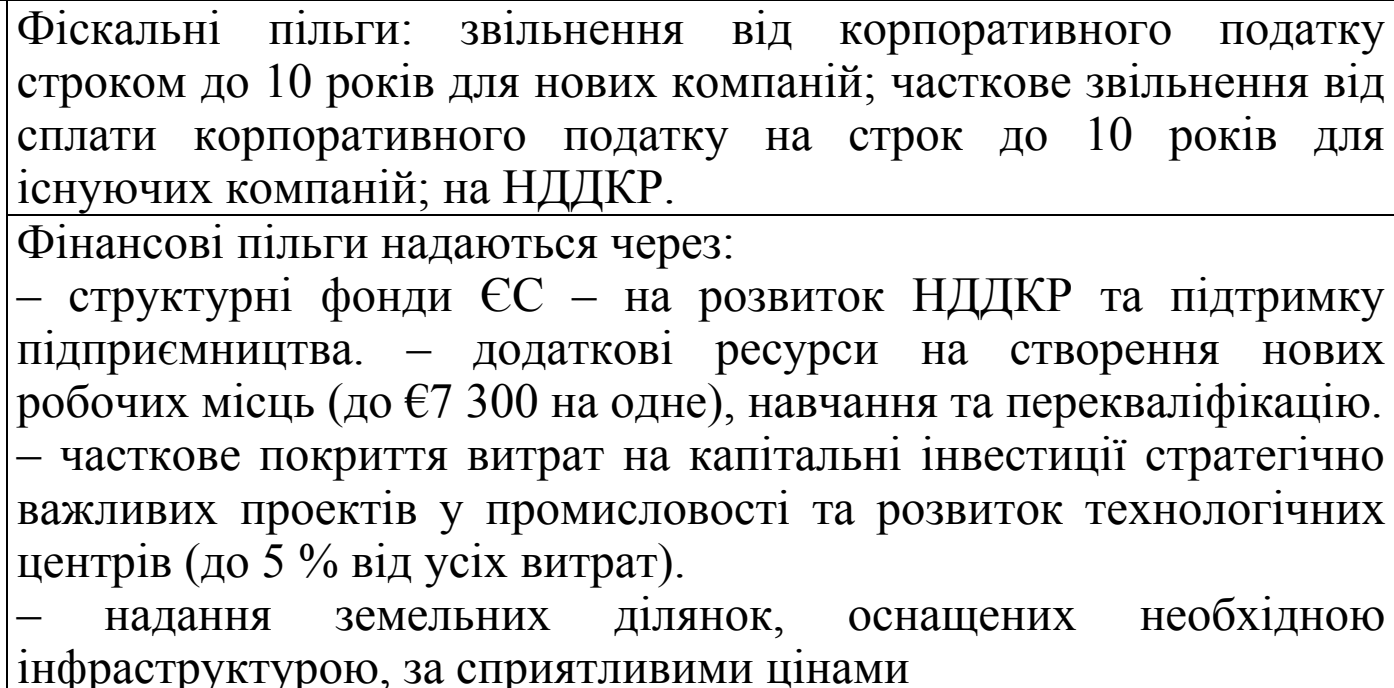 \\
\hline
\end{tabular}

Джерело: [5]

Для підвищення конкурентоспроможності своєї продукції на зовнішніх ринках, країни ЦСС (за винятком тих, хто ввів в обіг єдину валюту - євро) використовують як цінові, так і нецінові методи конкуренції. В рамках проведення політики щодо стимулювання експорту, i зниження витрат виробництва, держави готові послабити котирування національної валюти по відношенню до корзини валют. У 2000-2007 pp. номінальний курс національних валют виріс на $8 \%$, а реальний курс в той же період виріс на $28 \%$ [5]. 3 іншого боку виробникам з країн ЦСЄ вдалося підвищити частку експорту своєї продукції на світовому ринку за рахунок збільшення якості та інших характеристик своєї продукції [11].

Спостерігається великий розкид в частки легко-імітованих наукомістких товарів в експорті країн ЦСС, вище всіх цей показник був у Угорщині - 30\% [14]. Частка важко-імітованих наукомістких товарів в експорті країн ЦСЄ подібна і становить близько 26\%. Виняток становить Угорщина, у якої цей показник досягав 35\%. Наступило істотне зменшення частки товарів низькотехнологічних галузей промисловості (low-technology industries, LTI) 3 $31 \%$ в 1999 р до 21\% в 2006 р. Частка високотехнологічних галузей середнього рівня (medium-high technology industries, MHT) в структурі експорту в 1999-2006 pр. зросла на 5\% і склала 42\%. Найшвидші темпи зростання даної групи спостерігалися в Польщі (12\% - зростання) [11].

Позитивна тенденція спостерігалася також в області високотехнологічних галузей промисловості (high technology industries, HT). Їх частка в структурі експорту в 1999-2006 pp. зросла з 11\% до 16\%. За цим показником країни ЦСС майже наздогнали старих членів $\mathrm{CC}$ ( $С \mathrm{C}-15)$, але, незважаючи на це, вони все ще відстають від середньосвітових показників (23\%).

Найвища частка високотехнологічних галузей промисловості в структурі експорту у Угорщини (28\%), Чехії (16\%) та Словаччині (16\%). Необхідно також зауважити, що в більшості країн ЦСЄ частка інформаційно-комунікаційних галузей промисловості в експорті збігається з величиною високотехнологічних галузей промисловості. На підставі цього можна зробити висновок, що 
основною галуззю експорту високотехнологічних промислових товарів $\epsilon$ підгрупа товарів інформаційно-комунікаційної галузі [11].

Одна 3 найбільш складних тем в дослідженні економіки Вишеградської Європи - питання про те, функціонують чи країни регіону за єдиною для всіх соціально-економічною моделлю або ж розвиваються за індивідуальними моделями [12, с. 48].

Якщо збільшити рамки розгляду 310 до 25 років, тобто якщо оцінювати не ефективність членства в $\mathrm{CC}$, a ефективність самого трансформаційного процесу, то ситуація все одно не стає простіше. По-перше, немає якогось одного показника, за допомогою якого тільки і можна було б однозначно оцінити успіх або провал трансформації. По-друге, критерії оцінки з часом можуть змінитися: то, що було актуально на початку трансформації, в кінці може розглядатися вже як анахронізм або як показник, який не відображає сучасного розуміння сутності трансформації. По-третє, інтерпретація будьякого кількісного показника в кінцевому рахунку суб'єктивна і відображає здебільшого погляди особи, яка робить таку інтерпретацію, особливо, якщо динаміка показника не є вражаючою [2, с. 53].

Тому найкращим способом оцінки ефективності трансформації (в даному випадку - Вишеградських країн) $є$ розгляд декількох показників, що відображають різні сторони цього процесу. Зрозуміло, що тоді може виникнути проблема «поєднання непоєднуваного», але ж і сам процес трансформації не $\epsilon$ простим і лінійним. Найкращим способом оцінки ефективності трансформації (в даному випадку - Вишеградська країн) є розгляд декількох показників, що відображають різні сторони цього процесу. Показники пропанують розділити на дві групи: на ті що квантіфіціруються (в основі яких лежать параметри, що піддаються статистичному обліку) i що кваліфікуються (засновані на суб'єктивних думках). У свою чергу, в кожній з груп можна додатково виділити підгрупи. Показники, що квантіфіціруються можна об'єднати в підгрупи в залежності від вектору смислового навантаження. Так, першу групу формують показники, зміст яких зводиться до демонстрації позитивного ефекту того чи іншого вимірюваного явища. Другу групу складають такі показники, як річні прирости ВВП, динаміка інфляції, розмір бюджетного дефіциту або держборгу, рівень безробіття і деякі інші. Однак, наприклад, знання того факту, що Угорщина серед інших Вишеградської країн в 2011-2013 рр. мала найбільший рівень держборгу (порядку 77-80\% проти 52-55\% у Польщі та Словаччині i 45-46\% у Чехіiі) мало наближає нас до розуміння причин цього перевищення, особливо якщо намагатися знайти їх зв'язок з трансформацією або членством в ЄC $[2$, с. 51].

У рамках внутрішньої регіональної торгівлі чітко спостерігається домінуюча роль країн Вишеградської групи. Зростання зовнішньоторговельних поставок в регіоні Східної Європи обумовлений ущільненням економічного простору (можна використовувати і інші терміни - наприклад, кластерізація виробничих потужностей), збільшенням кількості зв'язків між економічними агентами країн регіону $[6$, с. 92$]$.

Певним індикатором цих процесів є тенденція збільшення потоків взаємних інвестицій між країнами В4, що в цілому набирає силу. Звичайно, масштаб такого збільшення значущий тільки для самих країн B4 і нікчемний в порівнянні не тільки з світовими лідерами, але і з низкою країн СС [6, с. 92]. 
Всі можливі дванадцять комбінацій зв'язків чотирьох країн Вишеградської Європи (наприклад, угорсько-польські, угорсько-чеські та угорсько-словацькі експортні потоки, а також зворотні їм польсько-угорські, чесько-угорські та словацько-угорські аналогічно для Чехії, Словаччини та Польщі і т .п.) знаходяться серед перших тринадцяти місць (трохи вибиваються із загального ряду угорсько-румунські поставки, але це якраз і $є$ наслідком вступу цієї країни в (С). На ці поставки припадає понад $60 \%$ внутрішньо регіональної торгівлі. Країни Вишеградської групи поступово формують інтеграційне ядро регіону, все помітніше перетворюючись в центр тяжіння для сусідніх держав. Цілком можливо, що ми спостерігаємо початок процесу консолідації країн регіону, який, знову-таки можливо, перетвориться у відносно самодостатнє утворення, в якийсь субрегіон [6, с. 92].

Певні передумови для цього є. Адже якщо виходити з того, що в будь-якому геополітичному утворенні виділяється ядро, що складається 3 однієї або декількох країн, які в найбільшій мірі відповідають критеріям виділення даного геополітичного утворення, і є якийсь «пріядерний пояс» країн, що тяжіє до цього ядра, то в рамках $Є С$ з його історичним ядром починає формуватися нове ядро, яке в потенціалі може перетворитися в регіон «Східна Європа».

Можливо, ядро складуть країни Вишеградської четвірки, а на них будуть орієнтуватися, але в меншому ступені, інші країни регіону. Дійсно, економічний простір аж ніяк не єдиний, а являє собою явище, що змінюється, якому постійно утворюються і розпадаються, знову утворюються і розпадаються різного ступеня ущільнення, деякі з яких в принципі можуть перетворитися в ядро, навколо якого і буде надалі концентруватися економічний простір. I це буде тривати до тих пір, поки економічні зв'язки всередині ядра не ослабнуть, i воно природним чином не розчиниться в навколишньому економічному хаосі. Подібне ядро в рамках сучасного Свросоюзу представлено Німеччиною, але це не означає, що в Свропі не існує і інших ядер, нехай і менш щільних. Однак проблема ідентифікації, як самих ядер, так і їх щільності наштовхується на відсутність придатних для цього інструментів. До торгівлі між країнами може бути застосована гравітаційна модель, коли визначають залежність односпрямованого зовнішньоторговельного потоку від географічних, соціально-політичних, економічних параметрів стану країни-експортера i країни імпортера. Вважається, що першим розробником цієї моделі серед економістів є Ян Тінберген, за яким була маса послідовників (Пеюхенен, Роуз, Андерсон і ін.). Вони внесли вагомий вклад в удосконалення гравітаційної моделі, але головним залишалося визнання (допущення) залежності інтенсивності товарного потоку від відстані між торгуючими країнами і обумовленість імпорту країни величинами їх валового продукту. 3 використання гравітаційної моделі випливає теза, що порівняно близькі за розмірами ВВП країни, до того ж розташовані поруч один з одним, тяжіють один до одного. I, отже, у них менше потреба в торгівлі з більш далекими країнами [6, с. 93].

Нами було проаналізовано низку показників економіки країн ВГ за період 20ти років за даними МВФ.

Аналіз графіку на рис. 1 показує, що за період дослідження динаміка була позитивною, за виключенням кризи 2008-2009 років та дещо понизилась за останні роки. 


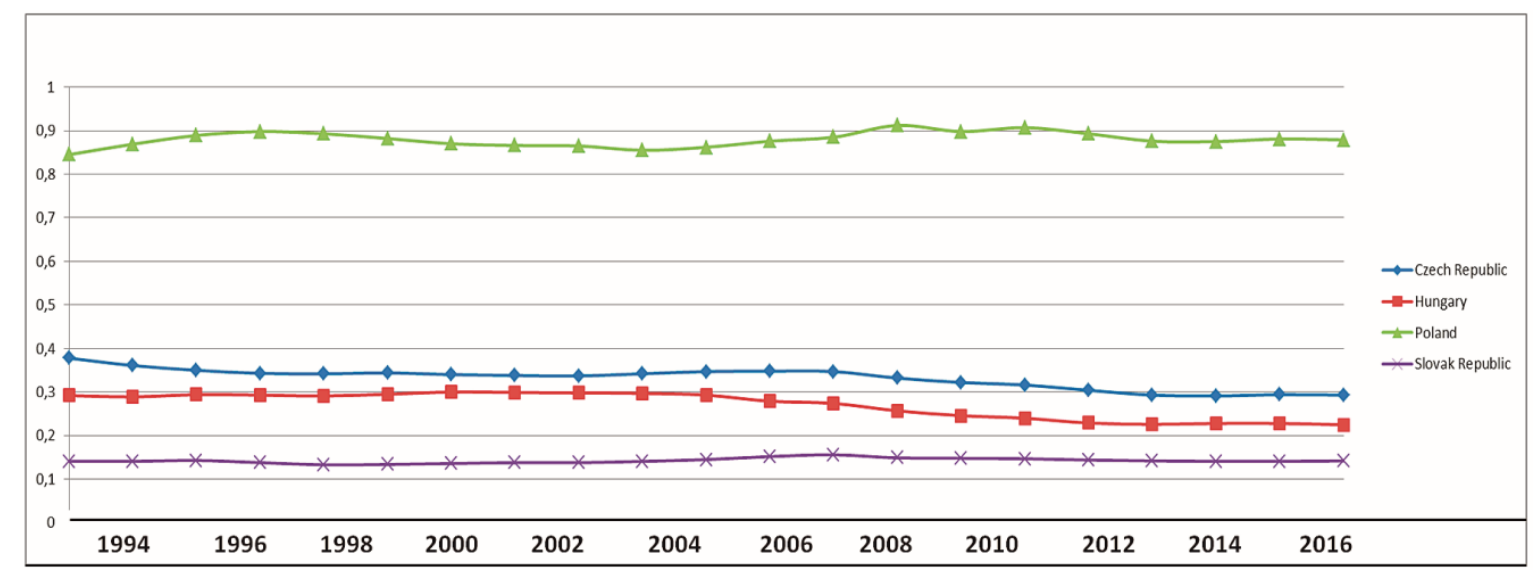

Рис. 1. Динаміка ВВП (за ПКС) у \% від світового обсягу

Джерело: складено автором на основі даних Міжнародного валютного фонду (www.imf.org)

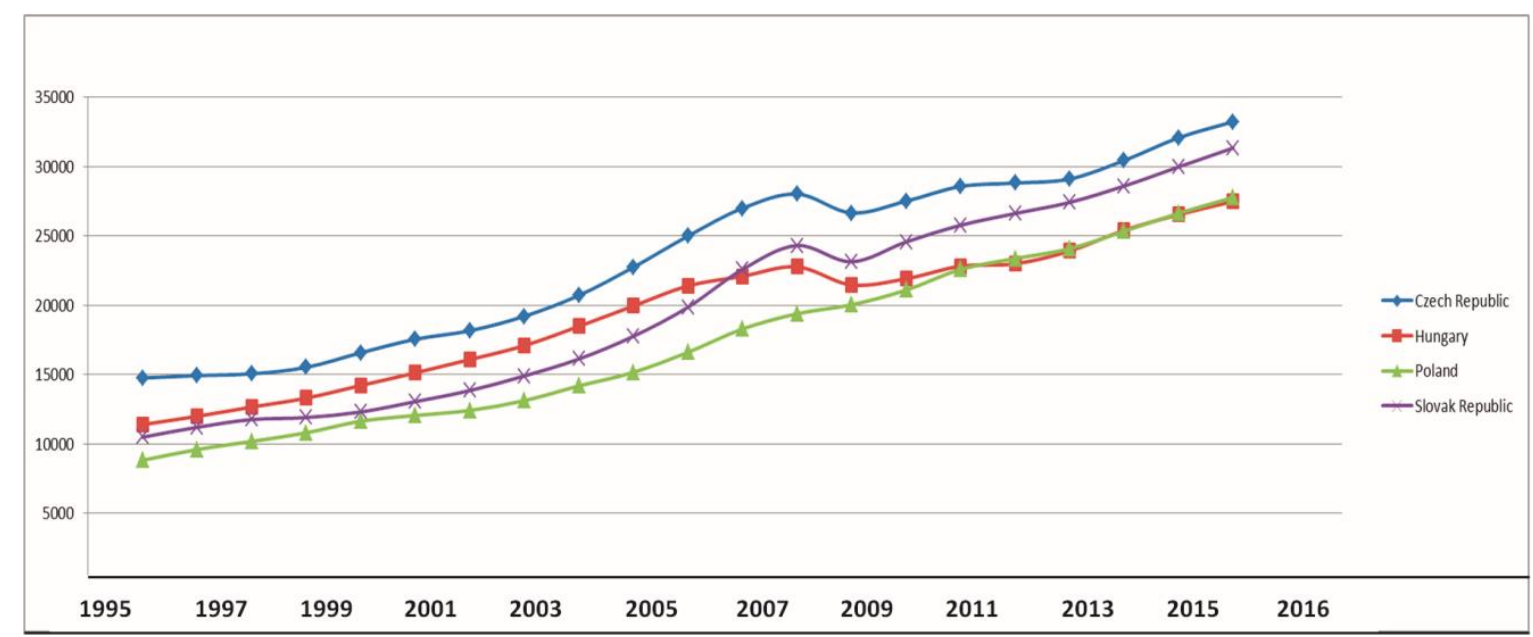

Рис. 2. Динаміка ВВП (за ПКС) на душу населення, дол.

Джерело: складено автором на основі даних Міжнародного валютного фонду (www.imf.org)

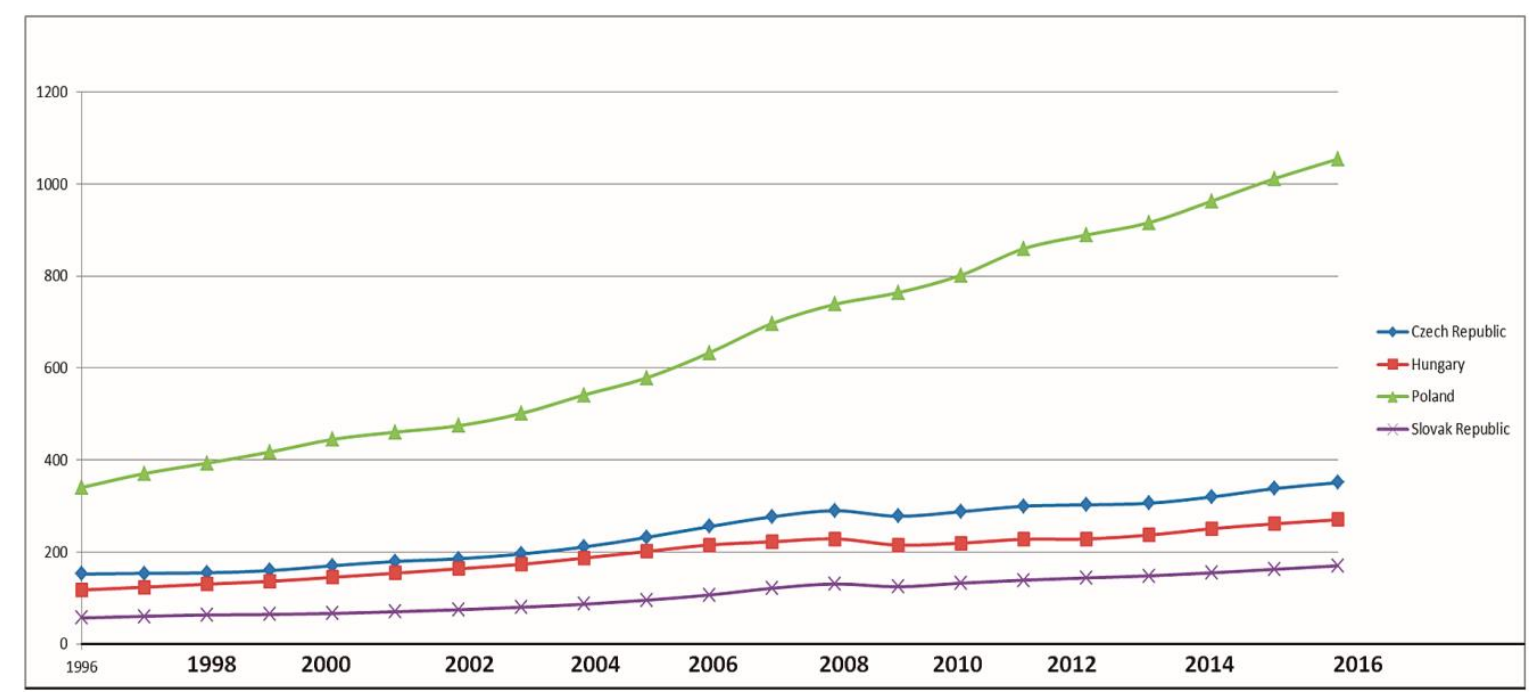

Рис. 3. Динаміка ВВП (за ПКС) країн ВГ, дол.

Дюсерело: складено автором на основі даних Міжнародного валютного фонду (www.imf.org) 
Аналіз графіку на рис. 2 показує, що ВВП (за ПКС) на душу населення має стійке зростання.

Аналіз графіку на рис. 3 показує, що ВВП (за ПКС) країн ВГ має постійне зростання, причому темпи росту Польщі значно перевищують інші країни групи.

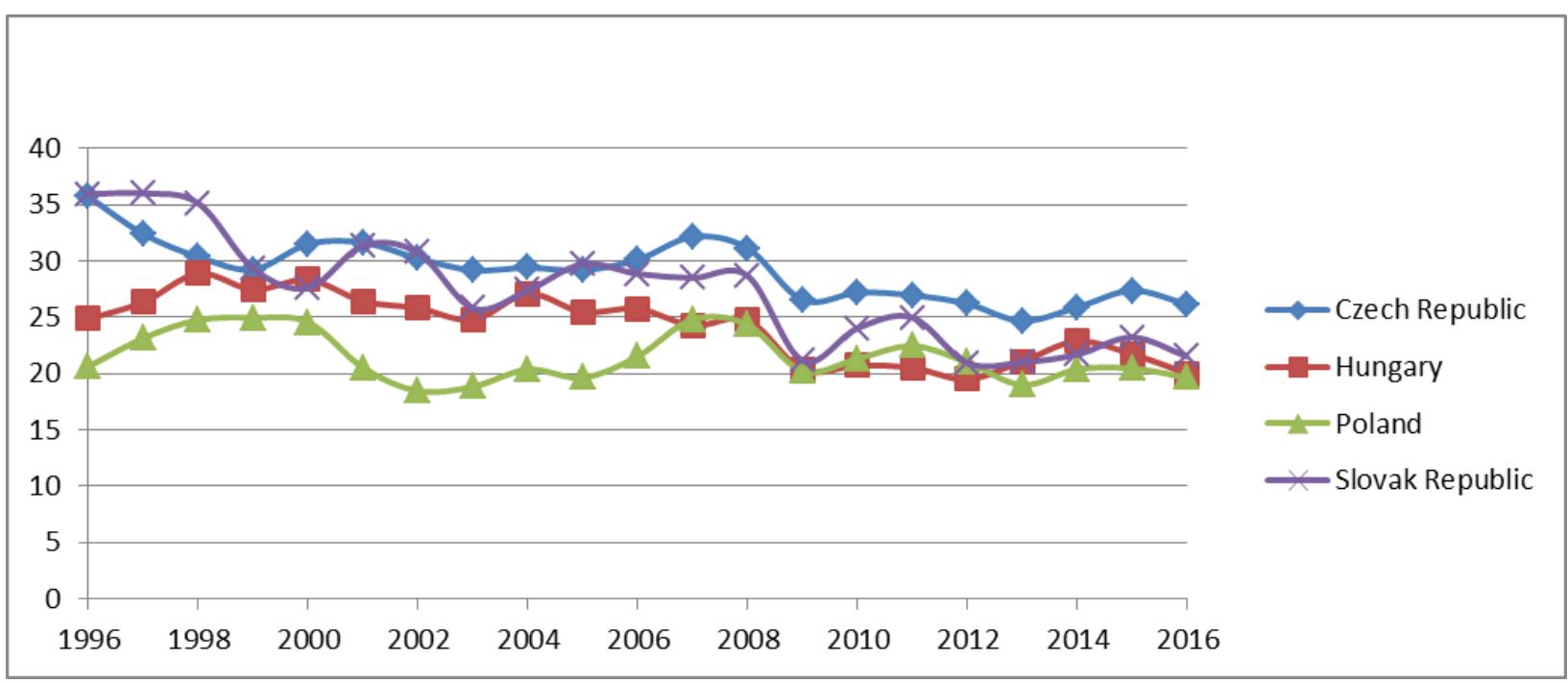

Рис. 4. Динаміка загального обсягу інвестицій (відсоток від ВВП)

Джерело: складено автором на основі даних Міжнародного валютного фонду (www.imf.org)

Одним 3 основних драйверів економічного зростання i соціально економічних перетворень після вступу країн Вишеградської групи в СС став приплив до них прямих іноземних інвестицій (ПІІ). Середній обсяг припливу ПII в 1993-2013 рр. становив близько 6,6 млрд дол. США на рік, причому найвищі показники в групі були у Польщі - 9,7 млрд і Угорщини - 9,4 млрд дол. США.

Таблиця 2

Коефіціснт кореляції (r) між ВВП за ПКС на душу населення і обсягом інвестицій на душу населення країн Вишеградської четвірки

\begin{tabular}{|c|c|c|c|c|}
\hline Країна & Чехія & Польща & Угорщина & Словаччина \\
\hline $\mathrm{r}$ & 0,53 & 0,97 & 0,88 & 0,91 \\
\hline
\end{tabular}

Аналіз кореляційної залежності показнику ВВП із розрахунку на душу населення i відповідно показника обсягу інвестицій відображає суттєві розбіжності країн ВГ за рівнем соціально-економічного розвитку. Для більш розвиненої Чехії інвестиції не мали надвеликого значення на відміну від трьох країн-партнерів по ВГ.

Загальний рівень економічного та соціального розвитку, велика доля сучасних високотехнологічних продуктів були домінуючими важелями зростання чеського ВВП за період 1996-2016 pp. 
Коефіціснт кореляції $\left(\mathrm{r}_{1}\right)$ між обсягом інвестицій на душу населення і обсягом національного заощадження на душу населення країн Вишеградської четвірки

\begin{tabular}{|c|c|c|c|c|}
\hline Країна & Чехія & Польща & Угорщина & Словаччина \\
\hline $\mathrm{r}_{1}$ & 0,97 & 0,94 & 0,73 & 0,91 \\
\hline
\end{tabular}

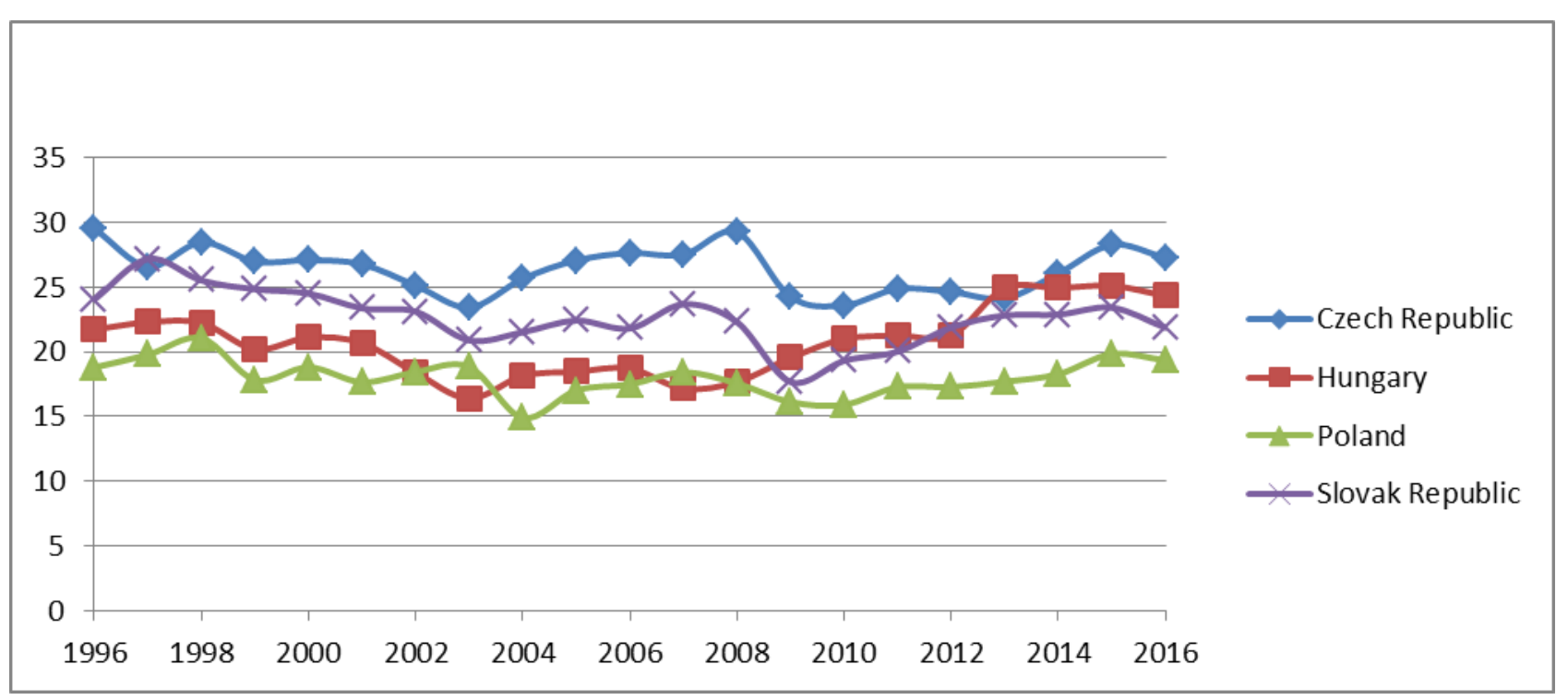

Рис. 5. Динаміка валового національного заощадження (\% від ВВП)

Джерело: складено автором на основі даних Міжнародного валютного фонду (www.imf.org)

Не менш важливими є результати аналізу кореляції між показниками обсягу національного заощадження та обсягами інвестицій ( у розрізі на душу населення) у динаміці за 20 років. Найнижчий показник кореляції для Угорщини кореспондує з високим рівнем податків притаманним угорської економіці в цілому, що повною мірою пригальмовує іії розвиток.

\section{Висновки}

Більш як чверть сторічний шлях перетворення економіки та суспільства в цілому із часу створення ВГ та майже півтора десятиріччя участі у ЄС дають змогу підвести деякі підсумки процесів трансформації та їх складових у країнах ВГ:

- четвірка посіла гідне місце на фоні більш розвинених країн СС (рівень показника ВВП у розрахунку на душу населення) сягає майже $2 / 3$ від рівня країн ядра $\mathrm{CC}$;

- країни ВГ увійшли до складу НАТО, що заощаджує певні фінансові та матеріальні ресурси та надає нове геополітичне позиціювання;

- імплементація у структури СС на основі процесів різношвидкісної європейської інтеграції створили своєрідне центрально-європейське ядро другого порядку. 


\section{Список використаних джерел:}

1. Бабынина Л.О. Страны Центральной Европы в ЕС: особенности регионального участия / Л.О. Бабынина // Современная Европа. - 2015. - №6 (66). - С. 32-35.

2. Дрыночкин А.В. Проблемы экономической оценки трансформационного развития Вишеградских стран / А.В. Дрыночкин // Современная Европа. - 2015. - №6 (66). - С. 50-59.

3. Габарта А.А. Опыт региональной интеграции и сотрудничества в рамках Вишеградской группы / А.А. Габарта // Современная Европа. - 2015. - №6 (66).- С. 76-88.

4. Шишелина Л.Н Вишеградская четвёрка: 25 лет на карте Европы/ Л.Н Шишелина // Современная Европа. - 2015. - №6 (66). - С. 9-26.

5. Юрчишин В. Маркевич К. Інвестиційна активність у країнах Вишеградської групи: виклики для України / В. Юрчишин К. Маркевич // Міжнародна економічна політика. 2015. - № 2 (23). - С. 126-148.

6. Дрыночкин А.В. Экономические аспекты функционирования вишеградских стран в рамках ЕС (предпосылки и проблема активизации субрегионального сотрудничества / А.В. Дрыночкин // «Современная Европа» - «Вишеградская Европа». - 2012. - №4. - С. 90-101.

7. Дрыночкин А.В. Сопоставительный анализ итогов трансформации в Чехии и Словакии / А.В. Дрыночкин // Мировое и национальное хозяйство. - 2015. - №2. - С. 1-11.

8. Шишелина Л.Н Вишеград в стихии глобальных преобразований / Л.Н Шишелина // Приложение к журналу «Современная Европа» - «Вишеградская Европа». Выпуск 1. 2012. - №4. - С. 7-35.

9. Савельєв, С. Куриляк В. Вплив глобалізації на економічний розвиток України / Є. Савельєв, В. Куриляк // Економіка України. - 2012. - № 9.

10. Електронний ресурс. Режим доступу: http://www.visegradgroup.eu/documents/visegraddeclarations/visegrad-declaration-110412

11. Габарта А.А. Влияние участия стран Вышеградской группы в ЕС на структуру их хазяйства / А.А. Габарта // Мировое и национальное хозяйство. - 2013. - №1 - - С. 1-11.

12. Вишеградская четвёрка в Европейском союзе: дилеммы конвергенции [отв. ред. Л.Н. Шишелина]. - М. : Ин-т Европы РАН, 2017. - 138 с. (Доклады Института Европы = Reports of the Institute of Europe / Федеральное гос. бюджет. учреждение науки Ин-т Европы Российской акад. наук ; № 342).

Якубовський С.O. доктор економічних наук, професор, завідувач кафедри світового господарства і міжнародних економічних відносин, Одеський національний університет імені I.I. Мечникова

Журавльов О.В. кандидат економічних наук, доцент, завідувач відділу міжнародного співробітництва, Національна академія статистики, обліку та аудиту (м. Київ)

\section{ЕКОНОМІЧНИЙ РОЗВИТОК КРАЇН ВИШЕГРАДСЬКОЇ ГРУПИ В УМОВАХ СВРОІНТЕГРАЦІЇ}

Анотація. Оцінено ефективність співробітництва країн Вишеградської групи, виявлено фінансовий складник у трансформації економічних систем країн регіону, визначено вплив макроекономічних факторів на платіжний баланс крайн. Проведений у монографії порівняльний аналіз макроекономічної ситуаиії в країнах Вишеградської групи дає можливість виявити і детально 
ідентифікувати національні економічні інтереси України в регіоні, а також надати новий стимул у зацікавленні Україною з боку їі традииійних партнерів з урахуванням нових геоекономічних та геополітичних зрушень 2014-2017 рр.

Вступ. Наприкінці XX - на початку XXI ст. інтенсивна глобалізація світового господарства та загострення конкурентної боротьби на міжнародних ринках створили систему, в якій досягнення економічного зростання у закритих економіках майже неможливе, тому кожна 3 країн світу намагається брати активну участь у міжнародному русі товарів, послуг та капіталу.

Разом із тим наслідки глобалізації для міжнародної конкурентоспроможності національних виробництв $€$ різними. Одна група країн завдяки зваженій грошово-кредитній та бюджетній політиці, залученню прямих іноземних інвестицій домоглася підвищення рівня конкурентоспроможності національних економік; інша - завдяки експансійній грошово-кредитній політиці, значному дефіциту бюджету і зростанню зовнішнього фінансування постійно збільшує розрив між внутрішнім споживанням і власним виробництвом товарів та послуг, погіршуючи баланс поточних операцій та нарощуючи обсяги пасивів міжнародної інвестиційної позиції. Зазначені дисбаланси відбиваються у платіжному балансі країн, структура та динаміка якого дають чітке уявлення як про рівень конкурентоспроможності національних економік, так і про ступень залежності країн від зовнішнього фінансування.

Результати більш ніж 20-річного трансформаційного процесу в постсоціалістичних країнах виявили нерівномірність їхнього розвитку і різної ступені залучення до загальноєвропейської інтеграції. Два попередні десятиліття ознаменувалися для країн Центральної та Східної Європи періодом трансформації економіки і переходом від адміністративно-командної моделі до моделі ринкового господарства. Країни Вишеградської групи показали позитивні результати в модернізації своїх фінансових структур, і на основі процесів, що відбулися там, можна проаналізувати не тільки внутрішню економіку, а й економіку СС у цілому.

До вступу в Європейський Союз Вишеградський регіон став головним східноєвропейським партнером Свросоюзу. Поряд з інтеграційними процесами з'явилися тенденції економіко-політичної диференціації у полюсі географічного сусідства пострадянських країн Східної Свропи. Це вплинуло як на внутрішні, так і на зовнішні макроекономічні процеси.

Порівняльний аналіз макроекономічної ситуації в країнах Вишеградської четвірки дає можливість виявити і конкретніше ідентифікувати національні економічні інтереси України в регіоні, а також надати новий стимул у зацікавленні Україною з боку їі традиційних партнерів з урахуванням нових геоекономічних та геополітичних зрушень періоду 2003-2017 pp.

\section{1. Передумови виникнення Вишеградської групи}

Економічний дискурс пострадянського розвитку суттєво змінився в період 2014-2017 pp. у зв'язку з різким загостренням міжнародної ситуації в Україні. Це ставить перед дослідниками нові завдання всебічного аналізу й інтерпретації нової економіко-політичної парадигми існування економічних систем не тільки Вишеградської четвірки, а й самого регіону Східноєвропейського порубіжжя під впливом низки факторів, яка вимагає міждисциплі- 
нарного підходу i нового етапу в осмисленні перспектив економічного зростання подвійних периферій.

Аналіз таких структурних трансформаційних зрушень протягом тривалого періоду (з кінця ХХ ст.) не тільки може допомогти врахувати помилки, виявити закономірності, більш глибинно зрозуміти зміст економічної політики, яка проводилася національними урядами, а й випрацювати нові шляхи виходу 3 тотальної військово-політичної та економічної кризи в Україні. Разом із тим майбутнє такого розвитку залежатиме від закінчення АТО в Україні, кон'юнктури світових ринків, міжнародної ситуації, нормалізації відносин між РФ та іiі партнерами.

Разом із тим такому угрупованню, як Вишеградська четвірка, у сучасній науковій літературі в Україні не приділяється значної уваги. Дослідження концентруються переважно на історичних та політологічних аспектах розвитку Словаччини, Чехії, Угорщини та Польщі.

Створення Вишеградської групи (B4), по-перше, було зумовлене переходом від авторитаризму до (ліберальної) демократії, яку можна охарактеризувати як перехід від централізованої планової економіки до ринкової економіки. Певні пріоритети внутрішньої та зовнішньої політики дали змогу політичним лідерам країн колишнього радянського блоку почати роботу на нових принципах.

3 історичного, геополітичного та культурного поглядів Чехословаччина, Угорщина i Польща були найближчими країнами, їхня співпраця була питанням часу. Крім того, на відміну від країн колишнього Радянського Союзу та Югославії, за винятком трьох країн Балтії та Словенії, для яких були характерні дезінтеграційні тенденції і політична нестабільність, три країни Центральної Свропи вибрали вектор інтеграції із Заходом і прагнули бути частиною Європи та увійти до трансатлантичних інтеграційних структур якнайшвидше. 3 цього погляду створення Вишеградської групи можна вважати невід'ємною частиною так званого проекту «широкої» Свропи.

Враховуючи вищезазначене, на сучасному етапі залишається актуальним питання обгрунтування перспектив розвитку Вишеградської групи через призму дослідження трансформацій їхніх економічних систем, а також ідентифікація напрямів оптимізованого розвитку України із цим угрупованням та врахуванням позитивного досвіду трансформацій для українських реалій.

У статті монографії, крім порівняльного аналізу особливостей економічної трансформації країн Вишеградської групи, також визначено їхню фінансову стійкість. Одним із підходів до дослідження фінансової стійкості країни є аналіз iii потенційних можливостей для обслуговування зовнішніх зобов'язань. При цьому, оскільки для більшості країн зовнішня заборгованість погашається в іноземній валюті, важливим показником платоспроможності $\epsilon$ відношення зовнішнього боргу та чистої міжнародної інвестиційної позиції (ЧМІП) до ВВП. Критичними показниками відношення від’ємної ЧІП до ВВП можуть бути значення 60\% (за аналогією з Маастріхськими критеріями) та 36\%. За цим критерієм країни умовно можна поділити на три групи: 3 високим, середнім $\mathrm{i}$ низьким рівнями залежності від зовнішніх інвесторів та кредиторів. До першої групи належать країни, в яких відношення від’ємної ЧМІП до ВВП по модулю вище за 60\%. Для другої групи цей показник коливається в інтервалі 60\% та 36\%. Для третьої групи - найбільш фінансово стійких країн відносно зовнішніх шоків - відношення від'ємної ЧМІП до ВВП по модулю менше за 36\%. 
Щодо наукового інструментарію, нами застосований логіко-теоретичний метод системного аналізу, індукції та дедукції, а також економіко-математичне моделювання для виявлення впливу економічних індикаторів на стан макроекономічної рівноваги в країнах Вишеграду.

Серед інших методів дослідження було використано: історичний (для здійснення ретроспективного аналізу розвитку В4), статистичний (для дослідження тенденцій розвитку економічних систем), порівняльно-описовий тощо.

У роботі використано статистичні дані та широке коло наукового матеріалу, що запозичені з авторитетних джерел, а також власні розробки авторів.

Період трансформацій, що почався наприкінці 1980-х років (в Угорщині ще раніше), дає теоретичну базу для дослідження зрушень як в економічних, так й у фінансових системах країн Вишеградської групи.

Святкування 20-річчя співробітництва Вишеградської групи (B4) дає можливість оцінити як позитивні, так і негативні аспекти розвитку чотирьох країн.

Ідея створення тіснішого співробітництва між країнами Центральної Свропи тісно пов'язана з ідеєю «повернення до Європи» колишніх соціалістичних країн. Політичні зміни в 1989 р. зумовили країни - сателіти колишнього Радянського Союзу почати процеси політичної та економічної трансформації. Певні пріоритети внутрішньої та зовнішньої політики дали змогу політичним лідерам країн колишнього радянського блоку почати роботу на нових принципах.

У 1994-1998 рр. зусилля країн Вишеграду переважно були спрямовані радше на інтеграцію з СС і НАТО, ніж на лобіювання взаємних інтересів, зустрічі голів держав відбувалися нерегулярно.

Перш за все, країни хотіли подолати комуністичну спадщину і штучне розділення Європейського континенту. «Повернення до Європи» стало одним із найбільш важливих питань порядку денного, хоча членство в європейських та трансатлантичних інтеграційних структурах було лише довгостроковим планом.

По-друге, незважаючи на розпуск Варшавського договору, на території країн Вишеградської групи ще знаходилися радянські війська. Таким чином, ще однією важливою політичною метою було вивести ці війська якомога швидше. Хоча інтеграція до європейських та трансатлантичних структур зайняла у країн Вишеградської групи більше часу, ніж очікувалося, виведення радянських військ було важливим заохоченням політичних лідерів усіх трьох країн. Цей успіх допоміг донести, що співпраця дає їм змогу досягти своїх національних цілей швидше, i, крім використання Вишеградської співпраці як платформи для обговорення, це також може служити інструментом для кращої координації позицій і узгодження спільних інтересів.

Це також означало, що В4 був переважно політичним проектом, розробленим відповідно до підходу «зверху-вниз». Навіть при тому, що політичні лідери трьох країн були колишні дисиденти і захисники громадянського суспільства, Вишеградська група не була створена як відповідь на будь-який рух громадян.

Також слід згадати, що люди у цих трьох країнах не знали своїх центральноєвропейських сусідів добре і відчували себе відчуженими від них. Певною мірою це було пов'язано з тим, що комуністичний режим досяг успіху в перетворенні інтернаціоналізму в ізоляціонізм. У результаті Вишеградській групі не вистачало громадянського виміру, і у В4 зайняло майже десять років, щоб відкрити себе для неурядових ініціатив та громадянського суспільства. Відсутня ланка громадянського суспільства i майже неіснуюче відчуття 
регіональної ідентичності також зробили свій внесок в уповільнення темпів співпраці в рамках В4.

Ще одним важливим фактором, який сприяв уповільненню темпів співробітництва в середині 1990-х років, була слабка інституціоналізація Вишеградської групи [3].

\section{2. Трансформація економічних систем країн Вишеградської групи}

Трансформація фінансового сектора була одним із найважливіших аспектів процесу переходу від централізовано-планованої до ринкової економіки. Реформування фінансових систем країн Центральної та Східної Свропи почалося 3 банківського сектора. Банківська система, яка на початку була найбільш зарегульованою, швидко перетворилася на один із секторів економіки, що найбільш динамічно розвивається. Цей процес почався на початку 1990-х років. Великі західні банки почали інвестувати у цей регіон, а вже через десять років іноземним банкам належало понад 70\% усіх активів банківського сектора країн ЦСЄ. Оскільки країни ЦСЄ є представниками континентальної моделі розвитку фінансового сектора, де домінують комерційні банки, то розвиток фондових ринків у цих країнах значно поступався темпам розвитку банківського сектора. Це стосується банківської системи, рівень розвитку якої не відповідає тому, що є в розвинених країнах Свропейського Союзу [3, с. 62].

На початку 1990-х років банківська система країн ЦСЄ не могла ефективно виконувати свої функції переважно через відсутність достатньої кількості капіталу, перевантаження безнадійними боргами, слабким корпоративним управлінням і цілою низкою інституційних чинників. Приплив іноземного капіталу, особливо прямих іноземних інвестицій у фінансовий сектор, розглядався як ключовий компонент для вирішення цих проблем. На початку переходу до ринкової економіки всі десять країн Центральної та Східної Свропи мали закритий рахунок операцій із капіталом і фінансовими інструментами. Лібералізація рахунку операцій із капіталом була основною передумовою для інтеграції держави у світову економіку та світову фінансову систему, залучення в економіку міжнародного капіталу. Проте слід сказати, що найважливішим стимулом для лібералізації рахунку операцій із капіталом у всіх країнах Центральної та Східної Свропи була перспектива членства в СС [5].

Також важливим $є$ те, що одним із основних завдань, які вирішувалися урядами країн ЦСС в процесі системної трансформації, стало формування національних ринків цінних паперів, які відіграють важливу роль в акумуляції капіталу для інвестицій у реальний сектор економіки, сприяючи, таким чином, раціональному розміщенню фінансових ресурсів. Важливим періодом для формування основи фінансових ринків є період 1990-х років, коли була проведена ціла низка структурних реформ, які повинні сприяти формуванню ефективного фінансового сектора, який на початку 90-х років був представлений неефективною однорівневою банківською системою [3].

Усі нові члени Свросоюзу, в тому числі й країни В4, уважно стежать за своїм становищем у різних рейтингах.

Із розширенням СС помітно більший інтерес буде представляти зіставлення показників країн В4 не стільки між собою, скільки 3 іншими членами СС. Причому для нових членів більш актуальне порівняння з менш розвиненими країнами СС - Португалією, Грецією, Іспанією. Зокрема, Угорський національ- 
ний банк уже досить давно займається діахронічним порівнянням цих країн $\mathrm{i}$ «малої вісімки» (країни, що вступили до ЄС у 2004 р., крім Кіпру та Мальти), у цілому виходить, що останні кілька років випереджають португальців, греків, іспанців, які вступили раніше, за хронологією поліпшення макроекономічних показників після вступу до СС [8].

У країнах В4 це вселяє певний оптимізм, але вивчення ступеню відповідності основних макроекономічних показників нових членів середнім показникам по $€ C$, які приймалися б за еталон, показує менш однорідну картину. Найчастіше проводиться порівняння національних показників ВВП на душу населення, перерахованих за паритетом купівельної спроможності (ПКС), «зважених» щодо середнього по ЄС рівня [7].

Якщо говорити про динаміку розвитку В4, то ще в 2001 р. відомий угорський вчений Т. Беренд робив прогноз, що країни регіону лише через 30 років зможуть підійти до порогу, що відокремлює їх від найменш розвинених країн Заходу. У 2003 р. Т. Паланкаі, голова УРКСС (Угорської Ради з комунікацій $з$ $(\mathrm{C})$, заявив, що за темпів зростання менше 3\% Угорщина зможе досягти середнього рівня країн $\mathrm{CC}$ тільки через 20-25 років. Австрійська газета Die Presse напередодні прийому до складу $€ C$ країн Вишеградської групи та Прибалтики стверджувала, що рівень життя на Заході і на Сході Європи вирівняється для такої країни, як Угорщина, через 38 років, а для Польщі, можливо, - через 50 із лишком років. У 2005 р. міністр економіки і транспорту Угорщини Я. Кока заявив, що за середніх щорічних темпів зростання в 4,2\% Угорщина наздожене Австрію через 16 років (тобто до 2021 р.). За оцінками словацьких фахівців, Словаччина до 2030 р. досягне тільки 97,6\% від середнього по ЄС-25 рівня (хоча середній по ЄС-27 рівень, можливо, й буде подолано), а продуктивність праці в країні становить 99,7\% від середнього по ЄС рівня.

У загальному вигляді виходить, що країни В4 досягають середнього рівня Євросоюзу десь у 2025-2030 рр. Однак уважалося, що навіть цей термін виглядає занадто оптимістичним. Якщо припустити, що зростання ВВП в СС у майбутньому буде щорічно становити $2 \%$ (а майже вся попередня динаміка розвитку ЄС дає змогу це припускати) і що населення європейських країн не буде рости (хоча прогнози міжнародних організацій на 2025 р. показують навіть зниження чисельності Свропи), то показник «ВВП на душу населення» в ЄС буде збільшуватися такими ж темпами [3, с. 386].

Співпраця Вишеградської групи була під впливом політичних подій у двох країнах: Чехії та Словаччини. Розкол Чехословаччини в 1993 р. навіть зміцнив позиції політичних лідерів. Тоді як у Чехії збільшення впевненості в собі призвело до переконання, що співпраця в рамках Вишеграду гальмує розвиток Чехії, у Словаччині було обрано шлях національної відбудови, який суперечив загальним тенденціям В4. Відхилення Словаччини від так званого Центральноєвропейського шляху політичних та економічних перетворень, який включав підвищення напруженості у відносинах з Угорщиною, призвів до виключення Словаччини з групи щодо вступу до $Є \mathrm{C}$, а також з першого раунду розширення НАТО.

Варто відзначити, що співпраця Вишеградської групи хоча й не була такою активною з боку Словаччини, продовжувала працювати у сфері міжнародної безпеки. Шлях на інтеграцію до НАТО, а також реальні перспективи членства в 
цій організації зумовив новий етап координації діяльності трьох країн та активізацію обміну інформацією.

Таблиця 2.1

Терміни досягнення середнього по СС-15 рівня
ВВП на душу населення, розраховані за ПКС (середньорічні темпи зростання ВВП Євросоюзу взяті за 2\%)

\begin{tabular}{|l|c|c|c|c|c|c|}
\hline \multicolumn{1}{|c|}{ Країна } & $\mathbf{3 \%}$ & $\mathbf{4 \%}$ & $\mathbf{5 \%}$ & $\mathbf{6 \%}$ & $\mathbf{7 \%}$ & $\mathbf{1 0 \%}$ \\
\hline Словаччина & 2038 & 2021 & 2015 & 2015 & 2015 & 2015 \\
\hline Чехія & 2050 & 2027 & 2019 & 2019 & 2019 & 2019 \\
\hline Угорщина & 2064 & 2034 & 2024 & 2024 & 2024 & 2024 \\
\hline Словаччина & 2078 & 2041 & 2028 & 2028 & 2028 & 2028 \\
\hline Естонія & 2088 & 2046 & 2032 & 2032 & 2032 & 2032 \\
\hline Литва & 2089 & 2046 & 2032 & 2032 & 2032 & 2032 \\
\hline Польща & 2091 & 2048 & 2033 & 2033 & 2033 & 2033 \\
\hline Латвія & XXII ст. & 2055 & 2038 & 2038 & 2038 & 2038 \\
\hline
\end{tabular}

Джерело: складено за [3]

Після активізації діяльності В4 наприкінці 1999 р. організація стала стратегічною платформою для обговорення питань, пов'язаних із процесом підготовки до вступу до ЄС [7]. Спільний вступ до ЄС був в інтересах усіх чотирьох країн, що також посилило почуття солідарності всередині групи. Обмін інформацією та досвідом почав відбуватися на регулярній основі [5].

Тим не менше це не означає, що країни В4 були завжди лояльні до інтересів один одного. Скептичні настрої всередині В4 загострилися наприкінці 2002 р., під час завершальної фази переговорів з Свропейським Союзом. Кожна 3 чотирьох країн боролася лише за свої інтереси, забуваючи про солідарність [6].

2000 p. знаменує собою важливий крок в інституційному розвитку співробітництва Вишеградської групи - був заснований Міжнародний Вишеградський фонд. Основна мета фонду - зробити діяльність В4 ближче до народу, зокрема шляхом забезпечення підтримки проектів, розроблених неурядовими організаціями, місцевими органами влади, університетами або іншими державними установами [3].

Зі структурного погляду ще одним важливим внеском у розвиток співробітництва та поглиблення координації стало президентство всередині Вишеградської групи. Ідея провести головування в групі на основі ротації 3 мандатом на один рік було прийнято прем'єр-міністрами в Братиславі в 1999 р. Ідея отримала подальший розвиток у вигляді окремого додатка в 2002 р. [8].

На думку Л. Янчука, початок інтеграції в рамках В4 не сприяв зміцненню співпраці і більш ніж прохолодні відносини між Прагою і Братиславою, викликані як певною орієнтацією чеської дипломатії, так і антидемократичним характером словацького режиму Володимира Мечіара.

Таким чином, поява Вишеградської групи розпочала новий етап у розвитку всього регіону Центральної і Східної Свропи. Деякі дослідники (Л.Н. Шишиліна) навіть ототожнюють появу Вишеградського об'єднання 3 формуванням «Вишеградської» Свропи, якій притаманні такі риси: синтез цивілізаційних характеристик, нова самоідентичність, динамізм економічного розвитку. 
Автори наполягають, що «ставши членами Свросоюзу, Вишеградські країни пустили на свій ринок «стару Свропу», але самі не отримали симетричного доступу на їі більш динамічні ринки» [3].

Однак, на нашу думку, попри значні політико-економічні складнощі країнам В4 вдалося досягнути найважливіших геополітичних та геоекономічних цілей: повне виведення радянських військ зі своїх територій, вступ до ЄС, НАТО, Єврозони (лише для Словаччини), Шенгенської угоди тощо.

Окрему увагу в дослідженні доцільно присвятити діагностиці платіжного балансу та міжнародної інвестиційної позиції для Вишеградської четвірки. Саме ці показники вказують місце і роль економічних систем В4 в реальному секторі ЄС.

Таблиця 2.2

Чиста міжнародна інвестиційна позиція, \% до ВВП

\begin{tabular}{|c|c|c|c|c|}
\hline Рікраїна & Угоршина & Словаччина & Чехія & Польща \\
\hline $\mathbf{2 0 0 3}$ & -78 & $-33,5$ & $-19,6$ & $-41,7$ \\
\hline $\mathbf{2 0 0 4}$ & -85 & $-39,9$ & $-28,2$ & $-41,6$ \\
\hline $\mathbf{2 0 0 5}$ & $-94,4$ & $-48,6$ & $-26,9$ & $-42,5$ \\
\hline $\mathbf{2 0 0 6}$ & $-102,8$ & $-53,5$ & $-32,3$ & $-45,7$ \\
\hline $\mathbf{2 0 0 7}$ & $-105,1$ & $-51,5$ & $-38,7$ & $-50,1$ \\
\hline $\mathbf{2 0 0 8}$ & $-106,0$ & $-57,4$ & $-40,1$ & $-56,3$ \\
\hline $\mathbf{2 0 0 9}$ & $-117,2$ & $-66,7$ & $-46,0$ & $-58,8$ \\
\hline $\mathbf{2 0 1 0}$ & $-113,3$ & $-63,1$ & $-48,3$ & $-65,4$ \\
\hline $\mathbf{2 0 1 1}$ & $-107,4$ & $-65,5$ & $-47,5$ & $-64,0$ \\
\hline $\mathbf{2 0 1 2}$ & $-103,2$ & $-64,1$ & $-48,8$ & $-66,5$ \\
\hline $\mathbf{2 0 1 3}$ & $-92,6$ & $-65,1$ & $-45,6$ & $-69,3$ \\
\hline $\mathbf{2 0 1 4}$ & $-75,5$ & -69 & $-36,7$ & $-68,5$ \\
\hline $\mathbf{2 0 1 5}$ & $-65,4$ & $-69,6$ & $-30,6$ & $-62,3$ \\
\hline
\end{tabular}

Джерело: систематизовано авторами за [7]

У регіональній структурі зовнішньоекономічних зв'язків Угорщини чільне місце посідає Європейський Союз. За підсумками 2013 р. на товарообіг 3 державами СС припало близько 74,6\% усієї угорської зовнішньої торгівлі, частка країн, які не входять до СС, дорівнювала приблизно 12,4\%, азіатських країн - 9,7\%, інших держав - 3,3\%. Динаміка товарообігу 3 основними партнерами була нерівномірною. Так, експорт Угорщини в індустріально розвинені західноєвропейські країни - члени СС збільшився за 2013 р. на 3,2\%, а імпорт - лише на $0,1 \%$ (у попередньому році було зафіксовано зростання відповідно на 0,4\% і 3,2\%) [7].

Необхідно відзначити поліпшення за останні роки цілої низки структурних і якісних показників зовнішньоекономічної рівноваги країни. Серед них особливо важливим $\epsilon$ зниження за минулі роки питомої ваги заборгованості в конвертованій валюті в загальній структурі державного боргу. До кінця 2013 р. цей показник знизився майже до $40 \%$, тоді як кілька років тому він перевищував $60 \%$. Слід указати, крім того, на дострокове погашення Угорщиною в 2013 р. заборгованості, що залишилася перед Міжнародним валютним фондом, а також 
зниження надмірного боргового навантаження органів місцевого самоврядування, інститутів соціальної сфери та населення [7].

Таблиця 2.3

Динаміка державного зовнішнього боргу, (\% до ВВП)

\begin{tabular}{|c|c|c|c|c|}
\hline & Угорщина & Словаччина & Чехія & Польща \\
\hline $\mathbf{2 0 0 1}$ & 51,9 & 48,3 & 22,8 & 37,6 \\
\hline $\mathbf{2 0 0 2}$ & 55,1 & 42,8 & 25,9 & 42,2 \\
\hline $\mathbf{2 0 0 3}$ & 57,8 & 41,5 & 28,1 & 47,1 \\
\hline $\mathbf{2 0 0 4}$ & 58,8 & 40,6 & 28,5 & 45,7 \\
\hline $\mathbf{2 0 0 5}$ & 60,8 & 33,8 & 28,0 & 47,1 \\
\hline $\mathbf{2 0 0 6}$ & 65,0 & 30,7 & 27,9 & 47,1 \\
\hline $\mathbf{2 0 0 7}$ & 65,9 & 29,8 & 27,8 & 45 \\
\hline $\mathbf{2 0 0 8}$ & 71,9 & 28,2 & 28,7 & 47,1 \\
\hline $\mathbf{2 0 0 9}$ & 78,2 & 36,0 & 34,1 & 50,9 \\
\hline $\mathbf{2 0 1 0}$ & 80,9 & 41,1 & 38,2 & 54,9 \\
\hline $\mathbf{2 0 1 1}$ & 81,0 & 43,5 & 41,0 & 56,2 \\
\hline $\mathbf{2 0 1 2}$ & 78,5 & 52,1 & 45,5 & 55,6 \\
\hline $\mathbf{2 0 1 3}$ & 77,3 & 54,6 & 45,7 & 57 \\
\hline $\mathbf{2 0 1 4}$ & 76,2 & 53,9 & 42,7 & 50,5 \\
\hline $\mathbf{2 0 1 5}$ & 75,3 & 52,9 & 41,1 & 51,3 \\
\hline
\end{tabular}

Джерело: систематизовано авторами за [7]

Під час загального огляду макроекономічних індикаторів країн Вишеграду можна зробити деякі висновки про успішність проведених трансформаційних перетворень.

Для європейських економік традиційно вразливим $\epsilon$ показник змін споживчих цін.

Серед країн В4 найбільш значимий цей показник в Угорщини. Це зумовлено як дефіцитом платіжного балансу країни, так і надмірним зростанням грошової маси.

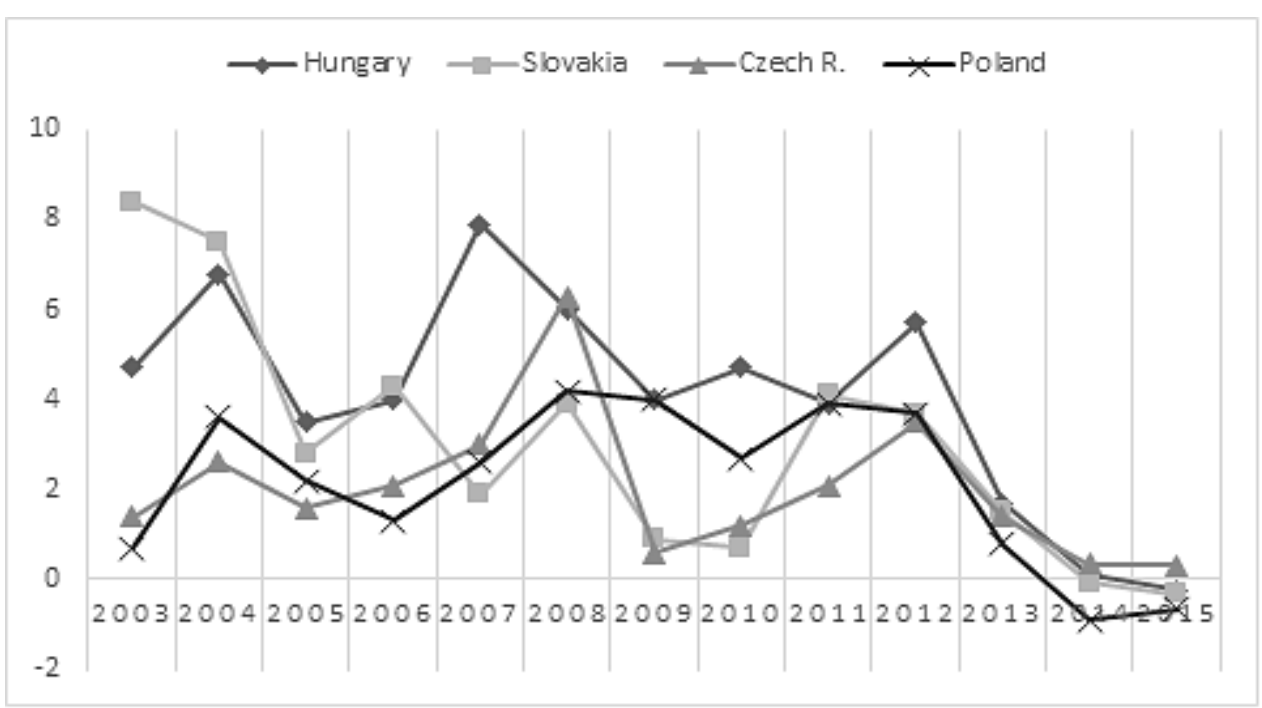

Рис. 2.1. Динаміка інфляції в країнах В4 (\% до попереднього періоду) [7] 
Найнижчий рівень інфляції спостерігається в економіці Словаччини. Це один із профітів, який отримала країна після вступу до зони євро. Однак зниження інфляції відбилося на рівні безробіття, який для Словаччини є традиційно високим.

Період 2014-2016 рр. супроводжувався дефляцією в усіх країнах Вишеграду, що було зумовлено загальною рецесією в СС, а 3 іншого боку - призвело до підвищення рівня безробіття.

На думку O.I. Брусиловської, 3 членством СС не всі проблеми набули позитивної динаміки. Головною загрозою для економічного зростання країн регіону залишається нестабільність ринку енергоносіїв. Усі вони залежать від російського газу. У Словаччині 90\% газу має російське походження. Саме на словацькій території нафтовий потік «Дружба» розділяється для подальшого транспортування до Чехії, Німеччини, Франції, Австрії та Італії [1].

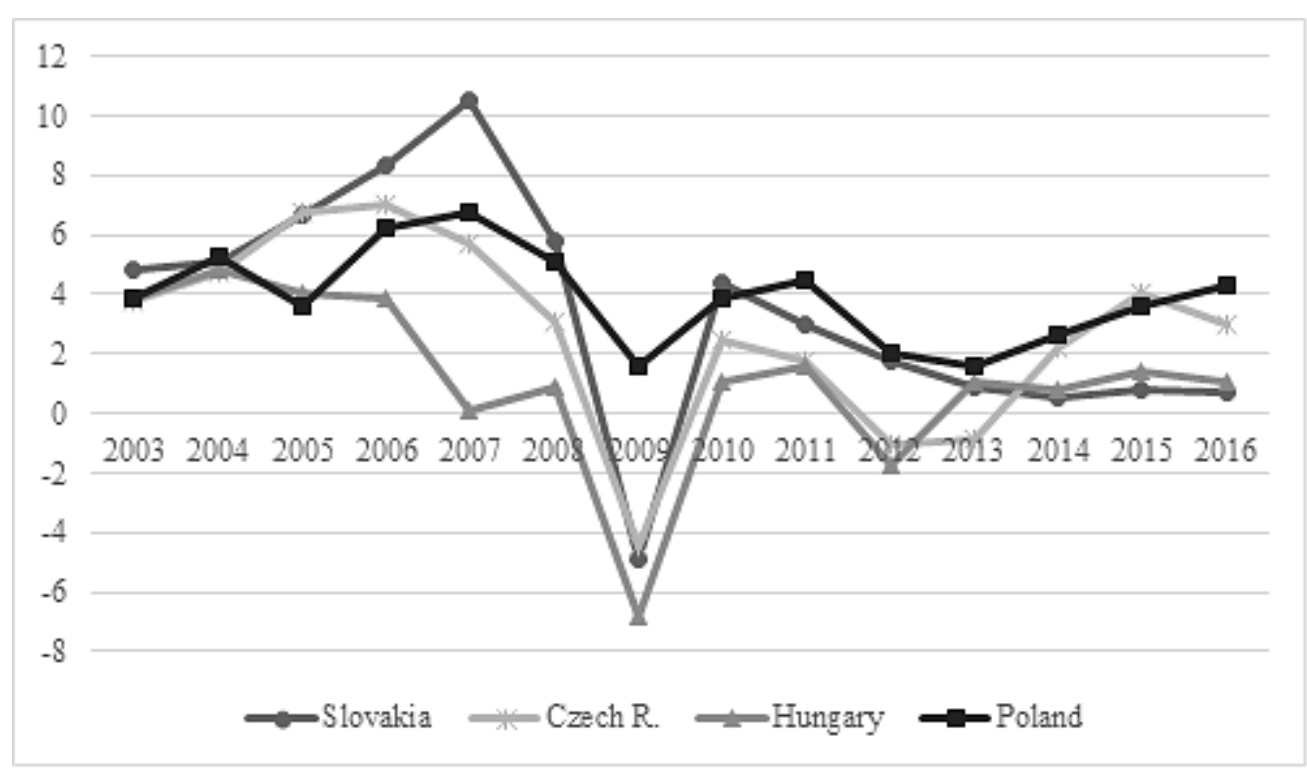

\section{Рис. 2.2. Динаміка темпів ВВП країн В4, \% до попереднього року [7]}

Протягом періоду, що досліджується, слід відзначити динаміку зростання польського ВВП: навіть під впливом кризових факторів спостерігається позитивне зростання, тоді як для інших країн групи кризовий період 2008-2009 рр. відзначився різким падінням.

Гіпотеза, яка пояснює таку макроекономічну поведінку, на нашу думку, - це відносна низька залежність польської економіки від експорту i, таким чином, менші дисбаланси поточного рахунку Польщі.

Найнижчий рівень безробіття традиційно спостерігається в Чехії, тоді як в Угорщині йде поступове збільшення проценту безробіття.

Характерною особливістю ринку праці для всіх країн В4 $є$ зростання безробіття після кризи 2008-2009 рр., особливо гостро - у Словаччині.

Для виявлення ефективності перебування країн в інтеграційному об'єднанні В4 доцільно прослідити динаміку внутрішньої торгівлі між країнами. Особливо цікавим представляється дослідження внутрішньої торгівлі Словаччини 3 партнерами по В4. 


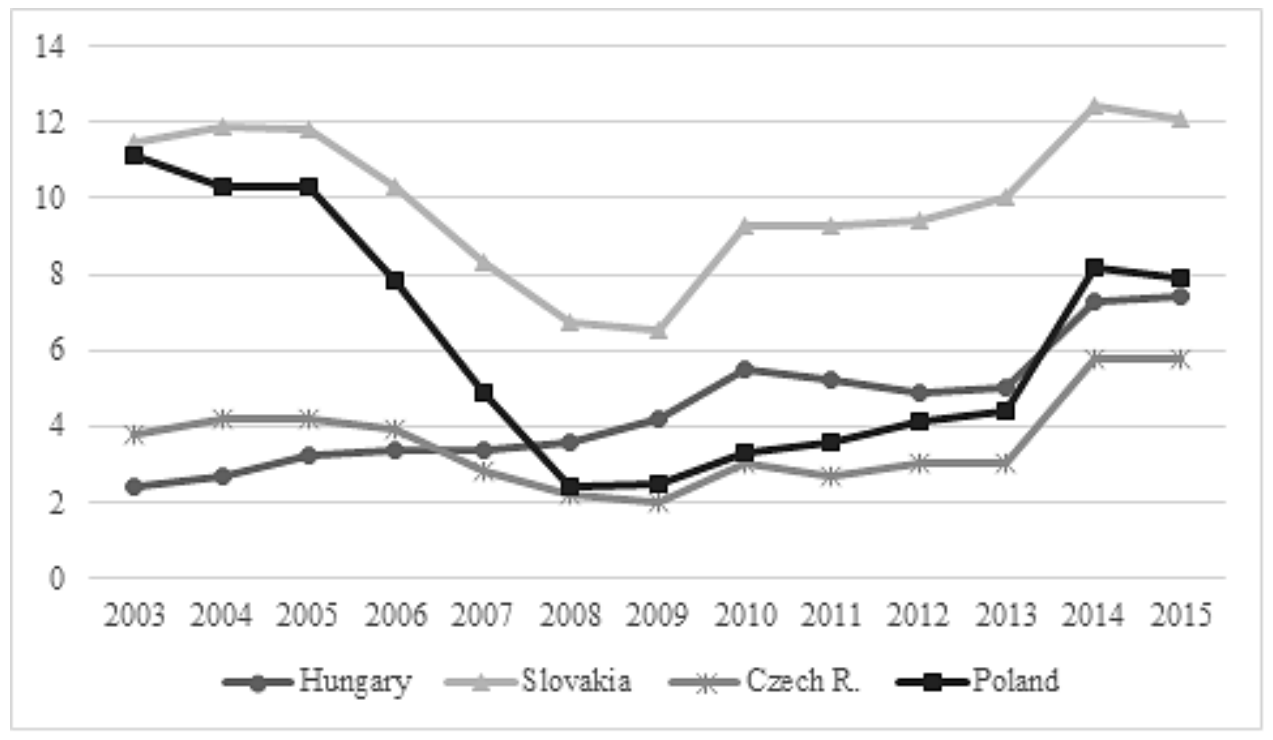

Рис. 2.3. Рівень безробіття в країнах В4, \% [7]
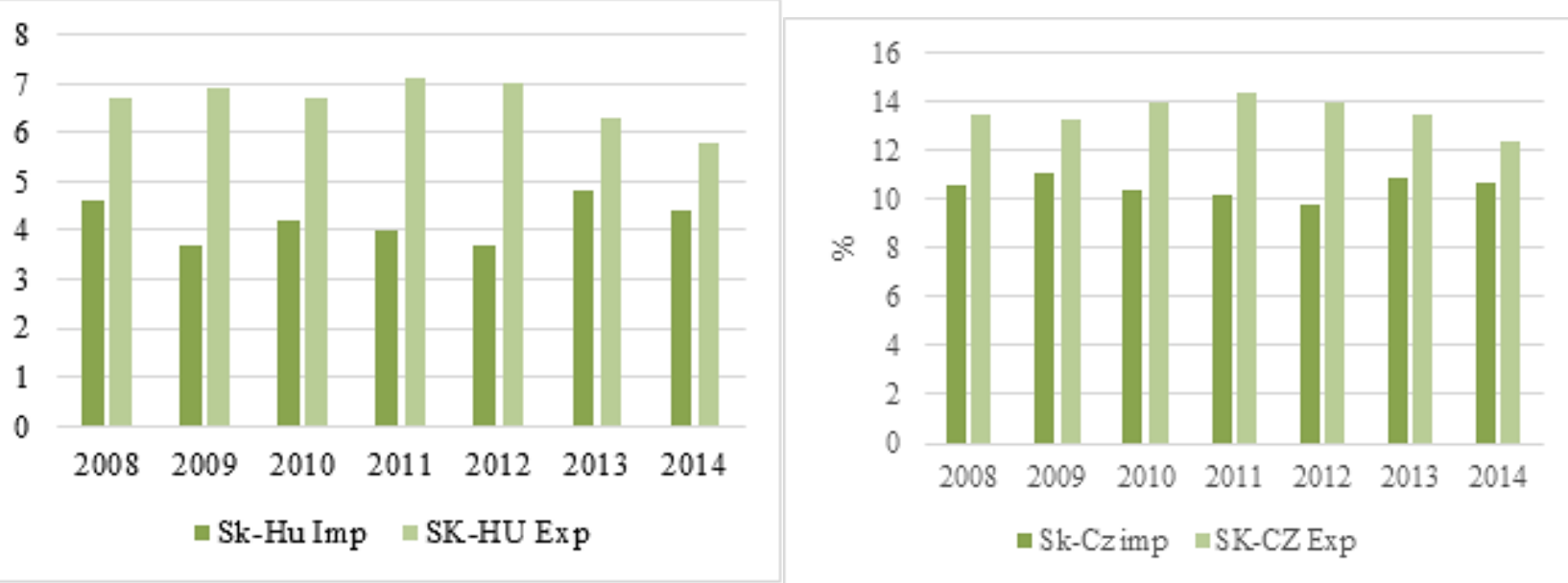

Рис. 2.4. Частка експорту-імпорту (А) Чехії та (Б) Угорщини в торговельному балансі Словаччини [7]

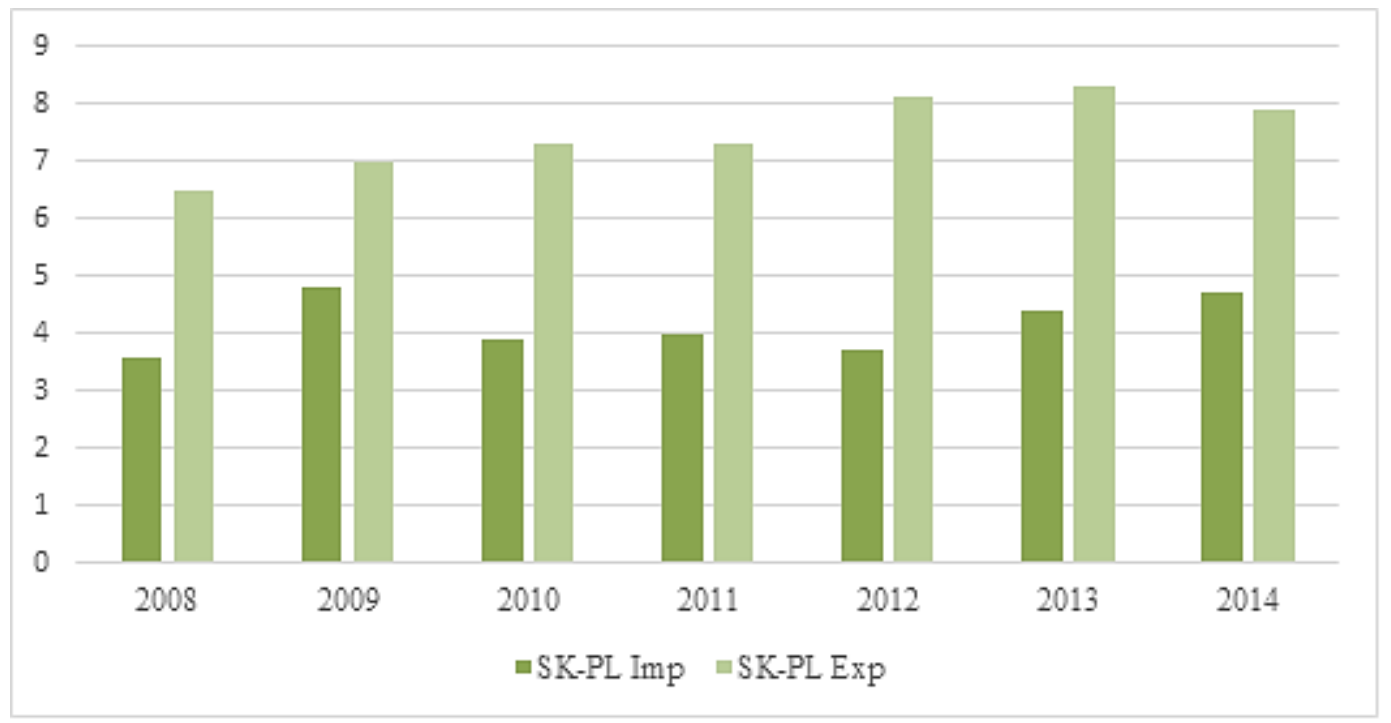

Рис. 2.5. Частка експорту-імпорту Польщі у торговельному балансі Словаччини [7] 
Характерною особливістю зовнішньої торгівлі Словаччини з партнерами по B4 є переважання експорту над імпортом. Окрім того, говорити про значне посилення ролі країн В4 для Словаччини можна лише у випадку Польщі. Загальними факторами, які пояснюють характер економічних відносин Словаччини з партнерами по В4, є: об'єктивна кон'юнктура європейського ринку, рівень попиту і споживання всередині В4, структурні зрушення словацької економіки (які відображаються у рахунках платіжного балансу та міжнародної інвестиційної позиції).

\section{3. Вплив макроекономічних чинників на економічне зростання в країнах Вишеградської четвірки}

Нами проведений економіко-статистичний аналіз впливу макроекономічних чинників на ВВП у країнах Вишеграду. Основна модель, яка була оцінена за двокроковим методом найменших квадратів, така:

$$
\mathrm{Y}(\mathrm{gdp})=\mathrm{c} \times \mathrm{X} 1 \times \mathrm{X} 2,
$$

де

Y(gdp) - квартальні дані ВВП для країни n;

X1 - рахунок поточних операцій платіжного балансу країни n;

$\mathrm{X} 2$ - обсяги промислового виробництва країни $\mathrm{n}$.

За схожої відкритості економік країн В4 вплив поточного рахунку на ВВП виявися різним. Для Польщі та Угорщини результат в довгостроковій перспективі виявився однаковим. Однак у короткостроковій перспективі в Угорщині спостерігається позитивний вплив поточного рахунку на економічне зростання. У довгостроковій перспективі ефект вирівнюється.

Результати для Чеської Республіки виявилися неочікуваними. Однак укріплення іноземної валюти разом із дефіцитом поточного рахунку, на нашу думку, є основними факторами, що пояснюють результати моделі, а саме негативний вплив поточного рахунку на ріст чеського ВВП.

I лише для Словаччини виявлено стимулюючий ефект негативного поточного рахунку на зростання ВВП.

В. Шевчук відзначає, що у Східній Свропі перехід до економічного зростання відбувся на тлі від'ємного сальдо поточного рахунку, що виразно контрастує 3 українським досвідом.

Таким чином, країни Вишеградської групи зазнали великих змін у період євроінтеграції. Було проаналізовано теорії, а також підходи до питання, пов'язаного з розвитком Польщі, Угорщини, Чехії та Словаччини.

Словаччина та Чехія пройшли тривалий час трансформаційних зрушень від соціалістичної моделі господарювання до повноцінного ринкового капіталізму. Євроінтеграційний шлях змусив країни суттєво реформувати власні економічні системи, зокрема щодо форми власності на ключових підприємствах, привабливість для залучення іноземного капіталу, експортна орієнтованість тощо.

У зоні євро словацька економіка дуже мала, менше $1 \% 3$ точки зору ВВП і населення. Крім того, іноземний сектор відіграє дуже важливу роль для словацької економіки з часткою експорту у ВВП на рівні більш ніж 80\%.

Після проведення комплексу економічної діагностики нами виявлено такі найбільш значимі результати для Словаччини. Після вступу до зони євро 
Словаччина отримала надійний базис для сталого розвитку власної економічної системи. Ця подія співпала із загостренням негативного впливу світової фінансово-економічної кризи на економіку Словаччини та стала одним із факторів оживлення економічного росту. Щодо економічних відносин Словацької Республіки, то нами виявлено деякі постінтеграційні особливості, які проявилися у зменшенні частки країн $С С$ у словацькому експорті-імпорті за одночасного зростання абсолютних об'ємів зовнішньої торгівлі. Також нами виявлено незначний вплив зміни валютного курсу євро/долар на частку експорту у відношенні до ВВП Словаччини.

Протилежна ситуація спостерігається в Чехії, яка традиційно притримувалася позиції «євроскептицизму» і залишила власну національну валюту. Така ситуація призвела до таких зрушень у економічних відносинах країни: частка країн СС у відношенні експорту-імпорту до ВВП зростає, особливо у відношенні до Німеччини та Словаччини. Нами виявлено, що за сучасних тенденцій укріплення чеської крони до євро в довгостроковій перспективі іiі вплив на експорт буде знижуватися та виявиться незначним.

У даному розділі розглянуто різноманітні аспекти розвитку фінансових систем Вишеградської групи. Досліджено фондові ринки, де чітко простежується благотворний вплив капіталізації цього ринку на зростання ВВП. Також ми проаналізували вплив ПІІ на економіку цих країн.

Тоді як велика кількість європейських економістів віднесли країни Вишеградської групи до категорії країн із високим доходом (статистично), душовий дохід в Польщі як мінімум на $30 \%$ нижчий, ніж у Німеччині.

Структурні зміни в економіках слід проводити через трансформацію від суто виробничого характеру господарств до креативної економіки, сутність якої полягає у:

- високій ролі нових технологій і відкриттів у різних сферах діяльності людини;

- високому ступені невизначеності;

- великому обсязі наявних знань і гострій необхідності генерації нових знань.

Окрім того, креативна економіка характеризується 3 погляду креативного підходу, в основі якого лежать проектне мислення, креативна уява (моделювання), практична спрямованість.

Як правило, креативна економіка зводиться лише до деяких аспектів функціонування сектору інформаційних технологій.

За сучасних обсягів фінансування перехід до креативної економіки може не відбутися.

Найвищій показник фінансування розробок і досліджень має Чехія - 1,88\% від ВВП (табл. 2.4). Однак порівняно з Фінляндією (3,55\%) це явно мало, не кажучи про Словаччину і Польщу. Однак у Чехії вже є успішні приклади інноваційних, основаних на парадигмах «нової економіки» бізнес-проектів, які перетворилися на значимих гравців світової економіки. Наприклад, компанії AVG та Avast, які є одними з флагманів IT-індустрії Чехії та спеціалізуються на антивірусному програмному забезпеченні.

Для Словаччини можна назвати приклад компанії ESET - лідера у галузі розроблення антивірусного програмного забезпечення. 3 головним офісом у Братиславі, підрозділами в Сан-Дієго (США), Уексфорді (Ірландія), Лондоні (Великобританія), Буенос-Айресі (Аргентина), Празі (Чехія) та Сінгапурі, а 
також загальною кількість співробітників понад 700 осіб, продукти ESET забезпечують надійний захист цифрового світу користувачів у більш ніж 180 країнах світу.

Таблиця 2.4

Витрати на R\&D, \% від BBП

\begin{tabular}{|c|c|c|c|c|}
\hline & Словаччина & Чехія & Угорщина & Польща \\
\hline $\mathbf{2 0 0 3}$ & 0,57 & 1,2 & 0,94 & 0,54 \\
\hline $\mathbf{2 0 0 4}$ & 0,51 & 1,2 & 0,88 & 0,56 \\
\hline $\mathbf{2 0 0 5}$ & 0,51 & 1,22 & 0,94 & 0,57 \\
\hline $\mathbf{2 0 0 6}$ & 0,49 & 1,29 & 1,01 & 0,56 \\
\hline $\mathbf{2 0 0 7}$ & 0,46 & 1,37 & 0,98 & 0,6 \\
\hline $\mathbf{2 0 0 8}$ & 0,47 & 1,3 & 1 & 0,6 \\
\hline $\mathbf{2 0 0 9}$ & 0,48 & 1,35 & 1,17 & 0,67 \\
\hline $\mathbf{2 0 1 0}$ & 0,63 & 1,4 & 1,17 & 0,74 \\
\hline $\mathbf{2 0 1 1}$ & 0,68 & 1,64 & 1,22 & 0,76 \\
\hline $\mathbf{2 0 1 2}$ & 0,82 & 1,88 & 1,3 & 0,9 \\
\hline
\end{tabular}

Джерело: систематизовано авторами за [4]

Одна 3 яскравих ілюстрацій «припливу мізків» до Польщі - Краків. За останній час у Кракові відкрилося близько 70 багатонаціональних компаній, де працюють 20 тис. кваліфікованих співробітників - поляків та іноземців.

У 2012 р. там відкрилася компанія Cisco, iii штат нині налічує 500 співробітників. Google перевела туди офіс R \& D.

У Кракові також з'явилися офіси компаній State Street, Capgemeni, Lufthansa, Shell, Brown Brothers i Philip Morris.

Оптимісти називають Краків маленькою Кремнієвою долиною Центральної Європи. Його активний розвиток став магнітом для кваліфікованих кадрів.

Краків являє собою маленький оазис польської богеми, де розташовані 14 коледжів та університетів. На відміну від Варшави, зруйнованої під час Другої світової війни, це місто зберегло австро-угорську архітектурну привабливість.

Багатонаціональне робоче середовище, впровадження нових бізнес-моделей i необхідність постійно бути в курсі останніх нововведень сприяють формуванню в Кракові нового менталітету.

Однак таких успішних прикладів занадто мало в регіоні, щоб говорити про становлення нової економічної системи. Проте робота у цьому напрямі продовжується, і цікавим може бути досвід венчурної компанії Early bird, яка розпочала власний проект, який може допомогти країнам Вишеграду у стимулюванні нових секторів економіки.

Одними з передумов ефективного формування нової економічної моделі та створення креативних регіонів $\epsilon$ наявність кваліфікованої робочої сили, велика кількість студентів (табл. 2.5) та висока якість технічної освіти.

Прикладом поєднання високих стандартів в освіті і зацікавленості венчурного бізнесу став проект Socialbakers. Компанія заснована в Чехії і надає статистичні дані й аналіз мережевих соціальних медіа Facebook, Twitter, Google+, LinkedIn i YouTube, допомагаючи компаніям контролювати ефективність їх соціальних кампаній у ЗМІ. Вони пропонують аналітичні інструменти 
(послуги), які дають клієнтам ідеї і дають їм змогу контролювати профілі в соціальних медіа за допомогою показників ефективності для відстеження ключових впливових факторів для аналізу цін, виміряти зростання аудиторії, відстежувати конкурентів, оптимізувати соціальну присутність 3МI і генерувати графічні звіти.

Таблиця 2.5

Кількість студентів на 10 тис. населення

\begin{tabular}{|c|c|c|c|c|}
\hline Рік & Словаччина & Чехія & Угорщина & Польща \\
\hline $\mathbf{2 0 0 3}$ & 303 & 292 & 403 & 497 \\
\hline $\mathbf{2 0 0 4}$ & 316 & 326 & 436 & 517 \\
\hline $\mathbf{2 0 0 5}$ & 349 & 343 & 452 & 534 \\
\hline $\mathbf{2 0 0 6}$ & 381 & 344 & 457 & 562 \\
\hline $\mathbf{2 0 0 7}$ & 419 & 369 & 451 & 563 \\
\hline $\mathbf{2 0 0 8}$ & 441 & 396 & 433 & 568 \\
\hline $\mathbf{2 0 0 9}$ & 451 & 417 & 417 & 564 \\
\hline $\mathbf{2 0 1 0}$ & 449 & 435 & 409 & 498 \\
\hline $\mathbf{2 0 1 1}$ & 433 & 442 & 403 & 540 \\
\hline
\end{tabular}

Джерело: систематизовано авторами за [7]

Висновки. Виходячи з проведеного аналізу, випливає висновок, що на даному етапі соціально-економічного розвитку сучасної системи міжнародних економічних відносин Польща $\epsilon$ однією 3 найбільш успішних країн Вишеградської групи у плані економічного розвитку, а також входить до числа лідерів за темпами розвитку фінансового сектора. Про це свідчить упевнений розвиток iї банківської системи, фондового ринку, ринку страхування, інвестиційних та пенсійних фондів.

Незважаючи на близькість Польщі до волатильної Сврозони, банківському сектору країни досі вдавалося впоратися 3 труднощами, які виникли в результаті світової фінансової кризи. Однак деякі польські банки мають свої активи в Україні і Росії, де політичні ризики зростають, а економічний прогноз погіршився 3 тих пір, як Росія анексувала Крим в березні 2014 р. Дана ситуація в перспективі може негативно відбитися на банківському секторі Польщі.

Фондовий ринок Польщі так само має значні темпи розвитку. Слід зазначити, що, незважаючи на велику кількість компаній, що котируються, Варшавська фондова біржа (ВФБ) лише недавно стала значним джерелом капіталу. ВФБ на даний момент $є$ ключовою фондовою біржею у Центральній і Східній Свропі із загальною ринковою капіталізацією приблизно в 838 млрд. злотих (понад 230 млрд. дол.) і 471 компанією в 2014 р. В останні роки на ВФБ було розміщено значну кількість IPО (первинні публічні пропозиції акцій).

Розвиток фінансового сектору позитивно вплинув на економічне зростання в країні. У 2014 р. темпи економічного зростання Польщі були відносно відновлені після спаду, який мав місце в 2012-2013 рр. Приріст становив 3,3\%, що було зумовлено значним внутрішнім попитом. Така тенденція продовжувалася і в 2015-2016 pp., а за попередніми оцінками темпи зростання за 2017 р. становитимуть 2-2,5\%. Економічне зростання в Польщі в 2015-2016 рр. 
збіглося з тенденцією економічного зростання і в інших країнах Центральної та Східної Свропи.

Необхідно відзначити, що внутрішня економіка Польщі залишається досить сильною і конкурентоздатною. Також слід зазначити, що, за прогнозами аналітиків, приватне споживання буде одним з основних факторів темпів зростання країни у 2017-2018 pр.

\section{Список використаних джерел:}

1. Брусиловська O.I. Економічна трансформація країн Східної Свропи в умовах членства в Свропейському Союзі / O.I. Брусиловська [Електронний ресурс]. - Режим доступу : http://dspace.onu.edu.ua:8080/bitstream/123456789/1606/1/\%D0\%92\%D0\%B5\%D1\%81\%D1\%82 \%D0\%BD\%D0\%B8\%D0\%BA\%20\%D0\%9E\%D0\%9D\%D0\%A3\%20\%D0\%A1\%D0\%BE\%D1\% $86 \% 20 \% \mathrm{D} 1 \% 82 \% 2013 \% 20 \% \mathrm{D} 0 \% \mathrm{~B} 2 \% \mathrm{D} 1 \% 8 \mathrm{~B} \% \mathrm{D} 0 \% \mathrm{BF} \% 203.179-186 . p d f$.

2. Зеленько Г.I. Інституціоналізація громадянського суспільства у постсоціалістичних країнах (на прикладі країн Вишеградської групи та України) : автореф. дис. ... доктора політичних наук : спец. 23.00.02 «Політичні інститути та процеси» / Г.І. Зеленько. - К., 2007. $-34 \mathrm{c}$.

3. Шишелина Л.Н. Вышеградская Европа: откуда и куда? Два десятилетия по пути реформ в Венгрии, Польше, Словакии и Чехии / Под ред. Л.Н. Шишелиной. - М. : 2010. $570 \mathrm{c}$.

4. Bočková N. Visegrad Four Countries: Evaluation in R\&D Sectors of Performance / Acta Universitatis Agriculture et Silviculturae Mendelianae Brunensis. - Vol. LXI. - № 4. - P. 873-880.

5. Koráb P. Pomenková J. Financial Crisis and Financing Constraints of SMEs in Visegrad Countries. - AIER, 2014. - 18 p.

6. Gal Z., Sass M. Role of Financial Sector FDI in Regional Imbalances in Visegrad 4 Countries and in Slovenia. - Warsaw: The Polish Institute of International Affairs, 2013. P. 20-28.

7. Statistical Database. Eurostat. European Commission [Electronic resource]. - Access mode : http://ec.europa.eu/eurostat/data/database.

8. Visegrad - Arrival, Survival, Revival [Electronic resource]. - Access mode : http://www.visegradgroup.eu/documents/bibliography/visegradarrival-survival-120628. 


\title{
3. ECONOMIC BENEFITS AND RISKS OF COUNTRIES OF THE VISEGRÁD FOUR FROM THE EU MEMBERSHIP
}

\author{
Ліщинський I.O. \\ кандидат економічних наук, \\ доцент кафедри міжнародної економіки \\ Тернопільського начіонального економічного університету \\ Лизун М.В. \\ кандидат економічних наук, дочент, \\ докторант кафедри міжнародної економіки \\ Тернопільського національного економічного університету
}

\section{ТРАНСФОРМАЦЙНИЙ ПРОЦЕС ТЕРИТОРІАЛЬНОГО УСТРОЮ КРАЇН ВИШЕГРАДСЬКОЇ ЧЕТВІРКИ: ВІД ДОІНТЕГРАЦЙНОГО ПЕРІОДУ ДО ПАН'ЄВРОПЕЙСЬКИХ ІНІЦАТИВ}

\section{1. Елементи трансформації територіального устрою} країн Вишеградської четвірки до вступу у СС

Головні характеристики трансформаційного процесу в країнах Вишеградської четвірки (B4) були детерміновані досить давно і включають наступні елементи:

- Лібералізація: процес адаптації більшість цін до світових ринкових рівнів на основі механізму конкуренції, а також зниження торговельних бар'єрів, які відключали зв'язок від цінової структури світових ринкових економік;

- Макроекономічна стабілізація: передусім процес, за допомогою якого інфляція стає підконтрольною і з часом знижується після первинного вибуху, тригером якого стала лібералізація. Цей процес потребує дисципліни державного бюджетування та збільшення грошових надходжень та кредитів (тобто, дисципліна у фіскальній та монетарній політиці) та прогресу у досягненні стабільного платіжного балансу;

- Реструктуризація i приватизація: процеси створення життєздатного фінансового сектору та реформування системи підприємництва на основі приватної власності;

- Правові і інституціональні реформи: необхідні для переосмислення ролі держави в економіках, встановлення верховенства права та запровадження відповідної політики конкуренції ${ }^{1}$.

Загалом, можна відмітити, що лібералізація і макроекономічна стабілізація у Вишеградських країнах відбулась досить швидко, як і приватизація малих підприємств (якщо порівнювати із менш успішними пострадянськими трансформаційними сусідами). Приватизація великомасштабних підприємств,

\footnotetext{
${ }^{1} 25$ years of transition: post-communist Europe and the IMF / James Roaf, Ruben Atoyan, Bikas Joshi, Krzysztof Krogulski and an IMF staff team. - Washington, D.C.: International Monetary Fund, 2014
} 
правові та інституційні реформи посилилися на більш пізньому етапі переходу і тривали значно довше.

Процес територіальних реформ у кожної із держав В4 вирізнявся своїми особливостями і «підводними каменями» і проходив із перемінним успіхом. Коротко розглянемо основні аспекти територіальної трансформації кожної із держав.

\section{1. Територіальні перетворення в Польщі}

Задля реорганізації територіального устрою польський уряд здійснив комплексну i всебічну перебудову державного управління та державних фінансів, що спершу неоднозначно сприймалося суспільством i фактично завершилося в 1999 році. 3 точки зору сучасників, адміністративно-територіальна реформа (на відміну, наприклад, від освітньої) визнається як одна із найбільш успішних реформ в широкому комплексі заходів із перебудови польської економіки.

Підгрунтя реформ забезпечено шляхом організаційної перебудови країни на три рівні - гміни, повіти та воєводства - із наданням місцевим органам влади більшої відповідальності за надання послуг. Децентралізація функціональних обов'язків значно зменшила зайнятість центрального уряду.

Місцеве самоврядування в Польщі функціонує із 1990 року і представлене 2489 гмінами. Реформи переважно стосувались двох нових рівнів самоврядування, котрі суттєво зменшили адміністративну присутність центрального уряду на субнаціональному рівні.

Уряд застосував децентралізований підхід до відповідальність та фінансової спроможності 308-ми демократично обраних місцевих органів самоврядування на рівні повіту та 65 т. зв. міських гмін, котрим надавалися права та бюджет повіту.

Реформи також суттєво скоротили кількість існуючих воєводств із 49 до 16, що дозволило їм вести повноцінну політику регіонального розвитку (але спершу було сприйнято не надто схвально).

До компетенції гмін відносять регулювання та організацію діяльності дит'ясел, дитячих садків, початкових шкіл, бібліотек та культурних центрів, підтримка місцевих доріг, а також відповідальність за всі суспільні питання місцевого значення, що не були зарезервовані законом для інших суб'єктів влади.

Гміни також виконують завдання делеговані центральним урядом та державною адміністрацією (але не повітами) і які залишаються під державним наглядом. Ці обов'язки можуть бути делеговані на підставі законів або через добровільні угоди з державними органами. Закон гарантує, що гмінам буде надано кошти, необхідні для виконання цих делегованих завдань.

Повіти складають другий рівень місцевого самоврядування і $\epsilon$ достатньо великими, щоб ефективно організовувати діяльність численних суспільних інститутів, таких як загальноосвітні школи, лікарні загального профілю, а також поліцейські відділення та пожежні станції, санітарні інспекції та податкові служби. Разом із тим вони є, одночасно, достатньо малими - в середньому 80-100 тисяч жителів - що дозволяє делегувати адміністрування і контроль над цими установами в руки місцевих громадян. 
На відміну від гмін, які відповідають за всі аспекти, які не були чітко визначені для інших рівнів влади, повіт виконує лише ті завдання, які були чітко визначені для нього в законі. Отже, відсутня залежність між повітами і гмінами: кожен 3 них виконує окремо визначені публічні завдання та обов'язки.

Шістнадцять нових воєводств, натомість, $є$ вже достатньо крупними (чисельність населення коливається від 1 до 5 мільйонів) територіальними одиницями із самостійною юридичною ідентичністю, власними бюджетами та широкими повноваженнями у сфері економічної політики. Інституційну основу воєводств становлять ради, відомі як «сеймики» (регіональні парламенти). Вони обираються на загальних виборах. Сеймики, у свою чергу, обирають Правління воєводства для здійснення виконавчої влади, які очолюють маршали ${ }^{1}$.

\section{2. Територіальні перетворення в Чехії}

Адміністративно-територіальна реформа в Чеській республіці тривала приблизно 10 років: 31989 до 2000 рр. і була проведена у два етапи. На першому етапі реформи Чехословаччина відмовилася від трьохрівневої структури адміністративного управління - муніципалітету, округу, провінції введеної у 1960 році, і повернулася до дворівневої структури. Проте, незважаючи на схвалення чеським парламентом закону про дворівневу структуру районування в 1997 р., фактична реалізація нового адміністративнотериторіального поділу країни відбулася лише у 2000, після прийняття законів про вибори до місцевих органів самоврядування, визначення їх статусу, повноважень і відносин між місцевими органами влади і центральним урядом.

Відповідно до Закону про регіони № 129/2000, Чеська Республіка ділиться на 13 регіонів (kraje) та одну столицю (hlavní město) 3 регіональним статусом; нижчий рівень самоврядування складається з 6242 місцевих громад. Більш старі адміністративні одиниці (сімдесят три округи okresy) все ще іноді визнаються, наприклад, в випадках територіальних представництв судової системи ${ }^{2}$.

\section{3. Територіальні перетворення в Словаччині}

Територіальні реформи в Словаччині завершились у 2002 р. і тривали понад 10 років. Можна виділити три етапи їх проведення.

Перший етап (1990-1996 рр.) включав: 1) формування однорівневої системи управління у муніципалітетах та містах; 2) Словацька національна рада затвердила ряд законів, згідно з якими місцеве самоврядування було відновлено та відображено у Конституції (1992р.), Муніципалітети отримали високу незалежність для вирішення місцевих проблем; 3) скасування регіонів та перехід від 3-хрівневої (провінції, райони, міста) до дворівневої системи територіального управління із збереженням їх попередніх кордонів та адміністративних центрів. Завдяки цим заходам уряд де-факто звів децентралізацію лише до деконцентрації.

\footnotetext{
${ }^{1}$ Innovative Strategies of Territorial Development of V4: Experience for Ukraine / Y. Savelyev, I. Lishchynskyy, M. Lyzun, K. Borsekova, M. Sokołowicz, K. Vitališova, Y. Kurylyak. - Ternopil: Terno-graf, 2016. - 216 p

${ }^{2}$ Innovative Strategies of Territorial Development of V4: Experience for Ukraine / Y. Savelyev, I. Lishchynskyy, M. Lyzun, K. Borsekova, M. Sokołowicz, K. Vitališova, Y. Kurylyak. - Ternopil: Terno-graf, 2016. - 216 p
} 
На другому етапі з 1996 по 1998 роки структурні зміни в уряді здійснювалися за принципом розподілу повноважень між адміністративними органами, а саме: 1) створено 8 регіонів та 79 районів; 2) одночасно збільшено кількість районних відділень 338 до 79 і скорочено кількість місцевих установ, що призвело до «горизонтальної» інтеграції; 3) прийнято поправку до Закону №369/1990 «Про муніципалітети» (1998р.) з метою визначення чіткої ролі муніципалітетів.

Практика показала, що така деконцентрація не виправдала очікувань щодо раціоналізації державного управління та стала інструментом для посилення позиції домінуючої політичної партії «Рух за демократичну Словаччину» напередодні парламентських виборів і призвело до збільшення чисельності посадових осіб та формування «непотрібної» бюрократії на районному рівні.

Третій етап реформи з 1998 по 2002 рік був ознаменований зміною політичної ситуації в країні, появою нового уряду, яка вплинула на попередні плани реформування адміністративної системи та державного управління та призвела до «широкомасштабної» реформи, яка виражалася в прийнятті Стратегії реформ публічної політики в Словаччині (грудень 1999 р.); Стратегії адміністративної реформи (2000 р.) та Концепція децентралізації та модернізації державного управління (2000р.). Останній документ був основним інструментом, через який сьогодні здійснюється передача повноважень та відповідальності між державою, органами місцевого самоврядування та територіальними одиницями вищого рівня.

Крім того, введення євро у Словаччині позитивно відбилося на багатьох економічних процесах, однак мало і свої недоліки. Серед переваг приєднання до єврозони слід виокремити зниження трансакційних витрат, зменшення валютних ризиків; цінова транспарентність, посилення тиску в реалізації фіскальної політики. При цьому існує ряд обмежень та ризиків, серед яких одним 3 найбільш істотних вважається втрата автономності в сфері валютної політики і можливість реагувати на кон'юнктурні дисбаланси розвитку світової економіки зміною обмінного курсу національної валюти.

Завершення реформ в Словаччині відбулося в 2002 році, в результаті якого було створено близько 3000 тисяч населених пунктів (міст та сіл) та 8 регіонів 3 власними правліннями. Проте після прийняття парламентом ряду законів про фіскальну децентралізацію та формування механізмів державного контролю, відбувся заключний етап адміністративної реформи Словаччини, яка включала перехід до децентралізації місцевого та регіонального самоврядування та зміцнення принципу субсидіарності ${ }^{1}$.

\section{4. Територіальні перетворення в Угорщині}

У випадку Угорщини особливо важливо, що підготовка до реформи місцевого самоврядування та політична дискусія вже почалися в 1987-1988 роках. Цей факт вплинув на форму реформи, яка була ратифікована парламентом ще в травні 1990 року. Фіскальна реформа була введена ще до політичного переходу 1989 року, як наслідок, локальній владі було «виділено» власну місцеву податкову базу та частку загальнонаціональних податків.

\footnotetext{
${ }^{1}$ Innovative Strategies of Territorial Development of V4: Experience for Ukraine / Y. Savelyev, I. Lishchynskyy, M. Lyzun, K. Borsekova, M. Sokołowicz, K. Vitališova, Y. Kurylyak. - Ternopil: Terno-graf, 2016. - 216 p
} 
По-друге, ранній етап підготовки до реформ також відбився на їх масштабі, оскільки вони застосовувались не тільки до комун, але й до округів, наступного рівня адміністрації. Це відрізняло угорську реформу від усіх інших постсоціалістичних країн.

В адміністративному відношенні Угорщина ділиться на 19 округів (теgуе, множина megyék). Крім того, столиця (föváros) Будапешт, не залежить від будьякого округу. Округи та столиця - 20 підрозділів третього рівня Угорщини. Округи далі підрозділяються на 198 місцевостей (járás, множина járások). Існують також 23 міста з правом округу (megyei jogú város), які іноді називають «urban counties» англійською мовою (хоча такого терміну угорською мовою неіснує). Місцеві органи влади таких міст мають розширені повноваження, однак вони все ж належать до території відповідного округу, а не $\epsilon$ незалежними територіальними одиницями.

Починаючи з 1996 року, округи та місто Будапешт були об'єднані в 7 регіонів для статистичних цілей та цілей розвитку. Ці сім регіонів являють собою підрозділи другого рівня Угорщини: Центральна Угорщина, Центральна Дадзунбія, Північна Велика рівнина, Північна Угорщина, Південне Придністров'я, Південна Велика рівнина та Західна Придністров'я.

\section{2. Участь країн В4 у пан'свропейських програмах територіального розвитку}

Після синхронного приєднання до СС у 2004 р. країни Вишеградської Четвірки стали повноцінними учасниками комплексних програм та фондів $\mathrm{CC}$, присвячених розбудові територіального устрою. Серед них можна окремо виділити: Стратегію «Свропа-2020» (комплексна програма розвитку, яка стосується також деяких регіональних аспектів); «Територіальний порядок денний Свропейського Союзу до 2020 р.»; національні програми розвитку, які представляють локальний підхід (place-based approach) (Рис. 1).

Крім того країни Вишеградської четвірки (Польща, Чехія, Словаччина, Угорщина), а також Болгарія та Румунія (V4+2) виділяють як окремий пріоритет формування і підтримку полюсів та осей розвитку на своїх теренах, заклавши принцип поляризації у національні програми просторового будівництва. Заради гармонізації національних ініціатив ними була сформована Спільна програма просторового розвитку країн Вишеградської четвірки, Болгарії і Румунії.

Нижче ми розглянемо основні аспекти притаманні двом вищезгаданим програмам.

\section{1. Суть та цілі стратегії «Європа 2020»}

«Європа 2020» являє собою 10-річну стратегію, розроблену Європейською Комісією як продовження Лісабонської стратегії на 2000-2010 роки. ÏÏ мета «розумний, стійкий, інклюзивний ріст», забезпечений вищим рівнем координації як національної, так і європейської політики.

В рамках стратегії «Свропа 2020» $Є С$ встановив п'ять амбітних цілей - у сферах зайнятості, освіти, інновацій, клімату та енергетики, та соціальної інтеграції, які, як очікується, будуть досягнуті до 2020 року (див. Таблиця 1). Кожен член ЄС затвердив свої власні національні цілі у кожній із цих сфер. 


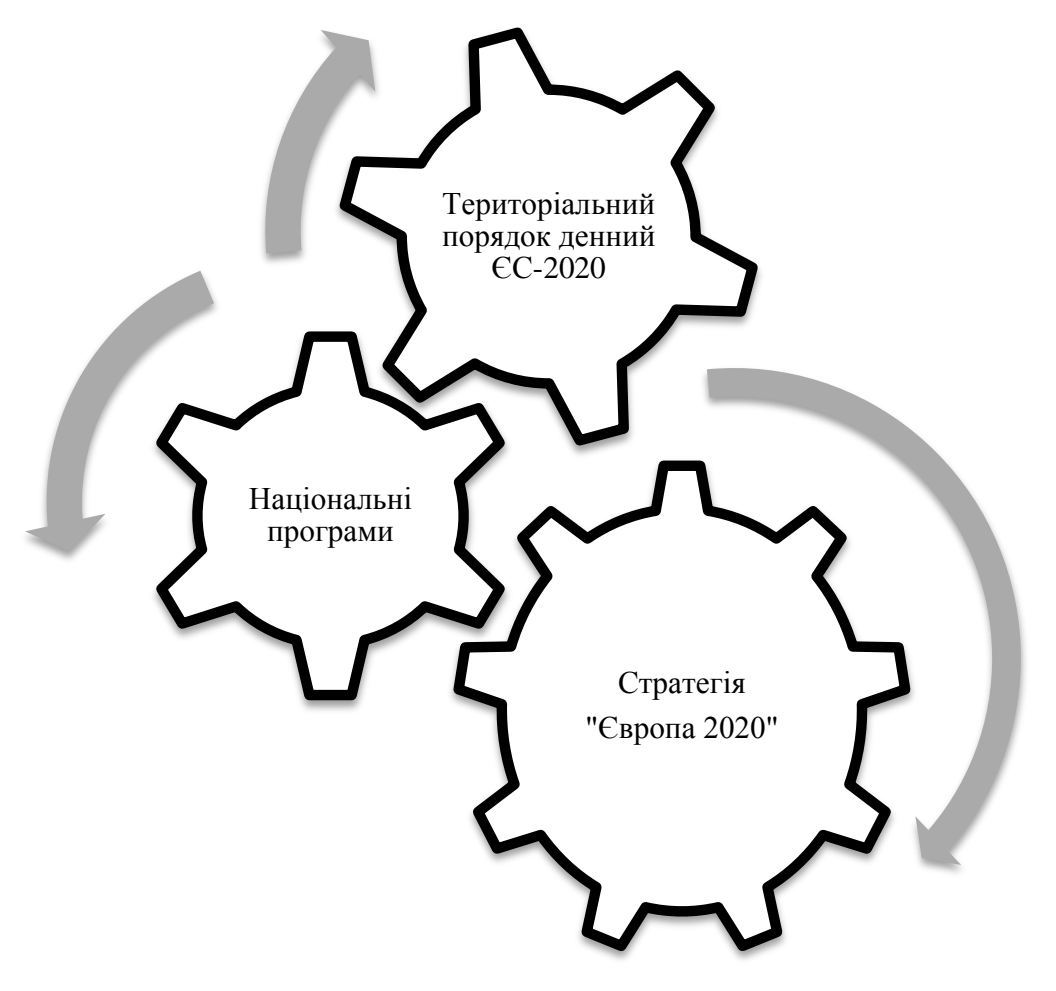

Рис. 1. Програми територіального розвитку в $\mathrm{EC}^{1}$

Таблиця 1

Завдання (таргети) стратегії «Свропа 2020» (рівень $\mathbf{C C})^{2}$

\begin{tabular}{|c|c|}
\hline Сфера & Ціль \\
\hline 1. Зайнятість & $\begin{array}{l}\text { • досягнення 75\%-ї зайнятості серед } \\
\text { 25-60-тирічного населення }\end{array}$ \\
\hline 2. R\&D/ Інновації & - 3\% ВВП ЄС будуть інвестовані в R\&D/ Інновації \\
\hline 3. Зміна клімату/енергія & $\begin{array}{l}\text { - } \quad \text { викиди парникових газів на 20\% нижчі, ніж в } \\
1990 \text { р. (або навіть } 30 \% \text { за певних умов) } \\
\text { • } 20 \% \text { енергії від поновлюваних джерел енергії } \\
\text { • } 20 \% \text { підвищення енергоефективності }\end{array}$ \\
\hline 4. Освіта & $\begin{array}{l}\text { - зменшення кількості незавершень шкільної } \\
\text { програми до } 10 \% \\
\text { • щонайменше } 40 \% \text { 30-34-річного населення } \\
\text { отримало вищу освіту }\end{array}$ \\
\hline $\begin{array}{l}\text { 5.Зменшення бідності } \\
\text { та соціальної ізоляції }\end{array}$ & $\begin{array}{l}\text { - усунення ризику бідності та соціальної ізоляції } \\
\text { як мінімум у } 20 \text { мільйонів людей }\end{array}$ \\
\hline
\end{tabular}

Очікується, що вищезазначені цілі будуть досягнуті за допомогою семи взаємопов'язаних флагманських ініціатив (див. Рис. 2). Влада ЄС та державичлени повинні координувати свої зусилля в межах кожної ініціативи.

\footnotetext{
${ }^{1}$ Territorial Agenda 2020 put in practice - Enhancing the efficiency and effectiveness of Cohesion Policy by a place-based approach. [Електронний ресурс] - режим доступу: http://ec.europa.eu/regional_policy/en/information/ publications/studies/2015/territorial-agenda-2020-put-in-practice-enhancing-the-efficiency-and-effectiveness-ofcohesion-policy-by-a-place-based-approach

${ }^{2}$ Europe 2020 Targets [Електронний ресурс] - режим доступу: http://ec.europa.eu/europe2020/pdf/targets_en.pdf
} 


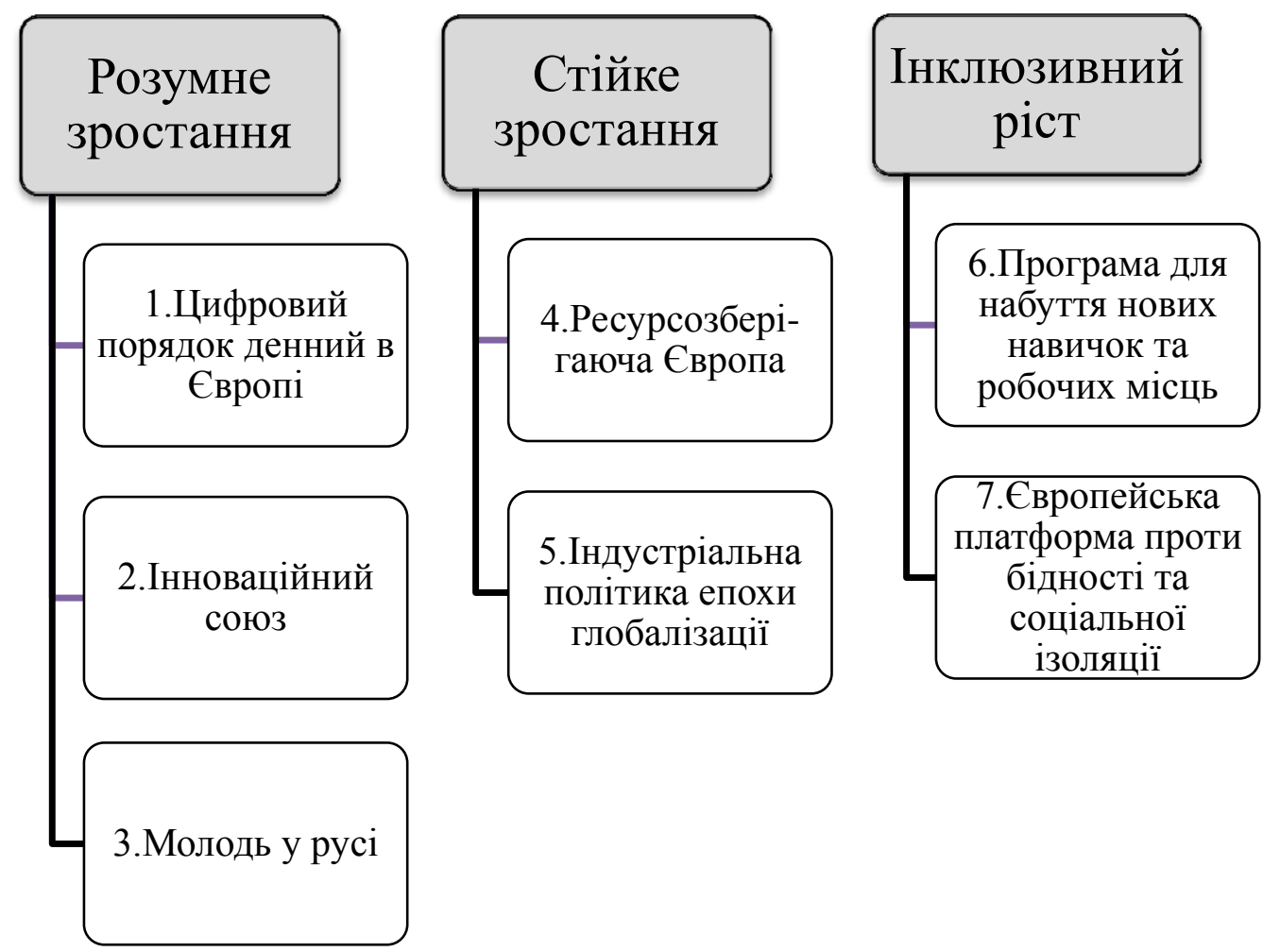

Рис. 2. Сім флагманських ініціатив стратегії Свропа 20201

Відповідно до Стратегії Свропа-2020 усіма державами-членами повинна бути підготовлені Національна програма реформ (НПР), що тісно пов'язана із Пактом про стабільність і зростання (ПСЗ). НПР регламентує структурну політику в галузі економіки та зайнятості, тоді як у ПСЗ розглядаються державні фінанси. Обидва документи засновані на тому ж макроекономічному середовищі. НПР виділяє вузькі місця та соціально-економічні реакції у сферах макрофінансової стабільності; ринку праці; зовнішньої рівноваги та конкурентоспроможності; соціального захисту та інтеграції. Як вже було зазначено, кожна держава-член визначає свої національні цілі. Наприклад, цілі країн В4 представлені в Таблиці 2.

Цілі стратегії «Європа-2020» потребують достатніх інвестицій. Крім того, якість витрат $є$ не менш важливою, ніж їх кількість. 3 фінансової точки зору, політика когезії може суттєво субсидіювати цілі стратегії «Європа-2020», але на місцевому, регіональному та національному рівнях також доступні численні інші джерела фінансування:

- власні ресурси місцевої влади;

- ресурси місцевих партнерів;

- субсидії муніципальних та регіональних органів;

- державно-приватне партнерство.

Протягом останніх років бюджет ЄС фінансує стратегію «Європа 2020» за допомогою трьох основних інструментів:

\footnotetext{
${ }^{1}$ Delivering on the Europe 2020 Strategy. Handbook for Local and Regional Authorities [Електронний ресурс] режим доступу: https://www.cor.europa.eu/en/documentation/brochures/Documents/delivering-on-theeurope/delivering-on-the-europe_English.pdf\&usg=AOvVaw1KY7XLrttv-i_x3BfJAkwJ
} 
- Європейський фонд регіонального розвитку (ERDF) фінансує розвиток конкурентоспроможності та співпраці регіонів, подолання економічного спаду в промисловості та сільському господарстві (201 мільярд євро);

- Європейський соціальний фонд (ESF), відповідальний за зайнятість, соціальну інтеграцію та боротьбу з дискримінацією (76 мільярдів євро);

- Фонд когезії (CF) охоплює витрати на навколишне середовище та транспорт (70 мільярдів євро).

Таблиця 2

Таргети стратегії «Свропа 2020» для країн $B 4^{1}$

\begin{tabular}{|c|c|c|c|c|c|c|c|c|}
\hline 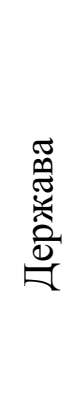 & 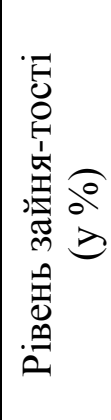 & 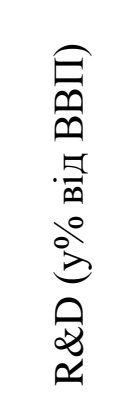 & 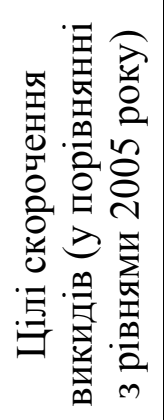 & 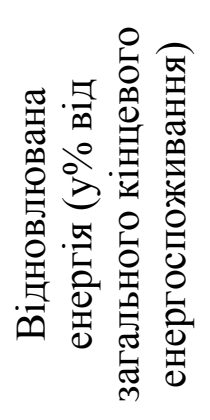 & 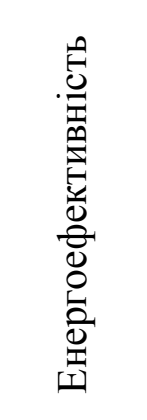 & 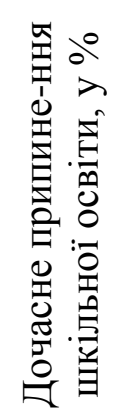 & 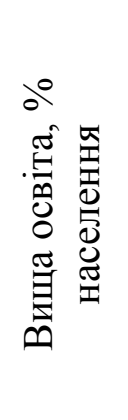 & \begin{tabular}{|c} 
Зниження кількості \\
населення, що \\
перебуває під \\
ризиком бідності або \\
соціального \\
відторгнення \\
(за кількістю осіб)
\end{tabular} \\
\hline CZ & $75 \%$ & $\begin{array}{c}1 \% \\
\text { (лише } \\
\text { держ. } \\
\text { сектор }\end{array}$ & $9 \%$ & $13 \%$ & $39,6 \%$ & $5,5 \%$ & $32, \%$ & \begin{tabular}{|c|} 
Підтримка кількості \\
осіб, які перебувають \\
під ризиком бідності \\
та соціальної ізоляції, \\
на рівні 2008 року \\
(15,3\% від загальної \\
чисельності \\
населення), із ціллю \\
зменшити ії до 30000
\end{tabular} \\
\hline $\mathrm{HU}$ & $75 \%$ & $1,8 \%$ & $10 \%$ & $14,65 \%$ & $26,6 \%$ & $10 \%$ & $30,3 \%$ & 450000 \\
\hline PL & $71 \%$ & $1,7 \%$ & $14 \%$ & $15 \%$ & $94,6 \%$ & $4,5 \%$ & $45 \%$ & 1500000 \\
\hline SK & $72 \%$ & $1,2 \%$ & $13 \%$ & $14 \%$ & $16,2 \%$ & $6 \%$ & $40 \%$ & 170000 \\
\hline
\end{tabular}

\section{2. Територіальний порядок денний Європейського Союзу 2020 року}

Концепція «територіальної когезії» досягла визнання на рівні $Є С$, особливо після ухвалення Лісабонського договору в 2007 році, де вона була однією із трьох основних цілей $Є С$. Важливим кроком на шляху практичної імплементації територіальної когезії є прийняття у 2011 році міжурядового «Територіального порядку денного Свропейського Союзу 2020» (англ. Territorial Agenda of the European Union 2020, ТА-2020) міністерствами СС, відповідальними за територіальний розвиток та територіальне планування.

Завданням ТА-2020 є надання стратегічних орієнтирів для розвитку територій, сприяння формуванню політики на місцях та затвердження Стратегії «Европа 2020» відповідно до принципів територіальної згуртованості, які передбачають гармонійний, ефективний, стійкий, збалансований територіальний розвиток.

Зокрема, ТА-2020 визначає шість територіальних пріоритетів для $\mathrm{CC}$, які можуть сприяти успішній реалізації Стратегії СС-2020:

\footnotetext{
${ }^{1}$ Europe 2020 Targets [Електронний ресурс] - режим доступу: http://ec.europa.eu/europe2020/pdf/targets_en.pdf
} 
- Сприяння поліцентричному та збалансованому територіальному розвитку як важливій передумові територіальної когезії та важливого фактору територіальної конкурентоспроможності;

- Заохочення інтегрованого розвитку міст, сіл та регіонів задля досягнення синергії та кращого використання місцевих територіальних активів;

- Територіальна інтеграція в транскордонні та транснаціональні функціональні регіони як ключовий чинник глобальної конкуренції, що сприяє кращому використанню потенціалів розвитку та захисту природного середовища;

- Забезпечення глобальної конкурентоспроможності регіонів на основі сильної місцевої економіки як ключового чинника глобальної конкуренції, що перешкоджає злиттю людського капіталу та зменшенню вразливості до зовнішніх потрясінь розвитку;

- Підвищення територіального зв'язку окремих осіб, громад та підприємств як важлива передумова територіальної когезії (наприклад, послуг загального інтересу); сильний фактор територіальної конкурентоспроможності та важлива умова сталого розвитку;

- Управління та поєднання екологічних, ландшафтних та культурних цінностей регіонів, включаючи спільне управління ризиками як важливу умовою довгострокового сталого розвитку.

«Європа 2020» - поточна ключова стратегія ЄС на наступні 10 років. Вона спрямована на забезпечення «нових робочих місць та кращого життя» шляхом стимулювання «розумного, сталого і всеохоплюючого зростання» протягом найближчого десятиліття. ТА-2020 також висуває амбіційну мету, хоча вона конкретно стосується територіального розвитку СС. Хоч цей документ також призначений для широкої аудиторії, він отримав нижчий рівень суспільного визнання, ніж «Стратегія Свропи 2020». Цей факт, мабуть, випливає з процесу розробки, який був, по суті, міжурядовим, тобто співпраці між національними органами, відповідальними за територіальне планування та територіальний розвиток в СС. Отже, ТА-2020 не був офіційно прийнятим жодним органом СС.

Таким чином, «Свропа 2020» та ТА-2020 беруть початок від різних політичних процесів і мають протилежний політичний статус. Проте існує тверде переконання, що їх слід використовувати для підсилення один одного. Зростання вимагає відповідних кроків політики територіального розвитку, включаючи просторову справедливість, охорону природи та культури, а також розумне використання територіальних ресурсів, багато з яких є (практично) невідновними. Ось чому в ряді країн СС стратегії розвитку поєднують просторові та соціально-економічні міркування.

Незважаючи на те, що поняття територіальної когезії неодноразово зустрічається в стратегії «Європа 2020», цей документ не пропонує жодних конкретних керівних принципів для територіального характеру своїх пріоритетів, а також не розглядає територіальні наслідки запропонованих заходів. Як підкреслено Генеральними директорами міністерських відомств, відповідальними за політику територіального розвитку в Свропейському Союзі, деякі питання, які розглядаються в стратегії «Європа 2020», мають значний вплив на європейський територіальний розвиток, проте посилання на територіальну єдність в документі могли бути більш очевидний.

TA-2020 спрямований на забезпечення стратегічних орієнтирів для розвитку територій, сприяння інтеграції територіального виміру в рамках різних політик 
на всіх рівнях державного управління, а також контролю за імплементацією стратегії «Європа 2020» відповідно до принципів територіальної єдності.

У наведеній нижче матриці проаналізовано зв'язок між пріоритетами ТА-2020 та «Європою 2020». Проте, слід зазначити, що це лише ілюстрація того, як цілі обох політик можуть бути співставленні разом і зміна інтерпретації цілей також призведе до зміни таблиці. Через «просторово сліпий» характер цілей «Свропа 2020» для значної кількості клітин не було знайдено кореспонденції.

Таблиця 3

Кореспонденція між пріоритетами «Свропа 2020» та ТА 2020 ${ }^{1}$

\begin{tabular}{|c|c|c|c|}
\hline & \multicolumn{3}{|c|}{ «Європа 2020» пріоритети/головні цілі } \\
\hline & $\begin{array}{c}\text { Розумне } \\
\text { зростання: } 3 \% \\
\text { BBП в R\&D }\end{array}$ & $\begin{array}{c}\text { Стійке } \\
\text { зростання: } \\
\text { 20/20/20 } \\
\text { кліматичні/ } \\
\text { енергетичні цілі }\end{array}$ & Інклюзивний ріст \\
\hline $\begin{array}{l}\text { 1. Поліцентричний та } \\
\text { збалансований } \\
\text { територіальний розвиток }\end{array}$ & + & $\begin{array}{c}\text { Відсутня пряма } \\
\text { відповідність }\end{array}$ & + \\
\hline $\begin{array}{l}\text { 2. Комплексний } \\
\text { розвиток у містах, } \\
\text { сільських та окремих } \\
\text { регіонах }\end{array}$ & + & + & + \\
\hline $\begin{array}{l}\text { 3.Територіальна } \\
\text { iнтеграція у } \\
\text { транскордонні, } \\
\text { транснаціональні } \\
\text { функціональні регіони }\end{array}$ & + & $\begin{array}{c}\text { Відсутня пряма } \\
\text { відповідність }\end{array}$ & $\begin{array}{c}\text { Відсутня пряма } \\
\text { відповідність }\end{array}$ \\
\hline 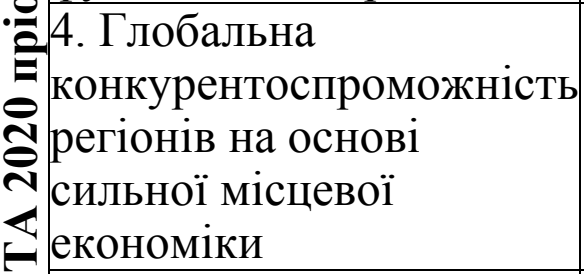 & + & + & + \\
\hline \begin{tabular}{|l}
. Покращення \\
територіального зв’язку \\
окремих осіб, громад та \\
підприємств
\end{tabular} & + & + & + \\
\hline $\begin{array}{l}\text { 6. Управління та } \\
\text { по'єднання екологічних, } \\
\text { ландшафтних та } \\
\text { культурних цінностей } \\
\text { регіонів }\end{array}$ & + & $\begin{array}{c}\text { Відсутня пряма } \\
\text { відповідність }\end{array}$ & $\begin{array}{c}\text { Відсутня пряма } \\
\text { відповідність }\end{array}$ \\
\hline
\end{tabular}

Але навіть у полях, позначених (+), що виражають існування відповідності, загалом нелегко знайти конкретні територіальні виміри для з'ясування їх

${ }^{1}$ Böhme, K., Doucet, P., Komornicki, T., Zaucha, J., \& Świątek, D. (2011). How to strengthen the territorial dimension of 'Europe 2020' and the EU Cohesion Policy. Report based on the Territorial Agenda, 2020 
характеру. Відносна недостатня синергія між «Європою 2020» та ТА 2020 може також частково пояснюватися психічними та інституційними бар'єрами, що розділяють сфери територіального розвитку та соціально-економічного зростання. «Європа 2020» недооцінює вплив територіальних структур на інтелектуальне, стале та інклюзивне зростання. Такі поняття, як доступність, функціональні зони, територіальний капітал та послуги із загальним економічним інтересом навіть не згадуються в документі, тоді як мережі обмежуються транспортними та інфраструктурними. I навпаки, ТА-2020 часто вживає такі терміни як розумний, стійкий та всеохоплююче зростання, але не дає конкретних прогнозів про те, як це зростання може перетворити територію ЄС у довгостроковій перспективі.

\section{3. Спільна стратегія просторового розвитку країн Вишеградської четвірки, Болгарії і Румунії}

Іншим важливим документом для розвитку регіонів В4 стала Спільна стратегія просторового розвитку країн Вишеградської четвірки, Болгарії i Румунії, т. зв. В4+2 (англ. Common Spatial Development Strategy of the V4+2 Countries). В даній програмі окреслюються «полюси розвитку», що являють собою осередки міських агломерацій, які впливають на прилеглі зони; а також «осі розвитку», тобто території, які з'єднують окремі полюси за наявності транспортної та іншої інфраструктури.

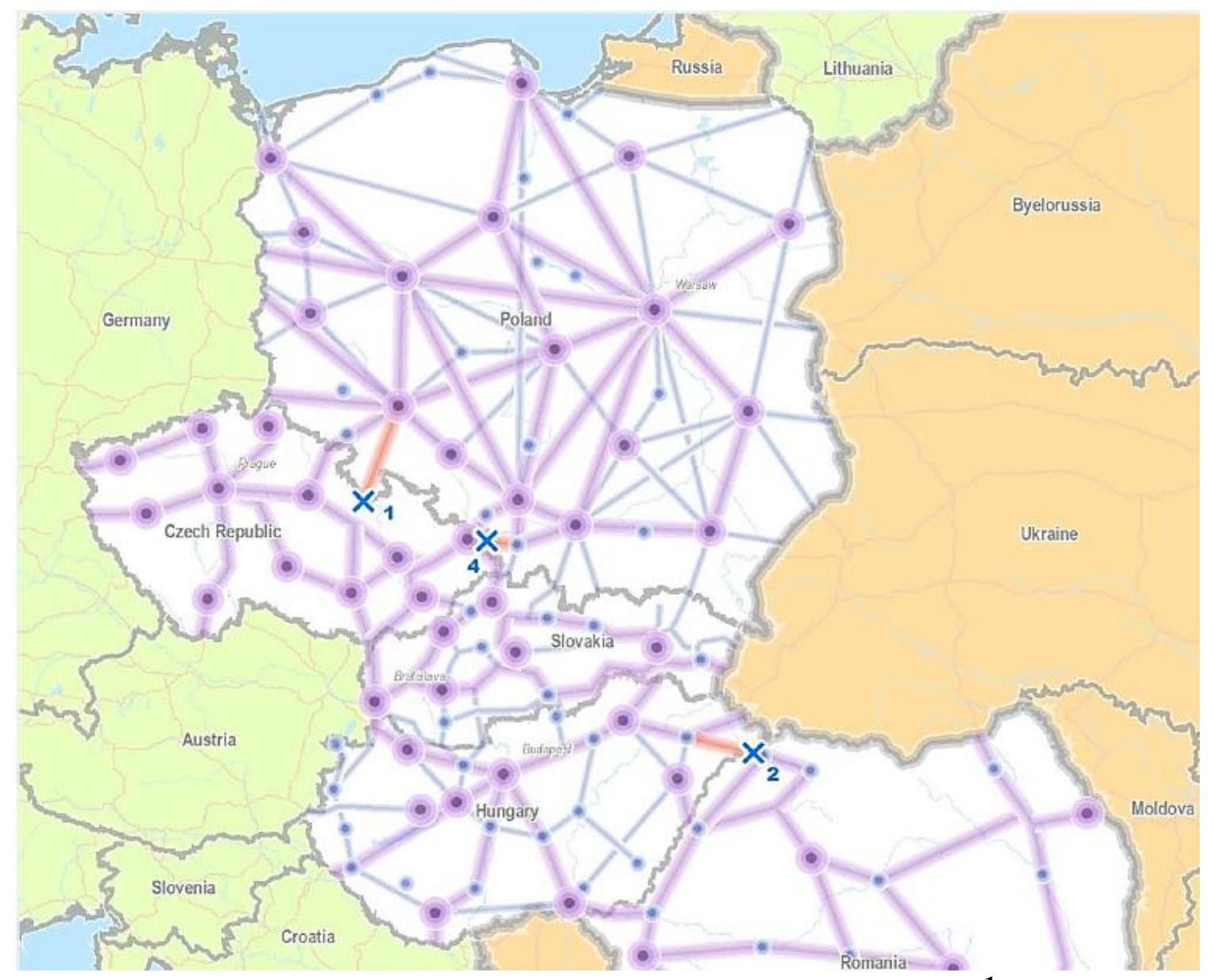

Рис. 3. Полюси та осі розвитку в країнах $\mathrm{B} 4^{1}$

\footnotetext{
${ }^{1}$ Common Spatial Development Strategy of the V4+2 Countries [Електронний ресурс] - режим доступу: http://www.v4plus2.eu/en
} 
Метою Спільної Стратегії є:

- сприяння узгодженню та оновленню національних документів про просторовий розвиток та розвитку транспортних мереж та мереж технічної інфраструктури;

- підтримка просторової когезії в Свропі (в руслі із ТА-2020);

- сприяння координації різних галузевих політик, які впливають на просторовий розвиток;

- аргументація та підтримка країн В4+2 під час дискусій на рівні ЄС щодо питань політики просторового розвитку, політики згуртованості, транспортної та енергетичної політики.

На Рис. 3 наведені основні полюси розвитку держав В4, а також осі розвитку, котрі їх сполучають. Окремо виділені потенційні міжкордонні осі, які наразі перебувають на початковому етапі становлення.

\section{3. Національні програми територіального розвитку країн В4}

Окрім загальноєвропейських чи регіональних програм територіального розвитку, кожна із держав В4 прийняли національні програми розвитку.

\section{1. Національна концепція просторового розвитку Польщі 2030}

Бачення територіального поступу Республіки Польща закріплене в Національній концепції просторового розвитку 2030 (пол. $K P Z K 2030)^{1}$, що була затверджена в 2011 p. Концепція KPZK бачення базується на п'яти бажаних характеристиках польського соціально-економічного простору: конкурентоспроможності та інноваційності, внутрішній згуртованості (когезії), біологічному багатству i різноманітності, а також безпеці і просторовому порядку.

Основною віхою Концепції стало формування поліцентричної мережі метрополій, які розглядались в якості полюсів розвитку, а також міст регіонального значення.

Згідно KPZK 2030 мережа метрополій включає:

- Метрополії:

- пан'європейського значення: столиця Варшава;

- національного значення: Сілезька агломерація, Краків, Лодзь, Тримісто (агломерація, що об’єднує Гданськ, Сопот та Гдиню), Познань, Вроцлав, Бидгощ, Торунь, Щецин, Люблін;

- міста, що виконують деякі функції метрополій: Білосток, Жешув, Зелона

Гура, Кельце, Ольштин, Ополе, Горжу Велькопольськи.

- Основні функціональні осі;

- Регіональні міста: Плоцьк, Влоцлавек, Кошалін, Славськ, Ельблонг, Грудзьондз, Бельско-Бяла, Рибнік, Ченстохова, Легниця, Валбжих, Тарнув, Радом, Каліш, Острув-Велькопольський;

- Додаткові функціональні осі.

Порівняння основних проектних полюсів та осей розвитку Польщі згідно програм 2010 та 2030 рр. наводиться на Рис. 4.

\footnotetext{
${ }^{1}$ Koncepcja Przestrzennego Zagospodarowania Kraju 2030
} 

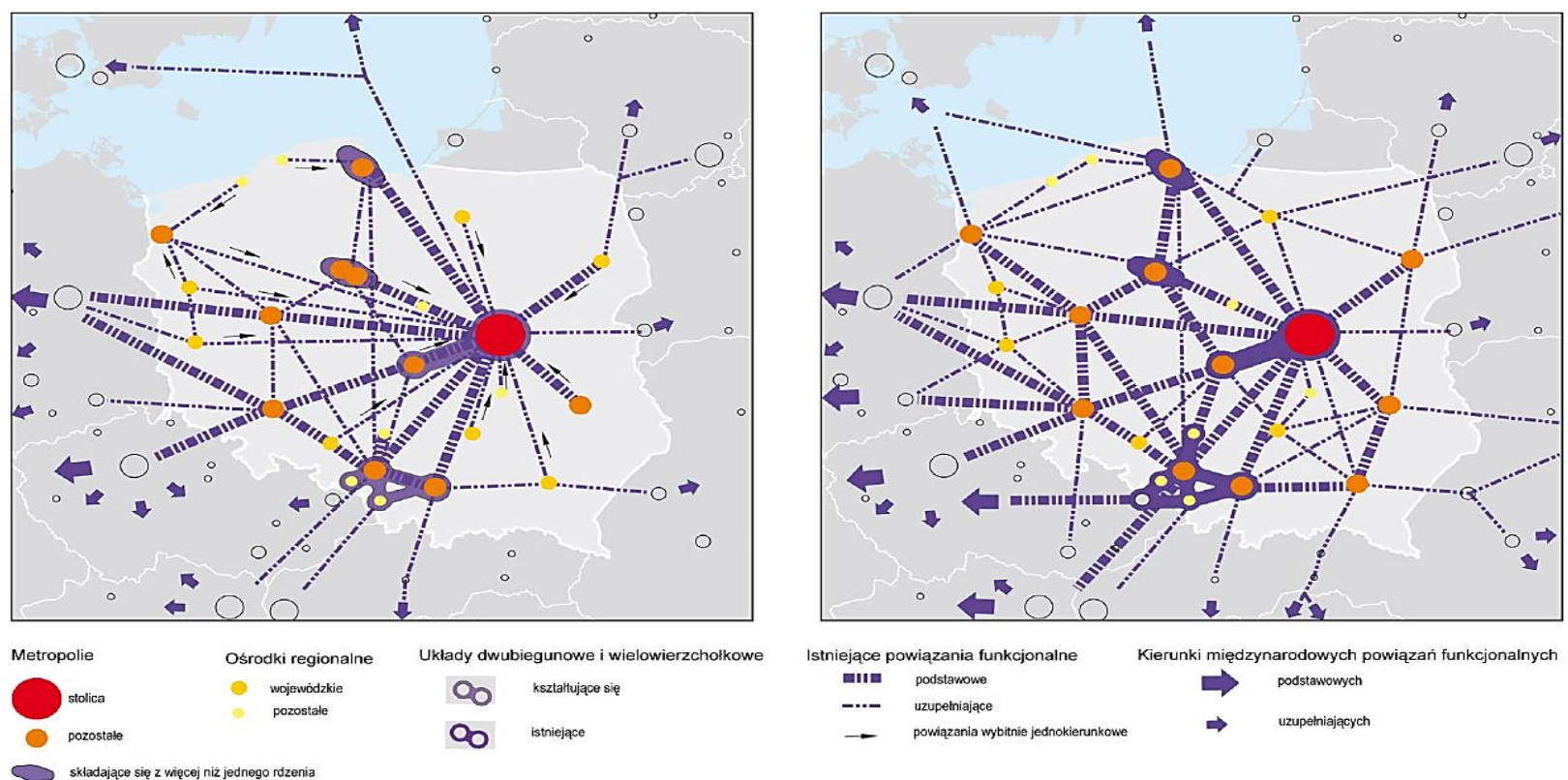

Рис. 4. Порівняння структури полюсів та осей розвитку Польщі в 2010 p. із проектом 2030 p.

Особливістю просторового розвитку Польщі є важлива роль, яку відводять спеціальним економічним зонам (СЕ3). Однак варто зауважити, що СЕЗ не $\epsilon$ панацеєю самі по собі і можуть розвиватись як за позитивним так і негативним сценаріями. Так, зони потенційно можуть стати платформою для появи несприятливих ефектів, які не тільки не стають тригерами економічного росту але, навпаки, можуть йому перешкоджати чи генерувати негативні процеси, які інтенсифікують один одного (тобто має місце феномен негативної синергії).

У Польщі спеціальні економічні зони створені в 356 муніципалітетах, що становить $14 \%$ усіх муніципалітетів (рівень LAU2 за NUTS) у Польщі, а їх загальна площа не перевищує 12000 га. Незважаючи на те, що феномен CE3 отримав значну популярність серед політиків та економістів, даним територіям притаманна висока географічна дисперсія, а відповідно вони значно впливають на локальну економіку лише у обмежених випадках, а їх роль для регіональних економік майже не відчутна.

Нещодавнє дослідження проведене групою дослідників ${ }^{2}$ (Г. ГодлєвскаМайковска, А. Комор, М. Тупа) продемонструвало взаємозв'язок між активністю СЕЗ та економічним розвитком муніципалітетів. Для аналізу враховувались показники кумулятивних інвестицій та кількості робочих місць (в т. ч. новостворених) в СЕЗ, кількість суб'єктів підприємницької діяльності на тис. осіб, частка податків до муніципального бюджету та інші індикатори.

Згідно результатів дослідження, спеціальні економічні зони продемонстрували значну важливість для економічного розвитку лише 27 iз 356 муніципалітетів. Проте із цих 27-ми муніципалітетів лише 8 володіли характеристиками полюса зростання (тобто були центрами поляризованого

\footnotetext{
Koncepcja Przestrzennego Zagospodarowania Kraju 2030 [Електронний ресурс] - режим доступу: https://www.mr.gov.pl/strony/zadania/polityka-rozwoju-kraju/zarzadzanie-rozwojem-kraju/koncepcja-przestrzennegozagospodarowania-kraju

${ }^{2}$ Godlewska-Majkowska, H., Komor, A., \& Typa, M. (2016). Special Economic Zones as Growth and Anti-growth Poles as Exemplified by Polish Regions. Entrepreneurial Business and Economics Review, 4(4), 189.
} 
регіону, що демонстрували значно вищий темп росту, у порівнянні із рештою території регіону), інші ж 19 муніципалітетів характеризувались нестабільним економічним розвитком. Полюси зростання розміщувались переважно в південно-західній Польщі (Polkowice, Legnickie Pole, Nowogrodziec, JelczLaskowice) та спорадично в інших регіонах (Glogow Malopolska, Nowe Skalmierzyce, Gliwice, Ksawerów).

\section{2. Концепція просторового розвитку Словаччини}

Перша фундаментальна програма територіальної організації Словаччини була прийнята в 2001 р. («Концепція просторового розвитку Словаччини») та доповнена в 2011 р. (з того часу загальновживаною абревіатурою програми стала KURS-2011). Основоположним принципом програми став поліцентричний розвиток регіонів, причому серед усіх розглянутих нами країн, саме в Словацькій програмі найбільш детально розписуються напрямки формування просторової структури держави.

Лейтмотивом програми KURS-2011 є ранжування системи населених пунктів на фокусні (фокальні) групи, що включають агломерації, групи населених пунктів та осі розвитку трьох рівнів. Очікувана структура полюсів та осей розвитку в Словаччині має наступний вигляд (Рис. 5):

1. Фокальні центри найвищого рівня (1-ша категорія):

a. особлива група: Братіславо-Трнавська агломерація;

b. Кошицько-Прешовська агломерація;

c. біполярні полюси: Банскобистрицько-Зволенський, Жилінсько-

Мартінський;

d. моноцентричні полюси: Нітранський, Тренчинський;

2. Осі розвитку першого рівня (1-ша категорія) - 10 пріоритетних осей;

3. Полюси другого рівня (2-га категорія) - Липтовски Мікулаш, Лученец, Міхаловце, Нове Замки, Попрад, Поважська Бистриця, Прієвіда;

4. Осі розвитку другого рівня (2-га категорія) - 13 осей;

5. Полюси третього рівня включають дві підгрупи. До першої підгрупи відносяться полюси, які виникли на основі доцентрових сил серед групи невеликих міст (8 полюсів). До другої групи відносять полюси меншої важливості, які сформувались на основі доцентрових сил в одному населеному пункті, тобто поляризація центру та околиць (19 полюсів);

6. Осі розвитку третього рівня - 29 осей.

Перспективи розвитку системи населених пунктів в Словаччині грунтується загалом на двох засадах:

- встановлення взаємозв'язків із пан'європейською системою населених пунктів;

- створення сприятливих умов для сталого розвитку суспільства.

Окрім економічних передумов соціального розвитку та поточних тенденцій глобалізації, які тісно пов'язані із просторовою структурою, можна також виділити низку інших факторів підвищеної важливості для міжнародного «включення» полюсів та осей розвитку Словаччини:

1. Геоморфологічні та локаційні особливості як окраїнних так і внутрішніх територій Словаччини (розташування між двома гірськими масивами Карпат та Альп, протікання Дунаю - річки європейсько значення). Гірський характер 
країни $€$ позитивним 3 огляду на становлення туристично-рекреаційного потенціалу, проте становить проблему для розвитку транспортної (в т. ч. транскордонної) мережі;

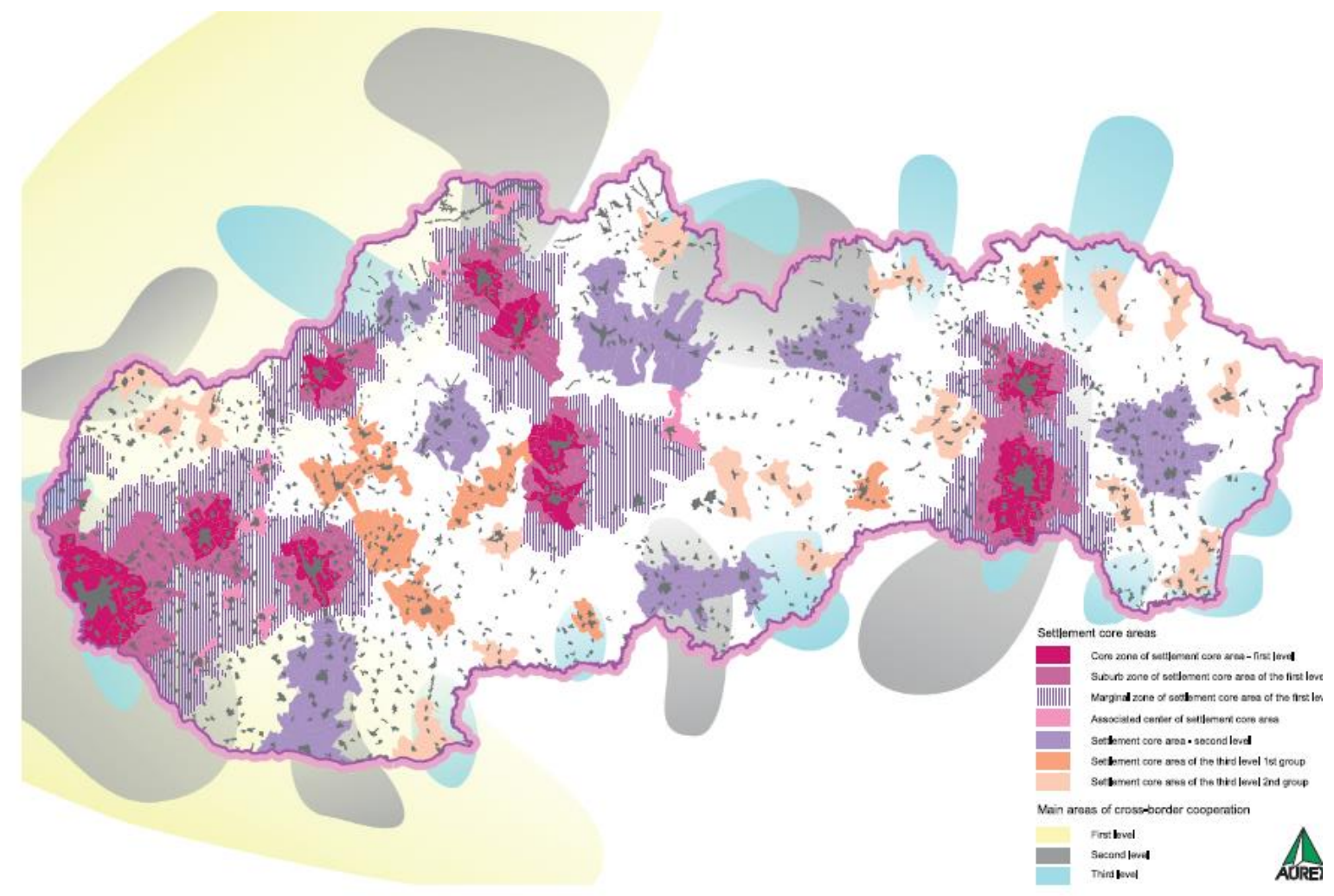

Рис. 5. Полюси розвитку в Словаччині ${ }^{1}$

2. Просторові особливості відносно сусідніх територій (розміщення в центрі Європи на межі СС та пост-радянського простору). Особливо в даному аспекті варто виділити наступні моменти:

- організація перспективної урбанізаційної осі розвитку переважно вздовж Дунаю за напрямком Штутгарт-Ульм-Мюнхен-Лінц/Зальцбург-Відень/ Братислава-Будапешт-Белград;

- наявність близьких густозаселених агломерацій європейського значення, таких як Відень, Будапешт та Катовіце-Острава;

- наявність поясу населених пунктів в напрямі із півночі на південь Моравії вздовж західного кордону Словаччини: Катовіце-Острава-Злін-БрноВідень;

- домінування агломерації Кошице-Прешов в «Карпатському регіоні» на стику із Польщею, Угорщиною та Україною.

3. Можливості організації транскордонних систем населених пунктів;

4. Наявність та проектування транспортних мереж через територію Словаччини (в першу чергу мається на увазі розвиток Трансєвропейської транспортної мережі TEN-T).

\footnotetext{
1 Slovak Spatial Development Perspective [Електронний ресурс] - режим доступу: http://www.telecom.gov.sk/index/index.php?ids=172817 


\section{3. Політика просторового розвитку Чеської Республіки 2008}

Одним із пріоритетів Політики просторового розвитку Чеської Республіки 2008 (PÚR ĆR 2008), затвердженого урядом у 2009 році, є сприяння поліцентричному розвитку структури населених пунктів. Вона окреслює так звані регіони та осі розвитку, які визначаються як райони, де за рахунок концентрації діяльності міжнародного, національного та трансрегіонального значення, висуваються підвищені вимоги до характеру змін. Регіони та осі розвитку не є ієрархіфіковані (існує лише одна категорія). Це спричиняє порівняно більшу кількість основних полюсів розвитку в Чеській Республіці порівняно з іншими країнами В4.

Основні регіони розвитку та осі розвитку складаються з:

- 12 регіонів розвитку: Брно, Ческе Будейовице, Градец Кралове/ Пардубіце, Йіглава, Карлові Вари, Ліберець, Оломоуц, Острава, Пльзень, Прага, Усті-надЛабем, Злін (1-а категорія);

- осі розвитку, котрі сполучають вищенаведені регіони (1-а категорія) (Рис. 6).

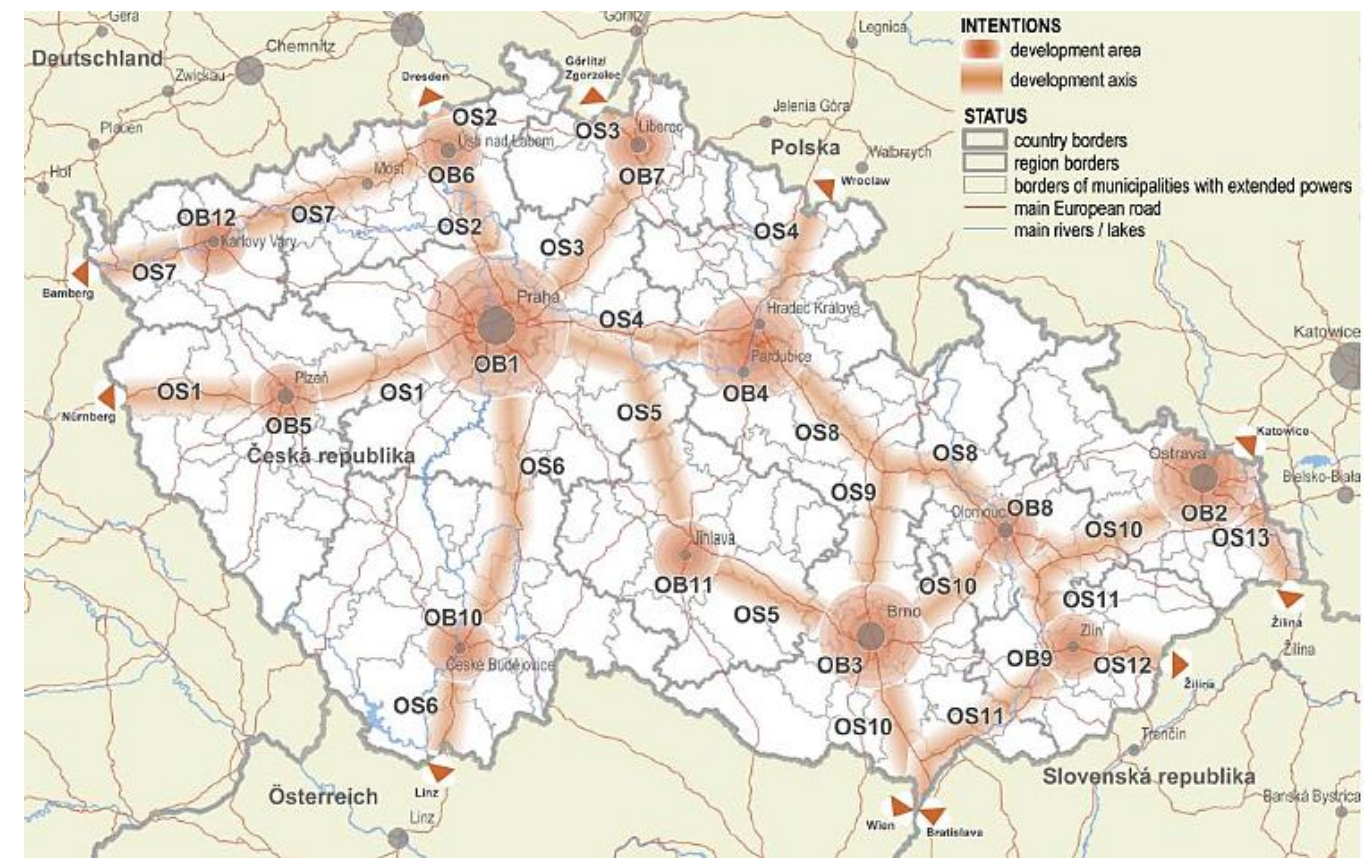

Рис. 6. Полюси та осі розвитку в Чехії Spatial Development Policy of the Czech Republic 2008

\section{4. Концепція національного розвитку та територіального розвитку Угорщини}

Концепція національного розвитку та територіального розвитку (National Development and Territorial Development Concept, NDTDC), прийнята парламентом у 2013 році, направлена на сприяння збалансованому поліцентричному розвитку в Угорщині. Для того, щоб розвиток не обмежувався лише територією столиці, економічні центри регіонів та округів залучаються до створення гармонійної, поліцентричної та кооперативної мережі, що покликана стати каталізатором зміцнення конкурентоспроможності.

Міська мережа складається 3 різних рівнів міських центрів та функціональних міських територій:

- столичний регіон Будапешт (категорія 0); 
- міські центри (потенційного) міжнародного значення (1-a категорія): Дебрецен, Сегед, Мішкольц, Печ, Дьор, Секешфехервар;

- міські центри державного значення (2-ая категорія): Кечкемет, Веспрем, Сольнок, Татабанья, Дунайваврос, Салготар'ян, Егер, Ниредьгаза, Шексард, Сомбатхей, Капошвар, Бекешчаба, Залаегерсег, Шопрон, Надьканіжа, Ходмежвасар'ї;

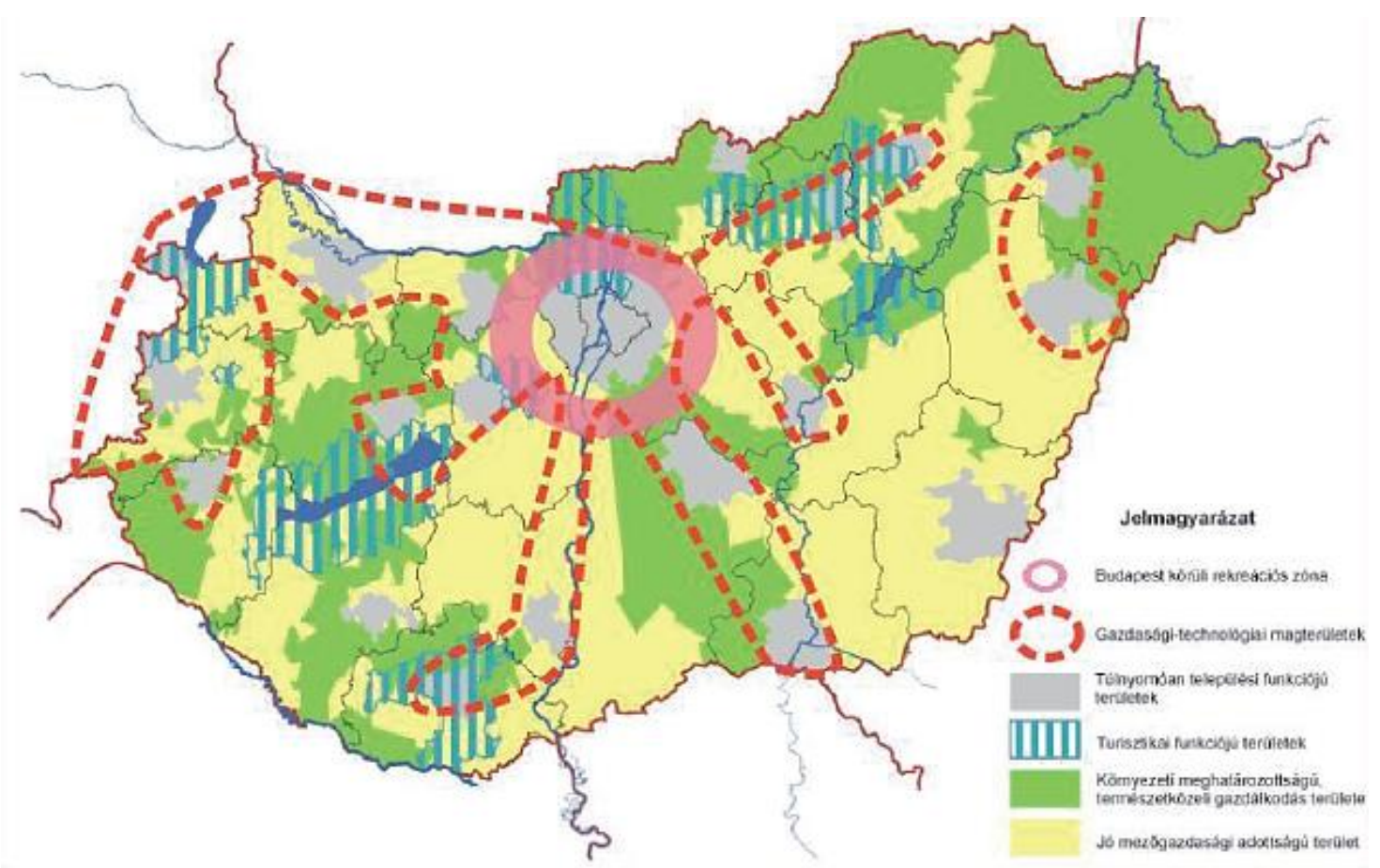

\section{Рис. 7. Функціональні регіони розвитку Угорщини ${ }^{1}$}

Осі розвитку Угорщини:

- міжнародні осі розвитку (1 категорія);

- осі регіонального розвитку (2-а категорія).

Oci регіонального значення також може перетинати державні кордони (у цьому сенсі вони також $є$ міжнародними або транскордонними осередками).

Висновки. Наведений вище матеріал дає можливість оцінити наскільки комплексним був підхід до територіального розвитку в держав Вишеградської четвірки. Приєднання до $Є \mathrm{C}$ надало новий стимул поліцентричному децентралізованому розвитку територій. Однак, варто відмітити, що пан'європейські програми не применшили важливість і не уніфікували національні особливості територіального поступу в регіоні.

Успішний досвід держав В4 може виявитись корисним і для України, яка тільки починає здійснювати перший етап адміністративно-територіальної реформи. Що ж стосується знову актуальних полюсів зростання, то вони в Україні розглядається переважно в суто теоретичній площині ${ }^{2}$. Крім того

\footnotetext{
${ }^{1}$ Nemzeti Fejlesztés 2030: Országos Fejlesztési és Területfejlesztési Koncepció [Електронний ресурс] - режим доступу: https://rio.jrc.ec.europa.eu/en/library/national-development-2030-national-development-and-territorialdevelopment-concept

2 Ліщинський, I. О. Стратегія формування полюсів зростання в Болгарії / I. О. Ліщинський // Вісник Тернопільського національного економічного університету. - 2016. - № 3. - С. 61-71.
} 
Україні ще потрібно пройти тривалий процес формування повноцінного активного громадянського суспільства. Значні зусилля також необхідно прикласти й в законотворчому процесі - насамперед в аспекті поліцентричного розвитку, нормативного регулювання діяльності великих міських агломерацій, становлення осей розвитку і т. п.

\section{Список використаних джерел:}

1. 25 years of transition: post-communist Europe and the IMF / James Roaf, Ruben Atoyan, Bikas Joshi, Krzysztof Krogulski and an IMF staff team. - Washington, D.C.: International Monetary Fund, 2014.

2. Agenda, T. 2020 (2011) Territorial Agenda of the European Union 2020-Towards an Inclusive, Smart and Sustainable Europe of Diverse Regions-Agreed at the Informal Ministerial Meeting of Ministers Responsible for Spatial Planning and Territorial Development on 19th May, Hungary: Gödöllő.

3. Böhme, K., Doucet, P., Komornicki, T., Zaucha, J., \& Świątek, D. (2011). How to strengthen the territorial dimension of 'Europe 2020'and the EU Cohesion Policy. Report based on the Territorial Agenda, 2020 [Електронний pecypc]. - Режим доступу: http://ec.europa.eu/regional_policy/sources/docgener/studies/pdf/challenges2020/2011_territorial_d imension_eu2020.pdf

4. Common Spatial Development Strategy of the V4+2 Countries [Електронний ресурс] режим доступу: http://www.v4plus2.eu/en/

5. Delivering on the Europe 2020 Strategy. Handbook for Local and Regional Authorities [Електронний pecypc]. - Режим доступу: https://www.cor.europa.eu/en/documentation /brochures/Documents/delivering-on-the-europe/delivering-on-theeurope_English.pdf\&usg=AOvVaw1KY7XLrttv-i_x3BfJAkwJ

6. Europe 2020 Targets [Електронний pecypc]. - Режим доступу: http://ec.europa.eu/ europe2020/pdf/targets_en.pdf

7. Godlewska-Majkowska, H., Komor, A., \& Typa, M. (2016). Special Economic Zones as Growth and Anti-growth Poles as Exemplified by Polish Regions. Entrepreneurial Business and Economics Review, 4(4), 189.

8. Innovative Strategies of Territorial Development of V4: Experience for Ukraine / Y. Savelyev, I. Lishchynskyy, M. Lyzun, K. Borsekova, M. Sokołowicz, K. Vitališova, Y. Kurylyak. - Ternopil: Terno-graf, 2016. - 216 p.

9. Koncepcja Przestrzennego Zagospodarowania Kraju 2030 [Електронний ресурс]. - Режим доступу: https://www.mr.gov.pl/strony/zadania/polityka-rozwoju-kraju/zarzadzanie-rozwojemkraju/koncepcja-przestrzennego-zagospodarowania-kraju/

10. Nemzeti Fejlesztés 2030: Országos Fejlesztési és Területfejlesztési Koncepció [Електронний pecypc]. - Режим доступу: https://rio.jrc.ec.europa.eu/en/library/nationaldevelopment-2030-national-development-and-territorial-development-concept

11. Slovak Spatial Development Perspective [Електронний ресурс]. - Режим доступу: http://www.telecom.gov.sk/index/index.php?ids=172817

12. Spatial Development Policy of the Czech Republic 2008 [Електронний ресурс]. - Режим доступу: http://www.uur.cz/Fimages/F1-uzemni-planovani-a-stavebni-rad/Fpolitika-uzemnihorozvoje-aktualizace-1-2015/Fpublikace-apur-cr-2015-

en.pdf\&usg=AOvVaw3EnvgQBzI2fq8si2Id5tQd

13. Territorial Agenda 2020 put in practice - Enhancing the efficiency and effectiveness of Cohesion Policy by a place-based approach. [Електронний pecypc]. - Режим доступу: http://ec.europa.eu/regional_policy/en/information/publications/studies/2015/territorial-agenda2020-put-in-practice-enhancing-the-efficiency-and-effectiveness-of-cohesion-policy-by-a-placebased-approach

14. Ліщинський, І. О. Стратегія формування полюсів зростання в Болгарії / I. О. Ліщинський // Вісник Тернопільського національного економічного університету. 2016. - № 3. - C. 61-71. 


\section{РЕФЛЕКСИВНІ ОРГАНІЗАЦІЯ ТА УПРАВЛІННЯ ПРАЦЕЮ ЯК РИСИ ПОСТСУЧАСНОЇ МОДЕРНІЗАЦЇ̈}

Анотація. Роботу присвячено важливим проблемам розвитку сочіальноекономічних відносин із погляду рефлексивних організаиї та управління працею. Досвід ЄС саме у иій сфері може стати вкрай важливим для підвищення можсливостей та мінімізації ризиків для країн Вишеградської групи. Для характеристики специфіки постіндустріальних тенденцій $i$ процесів використовуються також наукові праці з концепџій постмодерну, світосистемних змін, розробки дослідників шляхів рефлексивної модернізаиіі економіки та особливостей закономірностей постсоиіалістичних трансформацій. Вивчено актуальне співвідночення державного та корпоративного управління у формуванні трудових відносин постсучасного типу під впливом загальносвітових трансформацій завдяки посиленню тенденцій рефлексивноі модернізачії. Аналізуються зміни організаиійно-управлінських технологій під виливом загальносвітових тенденцій, можливості та межи рефлексивних впливів. Особлива увага надається змінам діапазону ефективного доповнення «жорсткої сили» (hard power) використанням «м'якого підходу» (sensitive side) до регулювання продуктивних сил та сочіально-економічних відносин. Використовується методологічна база відомої наукової школи Е. Гідденса.

Вступ. Соціально-економічне зростання суттєво залежить від уміння розвивати та використати наявний та можливий потенціал. Умови здійснення постсучасної модернізації як рефлексивної за своєю природою додатково потребують уваги саме до організації суспільного (зокрема, соціальноекономічного) середовища та кластерів ймовірних інновацій. Серед можливих напрямів змін особливо важливими для коротко-, середньо- та довготермінових наслідків перетворень $є$ системотворчі трудові та управлінські відносини. Причому характер проблем їх трансформацій є загальнорегіональним для країн Вишеградського співробітництва; втім, глибина розвитку та гострота проявів складних процесів суттєво залежать від якості та своєчасності організаційноуправлінських рішень. Відповідно, у цій сфері закладається баланс конкретних ризиків та можливостей від участі в інтеграційних трендах.

Аналіз літератури. Вже узагальнені фундаментальні положення у сфері організаційних технологій, а також менеджерських інновацій. В. Арнольд, I. Пригожин, Г. Хакен заклали основи синергетичних підходів до управління (зокрема, й працею). Помітний внесок до аналізу проблеми розвитку трудових відносин та їх детермінацій зробили вчені, що об'єдналися у відомий Римський клуб. В останні часи з'явилася низка цікавих робіт, у яких здійснено аналіз соціально-трудових проблем постсоціалістичного транзиту суспільства в руслі загальнозначимих світогосподарських зрушень, а також досліджень, що акцентують політичний аспект глобальних і регіональних трансформацій (С. Амін, С. Барнз, Ф. Бродель, Р. Мілібенд, Р. Фарен тощо). Змістовний аналіз 
постсучасного розвитку суспільства міститься у працях таких учених, як У. Бек, I. Валлерстайн, Е. Гідденс, А. Етціоні, Т. Карузерс, М. Кастельс, Н. Луман, В. Парето, Т. Парсонс, Р. Патнем, Дж. Пікклз, Ю. Хабермас тощо.

Окреслення мети. Західна теорія та практика управління детально розробили та застосували управлінсько-організаційні моделі, притаманні стабільній ринковій економіці. У країнах колишнього соціалістичного табору виходили дослідження з управління у відповідній господарській системі. Разом із тим дослідження цих проблем часто здійснювалися відокремлено, підходи та інструментарії різних шкіл не підтверджували, а послаблювали один одного. Водночас практична і теоретична апологетика адміністративного управління, його методів і системи прийшла до природної кризи. Але кризові моменти проявляються і в загальносвітових тенденціях розвитку раціонально-бюрократичного керівництва. Особливо недостатнім $є$ аналіз організації та управління в країнах, що водночас вирішують завдання постсучасних та пострадянських трансформацій, тому світова спільнота шукає нові шляхі та моделі у цьому напрямі.

Отже, метою роботи є аспект культивування економіки знань у країнах Вишеградської групи, що пов'язаний із можливостями стимулювання перспективних трендів, зокрема розвитком рефлексивних організації та управління працею.

\section{1. Креативні можливості соціально-економічних відносин під час здійснення рефлексивної модернізації суспільства}

Сьогодні співпали у часі найбільш кардинальні трансформації у зовсім різних сферах життя. Закладаються підвалини структури майбутнього. При цьому забезпечення довгострокової конкурентоспроможності національного проекту розвитку передбачає, що кожна країна (зокрема, Вишеградської групи) має ретельно узгоджувати зовнішньоекономічну діяльність зі ступенем зрілості внутрішніх реформ. Міжнародна спільнота інтенсивно шукає нові моделі взаємодії, балансу, економічного успіху, соціального розвитку та політичного устрою [1-4]. Без докорінної модернізації суспільства, зокрема соціальноекономічних відносин, будь-яка країна буде під загрозою кризи, отже, може підвищиться ймовірність перетворення на об'єкт зовнішніх маніпуляцій на користь чужих інтересів. Характерна риса постсучасного ешелону модернізації економіки та суспільства - рефлективність поведінки, відносин та процесів. Світовий досвід наочно продемонстрував, що для нормального функціонування національне господарство вимагає створення як адекватної інституційної бази у формі системи прав власності, юридичних інститутів, політичних механізмів прийняття рішень - усього, що прийнято називати «громадянським суспільством» $\mathrm{i}$ що формує необхідне середовище для функціонування ринкових агентів, так i кластерів майбутнього, котрі за глобального переходу до суспільства знань приймають вигляд науково-освітньо-виробничих комплексів. У цих умовах украй потрібні інституційна та структурна перебудова, зміни в технічному стані виробництва, який нині послаблює наші позиції в міжнародному поділі праці, визначає невигідну структуру імпорту й експорту. Проблема також у конкурентоспроможності вітчизняних товарів, в утриманні не тільки зовнішніх, а й внутрішніх ринків. Уже самі антидемпінгові заходи на міжнародний арені часто стають завуальованою зброєю протекціонізму, яку 
використовують для захисту від конкуруючого імпорту. Інколи антидемпінг 3 інструменту боротьби з недобросовісною конкуренцією сам перетворюється на iі інструмент.

Коли зростає рівень й жорсткість міжнародної конкуренції, необхідні адекватні відповіді, у тому числі з реалізації креативних можливостей цілісності соціально-економічних відносин, їх рефлексії [5-10]. В умовах глобалізації часто не тільки регіональна близькість, а й соціокультурні особливості, що формують соціокультурний капітал суспільства, за гармонії економічної свободи та державного регулювання стають чинниками, які багато в чому визначають конкурентоспроможність. До того ж маршрути й форми забезпечення цього успіху можуть бути вельми різноманітними та досить самобутніми. Ефективним є вивчення та аналіз логіки появи, ідеї певної інституції або механізму, а не автоматичне запозичення вдалої у конкретному середовищі схеми. Таким чином, існує переплетення чинників (і відповідних процесів) збереження національної ідентичності господарських структур і необмежених державними кордонами варіантів розвитку в реалізації стратегічних парадигм у конкурентній боротьбі, яке впливає на зрозуміння форм забезпечення національних інтересів у світі сьогодення. I питання не в тому, як «ліквідувати відставання» у чомусь, а в тому, як «зберегти та зростити наявні переваги», сконцентрувати ресурси та здійснити маневр ними, підтримати «точки росту», надати підтримку новим формам техніко-технологічного, соціально-економічного, духовно-ментального розвитку. До того ж у нинішніх господарських умовах бути успішним глобальним конкурентом означає знайти для себе адекватну своїм конкретним особливостям технологічну нішу. А це можливо і для невеликих структур, і для «аутсайдерів» (зміст цього терміну теж значно змінюється; зовсім різні шляхи можуть вести до необхідного результату). Аналогічні наявним у нашої країни можливості, пов'язані 3 географічним положенням, за своєчасної зміни спеціалізації вже були вдало використані, наприклад, деякими країнами форсованого розвитку, котрі виявилися здатні опанувати зовнішні ринки високотехнологічної продукції, перетворилися на регіональні центри логістики, здійснення маркетингових, інформаційних, транспортних та інших послуг. Отже, креативне використання власних особливостей дає змогу бути локомотивом подальшого росту сервисізації на базі рефлексії регіонального чиннику. Водночас під час їх дослідження, відбору, культивування та розповсюдження важливо не забігати наперед, не розпилюватися на другорядне, дрібне. Проте вкрай потрібні продуктивні соціально-економічні відносини за стабільними загальними «правилами гри», зокрема передбаченість темпів інфляції та курсу національної валюти, «законів iз вилучення» (податкових, митних зборів) та процедур їхнього застосування, відповідальність влади за свої дії перед суспільством і бізнесом. Важливо, що під час виконання сервісних послуг i відповідного зростання ролі регіону необхідно враховувати процеси на макрорівні, що кореняться в історичній спадщині та інституціональній пам'яті народу, а на мікрорівні використовувати соціопсихічні характеристики у взаємодії власне економічного та мотиваційного аспектів, отже, розвивати економічну психологію та поведінкову економіку [11-18].

Отже, кардинально змінюються умови, i щоб забезпечувати власну конкурентоздатність, необхідно змінюватися структурі соціально-економічного 
розвитку. Водночас досягнення інформаційної революції, 3 якими сьогодні асоціюється науково-технічний та соціально-економічний прогрес, досі репрезентовані часто-густо переважно у вигляді розрізнених анклавів, чужорідних вкраплень, в ліпшому випадку - відносно компактних надбудивль, які забезпечують зв'язок місцевих структур зі світовими ринками, але не мають глибоких коренів у середовищі. У цій ситуації концепція «рефлексивної модернізації» соціолога Е. Гідденса як раз і передбачає, що модернізація стає «рефлексивною», коли розрушуються базові принципи модерну, здійснюються «структурні мети зміни», непідвладні контролю і прогнозу. Ці трансформації йдуть під впливом таких чинників, як переорієнтація 3 матеріальних цінностей на постматеріальні, формування «суспільства знання», децентралізація влади. Згідно з ідеями Гідденса, постсучасність виробляє рефлексивне суспільство, де індивіди постають «соціальними теоретиками», здійснюючи переоцінку норм соціальної поведінки [19]. Система брендів починає визначати принципи організації соціально-економічних процесів. Здійснення моделей «рефлексивної модернізації» передбачає якісно нові моделі глобальної конкуренції, ефективне володіння якими вимагає більш повного використання творчих можливостей людей та креативного потенціалу економічних відносин узагалі. Коли творчий потенціал високого Модерну як мегапроекту розвитку ойкумени вичерпався та виявив свої межи, перспективи подальшого проведення прогресивних трансформації почали відкриватися у нових тенденціях, які інколи визначають як постмодерні. Природно, що сьогодні необхідні зовсім не контрмодерн, не заперечення Модерну та не відмова від його спадщини; було б невірно зводити зміст постмодерну і до банального перекладу як «після» модерну. Отже, йдеться про інше: зміну моделей розвитку та організації соціально-економічних відносин, підвищення ступені плюралізму трансформації, можливість конструктивного поєднання рис різноманітних тенденцій, рефлексивне враховування їх. Звісно, постсучасність - безпосередньо зовсім не контрмодерн, оскільки визнає розвиток та не відміняє можливості модерну. Але постсучасність може зірватися до контрмодерну. Тоді зміцнюються саме негативні форми відчуження, більш міцно відчуваються спроби маніпулювання методами потайного керування, психологічний тиск імовірності ситуації політичного хаосу, початку періоду політичної депресії в суспільстві, зростання політичних провокацій, поглиблення діапазону втрачених можливостей, поява нових форм розриву соціальної реальності: мнимих та дійсних, наявних та уявних. Тому зростає необхідність попередити цей сценарій за рахунок дієвих механізмів соціальної організації шляхами рефлексивної постсучасної модернізації.

Водночас, із точки зору наукової школи Е. Гідденса, «соціальні відносини вже неможливо сприймати як об'єктивну даність - вони не спадкуються, а створюються людиною, що веде до зростання невизначеності та риску, але водночас і відкривають нові можливості» [19, с. 33]. Це повертає до спроб аналізу відносин, що є повністю об'єктивними, незалежними від того, яким чином проходять через свідомість людей, але суб'єктними, тобто реалізуються виключно через суб'єктів [20, с. 12-22], що дає змогу значно поширити інструментарій вивчення та використання за рефлексивної модернізації. Причому характер цієї репрезентації потенційно дозволяє фетишизацію соціальності та іiі обертання зростанням ірраціонально перетворених явищ та форм. Здійснення рефлексивної модернізації нині передбачає й суттєві зміни у 
послідовності, темпах, формах, методах перетворень і збільшення ролі як духовно-інформаційного складника розвитку, так і технологій рефлексивних організації та управління працею.

\section{2. Особливості постсучасного управління трудовими ресурсами: макро- та мікрорівні}

Втім, в умовах інверсійного проведення модернізації (коли не громадське суспільство створює державу, а держава забезпечує складання і функціонування громадського суспільства) розвинена громадськість передбачає досягнення певного соціально-економічного рівня. При цьому частка економічних культур може забезпечувати основний упор на творчих можливостях індивідуалізму, інші - надавати цьому індивідові права та свободи в процесі відповідних реформ. Якщо за адміністративно-командної системи основною дійовою особою був «виконавець» незалежно від того, на якому щаблі ієрархічних сходинок він стояв, то за умов більш або менш відкритого суспільства суб'єктом управління виступають люди, які мають характеризуватися компетентністю, інформованістю, здатністю до інноваційної діяльності. Трансформація суспільства посилює протиріччя різних ієрархій цінностей суб'єктів економічних відносин та діапазон відмінностей чинників трудової та організаційно-управлінської поведінки.

На мікрорівні трудові відносини все більше орієнтують на вирішення проблем на підставі розвитку здібностей та обробки інформації. Виробничі ролі формуються у процесі праці, де присутній широкий діапазон нерутинних завдань і немає сталості процедур. Визначальне місце у відносинах належить ролевим сітям, причому вони великі та динамічні, характер, довжина та місце виявлення ролей мінливі, а ступінь взаємодії високий. Отже, реактуалізується потреба у «надмірному» знанні і досвіді для правильної поведінки в нестандартних ситуаціях, під час посадових ротацій та освоєння техніки. Новий тип економічного розвитку висунув на перший план творчу постать, таланти й здібності якої є основними двигунами науково-технічного прогресу. Водночас сам розвиток техніки здебільшого орієнтується на якості особистості. Звідси випливає актуалізація проблеми мотивації праці, створення умов для розвитку особистості працівника, реалізації його талантів i здібностей у процесі виробництва. Інноваційний процес, що грунтується на творчому підході до праці, вимагає ініціативного, висококваліфікованого, високомотивованого працівника, якого систематично залучають до прийняття управлінських рішень. I саме консервація застарілої моделі трудових відносин, перепони до зародження їх новітних форм і сприяють занепаду виробництва.

На макрорівні помітніше, що різні цивілізації по-різному віддзеркалюють у своєму розвитку риси світо-системних змін: зустрічаючись зі «світовими викликами», кожна держава знаходить свій варіант відповіді на них. Разом із цим посилюються можливості обережного запозичення частини моделей розвитку, котрі напрацьовуються іншими народами, що деактуалізує підхід, який однозначно відносить міжнародні стосунки до «вторинних», «похідних». Поліструктура світогосподарських зв’язків, що основана на вироблених та взаємоприйнятих нормативах відносин, а не блок 3 ідентичних атомівелементів, набуває вигляду постмодерної дійсності. У цьому зв'язку і саме поняття розвитку потребує оновлення: крім стабільного і збалансованого росту, 
воно має орієнтуватися на такі етичні цінності, як солідарність, свобода вибору, терпимість. Жодна система цінностей під час постмодерну вже не може розглядатися як єдино можлива для людства.

Водночас, безумовно, регуляторний та управлінський курс державної влади повинен найбільше відповідати національним інтересам, зокрема консолідованим сподіванням лідерів вітчизняного виробництва. На нашу думку, держава (особливо за сучасних трансформацій та наявності кризових моментів у світовому господарюванні) не має права відсторонятися від суттєвих проблем регулювання. Відповідно, якість соціально-економічного управління визначається його спрямованістю, комплексністю та єдністю гілок влади у його проведенні, а також адекватністю організаційно-управлінських технологій передовим світовим практикам та регіональному досвіду (зокрема, Вишеградського співробітництва). Для ефективного використання соціального управління найбільш суттєві масштаб особистості управлінців, їх готовність підкоряти індивідуальні та групові інтереси національним, здійснюючи розподіл сфер повноважень та представництво народних інтересів.

Утім, проблема збільшення матеріальної основи національного (у т. ч. економічного) суверенітету України сьогодні постає так: з одного боку, він неможливий без зміцнення та модернізації індустріальної серцевини виробництва (включно й кадрів відповідної кваліфікації та мотивації), 3 іншого - неможливо ігнорувати тенденції постмодернізації, іiі специфічні загрози та можливості. Здійснення проекту модернізації країни потребує першочергового зростання якості управління, яке, зокрема, повинно визначитися 3 орієнтирами, формами, методами та ресурсною базою трансформацій. «Запізнілий» розвиток узагалі надає додаткову змогу оцінювати та вибирати варіанти реалізації проектів із чужого досвіду, аналізувати різноманітні сценарії та їхні пускові механізми, створювати оптимальні форми поєднання національної самобутності та світових досягнень. Водночас в умовах багатократного посилення впливу транскордонних факторів i наднаціональних процесів можна запобігти участі ресурсного донора й об'єкта зовнішніх маніпуляцій виключно за рахунок чіткого виявлення і переслідування власних інтересів. Падіння «залізних лаштунків» посилило вимоги до самооборони цивілізації під час зустрічі 3 іншими, захисту національних інтересів. Зрозуміло, йдеться не про спроби відновлення автаркії, апології натурального господарства i закритого суспільства, відмови від товарно-грошового інструментарію і від участі в інтеграційних процесах. Питання в якості інтеграції, місці країну у ній, у пошуку оптимальних варіантів перетину тенденцій національного та міжнародного розвитку. Причому в питаннях забезпечення їхнього оптимуму на сьогодні проблем залишається набагато більше, ніж відпрацьованих методик. А проблеми, що постають ззовні, досить часто є боліснішими за внутрішні. Стандартні рішення у сфері вестернізації суспільства вже «не спрацьовують». Нинішнім реаліям не відповідають і спроби однозначного ототожнення позиції 3 якоюсь однією науковоаналітичною школою, лінійне бачення прогресу. Водночас динаміка характеру та ролі ціннісних параметрів зумовлена насамперед тим, що на цей час у людства недостатньо сформовано відчуття глобальної небезпеки, отже, сучасна загрозлива екологічна ситуація не містить у собі такого мотивуючого впливу на буденне життя, яке $є$ адекватним iї масштабу. В системі гуманістичних 
критеріїв буття сучасної людини пріоритетною стає цінність життя як абсолют. Відповідно, зростає роль якості життя й умов праці. Реалізація їхнього поліпшення можлива на шляху здійснення виваженого морального вибору 3 урахуванням досвіду не тільки минулих поколінь, а й усебічних наслідків сьогоденної суспільної ситуації для майбутнього на підставі оновлених філософсько-світоглядних принципів. Таке рішення як сукупне, що враховує не тільки дискурсивну логіку праксіологичного знання, а й цінніснонормативний його складник, саме й забезпечує орієнтацію на людину. При цьому 3'ясування умов існування людства у XXI ст. зовсім не обмежується тільки екологічною проблематикою. Йдеться про нові геополітичні реалії, що пов'язані як з інтернаціоналізацією економічних інтересів, так і з процесом змінювання стилю та образу мислення на підвалинах ненасильства та загальнолюдських цінностей.

Утім, саме сьогодні все активніше заявляє про себе логіка процесу трансформацій, яка передбачає співіснування, перехрещення і резонування різноманітних тенденцій розвитку, серед яких (на відміну від модерну) жодна не може претендувати на виняткове значення, що дає змогу, не зазнаючи шкоди, абстрагуватися від інших. Постмодерн, відповідно, - це не лише «проміжок», «стик» між минулим і майбутнім, «чорновий варіант майбутнього»; рух у його напрямі може розумітися як комплекс змін інституціональних, передусім соціокультурного середовища (отже, соціокультурного капіталу суспільства), що виводять суспільство за рамки індустріальних форм життя. Постмодерні підходи до управління взагалі не перекреслюють, а актуалізують потенціал модерну. Але разом із цим вони відкривають і нові можливості людського чинику, пов'язані з більш активним використовуванням традицій і звичаїв, колективних відносин і взаємодій, неформальних комунікацій і соціальних мереж, із синтезом елементів керованості, самокерованості та некерованості. При цьому конкретні риси суспільства після постмодерну, використання його моделі розвитку та набуття під впливом його тенденцій і підвалин майбутнього здебільшого залежать від стану культури (у тому числі соціально-економічної). Отже, Модерн забезпечує культуру спільної діяльності, спілкування, кооперації, але породжує проблеми «самітності в натовпі», нонконформистської «війни кожного проти всіх», озлоблення, непідготовленості людини до потреб суспільного оточення. Він передбачає особливий стан суспільства і культури, де нормативним є масове, стандартне виробництво, до того ж характер і риси діяльності кожної конкретної людини через усеохоплюючий суспільний розподіл праці задаються включенням до суспільної праці. Засоби виробництва обіймають колишню працю багатьох учасників виробництва, і вже самим відношенням до засобів виробництва закладена соціальна характеристика праці. Постмодерн успадковує і використовує цю соціальність: мало бачити в людині носія робочої сили, потрібно забезпечити розвиток особистості, тому що найбільшим виробничим чинником стає одухотворена творчість людини, що відображається у просуванні організації трудових відносін у напрямі виробничої демократії. Постмодерн розкривається через диверсифікацію та різноманітність культури, іiі безрепресивність, толерантність, полілогізм, подолання канону, «свято опору системі» та демонструє межи соціального управління, застерігаючи щодо небезпеки раціоналізму, утилітаризму i сцієнтизму в інтерпретації громадського життя [21-28]. 
Звільнена від спрощень об'єктивізму та розслаблюючого гарантування провіденціалізму, нова внутрішня цілеспрямованість розуму грунтується не на пізнанні об'єктивних тенденцій історії, що передбачає майбутнє, котре ми повинні очікувати, а на самоідентифікації суб'єкта засобами рефлективної діяльності для «утримання» в живій сучасності інтегральних нескінченостей, яких ми не в змозі не прагнути, свідомо орієнтуючись на синтез науковотеоретичної універсальності та універсально орієнтованої, самовідповідальної практики.

Причому вирішення протиріч, які виникають у рамках процесу трансформації, багато в чому залежить від стану та характеру трудових відносин, організації соціального партнерства. Визначальним елементом виробництва та соціального життя довгий час уважалася саме праця: вона надавала ресурсів економічному росту, зумовлювала якість життя, формувала цінності та відводила конкретні ниші фаховим і соціальним групам. Разом із тим вихід за звичні межі модерну розташовує поряд працю, навчання і гру в творчому процесі та змінює механізми подальшого відтворення та розвитку трудових відносин. Вивчення інституціональних і ціннісних засад організації різних типів господарських спільностей, альтернативних підходів до оцінки систем стимулювання дає змогу долати жорсткий виробничий детермінізм, відмовлятися від аналізу та оцінки господарських ситуацій $\mathrm{i}$ процесів виключно з позицій безвідкладної користі, переходити до дослідження трудової поведінки та трудових відносин з урахуванням історико-культурних, моральнопсихологічних, релігійно-етичних традицій, плюральних моделей персонального та групового вибору. Неправомірно при цьому зводити логіку змін у трудових відносинах виключно до детермінації культури технологічними інноваціями. Важливого значення набуває вплив саме культурного середовища на появу i сприйняття нововведень техніки та економіки. Гуманізовані технології постмодерну тому не $\epsilon$ соціально нейтральними, вже на стадії проектування в них закладається свідома орієнтація на розвиток і збагачення культури.

Нові горизонти розвитку відкриваються тим державам, де суспільний устрій максимально сприяє розвитку та реалізації творчого потенціалу громадян. Забезпечення гідного місця у світовій системі координат передбачає трансформацію держави на дійсно інноваційну, зі скороченням бюрократичних i збільшенням творчих функцій, будівництвом механізму фактично безперервної участі громадян у соціальної організації. На цій основі змінюється структура «людського капіталу»; сам зміст соціогосподарського життя щодалі більше задається не «владною елітою», а повсякденними контактами особистостей між собою. Постмодерн позначає різноманіття (і рівність) моделей прогресу, опору на наявні устої, а не боротьбу з ними. Єдність віри та розуму відкриває моделі нових соціальних укладів без станових обмежень. Актуалізація логіки парадокса базується на включеності в нові, невизначені виміри раціоналізму, креативні в нових умовах традиції - аж до використання практик міфотворчості: інтерпретації минулого повинні не заважати, а допомагати теперішньому та майбутньому. Органічність, успішність трансформацій забезпечує синтез заздалегідь різнопланових елементів здійснення мегапроекту розвитку, пов'язаних із формами народовладдя та моментами 
автократії та адаптованих до конкретних (зокрема, регіональних) умов соціально-економічних відносин певного соціуму [29-34].

\section{3. Взаємозв'язок державного та корпоративного управління у формуванні трудових відносин постсучасного типу}

Постсучасні тенденції рефлексивних організації та управління пов'язані 3 поширенням стимулювання, крім адміністрування, збільшенням діапазону «м'якої сили» під час організації економічних відносин. За умови задіяння різноманітних ефективних механізмів соціального партнерства як соціальних технологій інтеграції суспільства, наявність у країні секторів із суттєвими відмінностями розвиток диференціації стає додатковим ресурсом пошуку та розвитку. Використання у практиці соціального управління потенціалу соціокультурної організації, відповідно до моделей рефлексівної модернізації, дає змогу застосовувати наявні резерви розвитку як інституціональних, так і неінституціональних форм соціальної активності. При цьому саме в ході діяльності особистість створює річні форми рефлексії та налаштовується на певну структуру буття. Для соціальної організації економічних відносин необхідним $\epsilon$ регіональне (зокрема, на базі досвіду Вишеградської групи) поєднання універсальних демократичних цінностей та національних особливостей народовладдя, що впливає на різноманіття поглядів на сутність демократичного устрою. Країна повинна брати активну участь у процесі фундаментальних та динамічних трансформацій світу за рахунок свого варіанту модернізації, розвитку країни за інноваційною моделлю, більш повного використання свого потенціалу розвитку та посилення міжнародної уваги до систем цінностей кожного суспільства.

Разом із тим ідеї рефлексивного контролю дозволяють своє застосування в напрямі маніпулювання свідомістю 3 боку зовнішніх для людини сил іiі відчуження. Водночас практично повсюдна перемога риторики i форм демократії/народовладдя не завжди означає реальність відповідних механізмів і пріоритетів. Так, з одного боку, еліта не є абсолютно відокремленою групою деміургів (власне, події столітньої давності ще раз нагадують про це). 3 іншого - владна еліта інколи намагається вести інший спосіб життя, вчити своїх дітей, харчуватися, відпочивати і проживати окремо від трудівників, часом реактуалізуючи класичну концепцію «двох націй». Разом із тим часом інверсійні явища некласичної трансформації дають змогу більш повно використовувати наявні перетворені соціально-економічні форми в процесі рефлексивного управління. Природа рефлексивного управління процесами суспільного життя вимагає уваги й урахування якостей не тільки об'єктивного, а й суб'єктивного складників історичного процесу, зокрема діяльних учасників досягнення цілей i тих, хто вагається, активу та пасиву здійснюваного, союзників і супротивників, їх структурної та функціональної визначеності, перетворених форм їх співучасті в трансформаційних процесах. Наявність більшої кількості керованих процесів призводить як до необхідності їх ієрархічної організації (тобто до відтворення підходу ієрархічності структур поряд із побудовою мережевих, матричних тощо), так i до розвитку безструктурного регулювання та командного управління. При цьому успіх реформ суттєво залежить як від співвідношення реальних пріоритетів та їх відповідності логіці історії і очікуванням населення, так і від системи 
стимулювання їх досягнення. Співвідношення раціонального - ірраціонального, матеріального - духовного (ідеального) значимо зсувається потужним вторгненням віртуальних вимірювань життєдіяльності суспільства. Водночас сьогодні інформаційний вплив виступає і головним напрямом проведення спрямованих змін, і головним фактором сумарної/підсумковій конкурентоспроможності.

Необхідно розрізняти три аспекти використання засобів рефлексивної модернізації економічних відносин: техніко-технологічний (інструментальні засоби вирішення завдань), соціально-інституціональний (удосконалення інституціональної сфери суспільства) і культурно-ціннісний (народні традиції, історичний досвід, соціальна спадщина). Гуманізовані технології постмодерну не можуть бути соціально нейтральними, оскільки вже на стадії проектування в них закладається свідома орієнтація на розвиток і збагачення національної культури. А концепція рефлексивної модернізації надає варіанти використання продуктивного потенціалу економічних відносин, передусім завдяки більш повному задіянню людського чиннику виробництва шляхом доповнення засобів директивного керування стимулюванням бажаних трансформацій.

Суттєво, що сьогодні великого значення для підвищення продуктивності економічних відносин та ефективності творчих зусиль фахівців набувають зростання наукоемності всіх боків громадського життя і розвиток нових технологій, форм організації праці й ергономічних режимів трудової діяльності, поширення використання в економіці новітніх досягнень різних галузей науки, збільшення уваги до аналізу поточного стану корпорацій, визначення причин інтелектуальних, матеріальних, комерційних утрат та виробка на цей базі як оперативно-тактичних відповідей, так і стратегічних завдань соціальноекономічного розвитку. Так, наприклад, залежно від конкретних завдань та умов існування корпорації можуть бути задіяні щонайменше дві моделі організаційно-управлінського впливу на персонал: директивне керування за застосування вимоги діяти лише так, як визначено «жорсткою силою» (hard power), або стимулювання бажаної поведінки 3 використанням «м'якого підходу» (sensitive side). Miciï та завдання економічних та політичних корпорацій, становлячись єдиними для всіх учасників громадського життя, самі перетворюються на базу їх загального контролю над собою та виробничим процесом, приводячи до високого соціально-економічного ефекту. «Жорсткій менеджмент» із беззастережним виконанням наказів і розподілом трудового колективу на командирів та підлеглих змінюється демократичним «м'яким» управлінням, що стимулює командну дію, ініціативу та пошук, вивільняє продуктивні сили соціально-економічних відносин. Зміцнюється зрозумілість більшістю співпрацівників значення діяльності підприємства, взаємовпливу окремих операцій та їхньої ролі в загальній мережі. Під час «масової творчості» (відносно новий феномен: якщо раніше творчість базувалася на особистості, індивідуальності та була своєрідною антитезою масовості, то тепер саме їхня єдність - обов'язкова умова динамічного розвитку структури) затверджуються нові трудові мораль та соціально-політична культура, формується професійна поведінка, аномальна в епоху фордизму.

Активізація політики залучення найманих робітників до підприємництва вписується в загальний контекст глибоких змін у трудових відносинах виробничої демократії, які еволюціонують від системи «негативного контролю» 
до позитивної співпраці, децентралізації договірно-колективного регулювання, встановлення прямих контактів між адміністрацією та працівниками, якщо можливо - обминаючи профспілки, позиції яких у багатьох країнах значно ослабли протягом останнього десятиліття. У цьому виявилася кардинальна зміна в теорії та методах Human Resources Management. Від стратегії підкорення та контролю організація та управління працею рухається до стратегії «залучення» та партнерства. Ці зміни синхронізовані з новою фазою організації праці на принципах соціотехнічного підходу. Дискредитація як нереалістичних технократичних рецептів розвитку трудових відносин, посилення уваги до моральних цінностей та етичних орієнтацій продемонстрували, що традиції орієнтації на формально-бюрократичні ресурси поведінки не відповідають сучасній економічній та технологічній організації суспільства. Причому тоді як в Україні переважно досліджуються й упроваджуються класичні моделі, в СС традиції закріплення трудових відносин продовжують трансформуватися [35-41].

Але водночас саме тенденції регіоналізації (зокрема, культивування Вишеградської групи) можуть відкрити як додаткові механізми інтеграції, так i залучення нових продуктивних ресурсів, допомагаючи подоланню ризиків та поширенню можливостей. I без оволодіння постсучасними технологіями соціального управління успішне будівництво мегапроекта розвитку в теперішніх умовах неможливе. Перехід до інноваційно-синергетичного типу розвитку обов'язково породжує суспільний запит на працівника із широким кругозором, що тяжіє до демократичних порядків і ліберальних цінностей. Працівник такого типу бачить себе не просто «продавцем своєї робочої сили», а особистістю; місце, де він трудиться, - сферою не тільки трудових, але й набагато більш широких (соціальних, політичних) відносин. Таким чином, соціально-трудові й інші внутрішньокорпоративні відносини - найважливіший складник не тільки економічного фундаменту розвитку, але й характеру суспільства.

Висновки. Отже, нова соціально-економічна реальність суттєво трансформує можливості державних та корпоративних організації та управління працею, зокрема, поширюючи діапазон можливостей рефлексивної постсучасної модернізації суспільства та економіки. Україна увійшла в новий цикл перетворень економіки в умовах, які значно ускладнилися через те, що колишні ресурси розвитку досить вичерпані. Але зберігаються суттєві резерви в організації та управлінні, у тих питаннях, які класично належали до мікроекономіки, однак впливають на макрорівні, виявляють національні інтереси країни та повинні ретельно враховуватися в регуляторній системі Вишеградського співробітництва. Характерна риса постсучасного ешелону модернізації економіки та суспільства - рефлективність поведінки, відносин та процесів.

Якість рефлексивних організації та управління тісно пов'язана 3 домінантними формами раціональності/ірраціональності освоєння навколишнього світу. На глобальному, регіональному, державному, локальному рівнях господарський успіх може бути досягнутий на основі різноманітних комбінацій рішень. Але довгочасні та адекватні епосі стратегії базуються на акцентуванні економіки знань, а криза - природний час оновлення. Якщо душевне/духовне здоров'я суспільства передбачає високу напругу його сил в здійсненні 
Надпроекту розвитку, що дає змогу підтримувати тонус суспільної ідеології і психології, то занепад моральності сприяє розвитку різноманітного шарлатанства, що підриває базові ціннісно-смислові комплекси культурно-цивілізаційного світу.

Таким чином, саме забезпечення проведення адекватних викликам часу заходів рефлексивних організації та управління (а зовсім не володіння потужним потенціалом як таким) є вирішальним фактором історії, тим більше проведення рефлексивної модернізації в умовах посилення рис постіндустріалізму, постглобальності й у цілому постсучасності. Важлива передумова довгострокової міцності реформ - створення балансу структур державного управління та місцевого самоврядування, що спирається на традиції як державного, так і домашнього побуту, при цьому здатної до ефективного соціального новаторства. Тільки це може захистити вибір нової генеральної моделі розвитку. Причому в момент зрушень парадигмального рівня, за наближення до стану інституційної невизначеності, доводиться не стільки керуватися звичними регуляторними правилами, скільки орієнтуватися, 3 одного боку, на ціннісно-смислові комплекси свого культурно-цивілізаційного світу (які, реалізуючись у формах традицій, звичаїв, укладів і забезпечують відтворення і розвиток економіки і суспільства у цілому), з іншого ж - на загальну логіку історичного процесу і конкретні особливості: свої, регіону (отже, Вишеградської групи), а також цілей, завдань та пріоритетів.

\section{Список використаних джерел:}

1. Sarrazin T. Deutschland schafft sich ab. Wie wir unser Land aufs Spiel setzen / T. Sarrazin. München : Deutsche Verlags-Anstalt, 2010. - 463 s.

2. Hayek F.A. The Fatal Conceit. The Errors of Socialism / Friedrich A. Hayek. Ed by W. W. Bartley, III. 1988. - 194 p.

3. Полякова Н.Л. От трудового общества к информационному / Н.Л. Полякова. - М. : Наука, 1990. - 132 с.

4. Шедяков В. Система світогосподарських зв'язків переживає стан, близький до інституціональної невизначеності / В. Шедяков // Економіст. - 2015. - № 9. - С. 1-3.

5. Beck U. Risk Society: Towards a New Modernity / Ulrich Beck (University of Munich, Germany). - L. : Sage Publications, 1992. - 260 p.

6. Луман Н. Понятие риска / Н. Луман // THESIS. - 1994. - № 5. - С. 127-159.

7. Гидденс Э. Судьба, риск и безопасность / Э. Гидденс // THESIS. - 1994. - № 5. С. 91-126.

8. Шедяков В.Е. Культурно-цивилизационные миры и проведение новой модернизации: демифологизация проблемы / В.Е. Шедяков // ВУЗ. XXI век. - 2012. - № 1. - С. 46-66.

9. Шедяков В.С. Трансформації міжнародних економічних відносин як фактор удосконалення інтеграційних процесів / В.Є. Шедяков // Економіст. - 2014. - № 11. - С. 14-19.

10. Шедяков В.С. Міжрегіональна конкуренція макрорівня: інформаційна домінанта у постсучасних відносинах / В.С. Шедяков // Регіональна економіка та управління. - 2015. № 4(07). - Ч. 2. - С. 104-110.

11. Шедяков В.Є. Можливості рефлексивної модернізації: роль соціальної організації людського капіталу в запобіганні ризиків розвитку / В.С. Шедяков // Політологічний вісник. - 2012. - Вип. 60. - С. 260-271.

12. Шедяков В.Е. Взаимосвязь фундаментального и актуального уровней в осуществлении устойчивого социально-экономического развития / В.С. Шедяков // Розвиток економіки України: трансформації та інновації / заг. ред. О.Л. Гальцової : у 2-х т. - Запоріжжя : Гельветика, 2017. - Т. 2. - С. 34-48.

13. Китов А.И. Экономическая психология / А.И. Китов. - М. : Экономика. - 1987. - 303 с. 
14. Экономическая психология // Психология / Под ред. В.Н. Дружинина. - СПб. : Питер, 2000. $-672 \mathrm{c}$.

15. Экономическая психология: социокультурный подход / Под ред. И.В. Андреевой. СПб. : Питер, 2000. - $511 \mathrm{c.}$

16. Суименко Е.И. Ното economicus современной Украины. Поведенческий аспект / Е.И. Суименко, Т.О. Ефременко. - К. : Институт социологии НАНУ, 2004. - 244 с.

17. Бобух И. Поведінкова економіка та сталий розвиток: ключові аспекти взаємозв'язку / И. Бобух // Економіст. - 2016. - № 6. - С. 4-8.

18. Шедяков В.Е. Рефлексивная постсовременная модернизация и рефлексия постсовременной модернизации / В.Е. Шедяков // ВУЗ. ХХІ век. - 2012. - № 2. - С. 50-73.

19. Beck U. Reflexive Modernization: Politics, Tradition and Aesthetics in the Modern Social Order / Ulrich Beck, Anthony Giddens, Scott Lash. - Stanford, CA : Stanford University Press, 1994. $-233 \mathrm{p}$.

20. Отчуждение труда: история и современность / Я.И. Кузьминов, Э.С. Набиуллина, В.В. Радаев, Т.П. Субботина. - М. : Экономика, 1989. - 287 с.

21. Егоров И.А. Логика экономического процесса: социоэкономический синтез И.А. Егоров // Мировая экономика и международные отношения. - 2004. - № 4. - С. 27-36.

22. Шедяков В.Е. Парадигмальный переход в теории и на практике: стратегический дизайн форсированных трансформаций / В.Е. Шедяков // Науковий вісник Херсонського державного ун-ту. Економічні науки. - 2017. - Вип. 23. - Ч. 1. - С. 54-58.

23. Double Shift. Transforming Work in Postsocialist and Postindustrial Societies/ ed. by B. Silverman, R. Vogt, M. Yanowitch. - N.Y., L. : M.E. Sharpe, Inc., 1993. - 217 p.

24. Денисенко I.Д. Сучасне суспільство \& соціологічна теорія: проблеми концептуального осмислення 3 позиції Е. Гідденса / І.Д. Денисенко // Актуальні проблеми філософії та соціології. - 2015. - № 8. - С. 37-39.

25. Шедяков В.С. Постмодернізація трудових відносин як об'єкт соціального управління : автореф. дис. ... д. соц. н. / В.С. Шедяков ; Харк. держ. ун-т. - Харків, 1996. - 32 с.

26. Шедяков В.Е. От постсовременных трансформаций к постиндустриальному уровню производственной демократии / В.Е. Шедяков // Матер. XXXIII Междунар. науч.-практ. конф., посвященной проблемам общественных наук. - Москва, 2015. - С. 102-105.

27. Шедяков В.Е. Экономика управляемая, самоуправляемая и неуправляемая / B.Е. Шедяков // Integrated business structures: models, processes, technologies: Proceedings of the International Scientific Conference. - Moldova State University, Faculty of Economic Sciences. Chisinau, Republic of Moldova, 2016. - P. 5-7.

28. Шедяков В.Е. Создание привлекательных условий жизни и благоприятных для творчества предпосылок - цель и условие долгосрочного эндогенного социальноэкономического развития при формировании «умного общества» / В.Е. Шедяков // The Development of International Competitiveness: State, Region, Enterprise: Proceedings of the International Scientific Conference. - Nova School of Business and Economics, Nova University. Lisbon, Portugal, 2016. - Part II. - P. 34-36.

29. Шедяков В.Є. Системні основи розвитку трудових відносин / В.С. Шедяков // Вісник Київського національного ун-ту ім. Т.Шевченка. Філософія. Політологія. - 2012. - № 107. С. $43-46$.

30. Шедяков В.Є. Проблеми та перспективи модернізації системи трудових відносин в Україні / В.С. Шедяков // Економіст. - 2012. - № 8. - С. 33-36.

31. Шедяков В.Є. Стан i розвиток трудових відносин: пострадянський варіант / В.С. Шедяков, О.А. Блінов, П.Д. Морозов // Удосконалення трудових відносин як основа стійкості та розвитку громадянського суспільства ; заг. ред. П.Д. Морозова. - К. : Задруга, 2014. - С. 19-129.

32. Шедяков В.Е. Интеллектоёмкость и нравственность как атрибуты экономики, основанной на знаниях / В.Е. Шедяков // National Economic Development and Modernization: experience of Poland and prospects for Ukraine / ed. by A. Pawlik, K. Shaposhnykov. - Kielce, Poland : Izdevnieciba «Baltija Publishing», 2017. - Vol. 1. - P. 283-298.

33. Шедяков В.Е. Тенденции создания постиндустриальных отношений и стимулирование желательных трансформаций / B.С. Шедяков // Актуальные проблемы науки XXI века : матер. I Междунар. науч.-практ. конф. - Москва, 2015. - Ч. 2. - С. 183-187. 
34. Lansbury R.D. Perspectives of Industrial Relations in the Twenty-First Century / R.D. Lansbury // The Perspectives of Industrial Relations in the 21 st Century. IIRA $3{ }^{\text {rd }}$ Asian Regional Congress. - Vol. 4. - 1997. - P. 3-17.

35. Катькало В.С. Эволюция теории стратегического управления / В.С. Катькало ; 2-е изд. - СПб. : СпбГУ, 2008. - 548 с.

36. Брыль Р. Украинцы, идите домой. Как реформа рынка труда ЕС лишит наших сограждан работы в Европе / Р. Брыль // Власть денег. - 27 сентября 2017 [Электронный pecypc]. - Режим доступа : www.dsnews.ua/.../ukraintsy-idite-domoy-kak-reforma-rynka-trudaes-lishit-2609201...

37. Попова И.М. Стимулирование трудовой деятельности как способ управления / И.М. Попова. - К. : Наук. думка, 1976. - 207 с.

38. Шедяков В.С. Управління працею в умовах підвищення рівня взаємозалежності в економічному житті суспільства: актуальні питання стратегічних трансформацій / В.С. Шедяков // Економіст. - 2014. - № 7(333). - С. 26-32.

39. Шедяков В.Е. Менеджмент персонала в условиях переходного периода / В.М. Соболев, В.Е. Шедяков // Менеджмент в области инвестиций и персонала: особенности в переходной экономике. - Х. : Бизнес Информ, 1996. - Ч. II. - С. 81-173.

40. Шедяков В.С. Стратегічна культура проведення трансформацій: можливості та загрози / В.С. Шедяков // Розвиток економіки України під впливом економічних, соціальних, технологічних та екологічних трендів ; за ред. М.С. Пашкевич, Ж.К. Нестеренко ; М-во освіти і науки України, Запор. нац. техн. ун-т, Нац. гірн. ун-т. - Д. : НГУ, 2015. - С. 30-41.

41. Шедяков В.Є. Стимулювання в системі управління працею на тлі формування в глобальному масштабі економіки знань / В.С. Шедяков // Економіка XXI сторіччя: проблеми та шляхи їх вирішення ; за заг. ред. Г.О. Дорошенко, М.С. Пашкевич ; М-во освіти і науки України; Харк. ін-т фінансів; Нац. гірн. ун-т. - Д. : НГУ, 2014. - С. 379-388. 


\section{REGIONAL IDENTITY OF MEMBERS OF THE VISEGRÁD FOUR}

Zborovska O.M. Professor at Department of Finance, Banking and Insurance, Zaporizhzhia National University

Markov B.M. Candidate of Economic Sciences, Alfred Nobel University

\section{STRUCTURAL CHARACTERISTICS OF THE ECONOMY OF UKRAINE IN THE CONTEXT OF INTERNATIONAL COMPARISON}

Summary. The comparison of the structure of the Ukrainian economy with other countries of the world is carried out. Analysis of changes in volumes shows that the Baltic countries of the former USSR were mostly impacted by the global financial crisis, where the decline was 3-4 times higher than the GDP reduction for the EU-28 as a whole. The detailed structure of production of the Gross Value Added (GVA) of Ukraine's indicative of a significant reduction in the share of agricultural production, construction (more than twice) and manufacturing industry with a corresponding increase in the share of services. Ukraine occupies one of the last places not only in terms of GDP per capita, ahead of Armenia, Moldova, Kyrgyzstan, and Tajikistan but also in terms of final consumption expenditures. The studies conducted demonstrate that the structuring of the Ukrainian economy both during the crisis and at the stage of economic growth occurred mainly spontaneously, without the development of a clear concept and the implementation of targeted actions by the state.

Introduction. The structuring of the international economy is possible by many criteria. The main of them are the following: the level of development of national economies; forms of international economic relations and their regulation; regional integration groupings; objects of the world market.

After more than a decade of transformation, the economic situation in Ukraine, with a particular acuteness, raises the problem of structural renewal of the whole economy, as well as of its individual sectors, first of all - the industrial one. Existing structural proportions in their wider sense become increasingly constraining factors for implementing the transition of the national economy to an innovative model of development and acquiring the necessary dynamics of economic growth. Consequently, there are being formed the threats to national security in the sphere of production, social development, the international economic cooperation of the Ukrainian state.

The following works of domestic and foreign scientists are devoted to the analysis of the causes for transformational changes and factors of economic development under the conditions of market transformation: V. Heiets, S. Yerokhin, L. Shynkaruk, 
T. Artomova, O. Amoshi, F. Hayek and others [1; 3-6]. They have researched and covered a number of factors of transformation processes and economic development in general, including the institutional ones.

Comparison of the structure of the Ukrainian economy with other countries of the world makes it possible to estimate the reasons and depth of the fall for the entire period of Ukraine's independence in 1991-2015.

\section{Structural changes in the system of economic phenomena}

The national economy is a multi-sectorial system of the country's economy, which satisfies the highest demands and needs of the society. Modern national economies of different countries differ in their location, quantitative indicators (territory, population, resource potential, etc.), and in terms of the key qualitative characteristics.

The level of development of national economies is determined by:

- volume of GDP per capita;

- efficiency of production factors;

- state of scientific research and scientific achievements;

- demographic situation, the presence of qualified personnel;

- level of income and the level of consumption of the population;

- share and nature of the interaction of economic structures, mechanisms of market self-regulation, state and civil regulation of the economy;

- degree of integration of national economies into the international economy.

According to the level of development of the national economy, the classification of countries into the developed countries or industrialized countries, the countries with economies in transition and the developing countries is universal. Countries with a developed economy, or industrially developed countries, have consolidated their dominant position in the international economy. This classification depends on the interaction of the countries, their cooperation, the allocation of groups or subgroups, the availability of statistical data, membership in certain international organizations, etc. [8].

Combining several of these features and building on the works of Ukrainian and foreign scholars, it is possible to distinguish the main approaches to the classification and features $[2 ; 7-9 ; 11]$.

Regional approach lies in grouping countries geographically. Large regions of closely located countries with common natural conditions and peculiarities of historical and cultural development are distinguished [6, p. 98].

Geographical classification makes it possible to have a greater awareness of the choice of trading partners, business administration, of the study of possible market prospects, etc. Geographically, countries are systematized by particular regions.

The contemporary international economy examines and analyses major geographic regions. To date, the Asia-Pacific region is distinguished - a vast space that includes East and South-East Asia, Australia, and Oceania, the eastern regions of Russia and the countries of North and South America, which are around the rim of the Pacific Ocean. This region is characterized by the accelerated dynamism of economic development.

The regional economic approach comes from the confrontation of the world systems - the West and the East, the North and the South, the Centre and the Periphery. 
Contradictions between peoples and countries due to the differences between cultures and religions are viewed by this approach as the main cause of growing conflicts. There is also a vertical division: the rich North and the poor South.

Modern states of the world are at different stages of economic maturity, which gives grounds for grouping them according to their level of development and, at the same time, taking into account the geographical identification factor as much as possible.

The economic approach lies in grouping countries according to certain economic criteria.

Systematization of countries on an economic basis involves the division of the international economy into two levels. The first one is represented by the following structural elements of the international economy [7]:

a) industrialized countries-states where the volume of industrial production exceeds $50 \%$ of the gross domestic product;

b) agricultural countries where the volume of industrial production in the gross domestic product does not exceed 50\%;

c) industrial and agricultural countries. These include those countries of the world whose share of industry in the total industrial and agricultural production exceeds $50 \%$;

d) agricultural and industrial countries. These are those countries of the world where the share of agricultural production in the total volume of industrial production exceeds $50 \%$.

At the second level of the economic principle of structuring the international economy, its components are distinguished on the basis of the economic development of individual groups of the world countries. Accordingly, the international economy is divided into the following parts [6]:

a) economically developed world countries;

b) new industrialized countries-states, which, with the help of economically developed countries, intensively use modern achievements of the scientific and technological revolution in order to stabilize the economy and increase the national economy. New industrialized countries are divided into two waves. The first wave includes: South Korea, Taiwan, Singapore, Hong Kong ("Asian dragons"). The second wave is represented by Philippines, Malaysia, Indonesia, Thailand ("Asian tigers"), Brazil, Argentina, Chile.

c) developing countries.

Following the approach of the degree of market development, a separate structure of the international economy is distinguished, the components of which are [7]:

a) countries with the developed market economy. These include the industrialized countries of the world. According to the United Nations classification, in today's conditions there are about 40 such states;

b) market economy countries. This group generally includes developing countries;

c) transition economy countries, which evolve towards the market economy. According to the UN classification, the world currently has 26 transition countries;

d) countries with the command centralized economy. They include the world states of socialist orientation.

The socio-economic approach: in socio-economic terms, countries are divided into the developed, transitional and developing countries. Countries are divided into capitalist and socialist countries. 
On the ground of socio-economic origin, the systematization of national economies involves consideration of the structure of the international economy in two dimensions. The first of them examine the structure of the international economy on the basis of the level of civilization development. On its basis, there can be distinguished the following elements of the structure of the international economy [9]:

a) countries of the scientific age. These include the states of the world, which are constantly introducing into the production of the latest achievements of the scientific and technological progress. They are, as a rule, economically developed countries;

b) countries of the technological era. These include those, which periodically implement recent achievements of the scientific and technological revolution. These countries include new industrialized countries and individual countries with economies in transition;

c) countries of the industrial age. These are the countries that use traditional technologies in production and have no objective conditions for using modern science and technology. This group of states includes the majority of developing countries.

The organizational approach to systematizing countries lies in the fact that countries are grouped according to their belonging to the most important international economic organizations and institutions. Today, under the auspices of the United Nations, there are about 6,000 different international organizations. There are over 50 economic integration agreements.

Depending on the content of the economic phenomena and processes, relations between which are reflected in the proportions, the following main types of economic structure are distinguished: functional, territorial, sectorial.

The functional structure depends on the current state of development of the social division of labour in all its forms, including the state of the international division of labour. To date, analysing the state of the economy not only of economically developed countries but also of developing countries, it should go well beyond the examination of only the economic sectors. Almost everywhere there is a process of forming the inter-sectorial systems, and within the countries - inter-sectorial complexes. This process is determined by the development of technological connections, investment activities, and the requirements of modern management and marketing.

The territorial (regional) structure of the world economy characterizes the concentration and dispersion of the world economy through the prism of socioeconomic development of countries and regions of the world. Essentially, the territorial structure is the geography of its sectorial and functional-economic structures, levels of socio-economic development of the countries, expressed in the global dimension.

The sectorial structure characterizes the relationship between different divisions of the economy; industry, agriculture, construction, transport, non-productive sphere. These large divisions of the world economy, in turn, are divided into sectors - the whole complex of qualitatively homogeneous groups of production, united by the generality of final products or technological processes. Such sectors are metallurgy, mechanical engineering, radio electronics, and others (in the industry); plant growing, animal husbandry (in agriculture). The sectorial division of the economy is conditional and may vary in different countries.

In the world economic statistics, the following sectors are usually distinguished:

- primary sector of the economy - mining industry and agricultural production;

- secondary sector of the economy - manufacturing; 
- tertiary sector of the economy - transport and services;

- quaternary sector of the economy - management, education, science, and culture.

The structure of the economy reflects, first of all, the basic proportions between the production sphere (sphere of material production) and the non-productive sphere. In the sphere of material production, the following main sectors are distinguished: industry, agriculture, transport and communications, international trade.

International organizations rank countries according to different scales, indexes. Let us consider the main of them [2]. The UN has a system of national accounts (SNA), it is a system of interconnected indicators used to analyse the results of economic development.

The International Comparison Program of the United Nations (ICP) is the worldwide accepted statistical standard for international comparisons. The following indicators are used as general indicators of results of the functioning of the national economy for a certain period:

- Gross Domestic Product (GDP);

- Gross National Product (GNP);

- Net National Product (NNP);

- national income.

Assessing the country's level of development is more informative if you apply the above-mentioned indicators per capita.

Classification of countries with the help of indices is one of the widespread methods of comparing various objects.

The statehood index is used to determine the ability of the state to maintain its existence, to provide independent development, to solve internal and external tasks.

The index of external and internal threats captures the scale and intensity of the threats and challenges faced by specific states. This means both the challenges and threats from the outside (from other states, international terrorism, the world economy) and those that arise within the states themselves (internal conflicts, sociodemographic problems, the natural environment).

The index of the potential of international influence combines indicators that characterize the place of states in the system of modern international and international economic relations, instruments of their international influence, as well as the most significant and universal mechanisms for entry into the world politics and economy.

Thus, the country's economic development implies such changes that are in the interests of the majority of citizens, promote the quality of their lives, and allow them to confidently look into the future for a long time. Some shift of emphasis at the beginning of the formation of the corresponding concept led to the perception of sustainable development only as a supporter, with the fixation of the achieved level, stabilization of the situation.

Undoubtedly, to ensure sustainable development, it is necessary to ensure an adequate quality of economic growth. In the context of sustainable development, strategic shifts from the traditionally delayed reaction to disadvantaged socioecological phenomena to the perception of preventive measures, transition to the innovative way, which is based on qualitatively other factors of growth (human capital, quality, technology, management system), and thus is capable of providing new quality of economic growth. 
A number of researchers agree that the continuously growing global economy has already come close to many natural boundaries of its functioning. It is obvious that the productivist economy cannot be realized on an ever-increasing scale in the future.

Ensuring the development on the basis of sustainability, optimally structured for all its components in order to combine, in the best way, economic rationality, social care, and environmental safety of social development, can be a new moral and ethical compass for the XXI century.

As can be seen from the above, at the stage of the transition of Ukraine to the model of sustainable development, it is important to understand the methodology of the structured approach to the functioning of all spheres of life and gradually to ensure the targeted self-organization of the society for the implementation of adequate priority tasks.

\section{Structural characteristics of the economy}

Gross Domestic Product (GDP) is a measure of economic activity, it is defined as the value of all goods and services produced a net of the cost of any goods or services used in their production. The calculation of the annual rate of growth of GDP should allow for a comparison of the dynamics of economic development both over time and between the economies of different sizes. In order to measure the rate of GDP growth in terms of volumes, GDP at current prices is estimated at the prices of the previous year, and thus, these changes are calculated. Calculated GDP is imposed on the levels of the base year; this is called the chain series, the calculations are related to each other. Accordingly, the behaviour of prices will not drive up the growth rate.

The analysis of changes in GDP volumes (Table 1) [2.7] shows the deepest negative impact of the global financial crisis on the Baltic countries of the former USSR, where the level of decline was 3-4 times higher than the GDP reduction for the EU-28 as a whole. In other countries, contraction in manufacturing was more moderate, and Poland even achieved economic growth compared with the previous year.

Due to the improvement of the situation since 2010, the EU countries began to grow due to Ukraine's deep integration into the world economy and dependence on the world markets condition, and the beginning of GDP growth in Ukraine in 2010 coincided with the GDP growth of EU countries.

With the deterioration of the situation in Ukraine in 2014, GDP volume started dropping, but in 2016, the volume of GDP grew, indicating improvement in the economic situation in Ukraine.

The place of Ukraine in the world economy is characterized by the GDP per capita determined by taking into account purchasing power parities, based on the results of the Global Round of the International Comparison Program in 2005 prices in US dollars (Table 2).

Over the period under review, Ukraine's GDP declined by $36.7 \%$ and amounted to $63.3 \%$ of the 1990 level. In particular, during the times of the global crisis, the GDP decline in 2009 amounted to 14.8\%. Taking into account the reduction of the population, the fall of Ukraine's GDP per capita compared with 1990 was slightly lower $-28.7 \%$.

The above-mentioned Georgia (80\%), Kyrgyzstan (83\%), Moldova (65\%), and Tajikistan (52\%) have the similar results for the period of 1990-2009. On the other 
hand, Poland (204\%), Ireland (202\%) and Albania (199\%) reached doubling of GDP per capita over the same period. Belarus increased it by $76 \%$, Estonia and Luxembourg - by 1.6 times, this indicator has increased by almost one and a half times in Kazakhstan, Turkey, Norway, Bulgaria, and Romania.

Table1

GDP volumes change in 2005-2016 [2; 7]

\begin{tabular}{|c|c|c|c|c|c|c|c|c|c|}
\hline Country & 2005 & 2007 & 2008 & 2009 & 2010 & 2012 & 2014 & 2015 & 2016 \\
\hline 1 & 2 & 3 & 4 & 5 & 6 & 7 & 8 & 9 & 10 \\
\hline Ukraine* & 3 & 7.6 & 2.3 & -14.8 & 4.1 & 0.2 & -6.6 & -9.8 & 2,3 \\
\hline EU (28 countries) & 2.1 & 3.1 & 0.4 & -4.4 & 2.1 & -0.5 & 1.7 & 2.2 & 1.9 \\
\hline $\begin{array}{l}\text { Eurozone } \\
(19 \text { countries })\end{array}$ & 1.7 & 3.0 & 0.4 & -4.5 & 2.1 & -0.9 & 1.2 & 2.0 & 1.8 \\
\hline Belgium & 2.1 & 3.4 & 0.7 & -2.3 & 2.7 & 0.1 & 1.6 & 1.5 & 1.2 \\
\hline Bulgaria & 7.1 & 7.3 & 6.0 & -3.6 & 1.3 & 0.0 & 1.3 & 3.6 & 3.4 \\
\hline $\begin{array}{l}\text { The Czech } \\
\text { Republic }\end{array}$ & 6.4 & 5.5 & 2.7 & -4.8 & 2.3 & -0.8 & 2.7 & 4.5 & 2.4 \\
\hline Denmark & 2.3 & 0.9 & -0.5 & -4.9 & 1.9 & 0.2 & 1.7 & 1.6 & 1.3 \\
\hline Germany & 0.7 & 3.3 & 1.1 & -5.6 & 4.1 & 0.5 & 1.6 & 1.7 & 1.9 \\
\hline Estonia & 9.4 & 7.7 & -5.4 & -14.7 & 2.3 & 4.3 & 2.8 & 1.4 & 1.6 \\
\hline Ireland & 5.8 & 3.8 & -4.4 & -4.6 & 2.0 & -1.1 & 8.5 & 26.3 & 5.2 \\
\hline Greece & 0.6 & 3.3 & -0.3 & -4.3 & -5.5 & -7.3 & 0.4 & -0.2 & 0.0 \\
\hline Spain & 3.7 & 3.8 & 1.1 & -3.6 & 0.0 & -2.9 & 1.4 & 3.2 & 3.2 \\
\hline France & 1.6 & 2.4 & 0.2 & -2.9 & 2.0 & 0.2 & 0.9 & 1.1 & 1.2 \\
\hline Croatia & 4.2 & 5.2 & 2.1 & -7.4 & -1.7 & -2.2 & -0.5 & 2.2 & 3.0 \\
\hline Italy & 0.9 & 1.5 & -1.1 & -5.5 & 1.7 & -2.8 & 0.1 & 0.8 & 0.9 \\
\hline Cyprus & 3.7 & 4.8 & 3.9 & -1.8 & 1.3 & -3.2 & -1.5 & 1.7 & 2.8 \\
\hline Latvia & 10.7 & 9.9 & -3.6 & -14.3 & -3.8 & 4.0 & 2.1 & 2.7 & 2.0 \\
\hline Lithuania & 7.7 & 11.1 & 2.6 & -14.8 & 1.6 & 3.8 & 3.5 & 1.8 & 2.3 \\
\hline Luxembourg & 3.2 & 8.4 & -1.3 & -4.4 & 4.9 & -0.4 & 5.6 & 4.0 & 4.2 \\
\hline Hungary & 4.4 & 0.4 & 0.9 & -6.6 & 0.7 & -1.6 & 4.0 & 3.1 & 2.0 \\
\hline Malta & 3.8 & 4.0 & 3.3 & -2.5 & 3.5 & 2.5 & 8.3 & 7.3 & 5.0 \\
\hline The Netherlands & 2.2 & 3.7 & 1.7 & -3.8 & 1.4 & -1.1 & 1.4 & 2.0 & 2.2 \\
\hline Austria & 2.1 & 3.6 & 1.5 & -3.8 & 1.9 & 0.7 & 0.6 & 1.0 & 1.5 \\
\hline Poland & 3.5 & 7.0 & 4.2 & 2.8 & 3.6 & 1.6 & 3.3 & 3.8 & 2.7 \\
\hline Portugal & 0.8 & 2.5 & 0.2 & -3.0 & 1.9 & -4.0 & 0.9 & 1.6 & 1.4 \\
\hline Romania & 4.2 & 6,9 & 8,5 & $-7,1$ & $-0,8$ & 0.6 & 3,1 & 3,9 & 4,8 \\
\hline Slovenia & 4,0 & 6.9 & 3.3 & -7.8 & 1.2 & -2.7 & 3.1 & 2.3 & 2.5 \\
\hline Slovakia & 6.8 & 10.8 & 5.6 & -5.4 & 5.0 & 1.7 & 2.6 & 3.8 & 3.3 \\
\hline Finland & 2.8 & 5.2 & 0.7 & -8.3 & 3.0 & -1.4 & -0.6 & 0.3 & 1.4 \\
\hline Sweden & 2.8 & 3.4 & -0.6 & -5.2 & 6.0 & -0.3 & 2.6 & 4.1 & 3.2 \\
\hline The UK & 3.0 & 2.6 & -0.6 & -4.3 & 1.9 & 1.3 & 3.1 & 2.2 & 1.8 \\
\hline
\end{tabular}


Table 2

Calculation per capita by taking into account purchasing power parities, US dollars, in 2008 prices $[2 ; 7]$

\begin{tabular}{|c|c|c|c|c|c|c|}
\hline $\begin{array}{c}\text { Countries } \\
\text { (GDP in } \\
\text { prices) }\end{array}$ & 1990 & 1995 & 2000 & 2005 & 2010 & 2015 \\
\hline Ukraine & 8103 & 3920 & 3706 & 5605 & 41513 & 56353 \\
\hline $\begin{array}{l}\text { EU } \\
(28 \text { countries })\end{array}$ & & 706170.6 & 9243600.5 & 11128703.0 & 12337153.6 & 13068600.5 \\
\hline Belgium & 155310.6 & 217570.5 & 252543.0 & 303435.0 & 355791.0 & 382692.0 \\
\hline Bulgaria & 10036.7 & 9990.9 & 14035.1 & 23255.8 & 36052.4 & 39940.3 \\
\hline $\begin{array}{l}\text { The Czech } \\
\text { Republic }\end{array}$ & & 44203.3 & 63757.3 & 104628.8 & 149932.0 & 149491.1 \\
\hline Denmark & 107000.0 & 139129.2 & 173597.8 & 207366.9 & 236334.1 & 248974.8 \\
\hline Estonia & & 1929474.2 & 2047500.0 & 2224400.0 & 2495000.0 & 2737600.0 \\
\hline Greece & & 51931.5 & 105643.6 & 162896.8 & 158096.7 & 164049.8 \\
\hline Spain & & 89889.0 & 137929.5 & 193049.7 & 222151.5 & 182054.2 \\
\hline France & 401685.8 & 456494.7 & 629907.0 & 909298.0 & 1045620.0 & 1022988.0 \\
\hline Croatia & 979821.1 & 1202509.1 & 1439603.9 & 1718047.0 & 1936719.7 & 2059852.0 \\
\hline Italy & & 16867.9 & 23304.2 & 36030.1 & 44423.4 & 43127.9 \\
\hline Cyprus & 895949.2 & 865498.5 & 1198291.9 & 1436379.5 & 1551885.6 & 1560023.8 \\
\hline Latvia & & 7011.7 & 9949.0 & 13598.2 & 17406.0 & 16503.7 \\
\hline Lithuania & & 3804.7 & 8433.6 & 12927.8 & 18038.9 & 23372.1 \\
\hline Luxembourg & & 5146.1 & 12449.3 & 20969.1 & 27709.7 & 34631.2 \\
\hline Malta & & 34810.1 & 50334.7 & 88765.5 & 96243.0 & 97948.0 \\
\hline $\begin{array}{l}\text { The } \\
\text { Netherlands }\end{array}$ & & 2841.3 & 4377.8 & 4930.9 & 6458.5 & 7262.6 \\
\hline Austria & 232227.7 & 320502.2 & 417960.0 & 513407.0 & 586789.0 & 602658.0 \\
\hline Poland & 129728.5 & 182457.2 & 208473.6 & 245243.4 & 285165.3 & 313066.9 \\
\hline Portugal & & 106362.8 & 185713.8 & 244420.1 & 354616.1 & 389695.1 \\
\hline Romania & & 89801.6 & 127316.9 & 154268.7 & 172859.5 & 165690.0 \\
\hline Slovenia & 18545.5 & 28735.8 & 40651.3 & 79801.9 & 124327.7 & 142245.1 \\
\hline Slovakia & & 16024.8 & 21533.4 & 28730.9 & 35484.6 & 35274.9 \\
\hline Finland & & 14975.1 & 22046.9 & 38489.1 & 65897.0 & 72134.1 \\
\hline Sweden & 195515.5 & 193912.3 & 268252.6 & 298353.3 & 349945.1 & 420849.1 \\
\hline $\begin{array}{l}\text { United } \\
\text { Kingdom }\end{array}$ & 804192.7 & 902763.1 & 1619641.3 & 1867129.3 & 1731809.0 & 1899098.0 \\
\hline Switzerland & 192372.6 & 247840.1 & 277556.5 & 309428.4 & 414884.1 & 489673.2 \\
\hline Turkey & 119109.1 & 129590.3 & 289940.9 & 386936.8 & 550362.8 & 618626.1 \\
\hline The USA & 4695680.6 & 5859377.8 & 11135556.5 & 10524636.3 & 11287923.4 & 12625630.6 \\
\hline Japan & 2410872.7 & 4078506.4 & 5125766.6 & 3682155.6 & 4149900.2 & 3702977.0 \\
\hline
\end{tabular}

The represented figures show that Ukraine has the lowest level of GDP per capita among these countries in Europe and the CIS due to one of the deepest declines in GDP production in 1991-1999. Such a drop in GDP which exceeded 50\% of the initial level was observed only in Georgia, Moldova, and Kyrgyzstan. 
Changes in GDP production in Ukraine are characterized by the increase in the share of production of services, as opposed to the declining production of goods (Table 3).

For 1995-2015, the share of GVA in the production of goods decreased by almost a third. A special attention shall be given to the fact that although the production of services exceeds the production of goods by GVA, the cost of production has the opposite ratio and, in 2015, the release of goods was $52.6 \%$ and of services $-47.4 \%$. This is due to the fact that the production of goods requires a relatively higher intermediate consumption.

Table 3

The share of goods and services in GVA of Ukraine, \% of GVA activity types [2; 7]

\begin{tabular}{|l|c|c|c|c|c|c|c|}
\hline Indicator & 1995 & 2000 & 2005 & 2007 & 2009 & 2010 & 2015 \\
\hline Goods & 58.7 & 54.4 & 44.7 & 46.5 & 42.0 & 39.8 & 65.4 \\
\hline Services & 41.3 & 45.6 & 55.3 & 56.5 & 58.0 & 60.2 & 64.6 \\
\hline
\end{tabular}

The detailed structure of the GVA production indicates a significant reduction in the share of agricultural production, construction (more than twice) and manufacturing industry with a corresponding increase in the share of services, primarily financial services, and services to entrepreneurs (Table 4).

Table 4

The share of the GVA production of Ukraine by activity types, $\%$ of GVA activity types $[2 ; 7]$

\begin{tabular}{|l|c|c|c|c|c|c|}
\hline Indicator & 1995 & 2000 & 2005 & 2007 & 2009 & 2015 \\
\hline Agriculture, forestry, and fisheries & 15 & 16.8 & 10.3 & 8.4 & 7.2 & 7.6 \\
\hline Manufacturing industry & 36.7 & 33.7 & 30.3 & 30.8 & 30.4 & 28.8 \\
\hline Construction & 7.0 & 3.9 & 4.1 & 4.3 & 4.6 & 3.4 \\
\hline $\begin{array}{l}\text { Trade, hotels and restaurants, } \\
\text { transportation }\end{array}$ & 20.2 & 24.1 & 26.7 & 26.7 & 26.2 & 26.5 \\
\hline $\begin{array}{l}\text { Financial services and services to } \\
\text { entrepreneurs }\end{array}$ & 7.2 & 7.8 & 12.7 & 13.2 & 16.2 & 17.9 \\
\hline Other services & 13.9 & 13.7 & 15.9 & 16.6 & 15.6 & 15.8 \\
\hline On the whole by activity types & 100 & 100 & 100 & 100 & 100 & 100 \\
\hline
\end{tabular}

The corresponding changes in the structure of production in relation to increasing, the shares of services are characteristic of other countries of Europe and the CIS. However, the highest growth rate of the share of services in GVA was characteristic of the countries with a low development level: Moldova and Tajikistan (1.8 times higher than in 1995), Georgia (1.6), Ukraine and Armenia (1.5), Kyrgyzstan (1.4 times). Instead, the countries with high rates of development showed a moderate growth rate of the share of services: Poland, Estonia, the Russian Federation (1.1 times higher), Kazakhstan and Belarus (unchanged). Azerbaijan even reduced the share of services in GVA by a third.

The high level of services in GVA was characteristic of the old members of the European Union. Today, for the EU-27, it is $73.4 \%$, with Luxemburg (85\%), Cyprus, 
France, and Greece (78\%) having the highest positions. Among the post-Soviet countries, Latvia (76\%), Moldova and Estonia (71\%), Georgia and Lithuania (70\%) approached this position. In Ukraine, in 2009, the share of services production (65\%) significantly increased compared with the previous year $(60 \%)$, bringing it to the average position upon this ratio. Now it is in the middle position with Bulgaria, Poland, and Russia. The low level of services is characteristic for Belarus (48\%), Armenia (47\%), and Azerbaijan (32\%).

Agriculture makes a significant contribution to the formation of Ukraine's GVA (8\%), which is typical of the most post-Soviet countries and Eastern European countries, while the average level for the EU countries is $2 \%$. By the share of manufacturing industry close to Ukraine (25\%) are the following countries: Germany (22.2\%), Romania (26.4\%), the Russian Federation (27.3\%), Slovakia (25.6\%), the Czech Republic (30.4\%), and Belarus (30.8\%), the level of which exceeds the average level for the European Union (18.2\%). Instead, by the share of construction in GVA, Ukraine $(2.6 \%)$ occupies the last position among the countries under consideration, while the average level for the EU countries is almost twice as high (6.4\%). It should be noted that the contribution of this sector varies considerably and does not have a clear dependence on the country's economic development. Trade and transport activities are not so differentiated by the countries, and Ukraine has an average level of this industry (26.7\%), which is slightly higher than the EU-27 (21.3\%). Financial and business services in Ukraine (20.3\%) are lower than in the EU countries (28.5\%), which is typical for the post-Soviet and Eastern European countries.

As compared to 1993, Ukraine has one of the lowest indicators of the GDP growth; however, according to the types of economic activity, the trends are opposite.

The produced Gross Value Added of agriculture in Ukraine decreased by $1.8 \%$ which is close to the indicators of the Czech Republic, Kazakhstan, Romania, and Russia. Instead, a significant growth (more than twice) was demonstrated by Slovakia and Armenia, and Kyrgyzstan, Hungary, and Estonia had growth by one and a half times. By the level of fall in industry, Ukraine (-27.7\%) was surpassed only by Kyrgyzstan where industrial production was declined to almost a half. During the same period, Slovakia, Poland, Finland and the Czech Republic increased the volume of industrial production by 2-3 times. With no close analogues among other countries, construction in Ukraine has decreased catastrophically, while Armenia increased its volumes within this period by 6.7 times, Romania, Kazakhstan, and Latvia - threefold. Although there was a definite growth in trade (by 7.9\%), it turned out to be the lowest among the above-mentioned countries. The trade activity in Armenia increased sixfold, in Kyrgyzstan, Latvia, and Romania it tripled. The financial activity grew rapidly in all countries, with the exception of Kyrgyzstan. The top positions were occupied by Iceland and Lithuania where the volumes of these services almost tripled. According to this indicator, which doubled more than twice, Ukraine also occupied one of the numbered places. The growth of other services in Ukraine was observed by $4 \%$.

Ukraine occupies one of the last places not only in terms of GDP per capita, ahead of Armenia, Moldova, Kyrgyzstan, and Tajikistan but also by the level of expenditures on final consumption, where it is further ahead of Azerbaijan. However, Ukraine has a lower level of the gross accumulation of the fixed capital than Azerbaijan and Armenia. It is due to the devaluation of hryvnia in 2008.

Ukraine has a slightly negative net balance of external economic relations occupying an average position. Azerbaijan and Russia have the highest positive net 
balance among the CIS countries, while the lowest is with Belarus, Moldova, and Armenia. Although external economic relations are essential for Ukraine, the absolute level of export and import per capita is quite low. In terms of exports, Ukraine exceeds Turkey, Moldova, Kyrgyzstan, and Armenia, while in terms of imports it exceeds Azerbaijan, Turkey, Russia, Moldova, Armenia, and Kyrgyzstan. Analysis of the structure of GDP shows the main differences between the countries in the flow of funds for the consumption and accumulation.

By the share of expenditures on the final consumption of households in GDP, Ukraine has a rather high position (65\%). It should be noted that the countries with the highest rates of final consumption of households (Kyrgyzstan, Bosnia and Herzegovina, Tajikistan, Moldova, Montenegro, Georgia, and Armenia) achieve it at the expense of a large negative net balance of the foreign trade. While Luxembourg, Norway, Azerbaijan, the Netherlands, Kazakhstan, which have a high positive net balance, are characterized by a low share of consumer spending in GDP. The level of expenditures of the general government of Ukraine (20\%) is medium and slightly lower than of the EU (22\%), but the collective costs in Ukraine that are spent on the maintenance of public administration, science, and other collective needs of society are among the lowest (7\%), which is almost three times lower than in Georgia (19\%). The share of gross accumulation of the fixed capital stock decreased significantly (18\%) because of the crisis, as in the EU countries, and it is one and a half times lower than in Belarus, Armenia, Kazakhstan, Kyrgyzstan. The devaluation of hryvnia reduced the negative net balance of external economic relations of Ukraine and led to the decrease in exports and imports, resulting in Ukraine taking average positions among other countries by these indicators.

\section{Processes of structuring in the Ukrainian economy}

Processes of structuring in the Ukrainian economy show disparities in relation to final consumption and accumulation of the fixed capital stock, which may negatively affect the opportunities and results of managing the crisis phenomena of 2008-2010. This, in turn, became the development of risks for the further economic progress of Ukraine.

Confirmation of the narrowing of the possibilities for further economic development of Ukraine is the consideration of the change of these indicators for 2008 compared to 1993 (Table 5) [2, 7].

According to the analysis (Table 5), Ukraine with GDP growth of $1.0 \%$ in 2015 compared with 1993, occupies the penultimate position among the countries listed.

Having one of the last places in the final spending of the general public sector $(-12.1 \%)$ and the last place in the gross accumulation of the fixed capital stock $(-43.6 \%)$, Ukraine, however, doubled the final consumption of households $(+112.0 \%)$, which breaks the reproduction proportions of GDP.

A similar situation with regard to exceeding the growth rate of household consumption (by 1.5-2 times) over the GDP growth rates is also observed in Moldova, Belarus, and the Russian Federation. At the same time, only in Ukraine and Moldova, the gross accumulation of the fixed capital stock decreased. It is worth noting that the trend of significant (more than 1.5 times) excess of consumption growth over the accumulation is also typical only for Ukraine, Moldova, and the Russian Federation. In the vast majority of other countries, the growth rate of gross accumulation was significantly higher than the consumption growth. 
Change in the indicators in 2015 compared to 1991

\begin{tabular}{|c|c|c|c|c|c|c|c|}
\hline \multirow[b]{2}{*}{ Country } & \multirow[b]{2}{*}{ GDP } & \multicolumn{2}{|c|}{$\begin{array}{l}\text { Expenditures for } \\
\text { final consumption }\end{array}$} & \multirow{2}{*}{$\begin{array}{c}\text { Gross } \\
\text { accumulation of } \\
\text { fixed capital } \\
\text { stock (GAFCS) }\end{array}$} & \multirow{2}{*}{ 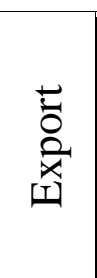 } & \multirow{2}{*}{$\begin{array}{l}\bar{\Xi} \\
\stackrel{0}{\Xi} \\
\text { : }\end{array}$} & \multirow{2}{*}{$\begin{array}{l}\text { Ratio of growth } \\
\text { rates of household } \\
\text { consumption } \\
\text { before GAFCS }\end{array}$} \\
\hline & & $\begin{array}{l}\text { of } \\
\text { house } \\
\text { holds }\end{array}$ & $\begin{array}{c}\text { general } \\
\text { government }\end{array}$ & & & & \\
\hline Azerbaijan & 318 & 284 & 150 & 1974 & 1727 & 1974 & 12 \\
\hline Estonia & 227 & 252 & 154 & 290 & 312 & 290 & 76 \\
\hline Belarus & 215 & 329 & 131 & 198 & 219 & 198 & 109 \\
\hline Latvia & 215 & 227 & 133 & 260 & 268 & 260 & 51 \\
\hline Poland & 208 & 199 & 171 & 458 & 490 & 458 & 61 \\
\hline Slovakia & 204 & 198 & 154 & 341 & 288 & 341 & 128 \\
\hline Kazakhstan & 196 & 133 & 150 & 170 & 115 & 170 & 76 \\
\hline Ireland & 190 & 164 & 166 & 348 & 315 & 348 & 96 \\
\hline $\begin{array}{l}\text { The Czech } \\
\text { Republic }\end{array}$ & 153 & 170 & 123 & 374 & 419 & 374 & 100 \\
\hline Hungary & 153 & 140 & $102 \mathrm{I}$ & 667 & 494 & 667 & 76 \\
\hline Greece & 151 & 150 & 162 & 190 & 198 & 190 & 91 \\
\hline Finland & 150 & 151 & 124 & 246 & 239 & 246 & 92 \\
\hline Luxembourg & 148 & 127 & 150 & 234 & 239 & 234 & 88 \\
\hline $\begin{array}{l}\text { The Russian } \\
\text { Federation }\end{array}$ & 145 & 202 & 131 & 254 & 320 & 254 & 168 \\
\hline Iceland & 140 & $125^{\prime}$ & 135 & 194 & 155 & 194 & 117 \\
\hline Sweden & 139 & 135 & 105 & 233 & 209 & 233 & 80 \\
\hline Norway & 136 & 156 & 135 & 136 & 179 & 136 & 83 \\
\hline Spain & 135 & 131 & 159 & 207 & 238 & 207 & 85 \\
\hline Great Britain & 135 & 142 & 126 & 179 & 195 & 179 & 97 \\
\hline The Netherlands & 135 & 126 & 142 & 216 & 222 & 216 & 91 \\
\hline Canada & 131 & 140 & 115 & 134 & 161 & 134 & 85 \\
\hline Austria & 131 & 120 & 127 & 214 & 186 & 214 & 104 \\
\hline Portugal & 128 & 132 & 139 & 186 & 193 & 186 & 110 \\
\hline The USA & 128 & 136 & 112 & 179 & 201 & 179 & 104 \\
\hline Kyrgyzstan & 128 & 132 & 71 & 106 & 92 & 106 & 70 \\
\hline Belgium & 128 & 119 & 123 & 171 & 167 & 171 & 87 \\
\hline Denmark & 123 & 123 & 131 & 182 & 220 & 182 & 78 \\
\hline France & 122 & 128 & 114 & 165 & 192 & 165 & 97 \\
\hline Germany & 120 & 117 & 122 & 253 & 222 & 253 & 106 \\
\hline Switzerland & 115 & 113 & 107 & 176 & 175 & 176 & 93 \\
\hline Italy & ПО & 114 & $\Pi О$ & 127 & 150 & 127 & 98 \\
\hline Ukraine & 101 & 212 & 88 & 168 & 249 & 168 & 376 \\
\hline $\begin{array}{l}\text { The Republic } \\
\text { of Moldova }\end{array}$ & 93 & 223 & 88 & $30 \ddot{~}$ & 389 & 301 & 243 \\
\hline
\end{tabular}


For the period of 1993-2016, primarily in the post-Soviet countries, the growth rate of actual final consumption of households significantly (by 1.5-2 times) outran the GDP growth rate, while in Ukraine and the Russian Federation the gross accumulation of the fixed capital stock decreased by about a quarter. It should be noted that the tendency of excess consumption growth and accumulation (by 1.5-2.4 times) is characteristic only for Ukraine, the Russian Federation, and Belarus. Predominately in other countries, the growth rate of gross accumulation was significantly higher than the consumption growth.

Among other European countries, the global financial crisis most negatively impacted the Baltic countries of the former USSR where the level of decline was 3-4 times higher than the level of the EU-27. In other countries, the decline in manufacturing was more moderate. The terms of the end of the recession in Ukraine coincide with the European ones, which indicate the deep integration of Ukraine into the world market.

Ukraine has one of the lowest levels of GDP per capita among European countries due to one of the deepest declines in GDP production in 1991-1999. At present, Ukraine's GDP is only 63\% of the 1990 level. Similar results for this period are with Georgia, Kyrgyzstan, Moldova, and Tajikistan. On the other hand, doubling of GDP per capita over the same period was reached by Poland, Ireland and Albania, Belarus increased it by 1.8 times, Estonia and Luxembourg - by 1.6 times, it was increased by almost one and a half times in Kazakhstan, Turkey, Norway, Bulgaria, and Romania. The Russian Federation demonstrates relatively low growth rates (107\%).

The reduction of Ukraine's GDP in 2009 was due to the fall in construction, processing industry, and trade. One of the reasons was the limitation of investment opportunities, which resulted in a decrease in demand for construction products, production of investment vehicles and construction materials, along with the reduction in external demand for metallurgical products. The decrease in the volume of wholesale trade is caused by the decrease in the purchasing power of enterprises, and the turnover of retail trade - a decrease in real recognised income of the population.

In GDP of Ukraine, the share of production of services is increasing, as opposed to the reduction of the production of goods. The share of production of agriculture, construction, and manufacturing industry is being significantly reduced, with a corresponding increase in the share of services, primarily financial and services to entrepreneurs, where Ukraine has already reached the average level among the postSoviet countries. Such high rates of increase in the share of services in GVA are typical for the CIS countries with a low level of development. Instead, the postsocialist countries with high rates of development showed moderate growth rates of service share. Consequently, economic development in the countries of the CIS and Eastern Europe is achieved first of all through the development of the commodity production.

Among the categories of the end use, the gross accumulation of the fixed capital stock, exports, and imports were mostly impacted by the crisis.

A significant contribution to the formation of agricultural GVA is characteristic of Ukraine, as of most CIS countries and the countries of Eastern Europe. The share of industry in Ukraine exceeds the average level for the European Union, but Ukraine occupies the last place in terms of the share of construction in GVA, while the average level for the EU countries is almost twice as high. 
Ukraine occupies one of the worst places in the development rate of industry, construction, and trade during the years of its independence, while, at the same time, by the level of growth of financial services and services for entrepreneurs, Ukraine is ahead of most countries selected for comparison.

The components of the end use of Ukraine's GDP per capita are at a rather low level even among the CIS countries, but Ukraine occupies one of the first places in terms of the share of actual final consumption of households in GDP.

Changing of these indicators over the years of independence indicates a significant redistribution of GDP use patterns. Thus, with a substantial reduction in the gross accumulation of the fixed capital stock, Ukraine, nevertheless, has occupied one of the highest places in the growth of actual final consumer expenditures of households. A similar situation is observed in the Russian Federation and Belarus.

The conducted research demonstrates that the structuring of the Ukrainian economy both during the crisis and at the stage of economic growth occurred mainly spontaneously, without the development of a clear concept and implementation of targeted actions by the state. As a result, the aggregated structure of the Ukrainian economy, though gradually, changes in line with global trends, but remains substantially deformed and significantly different from the structural parameters of the European Union countries, which complicates the process of convergence of Ukraine to this international community.

Conclusions. Different scholarly schools identified the relationship between the formation of multi-level economic structures with the development of the economy and the unforced nature of the market self-regulation. However, to date, theoretical justification for the structural coordination of development factors, their hierarchy is still insufficient given the importance of influencing the economic dynamics, depending on the phase of the cycle, as well as the structural causes and consequences of transformational changes. The formation of a new structure shows the transition of one or another formation into a new qualitative state, to a new level of development.

The structure of the economy of this or that country is a complex of productions that arose on the basis of a combination of the social division of labour, natural resources, historical traditions, and territorial specificity. The complexity of the structure of the national economy is determined not only through such concepts as the type of economic activity (industry), the sector of the economy, etc.

The most significant, qualitative changes in the structure of the economy are classified as economic changes. They act as a support, a framework for the formation of a new quality of productive forces and technical and industrial relations. In the case of structural changes in the macro level, the comparative structural elements and profiles of the economic structure should, above all, be the most important proportions in the production and consumption of gross output and its components intermediate consumption and GDP.

International organizations do not have unified approaches to the definition of subsystems in the global economy. The UN and the IMF, and the World Bank group the countries, but their composition is different. They analyse the state of the economies only of those countries that are their members: the UN - 191, the IMF 189, the World Bank - 186 (data for 2009). In addition, some of the countries 
participating in international organizations do not provide timely and complete information.

Thus, the economic development of countries implies such changes that meet the interests of the majority of citizens, promote the quality of their lives, and allow them to confidently look into the future for a long time.

\section{References:}

1. Amosha O. Industrial policy of Ukraine: conceptionsformedium-termprospects. Amosha O., Vyshnevskyi V., Zbarazska L. Economy of Ukraine, 2009,No. 11,pp. 4-13.

2. State Statistics Service of Ukraine. [Electronic source]. http://www.ukrstat.gov.ua/.

3. Yerokhin S.A. Structural information of national economy (theoretical and methodological aspects). Yerokhin C.A. K: Svit Znan Publ., 2002, 528 p.

4. Structural changes and economic development of Ukraine: monograph [Heiets V.M., Shynkaruk L.V., Artomova T.I. and others]; as revised by Dr.sc.Oec Shynkaruk L.V.; National Academy of Sciences of Ukraine; Institute of Economy and Strategic Research., K., 2011, 696 p.

5. Structural changes in manufacturing industry of Ukraine: the state and priority guidelines: Monograph. Amosha O.I., Makogon Yu.V., Zbarazska L.O.and others. National Academy of Sciences of Ukraine. Institute of industrial economy, Donetsk, 2004, 180 p.

6. Economy of Ukraine: strategy and policy of the long-term development, as revised by academician of the National Academy of Sciences of Ukraine Heyets V.M., K.: Institute of Economy and Strategic Research., Fenix Publ., 2003, 451 p.

7. Eurostat [Electronic source] http://ec.europa.eu/eurostat/data/database

8. Indicators of Sustainable Development: Guidelines and Methodologies. United Nations: NewYork, 2007.

Malakhovskyi Y.V. Candidate of Economic Sciences, Associated Professor, Senior Lecturer at Department of Economics, Management and Commercial Activity Central Ukrainian Technical University

Nabulsi H.N. Postgraduate Student, Central Ukrainian Technical University

Savitska I.M. Assistant Lecturer at Department of Economics, Management and Commercial Activity, Central Ukrainian Technical University

\section{FEATURES OF FINANCING OF THE INNOVATIVE-ORIENTED STRUCTURES USING MECHANISMS OF THE PUBLIC-PRIVATE PARTNERSHIP}

Summary. The aim of the publication is to study and generalize theoretical and methodological principles of the implementation of the public-private partnership $(P P P)$ for activity of scientific innovative-oriented cluster type structures (SIOCTS) in the scale of the national economy and the development of the recommendations for the formation, practical use, and further improvement of the mechanism of its 
regulation. Propositions are based on China, France, India, Indonesia, Japan, Malaysia, Singapore, South Korea, Thailand, United Kingdom experience. Modernization of the development of the PPP projects for SIOCTS in the increasing challenges of globalization and increasing international competition, based on the strategic lines of the development of the similar international models should be based on the following principles: clarifying the essential characteristics of the PPP projects with all of the functioning of the national economy; rationalization of the national model of the public-private partnership; updating the list of purposes of implementing the PPP policy; expanding of the list of economic activities that are within the practice of implementing cooperation agreements; expanding the list of species of legal registration of transactions; review of approaches to expand the list of entities that can initiate the conclusion of the partnership agreements; expanding and refining the content of individual stages of the implementation of the PPP; improving the current legislation on the regulation of the PPP; expanding the empowerment of parties involved in the transaction; improvement of tools and techniques of risk management transactions of the PPP; development of an effective mechanism to guarantee the return of invested funds of agreements on cooperation of $P A$ and private business; organization of constant monitoring of the PPP projects; development of the implementation mechanism "unsolicited proposals" for cooperation. Acting mechanism of the PPP regulation in Ukraine in the sphere of SIOCTS functioning is influenced by the characteristics of all risk factors countries and failure of parties of the partnership because of agreements of economic interests. Since the regulation of economic development, including the region of the state, pursues the goal of fulfilling of vital needs of both sides of the partnership, which are in commercial relations and all public stakeholders, preliminary examination of the partnership projects should include mandatory cash flow calculations and social indicators of the investment projects of the PPP; similar codes on the stage of determination of indicators of the commercial efficiency; cash flows in the case of budget efficiency assessment of the PPP projects.

Introduction. Global socio-economic transformations and the development of the market relations in Ukraine raise the question of transforming the role and place of the state, its main partner - private business, the use of hybrid forms of their cooperation in the functioning of a market economy, especially at the regional level. Despite global institutional reforms, the Ukrainian state continues to act as the main subject of the regulation (mainly by means of the economic influence) for the clear majority of spheres of society's life. At the same time, it clearly manifests the objective need for an active and effective influence of intervention into the production processes of the stakeholders, public organizations of entrepreneurs and employers, creating a complete system of public-private partnership (PPP) in the field of innovation.

In the writings of J. Keynes, M. Blaug, Paul Samuelson, P. Drucker, M. Porter, the fundamental theoretical approaches to the development of the PPP are developed, models, forms, and mechanisms of the productive cooperation of state governance and business innovation sector are tested. The issues of the interaction between state and small business, the formation and activities of its corporate unions are the most thoroughly investigated. Especially we note the significant contribution of well- 
known researchers as A. Akintoye [1], B. Flyvbjerg [2], D. Helm [3], G. Hodge [4], T. Merna [5], E. Savas [6], G. Teisman [7], R. Vickerman [8] et al.

Problems and prospects of the formation of the PPP are highlighted in the works of Ukrainian scientists: B. Vynnytskyi [9], V. Heiets [10], B. Danylyshyn [11], K. Pavliuk [12], P. Shylepnytskyi [13]. However, despite the numerous studies, the problems of adaptation of the best practices in using the PPP tools during the organization of the activity of the competitive innovation-intensive enterprises, which not only seek but also have all the grounds for the successful integration into the globalized space of the post-industrial economy, remain insufficiently highlighted.

The main result of carrying out research and development works (R\&D) in modern conditions are the innovative products, which, because of the complex activities on their creation, use, and distribution in the sectors of the national economy, turn into innovations - competitive technologies, products or services of production, administrative, commercial or otherwise.

The most economical and time-consuming way of implementing a cycle of transferring innovative products to profitable use in the real economy is the introduction and organization of the activity of the innovative-oriented cluster type structures (IOCTS).

\section{Organization and financing of the IOCTS activity}

IOCTS is a production and consumer complex formed based on the territorial concentration of the specialized suppliers, producers, and consumers of products/services related to the technological chain or a virtual structure created based of the formation of the innovative networks and not geographically linked to a separate territory.

The sequence and peculiarities of the individual stages of the life cycle of innovations - from (a) the emergence of the idea in the environment of generation and transfer of knowledge; (b) the introduction, production, and profitable commercial realization of the innovations in the real sector of the economy; (c) the regulation, control, and stimulation of the innovation activities by public administration (PA), (d) the promotion, diffusion, and use of the innovative product with the fully satisfy demand for active consumers and its next transformation into routine, form a set of mandatory and necessary elements of IOCTS.

The mentioned form of management of the innovative activity in the most effective way contributes to the emergence of a synergistic effect based on the pooling of efforts and competences of its participants (enterprises, research and educational institutions, state authorities, service companies, intermediaries, etc.), which operate for the creation, introduction, and commercialization of the innovative product to achieve competitive advantages in the market.

Industry IOCTS (IIOCTS) is an economic system that is a set of enterprises, organizations (production, service, universities, research institutes, engineering centres, innovators, technology, market institutions, consumers) that are located on the same territory, interact with on a contractual basis (cooperation agreements) do not undermine the rights of any of its members, work towards the same goal - to achieve the economic growth in the process of using innovations, characterized by certain stability that creates and engage participants provided a synergistic effect.

Territorial IOCTS (TIOCTS), unlike the territorial-production complex (TPC) as the main form of spatial organization of the production activities for the dominance 
of the economy on scheduled basis, are constantly evolving way of forming value chain by forming a cluster around an innovative core (innovation active enterprise or scientific institution) to increase the prosperity/competitiveness of the region [14].

Scientific IOCTS (SIOCTS) - classified on the basis of the integration of the vector orientation, geographic location, and degree vector combining innovative system of economic agents are able to regulate and control the process of commercialization of science in higher education, including the learning of future innovative specialist type of economically active structure that operates on the basis of a particular university, an investment project of socio-economic type, which provides justification of the economic feasibility of investments in order to achieve the enumeration of academic and non-academic results [15-17].

A fundamentally important issue for the functioning of IOCTS in Ukraine is the financing of their activities.

Public funding previously mentioned TPC based on software basis method of forming energy-chain cycles to minimize production costs, made at the initiative of the central government, which form the state order. It is to obtain a regional effect from the concentration and specialization of enterprises by central government bodies providing free and irrevocable provision of budget funds to state agents.

The procedure for funding production activity is significantly complicated in a modern economy. The general principles of financing state and municipal expenditures in the conditions of equal coexistence of institutional entities at all levels of the national economy are: planning; compliance of planned expenditures with the amount of state or municipal revenues; target allocation of funds; compliance of expenditures financed with the rights and interests of citizens, organizations, state, municipalities protected by current legislation; the compliance of the expenditures financed with the requirements of environmental, sanitary and hygienic and other statutory and corresponding norms; free and non-refundable funds allocated; control over the use of state and municipal funds and liability for offenses in this area.

The legal regime of financing (depending on the use of entities) are: securing property for state and municipal commercial organizations on the right of economic management; budget financing of state and non-profit municipal institutions, which were granted the right to operational management of the property.

Funding IOCTS is a dynamic process of attracting, accumulating, and using financial resources aimed at developing, implementing, and commercializing innovations to provide strategic objectives for the functioning of the cluster. Funding principles of IOCTS are subdivided into traditional ones - purposefulness, financing as the work is done (provision of services), compliance with financial discipline; as well as specific, which reflect the features of the innovation cluster - synergy, targeting, flexibility, differentiation. The complication of the principles of investing in SIOCTS manifests itself in a clear demarcation of their social and economic varieties.

The social objectives of the investment are to ensure the educational and scientific integration of the economic agents in the field of higher education and science, the activation of the social elevator for gifted university entrants, students, graduates of higher educational institutions - residents of SIOCTS, integration of university and state innovation policy aimed at increasing opportunities for the education of the innovation type, and as a consequence, the commercialization of science in higher education. 
The economic principles of investment of funds are multichannel and differentiated investment attraction, provision of organizational development of the innovation structure as a form of the integration of the university science to national and regional innovation systems, maximization of the positive effect, achievement of a competitive level in the innovation sphere, development of production cooperation between the participants of the SIOCTS, as well as their integration to the international scientific-production chains that are formed within the framework of the functioning of specific technologists platforms.

The model of financing of the innovation process is realized in the process of circulation of funds and diffusion of innovations between residents of SIOCTS producers of innovations; financial suppliers; PA; innovative active commercial enterprises; consumers of products (Fig. 1).

If the concluded matrix of estimation of separate leaks of funds with the coordinate axis "source of financing - level of accessibility, capacity, cost of attraction, level of risk" demonstrates the degree of suitability of the external revenues for the use in the financing process of SIOCTS, then formal warnings impose restrictions on variants of the use of means of production enterprises in the process of passing stages of the life cycle of the innovative products.

\section{International PPP experience in the innovation activity}

The management of the economy from the side of PA is carried out through the regulatory influence on the system of relations between the regulators (state corporations - public unions of entrepreneurs and industrialists - consumers of goods and services) that interact within a limited economic space to realize the goals and conditions of social production. If in the process of regulation, the question arises of the need to combine the material and intangible resources of society (in the person of the PA), as well as private business funds for creating public goods or providing public services, then, under the current conditions of the development of the national economy, this occurs mainly in the form of PPP.

From the point of view of the objective of the study, we will define the essence of the category "the mechanism of the regulation of the PPP in the innovation activity" as an ordered system of administrative measures of the PA on the complex of mutually beneficial relations between representatives of the authorities, business, civil society institutions, local communities on the redistribution of powers in the field of production of the innovative goods and provision of the innovative services, which at present are mainly carried out by state enterprises and institutions.

Effective use of the PPP mechanism ensures optimal coordination between the parties to a wide range of issues: the sharing of responsibilities, risks, obligations regarding financial security, design, construction, operation, ownership, participation in management, and distribution of profits.

Due to the direct and indirect influence of several reasons of legal and organizational nature, the list of the applied PPP models in Ukraine, as compared with international practice, is significantly narrowed.

It is limited with contracts for technical services, social services, government assets, and contracts of cooperation of the simplest type, lease agreements with lease payments to the state, concessions, infrastructure development, and the provision of services within the corporate responsibility of corporations. The international experience of using the PPP models in comparison with domestic ones is much more 
significant and extends to a much wider list of infrastructure objects. In view of this, we consider it necessary to introduce into the practice of domestic PPP regulation the international experience of cooperation between the PA and private investors, which provides for a few measures to reform it.

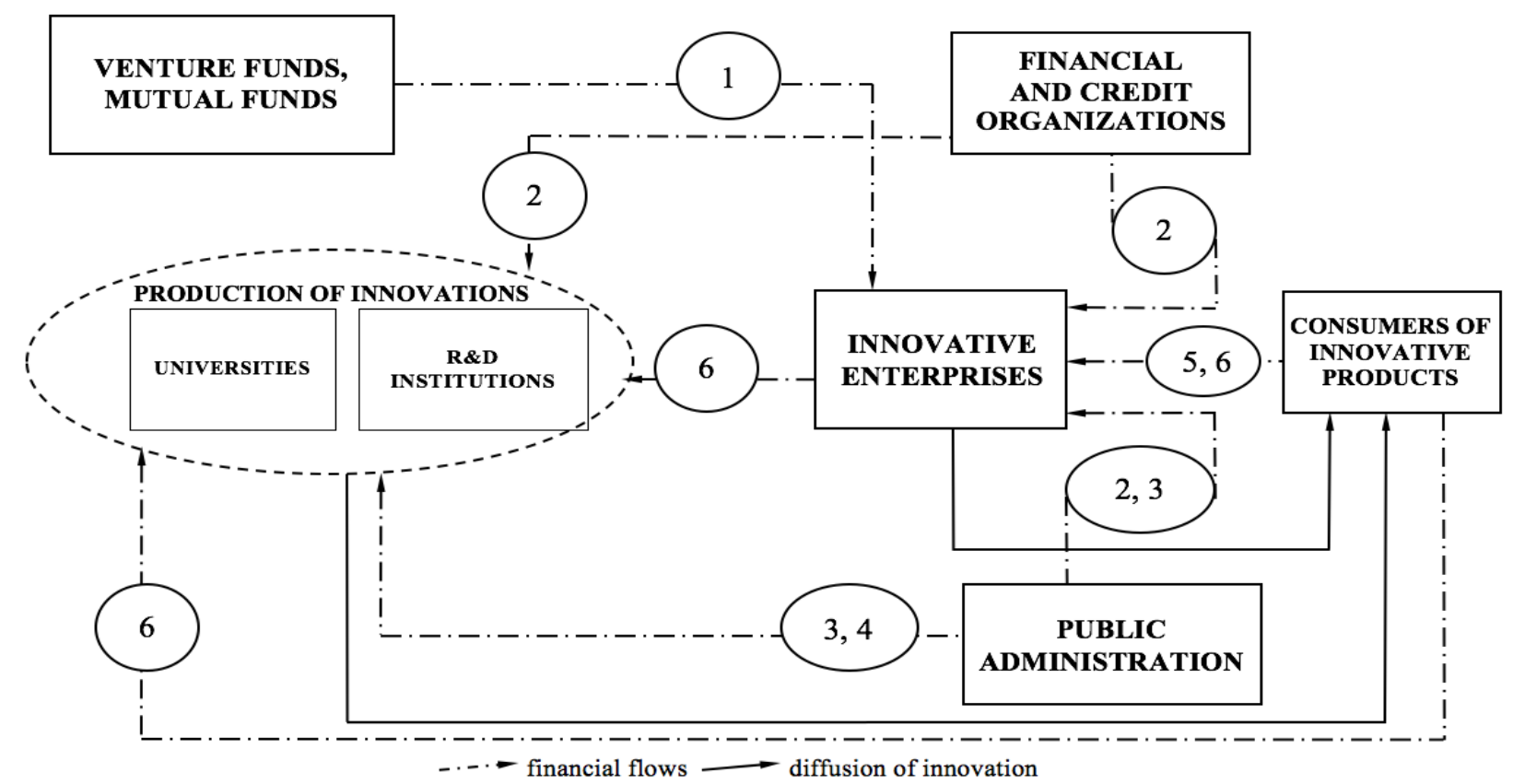

Notes: 1 - participation in the statutory fund through the purchase of shares; 2 - credits; 3 - subsidies; 4 - grants; 5 - issue of bonds; 6 - licensed payments from transferred rights for the use of intellectual property

Source: adapted by the author based on [18]

\section{Fig. 1. The financing model for the innovation process within the framework of the SIOCTS}

China. The existence of fundamental differences in the meaning of the coefficients of financial self-sufficiency, the sequence and the content of the technological processes and other operational-design characteristics cause significant deviations in the process of forming the PPP models in various areas of application of the partner relationships.

Thus, in the water supply sector of the national economy, different tariffs are used to pay for purified water and to compensate for its total consumption. Ultimately, water supply companies receive funds from the PAs only for purified water, and the authorities themselves collect funds from end users at a slightly higher rate. Thus, the treatment plants are transferred to the private business with schemes BOT (build operate - transfer) or TOT (transfer - operate - transfer). BOT schemes are the most popular model for toll roads, where private investors are directly receiving revenues from users. Incidentally, this means that it is the private business that puts the risks of organizing traffic and related revenues. The peculiarity of the Chinese experience modelling of the PPP is to spread these kinds of as SBOT (subsidies in build operate - transfer) and BSOT (build - subsidies in operation - transfer).

Despite the proliferation of the PPP models in most areas of infrastructure construction, there is still the lack of a perfect national base for regulating such partnership issues as project evaluation, procurement organization, decision-making processes, public accountability of partners, fair sharing of risks between them, and tariff adjustments in China [19;20]. 
France. The economic crisis of 2007 led to the need to formulate a new role of private finance in overcoming its consequences $[21 ; 22]$. The material basis of the state support of the PPP is announced three key elements: budget guarantees in the amount of 10 billion euro; budget expenditure on the formation of long-term loans in the amount of 8 billion euro managed through public savings banks (Caisse de Dépôts); the new legislation of 2009 is intended to accelerate the implementation of the PPP program especially by safeguarding the protection of private business interests in the partnership process. Another initiative of the President of the republic is to declare a "big loan" program with a budget of 35 billion euros, of which 22 billion is provided by financial markets. In the plans of providing an investment of 60 billion euros in four priority areas: higher education and research $(\mathrm{R} \& \mathrm{D})$ (additional university funding with program "Plan Campus"), industry, renewable energy, digital economy [22].

India. The PPP projects are defined by the government as such, based on contract or concession between PA and by the private sector to investments in the construction and maintenance of infrastructure assets and/or services infrastructure. In this case, the PPP projects involve the transfer or lease of state assets.

Institutional mechanisms for promoting PPPs are designed to maximize their role in the development of the national economy of India [23; 24]. This is supported by important political initiatives of the Government, consisting in implementing the activity of the PPP Appraisal Committee (PPPAC) - an institution whose main objective is to promote the development and implementation of the PPP projects; India Infrastructure Finance Company Limited (IIFCL), companies for the promotion of the inflow of long-term investments in the national economy (NE); India Infrastructure Project Development Fund (IIPDF), whose vocation is to cover a part of the costs in the development of the PPP projects.

Indonesia. The role of the government of this country in the provision of infrastructure services has long been significant enough $[25 ; 26]$. The Government continues to play a central role in the development of the policy and effectively monitor the implementation of the PPPs through a system of government bodies such as the National Planning Agency, KKPPI, IIF, and the Ministry of Finance. Although private businesses account for about $69 \%$ of Infrastructure projects in Indonesia, PAs remain key players in infrastructure development. One of the most vulnerable aspects of the implementation of the PPP projects in Indonesia is the lack of the effective evaluation and monitoring procedures.

Japan. The use of private financing for public services is one of the priorities of the development of the national economy of Japan [27; 28]. In 1980, when there was significant state budget deficit, the model of the "third sector" was used to ensure a broad access to private capital as a resource for additional funding of public projects. Due to some problems, especially around risk sharing, updated PFI model is designed to provide access to the PPP contracts for private capital, which will be defended in matters of equitable sharing of risk between the public and private sectors. Actively used, dominant today the model of PFI "Hakomono", provides the execution of the single obligations to stakeholders, entitled "value for money". Instead, the government's efforts today are designed to provide real cost of PFI (Private Financial Initiative). Today we note the four major areas of reform policy approaches to the PPPs in Japan: first, a departure from traditional models "hakomono", refocusing on the model concession cooperation; secondly, the focus is shifting to the analysis of the ratio of "price-quality" by improving the operating characteristics of the PPP 
projects, the attention which was insufficient; thirdly, measures to ensure the comprehensive cost reduction agreements in force revision policy in public procurement, i.e. "policy of the PFI without SPS" (Special Purpose Company); fourth, the formation of a proper understanding of the financial model of private initiative, which should eliminate the potential risks that may be caused by the opportunistic behaviour of private companies.

Malaysia. The feature of the Malaysian model is that it began and continues to consist of two main components - namely privatization and PFI. The first of these was implemented in 1983 and the last one - in 2006 [29]. Timing PFI and PPP (public-private partnership) in this country are often used interchangeably. PPP is carried out on a systematic basis, including through a five-year strategic plan for development.

Singapore. Overall, Singapore has very favourable conditions for the implementation of the PPP projects [30; 31]. However, the presence of barriers (six basic varieties) - social, political and legalization risks; adverse economic and business condition; inefficient public oversight procedures; lack of sophisticated financial engineering techniques; the problem of relations with the public sector; problems relations the private sector - delays the process of full implementation of mutually beneficial contracts. A unique feature of the implementation of the Malaysian model of the PPP is its absolute efficiency for private business and the lack of enforcement interests of the public (state) sector. This, in part, may explain the absence of central authority partnership settlement.

South Korea. In terms of population aging, while expenditure on maintaining a proper level of spending on welfare is steadily increasing, there is a restriction of public investment in infrastructure [32;33]. Thus, the government is actively promoting private investment in areas where the use of resources of private enterprise can effectively and competitively supplement budgetary costs. Meanwhile, the use of the PPP projects is prevented, firstly, with temporary difficulties in adapting national accounting with International Accounting Standards. Second, the super-fast growth of the aging population, coupled with low birth rates, a consequence of the reduction of the working age population.

\section{Modernization of funding IOCTS using the PPP mechanisms}

Currently, there is no single definition of the PPP, which would have universal spread around the world and could be used without warnings in all possible areas of cooperation between the state and private business.

Universally suitable for the practical use in consideration of the specifics of Ukrainian legislation is the United Kingdom PPP model. It should be noted that despite the relatively low level of the investment PPP projects involving private business, the country's Treasury Department constantly improves the procedures of the PA cooperation with these institutions.

In the United Kingdom, the PPP is defined as an agreement on cooperation between the public and private sectors. In the broadest sense, it covers all kinds of cooperation carried out by the interface between sectors to joint activities and sharing risks in the implementation of policies, services, and infrastructure. The most common type of the PPP is a private financial initiative (PFI). PFI is an agreement under which the public sector is committed to providing its inherent services using 
investment in assets received from the private sector on a long-term basis, over a long period (15 to 30 years).

Per the latest trends of the research in this area, promising recognized are such forms of cooperation, in which the public partner on a competitive basis with the private concludes an agreement for the design, construction, and operation of the facility throughout the lifetime service project pays instalments only after its introduction operation on condition of maintaining the private partner object per specific functional requirements [34].

Attracting investment funds is regulated by analogy to blending structural and investment funds of the PPP projects developed by the European Examinations Centre [35].

A new approach to the PPP defines government policy to attract private capital in public infrastructure service on basis of delivery through long-term contractual arrangements PF2, which significantly modernized traditional approach PFI (Private Finance Initiative) and related issues:

- universal growth of partnerships between the public and private sectors provided with the memorization of government equity participation in projects in the PPP in terms of PF2;

- speeding up and reducing the costs of the PA by:

- improving procurement opportunities for the public sector by strengthening the mandate of infrastructure support departments with centralized procurement;

- time limiting of the competitive phase of bidding for projects PF2 for term not exceeding 18 months;

- introduction of a standardized and efficient approach to procurement procedures and providing the complete set of standardized documents;

- strengthening of drafting the study by introducing additional checks on the part of the Treasury Department at the stage of preliminary procurement;

- improving service delivery flexibility by:

- removing "soft" services (cleaning and meals) project;

- introducing greater freedom of handling volumes of maintenance work at the beginning of the project and the possibility of adding or removing optional services during operation of the project;

- periodic reviews of the level and quality of service;

- transformations of the process to ensure transparency by:

- implementation management process for all liabilities arising in the implementation of off-balance sheet (accompanying) contracts;

- organization of mandatory publication of information on private sector equity participation in projects PF2;

- publishing an annual report detailing the project and financial information on all projects where the government will keep a controlling stake in the public sector;

- introducing the list of concluded business agreements on the website of the Treasury;

- the introduction of the mechanisms to regulate the funds to support the provision of services during its life cycle;

- improving information within the standard support moves projects;

- improving value connotation "value for money - risk-sharing" agreements PF2 by: 
- strengthening the management of individual species risks on the part of the PA, for example, the risk of additional capital expenditures arising from unforeseen general changes in legislation;

- amendments to existing regulations, which implement risk-sharing mechanisms indemnified for the necessary operational phase of projects;

- expanding the list of sources of debt and equity funding through:

- competitions to attract long-term investors before the financial closure phase of projects;

- promoting the use and quality assessment procedures different sources of debt financing, including public and private bonds, borrowing commercial banks, multilateral debt products;

- ensuring the highest quality of the money received infrastructure services their users during the replacement of the status of the evaluation of the partnership [20].

In the fully advanced requirements to the model PF2, moreover, adapted to the specific national legislation on the PPP corresponds to the model of "mixed contract life cycle", in contrast to the traditional "contract life cycle" - modification of PFI, which is analogous DBFO (Design - Build - Finance - Operate) of the PPP, involves its use in the composition of "mixed structural and investment funds", the usage of which are the prevailing in EU during the programming period of 2014-2020 [36].

Content DBFM can be defined as a form of contractual PPPs, in which the public partner on a competitive basis with the private conclude an agreement for the design, construction, and operation of the facility throughout the life cycle of the project pays equal instalments only after its commissioning on condition of maintaining the private partner facility in accordance with the specified functional requirements.

Thus, the private partner assumes all design and technical solutions and related risks. Unlike BFM model, the question of financing the first stage of the project lifecycle within SIOCTS functioning does not rely solely on the private partner, who is forced in this case to involve special project company.

The introduction of the mandatory procedures for monitoring the implementation of the PPP in the case of traditional and updated models of the partnership proposed to implement the algorithm that provides a consistent flow stages:

(1) evaluating current performance indicator implementation compared to its target value;

(2) setting needs for regulatory impact;

(3) analysing the reasons for rejection method and making choices of the method of impact on the value of the index;

(4) The adjustment parameters and conditions of the contract; change if necessary scheme of the project; change if necessary forms of interaction partners;

(5) calculation of performance goals, considering changes made.

The object of monitoring is the indicator of the efficiency of the PPP or their discounted value [36-38].

Conclusion. Modernization of the development of the PPP projects in the increasing challenges of globalization and increasing international competition, based on the strategic lines of the development of the similar international models should be based on the following principles: clarifying the essential characteristics of the PPP projects with all of the functioning of the national economy; rationalization of the 
national model of the public-private partnership; updating the list of purposes of implementing the PPP policy; expanding of the list of economic activities that are within the practice of implementing cooperation agreements; expanding the list of species of legal registration of transactions; review of approaches to expand the list of entities that can initiate the conclusion of the partnership agreements; expanding and refining the content of individual stages of the implementation of the PPP; improving the current legislation on the regulation of the PPP; expanding the empowerment of parties involved in the transaction; improvement of tools and techniques of risk management transactions of the PPP; development of an effective mechanism to guarantee the return of invested funds of agreements on cooperation of PA and private business; organization of constant monitoring of the PPP projects; development of the implementation mechanism "unsolicited proposals" for cooperation.

Acting mechanism of the regulation of the PPP in Ukraine in the sphere of functioning SIOCTS is influenced by the characteristics for all risk factors countries and failure of parties of the partnership because of agreements of economic interests. Since the regulation of economic development, including the region of the state, pursues the goal of fulfilling of vital needs of both sides of the partnership, which are in commercial relations and all public stakeholders, preliminary examination of the partnership projects should include mandatory cash flow calculations and social indicators of the investment projects of the PPP; similar codes on the stage of determination of the indicators of the commercial efficiency; cash flows in the case of budget efficiency assessment of the PPP projects.

\section{References:}

1. Akintoye, A. and Beck, M. (eds.) (2009), Policy, Finance and Management for Public Private Partnerships (Oxford: Wiley-Blackwell).

2. Flyvbjerg, B., Bruzelius, N. and Rothengatter, W. (2003), Megaprojects and Risk: An Anatomy of Ambition (Cambridge: Cambridge University Press).

3. Helm, D., Wardlaw, J. and Caldecott, B. (2009), Delivering a 21st Century Infrastructure for Britain (London: Policy Exchange).

4. Hodge, G.A. and Greve, C. (eds.) (2005), The Challenge of Public Private Partnerships: Learning from International Experience (Cheltenham, UK: Edward Elgar).

5. Merna, T. and Lamb, D. (2009), 'Application of Risk Analysis in Privately Financed Projects: The Value-for money Assessment through the Public-Sector Comparator and the Private Finance Alternative', in Akintoye and Beck (eds.) (2009), Policy, Finance and Management for Public Private Partnerships (Oxford: Wiley-Blackwell).

6. Savas, E. (2000), Privatization and Public Private Partnerships (New York: Chatham House Publishers).

7. Teisman, G. and Klijn, E.H. (2001), 'Public Private Partnerships in the European Union: Official Suspect, Embraced in Daily Practice', in Osborne, S. (ed.), Public Private Partnerships: Theory and Practice in International Perspective (New York: Routledge).

8. Vickerman, R.W. (2008), 'Cost-benefit Analysis and the Wider Economic Benefits from Megaprojects', in Priemus, H., Flyvbjerg, B. and van Wee, B. (2008), Decision making on Mega projects: Cost Benefit Analysis, Planning and Innovation (Cheltenham: Edward Elgar).

9. Винницький Б., Лендьел М., Онищук Б., Сегварі П. Досвід та перспективи впровадження державно-приватних партнерств в Україні та за кордоном. - Київ: К.І.С., 2008. - $146 \mathrm{c}$.

10. Геєць В.М. Суспільство, держава, економіка: феноменологія взаємодії та розвитку / В.М. Геєць. - К.: Ін-т екон. та прогнозув. НАНУ, 2009. - 864 с.

11. Данилишин Б. Державно-приватне партнерство - стратегічна форма взаємодії влади і бізнесу. URL: http://news.yuristonline.com/news/kmu/2. 
12. Павлюк К. В. Сутність і роль державно-приватного партнерства в соціальноекономічному розвитку держави / К.В. Павлюк, С.М. Павлюк // Наукові праці КНТУ. Економічні науки. - 2010. - Вип. 17.

13. Шилепницький П.І. Державно-приватне партнерство: теорія і практика: монографія / П.І. Шилепницький. - Чернівці, 2011. - 454 с.

14. Malakhovsky, Y.V. and Nabulsi, H.N. (2015) "Maximizing the value of entities of the region in the implementation of public-private partnerships", Naukovyy visnyk Uzhhorods'koho natsional'noho universytetu. Seriya "Mizhnarodni ekonomichni vidnosyny ta svitove hospodarstvo" - Uzhorod National University Herald. Series: International Economic Relation and World Economy, 5 URL: www.visnyk-econom.uzhnu.uz.ua/archive/5_2015ua/23.pdf.

15. Levchenko, O.M., Levchenko, A.O., Horpynchenko, O.V. and Tsarenko, I.O. (2017) "The impact of higher education on national economic and social development: comparative analysis", Journal of Applied Economic Sciences, Volume XII, Summer, 3(49) URL: http://cesmaa.org/Docs/ JAES\%20Summer\%20XII\%203(49)2017_online.pdf\#page=72.

16. Levchenko, O. and Tsarenko I. (2016) "Higher education as a factor of human capital development", International Scientific-Practical Conference Modern Transformation of Economics and Management in the Era of Globalization: Conference Proceedings, January 29, 2016 URL: dspace.kntu.kr.ua/jspui/handle/ 123456789/3595.

17. Levchenko O.M., Tkachuk O.V. and Tsarenko I.O. (2017) "The impact of cluster development on the countries' national competitiveness", Society for Cultural and Scientific Progress in Central and Eastern Europe, September, 12 URL: scaspee.com/all-materials/the-impactof-cluster-developmenton-the-countries-national-competitiveness-o-m-levchenko-o-v-tkachuk-i-otsarenko.

18. Шишкина А.В. Разработка модели проектного финансирования инновационных процессов в рамках инновационного кластера // Известия высших учебных заведений. Серия “Экономика: финансы и управление производством”. - 2012. - №2(12). - С. 54-63.

19. Ke, Y.J., Zhao, X.B, Wang, Y.Y. and Wang S.Q (2009b), 'SWOT Analysis of Domestic Private Enterprises in Developing Infrastructure Projects in China', Journal of Financial Management of Property and Construction, 14 (2): 152-70.

20. Wang, S.Q. (2006), 'Lessons Learnt from the PPP Practices in China', Keynote Speech, Asian Infrastructure Congress, Hong Kong.

21. Bergère F. (2007), Guide opérationnel des PPP (Paris : Editions du Moniteur).

22. Bougrain F. Carassus, J. Colombard-Prout, M. (2005), Partenariat public-privé en Europe : quels enseignements pour la France : retour d'expériences du Royaume-Uni, d'Italie, du Danemark et de France (Paris : Presses de l'Ecole Nationale des Ponts et Chaussées.

23. Government of India (2011), Public private partnerships in India. URL: http://www.pppinindia.com.

24. Planning Commission (2010), 'Compendium of PPP Projects in Infrastructure in India'. URL: infrastructure.gov.in/pdf/compendium-of-ppp-infrastructure.pdf.

25. Coordinating Ministry of Economic Affairs (2010), Public-Private Partnership: Investor's Guide (Indonesia).

26. Khanom, Nilufa Akhter (2009), 'Conceptual Issues in Defining Public-Private Partnership', paper presented at the Asian Business Research Conference, Australia.

27. Higuchi, T. (2006), 'Project Finance - Legal Issues of Project Finance in Japan', Japan Business Law Review, 1 (1): 51-5.

28. Iwamoto, Y. (2002), 'The Fiscal Investment and Loan Program in Transition', Government of Malaysia (2011), Tenth Malaysia Plan, 2011-2015 (Kuala Lumpur: Economic Planning Unit).

29. Khairuddin, A.R. (2007), 'PFI: Concept, Organizational and Contractual Structures', proceedings of a seminar on PFI: Concept, Implementation and Lessons Learned, organized by IIUM, Kuala Lumpur, 3 December.

30. Lee, K. and Rathbone, M. (2008), 'PPP Goes to Singapore', Project Finance International, 2 April 382.

31. Peebles, G. and Wilson, P. (2002), Economic Growth and Development in Singapore: Past and Future (Cheltenham: Edward Elgar). 
32. Ahn, H. and Kim, M. (2006), Regional Allocation of Transportation Infrastructure Investment and Development of Local Economy (Seoul: Korea Research Institute for Human Settlements).

33. KDI (Korea Development Institute) (2010), Public-Private Partnership in Infrastructure in Korea. URL: pimac.kdi.re.kr/eng/download/brochure2.pdf>.

34. A New Approach to Public Private Partnerships (2012). URL: www.gov.uk/government/ uploads/system/uploads/attachment_data/file/205112/

pf2_infrastructure_new_approach_to_public_private_parnerships_051212.pdf.

35. European PPP Expertise Centre (2014). Managing PPPs during their contract life: Guidance for sound management. Luxembourg: EPEC.

36. Nabulsi H. N. (2017). Suchasni modifikatsiyi modeli derzhavno-pryvatnoho partnerstva [Modern modifications of public-private partnership model PF2]. Naukovyy visnyk Uzhhorods'koho natsional'noho universytetu. Seriya "Mizhnarodni ekonomichni vidnosyny ta svitove hospodarstvo" - Uzhorod National University Herald. Series: International Economic Relation and World Economy, 12, 2 URL: www.visnyk-econom.uzhnu.uz.ua/archive/12_2_2017ua/ 12_2_2017.pdf.

37. Malakhovsky, Y. V. and Nabulsi, H. N. (March, 30, 2017) "Teoretychni ta praktychni zasady udoskonalennya mekhanizmu derzhavno-pryvatnoho partnerstva [Theoretical and practical basis for improving the mechanism of public-private partnership]", Development strategy of Science and education, Namur, Belgique. - pp. 235-239.

38. Malakhovsky, Y. V. and Nabulsi, H. N. (April, 28, 2017) "Osoblyvosti natsional'nykh modeley derzhavno-pryvatnoho partnerstva [Features of models of national public-private partnership]", Research: tendencies and prospects, Mexico City, Mexico. - pp. 32-36. 


\title{
5. PARTICIPATION OF COUNTRIES OF THE VISEGRÁD FOUR IN THE IMPLEMENTATION OF PROVISIONS \\ OF THE ENERGY CHARTER TREATY
}

Chichulina K.V.

Candidate of Technical Sciences, Senior Lecturer at Department of Enterprise Economics and Personnel Management, Poltava National Technical Yuri Kondratyuk University

\section{UKRAINE AND THE VISEGRÁD FOUR: THE EXPERIENCE OF ESCO MARKET}

\begin{abstract}
Summary. The experience of the Visegrád Four's ESCO market is presented in this report. The main barriers and prospects for the development of the ESCO market are revealed. Formation, features, and problems of the ESCO market in Ukraine are presented. The most widely used areas of the ESCOs application and the existing potential in Poland, Czech Republic, Hungary, Slovakia, and Ukraine are analysed. The article summarizes the evaluation of the ESCO Market in Visegrád Four. The main recommendations and proposals of ESCO mechanism in buildings are concentrated in this report. The work presents various models for ESCO services. The most important energy efficiency projects are analysed. The article considers the financial support of energy efficient projects in Ukraine due to providing financial support by international organizations. The work presents a summary of ESCO Market basic data in Visegrád Four and Ukraine.
\end{abstract}

Introduction. We know that ESCO is a company that specializes in energy saving or an energy-saving service. The ESCO runs a business by providing technologies or the necessary financing for energy users to replace or enhance existing energy facilities for the purpose of saving energy. Then, the ESCO retrieves the investment with the profit generated from the saved energy. The installation of energy-saving facilities by an ESCO does not require the energy user's initial investment, and the related technological risk caused by investment in facilities can be reduced because the professional service from the ESCO is used. Additionally, the ESCO generates profits from the energy-saving service, verifies the volume of energy saving through monitoring and maintenance, and facilitates financing for the investment in energy efficiency. ESCO business models can be divided into shared savings contracts and guaranteed savings contract depending on the type of contract [1-4].

An energy service company (ESCO) is a company specialising in projects that increase energy efficiency and lower energy expenditures incurred by ESCO's clients. ESCOs utilise their own funds to implement a particular modernisation project required by a client and recover their outlays (and remuneration) in payments distributed over time. These payments are covered by the client from energy savings generated by the project. In practical terms, there are various models for ESCO 
services. They apply different financing methods, strategies for risk allocation between an ESCO and a client or approaches to sharing profits from energy savings.

An energy performance contract (EPC) is an agreement between a client and an ESCO that defines technical and financial conditions, solutions for measuring energy savings and requirements for an energy savings guarantee [5].

\section{Experience of the Ukrainian ESCO market}

Ukraine. The main recommendations and proposals of ESCO mechanism in Buildings are concentrated in [6]. In particular (Fig. 1):

1) To stimulate using the ESCO approach to solve the problems in EE in buildings in Ukraine as ESCO works and services are guaranteed paid from energy savings;

2) EPC is allowable instrument for the current Ukraine's situation that should be used to retain energy cost savings in the state and locals multi-annual budgets in order to pay related ESCO works and services;

3) International cooperation between ESCOs should be activated for attracting investments into EE financing in buildings under EPC;

4) Municipal and commercial financing should be obligatory attracted;

5) To issue a municipal guarantee to ESCO;

6) Competitive and functional tendering should be provided;

7) To raise awareness of public and banking sectors on the development of ESCO projects in buildings.

According to the studies conducted by the author [8], the key condition for the successful implementation of energy efficient projects is sufficient funding. According to the Strategy of Ukraine for the period till 2030, it is provided to spend 1045.0 billion UAH on energy saving. But in the previous years, the target values of funding have not been reached in Ukraine. In terms of the investment plan to spend 30 billion UAH on energy efficient projects, only the amount of 10 billion was used, and only $5 \%$ of the above sum came from the state budget. This situation can cause total dependence of all sectors of our economy on energy resources. The state and local budgets under the current financial situation in the country cannot cover even $10 \%$ of the planned measures. Therefore, to implement more energy-saving projects, we have to seek the help of international financial donors will be able to intensify the economic growth of our country.

Formation of sources for energy saving measures funding is the basis for the successful implementation of energy saving policy. In Ukraine, investing into energy efficiency is often understood as improvement of the existing system: insulation (modernization) of buildings, new equipment of boiler stations, implementation of alternative and renewable energy sources, etc.

A particular attention should be paid to the use of energy-saving technologies and techniques in new building construction that will ultimately optimize or reduce energy consumption.

Defining the scope and sources of funding should be based on the investment project's data, which should contain the determined structure of the project, target indices of energy efficiency, project suggestions, estimated costs, and resources saving. It is advisable to determine the possibility of attracting co-financing from multiple sources. For example, the available own budget funds can be used to finance project development, energy audits and project management, and the borrowed funds or grants can be used for the implementation of the project. 
a)

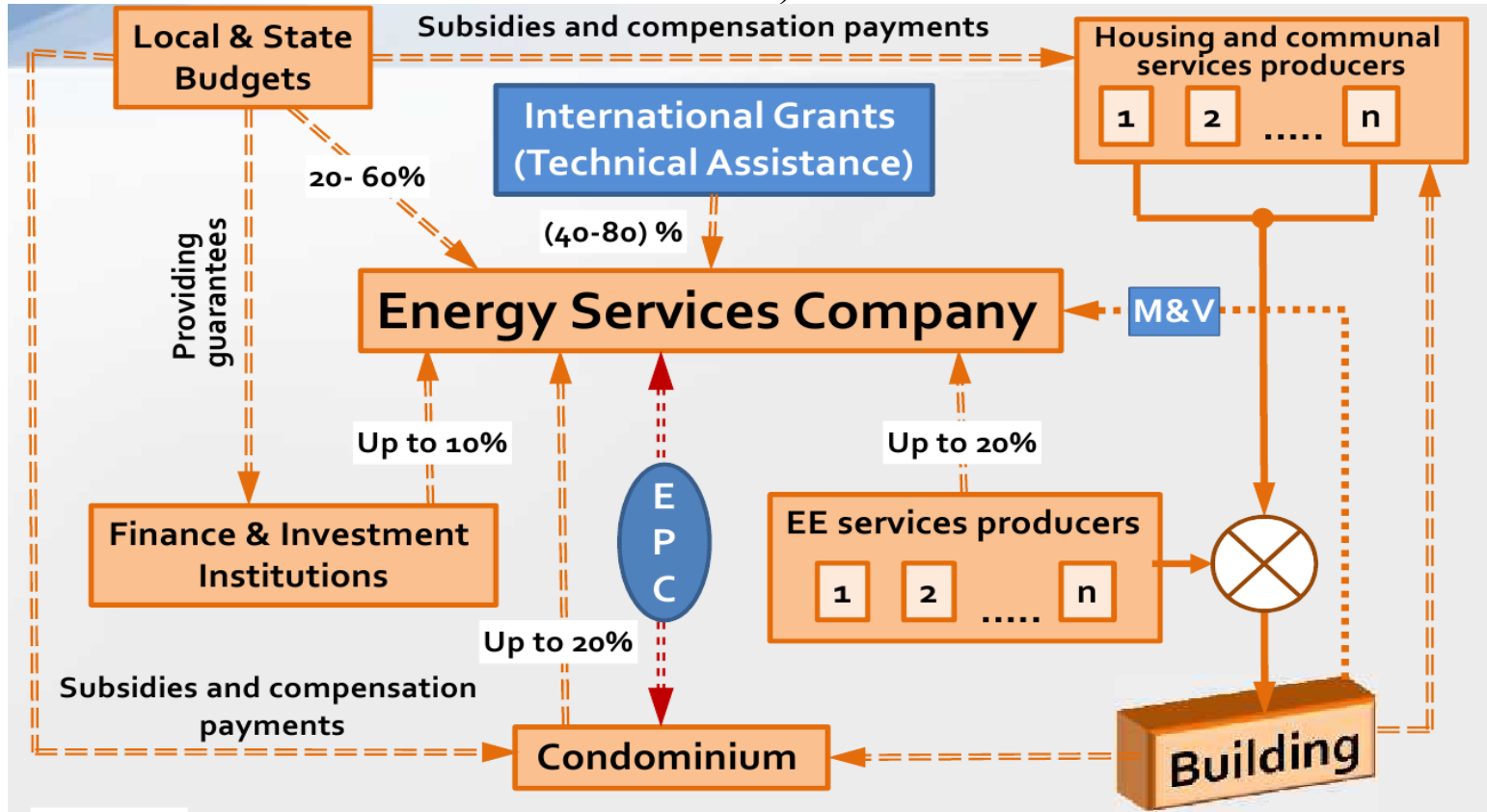

b)

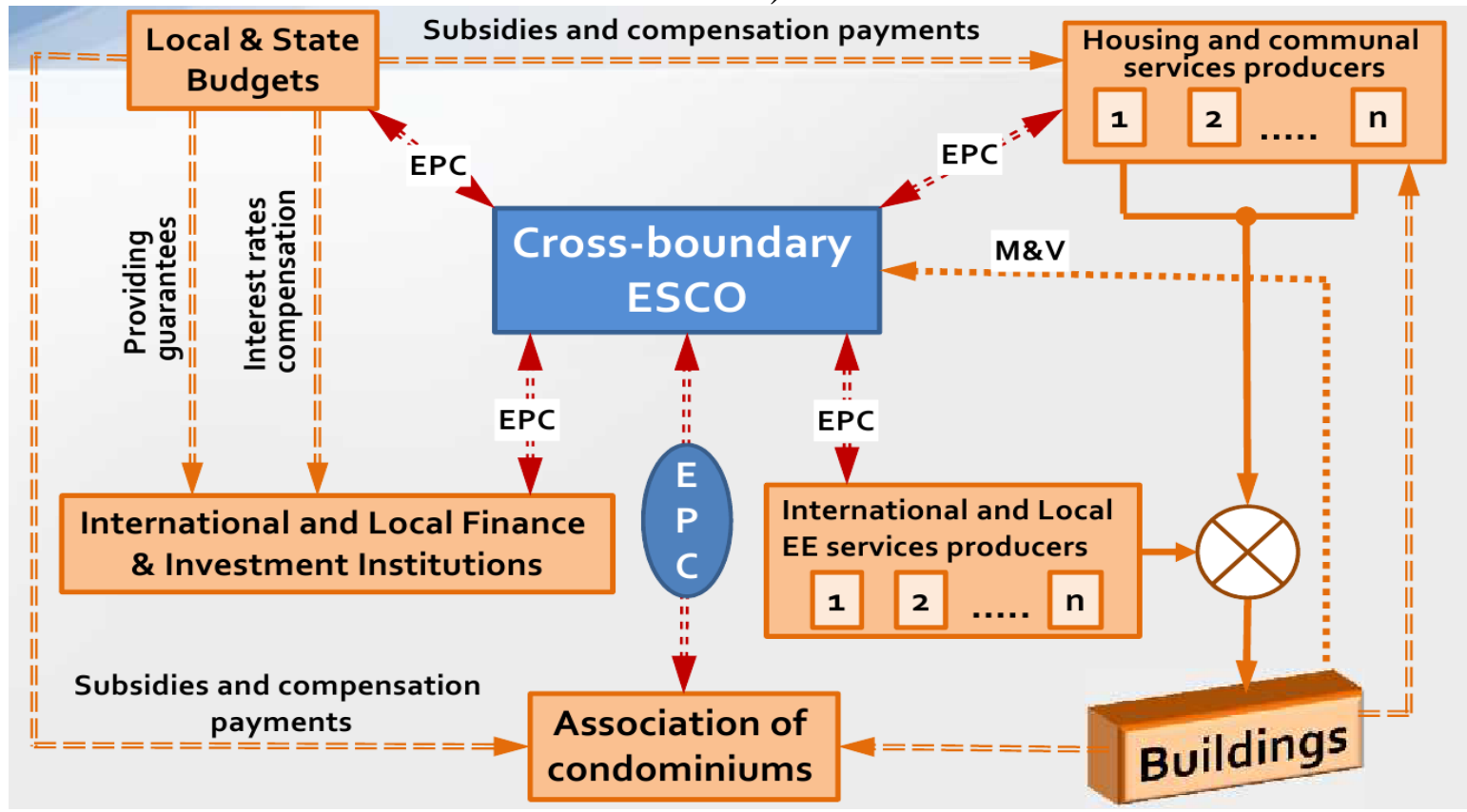

Fig. 1. a) basic model used for the demonstration of ESCO possibilities in Energy efficiency (EE) financing in Buildings in Ukraine; b) Perspective ESCO model for financing EE in Buildings. Marking: up to $25 \%$ - percent of investment made by the participant; Condominium - association of co-owners of apartment building; EPC - Energy Performance Contracting; M\&V - Measurement and Verification

In addition, enterprises and organizations should decide for themselves how valuable for them "deep" projects are, involving larger investments and longer payback periods, but in future providing more significant savings. Sometimes projects that promise a quick payback may at first glance seem more attractive, but in future, it may happen that they are not justifying either related transaction costs or time spent on them. This decision depends not only on the size of the benefits but also on the strategic goals of the project. 


\section{BARRIERS}

Information barriers can be systematically addressed by ESCOs and associations of ESCOs that can raise awareness and the needed information. There have been a few ESCOs that joined Ukraine's National Association of ESCOs through USAID's assistance. There are currently about three active ESCOs in Ukraine with a few dozen local ESCO-like engineering consulting firms. However, demonstration projects still need to be considered as an effective means of information to spread, understand and trust ESCOs and EPC.

Numerous ESCOs are interested in EPC but they can hardly find financing sources. ESCOs in Ukraine have very limited access to capital, both internally and externally. LFIs impose very high-interest rates and they are not readily involved in EE projects. Thus, there is not much that ESCOs themselves can do to improve their prospects. Ukrainian ESCOs need equity financing for marketing and project development including access to debt financing for energy end-users. Many ESCOs in the country realized that customer training is also a critical success factor to helping energy end-users understand the benefits of EPC mechanisms. Accordingly, Ukrainian ESCOs practically seek partnerships to attract financing and energy end-users.

Small engineering companies with in-depth knowledge of the local market have limited choice and partners with larger foreign companies with access to project financing, development, and implementation.

Improved energy arrears and energy tariff reform can also play a powerful role in promoting ESCOs and EE. Another essential barrier to increasing EE activities in Ukraine is the subsidized energy tariff. When energy is subsidized or non-payments are common, consumers have less motivation to invest in EE projects. Electricity end-users (especially in the residential sector) have an energy-intensive lifestyle. According to stakeholders in the Ukrainian ESCO market, low energy prices have hindered the development of ESCOs in the country.

Fig. 2. Barriers and perspectives of the ESCO market in Ukraine [7] 
Energy efficiency projects can be financed using various mechanisms and through various sources (funds receiving entities), but all the spending units should act in concert with each other in terms of technology or methodology. Therefore, here the important role is played by the agreed program of action, at least at the regional level, and the creation of infrastructure elements, such as information and advisory centres of energy saving).

International financial institutions (IFI) such as the World Bank (IBRD and IFC), European Bank for Reconstruction and Development (EBRD), and the Asian Development Bank (ADB) also support Ukraine.

MFU supports public sector's projects with benefits in terms of energy efficiency, using the following tools:

- debt financing (denominated in dollars or euros or, in exceptional cases, in the local currency);

- funds investment into the equity: share in ESCO or utility companies;

- technical assistance;

- partial guarantees on behalf of the state organization.

In assessing energy efficiency projects, issues not related to energy performance should also be considered. The most important ones are: financial performance, nonenergy benefits (e.g. environmental), the possibility of attracting funds, whether public or commercial. These characteristics play an important role in supporting energy efficiency programs and in providing a documentary display of all advantages.

Using mechanisms of financing energy efficiency projects, let us consider the algorithm of financial mechanisms choice to launch energy-saving projects with priority for the customer, the entity of the energy saving project with minimal dependence on the funds borrowed (Fig. 3).

This algorithm is a guide for the customer, the entity of an energy saving project, where it should run the gamut from the least costly financial sources in terms of additional payments to the most onerous compound interest of banks to launch an energy-efficient project. The developed algorithm can become guidance or guidelines for the selection of financial mechanisms to launch energy-saving projects with the priority of using first available and cheaper funding sources, and then other alternatives. Another famous promising solution for business and industry is to create a system of energy management.

Every company independently selects the mechanism of energy efficiency projects financing, by means of which the given transaction will be performed, but the major aspect of funding provided by international organizations is the requirements that they put before the projects.

Some authors argue [9] that New ESCO Concepts are as follows: budget and procurement regulations - proposed solutions will address known issues but are relatively complex so will need a careful preparation for first projects: experience of local authorities in developing contract structure and tender procedures - needs high level of technical assistance; local engineering and construction firms have limited experience of ESCO contracts and traditionally enjoyed plentiful work based on conventional contracting. However in current climate more willing to take some risk at least for construction; initial idea to establish dedicated fund to finance EPCs now considered for the second phase initially will finance municipal energy companies directly but still base repayment on energy savings; to borrow the experience of 
similar programs in the Visegrád Group (Visegrád Four). This is a group of four Central European countries: Poland, Czech Republic, Hungary, and Slovakia.

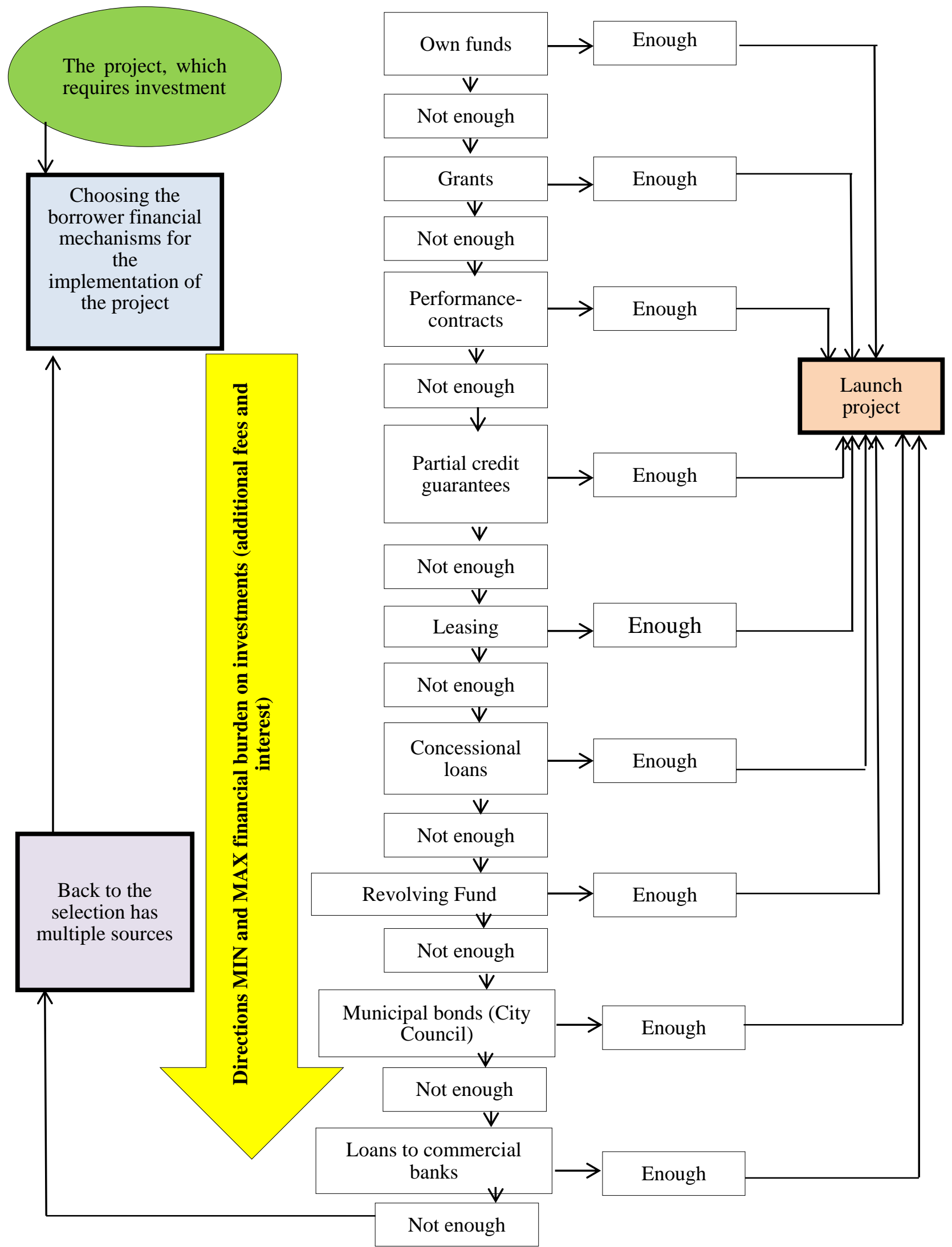

Fig. 3. The algorithm of financial mechanisms choice for an energy efficient project 


\section{Experience of the Visegrád Four's ESCO market}

Poland. According to [5], a great majority of the experts expresses positive opinions about the development potential of the Polish ESCO market, expecting that its turnover should increase. This optimistic approach results inter alia from information on tenders published so far and expected further ESCO investments in the private sector. Despite the legal barriers that impede a significant increase in the investment volume, the public sector should play an important role in the ESCO market growth. According to the experts, this sector stands some opportunities for becoming more open to ESCO contracts. Although the Polish ESCO market has a significant potential, it still remains at the initial stage of its development. The number of its players - both ESCOs and clients - is rather small. Experts agree that the market has been developing rather consistently for several years now. Nevertheless, considering various circumstances that favour this development, e.g. growing energy prices or the EU policy enhancing energy efficiency, this growth should be much faster. Moreover, it is worth noting that the Polish ESCO market still operates to a large extent as a market that is created by ESCO companies rather than as a response to spontaneous demand voiced by clients. This requires significant involvement of ESCOs and other institutions that support this market through information, education, and awareness-raising activities. ESCO companies are active in various sectors, performing activities for various types of clients. Some ESCOs offer a wide range of services, while others specialise in one segment. ESCOs provide services for the public sector, the commercial sector, the energy sector, industry, small and medium enterprises (SME) or even households. Considering their volume, the latter offer a significant potential for energy savings connected with the use of household appliances and lighting. Each of the above sectors has different characteristics and development potential. Summary of basic data of the Polish ESCO Market Presented is presented in Table 1.

Table 1

Summary of basic data of the Polish ESCO Market

\begin{tabular}{|l|l|}
\hline Number of ESCOs & $3-10$ \\
\hline Size of the market & $€ 3-10$ million \\
\hline ESCO Association & No \\
\hline Type of ESCOs & Energy services and supply companies \\
\hline Market development & No significant change \\
\hline $\begin{array}{l}\text { Sector ESCO Projects \& main EE } \\
\text { measures }\end{array}$ & $\begin{array}{l}\text { Street and indoor lighting and co-generation in the } \\
\text { public sector }\end{array}$ \\
\hline
\end{tabular}

By supporting the implementation of energy efficiency projects, public environmental funds lower the need for external financing for potential ESCO clients. Coupled with existing internal technical expertise, this provides little incentive for clients to work with ESCOs. Clients mistrust, lack of appropriate forms of finance and public procurement rules, along with a lack of experience in ESCO projects among public customers constitute the most common barriers for ESCO projects. The lack of recognition of the ESCO model in the Polish law reduces the confidence of potential customers. Tension is also seen in the market where electricity providers are perceived to hinder the realization of projects in the scope of street lighting. Financial institutions expect a very high security for opening credit lines and a lack of formal and financial support from the government and local authorities is felt [10]. 

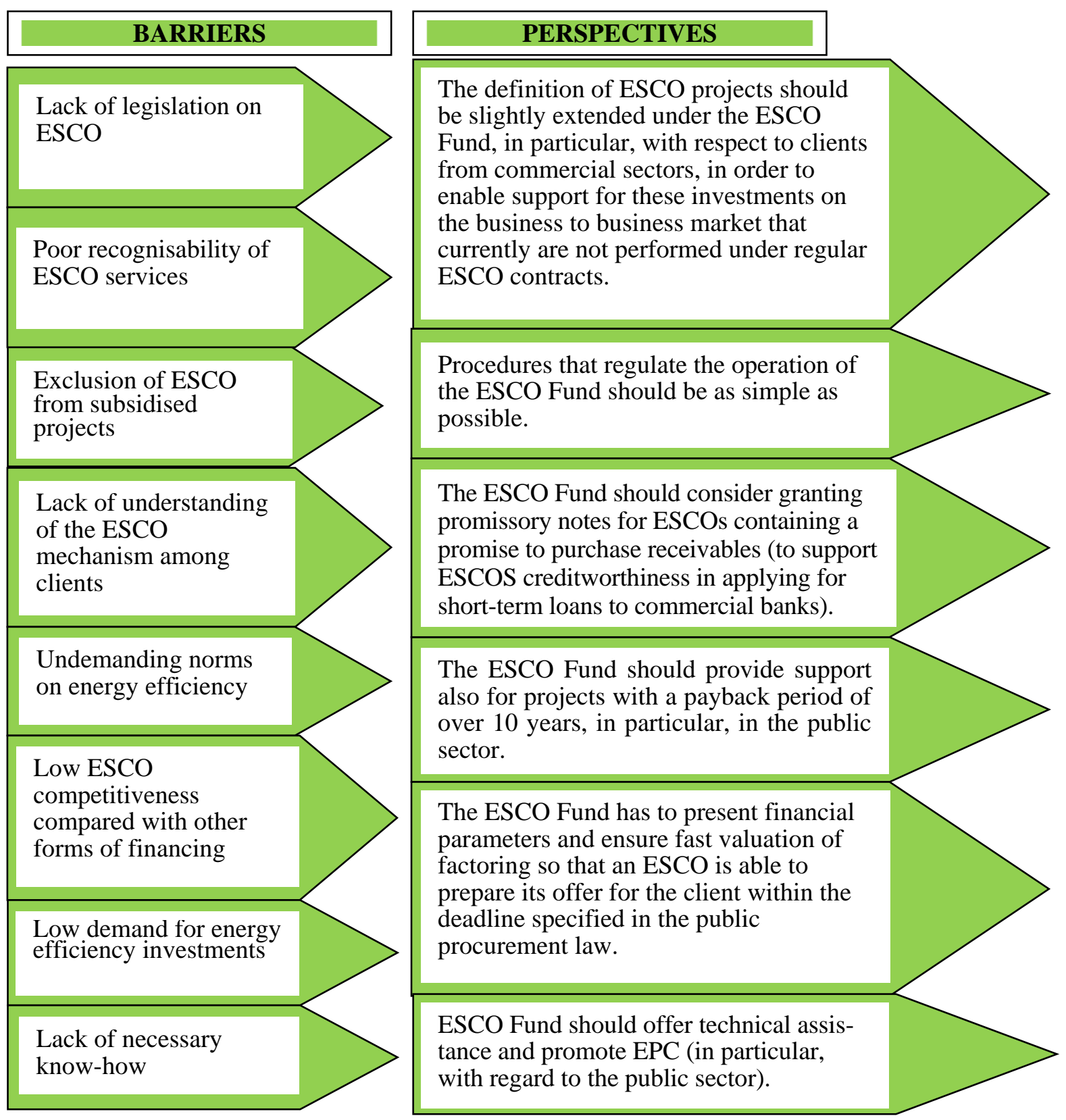

\section{Fig. 4. Barriers and perspectives of the ESCO market in Poland}

Accordingly, existing research [5] is a necessity and a prospect of the creation of the ESCO Fund. The ESCO Fund could play a significant role in stimulating the development of the ESCO market in Poland. In the course of the research, barriers and perspectives of the ESCO market were identified (Fig. 4).

The Czech Republic. During the analysis of literary sources [10], it was discovered that targeted market for ESCO projects remains the public buildings sector, which is estimated to cover about $80 \%$ of the market value. Besides public buildings, industry accounts for $10 \%$ of market value involving mainly co-generation projects. Private nonresidential buildings and district heating account for $5 \%$ of the market each. Projects in the public sector are mainly implemented with the guaranteed shared savings principles in schools, hospitals, social care facilities, administrative buildings. The energy efficiency measures implemented include mainly efficient HVAC system installation, improvement of energy performance of boiler houses or complete boiler house refurbishment. There are also projects for lighting and pipe insulation. A template 
contract has been developed for EPC, which is used in most public tenders and is based on a financial guarantee of savings, where the financing is provided by the ESCO. This can be adopted for cases where the excess savings (the savings over guaranteed amount) are split between client and ESCO. BOOT contract scheme is also applied, primarily in projects involving co-generation and renewable energy projects. $80 \%$ of projects are financed through TPF with local commercial banks' lending to ESCOs. The remaining $20 \%$ of the projects are financed by ESCOs' own corporate funding. The ESCO market is perceived to have grown. The main attributes for this growth are marketing activities 16 of local ESCOs and EPC consultants, increased energy prices and budget restriction in the public sector. High operational costs, obsolete energy infrastructure, lack of experience in how to improve energy efficiency (and achieve energy cost reductions), lack of internal financing and increasing freedom of building and facility managers in renovation and construction decisions has also increased the interest in EPC. Although financing has not been a significant obstacle for ESCO projects, the financial crisis has re-opened the issue in the private sector (commercial and industrial) due to higher business and financial risks. On the other hand, as a result of the budget restriction, the financial crisis is perceived to have induced more projects in the public sector. The main barrier to projects is the mistrust from clients towards ESCO projects, based on scepticism by management towards energy efficiency investments, complex solutions, and energy performance contracting due to past unclear definitions and unsuccessful contracts. Although high potentials exist in the industrial sector, EPC is less popular due to the risk associated with unstable (and insolvent) customers. Also beyond the industrial sector, the unpredictable financial future of potential clients (private and to a lower extent public), which influences the providers' availability to engage in long-term contracts (over 6 years) reduce the activity in sectors with important potentials, such as building retrofit involving insulation. Similar to other new member states, the absence of detailed, reliable information on present energy consumption and on the condition of the buildings complicates the definition of energy saving targets. The small size of projects and the related high transaction costs also remains a crucial obstacle, but, in the last years, this issue has been reduced due to the bundling of smaller projects into a package. Nevertheless, criticism is also raised on the lack of appropriate rules for the EPC projects' implementation in the public sector. The ESCO market has seen a continuing growth thanks to state support and marketing efforts by ESCOs to promote the ESCO market. Summary of basic data of the Czech ESCO Market is presented in Table 2.

We know that for outsourced energy services, the Czech Republic is considered a frontrunner in Europe. The ESCO market in the country is considered mature and the growth is stable with almost 200 projects in place. Taking all success factors into consideration, it can be seen that the supportive policies and implementing measure incentives are seen to be key to the success of the EPC in the Czech Republic. In addition, the steady rise in the energy costs is supporting the EPC success through ensuring profit through energy savings. Access to financial instruments and competence of the local authorities in contract management are also pointed out as significant contributors to the success story of the EPC in the country. Policy support is an essential factor for paving the way for energy performance contracting. In less developed markets, the first action should be to establish a favourable legal framework. Access to financial resources is a crucial factor for increasing EPC capacity. Ensuring reliable energy consumption data is important in order to establish 
trust. It is important not to forget that capacity building in energy performance contracting is not the only way but a good solution for increasing the energy efficiency implementations. Various other solutions and plans can be developed at the national and international level and each community must find its own [11].

Table 2

\section{Summary of basic data of the Czech ESCO Market [10]}

\begin{tabular}{|l|l|}
\hline Number of ESCOs & $8-10$ \\
\hline Size of the market & $€ 2-4$ million \\
\hline ESCO Association & Informal working group with efforts to create an ESCO association. \\
\hline Type of ESCOs & $\begin{array}{l}\text { Manufacturers of building automation \& control systems and energy } \\
\text { services and supply companies }\end{array}$ \\
\hline Market development & Stable \\
\hline $\begin{array}{l}\text { Sector ESCO Projects \& } \\
\text { main EE measures }\end{array}$ & $\begin{array}{l}\text { Public buildings involving HVAC-control system installation, boiler } \\
\text { houses, lighting and pipes insulation. }\end{array}$ \\
\hline
\end{tabular}

Hungary. Hungary has been often referred to as a success story of ESCO markets. The fast dissemination of ESCO projects was aided by many and, in particular, the following circumstances (Table 3).

Table 3

\section{Circumstances of distribution of ESCO projects}

\begin{tabular}{|c|c|}
\hline \multirow{6}{*}{ 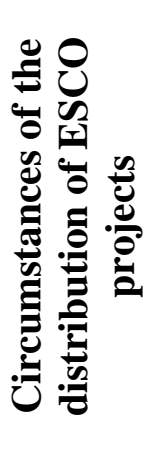 } & significant waste along the energy line as a legacy of the previous system \\
\hline & early energy market liberalization and the resulting increase in energy price \\
\hline & lack of financial resources of end-users \\
\hline & $\begin{array}{l}\text { lack of professional expertise at the end-users (often due to the privatization and } \\
\text { thus the disintegration of large public companies), matched with the local } \\
\text { engineering expertise }\end{array}$ \\
\hline & $\begin{array}{l}\text { willingness of financial institutions to invest in energy efficiency, and support from } \\
\text { international financing institutions (IFIs) during incubation }\end{array}$ \\
\hline & $\begin{array}{l}\text { strong willingness to open for new markets by engineering experts, SMEs, and } \\
\text { producers and operators of installations }\end{array}$ \\
\hline
\end{tabular}

The Hungarian ESCO market saw fluctuations, which continue currently, sustained also by the financial crisis. Numerous companies were forced out of the energy services business, while a few others got hold of new segments and extended their business offers or combined energy service provision with their existing portfolio. The current market value and the market potential have not been evaluated lately. The ratio of ESCO activity became approximately equal in the following three sectors: industry, district heating retrofits/development, and the municipal buildings sector. In parallel, certain companies also started ESCO projects in "new" market segments, such as RES and CHP. Complex refurbishment of residential block houses also became a fast emerging market area mainly due to state and municipal grants available for panel blockhouse refurbishment. Most of the ESCO clients still come from the municipal sector, while projects also take place in the residential (mainly block houses) and the industrial sectors. Typical projects are therefore related to lighting (street and indoor), boiler upgrades, modernization in industries, fuel switching, and district heating systems.

Both local and international ESCOs have been common in the Hungarian ESCO market, as well as daughter companies of energy suppliers. A few Hungarian ESCOs 
have been able to extend to other countries of the region. Today, officially ESCOs are considered as key players for national energy saving targets according to the Hungarian National Energy Efficiency Action Plan. Increasing pressure on the competitiveness and energy security translates into the need to promote energy efficiency improvements and to further decrease energy intensity of the Hungarian economy. This is combined with the policy pressure to implement the European acquis communautaire. In spite of the political commitment for the support of ESCOs and energy services, most of the implementing measures are still lagging behind. Indeed, one of the key barriers to the development of energy services is the fluctuation in energy efficiency policies, along with some policies with negative impact on energy efficiency, such as changes in the VAT system and cross-subsidies in energy prices, especially in the case of the residential natural gas price.

Financing of ESCO projects comes from very diverse sources. Banks and credit institutions continue to play a significant role, although the financial crisis has made it more difficult to obtain loans. While the involvement of international financial institutions has decreased, there are still available financing programmes, such as from the EBRD. In the residential sector, state grants for energy efficiency improvement have been important drivers for ESCO schemes.

One of the major issues is still the lack of information among potential customers and trust in the ESCO offers. ESCOs search for their clients, even by promoting the ESCO solutions personally to the local governments. On the other hand, there are also clients (even residential ones), which look for the ESCOs because of the positive results in some projects. ESCOs have difficulties with their contractors, and this can even jeopardize the success of the energy performance guarantees, as well as the reputation of the ESCO. Their role involves a strong quality check of the performance of the project, in order to be able to guarantee the savings. Availability of financing was previously a major issue. While many sources were readily available for investments, ESCOs were not able to draw these credit lines, only the clients [10]. The main barriers are shown in Figure 5.

Table 4

Summary of basic data of the Hungarian ESCO Market [10]

\begin{tabular}{|l|l|}
\hline Number of ESCOs & $\begin{array}{l}\text { 20-30, but fluctuating and many companies do ESCO projects as a } \\
\text { part of many other activities }\end{array}$ \\
\hline Size of the market & No current estimate available \\
\hline ESCO Association & None \\
\hline Type of ESCOs & $\begin{array}{l}\text { Local SMEs, daughter companies of energy suppliers, multinational } \\
\text { ESCOs }\end{array}$ \\
\hline Market development & Fluctuation, quasi-monopoly in some areas \\
\hline $\begin{array}{l}\text { Sector ESCO Projects \& } \\
\text { main EE measures }\end{array}$ & $\begin{array}{l}\text { Mainly in public sector, some in residential and CHP/renewables, } \\
\text { lighting, heating, boilers, energy system operation, CHP, and block } \\
\text { house renovation }\end{array}$ \\
\hline
\end{tabular}

It is clear that the coverage of ESCO projects has broadened in the last years in Hungary. The financial crisis has had an impact on the market by eliminating companies not strongly engaged in this market, which were offering ESCO solutions as a part of their portfolio. On the other hand, some companies have clearly strengthened, which raises the issue of market consolidation and market power. Some 
legislation and grant schemes have provided support for further strengthening ESCO business in already established areas, however, less attractive fields (longer payback time, higher transaction costs) seem to be still avoided. Giving priority to complex projects and specifically, ESCO projects would be desirable if the energy service market is to be engaged more. Actions should be taken to open up the market for new entries while avoiding financing businesses that are profitable without state grants.

\section{BARRIERS}

The lack of credible baseline data remains a technical barrier in EE projects resulting in prolonged and more expensive EE project development. Energy end-users sometimes pay averaged monthly fees in the absence of detailed billing systems. ESCOs are prompted to spend one to two years establishing the baseline information prior to project implementation in order to prove the savings.

Forms of financing are barriers found in the public sector. Municipal borrowing is limited with a cap. Local authorities cannot differentiate traditional loans from the EPC approach. There is a lack of information about opportunities with ESCOs and EPC. Procurement difficulties biased to cost-related items only, coupled with fear of redundancy accusations also limit municipalities' willingness to engage in ESCO projects. Furthermore, municipal authorities are often suspicious of the financial schemes and feel uneasy about sharing an EE project's financial benefits with a private company. As a result, proposed EE projects are either postponed or not implemented at all.

ESCOs have difficulty planning and concluding ESCO contracts that are longer than three to four years. ESCOs accord their proposed EE project tenure on the four-year election cycle. EE project development alone takes time. This approach limits the scale of potential EE projects.

In the residential sector, split incentives with investment and operational expenses coming from different budget lines have always been a major obstacle. The law requires the consensus of all apartment owners (decision makers) and entering into a longterm contract is very hard in the case of hot water, heating or insulation renovations of a large block house for instance. Furthermore, ownership of certain facilities is neither clear nor stipulated in the housing association contract, thereby causing a stalemate in EE project development. 
Slovakia. According to [10], small ESCOs-type enterprises were identified in the market. These companies are active as energy consultant companies, manufacturers of building automation \& control systems, and energy service companies. National companies offer mainly energy audits, energy consultancy and a part of energy contracting. About half of the ESCO projects involve renewable energy sources, approximately $15 \%$ are developed respectively in each of the following areas: commercial sector, co-generation, and district heating. A small percentage $(5 \%)$ of projects is carried out in street lighting. CEM is offered for projects in the industrial sector; EPC is not frequently used. The main source of financing for ESCO projects is EU structural funds and customers own corporate funds. The expected market value for energy efficiency projects in the non-residential sector is estimated to be around $€ 10-20$ million. Due to existing state programs and as a part of the economic recovery package, the financial crisis is said to have had no negative impact on the ESCO market in Slovakia. A program with a budget of $€ 30-60$ million for private building insulation and for changing to more energy efficient windows was created. The energy price also had a positive effect on the demand for energy efficiency investments. The most significant barriers of the Slovak ESCO market are shown in Figure 6.

\section{BARRIERS}

Lack of appropriate forms of finance remains the most common barrier to ESCO projects.

Mistrust from clients is the main reason for non-establishing a contractual arrangement in about $10 \%$ of the cases.

Energy efficiency funds are missing in Slovakia and no incentives for companies offering energy services are available.

Fig. 6. Barriers of the Slovak ESCO market [10]

Table 4

Summary of basic data of the Slovak ESCO market [10]

\begin{tabular}{|l|l|}
\hline Number of ESCOs & 5 \\
\hline Size of the market & $€ 10-12$ Million \\
\hline ESCO Association & No \\
\hline Type of ESCOs & $\begin{array}{l}\text { Energy consultant companies, manufacturer of building } \\
\text { automation \& control systems, and energy service companies }\end{array}$ \\
\hline Market development & Stable \\
\hline $\begin{array}{l}\text { Sector ESCO Projects \& } \\
\text { main EE measures }\end{array}$ & Complex building projects and co-generation \\
\hline
\end{tabular}

Conclusions. On the basis of the conducted research, the features of the ESCO Market of the Visegrád Four were identified. The result is Table 5 with the main characteristics. 
Evaluation of the ESCO Market in Poland, Czech Republic, Hungary, Slovakia (Visegrád Four) [7]

\begin{tabular}{|c|c|c|}
\hline $\begin{array}{l}\text { Elements of ESCO } \\
\text { Opportunities }\end{array}$ & Poland & Czech Republic \\
\hline $\begin{array}{l}\text { ESCO Market Preparedness: } \\
\text { Awareness and Application of } \\
\text { EPC, ESCO/EPC Demonstration } \\
\text { Project Availability, and Other } \\
\text { Implemented ESCO Projects }\end{array}$ & $\begin{array}{l}\text { The first company, ECOGY, conducted } \\
\text { the modernization of a coal boiler } \\
\text { house, which was designed to be re-paid } \\
\text { by the savings achieved by the client. } \\
\text { The ESCO model became a rather } \\
\text { commonly used method for the } \\
\text { modernization of heating systems at } \\
\text { military units. Presently, not many } \\
\text { ESCOs conduct EPC-based projects. }\end{array}$ & $\begin{array}{l}\text { The Czech Republic is the ESCO } \\
\text { frontrunner among Eastern European } \\
\text { countries, even though the market is } \\
\text { still considered to be in its initial } \\
\text { period. EPC is recognized as one of the } \\
\text { support mechanisms for energy saving. } \\
\text { The most common contracting form is } \\
\text { guaranteed savings. }\end{array}$ \\
\hline $\begin{array}{l}\text { Substantial Number of Active } \\
\text { ESCOs }\end{array}$ & $\begin{array}{l}\text { Large global and European companies } \\
\text { (Dalkia, MVV, Landys \& Gyr or } \\
\text { Siemens, Ineoineo, and Auxima } \\
\text { Services) began to open their branches } \\
\text { in Poland in the late 1990s. Three other } \\
\text { companies were founded by the Polish } \\
\text { Electro Energy Network. }\end{array}$ & $\begin{array}{l}\text { There are currently about } 17 \text { ESCOs in } \\
\text { operation: five companies focus on } \\
\text { providing services according to the } \\
\text { EPC concept, two companies work as } \\
\text { energy service providers and } \\
\text { approximately a dozen companies } \\
\text { provide long-term energy delivery } \\
\text { contracts. }\end{array}$ \\
\hline Sector/Technology Focus & $\begin{array}{l}\text { ESCO projects actually include all of } \\
\text { the market sectors. French Dalkia and } \\
\text { German MVV are active in municipal } \\
\text { projects. The most often implemented } \\
\text { EPC undertakings in the ESCO model } \\
\text { are the thermal modernization of } \\
\text { buildings, replacement of heating } \\
\text { sources, and the modernization of street } \\
\text { lighting. }\end{array}$ & $\begin{array}{l}\text { The public healthcare sector is the } \\
\text { primary focus for ESCOs, while } \\
\text { educational buildings, military, and } \\
\text { other state-owned sectors are appealing } \\
\text { projects, too. Apart from the public } \\
\text { sector, the private sector (typically } \\
\text { industry) is also on track regarding } \\
\text { energy efficiency investments. }\end{array}$ \\
\hline $\begin{array}{l}\text { Government Support Exists (energy } \\
\text { law, policies, programs, etc.) }\end{array}$ & & $\begin{array}{l}\text { A new law was passed in } 2001 \text { that } \\
\text { made energy audits obligatory for large } \\
\text { consumers. }\end{array}$ \\
\hline Potential ESCO Market & & $\begin{array}{l}\text { EE savings are estimated at about } 100 \\
\text { million EUR or } 10-20 \text { million } \\
\text { EUR/year. }\end{array}$ \\
\hline $\begin{array}{l}\text { Public-Private Partnerships and } \\
\text { EE Project Financing/Funding }\end{array}$ & $\begin{array}{l}\text { The main financing sources have been } \\
\text { commercial banks, private sources, } \\
\text { LFIs, the World Bank. }\end{array}$ & $\begin{array}{l}\text { Financial institutions, including mostly } \\
\text { local banks, are available and are ready } \\
\text { to participate in TPF. The IFC is } \\
\text { running its "Commercialization Energy } \\
\text { Efficiency Facility," providing loan } \\
\text { guarantees for ESCOs and end-users. } \\
\end{array}$ \\
\hline $\begin{array}{l}\text { Technical Framework Prepare- } \\
\text { dness (IGA, M\&V, tools, etc.) }\end{array}$ & & $\begin{array}{l}\text { It would appear that more attention } \\
\text { needs to be given to appropriate project } \\
\text { implementation and especially M\&V. }\end{array}$ \\
\hline Other Barriers to Consider & $\begin{array}{l}\text { The Industry sector has had real } \\
\text { difficulty accepting the ESCO model } \\
\text { due to negligible amounts of savings } \\
\text { compared to total operating costs. EPC } \\
\text { models lack references concerning the } \\
\text { financial settlement for this kind of } \\
\text { business activity leading to } \\
\text { apprehension among the potential } \\
\text { customers to adopt TPF. An important } \\
\text { area that restricts the efficient market } \\
\text { has been the lack of functional financial } \\
\text { instruments that are specialized in } \\
\text { ESCO companies. }\end{array}$ & $\begin{array}{l}\text { Scepticism by management towards EE } \\
\text { investments and EPC still lingers. } \\
\text { Prejudices against complex solutions } \\
\text { remain strong. ESCOs are not yet ready } \\
\text { to take projects with a long payback } \\
\text { period (more than } 6 \text { years). There is } \\
\text { still room to develop and some sectors } \\
\text { with a high savings potential have } \\
\text { hardly been tapped (such as the } \\
\text { military). }\end{array}$ \\
\hline
\end{tabular}


Continuation of Table 5

\begin{tabular}{|c|c|c|}
\hline $\begin{array}{l}\text { Elements of ESCO } \\
\text { Opportunities }\end{array}$ & Hungary & Slovakia \\
\hline $\begin{array}{l}\text { ESCO Market Preparedness: } \\
\text { Awareness and Application of } \\
\text { EPC, ESCO/EPC Demonstration } \\
\text { Project Availability, and Other } \\
\text { Implemented ESCO Projects }\end{array}$ & $\begin{array}{l}\text { The ESCO industry in Hungary dates } \\
\text { back to the early 1990s with EPC } \\
\text { training funded by USAID. After } 15 \\
\text { years, the market is experiencing } \\
\text { stagnation. }\end{array}$ & $\begin{array}{l}2003 \text { as the starting point for ESCOs. } \\
\text { The Energy Centre in Bratislava has } \\
\text { divided companies providing EPC to } \\
\text { their orientation and potential to offer } \\
\text { ESCO services. }\end{array}$ \\
\hline $\begin{array}{l}\text { Substantial Number of Active } \\
\text { ESCOs }\end{array}$ & $\begin{array}{l}\text { Based on a registry of the Energy } \\
\text { Centre, there are about } 30 \text { ESCOs or } \\
\text { ESCO-type companies but five or six } \\
\text { companies cover } 80 \% \text { of the market. }\end{array}$ & $\begin{array}{l}\text { By 2006, there were about } 30 \text { ESCOs } \\
\text { and ESCO-type companies. }\end{array}$ \\
\hline Sector/Technology Focus & $\begin{array}{l}\text { Projects were primarily focused on } \\
\text { public lighting, cogeneration, district } \\
\text { heating system improvements, heating } \\
\text { and hot water system interventions, } \\
\text { industrial water and steam supply, air } \\
\text { conditioning, automation, and biomass. } \\
\text { Recent figures suggest the distribution } \\
\text { of ESCO projects is } 30 \% \text { in industry, } \\
30 \% \text { in district heating retrofits and } \\
\text { development, and } 30 \% \text { in the municipal } \\
\text { sector. }\end{array}$ & $\begin{array}{l}\text { ESCO clientele includes municipal } \\
\text { buildings, schools, banks, and } \\
\text { hospitals. Outsourcing in the industry } \\
\text { and private facilities is becoming more } \\
\text { and more popular. ESCOs normally } \\
\text { participate in building renovation and } \\
\text { public lighting projects. }\end{array}$ \\
\hline $\begin{array}{l}\text { Government Support Exists (energy } \\
\text { law, policies, programs, etc.) }\end{array}$ & & $\begin{array}{l}\text { Government commitments have been } \\
\text { emphasized in the } 2005 \text { National } \\
\text { Energy Policy. This policy identified } \\
\text { many tools promoting energy } \\
\text { efficiency, such as minimum } \\
\text { requirements for the energy efficiency } \\
\text { of new and large existing buildings. }\end{array}$ \\
\hline Potential ESCO Market & $\begin{array}{l}\text { The ESCO market size is approximately } \\
150-200 \text { million EUR worth of } \\
\text { investments. }\end{array}$ & \\
\hline $\begin{array}{l}\text { Public-Private Partnerships and } \\
\text { EE Project Financing/Funding }\end{array}$ & $\begin{array}{l}\text { Municipal authorities often feel } \\
\text { uncomfortable about sharing the } \\
\text { financial benefit of their project with a } \\
\text { private company. TPF is a well- } \\
\text { accepted and widespread scheme. Banks } \\
\text { are particularly open to participation in } \\
\text { EPC. }\end{array}$ & $\begin{array}{l}\text { Foreign-based companies whose main } \\
\text { profile is energy systems operation, } \\
\text { such as district heating operators, are } \\
\text { public-private partnerships in the form } \\
\text { of joint ventures of private companies } \\
\text { with municipalities. }\end{array}$ \\
\hline $\begin{array}{l}\text { Technical Framework Prepare- } \\
\text { dness (IGA, M\&V, tools, etc.) }\end{array}$ & $\begin{array}{l}\text { Industrial/commercial sites and } \\
\text { buildings sometimes lack baseline data } \\
\text { as they do not have detailed billing } \\
\text { systems and pay average fees per } \\
\text { month, not according to the real } \\
\text { consumption. ESCOs cannot prove the } \\
\text { savings achieved using such } \\
\text { information or they have to spend one to } \\
\text { two years before a project begins. }\end{array}$ & $\begin{array}{l}\text { There is lack of data to construct } \\
\text { baselines. Energy prices are subsidized. }\end{array}$ \\
\hline Other Barriers to Consider & $\begin{array}{l}\text { Presently, EE project payback periods } \\
\text { are longer (5 to } 7 \text { years), which is } \\
\text { actually one of the major challenges } \\
\text { ESCOs are facing. International aid, } \\
\text { which was previously very substantial, } \\
\text { is decreasing or coming to an end. Most } \\
\text { local authorities are still not informed } \\
\text { about the opportunities ESCOs offer } \\
\text { and are often suspicious of the financial } \\
\text { schemes. }\end{array}$ & $\begin{array}{l}\text { The banking sector still has a limited } \\
\text { understanding of, and experience with, } \\
\text { EE project financing. Banks, therefore, } \\
\text { perceive such projects as risky, } \\
\text { resulting in lending terms that may not } \\
\text { be acceptable for ESCO project } \\
\text { developers. This limits ESCO activity } \\
\text { to the large ESCOs that can financially } \\
\text { support their own activity and could } \\
\text { limit the growth of the sector in the } \\
\text { medium term. }\end{array}$ \\
\hline
\end{tabular}




\section{References:}

1. Lee, M.; Park, H.; Noh, J.; Painuly, J.P. Promoting energy efficiency financing and ESCOs in developing countries: Experiences from Korean ESCO business. J. Clean. Prod. 2003, 11, 651-657.

2. Steinberger, J.; Niel, J.; Bourg, D. Profiting from megawatts: Reducing absolute consumption and emissions through a performance-based energy economy. Energy Policy 2009, 37, 361-370.

3. Patari, S.; Sinkkonen, K. Energy Service Companies and Energy Performance Contracting: Is there a need to renew the business model? Insights from a Delphi study. J. Clean. Prod. 2014, 66, 264-271.

4. Yi H., Lee S., Kim J. An ESCO Business Model Using CER for Buildings' Energy Retrofit. Sustainability. 2017, 9, 591.

5. ESCO market in Poland: current state and development perspectives. Inception report. Institute of Environmental Economics. 2012, 17.

6. Novoseltsev A., Kovalko A., Evtukhova T. Current status and perspectives of ESCO market in Ukraine: model and mechanisms for financing energy efficiency in buildings. Workshop on the Polices and Schemes for Financing Energy Efficiency in Buildings. Belgrade, 2013.

7. International Finance Corporation IFC Energy Service Company Market Analysis. Final report. Econoler, 2011, 121.

8. Skryl V., Chichulina K., Skrylnik A. Mechanisms of energy efficient projects' financial support by international financial institutions in Ukraine. Periodyk naukowy Akademii Polonijnei, Częstochowa, Akademia Polonijna w Częstochowie, 2017, 21 , 91-104.

9. Hobson P. EBRD's Experience on EBRD's Experience on Financing Energy Efficiency Financing Energy Efficiency in Buildings: in Buildings: instruments, challenges, opportunities. EBRD, Energy Efficiency and Climate Change Team, 2010.

10. Marino A., Bertoldi P., Rezessy S. Energy Service Companies Market in Europe. European Commission. Joint Research. Centre Institute for Energy. Luxembourg: Publications Office of the European Union, 2010, 109.

11. Daugaard N., Basar E. EPC in Croatia, Czech Republic \& Denmark. ManagEnergy capacity building workshops. Report, 2013. 


\title{
6. UKRAINE AND THE VISEGRÁD EUROPE - USING THE POTENTIAL OF ECONOMIC INTERACTION
}

\author{
Ganski U.A. \\ Candidate of Economic Sciences, \\ Candidate of Historical Sciences, Associate Professor, \\ Doctoral Student at Department of International Economic Relations, \\ Lviv University of Trade and Economics
}

\section{THE CULTURAL HERITAGE OF VISEGRÁD GROUP COUNTRIES AS A RESOURCE FOR LOCAL DEVELOPMENT}

Summary. The article discloses approaches to the use of heritage in strategies of economic development. Cultural heritage is analysed as a specific economic resource and asset and also as a resource for a tourism industry. The author analyses investment and profits of the commercialization of heritage. The article reveals methods economic revitalisation of the territory with the help of heritage and substantiates the necessity of using the cultural heritage of the Visegrád group countries as a resource for the sustainable development. Heritage, as process and experience, is a contemporary creation designed to serve many contemporary uses, both individual and collective. As such, it has become endowed with many public policy expectations, some of which are concerned with economic development not least at the local scale. However, although heritage possesses many economic dimensions and plays many roles in local development strategies, only rarely are economic considerations paramount in the selection and management of heritage resources and only rarely is heritage main support or justification for the economic development. Herein lie the ambivalences in this reluctant relationship between heritage as a ubiquitous, flexible and multi-used resource and the many instrumental roles it is expected to play in, largely local, economic development policies.

Introduction. As much, but not all, heritage is place-bound and heritage is a major contributor to the identification of people with specific places, it becomes inextricably involved in local place images, identities, and economic geographies. Heritage, therefore, is frequently called upon to perform many instrumental roles in, largely local, economic development strategies as commercial activity in itself, as a location factor for other economic enterprises, as a contributor to environmental amenity and local identity, as a constituent of place image promotion and branding, and as a frequently catalytic element in neighbourhood regeneration. However, all these expectations are based on a resource that was not created for these purposes, is not necessarily managed by agencies sympathetic to them, and which itself may be intrinsically an obstacle to development through the restrictions on change it imposes, the resources it consumes and fossilizes and above all the backward-looking mentality it may engender amongst those who seek refuge in the past from the challenges of the present and the future. 
Heritage is not artefacts, buildings, historic events or personalities or sites and places, although many agencies act as though it were. It is best regarded as a process and an outcome. It is a contemporary activity, in which the relict and imagined past is treated as a quarry of potential resources for the construction of contemporary products as a contemporary consumable experience and as a bequest to an imagined future. Its relationship to culture is partial and the use of the adjective "cultural" in front of the noun heritage, although a practice long established by UNESCO, is both tautological but, more important here, can be profoundly misleading. Because all heritage is a cultural construction, makes use of much drawn from the cultural productivity of the past and may, in turn, contribute to the cultural capital of societies and individuals, it is often seen as a near synonym for culture. It is not: culture is a much wider idea and heritage has many more uses than as an element of cultural production.

\section{Commercialisation of heritage as a necessary measure}

Heritage is created, destroyed, and recreated to serve many changing contemporary uses, both individual and collective. As such, it has become laden with many functions and expectations in both the private and public realms. For the individual, the shaping of a personal heritage is necessary for the formation of a stable selfidentity and for facilitating contacts with the world beyond the self. For a wider society, heritage is used as an instrument in collective policies for the legitimation of ideologies and governments at all spatial scales and for socialization, the creation and maintenance of the cohesion and exclusivity of social groups. Most of the academic literature on heritage, most of the policy documentation emanating from public agencies and most of the motivation of those professionally employed or voluntarily involved are concerned, implicitly or explicitly, with these uses. Although these are the most important uses of heritage, and indeed justify most heritage creation, maintenance and management around the world, they are not the central concern of this chapter, although they are a constant background to it.

However, heritage also has an economic dimension that is quite basic to the activity if only because heritage costs money but also may earn money. There is thus inherently an economics of heritage that is fundamental to the selection of resource elements, their subsequent maintenance, interpretation, packaging, marketing and use management, even if those engaged in many of these activities would vehemently deny that economic justifications were paramount or even existed. In addition, heritage is used as a primary resource in many commercial heritage industries, in which aspects of a commodified past are selected and packaged into heritage products for sale on various contemporary markets, including but not confined to tourism markets. It is also indirectly used in the construction of high amenity physical environments that may act as location factors for economic activities, as well as endowing places with extra value, expressed in real estate prices or just a sentiment of well-being. Heritage also often plays a major role in the shaping and promotion of place images on internal and external markets, often in support of economic goals that may have little direct concern with pasts.

Finally, in this definitional introduction, the role of place should be mentioned. Much, but by no means all, heritage is place-bound. The place or site may be an important aspect of the heritage but also heritage is a major contributor to placemaking. These senses of place become inextricably involved in the identification of 
people, whether insiders or outsiders, with specific localities. It is, therefore, not surprising that heritage is frequently called upon to play many different instrumental roles in local economic development strategies, as an industry in itself, as a factor influencing the establishment of other economic activities, as an element in place marketing and a contributor to place brands, and more generally in neighbourhood economic, social, and physical restoration, regeneration and revitalization. The argument of this chapter goes beyond just the recognition that heritage is used for local economic development purposes and its exemplification in suitably selected case studies. Despite the many economic opportunities conveyed by heritage as development, there are distinct limits to the efficacy of an economics of heritage as employed as an instrument in strategies for the local economic development. These constraints are largely intrinsic to the very multiplicity of uses of heritage, as well as the multiple expectations that are loaded onto it. Heritage in local economic development operates alongside and possibly in competition with the cultural, social and political objectives, a competition in which it is unlikely to be prioritized.

In the context of human history and the history of cities, heritage as a responsibility of governments and a concern of their citizens is an extremely recent phenomenon. Most of the legislation, governmental and non-governmental agencies, official subsidy and taxation structures have been created over the last century-and-ahalf in order to satisfy a quite specific collective political and social requirement, namely the creation, reinforcement and promotion of the imagined entity "nation" and the legitimation of the authority of its governing body the nation-state. The current consensus of official and popular support for 'our heritage' has the same basic justification. Economic uses were added subsequently and are of secondary importance. The point needs emphasis because museums, monument lists, public statuary and design, designated historic sites and districts, heritage cities and landscapes were not created for economic reasons and economic considerations were not decisive or even present at all in their creation.

It is only subsequently that economic uses have been added to the demand for the consumption of heritage, sometimes fortuitously and sometimes deliberately out of a reluctantly accepted economic necessity. Tourist uses of heritage, in particular, are often treated as a barely tolerated marginal use for heritage collections, sites and places, which have been identified, selected, designated, maintained, and interpreted for quite other groups and purposes. Tourists and saleable heritage products are endured for the marginal income or a possible justification through visitor numbers, that may be obtained from them but most existing heritage would continue to exist, albeit with fewer financial resources, in the service of its primary purposes if the economic function completely disappeared.

Indeed, many institutions and individuals involved in the heritage process regard the intrusion of economics into their endeavours as, at best a distasteful necessity to be reluctantly tolerated or, at worst, a distracting and even unwelcome commercialization of their undertakings.

Although many involved in the preservation and interpretation of heritage resources would rather ignore the economic dimension, they are confronted by the simple imperative that these activities cost money, an inconvenience that may be offset by its potential to earn money. However, the apparent symmetry of costs and benefits in the above statement is illusory as a result of the contexts, in which heritage exists. Much official heritage is a public good, in which public statuary, 
museums and galleries, conserved buildings, cityscapes, and landscapes are freely accessible and zero, or near zero, priced facilities, whose consumption cannot be denied. However, although free to many heritage consumers, it is costly to create and maintain. The initial protective heritage designation may appear to cost next to nothing: it involves just the adding of a structure or area to a list, the cost of drawing a protective line upon a map or erecting a sign. Indeed much of the inflation that has occurred in monument and heritage district designation lists in countries through the world over the last 30 years can be explained by this seductively cost-free undemanding designation process, which normally occurs at some political level of government. In reality, however, such designation brings with it a political and moral commitment to preserve, restore, and maintain into infinity. Also generally ignored are the less direct costs of heritage, including the alternative development opportunities forgone on what are often the most potentially valuable urban sites and the concomitant restrictions on the adaptation of buildings, neighbourhoods, and even wider landscapes to changing social and economic circumstances. Restricting the capacity to change can be a serious constraint upon the continuous evolution of cities. This locking up of economic resources and acquisition of an increasing financial commitment into the future was called the "heritage time-bomb", which is exacerbated by the age of building as increasing numbers of structures become eligible through their antiquity to receive a preservation designation. An economic mortgage is taken out in the future, to provide for what the present perceives to be its needs, to be paid by the sterilisation of scarce urban space and the fossilization of historic forms and morphologies, as well as by a financial burden on future public and private funds [2, p. 19-21].

However, and seemingly in fortuitous compensation, heritage seems to offer a potential to make money in a number of different ways, directly and indirectly as discussed below. It is notable that attitudes to the role of heritage, like the wider idea of culture in general, within economies have dramatically shifted. The traditional view of culture was a "merit good" that was acquired from the surplus of economic development once more essential needs had been met. It was regarded as an extra non-essential consumption conveying intrinsically aesthetic pleasure and satisfaction or other psychic profits to those who could afford it or were prepared as patron to bestow it upon society. The present view reverses this relationship between wealth generation and culture for, whereas once heritage was seen as a resultant and beneficiary of wealth, it is now expected to be a wealth generator being enlisted in the economic development process, not for its own merit but to further a range of extrinsic objectives. It may be that it is the completeness and abruptness of this role reversal that accounts for the reluctance and unease of many in being involved. Also, simply those creating and maintaining the heritage resources are often not the same people as those engaged in releasing its economic potential. The managers of the potential heritage resources often find it difficult to apply economic concepts and approaches to the heritage experience or indeed to cultural goods and services in general. They regard themselves as the custodians of cultural riches, with a responsibility to maintain and bequeath objects, sites, and memories of intrinsic worth even to a society that seems to be unaware and even uncaring. Thus there has been a reluctance among heritage "professionals" to think in economic terms or place their activities within an economic context, for which they are usually unfamiliar, untrained, and often unsympathetic. 


\section{Investment and profits of the commercialization of heritage}

All heritage needs investment for its maintenance and the realisation of its potential utility for whatever purpose. It is possible to view this investment in heritage in much the same way as any other economic investment, namely a building, area or landscape is preserved and renovated by an investing owner who then reaps the profits from the enhanced value of the asset.

However, when considering especially built environmental heritage, there are complications to this otherwise straightforward link between investment and return. First, the costs of building and area preservation, renovation and restoration are "front-loaded", that is most of the investment must be made long before any returns are obtained and may only be repaid over many years or even centuries. Such longterm and, intrinsic to heritage, intentionally intergenerational repayment renders it economically illogical for the individual to invest. Incremental investment to partially save or restore is rarely possible and deferring investment may raise costs or even render the project impossible. Second, as mentioned earlier, those making the investment and those reaping the profits are unlikely to be the same. However, even more fundamentally, both costs and benefits accrue more widely than just to those who own or are responsible for the heritage. Because much heritage is produced and consumed as a public merit good consumption cannot be restricted to those who pay for it and equally consumption may actually be compulsory as no-one can exclude themselves from experiencing built environments, whether such experiences convey positive or negative feelings. As with much cultural and environmental investment, the economic externalities, whether benefits or costs, accruing to a wider society are often more important and indeed may be the justification for the investment, than the internalities. This simple condition lies at the heart of the balance between public and private interests, which in turn has determined the nature of decision making in policies for using heritage in local economic development.

Consider the fundamental issue of private property ownership, which bedevilled attempts at public intervention in the historic built environment in Europe for almost a century, delaying protective legislation and public subsidy. Indeed, the issue remains unresolved in North American jurisdictions. Simply the judicially protected, and in some countries constitutionally supported, right of owners to an unfettered use and disposal of property made state intervention in the collective interest legally impossible.

The compromise eventually arrived at in most Western European countries and enshrined in legislation around the turn of the nineteenth and twentieth centuries, was to separate the private right to use and enjoy from the public right to preserve and bequeath. The ostensible confiscation of some private control by the state was compensated by public subsidy: the state, in effect, bought out some of the rights of private property in the common good.

This characteristic of investment in potential heritage whereby private and collective costs and benefits are interlinked through externalities has a major influence on the decision to invest. The rational process of the decision to invest in the preservation and renovation of heritage property may be explained by the simple idea of the "neighbour's dilemma". Two neighbours are considering whether it is financially worthwhile to invest in renovating their properties. If one does and the other does not, the investing neighbour receives a return from the value added to the property but this is depressed by the continued non-renovated condition of the 
neighbourhood. The investor suffers a loss while the non-investing neighbour reaps an unearned profit from the partially renovated neighbourhood.

There are two rational strategies. The first is to do nothing and hope that your neighbour invests: the second is for both to agree to invest together thereby reaping the external, as well as internal profits. So far in this story, only the costs and benefits to the individual have been considered, the third party is the community, which can be assumed to have an interest in neighbourhood renovation and is presumably represented by some local government agency. Only rarely will such agencies have the financial resources to invest themselves in neighbourhood renovation and even if they had the use of public finances to increase the value of private assets would need justification. In most cases, the role of the public sector is to create the conditions that encourage the individual owners to invest in their property. This may involve no more than the formal designation of a heritage or historic district, a line on the map, which declares the intent of a public authority. This alone may reassure the individual that private investment will be profitably secure and that the externalities are likely to be positive rather than negative. The act of designation can be enhanced by promotional measures such as a suitable naming of the district, by attention to public signage, street furniture, and landscaping, all of which cost little, as well as the renovation of publicly owned buildings and sites. Thus this "neighbour's dilemma" lies at the core of area development and regeneration issues, especially for historic districts.

Public intervention is thus justified by increased collective benefit, by redressing local market failure, by reconciling private and public economic interests and distinguishing between individual and collective costs, benefits, and responsibilities.

In the choice between public or private investment for property and district renovation, it is, of course, in theory, possible for the state to assume exclusive responsibility, in the collective interest, in a political system where private ownership of property does not exist or is severely curtailed. This avoids the "neighbour's dilemma" described above and directs renovation effectively to exactly where it is desired and presumably also to whom the benefits will accrue. Apart from the political and legal difficulties of such a state monopoly of funding and subsequent uses, the magnitude of the funds required normally precludes this happening on any substantial scale. The opposite extreme position would be for the state and its agencies to play no part in the process, leaving it entirely to private profit-seeking investors who both take the risks and reap the benefits. This abrogation of financial responsibility also implies an inability to influence where such renovation occurs and who benefits. In particular, private financial speculation is likely to result in social change among property users and in districts whose property improves or deteriorates, rising or falling in value, taking no account of any public policies for the economic or social area redevelopment. Public authorities thus effectively cease to engage in area management. Most historic area renovation over the last 50 years throughout most of the world has functioned through some compromise between these extremes. The "government's dilemma" is to obtain private risk-taking investment, while avoiding or mitigating what it regards as the undesirable social consequences of such investment. "Gentrification", as the process of physical, economic and social upgrading of areas became known, is both a welcome leverage of private investment and an unwelcome instigator of undesirable social changes through private speculation. The role of the state has been to devise policies, 
generally at the local level, that protect the public interest through measures to limit or mitigate the negative external effects of private restoration investment. Intervention here tends to be in the form of regulations and constraints such as rent controls, resale restrictions, security of tenure, the legal right of return and the like. The danger, of course, is that if such antispeculation measures have a little effect then they are futile but if they are effective then they restrict the rights of owners and investors thus lowering the value of the property, which in turn discourages the investment.

One common form of direct public intervention was for the public authority to play the role of the investing neighbour by operating rolling programmes of the purchase, restoration, and resale on the free market of individual properties as a sort of seed investment in the hope that this would send a positive signal to the market and encourage an imitation by private investors. A number of Central and Eastern European countries, for example, have nationally funded restoration funds of this sort as early as 1990s that there was a tradition in the Visegrád group countries of private conservation trusts, which again attempted to lead the market by example and again play the role of the initial investing neighbour in the model [1, p. 23-25].

However, there is a false sense of inevitability in the idea, which seems to suggest that the costs of renovating and maintaining heritage districts for the common good can quite easily be undertaken by private investment, as steered by public authorities. This sounds too good to be true, and it is. The illusion of automatic success was fostered from the experiences of Western European, North American, and Australasian cities from the late 1960s through to the 1990s. This period followed the enactment of heritage area legislation in much of the Western world, which shifted the focus of intervention from the monumental building to the historic area and from the aesthetic and cultural justifications to economic and social functional ones. The changes in approaches to local area planning and management were accompanied by an increasingly popular and political support for neighbourhood conservation. It is easy to find statements in policy documents, such as in 1996 from the Department of Canadian Heritage, "Main Street Canada has reported success in the historic business districts in towns across the country where investment in building preservation has been good for business." Similarly, from Canadian Heritage in the 2000s, conservation now plays a direct role in regeneration in some of the most deprived neighbourhoods in Central and Eastern European countries.

Suspicion about such statements should be aroused by the simple question of why logically this should occur. The designation of a building or an area as "historic" normally imposes constraints on use, which should lower the utility and thus the value of the building or area. If this seems not to have happened then this aberration needs explanation and there has been much speculation about valuing preserved historic structures.

Values actually rose with heritage listing. Estate agents have commonly argued that location within a conservation area or designation as a listed building can improve the asking price of a building by perhaps $10 \%$. What may well have been happening is that these changes in attitudes to the historic built environment did certainly lead to a revaluation of old property but that this also occurred against a background of a long-term boom in property values throughout most of this period in most Central and Eastern European cities. Investment in the renovation of historic properties became more profitable but then so also did investment in inner cities and 
indeed in real estate in general and whether the same processes would operate on a static or falling market began to be debated in the 1990s.

The single case study where the assumed link between heritage designation, increased private investment and rising property values did not occur may help to dispel the illusion of inevitability. Hajnowka, one of the oldest settlements in Eastern Poland, has the distinction of being Polish first and largest conservation area. Seed investment was to come from a coalition of business interests, funding agencies, residents, and private associations, which was empowered and financed by the provincial government to operate a rolling programme of purchase restoration and resale. It purchased and restored 28 key properties within the conservation area between 1997 and 2002 in the hope that this would encourage further investment from owner-occupiers. It failed. In 2002, the programme was abruptly terminated, remaining unsold publicly owned properties were unloaded at a loss onto the market and in the 2000s most of the Historic Conservation Area was effectively de-listed. What had occurred was that the property market was insufficiently stable over the short term to guarantee financial solvency and there was no longer-term rise in the value of property in the conservation area needed to encourage investment by owneroccupiers, which did not occur. These economic failings were then compounded by political failings. The city government was reluctant to pursue conservation policies that might discourage alternative economic strategies that offered more immediate returns in local employment, even to the point of allowing a number of visually incongruous developments that not only blocked important harbour views from the historic district but also sent discouraging messages to potential private investors in the renovation. The city planning authorities were also reluctant to penalize its constituents by enforcing conservation by-laws, on, for example, inappropriate and illegal property alterations, especially the construction of external decks, replacement window styles and vinyl sidings, all of which had an unfortunate damaging visual impact on the unity and integrity of the street scene but more significantly sent a clear message to potential investors about the lack of seriousness of the city's intentions, which in turn weakened the expectation of a general rise in property values. The idea that once the initial official designation of a heritage area is made then local business and political interests will unite in a coalition of support that will result in risk-free profitable investment in heritage renovation was dispelled.

\section{Approaches to using heritage in economic development strategies}

The most widely encountered approach to using heritage resources and facilities especially at the local level could be called the "windfall gain model" in which existing heritage, created, maintained, and managed to serve non-economic purposes, are utilized in addition for economic purposes. This can be viewed as a windfall gain because a marginal benefit is obtained without extra cost. Its attraction is that economic use obtains what appears to be a free resource, while the resource managers obtain what appears to be a marginal cost-free benefit. However, this win-win situation is dependent upon a number of assumptions. First, it presupposes that the additional economic demands can be accommodated alongside the other already existing demands without competing with, displacing or reducing the value of the heritage experience to other consumers. Much of the friction between users at the scale of the local site and much of the concerns of site management can be traced to the partial incorrectness of this assumption. Second, it also assumes that the 
additional marginal use does not damage, diminish or change the resource, upon which multiple uses depend. Third, it is implied that the addition of the economic use is conditional upon the above two assumptions being correct and, if they are proved not to be in practice, then there is an acceptance that the economic use will be monitored and regulated such that other users will be prioritized. This model also raises the issue of free-ridership (i.e. gaining benefits from a resource whose costs are borne by another), although who is riding free depends upon how the model is interpreted in a given situation. An economic enterprise may freely use a heritage facility created and maintained for other purposes: alternatively, a heritage enterprise may generate economic returns that maintain a facility in the existence of the free use by others. Both situations can exist simultaneously.

At the level of the individual heritage facility, it may not appear to matter much who consumes or why they are consuming the service and experience on offer. The critical variable becomes the customer or visitor numbers or expenditures (an approach known vulgarly as "bums on seats"). It is these figures that provide the economic returns or less directly the political justification for the facility. The dangers of this "turnstile model", however, are that it assumes that it is the same product that is being consumed in the same way and for the same reasons by each customer.

If heritage is conceived to be the commodification of the past, then a tradable product for sale on present markets is created from what were previously nontradable relics, structures, and sites. This can be viewed as an industrial assembly model, which combines resources, products, and markets. Within this model three processes occur, namely, resource discovery and activation, product assembly though resource selection and product packaging, and product delivery to final consumer markets. Such a model accommodates and explains some of the significant characteristics of heritage when viewed as a product range. In particular, it illustrates the vertical disintegration of the different stages in the process whereby different agencies are responsible for different phases in the process. It remains, however, something of an abstraction for two reasons. First, no such integrated assembly system actually exists: The three processes of which it is composed are performed by at least three groups of actors, namely, the resource caretakers, the product assemblers, and the market managers. Those operating at these different stages of the model often have little interest in, or even awareness of, each other, having different working practices and are usually quite differently motivated. Second, although the model is useful in stressing the essentially market rather than a resource-driven characteristic of heritage, there is a marked difference in this respect between the two sides of the assembly process. The demand side of the model is certainly market driven but the supply side rarely recognizes this, with the resource providers assuming the existence of intrinsic object-based values rather than ascribed societybased market values. From this discrepancy stems much of the lack of understanding and often friction between those operating at the different stages of the model.

\section{Heritage instrument for local economic development}

Heritage is used in many different ways within local economic development strategies. Each of these instrumental roles has been extensively studied but it is worth briefly reviewing these here if only to illustrate this variety and to reiterate that 
in local place management practice the different goals are often strongly interrelated and poorly distinguished.

Heritage as Culture Industry. Heritage can be used as an economic enterprise; as a part of a wider set of cultural industries producing distinctive cultural goods and services for sale. In this respect, it has a distinctive local geography of production. It has identifiable spatial location factors, distinctive industrial structures of production, patterns of employment and traceable inter-firm linkages and networks [5, p. 19-20]. Heritage enterprises can thus be planned and managed as other cultural enterprises in the public interest by using the distinctive characteristics of the industry. These include the prevalence of small enterprises each handling specific stages in the production and delivery process and a dependence on specialized labour pools, a feature typical of both cultural industries and tourism. These characteristics of production reinforce an often highly localized, spatial dimension leading to a marked spatial clustering, typified by Praha's Vyšehrad or Hradčany, Warsaw's Śódmieście.

Heritage as Tourism Industry Resource. The tourist use of heritage could be regarded as only a specialized cultural industry market consuming a particular set of heritage goods and services. However, its economic importance, both locally and beyond, demands special attention and has generated much political and academic interest. Suffice it here to add that the main economic problem with the commodification of heritage for tourism lies in the discrepancy between internalities and externalities of costs and benefits already discussed. Many of the primary tourism resources experienced by visitors are public goods, freely accessible at zero-cost. The economic returns from tourism are dominantly indirect, accruing to the secondary tourist support services. This imbalance of internal and external costs and benefits is also compounded by discrepancies of spatial scale in that many of the costs may occur at the local scale as externalities, while much of the benefit may be reaped as internalities outside the locality.

The way tourism as a user of local heritage is viewed depends upon the viewpoint. Heritage provides a flexible, ubiquitous and inexhaustible resource that is ideal for the creation of place-bound tourism products for ever-expanding leisure markets. The tourism industry, with low start-up costs and labour-intensive activities, seems to offer local economic benefits generated from resources that largely already exist and are often otherwise underused. Equally, tourism can be viewed as a parasitical freerider and potential despoiler of resources that it has not created and financed and does not manage, displacing other more worthy users and creating high external costs for many who receive no benefit from the activity. These largely irreconcilable viewpoints account for both the almost ubiquitous presence of tourism in local strategic development policies, as well as its prominence as a local political issue. The resolution depends upon the priorities set by local governments and local place managers.

Heritage as Location Factor. Heritage may be a variable, whether positive or negative, in the location decision of other economic enterprises and of potential residents. The existence of conserved districts and landscapes, museums, and heritage structures, and even just the idea that a place is historic may be an environmental amenity attractive to potential residents. Such a heritage may also be attractive to economic enterprises both indirectly through the enhanced residential amenity for employees but also and more directly if the enterprise can capitalize upon the place association with historicity and even upon the visitors that such a historicity may 
attract. Whether historical place associations are beneficial or detrimental will depend largely upon the nature of the product or service being produced. Equally, however, the restrictions on use, adaptation, and traffic circulation imposed by preservation designations upon buildings and areas are a cost to residents and enterprises and the heritage place associations may not be appropriate and profitably transferable to the firm.

Heritage as a Place Identifier. The link here between the built environmental heritage and economic development is through place identity. Here it is assumed that specific localities to varying degrees possess a quality called identity, that is that the people who use this place, or even imagine it from a distance, identify with it in some way and that this quality may confer a universal benefit in the form of a public good by its very existence. This is the "identity dividend". Such a dividend, whether economic or psychic, is expected to emanate from "identity-rich" regions and be automatically conferred upon their inhabitants and other users of such places. Governments have frequently assumed the role of encouraging the creation of strong local identities because of such assumed public benefits and heritage has generally been the most important instrument in such policies [4, p. 47-52].

Typical of many such national policies was the Hungarian programme, which ran from 2001 to 2012. It provided central government seed funding and encouragement to local public-private development consortia to discover or create and promote local place identities, mainly using heritage elements. About one-third of the total land area of the country and almost all its cities received such designation and funding through thousands of publicly and privately sponsored local programmes. No-one has as yet attempted to measure whether this policy has had any noticeable impact upon place identities and their consequences for economic development.

On the other hand, individuals do seek out places that possess a sense of place as long as that sense is composed of elements of visual comprehensibility, aesthetic gratification, and agreeable historical associations. Residents are prepared to pay a premium to own and inhabit buildings and places of such 'character', to use the real estate broker's term for the qualities described. Equally, tourists seek out and pay to visit such places, while commercial companies may well see advantages in locating in areas of high place-name recognition, beneficial historical associations, and high residential amenity. People, therefore, behave as if such an identity dividend exist and has economic value. The causal chain is from the heritagization of places, through place identity to individual well-being, which is reflected in economic indicators such as property values.

Heritage and Place-Product Promotion. Strongly related to place identity is the use of heritage components within place-marketing and place-branding strategies. All such strategies share the common element of attempting local differentiation: making one place different from another in the imagination of the consumer. The idea that pasts are distinctively local and unique explains why heritage associations are frequently used to promote places, and not only in tourism markets. Memorialized historic events, personalities, mythologies, folklore, and customs, as well as conserved monuments and areas, are seen as reinforcing the uniqueness of the placeproduct selling point, almost regardless of the nature of the product [3, p. 367].

Heritage in Economic Area Regeneration. Finally, in this list of the uses of heritage in economic development, there are a few cases where heritage has been used to reshape fundamentally the economy of a place through becoming in itself the 
dominant economic sector. Such cases are usually the result of a sudden and drastic failure in the local economy necessitating a complete reorientation. They also require much good fortune in time and place and are nearly impossible to replicate elsewhere. Much more widespread is the use of heritage indirectly, through its contribution to a broad-based amenity and environmental quality. Heritage in its many expressions may all contribute to area regeneration even when the economic development has little directly to do with heritage. Waterfront regeneration strategies (from Gdansk to Gdynia in Poland), in particular, have long used heritage in this way but always in combination with other place management instruments, such as landuse measures, area development investments, place marketing and promotion strategies and place management more generally.

Conclusion. Although it was made clear at the outset that heritage is an experience rather than an object, many of the arguments expounded above have in practice been overtly or covertly concerned with the built environment of monumental buildings and heritage districts. Of course, heritage meanings can be communicated by many other means including archaeological sites, museum artefacts, events and performances and site associations with historical deeds and personalities. However, even though any or all of these can play some role in the economic regeneration of local areas, it is buildings, spaces, and morphologies that have had the most obvious, long-term, and substantial impact upon such policies.

Heritage offers many possibilities for use in local economic development strategies but is also constrained by many limits. There is a school of thought that contradicts the whole argument of this chapter by not only dismissing any possible role of heritage in solutions to economic regeneration but by viewing it as a significant part of the problem. In these arguments, heritage is a cost both directly through the financial resources it consumes and more importantly indirectly through the opportunity costs foregone and the obstacles to development it imposes through the restrictions that preservation designations entail on buildings and areas. More broadly heritage is viewed as a constraint that fossilizes the existing morphological patterns and land uses and even more seriously engenders a backward-looking mentality that focuses upon the past, which is the antithesis of the forward-looking future orientation intrinsic to development.

It is still worth remembering that although heritage possesses many economic dimensions and plays many roles in local development strategies, only rarely economic considerations are paramount in the selection and management of the resources, from which it is created, and only rarely heritage is the main support or justification for economic development. Almost all the heritage was created and is maintained to fulfil contemporary political and social needs for the legitimation and socialization and it would continue to exist even if it had no economic significance. Also, it must be reiterated that many of the actors involved in the process of heritage resource creation and preservation, heritage product packaging, and even promotion and consumption are not motivated by its economic potential and may even be averse to the very idea of its use for economic gain. Nevertheless, and for whatever reason, it was created it offers ubiquitous, flexible and mutable resources rendering it in many ways an ideal instrument of local economic development. This is usually most effective in combination with other management instruments where heritage often plays a catalytic role by shaping a diffuse historicity and distinctive place identity, 
within which wider development policies can operate successfully. It must always be remembered, however, that heritage is inevitably about choices and in local economic development and the regeneration of areas this involves choices of objectives and instruments. Heritage may but equally does not have to be chosen to be among either the goals or the tools.

\section{References:}

1. Dziedzictwo kulturowe ma znaczenie dla Europy / K. Jagodzińska, J. Purchla, J. SanetraSzelig. - Warszawa: Międynarodowe Centrum Kultury. 2015. - 46 s.

2. Ganski U. Cultural heritage as a socio-economic development factor / U. Ganski // BalticBlack Sea Region: History, Economics, Culture, Society: Materials of International Scientific and Practical Conference, Riga, July 4-5, 2016. / University of Latvia; publishing board: Prof. Andris Lejinšs (chairperson) [etc.]. - Riga, 2016. - Vol. 5. - P. 18-21.

3. Handbook on the Economics of Cultural Heritage / I. Rizzo, A. Mingosa. - Northampton: Edward Elgar Publishing Inc., 2013. - 636 p.

4. Stanowicka A. Możliwości wykorzystania dziedzictwa kulturowego w kreowaniu wizerunku regionu / A. Stanowicka // Studia Ekonomiczne i Regionalne. - 2013. - Volume VI. - Nr 2. S. 47-55.

5. Vaughan D.R. The Cultural Heritage: an Approach to Analyzing Income and Employment Effects / D.R. Vaughan // Journal of Cultural Economics. - 1984. - Nr 2. - S. 1-36.

Гегедош К.В. магістр з менеджменту Мукачівського державного університету

\section{ВДОСКОНАЛЕННЯ МЕХАНІЗМУ ВЗАЕМОДІї УКРАЇНИ ТА КРАЇН ВИШЕГРАДСЬКОЇ ГРУПИ В РАМКАХ КАРПАТСЬКОГО СВРОРЕГІОНУ НА ЗАСАДАХ ІНТЕРАКТИВНОГО МАРКЕТИНГУ}

Анотація. Основи маркетингу в транскордонному співробітництві використовуються в міжнародній практиці вже достатній період часу. Однак унаслідок бурхливого розвитку ІТ-сфери набув потирення ще один 3 інструментів прямого впливу маркетингу - інтерактивний маркетинг. Інноваційний напрям розвитку даної концепщії сьогодні ще не $\epsilon$ добре дослідженим явищем, але якщо перенести його базові компоненти на систему транскордонного співробітниитва, то ие стане основою в розробленні сучасних методів щодо поліпшення співпраці на міжнародній регіональній арені. У даній науковій роботі автором зроблена спроба запропонувати та охарактеризувати поняття «інтерактивний транскордонний маркетинг» та на основі иього систематизувати основні теоретичні компоненти щодо становлення та розвитку даної інновачії в сучасній системі управління транскордонним економічним співробітництвом в Карпатському єврорегіоні.

Вступ. Сучасний розвиток інтеграційних процесів в Свропі є надзвичайно важливим явищем, що визначає теперішній та майбутній стан розвитку 
України в системі міжнародних економічних відносин. Головним здобутком України сьогодні є підписана Угода про асоціацію, встановлена поглиблена та всеохоплююча зона вільної торгівлі з Свропейським Союзом. Однак хоча ми за останній період і досягли певних етапів євроінтеграції, проте ті проблеми, які в нас залишалися раніше, присутні в нас і сьогодні. Якщо говорити про західні регіони нашої країни, які безпосередньо межують із країнами Європейського Союзу в рамках Карпатського єврорегіону, то ми мали б першими налагодити механізм співпраці через систему транскордонного співробітництва, на прикладі якого і встановлювався механізм міжнародних економічних відносин на регіональному рівні. Водночас ефективного механізму нині ще немає, крім реалізації разових проектів, які хоча й допомагають вирішити одну проблему, але не охоплюють увесь спектр. Вирішити цю проблему, на нашу думку, можна, застосувавши на практиці механізм міжнародного маркетингу в прикордонних економічних відносинах України з Європейським Союзом, що відіграє визначну роль у розвитку транскордонного співробітництва. Сьогодні маркетинг еволюціонував, змінивши традиційні інструменти маркетингових досліджень до інтерактивних.

Ми можемо спостерігати, що в усьому світі нині відбувається становлення інтерактивного маркетингу. Це спричинено бурхливим розвитком глобальних ринків та їх перенасиченням диференційованими товарними пропозиціями, науково-технічним прогресом у галузі інформаційних технологій та комп'ютерної техніки, тому традиційні інструменти маркетингу з кожним роком відходять на другий план. Викликано це передусім тим, що в режимі віртуальної економіки можна значно простіше зробити безліч операцій: володіти електронним магазином в необмеженому просторі та часі в режимі $24 / 7$ та проводити відповідну Інтернет-аналітику; здійснювати онлайн-опитування, яке буде більш точне на відміну від традиційного (оскільки анонімне опитування клієнтів тотожніше відкриває їх внутрішній світ 3 індивідуальними потребами), зекономив суттєві затрати на проведення реальних маркетингових досліджень.

Тематика наукових досліджень з інтерактивного маркетингу нині розвинута на рівні підприємства, хоча продовжує досліджуватися у тематиці навчальних планів дисципліни «Електронне врядування». Проте $\epsilon$ ще неабияка кількість сфер у галузі науки, де інтерактивний маркетинг як механізм сучасних відносин нетрансформований у різноманітну проблематику людських відносин, хоча й використовується майже в усіх сферах життя. Однак напрошується питання: чи використовується воно правильно і за призначенням? Тобто дискусійні та наукові теми 3 питань трансформації інтерактивного маркетингу в механізми різного роду економіки, культури, туризму та інших сфер набувають значної актуальності для подальших конкретизованих досліджень.

\section{1. Основи інтерактивного транскордонного маркетингу}

Об'єктом нашого дослідження виступає транскордонне співробітництво (ТКС) у рамках Міжрегіональної асоціації «Карпатський єврорегіон». Багато науковців розглядали це питання 3 негативної точки зору щодо його масштабності. Це і справді так було й $\epsilon$, оскільки між центрами відстань сягає майже 500 км, що спричинює труднощі та витрати на збирання, обговорення, аналіз теперішніх проблем, потенційних можливостей і т. д. 
Нами запропоновано розпочати використовувати переваги інтерактивного маркетингу в системі ТКС, де кожен учасник зможе, не відриваючись зі свого робочого місця, побачити, які проекти в нас $\epsilon$, які розвиваються, які підприємства $\epsilon$ найбільш активними учасниками транскордонних відносин, проблеми, недоліки, транскордонну статистику та іншу інформацію, яка передусім необхідна для ефективного менеджменту транскордонного економічного співробітництва. Але оскільки інтерактивний маркетинг у цій системі ще не є дослідженим явищем, то необхідно з наукової точки зору дослідити і запропонувати базові підходи до розуміння основних компонентів його використання.

У цілому поняття «інтерактивний маркетинг» являє собою форму прямого маркетингу, який здійснюється за допомогою інтерактивних комп'ютерних служб, які надають інформаційні послуги в оперативному режимі та використовують канали зв'язку в режимі реального часу за допомогою засобів електронної торгівлі. Для цього застосовуються інтерактивні комп'ютерні системи, які об'єднують у режимі реального часу покупців та продавців [1].

Якщо перейти до системи транскордонного співробітництва, то, на нашу думку, інтерактивний маркетинг можна трактувати як інтерактивний транскордонний маркетинг, під яким слід розуміти, що це схема відносин, яка створюється на основі бази даних регіонального вираження на web-сторінці інтерактивних транскордонних бізнес-центрів, де його суб'єкти можуть отримати достовірну та своєчасну інформацію про проекти ТКС, підприємницький, освітній та туристичні ринки, товари і послуги, запропоновані за відповідну ціну, та інші новини з проблемних та актуальних питань, які $є$ на території, що охоплює транскордонні взаємовідносини його учасників.

Необхідно розрізняти поняття «суб'єкти» та «учасники» інтерактивних транскордонних відносин. Суб'єктами у цьому разі будуть такі його користувачі, які використовуватимуть бази даних ТКС із метою отримання певної інформації для прийняття результативних рішень, а учасники - це ті зацікавлені особи, які надаватимуть на web-сайт інтерактивного транскордонного бізнес-центру (ІТКБЦ) дані щодо:

- опису своєї діяльності й перспектив іiі розвитку за рахунок ефективних інвестиційних вкладень;

- збуту продукції або надання послуг;

- пошуку відповідних постачальників;

- іншого залежно від того, хто саме буде цим учасником (інші суб'єкти ринку).

У цьому разі слід урахувати й те, що суб'єкти та учасники транскордонних відносин будуть одні й ті ж територіальні органи влади, громадські організації регіонального розвитку, юридичні чи фізичні особи, але по різні боки кордону змінюючи свої ролі. Механізм розуміння даної концепції досліджуватиметься далі.

Тобто під інтерактивним транскордонним маркетингом розуміють маркетинг, який забезпечує взаємодію суб'єктів та учасників транскордонних економічних відносин із використанням сучасних інтерактивних інформаційнокомунікаційних технологій для отримання певного позитивного результату від діяльності системи транскордонного співробітництва. 
Об'єктом інтерактивного маркетингу в системі ТКС, на нашу думку, виступає транскордонний регіон (або єврорегіон), який буде представлений у вигляді онлайн-карти 3 усіма його суб'єктами господарських відносин та галузями народного господарства (рис. 1,2 ). Тобто тут використовуватиметься географічна інформаційна система (ГIC), яка являє собою комп'ютерну базу просторово організованих (координатно визначених) даних у поєднанні 3 електронними засобами та програмами їх аналізу [2, с. 114]. ГІС є сукупністю географічних карт, які будуються за допомогою інформаційних технологій за певними заданими критеріями та ознаками, які задає користувач [3, с. 137-138].

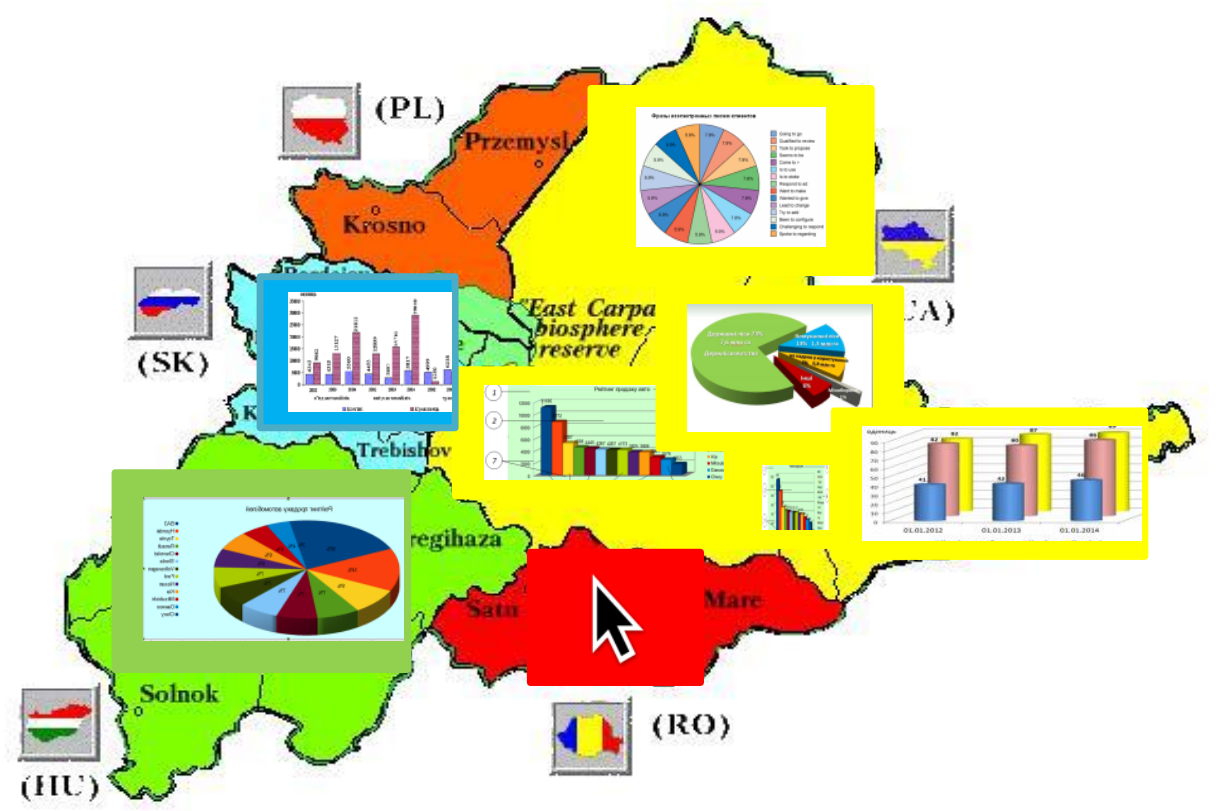

Рис. 1. Онлайн-карта щодо потенційних галузей країн членів Карпатського сврорегіону на веб-сайті інтерактивного транскордонного бізнес-центру

Джерело: авторська розробка

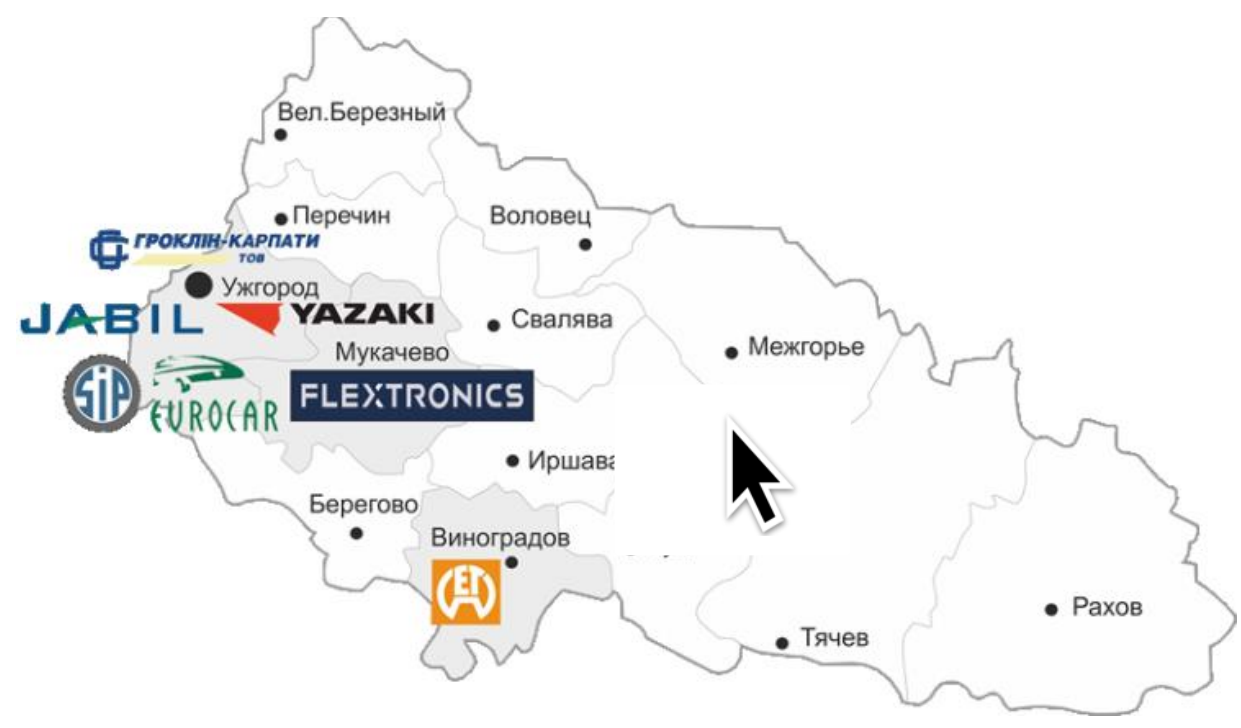

Рис. 2. Підприємницька онлайн-карта Закарпаття на веб-сайті інтерактивного прикордонного бізнес-центру в структурі української сторони Карпатського єврорегіону

Джерело: авторська розробка 
Предметом інтерактивного маркетингу в ТКС є збір, аналіз та формування інформаційного забезпечення, а також його презентація щодо паспортизації кожного учасника та суб'єкта транскордонних економічно-господарських відносин на веб-сайтах відповідного єврорегіонального утворення щодо: представлення інвестиційних проектів кожної бізнес-одиниці; презентація вироблення тієї чи іншої продукції або надання послуг для широкого охоплення кола споживачів; конкретної характеристики позитивних аспектів стосовно співпраці з тим чи іншим учасником економічних відносин (для розширення точок збуту чи пошуку нових постачальників); результатів дослідження попиту i пропозиції на товарному ринку (у вигляді графічного зображення для ознайомлення суб'єктів господарювання 3 потенційними регіональними ринками, де їх аналогова продукція знаходиться або в зародковому стані, або вона взагалі на даній території відсутня, або там іiі вдосталь і ринок перенасичений) та інших інформаційних даних залежно від того, хто буде користувачем та учасником інтерактивного транскордонного бізнес-центру.

Основними перевагами від застосування інтерактивного маркетингу в системі транскордонних економічних відносин будуть такі:

- надзвичайно зручно для всіх учасників ринку: не треба їздити на бізнесфоруми, конференції, робочі поїздки, витрачаючи кошти на пальне, проживання в готелях та час, який нині дуже дорого коштує для менеджерів будь-яких компаній; недоцільно проводити підприємствами громіздких маркетингових досліджень. Інтерактивний маркетинг надаватиме зацікавленим учасникам доступ до різноманітної порівняльної інформації про компанії, товари та конкурентів. Наявність на більшості підприємствах електронного підпису взагалі спрощує систему укладання договорів про співпрацю з тією чи іншою фірмою;

- на основі зазначених вище зекономлених витрат аналогічно знижуються собівартість продукції та ціна, що, своєю чергою, впливає на зростання попиту (на товар/послугу) та підвищення рентабельності через ефективність участі суб'єктів господарських відносин у системі транскордонного співробітництва.

\section{2. Методичні підходи інтерактивного маркетингу до транскордонного співробітництва}

Одним із найбільш популярних інструментів інтерактивних маркетингових досліджень $\epsilon$ онлайн-панелі та онлайн-спільноти. Спробуємо їх трансформувати в механізм транскордонного співробітництва.

Онлайн-панелі - це група зареєстрованих користувачів Інтернету, які усвідомлюють, що вони погодилися брати участь у маркетингових дослідженнях [4, с. 129]. Панель складається з бази респондентів, що постійно оновлюється, які добровільно погодилися на участь в опитуваннях. Але, оскільки це тільки тимчасові респонденти, які не будуть постійними суб'єктами - учасниками ТКС, необхідно виділити категорію онлайн-спільноти. Різниця полягає у тому, що до онлайн-спільнот можна віднести постійних учасників - суб'єктів транскордонних відносин: прикордонні торговопромислові палати, органи влади, громадські організації міжнародного розвитку, наукові та навчальні заклади; а до онлайн-панелей відносимо тимчасових, а саме інвесторів, туристів, потенційних абітурієнтів із різних країн 
прикордонних територій, тобто тих, які діятимуть одноразово. Проте як у першому, так і в другому випадку реєстрація учасників - суб'єктів ТКС дає змогу їх розподілити на сегменти, необхідні майбутньому досліднику. Нами була розроблена схема формування онлайн-спільноти учасників - суб'єктів ТКС щодо паспортизації в інтерактивному транскордонному бізнес-центрі (ІТКБЦ) для підвищення ефективності прийняття менеджментових рішень (рис. 3).

Однак слід урахувати, що учасники транскордонних відносин повинні двічі підтвердити своє бажання брати участь у такій співпраці онлайн-досліджень у віртуальному просторі (під час заповнення інформації в особистому онлайнкабінеті в ІТКБЦ, а також указавши і підтвердивши діючий e-mail установиучасниці). Тут обов'язково слід проконтролювати унікальність уведеної електронної пошти, щоб не було прецедентів подвійної реєстрації.

Під час опитувань перевіряється частота участі респондента в опитуваннях однієї тематики (за кодексом ICC/ESOMAR, єдиного для всіх онлайндосліджень, респондент повинен брати участь у схожих опитуваннях не частіше чотирьох разів на місяць), використовуються унікальні посилання для кожного респондента, порівнюються відповіді і дані, зазначені під час реєстрації, контролюється час заповнення анкети [5].

Що стосується кодексу ICC/ESOMAR, то тут потрібно зазначити, що він встановлює основні принципи, які повинні спрямовувати дії тих, хто здійснює або використовує маркетингові дослідження:

- під час отримання особистих даних від суб'єктів для проведення дослідження дослідники повинні повідомляти, яку інформацію вони планують зібрати, з якою метою, а також із ким і в якій формі вони можуть обмінюватися такою інформацією;

- дослідники повинні переконатися, що особисті дані, які використовуються в дослідженні, ретельно захищаються від несанкціонованого доступу, а також не розкриваються без згоди суб'єкта даних;

- дослідники повинні завжди керуватися етичними нормами і утримуватися від будь-яких дій, здатних завдати шкоди суб'єкту даних або завдати шкоди репутації маркетингових, соціальних досліджень i опитувань громадської думки [6, с. 7].

ESOMAR (Європейське товариство 3 вивчення громадської думки i маркетингових досліджень) - міжнародний представник спільноти дослідників i фахівців зі збору та аналізу даних, який виступає від імені більш ніж 4900 фахівців і 500 компаній, які надають або замовляють послуги 3 аналізу даних та проведення досліджень у більш ніж 130 країнах і які погодилися дотримуватися положень Міжнародного кодексу ICC/ESOMAR [3, c. 1]. 32001 p. національне представництво ESOMAR в Україні проводить Українська асоціація маркетингу [7].

Як i в багатьох онлайн-панелях, для того щоб учасники не нехтували постійним онлайн-опитуванням (наприклад, теми дня: «Проблеми онлайнопитувань у Карпатському єврорегіоні» чи «Інноваційні методики керування малим та середнім бізнесом у транскордонному регіоні», де буде представлено декілька запитань із запропонованими та/або рекомендаційними індивідуальними відповідями), необхідним атрибутом є представлення мотиваційного механізму. 
На сайті інтерактивного транскордонного бізнес-центру розміщуються спеціальні анкети для реєстрації та персоніфікації електронної сторінки всіх учасників та суб'єктів управління транскордонним співробітництвом задля формування банку даних (у кожному прикордонному регіоні здійснює дану операцію відповідний інтерактивний прикордонний бізнес-центр у структурі співвідносного єврорегіону)

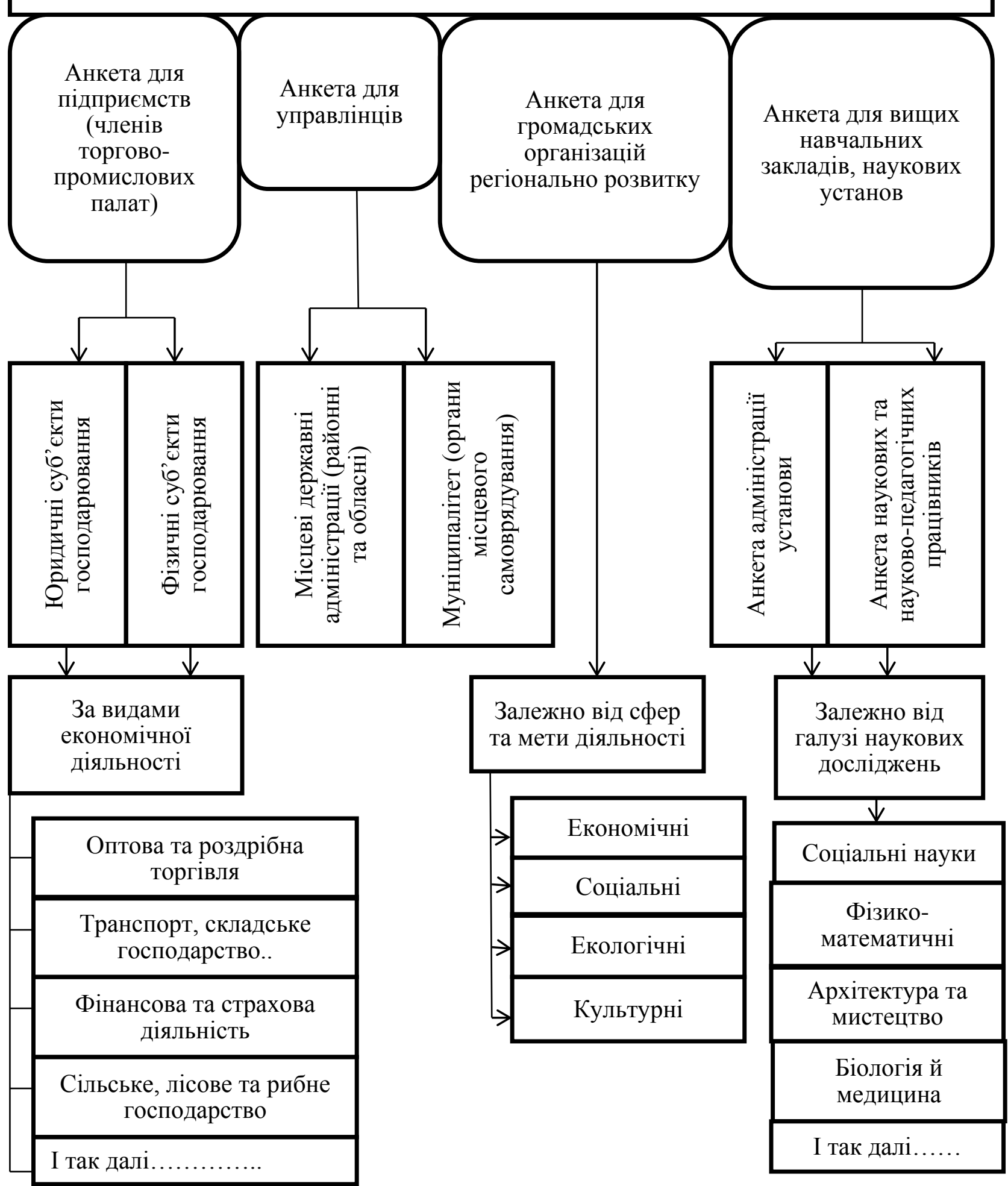

Рис. 3. Схема формування онлайн-спільноти учасників - суб'сктів ТКС щодо паспортизації в інтерактивному транскордонному бізнес-центрі Джерело: авторська розробка 
Якщо учасник $\epsilon$ активним респондентом онлайн-опитувань, то йому нараховуватимуться відповідні бали, за допомогою яких він зможе безоплатно отримувати різноманітну онлайн-консультацію чи маркетингову інформацію 3 тієї чи іншої сфери. Якщо ж респондент не $\epsilon$ активним учасником інтерактивного транскордонного співробітництва, то будь-яка послуга буде платною. Якщо ж учасник взагалі не здійснює ніякі дії, які б допомогли якісніше активізовувати транскордонне співробітництво, то його виключають із бази даних ІТКБЦ, після чого подальше його відновлення (реєстрація) також буде платною (перша реєстрація буде безоплатною, і весь процес підтримки сайту інтерактивного транскордонного бізнес-центру i його менеджерів фінансуватиметься фондами 3 розвитку ТКС, які аналізуватимуться в подальшому). За такого організаційного механізму буде явно видно, хто $є$ учасником транскордонного співробітництва і якою мірою.

Основною причиною появи онлайн-досліджень та зростання частки панельних чи спільнотних онлайн-опитувань $\epsilon$ фактор економії часу, фінансових та людських ресурсів. Онлайн-дослідження значно зменшує часовий інтервал, що є вкрай важливим за сучасного прискореного темпу життя, коли необхідно якнайшвидше відреагувати на потреби споживачів або отримати оперативну інформацію для прийняття управлінських рішень. Жоден із традиційних методів опитування не може забезпечити такої швидкості збору інформації, як онлайн-опитування. Притому коли традиційні маркетингові дослідження проводять самі ж суб'єкти підприємницької діяльності, крім того, що вони витратять значні ресурси, переваги від цієї інформації заздалегідь спрогнозувати точно неможливо. А використовуючи переваги інтерактивного транскордонного маркетингу через інтерактивні транскордонні бізнес-центри в тому чи іншому єврорегіоні, забезпечивши їх тільки відповідною інформацією для ефективного управління транскордонним співробітництвом і не вклавши значних фінансових ресурсів, але отримавши значний спектр різноманітної інформації про економічний, соціальний, політичний, юридичний, інтелектуальний ринки, підприємства, установи, організації різних форм власності уможливлюють отримання реального синергетичного ефекту за рахунок того, що вони є учасниками транскордонного співробітництва.

Не менш важливою перевагою онлайн-опитувань $є$ фактор доступності до респондента. Нові форми комунікації з респондентом із цікавим візуальним оформленням анкети (відео, зображення, анімації) стимулюють інтерес респондента до участі в опитуванні та надають йому відчуття психологічної свободи [4, с. 130].

Інтерактивний транскордонний маркетинг у цілому відрізняється від класичного інтерактивного маркетингу тим, що здебільшого останній розглядався з боку підприємства та його клієнтів (громадян). Однак у системі транскордонного інтерактивного маркетингу ситуація змінюється: фізична особа - підприємець, юридична особа, громадські організації регіонального розвитку, місцеві органи влади та самоврядування виступатимуть для одних продавцем товарів і послуг і покупцем - для інших, проте ці операції продавця і покупця різнитимуться категорією по різний бік кордону, але одного транскордонного регіону.

Для більш наочного представлення переваги інтерактивного транскордонного маркетингу над традиційним транскордонним маркетингом наведемо 
аналіз по відповідним ознакам, на які в транскордонному співробітництві можна звернути увагу (табл. 1).

Щодо збору інформації в інтерактивному транскордонному маркетингу, то тут, як і в традиційному маркетингу виділяють первинні та вторинні дослідження.

Вторинна маркетингова інформація, яка викладатиметься на веб-сайт інтерактивного транскордонного бізнес-центру, повинна містити численні інтерактивні дані різних країн транскордонних регіонів щодо списків учасників - суб' єктів транскордонних відносин, галузей господарства, звіти про ринки, різноманітних підписаних міждержавних угод, нормативно-правових актів та інших аспектів, які допоможуть приймати різноманітні ефективні менеджерські рішення, тому цю інформаційну базу необхідно згрупувати за такими напрямами:

- загальна інформація з прикордонних регіонів (дані про історію регіону (у т. ч. становлення транскордонного співробітництва), культурний, туристичний, інвестиційно-інноваційний клімат, якість життя, основні перспективи розвитку в зовнішньоекономічній діяльності регіону тощо);

- нормативно-правова основа міжнародних угод та підприємництва в системі ЗЕД;

- галузеві ресурси та їх потенційні можливості в інвестиційній та ЗЕД;

- статистичні та біржові матеріали;

- дані щодо митних тарифів, бар’єрів та нетарифних стандартів і т. д.;

- інформація про суб'єктів - учасників ТКС (банк даних повної характеристики підприємств суб'єктів господарської діяльності, органів влади, громадських організацій регіонального (міжнародного) розвитку, наукових установ та їх місце і місія в системі ТКС);

- міжнародні програми розвитку (програми $\mathrm{CC}$ щодо прикордонного співробітництва Європейського інструмента сусідства: «Східне партнерство», «Дунайська стратегія», «Горизонт 2020» та ін.).

Первинні маркетингові дослідження в Інтернеті класифікуються як активні та пасивні [8, с. 42]. За пасивного дослідження маркетинговий адміністратор сайту ІТКБЦ за допомогою сучасних аналітичних служб (Google analytics найпоширеніший) у будь-який час має доступ до докладних статистичних звітів за кількома сотнями різних параметрів його користувачів. Тобто учасник суб'єкт транскордонних відносин не здійснює жодних дій. А спеціалізований маркетинговий відділ IT (інтерактивного транскордонного бізнес-центру) автоматичного збирає, аналізує, систематизує та узагальнює інформацію про учасників - суб'єктів транскордонних відносин, про країну i місто їх перебування, дає змогу відстежити їх навігацію на веб-сайті ІТКБЦ та який пошук інформації на ньому здійснювався, тривалість перебування в окремих рубриках і на окремих сторінках й як часто, а також уможливлює здійснювати різноманітні прогнози на основі цього. Тобто це все дасть змогу зробити різноманітні висновки про учасників - суб'єктів ТКС, про інформаційноінтерактивне забезпечення ТКС i його ефективність, а також взагалі про транскордонне співробітництво і його значення для міжнародної інтеграції. 
Співвідношення позитивних ознак інструментів інтерактивного транскордонного маркетингу з традиційним транскордонним маркетингом

\begin{tabular}{|c|c|c|}
\hline Ознака & $\begin{array}{l}\text { Традиційні маркетингові } \\
\text { транскордонні інструменти }\end{array}$ & $\begin{array}{l}\text { Iнтерактивні маркетингові } \\
\text { транскордонні інструменти }\end{array}$ \\
\hline $\begin{array}{l}\text { Витрати на } \\
\text { транскордонні } \\
\text { дослідження }\end{array}$ & $\begin{array}{l}\text { Високі: } \\
\text { - витрати на проведення } \\
\text { реальних опитувань (фінансові, } \\
\text { матеріальні, часові та значні } \\
\text { трудові ресурси); } \\
\text { - друк довідників, газет та } \\
\text { інших публікацій вимагає так } \\
\text { само вищезазначених витрат; } \\
\text { - підвищені вимоги щодо } \\
\text { точності розрахунків, аналітики. } \\
\text { 3 урахуванням людського } \\
\text { фактора будь-яка помилка } \\
\text { загрожуватиме } \\
\text { непередбачуваними } \\
\text { економічними наслідками. } \\
\text { І головним критерієм є те, що } \\
\text { кожне виконання різноманітних } \\
\text { маркетингових операцій (у т. ч. } \\
\text { вищеописаних) потребуватиме } \\
\text { знову одних і тих самих } \\
\text { витратних ресурсів }\end{array}$ & $\begin{array}{l}\text { Низькі: } \\
- \text { витрати на проведення } \\
\text { віртуальних опитувань майже } \\
\text { зведені нанівець; } \\
- \text { публікації в онлайн-режимі не } \\
\text { потребують ніяких матеріальних, } \\
\text { людських, фінансових та часових } \\
\text { ресурсів; } \\
\text { - розрахунки та їх точність, } \\
\text { автоматичний онлайн-аналіз } \\
\text { відповідає 100\% надійності. } \\
\text { Основним витратним ресурсом є } \\
\text { закупівля спеціалізованого } \\
\text { програмного забезпечення. Але } \\
\text { проводячи майбутні різноманітні } \\
\text { дослідження, крім людських } \\
\text { ресурсів (на відміну від } \\
\text { традиційного транскордонного } \\
\text { маркетингу, до якого належать і } \\
\text { матеріальні, часові, значні } \\
\text { фінансові), ніяких більше затрат не } \\
\text { потребуватиметься. Водночас } \\
\text { трудових ресурсів використо- } \\
\text { вуватиметься значно менше }\end{array}$ \\
\hline $\begin{array}{l}\text { Місце проведення } \\
\text { транскордонних } \\
\text { досліджень }\end{array}$ & $\begin{array}{l}\text { Реальні просторові дослідження } \\
\text { в межах транскордонного } \\
\text { регіону }\end{array}$ & $\begin{array}{l}\text { Віртуальні дослідження в межах } \\
\text { веб-порталу учасників - суб’єктів } \\
\text { інтерактивного транскордонного } \\
\text { бізнес-центру } \\
\end{array}$ \\
\hline $\begin{array}{l}\text { Швидкість запиту, } \\
\text { обробки та доставки } \\
\text { інформації в межах } \\
\text { транскордонного } \\
\text { простору }\end{array}$ & Низька & $\begin{array}{l}\text { Висока. } \\
\text { Охоплення за короткий проміжок } \\
\text { часу значної кількості онлайн- } \\
\text { аудиторії для дослідження }\end{array}$ \\
\hline $\begin{array}{l}\text { Механізм обміну } \\
\text { різноманітною } \\
\text { інформацією щодо } \\
\text { вирішення будь- } \\
\text { яких нагальних } \\
\text { питань суб'єктів - } \\
\text { учасників ТКС }\end{array}$ & $\begin{array}{l}\text { Здійснюється зазвичай через } \\
\text { міжнародні конференції, бізнес- } \\
\text { форуми, семінари, круглі столи; } \\
\text { публікації в журналах, } \\
\text { довідниках, газетах }\end{array}$ & $\begin{array}{l}\text { Здійснюється через онлайн- } \\
\text { форуми, Інтерент-конференції, } \\
\text { електронні онлайн-публікації, } \\
\text { онлайн-новини транскордонних } \\
\text { регіонів тощо }\end{array}$ \\
\hline Менеджмент рішень & $\begin{array}{l}\text { Прийняття рішень на основі } \\
\text { публікаційних матеріалів } \\
\text { минулого періоду. Корегування } \\
\text { щодо зміни стратегії у майбут- } \\
\text { ньому, а також зворотний } \\
\text { зв’язок і діалог здійснюються } \\
\text { після завершення проектів }\end{array}$ & $\begin{array}{l}\text { Прийняття та корегування рішень } \\
\text { на основі реальної теперішньої } \\
\text { інформації, а також через } \\
\text { оперативно-інтерактивний } \\
\text { зворотний зв’язок і діалог }\end{array}$ \\
\hline $\begin{array}{l}\text { Частота проведення } \\
\text { маркетингових } \\
\text { досліджень }\end{array}$ & $\begin{array}{l}\text { За запитами окремих учасників - } \\
\text { суб'єктів ТКС }\end{array}$ & $\begin{array}{l}\text { Постійне проведення за } \\
\text { допомогою сучасних засобів } \\
\text { автоматичної онлайн-аналітики } \\
\text { всіх учасників - суб'єктів ТКС }\end{array}$ \\
\hline
\end{tabular}

Джерело: авторська розробка 
Щодо активного інтерактивного первинно-маркетингового транскордонного дослідження, то тут основними можемо запропонувати такі методи:

- інтерактивне анкетування (розміщення відповідних запитань відкритого/закритого типу або на загальному сайті ІТКБЦ, або в інтерактивних кабінетах відповідного сегменту суб'єктів - учасників ТКС інтерактивного транскордонного бізнес-центру);

- Інтернет-конференція - це можливість прямого спілкування однієї особи із цільовою аудиторією за допомогою комунікаційних програм у мережі Інтернет [9];

- веб-форум, який полягає у створенні користувачами своїх тем 3 їх подальшим обговоренням. Окремо взята тема, по суті, являє собою тематичну гостьову книгу. Користувачі можуть коментувати заявлену тему, задавати питання й отримувати відповіді, а також відповідати на запитання інших користувачів форуму і давати їм поради. Всередині теми також можуть влаштовуватися голосування [10].

Тобто, сьогодні методологія інтерактивного транскордонного маркетингу $є$ дуже цікавою й актуальною. Крім того, що суб'єкти - учасники ТКС зможуть вільно спілкуватися між собою і вирішувати нагальні питання, проводити маркетингові дослідження стає набагато простіше й автоматизованіше. Тут ми можемо побачити, що оскільки одне з основних завдань міжнародної інтеграції через транскордонне співробітництво полягає у розмиванні кордонів, то під час застосування інтерактивного маркетингу саме ця ідея й реалізується, тому що в мережі Інтернет немає фізичних кордонів. I тут також у практичному житті виконується суть транскордонного співробітництва, а саме - спільні дії всіх учасників та суб'єктів ТКС, що спрямовані на встановлення і поглиблення економічних, соціальних, науково-технічних, екологічних, культурних відносин, а також вирішення всіх тих проблем чи перспектив, які положено в основу співпраці прикордонних регіонів у системі транскордонного співробітництва.

Конкретні завдання, які вирішує інтерактивний транскордонний маркетинг, на нашу думку, такі:

1. для бізнесу:

- вихід на ринок у потрібному місці за найточнішою та своєчасною інформацією в режимі реального часу на основі онлайн-досліджень прикордонних територій єврорегіону, результатом яких буде максимальний охват потенційних споживачів (це актуально, як для малого, так і середнього й великого бізнесу), онлайн-дані про доступність відповідних ресурсів (природних, інфраструктурних, фінансових, трудових);

- прийняття найоптимальніших оперативних менеджерських рішень щодо ведення бізнесу в сучасних ринкових умовах господарювання на основі своєчасних даних як внутрішніх регіонів країни, так і міжнародних (у межах єврорегіону);

- онлайн-аналітика ринку для пошуку потенційних партнерів по бізнесу, постачальників ресурсів, логістичних компаній щодо доставки в потрібне місце та потрібний час за оптимальною ціною, а також виявлення конкурентів (для того щоб знати, чи виходити на цей ринок, чи це невигідно); 
- володіння нормативно-правовою базою прикордонних країн щодо ведення бізнесу на їхньому ринку;

- інвестиційна презентабельність для транскордонних та міжнародних інвесторів;

- на основі різноманітних учасників - суб'єктів ТКС легше вирішувати будь-які питання (на основі об'єднання думок через онлайн-форуми, онлайнголосування, Інтернет-конфернеції суб’єктів господарювання, органів влади, громадських організацій, наукових установ);

2. для органів влади:

- на основі володіння різноманітною об’єктивною інформацією про всі процеси транскордонного співробітництва складатимуть ефективні програми розвитку територій, їх міжнародної економічної інтеграції;

- надасть конкретні рекомендаційні запити (від бізнес-спільноти, наукових установ) щодо створення сприятливих умов для ведення вітчизняного за закордонного бізнесу;

- на основі аналітики ринку в режимі реального часу визначатиметься, які субсидії, податкові пільги чи кредити необхідні для конкретних представників бізнесу та їх моніторинг ведення діяльності;

- надасть реальні результати та принципи роботи кращих практик (у межах єврорегіону) щодо управління територією (селом, містом, районом, регіоном);

- якщо раніше органи влади в ТКС займали переважно позицію щодо інформаційного забезпечення (яке, на превеликий жаль, існувало в незадовільному стані, оскільки на сайтах місцевих та регіональних органів влади конкретну інформацію з ТКС не було висвітлено, а конференції чи різноманітні засідання в інформаційному полі носили тільки оглядовий характер), то тепер, оскільки це втратило для них актуальність, а інтерактивний транскордонний бізнес-центр надаватиме різноманітну інформацію в усіх сферах життя, органи влади зможуть зорієнтувати свою увагу на вирішенні реальних та нагальних проблем: дорожньої інфраструктури, екологічної безпеки, прикордонних пунктів перетину тощо;

3. для громадських організацій регіонального розвитку:

- краща практика власного представлення результатів у сфері проектного менеджменту та вивчення закордонних транскордонних аналогів;

- спрощений онлайн-пошук партнерів у транскордонному середовищі;

- налагоджена співпраця у віртуальному режимі 3 різноманітними підприємницькими структурами єврорегіону, органами влади, науковими установами щодо допомоги у написанні проектів, самостійного написання проектів та їх продаж зацікавленим суб’єктам - учасникам ТКС;

- виставлення на тендер в ІТКБЦ проектів щодо залучення виконавців, які втілять його в життя за найменшою ціною;

- допомога у вирішенні різноманітних територіальних питань, які $\epsilon$ нагальними, залежно від специфіки громадських організацій (оскільки органи влади не в змозі охопити вирішення всіх проблемних питань через брак часу, ресурсів та подекуди й повноважень) за рахунок сучасних різноманітних програм міжнародної технічної допомоги чи інших ресурсів, 
які представлені в інтерактивному транскордонному бізнес-центрі потенційним описом кожного залежно від призначення;

4. для наукових установ, вищих навчальних закладів:

- представлення на міжнародному ринку наукових установ, підприємств, владних структур єврорегіону;

- дає змогу легше укладати різноманітні угоди з установами, близькими за напрямами досліджень;

- дає змогу бачити реальні процеси розвитку ТКС за допомогою інформаційно-комунікаційних технологій (аналітичного огляду ринку, проектів регіонального розвитку ТКС і т. д.) та проводити відповідні наукові дослідження 3 різних напрямів та виявлення проблем, недоліків чи інноваційних шляхів рішення для будь-яких суб'єктів - учасників ІТКБЦ;

- брати участь в онлайн-форумах ІТКБЦ, де задіяні всі учасники суб'єкти ТКС, та можливість висвітлення власної науково обгрунтованої фахової думки з того чи іншого проблемного питання;

- здійснювати мобільність студентів із країнами-сусідами в межах єврорегіону, пряма трансляція онлайн-курсів із заочним навчанням та отриманням подвійного диплому.

Однак щоб інтерактивний транскордонний маркетинг як новітня концепція розвитку ТКС функціонував на належному рівні, необхідним атрибутом постає дотримання відповідних принципів, серед яких:

- вірність та надійність вхідної та вихідної інформації;

- доречна та придатна для використання;

- доступність до даних та повнота їх відображення;

- обов’язкова участь у наповнюванні їі всіма суб'єктами - учасниками $\mathrm{TKC}$;

- під час збору відповідних даних ІТКБЦ постійно узгоджувати іiі 3 власниками носіїв інформації;

- захист від несанкціонованого доступу до інформації суб'єктів учасників ТКС для тих, хто не $є$ такими учасниками (крім тих, які $\epsilon$ учасниками інших єврорегіонів). Причина полягає у тому, що в межах даного єврорегіону учасники - суб'єкти ТКС, які використовують певні дані i представлятимуть власні, тому в такому разі інформаційна прозорість між ними всіма виявляється нормальною здоровою конкуренцією. Проте якщо користувач, який не буде входити до даної структури ІТКБЦ і взагалі не $\epsilon$ учасником будь-якого єврорегіонального об'єднання (який функціонуватиме на принципах побудови ІТКБЦ подібного до нашого), тобто не надаватиме певну інформацію про свою діяльність та інші обов'язкові інформаційні компоненти, а користуватиметься на рівні 3 тими, які $є$ такими учасниками, це буде несправедливо і недобросовісно.

Висновок. Узагальнюючи ідею застосування концепції інтерактивного транскордонного маркетингу, слід указати, що основна мета останнього підвищити ефективність суб'єктів - учасників транскордонного співробітництва на основі використання сучасних засобів інформаційнокомунікаційних технологій, які в режимі реального часу на віртуальній основі, здійснюючи постійний моніторинг, аналіз, прогноз усіх систем, сфер, які 
стосуються транскордонного співробітництва, дадуть змогу виявляти приховані закономірності розвитку економіки на рівні бізнесу, потенційні можливості соціального благополуччя громад та найкращі напрями розвитку інтеграції України до СС.

\section{Список використаних джерел:}

1. Чучка I.M., Студеняк І.П. Інтерактивний маркетинг : [навч. посіб.] / I.М. Чучка, І.П. Студеняк. - К. : Кондор, 2009. - 122 с.

2. Топчієв О.Г. Суспільно-географічні дослідження: методологія, методи, методики : [навч. посіб.] / О.Г. Топчієв. - Одеса : Астропринт, 2005. - 632 с.

3. Дейнека O.I. Система інформаційно-аналітичного забезпечення «Маркетинг регіону»основне джерело інформації про регіон / O.І. Дейнека // Соціально-економічні дослідження в перехідний період. Міжрегіональне співробітництво: стан та перспективи ; НАН України. Ін-т регіональних досліджень / Відп. ред. С.І. Бойко. - Львів, 2007. - Вип. 4(66) - С. 129-139.

4. Цифровий маркетинг - модель маркетингу XXI сторіччя : [монографія] / М.А. Окландер, Т.О. Окландер, О.І. Яшкіна [та ін.] ; за ред. д. е. н., проф. М.А. Окландера. Одеса : Астропринт, 2017. - 292 с.

5. Что такое онлайн-панели [Електронний ресурс]. - Режим доступу : https://spark.ru/ startup/anketolog/blog/18735/chto-takoe-onlajn-paneli.

6. Международный кодекс ICC/ESOMAR [Електронний ресурс]. - Режим доступу : https://www.esomar.org/uploads/public/knowledge-and-standards/codes-and-

guidelines/ICCESOMAR_Code_Russian_.pdf

7. ESOMAR / Вікіпедія [Електронний ресурс]. - Режим доступу : https://uk.wikipedia.org/ wiki/ESOMAR.

8. Литовченко І.Л. Інтернет-маркетинг : [навч. посіб.] / І.Л. Литовченко. - К. : Центр учбової літератури, 2011. - 332 с.

9. Веб-форум [Електронний ресурс]. - Режим доступу : https://uk.wikipedia.org/wiki/ \%D0\%92\%D0\%B5\%D0\%B1-\%D1\%84\%D0\%BE\%D1\%80\%D1\%83\%D0\%BC

10. Інтернет-конференція [Електронний ресурс]. - Режим доступу : https://ru.wikipedia.org/wiki/Интернет-конференция 
Грубінка I.I.

кандидат економічних наук, викладач Відокремленого підрозділу Національного університету біоресурсів і природокористування України «Мукачівський аграрний коледж»

Верзун А.A. кандидат економічних наук, дочент, дочент кафедри фінансів і кредиту Львівського національного аграрного університету

\section{ВИШЕГРАДСЬКА ЧЕТВІРКА Й УКРАЇНА: СТАН РОЗВИТКУ ЕКОНОМІЧНОЇ СИСТЕМИ І ДЕРЖАВНОЇ ПІДТРИМКИ СІЛЬСЬКОГО ГОСПОДАРСТВА}

Анотація. У статті визначено важливість співробітництва України і країн Вишеградської четвірки. Наведено показники макроекономічного розвитку досліджуваних країн. Здійснено порівняння ВВП, ВВП на душу населення, інфляції, проаналізовано такі галузеві показники, як площа сільськогосподарських угідь, додана вартість у сільському господарстві, внесення добрив на одинищю площі угідь. Показано причини економічного відставання Украӥни від країн Вишеградської групи, зокрема недостатність ринкових перетворень. Проаналізовано досвід і методи державної підтримки сільського господарства країн Вишеградської четвірки як однієї з найважливіших галузей економіки Украӥни. Вказано роль ЄС у підтримиі розвитку сільського господарства, зокрема фермерства держав Вишеградської групи. Зроблено висновки стосовно можливості й важллвості застосування досвіду країн Вишеградськоӥ четвірки щьодо підтримки сільськогосподарських товаровиробників в Украӥні.

Вступ. Одним із базисів розвитку ринкових відносин $є$ постійний обмін досвідом і співробітництво між країнами, що досягли успіхів у такій розбудові, і країнами, які прагнуть повторити їхній шлях, особливо актуально це тоді, коли такі країни пов'язує спільний історичний розвиток. Для України, безумовно, таке співробітництво особливо актуальне з країнами Вишеградської групи як колишніми членами соціалістичного табору, які (деякі більшою мірою, деякі - меншою) змогли побудувати ефективну ринкову економіку i, таким чином, забезпечити поступальний економічний розвиток і зайняти своє місце в міжнародному поділі праці.

Вважаємо, що одним з основних факторів такого розвитку була інтеграція названих країн до Європейського Союзу, яка дала їм змогу перейняти досвід ринкової розбудови від ефективних і успішних економік Великобританії, Німеччини, Франції та інших країн. Водночас вона відкрила доступ до фондів $€ C$, які нині $\epsilon$ одними 3 головних донорів розвитку цілих галузей країн Вишеградської четвірки.

Проаналізувавши макрофінансові показники економік країн, можна зробити певні висновки щодо їх стану та тенденцій розвитку, а головне - здійснити їх порівняльний аналіз. Кожна країна має свої конкурентні переваги на світовому 
ринку, ці переваги формують спеціалізацію країни та їі головні галузі. Звісно, у сучасному високотехнологічному виробництві лише їх розвиток не може забезпечити повноцінного економічного росту. Проте перейняття досвіду їх розбудови для країн, що прагнуть інтегруватися в $\mathrm{CC}$, зокрема України, $\epsilon$ надзвичайно важливим.

Однією 3 головних і перспективних 3 огляду на світові тенденції галузей економіки України є сільське господарство. Однак за всіх об’єктивних переваг в Україні воно не досягло бажаного ступеня розвитку, в тому числі через недосконалі механізми підтримки з боку держави, тому вивчення здійснення такої підтримки в країнах Вишеградської групи є одним із важливих аспектів співробітництва між нашими країнами в процесі інтеграції України до Європейського Співтовариства.

\section{1. Порівняння економічного розвитку та аграрного виробництва країн Вишеградської четвірки та України}

Розвиток кожної країни визначається через призму багатьох показників, зокрема й макроекономічних, що характеризують загальний стан $\mathrm{i}$ тенденції розвитку економічної системи, дають змогу здійснити порівняльну характеристику економіки різних країн. До таких показників належать, зокрема, ВВП, інфляція, ВВП на душу населення, прямі іноземні інвестиції, частка доданої вартості та ін. У своєму аналізі ми будемо спиратися на методику розрахунку і дані Світового банку як однієї з найавторитетніших світових фінансових установ.

Порівняння показників ВВП, наведених у табл. 1, дає можливість визначити рівень розвитку економіки кожної з країн.

Таблиця 1

ВВП країн Вишеградської четвірки та України в цінах 2010 р., млрд. дол.

\begin{tabular}{|l|c|c|c|c|c|c|}
\hline \multicolumn{1}{|c|}{ Показник } & 2011 p. & 2012 p. & 2013 p. & 2014 p. & 2015 p. & 2016 p. \\
\hline Чехія & 211,2 & 209,5 & 208,5 & 214,1 & 223,8 & 229,3 \\
\hline Угорщина & 132,5 & 130,4 & 133,2 & 138,5 & 142,9 & 145,7 \\
\hline Польща & 503,4 & 511,5 & 518,6 & 535,6 & 556,2 & 571,1 \\
\hline Словаччина & 92,1 & 93,5 & 94,9 & 97,4 & 101,1 & 104,4 \\
\hline Україна & 143,4 & 143,8 & 143,8 & 134,3 & 121,2 & 124,0 \\
\hline
\end{tabular}

Джерело: складено за [10]

3 табл. 1 видно, найбільший обсяг ВВП за останні п'ять років із країн Вишеградської четвірки був у Польщі - 571,1млрд. дол., за нею розташувалися Чехія, Угорщина та Словаччина. Україна за розміром ВВП переважає Словаччину, однак поступається іншим. Проте за кількістю населення, площею, обсягом природних багатств Україна має найбільший потенціал, який, однак, ефективно не використовується (Словаччина має територію у шість разів менше за Україну і населення у 8,5 рази менше). Це вказує на явні недоліки саме в побудові економічної системи, яка не дозволяє таке ефективне використання. 
Якщо брати до уваги головний якісний показник розвитку економіки - ВВП на душу населення, то він дає змогу краще оцінити ефективність економіки 3 огляду на іï ресурсний потенціал, зокрема трудовий (табл. 2).

Таблиця 2

\section{Порівняння ВВП на душу населення країн Вишеградської четвірки} та України в цінах 2010 р., дол.

\begin{tabular}{|l|c|c|c|c|c|c|}
\hline \multicolumn{1}{|c|}{ Показник } & $2011 \mathrm{p}$. & $2012 \mathrm{p}$. & $2013 \mathrm{p}$. & $2014 \mathrm{p}$. & $2015 \mathrm{p}$. & $2016 \mathrm{p}$. \\
\hline Чехія & 20,118 & 19,929 & 19,826 & 20,343 & 21,224 & 21,707 \\
\hline Угорщина & 13,289 & 13,144 & 13,459 & 14,042 & 14,518 & 14,840 \\
\hline Польща & 13,224 & 13,437 & 13,632 & 14,090 & 14,641 & 15,049 \\
\hline Словаччина & 17,046 & 17,299 & 17,538 & 17,972 & 18,642 & 19,237 \\
\hline Україна & 3,138 & 3,153 & 3,160 & 3,123 & 2,828 & 2,905 \\
\hline
\end{tabular}

Джерело: складено за [10]

Iз табл. 2, видно, що наша країна значно відстає від показників країн Вишеградської четвірки. Найбільш ефективно функціонує економіка Чехії, де станом на 2016 р. ВВП на душу населення - 21707 дол., що в 11 разів перевищує український показник; найменший показник із «вишеградських» країн у Угорщині - 14840 дол. (перевищує український у 6,5 рази!). Це $\epsilon$ наслідком повільної розбудови ринкової економіки в країні; очевидно, курс на повільні перетворення, взятий на початку 90 -х років XX ст., виявився хибним, доповнений популізмом, він майже на 25 років заглибив економічну систему в трансформаційний (перехідний) стан олігархічної спрямованості. Водночас «шокова терапія», проведена в той же період країнами Вишеградської групи, вже за три роки дала результат і заклала підвалини розвитку на основі малого і середнього бізнесу майже в усіх галузях. Водночас довготривалий період перехідної економіки позначився появою фактичних монополістів у всіх галузях вітчизняної економіки. Якщо в промисловості це не мало значних соціально-економічних наслідків, то для сільського господарства, зокрема, соціальні наслідки через обмеженість попиту на робочу силу і складність умов ведення малого бізнесу були досить негативні: масовий виїзд трудових ресурсів, занепад інфраструктури, нераціональне землекористування - лише деякі 3 них. Господарювання на сільських територіях здійснюється 3 огляду лише на комерційну вигоду людьми, які не мають жодного відношення до них. Досвід країн Вишеградської групи вказує, що одним із головних шляхів розв'язання цієї проблеми є розвиток фермерства як альтернативи великому бізнесу, однак він зараз без фінансової підтримки $є$ утрудненим; країни «Вишеграду» мають тут значну превагу, оскільки можуть розраховувати, крім своїх локальних фондів, на фонди ЄС. Ще одним, вже організаційним недоліком побудови ефективної економіки в Україні $\epsilon$ незахищеність прав власності в аграрному виробництві, сюди слід додати також і невизначеність, що в умовах значних корупційних ризиків стає значним демотиватором розвитку економіки.

Якщо брати до уваги економічні чинники стану та розвитку, то важливим із погляду забезпечення сталості ведення бізнесу є рівень інфляції, оскільки він 
визначає стабільність цінового механізму ринку і, відповідно, прогнозованість розвитку ринку.

Таблиця 3

Рівень інфляції країн Вишеградської четвірки та України,\%

\begin{tabular}{|l|c|c|c|c|c|c|}
\hline \multicolumn{1}{|c|}{ Показник } & $2011 \mathrm{p}$. & $2012 \mathrm{p}$. & $2013 \mathrm{p}$. & $2014 \mathrm{p}$. & $2015 \mathrm{p}$. & $2016 \mathrm{p}$. \\
\hline Чехія & 0 & 1,5 & 1,4 & 2,5 & 1 & 1,1 \\
\hline Угорщина & 2,2 & 3,4 & 2,9 & 3,4 & 1,7 & 1 \\
\hline Польща & 3,2 & 2,3 & 0,3 & 0,5 & 0,8 & 0,2 \\
\hline Словаччина & 1,6 & 1,3 & 0,5 & $-0,2$ & $-0,2$ & $-0,4$ \\
\hline Україна & 14,2 & 7,8 & 4,3 & 15,9 & 38,9 & 17,1 \\
\hline
\end{tabular}

Джерело: складено за [10]

Слід відзначити, що, згідно 3 рекомендаціями провідних міжнародних фінансових установ, рівень інфляції не повинен перевищувати 2-3\%, тоді вона буде виконувати навіть певний стимуляційний ефект. Дані таблиці вказують на дотримання цих норм державами Вишеградської групи. У Словаччині, наприклад, останні три роки спостерігалася навіть дефляція. Водночас в Україні рівень інфляції завжди перевищував рекомендований показник, а на протязі останніх трьох років набрав високих значень (особливо 2015 р.). Цьому сприяла низка причин, основна 3 них - падіння курсу національної грошової одиниці в умовах імпортнозалежної економіки, особливо в побутовому споживанні й енергетичній сфері. Ми вважаємо, що така девальвація була об'єктивною необхідністю, однак її проведення потрібно було зробити більш довготривалим, доведення курсу до рівня ринкового, без потреби в постійних інтервенціях із валютних резервів - одна 3 основ незалежності й стійкості економічної системи, водночас і стимул до росту вітчизняного виробництва та здійснення інвестицій, а отже, зростання ВВП. Щодо показника прямих іноземних інвестицій, то він прямо показує на обгрунтованість таких висновків і наведений у табл. 4.

Таблиця 4

Показник прямих іноземних інвестицій в економіку, млн. дол.

\begin{tabular}{|l|c|c|c|c|c|c|}
\hline \multicolumn{1}{|c|}{ Показник } & $2011 \mathrm{p}$. & $2012 \mathrm{p}$. & $2013 \mathrm{p}$. & $2014 \mathrm{p}$. & $2015 \mathrm{p}$. & $2016 \mathrm{p}$. \\
\hline Чехія & 2,592 & 6,180 & 379 & 4,014 & 2,026 & 5,845 \\
\hline Угорщина & 1,859 & 2,764 & 151 & 3,676 & 2,598 & 3,753 \\
\hline Польща & 13,670 & 6,031 & 4,206 & 12,977 & 9,815 & 4,999 \\
\hline Словаччина & 2,731 & 3,009 & 272 & 642 & 6,431 & 567 \\
\hline Україна & 7,015 & 7,195 & 4,079 & 299 & 3,012 & $\ldots$ \\
\hline
\end{tabular}

Джерело: складено за [10]

Як видно з таблиці, найвищий рівень інвестицій спостерігався у Польщі. Слід зазначити, що відображені тут переважно приватні інвестиції, без урахування фондів ЄС. Якщо брати до уваги і порівняти територіальний, ресурсний, людський потенціал України, то рівень прямих іноземних інвестицій є не відповідним 3 об’єктивних політично-економічних причин, він значно 
зменшився у 2014 р., однак уже у наступному році показав високе зростання, яке, зважаючи на політичну стабілізацію й економічну перебудову, i надалі продовжить збільшуватися. Проблемними питаннями інвестиційної привабливості країни й далі залишаються високі корупційні ризики (особливо в судовій і правоохоронній системах) і складна податкова система, що породжує непрозорість у тлумаченні їі положень.

Кожна країна в міжнародному поділі праці займає своє місце, його визначають 3 огляду на структуру ВВП, це місце зумовлюється природними перевагами, рівнем науково-технічного розвитку, економічною політикою уряду та низкою інших чинників. Якщо брати до уваги чинник природних переваг, то провідна для нас галузь - сільське господарство, однак сучасна економічна система характеризується визначальною роллю науково-технічного чинника. Саме галузі 3 наукоємним виробництвом мають високий рівень доданої вартості. Не розвиваючи переробку і виробництво кінцевої, готової до споживання продукції, країна навіть із природними перевагами буде значним імпортером продукції, у тому числі й тієї, що виготовлена із її сировини.

Таблиця 5

Частка аграрної продукції в імпорті країни, \%

\begin{tabular}{|l|c|c|c|c|c|c|}
\hline \multicolumn{1}{|c|}{ Показник } & $2011 \mathrm{p}$. & $2012 \mathrm{p}$. & $2013 \mathrm{p}$. & $2014 \mathrm{p}$. & $2015 \mathrm{p}$. & $2016 \mathrm{p}$. \\
\hline Чехія & 5,6 & 6 & 6,3 & 6 & 6,1 & 6,2 \\
\hline Угорщина & 5,1 & 5 & 5,2 & 5,2 &.. & 5,4 \\
\hline Польща & 7,8 & 8,3 & 8,6 & 8,4 & 8,5 & 8,9 \\
\hline Словаччина & 6,4 & 6,5 & 6,2 & 6 & 5,7 & 5,9 \\
\hline Україна & 7,4 & 8,6 & 10,3 & 10,8 & 9 &.. \\
\hline
\end{tabular}

Джерело: складено за [10]

Табл. 4 підтверджує цю тезу. Порівняно з країнами Вишеградської групи Україна в силу природних переваг має значно більшу частку аграрної продукції у ВВП - майже $20 \%$. Однак при цьому в неї найбільша частка аграрної продукції в імпорті країни; наші сільськогосподарські товаровиробники, особливо фермери, повинні забезпечити не тільки вирощування, а й переробку своєї продукції, це потребує значного інвестиційного ресурсу, який, з огляду на досвід наших сусідів 3 Європейського Союзу, без сприяння держави самі фермери акумулювати не можуть. Це сприяння стосується не тільки прямої підтримки, а й програм підтримки з боку фінансово-кредитної системи.

Нестача такого фінансового ресурсу призводить не тільки до неможливості переробки виготовленої продукції, а й до неефективного використання ресурсів виробництва або неможливості відновлення їх якісних характеристик. Зокрема, це стосується і головного ресурсу аграрного виробництва - сільськогосподарських угідь. Для підтримки високої врожайності і забезпечення інтенсивного розвитку галузі необхідно забезпечити внесення добрив.

Дані табл. 6 показують, що за наведеним показником Україна значно відстає від країн «Вишеграду». Це $\epsilon$ наслідком проблем із наявністю фінансових ресурсів, тобто їх не вистачає на формування відповідної кількості оборотних засобів, із чого можемо зробити висновок про нестачу фінансування реальних інвестицій, оскільки першочергово фінансуються оборотні засоби. 
Внесення добрив на 1 га сільськогосподарських угідь, кг*

\begin{tabular}{|l|c|c|c|c|c|c|}
\hline \multicolumn{1}{|c|}{ Показник } & $2011 \mathrm{p}$. & $2012 \mathrm{p}$. & $2013 \mathrm{p}$. & $2014 \mathrm{p}$. & $2015 \mathrm{p}$. & $2016 \mathrm{p}$. \\
\hline Чехія & 100,6 & 127,7 & 128,3 & 128,8 & $\ldots$ & $\ldots$ \\
\hline Угорщина & 93,3 & 97,1 & 109,4 & 99,1 & $\ldots$ & $\ldots$ \\
\hline Польща & 169,7 & 177,9 & 179,3 & 231,6 & $\ldots$ & $\ldots$ \\
\hline Словаччина & 95,9 & 106,9 & 113,6 & 124,2 & $\ldots$ & $\ldots$ \\
\hline Україна & 38,9 & 41,3 & 45,8 & 45,2 & $\ldots$ & $\ldots$ \\
\hline
\end{tabular}

Джерело: складено за [10]

Таблиця 7

Додана вартість сільськогосподарської продукції, \%

\begin{tabular}{|l|c|c|c|c|c|c|}
\hline Показник & $2011 \mathrm{p}$. & $2012 \mathrm{p}$. & $2013 \mathrm{p}$. & $2014 \mathrm{p}$. & $2015 \mathrm{p}$. & $2016 \mathrm{p}$. \\
\hline Чехія & 2,4 & 2,6 & 2,7 & 2,7 & 2,5 & 2,5 \\
\hline Угорщина & 4,6 & 4,6 & 4,6 & 4,7 & 4,1 & 4,5 \\
\hline Польща & 3,2 & 3 & 3,2 & 2,9 & 2,5 & 2,4 \\
\hline Словаччина & 3,4 & 3,5 & 4 & 4,4 & 3,7 & 3,8 \\
\hline Україна & 9,5 & 9,1 & 10 & 11,7 & 14,2 & 13,7 \\
\hline
\end{tabular}

Джерело: складено за [10]

Як бачимо, попри всю проблематику в діяльності сільськогосподарські товаровиробники, зокрема й фермерські господарства, демонструють досить високий рівень доданої вартості, використовуючи природні переваги, не маючи достатнього фінансового ресурсу. Тобто діяльність у галузі $\epsilon$ досить прибутковою, однак, зважаючи на показники попередніх таблиць, до досягнення максимальної ефективності ще далеко, без розроблення відповідних фінансових інструментів і механізмів це не буде досягнуто.

Порівняно з досліджуваними країнами Україна має значні природні переваги, вони проявляються передусім у масштабності й якості сільськогосподарських угідь.

Таблиця 8

Площа сільськогосподарських угідь, кв. км

\begin{tabular}{|l|c|c|c|c|c|c|}
\hline \multicolumn{1}{|c|}{ Показник } & $2011 \mathrm{p}$. & $2012 \mathrm{p}$. & $2013 \mathrm{p}$. & $2014 \mathrm{p}$. & $2015 \mathrm{p}$. & $2016 \mathrm{p}$. \\
\hline Чехія & $42,290.0$ & $42,250.0$ & $42,190.0$ & $42,160.0$ & $\ldots$ & $\ldots$ \\
\hline Угорщина & $53,370.0$ & $53,380.0$ & $53,400.0$ & $53,460.0$ & $\ldots$ & $\ldots$ \\
\hline Польща & $147,790.0$ & $145,290.0$ & $144,100.0$ & $144,240.0$ & $\ldots$ & $\ldots$ \\
\hline Словаччина & $19,297.0$ & $19,274.0$ & $19,285.0$ & $19,246.0$ & $\ldots$ & $\ldots$ \\
\hline Україна & $412,810.0$ & $412,970.0$ & $412,750.0$ & $412,720.0$ & $\ldots$ & $\ldots$ \\
\hline
\end{tabular}

Джерело: складено за [10]

Загальна площа сільськогосподарських угідь України перевищує сумарну площу угідь Вишеградської групи на 64\%, більше третини цих угідь є високої якості - чорноземи, це наші природні конкурентні переваги, основні чинники високого рівня доданої вартості. За умов додаткового фінансового 
стимулювання для можливості переробки своєї продукції і поліпшення її якості для відповідності стандартам ЄС ці конкурентні переваги можуть демонструвати кращі показники рентабельності.

Порівняння експортно-імпортних операцій в аграрній сфері підтверджує вже названу нами тезу про важливість розвитку переробки. Під час порівняльного аналізу зовнішньоторговельних операцій 3 аграрною продукцією України i Польщі позитивне сальдо польської сторони за 2015 р. становило майже 160 млн. дол. Хороший досвід отриманий країнами Вишеграду, особливо Польщі: під час вступу до ЄС їм довелося адаптувати аграрне виробництво до його стандартів. Ця адаптація позитивно вплинула на функціонування галузі. За 10 років такого функціонування аграрний експорт Польщі зріс у чотири рази, прибутки сільськогосподарських товаровиробників зросли в 1,5 рази. При цьому в аграрне виробництво активно залучається молодь: $40 \%$ польських фермерів $є$ віком менше 44 років. Середній показник по $\mathrm{CC}-20 \%$. Допомога 3 боку СС у цьому розвитку є значною. Згідно із затвердженою Свропейською Комісією програмою, протягом 2014-2020 рр. Польща отримає 13,5 млрд. євро на розвиток сільських територій. Більше третини цієї допомоги отримають 200 тис. польських фермерів на поліпшення їх конкурентоспроможності й упровадження екологічних технологій у виробництво [9].

Стратегія розвитку аграрного виробництва в країнах $С С$ передбачає розвиток сільських територій. Загальнозрозумілим $\epsilon$ те, що цей розвиток можливий лише на основі розвитку власне фермерства, оскільки саме ці виробники сільськогосподарської продукції проживають на тих територіях, де здійснюють своє виробництво й є найбільш зацікавлені в такому розвитку на відміну від агрохолдингів, які в кут питання ставлять отримання фінансових вигод. Зважаючи на масштабність галузі в Україні і стан розвитку сільських територій, розвиток фермерських господарств потребує не тільки створення відповідних умов, а й значного фінансового ресурсу.

Сучасний економічний розвиток України порівняно з країнами Вишеградської групи є незадовільним, це пов'язано передусім із повільними ринковими трансформаціями. Країна має значний ресурсний потенціал, особливо це стосується сільського господарства, однак не створено відповідні ринкові умови для його розвитку через незахищеність і непрозорість прав власності, високий корупційний ризик, відсутність ринку сільськогосподарської землі та ін. Недостатньо напрацьовані механізми фінансової підтримки аграрних товаровиробників, зокрема фермерських господарств, що пов'язано передусім iз нестачею фінансових ресурсів. Отже, дуже важливими є їх підтримка, як вітчизняна, так і закордонна, та перейняття позитивного іноземного досвіду від наших сусідів із країн Європейського Союзу.

\section{2. Європейський досвід фінансової підтримки розвитку сільського господарства і сільських територій}

У більшості країн світу діяльність сільськогосподарських товаровиробників базується на відповідній фінансовій підтримці, дотуванні.

O.C. Гудзь зазначає, що державна підтримка аграрного сектору економіки як основний механізм реалізації державної аграрної політики $\epsilon$ свідомим створенням сприятливих економічних, правових, організаційних та інших умов 
розвитку сільськогосподарського виробництва, забезпеченого матеріальними та фінансовими ресурсами [1, с. 60].

Фінансова підтримка розвитку агропромислового комплексу може здійснюватися за такими основними формами, як пряма та непряма.

На державному рівні форма прямої бюджетної підтримки передбачає надання субсидій на сільськогосподарське виробництво і матеріально-технічні ресурси; субсидування короткострокового та інвестиційного кредитування підприємств та організацій АПК; надання субсидій на компенсацію частини витрат товаровиробників на страхування врожаю сільськогосподарських культур; субсидії на витрати капітального характеру, лізинг та ін.

Форма непрямої бюджетної підтримки полягає у здійсненні закупівель сільгосппродукції і продовольства для державних потреб; регулюванні виробничого ринку за допомогою проведення закупівельних i товарних інтервенцій із зерном; захисту економічних інтересів товаровиробників під час здійснення зовнішньоекономічної діяльності у сфері АПК та ін. До цієї форми можна віднести підтримку аграрної науки, розвиток соціальної сфери та сільських територій тощо [7].

32017 р. в Україні фінансова підтримка агропромислового комплексу здійснюється значною мірою за рахунок прямого бюджетного фінансування. 3 непрямих форм державної фінансової підтримки у 2017 р. залишилися: спрощена система оподаткування сільськогосподарських товаровиробників, яка грунтується на грошовій оцінці сільськогосподарських угідь, фінансування програм, спрямованих на інформаційне, освітнє забезпечення діяльності аграрних товаровиробників, науково-технічний розвиток галузі тощо.

Серед непрямих форм державної фінансової підтримки до 2017 р. вагоме місце належало спеціальному режиму справляння податку на додану вартість у сільському господарстві. Даний режим оподаткування дозволяв суму ПДВ, що нарахована сільськогосподарським підприємством на вартість поставлених ним сільськогосподарських товарів (послуг), не сплачувати до бюджету та повністю залишати для відшкодування сплаченої (нарахованої) постачальнику суми ПДВ на вартість виробничих факторів, а за наявності залишку такої суми податку для інших виробничих цілей.

У структурі обсягу державної фінансової підтримки непрямі форми становили близько $80 \%$.

У 2017 р. скасовано спеціальний режим справляння ПДВ у сільському господарстві та замінено дану форму непрямої фінансової підтримки на пряме бюджетне фінансування. У державному бюджеті України на 2017 р. на ці цілі передбачено близько 5,5 млрд. грн., 3 яких безпосередньо на фінансову підтримку сільгосптоваровиробників - 4,8 млрд. грн., у тому числі за рахунок коштів загального фонду бюджету - 1,5 млрд. грн. та 3,3 млрд. грн. - за рахунок коштів спеціального фонду бюджету [5].

Такий формат державної фінансової підтримки є більш наближеним до європейської моделі, ніж той, який реалізовувався в Україні до 2017 p. Асоціація з СС, євроінтеграційні прагнення зумовлюють необхідність адаптації діючих механізмів державної фінансової підтримки вітчизняного сільського господарства до європейських стандартів.

Для ефективного переходу на європейську модель державної фінансової підтримки аграрних товаровиробників та розвитку сільських територій 
доцільно вивчити досвід країн, які набули статусу членів СС та наближені до України географічно, а також історично.

Серед таких країн чільне місце належать країнам Вишеградської четвірки Польщі, Угорщині, Словаччині та Чехії, серед яких три перші мають спільний кордон з Україною, а за останнє століття історично поєднані, зокрема, відношенням до так званого соціалістичного табору.

Ці країни успішно пройшли період перебудови економіки та переведення іiі на ринкові рейки, адаптації національного законодавства до вимог $\epsilon \mathrm{C}$, забезпечили подолання корупції тощо, тобто створили всі передумови для вступу до Свропейського Союзу, повноправними членами якого стали 1 травня $2004 \mathrm{p}$.

Нині державна фінансова підтримка сільського господарства та розвитку сільських територій відбувається з національних бюджетів країн - учасниць СС та за рахунок бюджету Європейського Союзу в рамках реалізації спільної аграрної політики (САП - з англ. Common Agricultural Policy).

Починаючи з 2014 р. САП зазнала змін, основний зміст яких передбачає:

1. Цільовий розподіл грошових субсидій для забезпечення дохідності сільськогосподарського виробництва, орієнтованої на стимулювання економічного зростання і збільшення зайнятості у селі.

2. Ефективніші i гнучкіші інструменти кризового менеджменту для розв'язання нових економічних проблем.

3. Екологізація для досягнення довготривалої продуктивності і збереження екосистем.

4. Додаткове інвестування у наукові дослідження та інноваційні розробки.

5. Створення конкурентоспроможного і збалансованого ринкового ланцюга забезпечення продуктами харчування від виробника до споживача.

6. Стимулювання заходів щодо захисту навколишнього середовища у сільському господарстві.

7. Полегшення відкриття для фермерів-початківців власного сільгосппідприємства.

8. Стимулювання зайнятості і підприємництва у сільських регіонах.

9. Уважніше врахування інтересів структурно слабких регіонів.

10. Проста й ефективна Спільна аграрна політика (спрощення деяких механізмів без утрати їх ефективності) [4, с. 90].

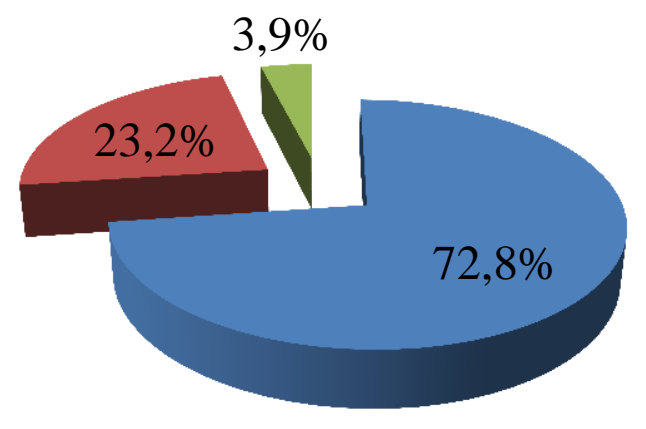

п прямі виплати та маркетингові витрати

- розвиток сільських регіонів

- інші програми фінансування

Рис. 1. Структура бюджету САП СС на 2014-2020 pp. [2] 
Частина цих змін набула чинності з 01.01.2015, перебачивши, таким чином, перехідний період для адаптації надавачів та отримувачів субсидій до нових законодавчих вимог.

На реалізацію САП протягом 2014-2020 pp. Європейською Комісією передбачено 386,9 млрд. євро [2].

Левову частку бюджету САП - 72,8\% передбачено на прямі виплати товаровиробникам та фінансування маркетингових заходів. У цілому на ці потреби планується витратити за вказаний період 281,8 млрд. євро. 89,9 млрд. євро, або 23,2\% бюджету САП, протягом 2014-2020 pр. буде спрямовано на фінансування розвитку сільських регіонів.

3,9\% бюджету САП передбачено на фінансування інших програм розвитку, зокрема:

- продовольча безпека - 2,2 млрд. євро;

- підтримка найбідніших верств населення - 2,5 млрд. євро;

- продовольчі резерви в разі кризи в сільськогосподарському секторі 3,5 млрд. євро;

- європейський фонд глобалізації - до 2,5 млрд. євро;

- наукові дослідження та інновації у сфері продовольчої безпеки, біоекономіки і стійкого розвитку сільського господарства - 4,5 млрд. євро.

Серед країн Вишеградської четвірки Республіка Польща (РП) посідає провідне місце за показниками економічного розвитку, географічно та історично наближена до України. Саме тому досвід Польщі у фінансуванні програм державної підтримки сільського господарства є цікавим для України.

Реалізацію програм із підтримки розвитку сільського господарства, сільських територій покладено на Агенцію реструктуризації та модернізації сільського господарства (Agencja Restrukturyzacji i Modernizacji Rolnictwa - ARiMR). Контроль над діяльністю ARiMR здійснюють Міністерство сільського господарства та розвитку сільських територій і Міністерство фінансів.

Агенція забезпечує виконання заходів, передбачених САП СС, а також фінансування програм підтримки розвитку сільського господарства за рахунок коштів, передбачених у державному бюджеті Польщі.

3 моменту створення Агенції загальний обсяг видатків на розвиток сільського господарства та сільських територій становив 279,4 млрд. злотих, 3 яких 266,9 млрд., тобто 95,5 \% загального обсягу фінансування, надійшло після вступу Польщі до СС (із 2004 р.). Майже третина загальної суми фінансової підтримки, яка надійшла за посередництва ARiMR - 82,8 млрд. злотих припадає на період реалізації реформованої САП СС (табл. 9).

Таблиця 9

\section{Структура підтримки, наданої за посередництва ARiMR, станом на 31.12.2016, млрд. Злотих}

\begin{tabular}{|c|c|c|}
\hline Показник & Сума & Структура, \% \\
\hline Обсяг фінансування у 1994-2016 pp. & 279,4 & 100 \\
\hline Обсяг фінансування у 2004-2016 pp. & 266,9 & 95,5 \\
\hline Обсяг фінансування у 2014-2016 pp. & 82,8 & 29,6 \\
\hline
\end{tabular}

Джерело: складено за [8] 
Починаючи 32010 р. щорічний сумарний обсяг фінансування програм у рамках САП СС перевищує 20 млрд. злотих. Максимальна сума фінансування припадає на 2015 р. - 29,8 млрд. злотих.

Цікавим для України $є$ досвід прямого фінансування розвитку галузі за відповідними напрямами, суть якого полягає у виділенні коштів у розрахунку на гектар сільськогосподарських угідь, одиницю поголів'я сільськогосподарських тварин або кг виробленої продукції (табл. 10).

На відміну від європейських країн в Україні пряма фінансова підтримка у 2017 р. надається товаровиробникам, які здійснюють діяльність за такими напрямами:

- вирощування овочів і баштанних культур, коренеплодів і бульбоплодів, таких як картопля, тощо;

- вирощування зерняткових i кісточкових фруктів, вирощування ягід i їстівних горіхів;

- перероблення молока, виробництво масла, сиру та сметани;

- розведення великої рогатої худоби, коней, свиней, свійської птиці, інших тварин та виробництво м'яса;

- виробництво яєць та яєчних продуктів.

Таблиця 10

Ставки прямих платежів у рамках САП ЄС, 2017 р.

\begin{tabular}{|c|c|c|}
\hline Види виплат & $\begin{array}{c}\text { у національній } \\
\text { валюті РП }\end{array}$ & У євро \\
\hline Одноразова виплата & 461,55 злотих/га & 107,23 євро/га \\
\hline Виплата за зазеленення & 309,77 злотих/га & 71,97 євро/га \\
\hline $\begin{array}{lll}\text { Додаткова виплата (для } & \text { господарств, } \\
\text { які користуються } & \text { одноразовою } \\
\text { виплатою із площею від } 3 \text { до } 30 \text { га) }\end{array}$ & 177,02 злотих/га & 41,13 євро/га \\
\hline Підтримка молодих фермерів & 214,82 злотих/га & 49,91 євро/га \\
\hline \multicolumn{3}{|c|}{ Платежі, пов'язані з виробництвом, у тому числі } \\
\hline BPX & 291,03 злотих/гол. & 67,62 євро/гол. \\
\hline корів & 371,46 злотих/гол. & 86,30 євро/гол. \\
\hline овець & 101,85 злотих/гол. & 23,66 євро/гол. \\
\hline кіз & 60,08 злотих/гол. & 13,96 євро/гол. \\
\hline бобових на зерно площею до 75 га & 606,52 злотих/га & 140,91 євро/га \\
\hline бобових на зерно площею понад 75 га & 303,26 злотих/га & 70,46 євро/га \\
\hline фуражних рослин & 386,46 злотих/га & 89,79 євро/га \\
\hline хмелю & 2198,06 злотих/га & 510,68 євро/га \\
\hline картоплі крохмальної & 163,02 злотих/га & 37,87 євро/га \\
\hline цукрових буряків & 1563,46 злотих/га & 363,24 євро/га \\
\hline помідорів & 1654,3 злотих/га & 384,35 євро/га \\
\hline ягід & 1118,75 злотих/га & 259,92 євро/га \\
\hline льону & 374,86 злотих/га & 87,09 євро/га \\
\hline коноплі волокнистої & 303,06 злотих/га & 70,41 євро/га \\
\hline тютюну (група сортів Вірджинія) & 3,82 злотих/кг & 0,89 євро/кг \\
\hline тютюну (інші сорти) & 2,68 злотих/кг & 0,62 євро/кг \\
\hline
\end{tabular}

Джерело: складено за [8] 
При цьому щомісячний розмір бюджетної дотації товаровиробникам, які займаються птахівництвом, не може перевищувати 50\% виділених асигнувань на бюджетну дотацію у поточному місяці.

Бюджетна дотація виплачується товаровиробникам щомісяця з урахуванням вартості реалізованої продукції пропорційно частці сплаченої до бюджету суми податку на додану вартість (ПДВ) за визначеними видами діяльності в загальній сумі сплати податку на додану вартість за умови, що такі товаровиробники не мають податкового боргу з податку на додану вартість на наступний день після граничного строку сплати такого податку за звітний період, за який надається бюджетна дотація [6].

Таким чином, в Україні виплата прямих бюджетних дотацій не прив'язується до площ сільськогосподарських угідь чи поголів'я тварин, а до обсягу сплаченого ПДВ. Це суттєво ускладнює доступ малим формам господарювання до прямого бюджетного фінансування.

Для прикладу зазначимо, що протягом першого півріччя 2017 р. бюджетні дотації в Україні отримали 1140 товаровиробників на загальну суму 1 914,7 млн. грн., 3 яких 809 млн. - компанії агрохолдингу «Миронівський хлібопродукт», 142 млн. - компанії агрохолдингу «Укрлендфармінг», 33 млн. ТзОВ «Даноша» та 930,7 млн. грн. - інші 1137 товаровиробників [3].

Таким чином, три великі товаровиробники в Україні отримали понад 50\% загального обсягу прямої державної фінансової підтримки. Доцільно зазначити, що в руках даних товаровиробників сконцентровано значні площі сільськогосподарських угідь, задіяних для виробництва сільськогосподарської продукції. На даний час група компаній агрохолдингу «Миронівський хлібопродукт» $є$ землекористувачем 370 тис. га, група компанії агрохолдингу «Укрлендфармінг» - 605 тис. га. [11] При цьому агрохолдинги є землекористувачами не на правах приватної власності, а на правах довготривалої оренди.

На відміну від України в Польщі пряма фінансова підтримка розрахована переважно на малі форми господарювання. За даними ARiMR, станом на кінець вересня відповідного року площа землекористування господарств, які звертаються із заявками на отримання фінансової підтримки, в середньому по країні за останні чотири роки не перевищує 11 га та коливається в межах 10,4810,65 га в розрахунку на одне господарство.

У 2014-2017 рр. найменшою є середня площа господарств, які звертаються із заявками на отримання фінансової підтримки, у Малопольському воєводстві (Województwo mazowieckie) - 3,95-4,04 га, а найбільшою - у Західнопоморському воєводстві (Województwo zachodniopomorskie) - 30,29-30,35 га (табл. 11).

Таблиця 11

Середня площа земель сільськогосподарського призначення господарств, які звернулися із заявками на отримання фінансової підтримки, га

\begin{tabular}{|l|c|c|c|c|}
\hline \multicolumn{1}{|c|}{ Показник } & $2014 \mathrm{p}$. & $2015 \mathrm{p}$. & $2016 \mathrm{p}$. & $2017 \mathrm{p}$. \\
\hline Площа землекористування: & $\mathrm{x}$ & $\mathrm{x}$ & $\mathrm{x}$ & $\mathrm{x}$ \\
\hline $\min$ & 3,95 & 3,98 & 4,02 & 4,04 \\
\hline $\max$ & 30,29 & 30,00 & 30,20 & 30,35 \\
\hline в середньому по країні & 10,48 & 10,49 & 10,56 & 10,65 \\
\hline
\end{tabular}

Джерело: складено за [8] 
У рамках реалізації реформованої САП СC за посередництва ARiMR фактично профінансовано реалізацію різноманітних програм на загальну суму 674, млрд. злотих, тобто 15,9 млрд. євро.

Особливістю видатків 2016 р. за інструментами прямого фінансування було те, що загальна сума платежів становила 21308 млн. злотих, 3 яких 9 919,9 млн. злотих - у рамках видатків 2016 р., 11 369,1 млн. злотих - у рамках.

Особливої уваги заслуговує стаття «інші видатки», яка становить $15,9 \%$ у загальній структурі фінансування. Сюди ми включили видатки, спрямовані на фінансування операційної програми «Рибництво і море» 2014-2020 pp. та фінансування тих видатків, які стосуються реалізації САП СС у 2007-2013 рр.

Таблиця 12

Фактичний обсяг фінансування програм розвитку сільського господарства та сільських територій Польщі в рамках реалізації реформованої САП СС, 2014-2016 pp.

\begin{tabular}{|c|c|c|c|c|c|c|c|c|}
\hline \multirow{2}{*}{ Показник } & \multicolumn{2}{|c|}{2014 p. } & \multicolumn{2}{|c|}{2015 p. } & \multicolumn{2}{|c|}{$2016 \mathrm{p}}$. & \multicolumn{2}{|c|}{\begin{tabular}{|c} 
Разом за \\
2014-2016 pp.
\end{tabular}} \\
\hline & $\begin{array}{l}\text { млрд. } \\
\text { злотих } \\
\end{array}$ & $\begin{array}{l}\text { млрд. } \\
\text { євро }\end{array}$ & $\begin{array}{l}\text { млрд. } \\
\text { злотих }\end{array}$ & $\begin{array}{l}\text { млрд. } \\
\text { євро }\end{array}$ & \begin{tabular}{|c|} 
млрд. \\
Злотих
\end{tabular} & \begin{tabular}{|l|} 
млрд. \\
євро
\end{tabular} & $\begin{array}{l}\text { млрд. } \\
\text { злотих }\end{array}$ & $\begin{array}{c}\text { млрд. } \\
\epsilon в р о \\
\end{array}$ \\
\hline $\begin{array}{l}\text { Загальний обсяг } \\
\text { фінансування, } 3 \text { них: }\end{array}$ & 26,4 & 6,3 & 15,5 & 3,7 & 25,5 & 5,9 & 67,4 & 15,9 \\
\hline $\begin{array}{l}\text { Прямі платежі } \\
\text { 2014-2020 }\end{array}$ & 14,1 & 3,4 & 14,6 & 3,4 & 21,3 & 4,9 & 50,0 & 11,7 \\
\hline $\begin{array}{l}\text { частка прямих } \\
\text { платежів у } \\
\text { загальному обсязі } \\
\text { фінансування, \% }\end{array}$ & 53,4 & 53,4 & 94,2 & 94,2 & 83,5 & 83,5 & 74,2 & 74,2 \\
\hline $\begin{array}{l}\text { Програма розвитку } \\
\text { сільських територій } \\
\text { (PROW) 2014-2020 }\end{array}$ & 0,7 & 0,2 & 0,0 & 0,0 & 3,9 & 0,9 & 4,6 & 1,1 \\
\hline $\begin{array}{l}\text { частка PROW у } \\
\text { загальному обсязі } \\
\text { фінансування, \% }\end{array}$ & 2,7 & 2,7 & 0,0 & 0,0 & 15,3 & 15,3 & 6,8 & 6,8 \\
\hline $\begin{array}{l}\text { Організація } \\
\text { плодоовочевих } \\
\text { ринків 2014-2020 }\end{array}$ & 1,1 & 0,3 & 0,7 & 0,2 & 0,3 & 0,1 & 2,1 & 0,5 \\
\hline $\begin{array}{l}\text { частка видатків на } \\
\text { організацію плодо- } \\
\text { овочевих ринків у } \\
\text { загальному обсязі } \\
\text { фінансування, \% }\end{array}$ & 4,2 & 4,2 & 4,5 & 4,5 & 1,2 & 1,2 & 3,1 & 3,1 \\
\hline Інші видатки & 10,5 & 2,5 & 0,2 & 0,0 & 0,0 & 0,0 & 10,7 & 2,6 \\
\hline $\begin{array}{l}\text { частка інших } \\
\text { видатків у } \\
\text { загальному обсязі } \\
\text { фінансування, \% }\end{array}$ & 39,8 & 39,8 & 1,3 & 1,3 & 0,0 & 0,0 & 15,9 & 15,9 \\
\hline
\end{tabular}

"Офіційний курс євро, згідно з яким розраховуються ставки прямих виплат, установлений ЄЦБ станом на останній робочий день вересня.

Джерело: складено за [8] 
Станом на кінець 2016 р. загальна кількість суб'єктів, зареєстрованих у ARiMR для отримання різноманітних форм фінансової підтримки, становить більше 2,1 млн., 3 яких 98,2\% - фізичні особи.

Значна частка програм фінансової підтримки фінансується з бюджету $\mathrm{CC}$, але при цьому частина коштів виділяється 3 державного бюджету Польщі в рамках співфінансування програм САП ЄС. За найбільш витратними проектами на Європейський Союз припадає понад 95\% фінансування. Протягом 2014-2016 pp. у рамках САП СС часка фінансування за рахунок Польщі становить 9,9\% (табл. 13 ).

Таблиця 13

Спів фінансування програм, передбачених САП ЄС у 2014-2016 pp.

\begin{tabular}{|c|c|c|}
\hline Показник & $\begin{array}{c}\text { Сума, млрд. } \\
\text { злотих }\end{array}$ & $\begin{array}{c}\text { Частка у } \\
\text { видатках, \% }\end{array}$ \\
\hline Загальна сума фінансування, тому числі: & 67,4 & 100 \\
\hline кошти ЄC & 60,7 & 90,1 \\
\hline кошти РП & 6,7 & 9,9 \\
\hline 3 них: & $\mathrm{x}$ & $\mathrm{x}$ \\
\hline Система прямої підтримки, в тому числі: & 50 & 100 \\
\hline кошти СС & 48,6 & 97,2 \\
\hline кошти РП & 1,4 & 2,8 \\
\hline $\begin{array}{l}\text { Програма розвитку сільських територій } \\
\text { 2014-2020, у тому числі: }\end{array}$ & 4,6 & 100 \\
\hline кошти $\mathrm{CC}$ & 2,7 & 58,7 \\
\hline кошти РП & 1,9 & 41,3 \\
\hline 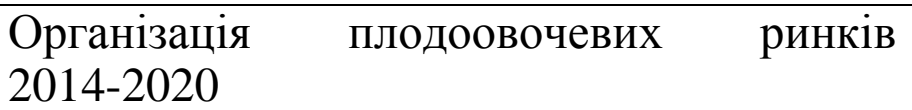 & 2,1 & 100 \\
\hline кошти $€ \mathrm{C}$ & 1,4 & 66,7 \\
\hline кошти РП & 0,7 & 33,3 \\
\hline Інші видатки & 10,7 & 100 \\
\hline кошти СС & 8 & 74,8 \\
\hline кошти РП & 2,7 & 25,2 \\
\hline
\end{tabular}

Джерело: складено за [8]

Поза межами програм САП ЄС кошти з державного бюджету уряд Польщі спрямовує на кредитування діяльності сільськогосподарських товаровиробників за такими основними напрямами:

- позики для інвестицій у переробку сільськогосподарської продукції, риби, ракоподібних та молюсків та на придбання акцій;

- позики для інвестицій у сільське господарство та рибальство;

- кредити на придбання сільськогосподарських земель;

- безвідсоткові кредити сільськогосподарським товаровиробникам;

- інвестиційні та відновлювальні кредити для постраждалих унаслідок стихійних лих. 
Висновки. Свропейська модель розвитку суспільства попри певні недоліки довела свою життєздатність. Країни Європи прагнуть набути статусу члена СС, оскільки це відкриває широкі можливості для країн-претендентів. Великий ринок (населення близько 500 млн. осіб), високі соціальні стандарти, боротьба 3 корупцією, повага до прав людини - це лише мала частка цінностей, що сповідуються в СС.

Україна робить чіткі кроки, спрямовані на євроінтеграцію. Економічний складник Асоціації з СС відкрив перед вітчизняними товаровиробниками доступ до одного з найбільших ринків, юридичний - окреслив зобов'язання 3 розбудови основних елементів цивілізованого суспільства.

Подальші кроки, спрямовані на зближення з СС, повинні спиратися на досвід країн, які не так давно стали повноцінними членами $\mathrm{CC}$, зокрема країн Вишеградської четвірки, та його адаптації до вітчизняних реалій. Значною мірою це стосується трансформації форм та методів державної фінансової підтримки сільськогосподарських товаровиробників та розвитку сільських територій. Така підтримка повинна бути спрямована на:

- переважне використання прямих форм фінансової підтримки;

- забезпечення пріоритетності функціонування малих форм господарювання, підвищення їх конкурентоспроможності;

- обгрунтованість цільового характеру фінансової підтримки, орієнтація на стимулювання економічного зростання на паритетних засадах виділення фінансових ресурсів;

- розвиток кооперації на селі як вагомого інструмента збільшення доходності сільськогосподарських товаровиробників;

- обмеження доступу високоприбуткових підприємств до бюджетних дотацій, боротьба з таким явищем, як аграрний лобізм;

- стимулювання зайнятості і підприємництва у сільських регіонах;

- екологізацію розвитку сільських територій.

\section{Список використаних джерел:}

1. Гудзь О.Є. Фінансово-кредитна інфраструктура аграрної сфери України / О.Є. Гудзь // Економіка АПК. - 2009. - № 6. - С. 58-63.

2. ЄС: В 2014-20 гг - с новой, справедливой, аграрной политикой [Електронний ресурс]. Режим доступу : http://agroconf.org/content/es-v-2014-20-gg-s-novoy-spravedlivoy-agrarnoypolitikoy

3. Косюк за півроку отримав 3 бюджету $42 \%$ всіх дотацій для аграріїв [Електронний pecypc]. - Режим доступу : https://www.epravda.com.ua/news/ 2017/08/21/628247/

4. Попова О. Нові пріоритети Спільної аграрної політики СС на 2014-2020 роки: стратегічні орієнтири для розвитку агросфери України / О.П. Попова // Економіка АПК. 2013. - № 12. - С. 89-96.

5. Про Державний бюджет України на 2017 рік : Закон України від 21.12.2016 № 1801 VIII [Електронний ресурс]. - Режим доступу : http://zakon2.rada.gov.ua/laws/show/1801-19/page

6. Про затвердження Порядку розподілу бюджетної дотації для розвитку сільськогосподарських товаровиробників та стимулювання виробництва сільськогосподарської продукції у 2017 році : Постанова КМУ від 08.02.2017 № 83 [Електронний ресурс]. - Режим доступу : http://zakon2.rada.gov.ua/laws/show/83-2017$\% \mathrm{D} 0 \% \mathrm{BF}$

7. Радченко О. Структура та форми бюджетної підтримки аграрного сектору України / О. Радченко [Електронний ресурс]. - Режим доступу : http://sophus.at.ua/publ/ 2014_05_22_23_kampodilsk/sekcija_4_2014_05_22_23/struktura_ta_formi_bjudzhetnoji_pidtrimk i_agrarnogo_sektoru_ukrajini/62-1-0-1035. 
8. Сайт Agencji Restrukturyzacji i Modernizacji Rolnictwa [Електронний ресурс]. - Режим доступу : http://www.arimr.gov.pl/

9. Сайт Agravery [Електронний ресурс]. - Режим доступу : http://agravery.com/uk/posts/section/show/export-geography.

10. Сайт Світового банку [Електронний ресурс]. - Режим доступу : http://projects.worldbank.org/country?lang=en\&page=.

11. Топ 100 латифундистов Украины [Електронний ресурс]. - Режим доступу : http://latifundist.com/rating/top100\#136

Karkovska V.Ya.

Candidate of Economic Sciences, Senior Lecturer at Department of Administrative and Financial Management, Institute of Administration and Postgraduate Education,

Lviv Polytechnic National University

Yaremko I.I.

Candidate of Economic Sciences, Senior Lecturer at Department of Administrative and Financial Management, Institute of Administration and Postgraduate Education,

Lviv Polytechnic National University

Blynda Y.O.

Assistant Lecturer at Department of Administrative and Financial Management, Institute of Administration and Postgraduate Education,

Lviv Polytechnic National University

\section{DEVELOPMENT MANAGEMENT OF THE NATIONAL ECONOMY BASED ON THE RESEARCH ON THE IMPACT OF SAVINGS AT THE LEVEL OF GROSS DOMESTIC PRODUCT}

Summary. The management of savings of the national economy and their impact on the level of GDP are considered, taking into account components such as savings of the general government, households, financial and non-financial corporations, and foreign direct investment. Econometric modelling is carried out on the basis of the conceptual statement of the task, model specification, data collection, and evaluation of model parameters, model testing for adequacy, model verification. Researching the problems of the transformation of savings into investment, it is necessary to assess the impact of savings on gross domestic product. Investment activity depends on increasing the use of savings, which has an impact on the economic growth of the national economy. The use of multi-factor econometric models of the effect of savings of the national economy and foreign investments on the level of GDP can predict GDP growth rates and assess the impact of each component of savings on the change of GDP. The state can directly influence the investment resources of enterprises and sectors through the management of existing income that remains at their disposal, that is, precisely because of the state procurement of products of these enterprises, their subsidization and the level of the tax burden. An analysis of the investment potential of the national economy provides grounds for arguing that the level of its 
use is low. In order to increase investment potential, it is necessary to increase the level of transformation of savings into investments.

Introduction. The most important factor in the study of a certain phenomenon is the establishment of interrelationships between economic quantities. Therefore, in order to effectively manage economic processes and phenomena, one must be able to measure these relationships quantitatively.

Researching the problems of the transformation of savings into investment, it is necessary to assess the impact of savings on gross domestic product. Investment activity depends on increasing the use of savings, which has an impact on the economic growth of the national economy.

Such an interpretation, first of all, requires clarification as to whether there is indeed a connection between such categories as GDP and savings, and if so, what kind of connection and how tight it is.

A particular attention should be paid to the share of net savings since they are the source of investment, and the greater the growth of investment, the higher the rate of economic growth. That is, a lack of savings generates a lack of investment, which is accompanied by a mismatch in the quality of fixed capital, which results in lower volumes of production and indirectly the quality of products, which in turn affects the level of income. The relevant situation leads to a lack of savings, which results in an inappropriate proportion of the distribution of income between consumption and savings and the national institutional structure of the distribution of savings. An important factor in GDP growth is the mobilization of domestic and foreign investment in order to accelerate economic growth.

In the study of managing the savings of the national economy and their impact on the level of GDP, it is necessary to take into account such components as savings in the general government, households, financial and non-financial corporations, and foreign direct investment, because in the absence of foreign economic relations there is no automatic equalizing the growth rates between the countries that remain unchanged and depend on the level of savings and development of scientific and technological progress(STP) in this country.

In the national economy, the reason for the slow growth of GDP may be not only the low rate of savings but also the ineffectiveness of economic incentives, irrational allocation of resources. Therefore, it is expedient to allocate such elements, without which it is impossible to manage the development of the national economy. These include the following elements as $[1 ; 4 ; 5]$ :

- the need to mobilize savings to attract sufficient investment in the national economy, with their extension is necessary, but not sufficient, for effective development;

- the openness of the domestic market and foreign trade, which leads to an increase in the amount of savings and foreign investment in the country's economy;

- effective development is directly related to the effects of factors such as the accumulation of capital (through savings and investments).

\section{Econometric modelling of the effect of savings on GDP}

The study of management of the development of the national economy based on the effect of savings on the level of GDP covers the following tasks:

1. Installation dependencies between the total amount of savings and GDP. 
2. Installation dependencies between the most important components of savings and GDP.

3. Installation dependencies between the structure of savings and GDP.

4. Installation dependencies between savings and GDP considering time factor.

Quantitative research of such tasks should be carried out by constructing appropriate econometric models of the power type, which are most used in the study of economic processes at the macro level $[2 ; 3]$.

Econometric modelling is carried out in the following sequence: conceptual statement of task, model specification, data collection and evaluation of model parameters, model testing for adequacy, model verification [1].

Consider the process of econometric modelling of each of the tasks.

1. The effect of savings on the level of GDP can be conditionally written down by means of an econometric model of functional connection of general form:

$$
V=f(Z),
$$

where $V$ - gross domestic product, UAH million;

$Z$ - total amount of savings, UAH million.

This effect can be specified using a model that looks like this:

$$
\mathrm{V}=\mathrm{e}^{\alpha_{0}} \times Z^{\alpha_{1}},
$$

where ${ }^{\alpha_{0}}$ - a parameter that characterizes the influence of all other factors;

$\alpha_{1}$ - a parameter that characterizes the effect of savings on the level of GDP.

Let us consider a more detailed connection between GDP and savings using the coefficient of elasticity $(E)$ :

$$
E=\frac{Z}{V} \times \frac{d Z}{d V}=\frac{Z}{e^{\alpha_{0}} \times Z^{\alpha_{1}}} \times e^{\alpha_{0}} \times \alpha_{1} \times Z^{\alpha_{1}-1}=\alpha_{1}
$$

Consequently, the coefficient of elasticity is equal to the parameter $\left(\alpha_{1}\right)$, on the basis of which it will be possible to reflect the change in savings and their impact on GDP.

Under all other factors of management of the development of the national economy on the effect of savings on the level of GDP should be understood as factors that can be distinguished from the following groups:

- price factors, which include: the effect of the interest rate (with rising prices, the demand for money increases, which results in an increase in the interest rate. Which, as a result, reduces GDP due to demand for those goods, for which a loan is required); the effect of wealth (the rise in prices causes a decrease in fixed income); the effect of net exports (affects GDP through foreign economic activity, that is, it manifests itself when there is a change in prices for goods in the domestic market);

- non-price factors:

- expectations: this factor is usually generated by the psychology of the behaviour of the economic subject. Expectations can affect the current behaviour of both households and enterprises. Expectations of growth of inflation rate have an impact on GDP because in this case, current purchases of consumer goods are increasing, ahead of rising prices. Changes in investment costs depend on the expectations of 
enterprises. If prospects for high returns from future investments are unconvincing, investment costs will decrease, that will cause GDP reduction;

- the state's economic policy: by increasing government procurement, the government contributes to GDP growth. By raising the income tax on the population, the government reduces the tax-free income of the population, reducing the volume of GDP. Raising taxes on corporate profits, the government causes a decrease in the expected rate of net income from investments. This will reduce the investment component of GDP. An increase in the money supply in the economy raises GDP, and its reduction leads to a decrease in GDP;

- changes in the global economy: Since GDP is affected by net exports, this means that changes taking place in the international trade situation also have an impact on GDP. These changes can be affected as follows:

- the growth of economic activity of foreign partners, accompanied by the growth of their GDP, causes the growth of domestic exports, which in turn - GDP growth;

- change in the level of prices (growth) in the country of foreign partners, this causes an increase in exports in the domestic economy, which leads to GDP growth;

- macroeconomic factors: supply, demand, and distribution. Supply factors include the quantity and quality of natural and human resources, the volume of fixed capital, scientific and technological progress. Exactly these factors that determine the ability of GDP grows, but the ability to grow and real growth, which follows from the following factors, must be taken into account. Factors of demand foresee the growth of production potential by ensuring the full utilization of the volumes of all resources. Distribution factors include the distribution of growing resources in order to obtain the maximum amount of useful products.

- scientific and technological progress: STP is closely linked to investment activity. Investments in different ways can affect the economy. On the one hand, investments lead mainly to saving labour costs and increasing the cost of fixed capital, which is called labour-saving. On the other hand, investments are fundsaving. If the former lead to an increase in earnings for wages, then the second - to increase wages in relation to profits. In fact, the growth of GDP contributes to investment in fixed capital.

Along with the factors that have a significant impact on GDP growth, there are factors that lead to its reduction, which include the legislative activity of the state in the field of labor protection, the environment protection, etc.

There are also a number of factors that influence on GDP growth, but quantitative assessment of them is very difficult. These include the provision of the country with varied natural resources, the quantity and quality of land, climatic conditions, social, cultural, political environment, and even national traditions.

Consider the effect of national economy savings and foreign investment on the level of GDP taking into account data for 1997-2014.

In order to research the dependence of GDP of savings, we will provide a power function (2) in linear logarithmic form. The general view of the developed linear model $V(Z)$ will be as follows:

$$
\ln V=4.157+0.76 \ln Z, R^{2}=0.98 .
$$

The econometric model of financial and economic security, based on the effect of savings on the level of GDP in the power form, will take such form: 


$$
V=e^{4.157} \times Z^{0.76} .
$$

The elasticity of GDP relative to savings shows that a $1 \%$ increase in savings leads to a GDP growth of $0.76 \%\left(\alpha_{1}=0.76\right)$. The impact of all other factors $\left(\alpha_{0}\right)$ is $4.16 \%$. The correlation coefficients (0.99016) and the determination (0.98041) indicate the adequacy of the constructed model because the calculated value of Fisher's Fcriterion exceeds the critical value (Table 1).

2. Based on the analysis of data on the volumes of savings of the national economy and foreign investments in the distribution by sectors of the economy, the following tendencies can be identified:

- financial and non-financial corporations, non-profit organizations that are serving households, do not spend gross income on consumption. At the same time, all funds are used for savings, which is characterized by the necessity of growth of gross income as a source of renewal of fixed capital and expanded reproduction;

- the savings of the public administration sector have decreased that characterizes the decrease of the value of this sector indicator in the accumulation of assets of the national economy;

- savings in the household sector increased over the period under study, which is positive because households themselves should be the largest lender of the national economy;

- direct foreign investment grew during the analysed period that is evidence of the attractiveness of the national economy for foreign investors.

The effect of savings on the level of GDP $(V)$, taking into account the most important components of savings $(Z i)$, is represented by the power function of this type:

$$
V=V(Z i)=e^{\alpha_{0}} \times Z 1^{\alpha_{1}} \times Z 2^{\alpha_{2}} \times Z 3^{\alpha_{3}} \times Z 4^{\alpha_{4}},
$$

where $Z 1$ - savings in the general government sector;

$Z 2$ - savings of households;

Z3 - savings of financial and non-financial corporations and non-profit organizations that are serving households;

Z4 - direct foreign investment.

$\alpha_{0}, \alpha_{1}, \alpha_{2}, \alpha_{3}, \alpha_{4}$ - the desired parameters of the multifactor model.

The model $V(Z i)$ of the dependence of GDP on the separate components of savings, taking into account the reduction of the power function to the linear logarithmic form, will take the following form:

$$
\ln V=1.561+0.199 \times \ln Z 1+0.607 \times \ln Z 2+0.060 \times \ln Z 3+0.251 \times \ln Z 4,
$$

$R^{2}=0.99$

In a power form, the econometric model (14) takes the form:

$$
V=e^{1.561} \times Z 1^{0.199} \times Z 2^{0.607} \times Z 3^{0.060} \times Z 4^{0.251} .
$$

The constructed multifactor model $V(Z i)$ is adequate, calculated by the value of the determination coefficient (0.98591) the Fisher's F-criterion value exceeds the critical value. The calculations made allow making certain conclusions based on the economic content of the parameters of the growth of savings in the general government sector by $1 \%$, while the sustainability of all other components of savings 
will lead to a GDP growth of $0.199 \%$. The growth of household savings by $1 \%$ leads to a GDP growth of $0.607 \%$, provided that $Z 1, Z 3, Z 4$ are - steady. In turn, if growth in savings of financial and non-financial corporations is observed at $1 \%$ with a constant amount of other components, GDP will grow by $0.060 \%$. The growth of direct foreign investment by $1 \%$ will be accompanied by GDP growth of $0.251 \%$.

3. The effect of structural shifts $\left(d_{z i}\right)$ in the total amount of national economy savings on GDP $(V)$ reflects the model: $V=V\left(d_{z i}\right)$

Specific weight of each component of savings is determined by dividing a separate component of savings into their total amount:

-specific weight of savings in the government sector $\left(d_{z 1}\right)$ :

$$
d_{z 1}=\frac{Z 1}{Z} \times 100 \%
$$

-specific weight of household savings $\left(d_{z_{2}}\right)$ :

$$
d_{z 2}=\frac{Z 2}{Z} \times 100 \%
$$

-specific weight of savings of non-profit organizations that are serving households, financial corporations, and non-financial corporations $\left(d_{z 3}\right)$ :

$$
d_{z 3}=\frac{Z 3}{Z} \times 100 \% ;
$$

-specific weight of direct foreign investment $\left(d_{z^{4}}\right)$ :

$$
d_{z 4}=\frac{Z 4}{Z} \times 100 \% \text {. }
$$

So, the overall look of the model would be:

$$
V=V\left(d_{z i}\right)=e^{\alpha_{0}} \times d_{z 1}{ }^{\alpha_{1}} \times d_{z 2}{ }^{\alpha_{2}} \times d_{z 3}{ }^{\alpha_{3}} \times d_{z 4}{ }^{\alpha_{4}} .
$$

Taking into account the estimations of the parameters of the model (13), the model of the influence of structural changes in savings on GDP will come in the form of:

$$
\ln V=10.395-0.449 \times \ln d_{z 1}-0.534 \times \ln d_{z 2}-0.328 \times \ln d_{z 3}+1.539 \times \ln d_{z 4},
$$

$R^{2}=0.91$.

In a power form, an econometric model will come in the form of:

$$
V=e^{10.395} \times d_{z 1}^{-0.449} \times d_{z 2}{ }^{-0.534} \times d_{z 3}{ }^{-0.328} \times d_{z 4}^{1.539} .
$$

The estimated determination coefficient (0.90966) and Fisher's F-criterion (17.69) confirm the statistical adequacy of the constructed model. In the power model of the parameters estimation $\alpha_{0}, \alpha_{1}, \alpha_{2}, \alpha_{3}, \alpha_{4}$ are characterized by the quantitative relationship between GDP and, respectively, each share of the national economy's savings component in relative (percentage) terms. Therefore, their interpretation will be as follows: if the specific weight of savings in the public sector in the total savings will increase by $1 \%$, and the specific weight of savings in households, financial, nonfinancial corporations, and direct foreign investment will not change, GDP will decrease by $0.449 \%$; if the specific weight of savings in households in the total savings will increase by $1 \%$ and other components remain unchanged, GDP will 
decrease by $0.534 \%$; if the specific weight of savings of financial, non-financial corporations will increase by $1 \%$, and the rest of the specific weight of components will be constant, GDP will decrease by $0.328 \%$; and finally, if the specific weight of direct foreign investment grows by $1 \%$, and the specific weight of other components remains unchanged, GDP will increase by $1.539 \%$.

The negative significance of the parameters $\alpha_{1}, \alpha_{2}, \alpha_{3}$ from an economic point of view reflects the current tendency to reduce the specific weight of savings in the public sector, households, financial, and non-financial corporations in terms of GDP, as opposed to foreign investment, that significantly increases their role.

4. In the research of management of the development of the national economy based on the impact of savings on the level of GDP should take into account the effect of certain time factors, namely:

- temporary changes: in the case of a temporary decrease (increase) in the income received, there is a decrease (growth) in consumption. As a result, there is a decrease (increase) in savings. Because it is a matter of temporary fluctuations of income, the change in savings is due to the reduction (increase) of the most liquid part of it savings in cash, thus, other components of savings can remain practically unchanged;

- constant changes: in case of fixed decrease (growth) of incomes, the final consumption will constantly decrease (increase), and savings remain unchanged to a certain moment;

- expectations of future changes; income remains unchanged, but there is a tendency to reduce future income. In this case, the specific weight of savings in the initial period will increase. This means the growth of less liquid and short-term savings components.

The impact of the time factor $(t)$ and savings $(Z i)$ on GDP $(V)$ can be reflected using a model that includes the time factor $(t)$, saving of sector of the general government(Z1), saving households $(Z 2)$, savings of financial and non-financial corporations $(Z 3)$, and direct foreign investment (Z4) as independent variables.

This dependence can be represented using a model $V(t i, Z i)$ :

$$
V=(t i, Z i)=e^{\alpha_{0}+\beta \times t} \times Z 1^{\alpha_{1}} \times Z 2^{\alpha_{2}} \times Z 3^{\alpha_{3}} \times Z 4^{\alpha_{4}} .
$$

where $t$ - is the time factor.

As a result of calculating the parameters of the model (16) of financial and economic security, based on the effect of savings on the level of GDP using time factor $(t)$, we obtain the following model:

$$
\ln V=7.81+0.128 \times t+0.049 \times \ln Z 1+0.158 \times \ln Z 2+0.030 \times \ln Z 3+0.152 \times \ln Z 4,
$$

$R^{2}=0.99$,

Or in a power form:

$$
V=e^{7.81+0.128 x t} \times Z 1^{0.049} \times Z 2^{0.158} \times Z 3^{0.030} \times Z 4^{0.152} .
$$

Calculated values of the determination coefficient (0.99694) and Fisher's Fcriterion indicate its adequacy (Table 1).

The research of the model of the effect of savings of the national economy and foreign investments on GDP, taking into account the time factor, allows us to draw the following conclusions: with the growth of general government savings (Z1) by 
$1 \%$, and the sustainability of the savings of households (Z2), financial and nonfinancial corporations (Z3), and direct foreign investment(Z4), GDP will increase by $0.049 \%$; with the growth of household savings by $1 \%$, and the sustainability of all other factors, the GDP will grow by $0.158 \%$; in turn, the growth of savings of financial and non-financial corporations by $1 \%$ with a constant amount of other components will lead to a GDP growth of $0.030 \%$; if direct foreign investment grows by $1 \%$ with the constancy of all other factors, GDP will grow by $0.152 \%$. The most important factor is $Z 2$ than $Z 4, t, Z 1, Z 3$ factors.

The summary results of the study of the dependence of GDP on the amount of savings are given in Table 1.

Table 1

\section{Results of the research of the effect of savings on the level of GDP}

\begin{tabular}{|c|c|c|}
\hline Content of dependence & Dependency type & $\begin{array}{l}\text { Assessment } \\
\text { of the adequacy } \\
\text { of the model }\end{array}$ \\
\hline $\begin{array}{l}\text { 1. Impact of total } \\
\text { amount of savings }(Z) \\
\text { on GDP }(V)\end{array}$ & $\begin{array}{r}\text { Model } V(Z) \\
V=e^{4.157} \times Z^{0.76}\end{array}$ & $\begin{array}{c}R^{2}=0.98 \\
\text { F estimated }=200,2 \\
\text { F critical }=5,99 \\
\text { The model is } \\
\text { adequate }\end{array}$ \\
\hline $\begin{array}{l}\text { 2. Impact of savings on } \\
\text { the level of GDP }(V) \\
\text { taking into account the } \\
\text { most important } \\
\text { components }(Z i) \text {. }\end{array}$ & $\begin{array}{c}\text { Model } \\
V(Z i) \\
V e^{1.561} \times Z 1^{0.199} \times Z 2^{0.607} \times Z 3^{0.060} \times Z 4^{0.251}\end{array}$ & $\begin{array}{c}R^{2}=0.99 \\
\text { F estimated }=122,5 \\
\text { F critical }=6,39 \\
\\
\text { The model is } \\
\text { adequate }\end{array}$ \\
\hline $\begin{array}{l}\text { 3. Impact of structural } \\
\text { shifts }\left(d_{z i}\right) \text { in the total } \\
\text { amount of savings on } \\
\text { the level of GDP }(V)\end{array}$ & $\begin{array}{c}\text { Model } V\left(d_{z i}\right) \\
V=e^{10.395} \times d_{z 1}{ }^{-0.449} \times d_{z 2}{ }^{-0.534} \times d_{z 3}{ }^{-0.328} \times d_{z 4}{ }^{1.539} \\
d_{z 1}+d_{z 2}+d_{z 3}+d_{z 4}=100 \%\end{array}$ & $\begin{array}{c}R^{2}=0.91 \\
\text { F estimated }=17,62 \\
\text { F critical }=6,39 \\
\text { The model is } \\
\text { adequate }\end{array}$ \\
\hline $\begin{array}{l}\text { 4. Impact of time factor } \\
(t) \text { and savings } \\
(Z i) \text { on GDP level }(V)\end{array}$ & $\begin{array}{c}\text { Model } V(t i, Z i) \\
V=e^{7.81+0.128 \times t} \times Z 1^{0.049} \times Z 2^{0.158} \times Z 3^{0.030} \times Z 4^{0.152}\end{array}$ & $\begin{array}{c}R^{2}=0.99 \\
\text { F estimated }=390,8 \\
\text { F critical }=4,39 \\
\text { The model is } \\
\text { adequate }\end{array}$ \\
\hline
\end{tabular}

It should be noted that the use of multi-factor econometric models of the effect of savings of the national economy and foreign investments on the level of GDP can predict GDP growth rates and assess the impact of each component of savings on the change of GDP. 


\section{Management of the development of the national economy based on the transformation of savings into investments depending on the investment potential and GDP}

The state can directly influence the investment resources of enterprises and sectors through the management of existing income that remains at their disposal, that is, precisely because of the state procurement of products of these enterprises, their subsidization and the level of the tax burden. Capital transfers, which are manifested in the form of state investment subsidies, also play a role. However, the growth of the investment potential of enterprises due to an increase in the budget deficit, violation of principles of self-financing can lead to a decrease of the total volume of the resources of domestic credit.

The household sector has the most complex direct and indirect links with other sectors of the economy because households ultimately own the largest share of national capital and preferentially receive income in the form of personal income. Therefore, it is precisely in households that there is a clear link between income and savings that is aimed at maintaining an appropriate level of income throughout the lifecycle and providing an adequate level of financial and economic security. An important place among household investments is the purchase of housing, financial investments, and physical investments that belong to individual families.

Analysing the investment potential of Ukraine as a basis for transforming savings into investments, the following restrictions need to be highlighted:

- level of transformation of savings into investment. Lack of savings slows down the growth rate of the country. If the savings are compensated by foreign investments, which will lead to an excess of imports over exports, then the country can provide the planned growth rate;

- the country's ability to attract investment depends on the availability of labour, managerial, and administrative factors that contribute to the transformation of savings into investment. This ability also depends on the availability of demand for products produced as a result of investment;

- attraction of foreign investments provides transformation in the event of a lack of own savings, but it creates a number of restrictions, namely, dependence on external and internal factors.

We illustrate schematically the research of financial and economic security based on the transformation of savings into investment, depending on the investment potential and GDP (Fig. 1).

It is reasonable to assume that at the initial stage of the transformation of savings into investments, the main limitation is the attraction of capital because the lower boundary of the initial stage is precisely the investment and the highest - the savings, which should be used as a source of investment.

The initial stage is characterized by the excess of gross savings in domestic investment, that is, excessive savings, along with insufficient real opportunities for investing. According to this, the main obstacle to the transformation of savings into investment is not a lack of investment resources, namely, unfavourable investment climate accompanied by small volumes of foreign investment. If there are not enough foreign investment, national (gross) savings will be possible to activate the transformation. This stage is determined by the critical level of management. 


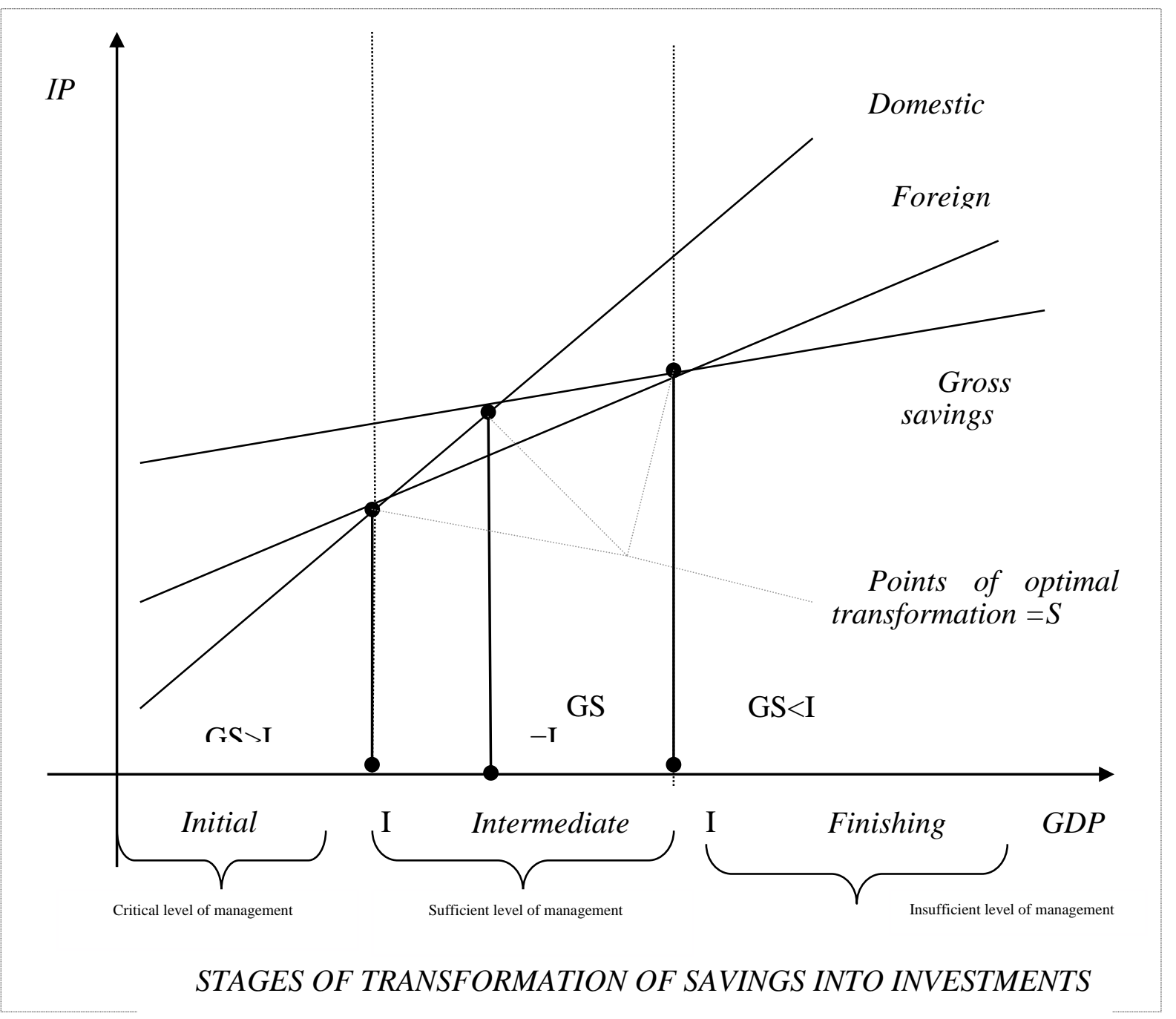

Fig. 1. Research on the management of the development of the national economy based on the transformation of savings into investments depending on the investment potential and GDP (source: own development based on [11])

For this stage, it is important to maximize the attraction and effective use of national (gross) savings. This can be achieved through a policy of active and purposeful investment.

The point II reflects the transition to an intermediate stage, which characterized by a limitation of foreign investment and is characterized by an adequate level of management. The point of optimal transformation ensures the transformation of the total volume of national savings into domestic investment. At this stage, there are so-called "points of optimal transformation" that are characterized by the equality of savings and investments. Such a situation is positive for the national economy. However, over time, there may be a much greater need for investment, which leads to the use of much larger investment resources. In such a situation, foreign investments are additionally required, which at this stage are limited. In order to attract foreign investment, it is necessary to create attractive and favourable conditions.

The beginning of the final stage demonstrates the point $I F$. This stage is characterized by restrictions on national (gross) savings and insufficient level of management. To increase the volume of domestic investment, the country attracts foreign investment. At this stage, there is a significant need for domestic investment, 
which is accompanied by the development of the national economy, in particular, innovation. A limited level of national savings and a small amount of foreign investment do not provide the required amount of domestic investment. In such a situation, it is necessary to develop measures to attract investment sources from the shadow economy. Stages of the transformation of savings into investments form a continuous process, that is, after the final stage begins the initial one.

Table 2

The investment potential of the national economy for 2003-2014

\begin{tabular}{|c|c|c|c|c|c|}
\hline \multicolumn{6}{|c|}{ Indexes } \\
\hline \multicolumn{3}{|c|}{$G D P$, UAH million } & $I$, UAH million & $G S$, UAH million & $I P, \%$ \\
\hline \multirow{12}{*}{$\underset{\partial}{\circlearrowright}$} & 2003 & 267344 & 51011 & 74330 & 28 \\
\hline & 2004 & 345113 & 75714 & 109251 & 32 \\
\hline & 2005 & 441452 & 93096 & 113362 & 26 \\
\hline & 2006 & 544153 & 125254 & 126980 & 23 \\
\hline & 2007 & 720731 & 188486 & 177217 & 25 \\
\hline & 2008 & 949864 & 233081 & 197473 & 21 \\
\hline & 2009 & 913345 & 250158 & 151746 & 17 \\
\hline & 2010 & 1079346 & 195927 & 197649 & 18 \\
\hline & 2011 & 1299991 & 241785 & 208406 & 16 \\
\hline & 2012 & 1404669 & 283116 & 198619 & 14 \\
\hline & 2013 & 1465198 & 263661 & 152610 & 10 \\
\hline & 2014 & 1586915 & 224327 & 183587 & 12 \\
\hline \multicolumn{6}{|c|}{ GDP-Gross Domestic Product } \\
\hline \multicolumn{6}{|c|}{ I- investment in fixed capital } \\
\hline \multicolumn{6}{|c|}{ B3-gross savings } \\
\hline \multicolumn{4}{|c|}{$\begin{array}{l}\text { IP-investment potential } \\
\text { of the national economy }\end{array}$} & \multicolumn{2}{|c|}{$I \Pi=(B 3 / B B \Pi) * 100 \%$} \\
\hline \multicolumn{6}{|c|}{ Trend model } \\
\hline \multicolumn{3}{|c|}{$I P$} & \multicolumn{3}{|c|}{$\begin{array}{l}y=30,729 x^{-0,2039} \\
R^{2}=0.84\end{array}$} \\
\hline
\end{tabular}

* own development based on [12]

In general, the country has the opportunity to avoid restrictions that prevent the transformation of savings in investment. This is the use of political instruments (tax, amortization, foreign policy), designed to reduce such restrictions.

The calculation of the investment potential of Ukraine (Table 2) and the degree of its use can be characterized as follows:

- the investment potential of 2004 increased by 4\% in comparison with 2003 due to the growth of gross savings in GDP;

- in 2014 , compared with 2003 , investment potential decreased by $16 \%$, which indicates a low level of investment activity.

An analysis of the investment potential of the national economy provides grounds for arguing that the level of its use is low. In order to increase investment potential, it is necessary to increase the level of transformation of savings into investments. 
Characteristics of measures for the management of savings as the main source of investment in the national economy of Ukraine

\begin{tabular}{|c|c|}
\hline $\begin{array}{l}\text { Participants of the } \\
\text { transformation } \\
\text { process }\end{array}$ & Measures \\
\hline $\begin{array}{l}\text { financial and non- } \\
\text { financial } \\
\text { corporations }\end{array}$ & $\begin{array}{l}\text { The development of measures to promote the growth of national } \\
\text { enterprises' production, decrease production costs, and increase its } \\
\text { efficiency provides for the orientation towards activisation of } \\
\text { investment activity at enterprises. Priority to stimulate investment } \\
\text { should be given to innovations that will help to achieve a rapid } \\
\text { development of production, to generate financial resources, the } \\
\text { development of which will have a multiplier effect for other } \\
\text { industries and sectors of the national economy. The restructuring of } \\
\text { enterprises should be encouraged, which will ensure better manage- } \\
\text { ment of assets, the implementation of effective financial planning, } \\
\text { the recovery of long-term investment activity of the enterprise. }\end{array}$ \\
\hline households & $\begin{array}{l}\text { Development of measures to increase the level of incomes of the } \\
\text { population, adjusting them according to the level of inflation in } \\
\text { accordance with the current legislation, and focusing on measures } \\
\text { to increase savings and accumulation of temporarily free funds of } \\
\text { the population into investments. It is necessary to restore public } \\
\text { confidence in domestic credit and financial institutions and securi- } \\
\text { ties, as well as stimulate the transformation of the population's } \\
\text { savings for the needs of entrepreneurship and formation of small } \\
\text { enterprises. }\end{array}$ \\
\hline $\begin{array}{l}\text { general } \\
\text { government sector }\end{array}$ & $\begin{array}{l}\text { A particular attention should be paid to measures to ensure } \\
\text { adequate filling of the state budget, the balancing of its } \\
\text { expenditure part, and the focus on improving the efficiency of the } \\
\text { use of state savings. Benefits in choosing public investment should } \\
\text { be provided to the industries that are necessary to ensure economic } \\
\text { development and are not attractive enough for private investors. } \\
\text { Public investment should also be used as an instrument of creating } \\
\text { prerequisites for attracting private and foreign investment in } \\
\text { priority sectors. }\end{array}$ \\
\hline foreign subjects & $\begin{array}{l}\text { It is necessary to provide favourable conditions for foreign } \\
\text { investors to invest in Ukrainian economy along with Ukrainian } \\
\text { investors, to focus on providing balanced privileges to long-term } \\
\text { investment projects that are aimed to further reinvest a part of the } \\
\text { profits received into priority sectors of the economy. At the same } \\
\text { time, it is necessary to promote the increase of the efficiency of } \\
\text { the use of foreign investments, compliance of monitoring and } \\
\text { controlling, development of investment policy taking into account } \\
\text { the interests of potential investors. It is necessary to create } \\
\text { conditions for the development and implementation of joint } \\
\text { investment projects on the basis of regional cooperation. }\end{array}$ \\
\hline
\end{tabular}

For the formation of savings as the main source of investments of Ukrainian economy, which have an impact on the level of GDP and the management of the 
development of the national economy, it is necessary for each participant in the process of transformation, i.e. enterprises, population, state, foreign subjects to develop certain measures $[6 ; 7 ; 8 ; 9 ; 10]$.

For a deeper research of savings formation, we systematize and characterize the factors that have an impact on it:

- socio-economic factors:

- Incomes. The dependence of savings on incomes has a great practical importance in conducting financial policy. On the one hand, achieving a high standard of living gives the economy a great incentive for saving and the possibility of transforming them into investment. On the other hand, it is necessary to pay a special attention to the high-income groups of the population, as a source of a significant part of savings. There is another aspect of income generation, that is, the income received illegally (shadow revenues), which create problems with their use. There is a problem of the legalization of such incomes, but so far of them are formed non-mobilized savings, as well as their withdrawal abroad. Therefore, the more shadow revenues, the greater the volume of non-mobilized savings. Stimulating such savings is not feasible;

- financial market incomes. This factor is important, especially for savings that are geared towards earning revenue. The higher the yield of financial instruments, the greater will be an incentive for the formation of savings. The imperfection of financial markets, as well as their insignificant development, is negative for savings;

- inflation. A complicated and ambiguous factor that has an impact on the potential of savings. On the one hand, the income level of in financial market includes the inflation component. High inflation allows you to get a high nominal return on investment. However, this indicates an unstable development of the economy and a high level of risk. With a steady development of the economy and a normal level of inflation (5-7\% per year), income will bring only the amount of savings that are not available to everyone. Therefore, this aspect will play a mainly secondary role. However, on the other hand, inflation reduces the level of real incomes, including income from investments. And this, in turn, weakens the formation of savings potential. In addition, inflation devalues already existing volume of savings. Exit from such a situation is the formation of savings in foreign currency, etc. Thus, inflation has a dual influence on the formation of savings;

- taxes. Their level has a significant impact on the savings formation, namely, the higher the tax rates, the lower the part of savings in income. The growth of taxes will lead to an increase in shadow revenues, the withdrawal of capital abroad. Therefore, the application of tax privileges will lead to an increase in savings;

- consumption and its features. One of the most important factors that affect savings. The impact is manifested through the level of income (the higher the level of income, the higher the savings), the accumulated tangible and intangible assets (the more they are, the less is the need in them). However, a significant part of assets acquired long ago physically and morally already worn out and needs to be replaced. This will lead to the need to generate savings for these goals;

- the socio-economic situation in the country. Development of the national economy activates the formation of savings potential. However, socio-economic instability leads to a decrease in savings;

- political factors. Savings depend on the political situation, first of all, due to its orientation to the development of the national economy. The negative political 
situation leads to instability and a decrease in the amount of savings. For this, the state should develop special measures that will help to restore confidence of the general public to the authorities and market regulation mechanisms;

- psychological factors. Possibilities of management of psychological factors are limited and are realized mainly in the long-term period (increase of intellectual and cultural level, or increase of level of trust).

The value of the described factors is important in practical terms, that is, it enables to regulate the formation of savings, including stimulating the transformation of savings into investments. The formation of savings implies the need for the maximum realization of the interests of all participants in the process of saving, which will serve to increase the efficiency of their use.

Conclusions. Increasing the efficiency of using savings is to implement the following conditions:

- sufficient and stable level of income, which can help to transform the savings;

- activisation of the investment orientation of savings in the condition of obtaining a certain return on investment, protection against unscrupulous financial and credit organizations and the negative consequences of political and economic events in the country.

Therefore, it is proposed to use certain measures to protect the interests of the owners of savings:

- development of financial market infrastructure, which offers a large variety of forms of accumulation and placement of savings, ways of investing savings and conditions of their attractiveness;

- the production orientation of investing savings with a guarantee of social and economic benefits, however, in the real sector there should be a substantial demand for additional financial resources;

To increase the part of savings, you need to focus on solving a number of following aspects:

- an appropriate comparison of the actions of market self-regulation with the active state influence on the process of saving;

- stabilization of the macroeconomic situation, which will help to activate savings in the investment process;

- development and further implementation of the savings policy aimed at the efficient transformation of savings;

- termination of activity of speculative financial structures;

- control over and management of external and internal government obligations;

- rationing of the reproductive process in the main production complexes;

- creation of competitive branches in the domestic industry;

- putting into operation a system of state guarantee of bank deposits;

- development of collective financing institutions that will help to accumulate savings and reduce investment risks.

Management of the national economic development based on the research of the effect of savings on the level of GDP in Ukraine shows that in order to activate this process, it is needed to create the necessary conditions for the effective formation and use of both national and foreign savings. 


\section{References:}

1. Krupka M.I. Finansovo-kredytnyj mekhanizm innovatsijnoho rozvytku ekonomiky Ukrainy / M.I. Krupka - L'viv.: Vydavnychyj tsentr l'vivs'koho natsional'noho universytetu im. I. Franka, 2001. -608 s.

2. Luk'ianenko I.H. Ekonometryka / I.H. Luk'ianenko, L.I. Krasnikova. - K.: Tovarystvo «Znannia», KOO, 1998. - 494 s.

3. Nakonechnyj S.I. Ekonometriia / [S.I. Nakonechnyj , T.O. Tereschenko, T.P. Romaniuk]; [vyd. 4-te, dop. ta pererob.] - K.: KNEU, 2006. - 528 s.

4. Natsional'na ekonomika / O.Ye. Kuz'min, U.I. Kohut, I.S. Protsyk, H.L. Verbyts'ka: za zah. red. O.Ye. Kuz'mina. - L'viv: V-vo Nats.un-t «L'vivs'ka politekhnika», 2010. - 188 s.

5. Natsional'ni zaoschadzhennia ta ekonomichne zrostannia / [za red. d.e.n. B.Ye. Kvasniuka]. K.: «MP Lesia», 2000. - 304 s. (In-t ek. prohnoz)

6. Pro Derzhavnu prohramu ekonomichnoho i sotsial'noho rozvytku Ukrainy na 2010 rik: ZU vid 20. 06. 2010 // Vidomosti Verkhovnoi Rady Ukrainy. - 2010. - № 2278-VI. - st. 470.

7. Pro Natsional'nu prohramu spryiannia rozvytku maloho pidpryiemnytstva v Ukraini: ZU vid 01. 07. 2010 // VVR. - 2010. - № 37. - st. 496.

8. Pro zasady derzhavnoi rehuliatornoi polityky u sferi hospodars'koi diial'nosti: ZU vid 11. 09. 2003 // Vidomosti Verkhovnoi Rady Ukrainy. - 2004. - № 9. - St. 79.

9. Pro derzhavne prohnozuvannia ta rozroblennia prohram ekonomichnoho i sotsial'noho rozvytku Ukrainy: ZU vid 23.03.2000 / Vidomosti Verkhovnoi Rady Ukrainy. - 2000. - № 25. - st.195.

10. Pro poriadok zdijsnennia rozrakhunkiv v inozemnij valiuti ZU vid 31. 05. 07 // Vidomosti Verkhovnoi Rady Ukrainy. - 2007. - № 44. - st.510.

11. Rut Franklin R. Mizhnarodna torhivlia ta investytsii / Rut Franklin R., Filipchenko A.: per. z anhl. - K.: Osnovy, 1998. - 743 s.

12. Derzhavnyj komitet statystyky Ukrainy: http://www.ukrstat.gov.ua.

Rybina L.O. Candidate of Economic Sciences, Associate Professor, Senior Lecturer at Department of Finance, Sumy National Agrarian University

Samoshkina I.D. Candidate of Economic Sciences, Associate Professor, Senior Lecturer at Department of Finance, Sumy National Agrarian University

Mikulina M.O.

Candidate of Economic Sciences,

Senior Lecturer at Department of Finance, Sumy National Agrarian University

\section{WAYS TO INCREASE THE COMPETITIVENESS OF UKRAINE ON THE BASIS OF THE VISEGRÁD EXPERIENCE}

Summary. The paper explores the reasons why Ukraine lost its position in the global competitiveness index. Based on the analysis of the transformational experience of the Visegrád countries, the main directions of increasing national competitiveness are identified. It has been established that the factors of competitiveness should be considered in dynamics. Because they are managed by the 
parameters, the management of which is aimed at the formation, support and development of competitive advantages of the business environment of the country. It is concluded that the level and nature of the competitive advantages of the country is determined mainly by the chosen innovation strategy and the well-considered innovative policy. The effectiveness of innovation policy is determined by the ongoing reforms aimed at the development of small and secondary business and the welfare of the population.

Introduction. The desire for possible membership of the EU and NATO prompts Ukraine to build economic, cultural, and educational ties with the Central European countries of the Visegrád Bloc because of their geographical neighbourship and their statements to promote the process of enlargement of European integration. The Visegrád Group (also known as the "Visegrád Four" or simply "V4") reflects the efforts of the countries of the Central European region to work together in a number of fields of common interest within the all-European integration. The Czech Republic, Hungary, Poland, and Slovakia have always been a part of a single civilization sharing cultural and intellectual values and common roots in diverse religious traditions, which they wish to preserve and further strengthen. All the V4 countries aspired to become members of the European Union, perceiving their integration in the EU as another step forward in the process of overcoming artificial dividing lines in Europe through mutual support. They reached this aim in 2004 ( $1^{\text {st }}$ May) when they all became members of the EU [1]. Today, the Visegrád countries cooperate to strengthen stability in Central Europe, in the field of information exchange, scientific, and cultural exchange and education. The Group aims at encouraging optimum cooperation with all countries, in particular, its neighbours, its ultimate interest being the democratic development in all parts of Europe.

It is believed that the Visegrád countries are successful real models of economic transformation and can be an example for other states that have embarked on reform. Due to the similarity of historical preconditions the partnership with the Visegrád countries is a natural direction for the development of integration Ukraine policy [2]. Accordingly, the analysis and adaptation to the modern conditions of development of the society of the transformational experience of the Visegrád countries are very important for bringing Ukraine closer to the European and Euro-Atlantic structures. It is also necessary to take into account that the dynamic competitive environment of the world economy requires constant renewal and strengthening of international economic relations.

The main requirements for the applicant countries for EU membership are identified and declared by the Copenhagen criteria in June 1993. The above criteria determine three main groups of requirements: political, economic, and so-called "membership". The first group regulates the stability of institutions guaranteeing democracy, the rule of law, respect for human rights, respect for and protection of the rights of national minorities; the second - implies the existence of a functioning market economy and the ability to withstand competitive pressure and the effect of market forces within the EU; the third - provides for the ability to assume the obligations arising from EU membership, including strict adherence to the objectives of the political, economic, currency union [3].

The fulfilment of economic requirements on the way to European integration involves, first of all, modernization of the Ukrainian economy, overcoming technical 
and technological backwardness, creating an investment and innovation climate in the business environment, raising the level of competitiveness Ukrainian business and filling vacancies in the European market. Strengthening cooperation with the Visegrád countries will contribute to meeting these requirements and, accordingly, to increase the competitiveness Ukrainian business. All this determines the relevance of the study on improving the competitiveness Ukrainian business in cooperation with the countries of the Visegrád bloc.

It is the purpose of the present paper to provide identification of Ukraine's problems and growth factors in competitiveness in Visegrád countries (Czech Republic, Hungary, Poland and Slovakia) in order to illustrate successful experiences.

\section{The assessment of the competitiveness of the Ukraine and V4 business}

The assessment of the country's ability to achieve high rates of economic growth in the long run is one of the scientific approaches to assessing the national competitiveness. Within forming the strategic policy of economic development, the competitiveness of business at the macroeconomic level is interpreted as the measure of the country's ability in a competitive market to produce goods and services that meet the requirements of world markets, while simultaneously preserving or increasing the real incomes of its citizens [4]; as the ability of the country to create internal and external conditions that enable businesses to produce goods and services that withstand the testing of international markets, and its population - to steadily increase incomes and quality of life [5].

With the development of science and technology, the demand of the consumer also increases. With the increase in demand, the exchange of goods and services between countries also expands. Virtually no country in the world is unable to fully meet the demand of its people, so it is obliged to trade in goods and services with other countries. But, each country must have required number of currency for the international trade in goods and services. Thus, import is needed to export. Nevertheless, each country imports a required number of goods and services in only two situations. First, when these goods and services are not produced in the country. Second, when the production of similar goods and services is worth more in this country. Therefore, trade between the countries is not mandatory but is a voluntary and mutually.

Ukraine and the Visegrád Group cooperate in the field of mutual trade in goods and services, investment and migration processes. The trade turnover of Ukraine with these countries amounted of 11041075 thousand USD in 2014, 8661957 thousand USD in 2015, 6563777 thousand USD for 9 months of 2016 [6]. Analysing the foreign trade in goods of Ukraine with the EU countries, it should be noted that the most important partner in exports and imports is Poland, the share of exports in Hungary, Slovakia, and the Czech Republic is insignificant. The foreign trade balance with EU countries, V4 is negative at 2015, but Ukrainian commodity exports are dominated by imports from Slovakia and the Czech Republic.

In the international market, the intensification of the competitive struggle for product sales forces countries to constantly seek new opportunities and reserves for the marketing of their products, to improve technology in order to create quality goods [7], and thus increase its competitiveness to benefit and revitalize economic development. This is due to the fact that externally mutually beneficial international trade is accompanied by a number of problems. 
First, the constant import of goods that are not produced in the country hinders the growth of the personnel, knowledge, and skills necessary for the production of these goods in the future.

Second, imports of the same goods that are produced in the country create additional competition for local goods and in most cases drives them out of the market. And this harms to the incomes of local producers and creates additional social problems. In general, the quality of the imported goods is significantly different from the quality of the local goods and, therefore, the market's competitive environment changes according to the new criteria.

For this reason and because of constant changes in the competitive environment, economic entities use different methods of managing their competitiveness. The economic competitiveness may be seen as a process of implemented specific economic relations. This suggests that it is the dynamic and purposeful category. These dynamics are conditioned by the dynamics of external and internal factors that arise as a result of changes in the competitive environment. That is why, the factors of competitiveness are considered in dynamics as managed parameters, the management of which is aimed at the formation, support, and development of competitive advantages of economic entities [8].

Integration processes are one of the key factors in the survival of countries in a competitive environment, strengthening their economic power. The Visegrád countries have consistently introduced measures in various fields to increase the competitiveness of their enterprises' productions and goods. First of all, it concerned the perception of their economic environment by international business, increased trade and increased inflow of foreign investment, which, in turn, ensured the sustainability of economic growth, improvement of the structure of the economy in general and exports in particular [9].

The UN Economic Commission for Europe has identified the main conditions for achieving a high level of competitiveness of the country (or at least part of them) [10]:

1) exporters should maintain and increase their share in foreign markets;

2) the share of exports in the form of products with high added value and modern technology should increase steadily;

3 ) the average specific value of the country's exports should increase.

Some feel that the significant structural problems limit the use of national competitive benefits of the Ukrainian goods exports. Among them stand out:

- a long-term tendency to reduce demand and prices in the world markets of traditional Ukrainian exports;

- strengthening international competition against the backdrop of growing state support for exports and the active use of protective measures in the interests of national producers in the leading countries of the world;

- preserving the tendency of discrimination of Ukrainian goods in foreign markets, including tacit agreements on the displacement or restriction of Ukraine's admission to promising markets;

- rapid increase of consumer requirements to quality, service support, technological level of products;

- insufficient investments in the technological and organizational upgrading of Ukrainian enterprises, which hinders their competitiveness and expansion to new global markets; 
- absence of a purposeful and consistent policy of state support for export development, indirect obstacles for exporters in the form of real hryvnia revaluation, non-return of value-added tax, the unfavourable business climate within the country as a whole, etc.;

- undeveloped infrastructure of organizational, legal, informational, financial support, and support of exporters [11].

The emergence of these problems is due to the fact that Ukraine, unlike the countries of the Visegrád Group, has not radically changed its economic environment in the process of transition to market relations. Post-socialist countries immediately began to radically go towards institutional and economic transformations, opened up opportunities for the rapid development of private entrepreneurship, demonopolization, productive efficiency and effectiveness (Table 1), and thus - sustainable improvement of the welfare of the country's citizens and improvement of the quality of life standards.

In parallel, the liberalization process, carried out within the context of a stable and predictable regulatory framework, has resulted in well-functioning factor markets. The Visegrád countries have managed to change for the better the socio-political and economic system, have a strong economy with high-tech production due to the fact that the Government had implemented a series of radical reforms in the direction of European integration. The outcome was also a result of improvement in the competitiveness of the Visegrád industry and today, they take a significant place in the European economy on individual indicators.

Table 1

\section{Economic transformations in the countries of the Visegrád Four on the path to the formation of a market economy [12]}

\begin{tabular}{|l|l|}
\hline \multicolumn{1}{|c|}{ Direction } & \multicolumn{1}{|c|}{ Major activities } \\
\hline Liberalization & $\begin{array}{l}\text { Elimination of trade protectionism; elimination of price } \\
\text { administration, wages, interest rate, exchange-rate and so on; } \\
\text { elimination of binding public agency in foreign trade relations }\end{array}$ \\
\hline Property reform & $\begin{array}{l}\text { Privatization of small and large enterprises, restructuring of large } \\
\text { enterprises, building of new private enterprises, introducing } \\
\text { rigorous budget restrictions, strengthening of property rights and } \\
\text { the establishment of corporate governance institutions }\end{array}$ \\
\hline $\begin{array}{l}\text { Deregulation in } \\
\text { the financial } \\
\text { markets }\end{array}$ & $\begin{array}{l}\text { The building of institutional bases of autonomous banking and } \\
\text { monetary system functioning; development of real deregulation } \\
\text { of financial markets; establishment of the regulatory standards } \\
\text { for financial markets, which are binding in the European Union }\end{array}$ \\
\hline $\begin{array}{l}\text { Deregulation in } \\
\text { the labour market }\end{array}$ & $\begin{array}{l}\text { Restricting public intervention in the labour market, increasing } \\
\text { the freedom of entrepreneurs in terms of employment, time, } \\
\text { form of work, wages, the attraction of free labour resources in } \\
\text { the outcome of the reform }\end{array}$ \\
\hline $\begin{array}{l}\text { Deregulation in } \\
\text { the goods market }\end{array}$ & $\begin{array}{l}\text { Liquidation of state production and trade monopolies; granting } \\
\text { to all economic entities the right to export and import without a } \\
\text { license (with few exceptions, on the import of armaments and } \\
\text { military equipment, radioactive materials, etc., as well as the } \\
\text { export of energy resources) }\end{array}$ \\
\hline
\end{tabular}


GDP per capita, PPP (purchasing power parity) is the basic indicator of the level of socio-economic development of the country, the productivity of the national economy, private and public consumption. After all, economic growth becomes steady, when structural and qualitative parameters of economic development are improving along with increasing production. Gross domestic product (GDP) per capita is the most widely used indicator for country-level income and has been used in modelling health outcomes, mortality trends, cause-specific mortality estimation, health system performance and finances, and several other topics of interest [13].

GDP per capita dynamics indicates a progressive trend of GDP growth in the Visegrád Group. What cannot be said about Ukraine? The growth of Ukraine's GDP per capita was only $10 \%$ over the past 10 years. For Poland, this indicator was $67.3 \%$. Thus, Ukraine remains a country with a low GDP, as a consequence, leads to poor living standards, stable low wages for the able-bodied population and no skilful state policies for social campaigns and social welfare. In that context, the objective no longer seemed to be a reduction of economic inequality between the developed and the developing countries but merely poverty reduction in developing countries. The GDP per capita indicator contains a considerable amount of information on the welfare of different countries (Table 2).

Table 2

GDP per capita, PPP (purchasing power parity) Visegrád countries and Ukraine for the period of 1991-2016 [14], USD

\begin{tabular}{|l|c|c|c|c|c|c|c|c|c|}
\hline & 1991 & 1995 & 2000 & 2005 & 2010 & 2014 & 2015 & 2016 & $\begin{array}{c}\text { Changes } \\
\text { over } \\
\text { years, } \%\end{array}$ \\
\hline Hungary & 10014 & 11162 & 14208 & 19940 & 21906 & 25399 & 26537 & 27482 & 28,5 \\
\hline Poland & 6296 & 8152 & 11630 & 15157 & 21084 & 25333 & 26623 & 27764 & 67,3 \\
\hline Slovakia & - & 9642 & 12296 & 17755 & 24555 & 28590 & 29975 & 31339 & 57,9 \\
\hline $\begin{array}{l}\text { Czech } \\
\text { Republic }\end{array}$ & - & 13874 & 16564 & 22732 & 27498 & 30432 & 32076 & 33232 & 33,0 \\
\hline Ukraine & - & 3861 & 3976 & 6750 & 7712 & 8733 & 7996 & 8305 & 10,3 \\
\hline
\end{tabular}

Globalization and internationalization of world economic processes determine the modern order in the economic and business. This is because they formalize the individualist needs and methods of their provision on large scales; make integrate sovereign states, markets, and technology. This allows any economic subject to be faster in its activity than ever, the much cheaper cost to establish to contact with partners, dispersed around the world. International business is the product of this phenomenon. The forms of this phenomenon are the widespread impact methods of taking profit in the convergence of socio-economic, political-legal, technological, and religious-cultural standards today.

Since 1979, annual Global Competitiveness Reports have examined the factors enabling national economies to achieve sustained economic growth and long-term prosperity. The most important criteria for the competitiveness of the national economy are reflected in the global competitiveness index - a complex integrated index of comparative competitiveness of countries, calculated on the basis of a combination of relative values. So, the country's competitiveness rating is determined 
by a consolidated index in the reports on global competitiveness, which are periodically published under the World Economic Forum in Davos (Switzerland). This consolidated index evaluates the ability of economies to provide higher business productivity, and thus, higher rates of economic growth and economic well-being of the nation based on the following requirements: institutions quality, infrastructure, macroeconomic environment, health and primary education); efficiency enhancers: higher education and training, goods market efficiency, labour market efficiency, financial market development, technological readiness, market size, and innovation and sophistication factors: business sophistication and innovation.

The selection of the said requirements is based on theoretical and empirical research and none of them can ensure the competitiveness of the economy alone. As, the effect of increasing educational expenditures can be reduced due to the inefficiency of the labour market, other institutional weaknesses and, as a consequence, the lack of opportunities for graduates to be suitably employed. Attempts to improve the macroeconomic environment, for example, to optimize control over public finances, will be successful only with the due transparency of the financial management system, the absence of corruption and large-scale violations. Entrepreneurs will introduce new technologies only if the potential profit exceeds the necessary investments. Thus, according to the conclusions of the World Economic Forum, the most competitive economies are those countries that are able to pursue a comprehensive policy, take into account the full range of factors and the interrelations between them [15]. Graphic 1 presents the rankings of the GCI 2012-2013 and 2017-2018 for countries of the Visegrád Group and Ukraine.

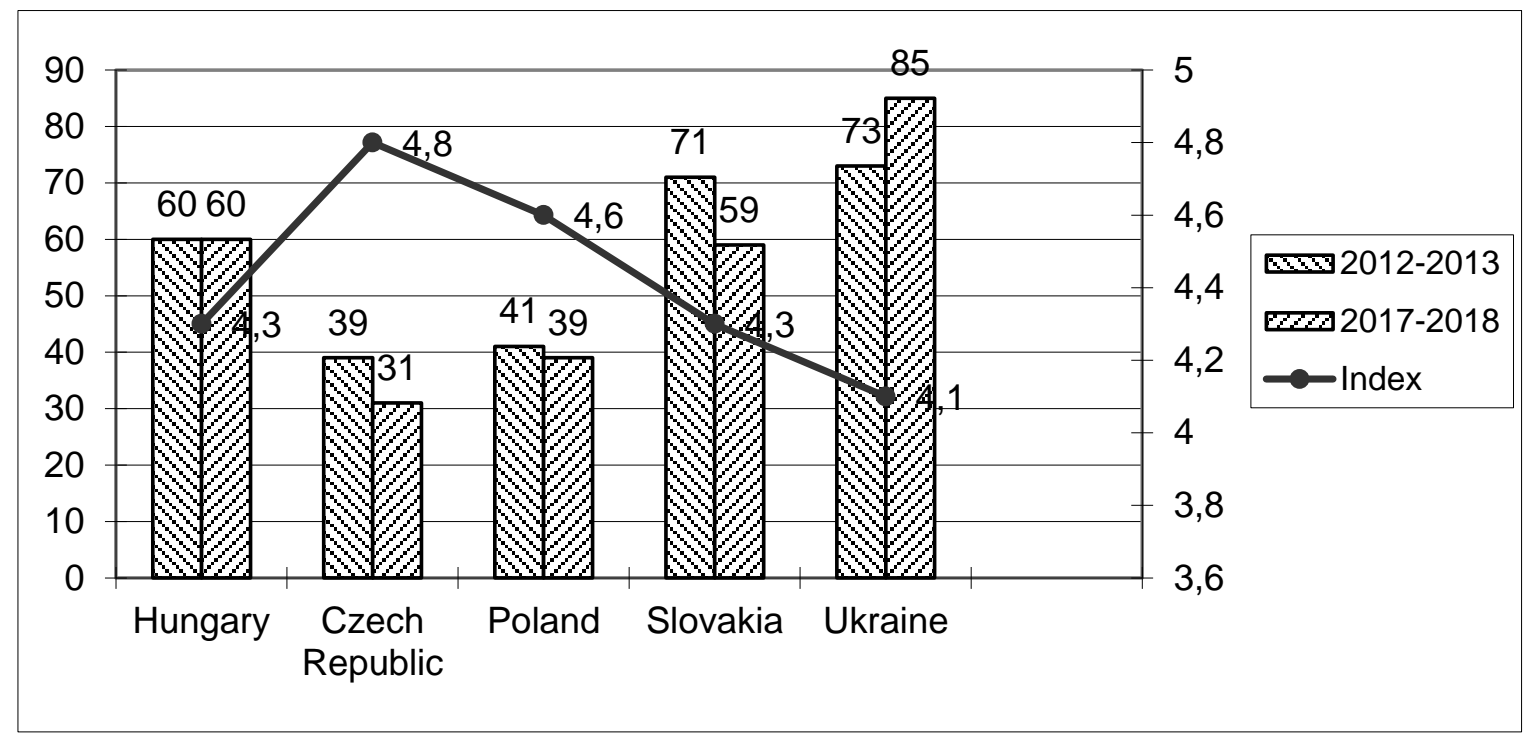

\section{Graphic 1. The Global Competitiveness Index 2012 and 2017 Rankings of Ukraine and the Visegrád Group}

The review of the Global Competitiveness Index 2012 and 2017 Rankings of Ukraine shows a loss of position in the global ranking of countries of the world in terms of economic competitiveness. Ukraine took the 85th place in the ranking on the Global Competitiveness Index among 137 countries in 2017, losing 5 positions over the last 5 years (taking 73rd among the 144 countries in the 2012-2013 ranking). The competitiveness of the Visegrád bloc, au contraire, increased over the years. As the 
Poland took the 39th place in the ranking (41st place in 2012), Czech Republic took the 31st place in the ranking (39th place in 2012), Slovakia took the 59th place in the ranking (71st place in 2012).

However, the loss of positions in ratings often does not mean worse the country's indicators - just other countries can improve their position at a faster pace. Doing business in Ukraine is not a walk in the park! This is because there are lots of problematic factors business leaders will need to overcome in order to successfully do business in the country. Respondents to the Executive Opinion Survey were asked to select the five most problematic factors for doing business in Ukraine, Hungary, Poland, Slovakia, Czech Republic and rank them between 1 (most problematic) and 5 (less problematic). The score (in the image below) corresponds to the responses weighted according to their rankings for these countries.

In 2017, inflation was considered the most problematic factor for doing business in Ukraine, followed by corruption that depressed business activity further. Policy instability emerged as the third-ranked concern followed by tax rates. According to the Polish entrepreneurs who participated in the research, the evaluation of infrastructure, macroeconomic environment, education, and health has improved in Poland as the main factors influencing the economy. Instead, indicators related to the functioning of institutions have decreased. Traditionally, the biggest obstacle in the conduct of economic activity was recognized by the tax law. On the other places, the ranking was obstructed by laws regulating the labour market and the instability of economic policy.

Graphic 2 presents the most problematic factors for doing business in the countries of the Visegrád Group and Ukraine.

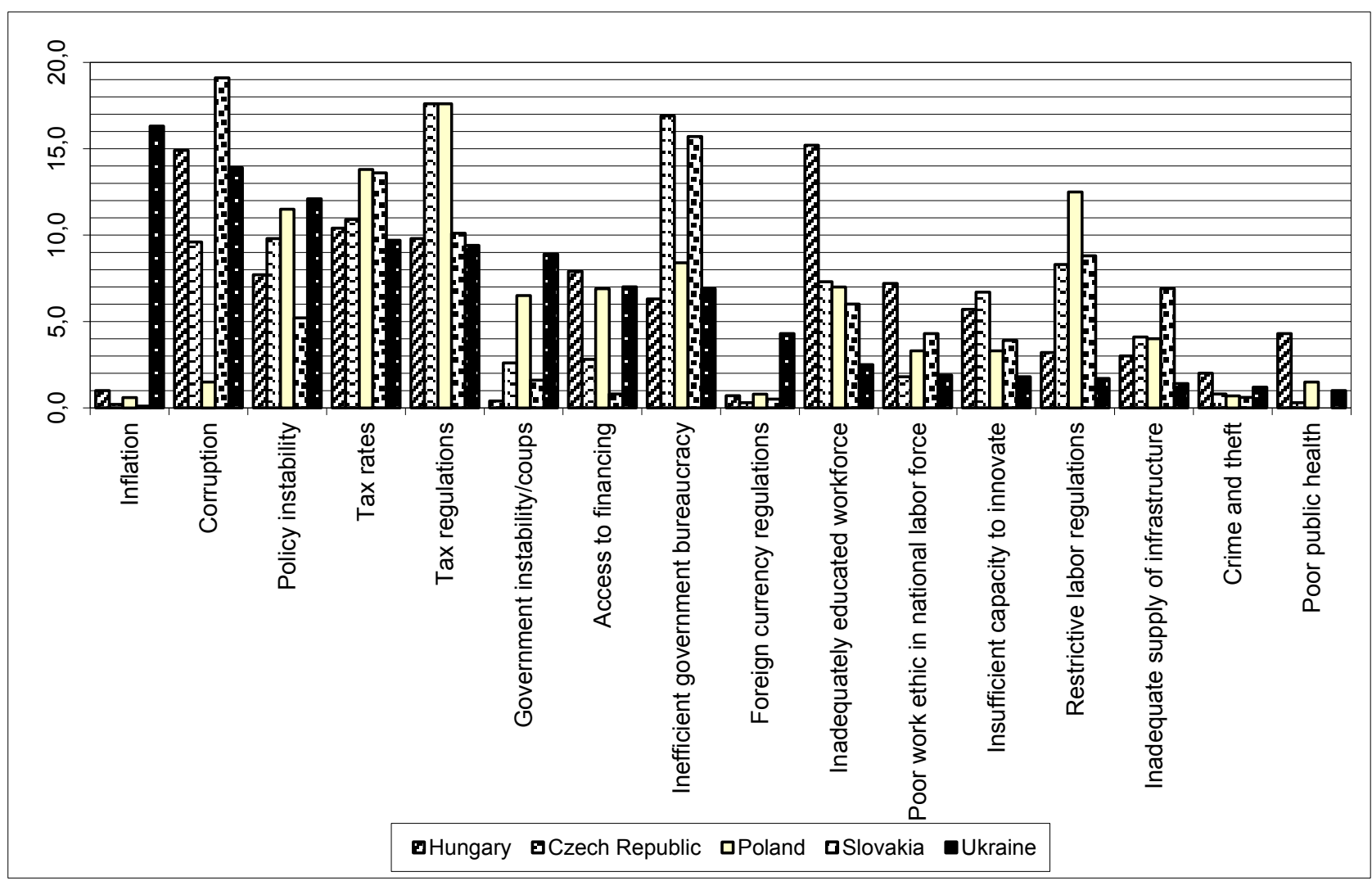

Graphic 2. Most problematic factors for doing business in Visegrád Group and Ukraine [16] 
Overall the results indicate that the discrepancy between the Ukraine's GDP structure and those achieved by developed countries is exacerbated by international competitive forces: the decline due to raw material and technological imbalances, or vice versa - a resource and conjuncture supplement in the structure of export-import balance. In this case, the radical difference is determined by the properties of the prevailing export goods groups, which have fundamentally different quality sources of competitive advantage. If integration into the international economic community is ensured through the development of new knowledge and technologies, the development of $R \& D$ and innovation production, the development of the national economy is driven by an increase in labour productivity within the framework of innovative technologies, which requires the involvement of a highly educated, skilled workforce with high wage level. The need for a national economy in such a workforce affects both the demand for education and general living standards, forming a stable middle class and a social macrostructure that is promising for a stable development.

Integration into the world economy, based on the export of mainly mining industries and industries engaged in primary processing and enrichment of raw materials for the manufacture of semi-finished products, does not require the use of high-tech and new knowledge in such types of economic activity. The products manufactured at the same time are characterized as mass and have standard unified parameters, and the most promising competitive advantage is price dumping. In this case, an economically justifiable competitive strategy is "focusing on costs," which is ensured not by innovation improvements but by the extensive expansion of production volumes. The reserves in this way are quickly exhausted because profit growth is due to lower wages and a reduction in the cost of modernization production assets. It does not contribute to the growth of wages of a national producer, limits domestic purchasing power, the need for a high level of education and science and technological upgrading of production. All this limits the preconditions for the emergence of entrepreneurial initiatives and the increase of the tax base and reducing the tax burden on economic entities.

\section{Ways to increase the competitiveness of Ukraine}

As a result of many years of WEF research, a number of fundamental recommendations have been developed, following which the country can achieve its competitiveness:

- stable and predictable legislation;

- flexible structure of the economy;

- investment in traditional and technological infrastructure;

- stimulating private savings and domestic investment;

- increase of export aggressiveness along with the attraction of foreign direct investment;

- improving the quality, efficiency, and transparency of management and administration;

- the interdependence of wages, labour productivity, and taxes;

- reducing the gap between minimum and maximum earnings in the country and strengthening the middle class;

- significant investments in education, especially secondary education, as well as in the continuous improvement of skills of the personnel; 
- balance the benefits of globalization of the economy and national characteristics and benefits [17].

In that context, the objective no longer seemed to be a reduction of economic inequality between the developed and the developing countries but merely poverty reduction in developing countries.

Cooperation with the Visegrád countries can help solve these issues. Relying on the common aspiration of the four States to strengthen their friendship and mutual trust can be to resolve issues in a spirit of equality and mutually advantageous partnership, taking into account their mutual interests.

For example, economic cooperation between Ukraine and Poland, having undergone a long-term development, continues to grow actively. This applies primarily to such sectors as agriculture and the processing of its products, machine building and aircraft engineering, energy and heat supply, the military-industrial complex, pharmacy and medical equipment. It is through the development of mutually beneficial cooperation in these areas and many other promising areas that it is possible to increase the share of manufactured products in the Ukrainian-Polish trade turnover several times and to prevent it from falling.

The trade turnover between Ukraine and Poland is growing sharply and has increased by 6 times compared to 1992. According to expert data, the capital of Ukrainian investors in Poland today is about 1 billion USD [2]. But still, in the commodity circulation between Ukraine and Poland, Polish exports considerably exceed imports.

The most striking change is the surge of access to finance as one of the most serious problems for business in many countries, a consequence of the global financial crisis in 2008. Because of deleveraging and stricter regulations in the banking sector, uncertain economic prospects, and despite extremely low interest rates, obtaining finance is still very difficult, especially for small- and medium-sized enterprises. In a political crisis, competition for the sphere economic impact, demographic crisis, deficit skilled personnel Ukraine loses national competitiveness in the global economic system.

Summarizing the experience of developed countries, one can conclude that the level and nature of competitive advantages of the country is determined by the predominantly chosen innovation strategy and well-balanced innovation policy. Effective is the innovative strategy of "building up", which consists in the implementation of radical innovations implemented in the industrial and social spheres, on the basis of the development of its own scientific and technological potential, the involvement of leading scientists and designers, as well as the integration of fundamental, applied science, education and entrepreneurship. It allows us to form the real type of competitiveness of the national economy, which manifests itself in the expansion of markets in the European space.

Innovation is one of the prerequisites for the formation of global competitiveness. Some feel that its growth is conditioned by eliminating the causes of its inhibition, which can be attributed to [18]:

1) impairment position of the financial market development due to the instability of the banking system - according to the NBU at the stage of liquidation, there are 81 banks in 2016; 
2) the decrease in the country's credit rating due to the growth of the state debt according to the Ministry of Finance, Ukraine's foreign debt to creditors is more than $50 \%$ of GDP;

3 ) reducing the protection of national investors due to the ineffective mechanism of state guarantees of investment protection, the imperfection of the system of protection of property rights and private property, the corruption of the incompleteness of the judiciary, which leads to "selective" equality before the law;

4) need for professional management due to the involvement in the management of relatives and close people;

5) failure of the country to hold "talents", lack of state incentives for employment. Consequently, the intellectual potential of Ukraine is migrating abroad (5 million Ukraine's citizens). So Poland is ready to accept 1.5 million migrant workers from Ukraine, the same idea is supported by Hungary;

6 ) reducing the impact of business on conditions of direct foreign investment, due to the lack of effective levers of cooperation between the state and the private sector in investment policy - the state system does not take into account business interests;

7) increase in the impact of taxation on investment incentives is due to the lack of tax privileges and the ineffectiveness of special economic zones - taxes only serve a fiscal function rather than a stimulus;

8) reducing intellectual property rights is a violation of intellectual property rights;

9) the decline in the position of business development is due to ineffective antimonopoly legislation and the lack of mechanisms to stimulate the development of small- and medium-sized enterprises;

10) deterioration of infrastructure quality: roads, railways, maritime and air transport.

Implementation of the innovation policy of the Visegrád countries is due to:

- financial support of small and medium enterprises to stimulate innovation activity;

- interaction and university science and industry in the field technology transfer to ensure the commercialization of $\mathrm{R} \& \mathrm{D}$ results;

- organization of public-private partnership for the creation of breakthrough technological innovations and infrastructure development;

- development of a unified European training strategy for competent professionals for high-tech spheres of activity.

The Global Competitiveness Index reflects the country's competitive advantage as a roadmap for potential foreign investors and governments from other countries. The regress in the formation of international competitiveness, above all, is due to the lack of both integrated and sectorial strategies for the country's long-term development. Developing a long-term strategy, taking into account the strengths and weaknesses in line with the Global Competitiveness Index, will enable the Government of Ukraine to formulate tactical and strategic tasks, will contribute to the investment attractiveness of Ukraine and the formation of the country's brand [17].

The international competitiveness optimization model should be based on their preferences and establish priority directions for improving the competitive state of the world market. The primary and higher education, market size, and some elements of the infrastructure are the strengths of Ukraine's competitiveness. The quality of institutions, infrastructure, and the macroeconomic environment, the efficiency of the market for goods, labour, and innovation are weaknesses of Ukraine's competi- 
tiveness. State regulation, payment of taxes, protection of investors and property rights, solving insolvency issues, political independence, cross-border trade and the development of financial the market is the most neglected areas that require more farsighted reforms.

Contemporary competitive countries own driving factors in the legalization of the economy. They characterize by the ability to maximize the implementation of national interests for the sake of safety and high living standards of the population [19]. The most important advantage will be the improvement of the domestic investment climate by introducing norms of the developed EU legislation into national legislation.

These changes will lead to the creation of a regulatory environment familiar to foreign investors and, accordingly, more attractive to them. Free access to a huge European the market for most Ukrainian goods will create significant business opportunities and increase the number of small- and medium-sized enterprises. It should also be remembered that all regulatory changes, which will lead to increased competitiveness and development Ukrainian sector of small- and medium-sized businesses, will increase the welfare of Ukrainians. Consumers will have a better access to a larger range of goods, more stringent security requirements for goods in the domestic market, new business opportunities, as well as effective internal distribution resources.

Conclusions. The results indicate on the whole, that the Ukraine's competitive factors are not considered progressive, or they can provide a long-term effect. They testify to the dependence of the country on domestic economic conditions and the available gold and foreign currency reserves. But key factors of the competitiveness of modern economic systems such as technological readiness, innovation, foreign trade, the absence of excessive regulation of the economy and human capital remain neglected.

The formation of competitiveness - is a complex dynamic phenomenon, aimed at creating and maintaining certain competitive advantages, aimed at providing a dominant position in relation to other actors in the international market. The modern tendencies in the functioning of the Visegrád Group's economy show that the following priorities should become the basis for the formation of a national strategy for ensuring a sufficient level of competitiveness of the national economy: innovative development, the possibility of upgrading technologies and the purchase of high technologies at the state level, improving market infrastructure and improving the investment climate, attracting entrepreneurship to innovation activity, as well as the development of the institutional environment.

Numerous think tanks and educational projects representing civil society of V4 countries were the main driver for introducing new economic approaches, namely: macroeconomic reforms and public finance management; tax reform, pension reform, health care reform; labour market reform, reform of public administration and fiscal decentralization, improvement of the business climate in the country. Formally, most reforms with similar names are already running. However, their effectiveness depends on the political will to carry out such reforms. Unfortunately, it is absent today due to fears of rising social discontent. The introduction of new reforms requires a clear plan of action, dialogue with business, and building trust in the government. 
The experience of the Visegrád countries for modern Ukraine is an invaluable source of knowledge and approaches to reforming the country's economy, including through its ethnocultural proximity. It is important that the Ukrainian government and officials want to hear the advice of those who were able to achieve a much better result, despite the same problems at the beginning of the path.

\section{References:}

1. About the Visegrád Group [Official Website of Visegrád Group] $<$ http://www.Visegrádgroup.eu $>$ (2017, October, 28) [in Ukrainian].

2. Zub S.V. (2017) Mizhnarodno-pravovyy mekhanizm rehulyuvannya suchasnykh vidnosyn mizh Ukrayinoyu i V4 [International legal mechanism of regulation of modern relations between Ukraine and V4]. Istorichni i politolohichni doslidzhennya, 1. 262-267 [in Ukrainian].

3. Kopengagins'kyy kryteriyi chlenstva v Evropeys'komu Soyuzi [Copenhagen criteria for membership in the European Union] Ofitsiynyi sait Ministerstva zakordonnykh sprav [Official Website of Ministry of Foreign Affairs of Ukraine < http://mfa.gov.ua/ua/page/open/id/774> (2017, October, 26) [in Ukrainian].

4. Krapivniy I., Nilova N. (2004) Konkurentospromozhnist' ekonomiky ta chynnyky yiei zrostannya [Competitiveness of the economy and its growth factors] Visnyk Sums'koho derzhavnoho universytetu. Seriya Ekonomika, 6(65). 12-16 [in Ukrainian].

5. Khadzhoyan A.O. (2008) Konkurentospromozhnist yak sotsialno-ekonomichne ponyattya i katehoriya [Competitiveness as a socio-economic concept and category] Ekonomichnyi visnyk NHU, 4. 19-25 [in Ukrainian].

6. Ofitsiynyi sait Derzhavnoiy sluzhby statystyky Ukrainy [Official Website of the State Statistics Service of Ukraine]. < www.ukrstat.gov.ua / (2017, October, 23) [in Ukrainian].

7. Sulima O. (2014) Teoretiko-metodolohichni zasady konkurentospromozhnisti pidpryyemstv [Theoretical and methodological principles of enterprise competitiveness] Elektronne naukove fakhove vydannia "Efektyvna ekonomika", [Online], vol.1, available at: http://www.economy.- nayka.com.ua/?op=1\&z=2675 (2017, October, 26) [in Ukrainian].

8. Kolomyitseva A.O., Holovan L.O. (2013) Otsinka konkurentnoyi dynamiky v umovakh vplyvu innovatsiyi [Assessment of competitive dynamics under the influence of innovations] Marketinh i menedzhment innovactiy, 2. 168-172 [in Ukrainian].

9. Uyrchyshyn V.V., Markevich K.L. (2015) Investytsiyna aktyvnist' u kraynakh Vyshehrads'koyi hrupy: vyklyky dlya Ukrayiny [Investment activity in the Visegrád countries: challenges for Ukraine] Mizhnarodna ekonomichna polityka, 2. 126-148 [in Ukrainian].

10. Ofitsiynyi sait Yevropeyckoyi Komisii [Official Website of the European Commission] <http://ec.europa.eu/index_en.htm > (2017, October, 23) [in Ukrainian].

11. Bilotserkovets V.V., Zavhorodnya V.K., Lebedyev (2012) Mizhnarodna ekonomika: monohrafiya [International Economics: monograph]. Kyiv: CUL, 416 [in Ukrainian].

12. Luk"yanenko D., Chuzhykov V., Vozhnyak M. ta in. (2010) Konverhentsiya ekonomichnykh modeley Pol'shchi ta Ukrayiny: monohrafiya [Convergence of Economic Models of Poland and Ukraine: monograph]. Kyiv: KNEU, 719 [in Ukrainian].

13. Spencer L James, Paul Gubbins, Christopher JL Murray and Emmanuela Gakidou (2012) Developing a comprehensive time series of GDP per capita for 210 countries from 1950 to 2015 [Official Website of Population Health Metrics] <https://doi.org/10.1186/1478-7954-10-12> (2017, October, 23) [in Ukrainian].

14. GDP per capita of Countries ratings [Official Website of IMF] <http://svspb.net/ danmark/vvp-stran-na-dushu-naselenija.php> (2017, October, 23) [in Ukrainian].

15. Index hlobal'noy konkurentosposobnosty. Humanytarnaya éntsyklopedyya.(2006-2017) [Global Competitiveness Index. Human encyclopedia] <http://gtmarket.ru/ratings/globalcompetitiveness-index/info>(2017, October, 28) [in Ukrainian].

16. The Global Competitiveness Report 2017-2018: Insight Report WEF (2017) [Official Website of WEF] < http://www3.weforum.org/docs/GCR2017-2018/05FullReport/TheGlobal CompetitivenessReport2017-2018.pdf> (2017,October, 23) [in Ukrainian]. 
17. Antonenko K., Batyulyeva A. (2011) Chynyky formuvannya mizhnarodnoyi konkurentospromozhnosti krain v umovakh hlobalizactii [Factors of formation of international competitiveness of countries in the conditions of globalization] Kultura narodov Prichepnomopya, 214. 10-13.

18. Khomenko O. (2016) Top-10 prichin, chomu Ukraina opustilas v hlobalnomu reytinhu konkurentospromozhnosti [Official Website of Khvylya] <http://hvylya.net/analytics/ economics/top-10-prichin-chomu-ukrayina-opustilas-v-globalnomu-reytingu-

konkurentospromozhnosti.html> (2017, October, 28) [in Ukrainian].

19. Verstyak O., Kelaru I. (2016) Tinizatsiya i konkurentospromozhnist' natsional'noyi ekonomiky Ukrainy [Shadowing and competitiveness of the Ukraine's national economy] International Scientific Journal , 2. 98-101. [in Ukrainian].

Савельєв С.B. доктор економічних наук, професор кафедри міжнародної економіки Тернопільського начіонального економічного університету

Куриляк В.Є. доктор економічних наук, професор, завідувач кафедри міжнародної економіки Тернопільського національного економічного університету

Куриляк Є.Ю. кандидат економічних наук, викладач кафедри міжнародних економічних відносин Тернопільського начіонального економічного університету

Куриляк М.Ю. аспірант кафедри міжнародної економіки

Тернопільського начіонального економічного університету

\section{РОЗВИТОК ПРОМИСЛОВИХ КЛАСТЕРІВ В КРАЇНАХ ВИШЕГРАДСЬКОЇ ЧЕТВІРКИ: ДОСВІД ДЛЯ УКРАЇНИ}

\section{1. Формування кластерної політики регіонів}

Регіональний розвиток в першу чергу залежить від використання власних ресурсів регіону. У цьому контексті важливим може бути вивчення кластерних форм промислової організації, які поширені, зокрема, у всій Європі. Загальновідомо, що кластерна політика в першу чергу орієнтована на розвиток малих та середніх підприємств, оскільки вони дають можливість вирішити проблеми з працевлаштуванням і залучити велику кількість працівників до інноваційної діяльності, активізуючи розвиток усього регіону.

У розвинутих країнах частка працівників, що працюють на таких підприємствах, досягає 50-70\%, а їх внесок у ВВП складає від 50 до 60\% ${ }^{1}$. Ці підприємства є основою для створення кластерних виробничих систем, які можуть використовувати традиційні переваги малого бізнесу, такі як: здатність

\footnotetext{
1 Bazylevych, V. D. (n.d.). Economic theory: Political economy. Retrieved from http://pidruchniki.ws/ 1299101039956/politekonomiya/klasifikatsiya_pidpriyemstv_rozmirom_maliy_biznes_novi_vidi_pidpriyemnitskoyi_ diyalnosti
} 
швидко реагувати на зміни умов ділового середовища, розширення меж економічної свободи, створення додаткових робочих місць, інноваційна діяльність i формування середнього класу. Інтеграція малих та середніх підприємств у кластери дозволяє отримувати переваги, які традиційно характерні для великомасштабного виробництва, серед яких варто виділити: збільшення фінансових можливостей для використання досягнень науковотехнічного прогресу та економії масштабу.

Зарубіжний досвід свідчить, що успішна реалізація кластерного підходу потребує розробки спеціальної національної програми, яка визначатиме стимули та підтримку кластерів у різних сферах економіки. В зв'язку 3 цим доцільно розглядати як традиційні підходи до створення локальних виробничих систем, широко інтерпретованих як агломерації, так i конкретні способи створення інноваційних кластерів світового рівня.

Програма аналізу економічних реформ в Україні (зокрема іiі регіональної політики), яка охоплює як поточні, так і майбутні періоди, показує, що малому бізнесу та кластеризації не приділяється належної уваги. Кластеризація - це нове економічне явище, яке стало механізмом, що дозволяє протистояти тиску світової конкуренції та формувати внутрішньодержавні та підприємницькі конкурентні переваги. Розробка державної програми кластеризації повинна чітко визначити рівень, на який вона орієнтована.

Оскільки кластерний підхід, насамперед, є управлінським методом інтеграції малих та середніх підприємств, це означає, що він повинен бути орієнтований на підвищення конкурентоспроможності регіону, де розташовані учасники кластеру. Саме через призму регіонів слід враховувати вплив кластеризації на розвиток промисловості та загалом всієї держави. Як правило, національні міністерства формулюють загальні стратегічні цілі, вони також визначають бюджетні цілі та приймають рішення про створення нових органів влади. Інші державні установи та регіональні органи влади також відіграють важливу роль у розробці програм та управлінні ними. Програми включають конкретні ініціативи, які реалізуються шляхом застосування інструментів на розсуд окремих регіонів або секторів. Важлива роль у цьому процесі належить інституціям, які розробляють ініціативи. Виходячи з цього, участь у розробці та реалізації кластерної політики беруть багато дійових осіб, координація дій яких, вимагає розробки ефективних механізмів їх взаємодії.

Для диференціації кластерної політики доцільно застосувати методологію, яка була розроблена експертами Свропейської кластерної обсерваторії. Суть іï полягає в тому, що подібно до класифікації готелів кластери позначаються зірками як вимір їх ефективності від нуля до одного, двох та трьох зірок залежно від розміру кластера, спеціалізації та фокусних показників.

Методологія присвоєння зірок європейським кластерам була проаналізована такими українськими дослідниками, як Бурмич, Лук'яненко, Панченко та Чужиков. Розмір кластера $є$ виміром його впливу на зайнятість. Його найвищий рівень повинен перевищувати 10\% від стандартизованого показника для провідних регіонів СС, і він розраховується як відношення кількості осіб, що працюють у кластері, до загальної кількості працівників, що працюють в

\footnotetext{
${ }^{1}$ Чужиков В. І. (2013р.). (Ред.). Технологічна модернізація в європейській економіці. [Монографія]. Київ, KHEУ
} 
ЄС. Спеціалізація в методології «зірки» визначається, якщо регіон в межах європейського розподілу праці виділяється у конкретній кластерній категорії серед провідних 10\% регіонів СС з найвищою зайнятістю у відповідній галузі. Третій показник - «фокус» - використовується для призначення зірки кластеру, якщо він складає основну частку регіональної зайнятості, зокрема, якщо кластер потрапляє до $10 \%$ схожих кластерів з найбільшою часткою зайнятості в цьому регіоні.

Для розвитку кластерної політики потрібні відповідні інформаційні системи. Вони можуть бути створені закладами, що спеціалізуються на інформаційній функції. Зокрема, в СС вихідні дані про кластери формуються за допомогою TrendChart INNO-Policy ${ }^{1}$ у співпраці з ERAWATCH ${ }^{2}$.

До цього часу було зареєстровано понад 130 національних заходів щодо підтримки кластерів ${ }^{3}$. У той же час розробляється нова схема збору інформації про кластерну політику. Основна увага приділяється наданню інформації про горизонтальні та вертикальні кластерні стратегії, а також програми фінансової підтримки кластерів.

Розробка кластерної політики для української економіки базується на досвіді, накопиченому протягом останніх десятиліть у країнах євроатлантичного простору, однак він ніколи не був системним за своїм характером. Українська література в основному аналізує окремі спроби створення мережевих структур у європейських країнах. 3 таким підходом важко очікувати досягнення належної реалізації найкращих світових практик.

Інший підхід розвинувся у країнах Центральної та Східної Європи. Таким чином, з 2002 року в Польщі відбувається систематичне дослідження розвитку кластерів 3 урахуванням досягнень розвинутих країн. Основна увага приділяється малим і середнім підприємствам, їх інноваційним можливостям та реалізації явища «Третя Італія». ${ }^{4}$

\section{2. Кластери в Польщі}

Наприкінці 2015 р. Польська агенція розвитку підприємництва (PARP) визначила більш ніж 130 кластерів у Польщі, які являють собою конкретні форми співпраці з географічно зосередженими установами та організаціями, переважно підприємствами, що працюють у тій самій або суміжній галузі.

Найстаріші кластери в Польщі існують більше 13 років, але більшість із них (понад 60\%) - це молоді структури, створені в період між 2011 та 2015 роками.

В усіх зазначених кластерах в загальній кількості налічується майже 6000 суб'єктів господарювання, 3 яких 78\% підприємств. Найбільша кількість кластерів діє в таких секторах: IКТ, енергетика/відновлювана енергетика та будівництво, а також у галузі охорони здоров'я. Значна кількість кластерів

\footnotetext{
${ }^{1}$ Innovation Cooperation (PRO INNO Europe $($ )). Retrieved from http://ec.europa.eu/enterprise/policies/ innovation/support/pro-inno/index_en.htm?fuseaction=page. display\&topicID $=52 \&$ parentID $=52$

${ }_{2}^{2}$ CORDIS. Community Research and Development Information Servic. Retrieved from http://cordis.europa.eu/ guidance/welcome_en.html

${ }^{3}$ DG Enterprise and industry report. Innovation Clusters in Europe: A statistical analysis and overview of current policy support, p. 17. Retrieved from http://www.central2013.eu/fileadmin/user_upload/Downloads/Tools_Resources/ Cluster.pdf

${ }^{4}$ PARP. (2010). Benchmarking klastrów w Polsce. Raport z badania. Warscawa, p. 13.
} 
представляють металургійну галузь, технології виробництва, туризм та бізнеспослуги ${ }^{1}$.

Для досягнення цілей кластерної політики, створено Польську групу 3 кластерної політики, у 2014 році Польська агенція розвитку підприємництва спільно 3 Міністерством економіки та зовнішніми експертами розробила комплекс критеріїв для визначення ключових національних кластерів. Методологія грунтувалася на аналізі наявних національних та міжнародних джерел для висвітлення критеріїв та вимог щодо перевірки, які на кінцевому етапі проходили консультації з міністерствами, установами та громадськістю.

Схема ключового національного кластеру була результатом поєднання очікувань до кращих кластерів у різних державах, особливо європейських, та фактичної ефективності польських кластерів.

Критерії стосуються наступних аспектів ${ }^{2}$ :

1) розмір та структура кластера (кількість учасників, особливо малого та середнього бізнесу та великих компаній);

2) зайнятість;

3) спільні дії учасників кластерів та внутрішня співпраця;

4) географічна концентрація учасників кластеру;

5) кластерна спеціалізація;

6) НДДКР;

7) інноваційна продуктивність;

8) ресурси (фізичні, людські, фінансові тощо);

9) наявність кластера та його компаній на зовнішніх ринках;

10) національне та міжнародне представлення кластера;

11) кластерні координаційні послуги та управління.

Процес призначення ключових національних кластерів організовується Міністерством економічного розвитку у співпраці 3 PARP. PARP несе відповідальність за заснування секретаріату Комітету з оцінки для належної роботи на кожному етапі процесу валідації ${ }^{3}$.

Положення та умови для Комітету з оцінки та процесу оцінки були визначені в основних національних кластерних правилах (табл. 1.1).

Таблиця 1.1

Список ключових національних кластерів у Польщі

\begin{tabular}{|c|c|c|c|c|c|}
\hline Назва кластера & $\begin{array}{c}\text { Галузь } \\
\text { промисловості }\end{array}$ & $\begin{array}{c}\text { Назва кластерної } \\
\text { організації } \\
\text { (координатор) }\end{array}$ & $\begin{array}{c}\text { Розташування } \\
\text { координатора } \\
\text { кластеру }\end{array}$ & $\begin{array}{c}\text { Статус } \\
\text { дійсний } \\
\text { до }\end{array}$ \\
\hline \multirow{2}{*}{1} & Авіаційна долина & Авіація & $\begin{array}{c}\text { Stowarzyszenie } \\
\text { Grupy } \\
\text { Przedsiębiorców } \\
\text { Przemysłu } \\
\text { Lotniczego «Dolina } \\
\text { Lotnicza» }\end{array}$ & Ря́шів & 30 \\
& & $\begin{array}{c}\text { вересеня } \\
2018\end{array}$ \\
\hline
\end{tabular}

\footnotetext{
${ }^{1}$ Ministry of Regional Development of the Republic of Poland (2011), Przewodnik Aktualizacji Strategii Rozwoju Województw, Warsaw

Innovative Strategies of Territorial Development of V4: Experience for Ukraine / Y. Savelyev, I. Lishchynskyy, M. Lyzun, K. Borsekova, M. Sokołowicz, K. Vitališova. - Ternopil: Terno-graf, 2016. - 216 p.

${ }_{3}$ PARP. (2010). Benchmarking klastrów w Polsce. Raport z badania. Warscawa, p. 13 
Продовження таблиці 1.1

\begin{tabular}{|c|c|c|c|c|c|}
\hline 2 & $\begin{array}{c}\text { Польський } \\
\text { алюмінієвий } \\
\text { кластер } \\
\end{array}$ & Металургія & $\begin{array}{l}\text { City Consulting } \\
\text { Institute Sp. z O.O. }\end{array}$ & Катовіце & $\begin{array}{c}30 \\
\text { вересеня } \\
2018 \\
\end{array}$ \\
\hline 3 & $\begin{array}{l}\text { Мазовійський } \\
\text { кластер IКТ }\end{array}$ & IKT & $\begin{array}{c}\text { Stowarzyszenie } \\
\text { Rozwoju Społeczno- } \\
\text { Gospodarczego } \\
\text { «Wiedza» }\end{array}$ & Варшава & $\begin{array}{c}30 \\
\text { вересеня } \\
2018\end{array}$ \\
\hline 4 & Interizon & IKT & Fundacja Interizon & Гданськ & $\begin{array}{c}30 \\
\text { вересеня } \\
2018\end{array}$ \\
\hline 5 & $\begin{array}{c}\text { Східний } \\
\text { будівельний } \\
\text { кластер }\end{array}$ & Будівництво & $\begin{array}{c}\text { Polskie } \\
\text { Stowarzyszenie } \\
\text { Doradcze i } \\
\text { Konsultingowe } \\
\end{array}$ & Білосток & $\begin{array}{c}30 \\
\text { вересеня } \\
2018\end{array}$ \\
\hline 6 & $\begin{array}{c}\text { Кластер обробки } \\
\text { металів }\end{array}$ & $\begin{array}{c}\text { виготовлення } \\
\text { машин,приладів } \\
\text { та інструментів } \\
\text { для промислово- } \\
\text { го використання }\end{array}$ & $\begin{array}{l}\text { Centrum Promocji } \\
\text { Innowacji i Rozwoju }\end{array}$ & Білосток & $\begin{array}{c}30 \\
\text { вересеня } \\
2018\end{array}$ \\
\hline 7 & $\begin{array}{c}\text { Зелена хімія } \\
\text { Західнопоморський } \\
\text { хімічний кластер }\end{array}$ & $\begin{array}{c}\text { хімічна } \\
\text { промисловість }\end{array}$ & $\begin{array}{c}\text { Stowarzyszenie } \\
\text { Zachodniopomorski } \\
\text { Klaster Chemiczny } \\
\text { «Zielona Chemia» }\end{array}$ & Щецін & $\begin{array}{c}30 \\
\text { вересеня } \\
2018\end{array}$ \\
\hline
\end{tabular}

Джерело: Польський інноваџійний портал http://www.pi.gov.pl/eng/chapter_95931.asp

\section{3. Кластери в Чехії}

На основі картографічних досліджень, проведених Abrhám \& Herget (2013) ${ }^{1}$, в Чеській Республіці було виявлено понад 70 нових кластерних ініціатив. 3 цих 62 ініціативи виявились функціональними. Відповідна інформація може бути отримана у випадку 46-ти кластерів (табл. 1.2).

Таблиця 1.2

\section{Огляд кластерних ініціатив у Чеській Республіці}

\begin{tabular}{|c|c|c|c|c|c|}
\hline Кластер & Спеціалізація & Члени & Кластер & Спеціалізація & Члени \\
\hline ABC Wood & $\begin{array}{c}\text { обробка дере- } \\
\text { вини, пилома- } \\
\text { теріали } \\
\end{array}$ & 7 & Czech Pellets & $\begin{array}{l}\text { оборобка } \\
\text { деревини }\end{array}$ & 54 \\
\hline $\begin{array}{l}\text { Кластер } \\
\text { технологій } \\
\text { безпеки } \\
\end{array}$ & $\begin{array}{l}\text { технології } \\
\text { безпеки }\end{array}$ & 31 & $\begin{array}{c}\text { Чеський } \\
\text { кластер } \\
\text { нанотехнологій } \\
\end{array}$ & нанотехнології & 13 \\
\hline Clutex & $\begin{array}{c}\text { технічний } \\
\text { текстиль }\end{array}$ & 26 & CGMC & $\begin{array}{c}\text { загальне } \\
\text { машинобудування }\end{array}$ & 75 \\
\hline $\begin{array}{l}\text { Чеський } \\
\text { кам’яний кластер }\end{array}$ & $\begin{array}{c}\text { нарізка, } \\
\text { формування, } \\
\text { обробка каменю }\end{array}$ & 19 & $\begin{array}{l}\text { Чеський IT } \\
\text { кластер }\end{array}$ & $\begin{array}{c}\text { інформаційні } \\
\text { технології }\end{array}$ & 41 \\
\hline $\begin{array}{l}\text { Чесько- } \\
\text { словацький } \\
\text { промисловий } \\
\text { кластер }\end{array}$ & $\begin{array}{l}\text { Інформаційні } \\
\text { технології, } \\
\text { інжиніринг }\end{array}$ & 34 & $\begin{array}{c}\text { Чеський } \\
\text { кластер зв`язку }\end{array}$ & $\begin{array}{c}\text { комунікація, } \\
\text { мобільний зв'язок, } \\
\text { мережа }\end{array}$ & 51 \\
\hline
\end{tabular}

\footnotetext{
${ }^{I}$ Abrhám, J., \& Herget, J. (2013). Identification, Current State and Development of Clusters in the Czech Republic. Mediterranean Journal of Social Sciences, 4(11), 144.
} 
Продовження таблиці 1.2

\begin{tabular}{|c|c|c|c|c|c|}
\hline CREA & $\begin{array}{c}\text { гідротехнічні } \\
\text { споруди, } \\
\text { енергетика } \\
\end{array}$ & 19 & IKT кластер & $\begin{array}{l}\text { інформаційні } \\
\text { технології }\end{array}$ & 12 \\
\hline Atomex Group & $\begin{array}{c}\text { атомна } \\
\text { енергетика }\end{array}$ & 16 & Czech Bio & біотехнології & 37 \\
\hline $\begin{array}{l}\text { Чеський } \\
\text { пивоварний } \\
\text { кластер } \\
\end{array}$ & $\begin{array}{c}\text { виробництво } \\
\text { пива }\end{array}$ & 15 & ENVICRACK & $\begin{array}{c}\text { джерела } \\
\text { альтернативної } \\
\text { енергії }\end{array}$ & 28 \\
\hline ELECTRA-CITY & міська логістика & 23 & EKOGEN & $\begin{array}{l}\text { екологічні } \\
\text { споруди }\end{array}$ & 16 \\
\hline HIT Cluster & $\begin{array}{c}\text { інформаційні } \\
\text { технології }\end{array}$ & 18 & IQ Cluster & $\begin{array}{c}\text { інформаційні } \\
\text { технології }\end{array}$ & 22 \\
\hline IT кластер & $\begin{array}{c}\text { інформаційні } \\
\text { технології }\end{array}$ & 39 & $\begin{array}{l}\text { ENERGO } \\
\text { Cluster }\end{array}$ & Енергетика & 16 \\
\hline $\begin{array}{l}\text { ERGOMED } \\
\text { Cluster }\end{array}$ & $\begin{array}{c}\text { ергономіка, } \\
\text { протезування }\end{array}$ & 22 & $\begin{array}{c}\text { Cluster } \\
\text { BIOGAS }\end{array}$ & $\begin{array}{c}\text { виробництво } \\
\text { промислових газів }\end{array}$ & 16 \\
\hline $\begin{array}{l}\text { Кластер } \\
\text { деревообробки - } \\
\text { Південна Чехія }\end{array}$ & обробка деревини & 12 & $\begin{array}{l}\text { Vysocina } \\
\text { Precision } \\
\text { Engineering } \\
\text { Cluster } \\
\end{array}$ & $\begin{array}{c}\text { виробництво } \\
\text { машин та } \\
\text { устаткування }\end{array}$ & 17 \\
\hline KLACR & туризм & 39 & NUTRIPOL & $\begin{array}{c}\text { харчова } \\
\text { промисловість }\end{array}$ & 15 \\
\hline $\begin{array}{l}\text { Чеський } \\
\text { столярний } \\
\text { кластер }\end{array}$ & $\begin{array}{c}\text { виробництво } \\
\text { меблів }\end{array}$ & 38 & $\begin{array}{c}\text { Cluster } \\
\text { Mechatronic }\end{array}$ & мехатроніка & 14 \\
\hline OMNIPACK & $\begin{array}{c}\text { виробництво } \\
\text { картонно- } \\
\text { продуктів } \\
\end{array}$ & 57 & $\begin{array}{l}\text { Зелений } \\
\text { кластер }\end{array}$ & $\begin{array}{c}\text { послуги } 3 \\
\text { управління } \\
\text { відходами } \\
\end{array}$ & 39 \\
\hline $\begin{array}{l}\text { Кластер } \\
\text { управління } \\
\text { знаннями }\end{array}$ & підприємництво & 31 & $\begin{array}{c}\text { Моравсько- } \\
\text { сілезський } \\
\text { енергетичний } \\
\text { кластер } \\
\end{array}$ & енергетика & 21 \\
\hline $\begin{array}{l}\text { Моравсько- } \\
\text { сілезький } \\
\text { автомобільний } \\
\text { кластер }\end{array}$ & $\begin{array}{c}\text { виробництво } \\
\text { деталей та } \\
\text { автотранспортних } \\
\text { засобів }\end{array}$ & 64 & $\begin{array}{c}\text { Моравсько- } \\
\text { сілезький } \\
\text { деревообробний } \\
\text { кластер }\end{array}$ & обробка деревини & 28 \\
\hline NANOPROGRES & нанотехнології & 20 & MedChemBio & біомедицина & 26 \\
\hline $\begin{array}{l}\text { Чеський } \\
\text { апаратний } \\
\text { кластер }\end{array}$ & $\begin{array}{c}\text { виробництво } \\
\text { кінцевого } \\
\text { машинного } \\
\text { обладнання }\end{array}$ & 66 & $\begin{array}{c}\text { Кластер } \\
\text { моніторингу } \\
\text { мережевої } \\
\text { безпеки }\end{array}$ & $\begin{array}{c}\text { інформаційні } \\
\text { техногії }\end{array}$ & 20 \\
\hline $\begin{array}{l}\text { Моравський } \\
\text { лісовий кластер }\end{array}$ & $\begin{array}{l}\text { лісництво та } \\
\text { лісозаготівля }\end{array}$ & 13 & NutriKlastr & $\begin{array}{c}\text { продукти } \\
\text { харчування }\end{array}$ & 23 \\
\hline $\begin{array}{l}\text { Регіональний } \\
\text { продовольчий } \\
\text { кластер }\end{array}$ & $\begin{array}{c}\text { харчова } \\
\text { промисловість }\end{array}$ & 19 & $\begin{array}{l}\text { Кластер } \\
\text { пластмас }\end{array}$ & $\begin{array}{c}\text { виробництво } \\
\text { пластмасових } \\
\text { виробів } \\
\end{array}$ & 34 \\
\hline $\begin{array}{l}\text { Промисловий } \\
\text { кластер }\end{array}$ & $\begin{array}{c}\text { обробна } \\
\text { промисловість }\end{array}$ & 11 & NIPAS & $\begin{array}{c}\text { низькоенергетичні } \\
\text { та пасивні } \\
\text { будинки }\end{array}$ & 13 \\
\hline
\end{tabular}

Джерело: Abrhám, J., \& Herget, J. (2013). Identification, Current State and Development of Clusters in the Czech Republic. Mediterranean Journal of Social Sciences, 4(11), 144. 
Виявлені кластери розподіляються досить нерівномірно 3 точки зору їх розташування. Більшість кластерів розташовані в регіоні Моравія-Сілезія (12) і найменше в областях Прага (1) i Пльзень (1). Більше 50\% кластерів розташовано в трьох регіонах (Моравія-Сілезія, Південна Чехія та Південна Моравія).

3 точки зору галузевої спрямованості, кластерні ініціативи включають наступні сектори: харчова промисловість, машинобудування, текстиль, харчова промисловість, інформаційні технології, мехатроніка, пластмаса, упаковка, поновлювані джерела енергії, біотехнологія, нанотехнології, туризм, біомедицина тощо. Більшість кластерів активні у галузях інформаційних технологій (6), енергетики (6) та деревообробної промисловості ${ }^{1}$.

Потужні кластери виникли в таких переробних галузях, як машинобудування, точне та загальне машинобудування, технічний текстиль, пластмаси, упаковка та деревообробка; у різних галузях техніки, таких як екологічні технології, біотехнології, відновлювані джерела енергії; нанотехнології або ІКТ.

\section{4. Кластери в Словаччині}

Кластери в Словаччині сформувалися або спонтанно, використовуючи специфічні особливості, потенціал або джерела регіонів, або утворилися навколо багатонаціональних фірм (як правило, вони також $\epsilon$ найбільш важливим джерелом прямих іноземних інвестицій для приймаючого регіону, а також для всієї Словаччини вцілому), які вирішили інвестувати в Словаччину (наприклад, автомобільні кластери в Трнаві, Братиславі та Жиліні). Їх підприємницька діяльність залучила багато інших фірм, особливо субпідрядних, як частину власного ланцюга цінностей ${ }^{2}$.

Більшість кластерів мають характер технологічних, туристичних або кластерів знань. В останні роки також спостерігається формування кластерів у творчих галузях, де важливу роль відіграє Братиславська область. Це один 3 провідних європейських регіонів з точки зору концентрації зайнятості в творчій галузі. У цьому секторі зайнято близько 5\% працівників, що вказує на значну спеціалізацію. Крім того, близько 46\% усіх підприємств у креативних галузях розташовані у Братиславській області та близько 91\% безпосередньо у Братиславі. В даний час найбільш перспективними секторами креативної індустрії вважаються проектування та програмне забезпечення ${ }^{3}$.

Кластери, на відміну від інших типів об'єднань, у Словаччині не можуть бути офіційно визначеними як юридичні особи i функціонують на неофіційній основі. Правова форма бізнес-кластерів у світі визначається індивідуальним законодавством, яке діє в кожній країні. Це законодавство також відрізняється в країнах-членах Європейського Союзу. У Словаччині спеціального законодавства про бізнес-кластери не існує, при цьому у словацькому законодавстві немає терміну «кластер». Таким чином, якщо

\footnotetext{
${ }^{1}$ Ministery of Industry and Trade, Czech Republic (2013): Cluster Organisations in the Czech Republic. Prague.

2 Barca F., (2009), An agenda for a reformed cohesion policy. A place-based approach to meeting European Union challenges and expectations. Independent Report prepared at the request of Danuta Hübner, Commissioner for Regional Policy

Ministerstvo Hospodárstva Slovenskej Republiky. (2013) Stratégia výskumu a inovácií pre inteligentnú špecializáciu Slovenskej republiky. [Online] Available from: file:///D:/SK_RIS3\%20(3).pdf [Accessed: 16th November 2014]
} 
фірми в Словаччині хочуть формально організувати кластери, то вони повинні вибирати свої юридичні форми в рамках вже існуючого законодавства. Виходячи з цього, кластерні організації чи офіційні кластерні ініціативи в країні можуть набирати форми об'єднання юридичних осіб або об'єднання громадян, які зареєстровані в Реєстрі профільних об'єднань юридичних осіб або в Відомствах громадянських асоціацій, і регулюються Цивільним кодексом (Закон № 40/1964 Coll., Цивільний кодекс 3 поправками) та актом про об'єднання громадян (Закон № 83/1990 3б. про Асоціацію громадян із змінами). Проте законодавство цих асоціацій є загальним i не враховує жодної специфіки кластерних ініціатив ${ }^{1}$.

Юридично існуючі кластерні організації в Словаччині (включаючи як активні, так і неактивні ініціативи) наведені в таблиці нижче (табл. 1.3). Здебільшого вони працюють в галузях автомобільної промисловості, IT-технологій, електронної промисловості, енергетичної галузі (найважливіші галузі з точки зору ПІІ Словацької Республіки) та туризму.

Таблиця 1.3

Кластерні ініціативи в Словаччині

\begin{tabular}{|c|c|c|c|}
\hline $\begin{array}{c}\text { Офіційна назва кластера } \\
\text { (Словацькою) }\end{array}$ & $\begin{array}{c}\text { Офіційна назва кластера } \\
\text { (Англійською) }\end{array}$ & Perion & $\begin{array}{c}\text { Рік } \\
\text { заснування }\end{array}$ \\
\hline BITERAP & BITERAP & Кошицький край & 2004 \\
\hline $\begin{array}{l}\text { Automobilovy klaster } \\
\text { Slovensko }\end{array}$ & $\begin{array}{l}\text { Automotive Cluster } \\
\text { Slovakia }\end{array}$ & Трнавський край & 2007 \\
\hline Kosice IT Valley & Kosice IT Valley & Кошицький край & 2007 \\
\hline $\begin{array}{l}\text { ABC - Academic Business } \\
\text { Cluster }\end{array}$ & $\begin{array}{l}\text { ABC - Academic Business } \\
\text { Cluster }\end{array}$ & $\begin{array}{l}\text { Братиславський } \\
\text { край }\end{array}$ & 2007 \\
\hline Z@aict & Z@aict & $\begin{array}{l}\text { Жилінський } \\
\text { край }\end{array}$ & 2008 \\
\hline $\begin{array}{l}\text { Zdruzenie cestovneho ruchu } \\
\text { Balnea }\end{array}$ & $\begin{array}{l}\text { Turism association Balnea } \\
\text { Cluster }\end{array}$ & $\begin{array}{l}\text { Банська } \\
\text { Бистриця }\end{array}$ & 2008 \\
\hline 1. slovensky strojarsky klaster & $\begin{array}{l}\text { 1st Slovak Engineering } \\
\text { Cluster }\end{array}$ & $\begin{array}{l}\text { Банська } \\
\text { Бистриця }\end{array}$ & 2008 \\
\hline $\begin{array}{l}\text { Elektrotechnicky klaster - } \\
\text { zapadne Slovensko }\end{array}$ & $\begin{array}{l}\text { Electrotechnical Cluster - } \\
\text { West Slovakia }\end{array}$ & Трнавський край & 2008 \\
\hline $\begin{array}{l}\text { Klaster cestovneho ruchu - } \\
\text { zapadne Slovensko }\end{array}$ & $\begin{array}{l}\text { Cluster of Turism - West } \\
\text { Slovakia }\end{array}$ & Трнавський край & 2008 \\
\hline $\begin{array}{l}\text { Klaster LIPTOV - zdruzenie } \\
\text { cestovneho ruchu }\end{array}$ & $\begin{array}{l}\text { Cluster LIPTOV - } \\
\text { association of turism }\end{array}$ & Трнавський край & 2008 \\
\hline $\begin{array}{l}\text { Energeticky klaster - zapadne } \\
\text { Slovensko }\end{array}$ & $\begin{array}{l}\text { Energetic Cluster - West } \\
\text { Slovakia }\end{array}$ & Трнавський край & 2009 \\
\hline $\begin{array}{l}\text { Klaster TURIEC - zdruzenie } \\
\text { cestovneho ruchu }\end{array}$ & $\begin{array}{l}\text { Cluster TURIEC - } \\
\text { association of turism }\end{array}$ & $\begin{array}{l}\text { Жилінський } \\
\text { край }\end{array}$ & 2009 \\
\hline Slovensky plastikarsky klaster & Slovak Plastic Cluster & $\begin{array}{l}\text { Нітранський } \\
\text { край }\end{array}$ & 2009 \\
\hline Klaster ORAVA & Cluster Orava & $\begin{array}{l}\text { Жилінський } \\
\text { край }\end{array}$ & 2009 \\
\hline Dunajsky vedomostny klaster & Danube Knowledge Cluster & $\begin{array}{l}\text { Братиславський } \\
\text { край }\end{array}$ & 2010 \\
\hline
\end{tabular}

${ }^{1}$ Kicova, E. et al. (2014). The Cluster Initiatives (No. 0902966). International Institute of Social and Economic Sciences. 
Продовження таблиці 1.3

\begin{tabular}{|c|c|c|c|}
\hline $\begin{array}{l}\text { Energeticky klaster } \\
\text { CENTROPE }\end{array}$ & $\begin{array}{l}\text { Energetic Cluster } \\
\text { CENTROPE }\end{array}$ & Трнавський край & 2010 \\
\hline Klaster AT+R & Cluster AT+R & Кошицький край & 2010 \\
\hline Klaster pohranicnych hradov & Cluster of Border Castles & $\begin{array}{l}\text { Банська } \\
\text { Бистриця }\end{array}$ & 2010 \\
\hline Klaster Smolenice & Smolenice Cluster & Трнавський край & 2010 \\
\hline $\begin{array}{l}\text { Klaster cestovneho ruchu } \\
\text { Kosice Turizmus }\end{array}$ & $\begin{array}{l}\text { Cluster of Turism Kosice } \\
\text { Turism }\end{array}$ & Кошицький край & 2010 \\
\hline Stavebmcky klaster Slovenska & Construction Cluster Slovakia & Трнавський край & 2010 \\
\hline $\begin{array}{l}\text { Klaster HOREHRONIE - } \\
\text { zdruzenie cestovneho ruchu }\end{array}$ & $\begin{array}{l}\text { Cluster HOREHRONIE - } \\
\text { association of turism }\end{array}$ & $\begin{array}{l}\text { Банська } \\
\text { Бистриця } \\
\end{array}$ & 2011 \\
\hline $\begin{array}{l}\text { Energeticky klaster } \\
\text { Presovskeho kraja }\end{array}$ & $\begin{array}{l}\text { Energetic Cluster of region } \\
\text { Presov }\end{array}$ & $\begin{array}{l}\text { Пресовський } \\
\text { край }\end{array}$ & 2012 \\
\hline $\begin{array}{l}\text { Klaster pre podporu } \\
\text { inovatlvnych a zelenych } \\
\text { technology }\end{array}$ & $\begin{array}{l}\text { Cluster for Green and } \\
\text { Innovative Technologies } \\
\text { Support }\end{array}$ & Трнавський край & 2012 \\
\hline Klaster TOPOECANY & Cluster Topol'cany & Нітранський край & 2012 \\
\hline $\begin{array}{l}\text { Narodny energeticky klaster } \\
\text { NEK }\end{array}$ & $\begin{array}{l}\text { National Energetic Cluster } \\
\text { NEK }\end{array}$ & $\begin{array}{l}\text { Братиславський } \\
\text { край }\end{array}$ & 2012 \\
\hline $\begin{array}{l}\text { KlTech klaster inovacnych } \\
\text { technology pre nakladanie s } \\
\text { prasnymi anorganickymi } \\
\text { odpadmi }\end{array}$ & $\begin{array}{l}\text { KlTech Cluster of Innovation } \\
\text { Technologies for the } \\
\text { Handling with Dusty } \\
\text { Inorganic Waste }\end{array}$ & Тренклен & 2012 \\
\hline Klaster MONOCRYSTAL & Cluster MONOCRYSTAL & Жилінський край & 2013 \\
\hline Slovak IT klaster & Slovak IT Cluster & Тренклен & 2013 \\
\hline $\begin{array}{l}\text { Trnavsko-myjavsky strojarsky } \\
\text { klaster }\end{array}$ & $\begin{array}{l}\text { Trnavsko-myjavsky } \\
\text { engineering cluster }\end{array}$ & Трнавський край & 2013 \\
\hline $\begin{array}{l}\text { Klaster pre akumulacie } \\
\text { energie z OZE }\end{array}$ & $\begin{array}{l}\text { Cluster for Energy Storage of } \\
\text { RE }\end{array}$ & Нітранський край & 2013 \\
\hline 1. spissky klaster & 1st Cluster of Spis & Кошицький край & 2014 \\
\hline Klaster Huculska magistrala & Claster Hucuslka magistrala & $\begin{array}{l}\text { Банська } \\
\text { Бистриця }\end{array}$ & 2014 \\
\hline $\begin{array}{l}\text { EMOCITY - Klaster pre } \\
\text { elektromobilitu a smart city }\end{array}$ & $\begin{array}{l}\text { EMOCITY - Cluster for E- } \\
\text { mobility and Smart City }\end{array}$ & $\begin{array}{l}\text { Братиславський } \\
\text { край }\end{array}$ & 2014 \\
\hline Potravinarsky klaster & Food Cluster & Нітранський край & 2014 \\
\hline Zeleznicny dopravny klaster & Railway Transport Cluster & $\begin{array}{l}\text { Пресовський } \\
\text { край }\end{array}$ & 2014 \\
\hline
\end{tabular}

Джерело: Kicova, E. et al. (2014). The Cluster Initiatives (No. 0902966). International Institute of Social and Economic Sciences.

\section{5. Кластери в Угорщині}

У Угорщині існує більше 180 ділових мереж, які визначають себе як кластери. Це число більше, ніж сукупна кількість самостійно визначених кластерних організацій у всіх сусідніх країнах Угорщини. У той же час угорська «популяція» кластерних організацій характеризується «високим рівнем народжуваності» як i «високим рівнем смертності». У багатьох консорціумах рівень активності та зміст міжфірмового співробітництва різняться в часі. Переважна більшість кластерних організацій були організовані для реалізації періодичних проектів, а між цими інтервалами бізнес-мережа 
неактивна ${ }^{1}$. Однак серед таких кластерних організацій в кінцевому підсумку сформувалась дуже помітна, активна та успішна еліта кластерів, особливо в фармацевтичній, біотехнологічній, екологічній, галузевій та інформаційнокомунікаційних галузях (табл. 1.4).

Таблиця 1.4

Основні кластери в Угорщині

\begin{tabular}{|c|c|c|c|}
\hline $\begin{array}{c}\text { Регion } \\
\text { NUTS-2 }\end{array}$ & Назва & Місто & Галузь \\
\hline \multirow[t]{9}{*}{$\begin{array}{l}\text { Дель- } \\
\text { Альфотл }\end{array}$} & $\begin{array}{l}\text { 3Р кластер (пластмасова } \\
\text { промисловість, пакувальна } \\
\text { промисловість, полімерна } \\
\text { промисловість) }\end{array}$ & Kecskemét & Пластмаса, упаковка \\
\hline & $\begin{array}{l}\text { Аргенгер регіональний } \\
\text { відновлюваний енергетичний та } \\
\text { будівельний кластер }\end{array}$ & Szeged & $\begin{array}{l}\text { Захист } \\
\text { навколишнього } \\
\text { середовища }\end{array}$ \\
\hline & Обробка кластеру біомаси & Szeged & $\begin{array}{l}\text { Текстильна } \\
\text { промисловість }\end{array}$ \\
\hline & $\begin{array}{l}\text { Dél-alföldi Regionális Textilipari } \\
\text { Klaszter }\end{array}$ & Hódmezõvásárhely & $\begin{array}{l}\text { Текстильна } \\
\text { промисловість }\end{array}$ \\
\hline & Гудвіл Біотехнологічний кластер & Szeged & Біотехнології \\
\hline & Hod Iparos Klaszter & Hódmezõvásárhely & $\begin{array}{l}\text { Машинне } \\
\text { устаткування }\end{array}$ \\
\hline & PharmacoFood Cluster & Szeged & Біотехнології \\
\hline & $\begin{array}{l}\text { Південний великий рівнинний } \\
\text { дорожньо-будівельний кластер }\end{array}$ & Szeged & Будівництво \\
\hline & $\begin{array}{l}\text { Szoftveripari Innovációs Pólus } \\
\text { Klaszter }\end{array}$ & Szeged & IKT \\
\hline \multirow{4}{*}{$\begin{array}{l}\text { Дель- } \\
\text { Дунантул }\end{array}$} & Biotechnológiai Innovációs Bázis & Pécs & Біотехнології \\
\hline & \begin{tabular}{|l|} 
Interregionális Megújuló Energia \\
Klaszter Egyesület
\end{tabular} & Pécs & $\begin{array}{l}\text { Відновлювальна } \\
\text { енергетика }\end{array}$ \\
\hline & $\begin{array}{l}\text { Південна придунауйська } \\
\text { культурна індустрія кластерів }\end{array}$ & Pécs & Науково-дослідна \\
\hline & \begin{tabular}{|l} 
Південний дунайський \\
енергетичний кластер
\end{tabular} & Pécs & Енергетика \\
\hline \multirow[t]{3}{*}{$\begin{array}{l}\text { Есзак- } \\
\text { Альфолд }\end{array}$} & INNOVA Észak-Alföld & Debrecen & \begin{tabular}{|l} 
Освіта, захист \\
навколишнього \\
середовища \\
\end{tabular} \\
\hline & Opto Mechatronikai Klaszter & Nyíregyháza & Оптика \\
\hline & Фармаполіс Дебрецен & Debrecen & Фармацевтика \\
\hline \multirow[t]{3}{*}{$\begin{array}{l}\text { Есзак- } \\
\text { Мадьярсзаг }\end{array}$} & $\begin{array}{l}\text { ENIN environmental Industry } \\
\text { Cluster }\end{array}$ & Miskolc & \begin{tabular}{|l} 
Захист \\
навколишнього \\
середовища \\
\end{tabular} \\
\hline & Miskolc Holding & Miskolc & Будівництво \\
\hline & Північно-угорський IT-кластер & $\begin{array}{l}\text { Miskolc- } \\
\text { Egyetemváros }\end{array}$ & IKT \\
\hline
\end{tabular}

${ }^{1}$ Lishchynskyy I. Agglomerationsformen der internationalen Wirschafts- und Raumintegration.// The world economy. Global and country-specific aspects. Berlin, 2014. - P. 190-203. 
Продовження таблиці 1.4

\begin{tabular}{|c|c|c|c|}
\hline \multirow[t]{4}{*}{$\begin{array}{l}\text { Козпе- } \\
\text { Дунантул }\end{array}$} & $\begin{array}{l}\text { Автомобільний Консалтинг } \\
\text { Кластер }\end{array}$ & Budapest & Атомобілебудування \\
\hline & $\begin{array}{l}\text { Кластер «деревообробна та } \\
\text { меблева промисловість» }\end{array}$ & Székesfehérvár & Деревообробна \\
\hline & $\begin{array}{l}\text { Közép-dunántúli Regionális } \\
\text { Informatikai Klaszter }\end{array}$ & Székesfehérvár & IKT \\
\hline & Фармагор якість життя кластер & Balatonfüred & Біомедицина \\
\hline \multirow{6}{*}{$\begin{array}{l}\text { Козеп- } \\
\text { Мадьярсзаг }\end{array}$} & Угорський аерокластер & Budapest & Літакобудування \\
\hline & $\begin{array}{l}\text { Hungarian Medical Instruments } \\
\text { Producers and Service Providers } \\
\text { Cluster }\end{array}$ & Budapest & Медичне обладнання \\
\hline & $\begin{array}{l}\text { Медичний біотехнологічний } \\
\text { кластер }\end{array}$ & Budapest & Біотехнології \\
\hline & Mobility and MultiМедіа Cluster & Budapest & IKT \\
\hline & Omnipack & Budapest & Пакування \\
\hline & $\begin{array}{l}\text { Технологія переробки відходів } \\
\text { інноваційний кластер }\end{array}$ & Budapest & $\begin{array}{l}\text { Збереження водних } \\
\text { ресурсів }\end{array}$ \\
\hline \multirow{9}{*}{$\begin{array}{l}\text { Нюгат- } \\
\text { Дунантул }\end{array}$} & PanLog & Szombathely & Логістика \\
\hline & Pannon Automotive Cluster & Gyõr & Автомобілебудування \\
\hline & Pannon Local Product Cluster & Vasvár & $\begin{array}{l}\text { Сільське } \\
\text { господарство }\end{array}$ \\
\hline & Pannon Mechatronics Cluster & Zalaegerszeg & Мехатроніка \\
\hline & Pannon Textile Cluster & Szombathely & Текстиль \\
\hline & Pannon Thermal Cluster & Bükfürdõ & Туризм \\
\hline & Pannon Wood and Furniture & Zalaegerszeg & Деревообробка \\
\hline & Sopron Regional Logistics Cluster & Sopron & Логістика \\
\hline & Észak-alföldi Informatikai Klaszter & Debrecen & IKT \\
\hline
\end{tabular}

Джерело: Свропейська кластерна обсерваторія

Співпраця всередині кластерів мотивована комерційними відносинами шляхом існування та використання загальної бази знань для інновацій. Компанії та інші організації, що створюють кластери, запустили різні проекти для спільного використання ресурсів, для участі у цільовому ланцюжку, отримання нових ринків або спільного впровадження їхніх інтересів у місцевому або центральному урядах ${ }^{1}$.

Само-ідентифікація і місія кластерів є надзвичайно важливою. Кластери, в яких неадекватно визначені масштаби та форма співпраці, $\epsilon$ вразливими. Відсутність послідовної ідентичності кластерів може зменшити професіоналізм співпраці та призвести до втрати довіри серед фірм. Серед досліджених кластерів сегментація може розвинутися, якщо певні окремі підгрупи розвиваються на основі певної промислової/професійної культури, або якщо деякі з найбільших компаній-членів кластера розвиватимуть зв'язки постачаль-

1 Ліщинський І. Інноваційні форми агломерації виробництва: кластери та креативні регіони // Вісник Тернопільського національного економічного університету. - 2010. - Вип. 5-1. - 494 с. C. 158-166. 
ників лише з окремою частиною учасників. Особливо це стосується класичного сектора виробництва, де в кластері часто містяться кілька фірм-учасниць конкурентів. Взаємна довіра, швидше за все, руйнується під час кризи або у випадку скорочення зовнішніх ресурсів.

Більшість досліджених груп відносяться до певного регіону Угорщини. Зокрема, приблизно дві третини кластерів вважають себе регіонально орієнтованими: у таких випадках більшість членів знаходяться в одному регіоні. Підприємства екологічної та енергетичної промисловості, IT та телекомунікаційного сектора, сектору біотехнології та охорони здоров'я та деяких відібраних галузей виробництва (пластмаси, текстилю, деревини, автомобільних продуктів) створили кластери 3 відчутною професійною приналежністю. Кластери з сильним галузевим/професійним обов'язком часто демонструють відсутність приналежності до певного регіону. Кластери, організовані на галузевому/професійному рівні, є більш ефективними та більш стійкими, ніж ті, які організовані на сильній регіональній основі.

Кластери, в яких переважає одна чи дві «флагманські» компанії, називаються централізованими. Такі мережі - це або ієрархія субпідряду, або мережі, організовані навколо спільних проектів 3 досліджень та розробок, де учасники мають нерівний доступ до ноу-хау. Централізоване формування кластерів можна знайти в першу чергу в секторах IT та біотехнологій. У більшості випадків той факт, що деякі компанії в межах мережі мають монополію у конкретному ноу-хау чи фінансах, може пояснити їхню домінуючу позицію.

Кластери називаються сегментованими, якщо в межах мережі формуються кілька підгруп, в яких співпраця є задовільною, але зв'язки між підгрупами $є$ слабкими, випадковими або зовсім відсутніми. Сегментовані кластери спостерігаються, але не дуже часто.

Характеристики мережі є основним фактором успіху чи занепаду кластера. Консорціуми, побудовані навколо «флагманських» фірм, мають більше шансів на успіх, особливо якщо компанії-учасниці інтегровані певною професійною культурою. Сегментовані кластери, як правило, менш стійкі, ніж традиційні кластери. Кластери можуть гнучко адаптуватися до змін у ринкових умовах, до варіацій бізнес-циклу або бізнес-середовища, створюючи нові підгрупи в мережі, здатні запускати нові проекти, для повторного використання результатів попередніх проектів. Дійсно, здатність реорганізувати структуру мережі $\epsilon$ найважливішим критерієм ефективної адаптації в рамках певного кластера.

Інноваційні заходи $\epsilon$ важливими елементами ефективності кластерів. У багатьох випадках дослідження та розробки не впроваджуються самими кластерним організаціям, але одним із ії учасників, наприклад, університетським відділенням. Той факт, що науково-дослідний інститут або університет є членом кластеру, сам по собі не гарантує інноваційної діяльності в кластері; часто на практиці у багатьох випадках спостерігається зворотне. Близько половини кластерів беруть участь у розповсюдженні інновацій, навіть якщо один із учасників кластеру не взяв участь у розробці конкретного інноваційного продукту, технології або сервісу. Інновації, втілені в деяких продуктах або 
технологіях, спостерігались набагато частіше, ніж інновації абстрактного, менш відчутного характеру, такі як організаційні та сервісні інноваці1̈

Кластерна політика в Угорщині може розглядатись як частина політики регіонального розвитку, політики розвитку підприємництва або інноваційної політики. Основною метою кластерної політики $\epsilon$ сприяння розвитку та функціонуванню спільних мереж серед (а) компаній та (б) між компаніями та іншими організаціями, такими як професійні асоціації, науково-дослідні інститути. Негативні побічні ефекти кластерних субсидій значно менші, ніж наслідки прямих субсидій окремим фірмам. Остання стратегія часто дає штучні переваги окремим компаніям шляхом вибору переможців конкурсу.

Кластерна акредитація $є$ інноваційним елементом угорської кластерної політики, що покращує конкурентну позицію перспективних кластерів. Акредитація також необхідна для того, щоб відрізнити ці угорські кластери, від інших мереж, таких як тимчасові консорціуми та проектні організації․

\section{6. Пріоритети формування інноваційних кластерів у регіонах України}

Сьогодні для України є перспективною та необхідною розробка програм кластеризації в таких сферах, як інформаційні та брокерські послуги; технічна допомога та консультації; пряме фінансування; організація офіційних та тренувальних заходів; організація мережевих подій; лобіювання; маркетинг; моніторинг та звітність. Ці програми можуть створювати підстави для досягнення таких цілей, як підвищення кваліфікації, розширення кластерів, розвиток бізнесу, поглиблення та розширення ділової співпраці; інновації, використання та вдосконалення умов ділового середовища.

Слід підкреслити, що представлення інформації для розробки та впровадження процесів кластерної політики є досить складним завданням, для поліпшення якого необхідно знайти та випробувати нові ефективні методи. При цьому слід враховувати, що політика для конкретного кластера може охоплювати широке коло різних завдань та заходів, які отримують його підтримку. Джерелами для цього можуть бути «м'які політичні» заходи, спрямовані на полегшення самоорганізації через різні мережі та обмін інформацією.

Не можна виключити застосування «жорстких» горизонтальних каналів, які регіональні органи влади встановлюють на кластери (це часто можна пояснити, зв'язавшись із жорсткістю фінансової політики).

Структура кластерної політики повинна відображати переваги такої інтеграції учасникам новоствореної виробничої мережі. Досвід компаній, що працюють на євроатлантичному просторі, показує, що конкурентоспроможність кластерів в цілому та їхніх учасників зокрема, зростає завдяки синергетичним ефектам, що виникають внаслідок розподілу ресурсів, посилення ринкової активності, підвищення продуктивності та можливості накопичення потенціалу на майбутнє.

Економічна політика у сфері кластеризації має базуватися на тому, що кластери як форма регіональної та інноваційної організації повинні відповідати адекватним фінансовим та інфраструктурним ресурсам. Останні повинні бути

\footnotetext{
1 Ліщинський I. Інноваційні форми агломерації виробництва: кластери та креативні регіони// Вісник Тернопільського національного економічного університету. - 2010. - Вип. 5-1. - 494 с. - C. 158-166

Futó, P. (2014). The network structure of Hungarian business clusters. Vezetéstudomány/Budapest Management Review, 45(1), 41-54.
} 
сформовані нетрадиційними ресурсами компанії. Як правило, це внутрішні та зовнішні фонди або інвестиції, що беруть участь у спільному фінансуванні проекту. 3 точки зору інфраструктури, кластери можуть мати доступні офісні приміщення, конференц-зали, внутрішні комунікаційні мережі та лабораторії. Важливо гарантувати, що ресурсний потенціал не $\epsilon$ одноразовим, але доступний для загального використання учасників кластерів у довгостроковій перспективі ${ }^{1}$.

Навіть незважаючи на те, що підприємства та організації, які приєднуються до виробничих мереж у кластерних утвореннях, повинні підтримувати рівень продуктивності, викликаний конкуренцією, вони намагаються, принаймні, не дозволяти йому зменшуватися. Проте сам факт створення кластерів робить можливим і необхідним підвищення продуктивності мережі. Для досягнення цього необхідно планувати діяльність, спрямовану на розвиток людських ресурсів, зростання конкурентоспроможності, посилення інноваційного потенціалу кластеру та його інтернаціоналізації. Ці заходи не повинні дублювати внутрішню активність учасників кластера, але бути визначеними та реалізованими на сукупному рівні кластера. Загалом, цілком обгрунтовано сказати, що потенціал зростання кластера полягає в самій моделі кластеру, що дозволяє краще використовувати регіональні ресурси, науку та технології, робочу силу, а також фінансову, інформаційну та управлінську спроможність. Водночас, потенціал управління повинен бути інтегрований у систему державної макроекономічної політики, посилюючи свої позиції на світовому ринку.

Очікування ефективного використання кластерних систем у промисловій організації можуть стати реальністю, принаймні за умови виконання трьох умов. По-перше, процеси кластеризації повинні відповідати реальній економічній ситуації в Україні. По-друге, існуючі та майбутні кластери повинні бути вбудованими в систему економічних реформ, передбачених Угодою про асоціацію між Україною та ЄС. По-третє, в українській економіці кластеризації слід коригувати світовий досвід експлуатації кластерних мереж до національних умовах ${ }^{2}$.

Використання досвіду німецьких мереж компетентності в українських умовах вимагає встановлення пріоритетів у науково-технічній політиці. Навіть така розвинута країна, як Німеччина, не може дозволити собі фінансування «на замовлення»; тому Україна повинна бути особливо обережною, направляючи кошти на напрямки, які можуть перешкоджати формуванню економіки знань.

Логічно було б побудувати цей процес у відповідності до схеми «пріоритети - людське та матеріальне забезпечення - фінансування». Проте в сучасних умовах цей процес має бути зворотнім. Найбіднішим ресурсом в Україні $\epsilon$ фінанси; тому надзвичайно важливо визначити необхідні та можливі обсяги інвестицій для мереж компетенції, і з огляду на це обгрунтувати пріоритети.

Пріоритети у науково-технічній сфері України повинні в першу чергу визначатися як альтернативи для розгляду. Останнім часом їх обговорювали у зв'язку з примусовою переорієнтацією експортних потоків з російського ринку на європейський ринок. Вони можуть бути організовані в наступному порядку:

\footnotetext{
1 Ліщинський I. Нова економічна географія та альтернативні концепції агломерації виробництва// Журнал Європейської економіки. - 2009. - Том 8. - №3. - 348c. - С. 241-264.

${ }^{2}$ Kuryliak V., Lishchynskyy I.O., Lyzun M., Komar N. Benchmarking of local production systems in Eastern Europe and Ukraine// Management \& Gouvernance - 2017. - №17. - C. 15-29.
} 
1. Сільське господарство та харчова промисловість.

2. Медицина та медичний туризм.

3. Машинобудування і суднобудування.

4. Авіаційна і космічна промисловість.

Слід зазначити, що фундаментальні дослідження в сільському господарстві, харчовій промисловості, медицині та медичному туризмі можуть мати одну міжгалузеву програму. На перетині цих наук завжди слід очікувати появи найбільш перспективних напрямків для прикладних досліджень, які будуть адаптовані до ноу-хау у виробництві та практичній медицині. Зазначена методологія може покласти основу стратегії побудови мережі компетенції, яка включатиме машинобудівну, суднобудівну, авіаційну та космічну галузі. Такі підходи дозволяють досягти максимальних результатів при мінімальних витратах.

Варто передбачити, що у випадку започаткування ініціатив 3 мережею компетенції існують високі шанси, що може виникнути спокуса монополізувати доступ до фінансування на основі існуючої галузі промисловості регіону. Таким чином, у машинобудівному та суднобудівному господарстві Дніпро, Харків, Миколаїв, Одеса та Київ можуть претендувати на те, щоб мати виключні права на формування науково-технологічної політики галузі. Тому варто вибрати нове географічне розташування для координаційного центру мережі компетенції, наприклад, центру країни, полегшить залучення нових людських ресурсів, аніж тоді, коли найбільші підприємства та організації галузі розташовані в традиційних місцях.

Як показано на рис. 1.1, доцільно вибрати центральну Україну як місце для координаційного центру мережі компетенцій для сільського господарства та харчової промисловості. Це може бути південь Вінницької області, де клімат подібний до всіх інших регіонів країни. Центром медицини та медичного туризму може стати Західна Україна, яка має комплексні умови для наукових досліджень у галузі медицини та створення нових медичних закладів на основі використання факторів природи та клімату. Для узгодження нових підходів у машинобудівній та суднобудівній галузях доцільно розглянути Київську область (але не місто Київ) або кут, сформований південною частиною Київської області та північчю Хмельницької області - південний черкаський район області. Вони розташовані поряд 3 провідними науково-технічними інститутами (Київ, Житомир, Полтава, Харків, Дніпро, Чернігів). Розташування координаційного центру мережі компетенції авіаційної та космічної промисловості в області м. Кропивницький $є$ можливим 3 урахуванням економічних та політичних чинників. Цей регіон $є$ відносно далеко від кордонів і негусто заселений, що сприяє підвищенню рівня безпеки комерційної таємниці.

Створення центрів для мереж компетенції забезпечить розвиток їхніх людських та матеріальних цінностей, які будуть відповідати за основні наукові проблеми та залучати найкращі кластери до досягнення мети. 3 часом вони стануть основою національних наукових та промислових корпорацій iз глобальними стратегічними цілями. Певна відстань центру від головних обласних міст дозволить уникнути корупції при відборі персоналу та сприяти вирішенню повсякденних проблем. Для цього необхідно буде виділити території для будівництва та розвитку науково-виробничих та житлових комплексів. 


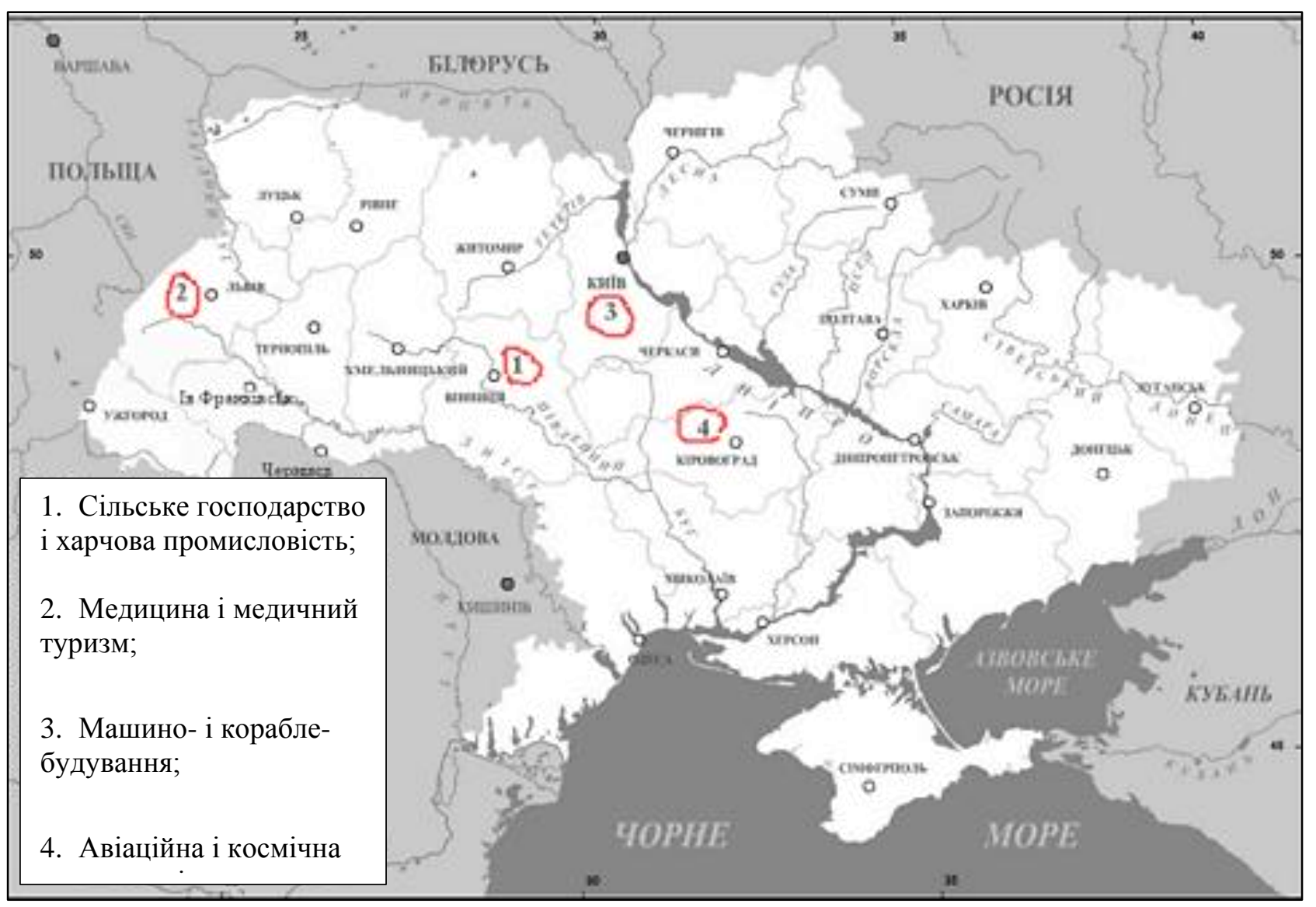

\section{Рис. 1.1. Місця розташування координаційних центрів компетентних мереж в Україні (проект).}

Прототип подібного підходу можна знайти в політиці підтримки кластерів у Великобританії, де Північно-східний кластер промисловості (NEPIC) у хімічній промисловості був створений у 2005 р. в Теессайде як один з найуспішніших кластерів у Північно-східній Англії.

Кластер виявився досить успішним, особливо в тому, що стосується залучення нових інвестицій. Його співробітники були переважно місцевими, тому що хімічна промисловість є місцем успішної кар'єри.

NEPIC розвивається в результаті двох регіональних кластерних ініціатив: кластеру фармацевтики (P \& S) та хімічної ініціативи Тессайд (TCI). Їх учасники прийшли до висновку, що фармацевтична та хімічна промисловість настільки взаємопов'язані, що це може породжувати переваги взаємної інтеграції.

Діяльність кластеру включає фармацевтичні препарати; біотехнологію; хімікати, полімери, гуму, нафтохімію та інші продукти. У цих галузях компанія стала рушійною силою регіонального та національного економічного розвитку. Компанії кластера приносять майже мільярд фунтів стерлінгів щорічно до регіонального ВВП (25\%) і забезпечують 20\% регіональної зайнятості. 3 точки зору виробництва, нафтохімічна промисловість в Теессайд посідає перше місце в Великобританії та друге у Свропі.

Формування нових мереж компетенції в рамках політики трансформації національної економіки в економіку знань вимагає системного підходу до вибору учасників. Він має базуватися на врахуванні соціально-економічних тенденцій, властивих країні протягом відповідного періоду його розвитку. 
Особливо важливо провести оцінку правового забезпечення розвитку довгострокової добросовісної співпраці, що унеможливило б розірвання мережі, тобто вихід з системи важливих зв'язків, які можуть сповільнити або навіть перешкоджати досягненню мети. Операційний горизонт для всіх учасників проекту повинен бути глобальним, щоб гарантувати високу конкурентоспроможність кінцевої продукції.

Зазначимо, що для генерації нових знань необхідно, щоб науково-освітні установи були включені до мережі компетенції. Новий закон про вищу освіту, затверджений Верховною Радою України у червні 2014 року, наближає країну до європейських стандартів. Проте пошуки нової моделі організації для науки та освіти не можуть зупинитися на цьому етапі. Навпаки, затверджений закон створює певні підстави для нового процесу пошуку. У той же час слід враховувати досвід надання нових функцій академічним центрам, що розвиваються після Другої світової війни в США, зокрема, піонерські експерименти з організації ділових контактів, що проводиться Массачусетским технологічним інститутом (МIT) і Стенфордським університетом.

Комерціалізація наукових досліджень стає не менш важливою для нових підходів, ніж наука та освіта. За словами Матусяка ${ }^{1}$, завдання вищих навчальних закладів в епоху глобалізації повинні перетворитись на міжнародні центри підприємництва та трансферу технологій, щоб підвищити якість освіти та наукових досліджень. Академічна трансформація - це специфічне поєднання ідей, запропонованих Гумбольдтом (єдність освіти та наукових досліджень) і Шумпетером (творче знищення).

Комерціалізація наукової діяльності не повинна залежати лише від субсидій та різноманітних грантів. Не менш ефективним може бути співпраця за посередництвом установ, що спеціалізуються на організації прямих контактів між наукою та бізнесом. Така практика розвивається у Великій Британії, де Агентство регіонального розвитку розробило 9 програм зі створення Центрів промислової співпраці (ЦПС). Вони сприяють адаптації регіональних науковотехнічних ресурсів до потреб підприємців шляхом полегшення їх доступу до самих останніх досягнень науки та техніки. Реалізація програми дозволить розширити завдання місцевих університетів у сфері маркетингу, маркетингових досліджень, розробки політики ціноутворення, ведення переговорів та укладання контрактів. Орієнтація університетів на потреби бізнесу підкреслюється тим фактом, що ЦПС розміщують свої офіси в безпосередній близькості від відділів університетів.

Слід відмітити і той факт, що підприємства, які співпрацюють з ЦПС, не отримують жодних грантів. Включення в мережу ЦПС дозволило забезпечити доступ до розробок вчених та модернізацію промисловості 3 установкою високоякісного обладнання. Важливо, щоб замовник досліджень встиг забезпечити його реалізацію протягом узгодженого часу та у межах зазначеного бюджету. ${ }^{2}$ Так, у регіоні Йоркшир і Хамбер ініціативи ЦПС призвели до зростання обсягів продажів, розширення доступу до нових ринків та розвитку

\footnotetext{
${ }^{1}$ Matusiak, K. (2006). (Ed.). Innowacje i Transfer Technologii - Słownik Pojęć. Warszawa, Polska Agencja Rozwoju

${ }^{2}$ Sztern, Ł. (2013). Współpraca nauki z biznesem. Formy i narzędzia wspierania. In: Wspótpraca nauki $i$ biznesu. Doświadczenia i dobre praktyki wybranych projektow w ramach Programu Operacyjnego Innowacyjna Gospodarka na lata 2007-2013. Warszawa, Polska Agencja Rozwoju Przedsiębiorczości, p. 38. Retrieved from http://www.parp.gov.pl/files/74/81/626/18863.pdf
} 
бізнесу для сотень підприємств. ЦПС співпрацювали у виконанні 1700 проектів разом 3 підприємствами загальною вартістю 40 млн. фунтів стерлінгів та зберегли 1300 робочих місць у регіоні.

Розробка державної кластерної програми повинна чітко визначати рівень, на який вона спрямована. Оскільки кластерний підхід, насамперед, $\epsilon$ управлінським методом інтеграції малих та середніх підприємств, він має бути принципово орієнтованим на підвищення конкурентоспроможності регіону, де розташовані учасники кластеру. Саме через призму регіону слід проаналізувати вплив кластеризації на розвиток галузі та держави.

Розвиток кластерної політики має багатофункціональну структуру управління та залежить від профілю предметів управління кластером. Можливо диференціювати кластери за методологією зірки. Ця система була розроблена експертами Європейської кластерної обсерваторії за аналогією з класифікацією готелів. Метод має чотири класи - нульову, одну, дві, і три зірки, які призначаються для кластерів за показниками розміру, спеціалізації та фактору розташування.

3 огляду на особливості організації кластерів, пріоритетними напрямками в рамках політики кластерів повинні бути орієнтація на виклики ринку та лідерство в аспектах технології та продукту, підприємницька діяльність; маркетинг та PR, внутрішні комунікації; застосування досягнень науки, генерація нових знань, інновації та унікальна цінність.

Solodovnik G.V.

Candidate of Technical Sciences, Associate Professor, Senior Lecturer at Department of Economic Cybernetics and Information Technologies, Kharkiv National University of Civil Engineering and Architecture Venhrina O.S. Assistant Lecturer at Department of Economic Cybernetics and Information Technologies, Kharkiv National University of Civil Engineering and Architecture

\section{THE DETERMINATION OF THE RATIONAL SIZE OF THE DEVELOPMENT FUND OF A MANUFACTURING ENTERPRISE}

Summary. The current economic state of the country requires a constant development of enterprises. A permanent turbulence of the functioning conditions, which especially affects the state of production of the enterprises of small-and medium-sized business, demands a scientific substantiation of managerial decisions that define the strategy of the development. The paper is devoted to the development of methods and tools of decision-making on the development of enterprises of a small and medium-sized business. The problem of determining the rational quantity of financial means of the development and their optimal distribution among the 
measures of improving the attractiveness of the company and its products is considered. The solution to the problem is based on the game-theoretic model of decision-making under risk and uncertainty. The analysis of risks is conducted to build the model. The optimal distribution of means of development among the relevant measures is calculated by the method of the dynamic simulation.

Introduction. A clear vector of Ukraine towards European integration causes the necessity of permanent changes in the political, social, and economic spaces of activities with the aim of developing and achieving global standards. One of the first steps towards European integration of the country is changing its administrative structure in the direction of decentralization. The projection of such a policy on the economic sphere is the expansion of the sector of small- and medium-sized businesses.

The members of the Visegrád Group are neighbours of Ukraine of the first order and its economic partners that are interested in a security and an economic development of Ukraine. According to the data of National Institute of Strategic Research, the Visegrád countries take the initiative on technical, consultative assistance to Ukraine in the issues of the support of the development of a small- and medium-sized business, establishing the free trade regime with the EU.

The analysis of the economy of developed countries shows that the sector of smalland medium-sized business is one of the most important, which is associated with the primitive accumulation of a capital, the formation of the middle class, and a significant expansion of the labour market. This sector plays an important innovative role. On the other hand, enterprises of small- and medium-sized businesses are subjects of the greatest risk.

The conclusion from these facts is the topicality of creation of scientific basis of management of the development of enterprises of the sphere of small- and mediumsized business, the development of methodological and theoretical foundations of decision-making under conditions of incomplete information.

The aim of this paper is to develop mathematical models of decision-making regarding the development of an enterprise in the conditions of a risk and uncertainty.

The object of the research is an enterprise of small- and medium-sized business. The subject is the process of funding for the development and the increase in the competitiveness of an enterprise of a small- and medium-sized business.

The tool of research is a game-theoretic decision-making framework under risk and uncertainty.

\section{Analysis of risks. Formation of sets of strategies of the first player and state of the environment}

\subsection{Qualitative analysis of risks for a manufacturing enterprise}

To identify the most significant risks for a certain kind of business activities, the main factors of risk situations should be identified and the risk classification should be conducted.

Analysing an objective area of the research, we can conclude that since this is an enterprise that produces and sells a certain type of a product, most likely risks are industrial and commercial. The emergence of a financial risk is also possible (or rather credit) in case of impossibility to return loan funds or non-performance of 
payments with suppliers. As a manufacturing enterprise is an open system, it can be considered as an element of a metasystem economy of the country, so it is influenced by the risks of economic, political and, separately highlighted, risks associated with changes in taxation.

During the qualitative analysis of the occurrence of adverse situations in the industrial sector, the following possible risks are identified.

The risk of lack of demand for products $\left(R_{l}\right)$ - arises due to a failure of a consumer from a purchase of products. The risk is characterized by a magnitude of a possible economic and moral damage incurred by a manufacturer for this reason.

The risk of increased competition $\left(R_{2}\right)$ - a leakage of confidential information can occur either through a fault of employees of the company or as a result of an industrial espionage.

The risk of unforeseen costs and decline of revenues $\left(R_{3}\right)$ - occurs in the case of the increase of market prices for resources (services), purchased in the course of production activities above the planned level, changes in policy of the pricing from material suppliers with whom a manufacturer has concluded long-term contracts providing the possibility of revising a price.

Force majeure risks $\left(R_{4}\right)$ - risks that operations will be suspended for a long period of time after a completion of a project funding due to circumstances beyond a control of project sponsors.

Business risk $\left(R_{5}\right)$ is the risk arising from any kinds of business activities related to a production of goods and services and their implementation.

\subsection{Formation of a set of strategies of the first player}

A tough competition requires each participant of market relations continuous development to increase or even keep his or her own market share, i.e. a part of a consumer segment of a product (or a service). The development and increase of the competitiveness require investment; a part of available funds should be spent on activities related to improving the attractiveness of a product and a firm to consumers.

On the other hand, the analysis of works on the management of socio-economic systems has clearly shown the need to consider adverse events and incomplete information when making management decisions. It is therefore advisable to consider the situation of operation of an enterprise in the competitive market of a limited capacity from the point of the game-theoretic model of decision-making under risk and uncertainty.

In this paper, we consider the conflict caused by the operation of several competing producers in the market of the limited capacity of a certain type of product. In general, the capacity of the market of any goods or services at a certain period of time is limited. The profit of each manufacturer depends on its market share, therefore, everyone tries to increase or at least keep their own market share at the level of the previous period. The increase in the share of one of the competitors leads to a decrease in the share of other, from which arises the conflict for several market subjects.

Additionally, the incompleteness of information is caused by the fact that values of environmental factors are unknown for the subject of decision-making, namely, the distribution of a demand under the influence of circumstances beyond its control and other market agents; actions of a metasystem in the next period of time (for example, 
state regulators that define the functioning of the state economy); force majeure events, etc.

A well-known model of decision making under conditions of uncertainty is a static model, generated by the game-theoretic concept [1].

In the framework of the game theory, the situation of decision-making is characterized by the multiplicity $\{X ; \Theta ; \Phi\}$, where $X$ is the set of solutions (strategies) of the subject of management (the first player), $\Theta$ - is the set of states (strategies) of the economic environment (the second player), $\Phi=\{\phi(x ; \theta) ; x \in X ; \theta \in \Theta\}$. The functional of the estimation, which is defined on the multiplicity $X \times \Theta$, such that takes the value of space $R^{l}$ (one-dimensional space), feature $\phi(x ; \theta)$ is the feature of the win of the first player.

In the discrete case, the situation of decision-making is characterized by a matrix of wins of the first player $\Phi\left\{\phi_{k j}\right\}_{m \times n}$, which elements are a quantitative estimate of the winnings of the first player, if he chooses a solution $x_{k} \in X$, provided that the environment is in a state $\theta_{j} \in \Theta$.

There is another way to define the matrix of the game with nature, in the form of the so-called risk matrix $R=\left\|r_{k}\right\|_{m, n}$ or the matrix of missed opportunities. Risk $r_{i j}$ of the player in case of using the strategy $x_{i}$ and the state of the environment $\theta_{j}$ we call the difference between the wins that the player gets if he knows that the state of the environment will be $\theta_{j}$, and the win that the player receives without having this information. Knowing the state of the environment (the strategy) $\theta_{j}$, the player chooses the strategy, in which the win is maximum, i.e. [2]:

$$
r_{k j}=\underset{1 \leq k \leq m}{\max } \phi_{k j}-\phi_{k j}, j=\overline{1, n} .
$$

In the case when a priori probability of the distribution of states of the economic environment is known,

$$
P=\left\{p_{1} ; p_{2} ; \ldots ; p_{n}\right\} ; p_{j}=P\left(\theta_{j}=q_{j}\right) ; \sum_{j=1}^{n} p_{j}=1,
$$

we have a situation of decision-making under risk otherwise the situation of decision making under uncertainty.

A priori distribution of probabilities of states of the economic environment can be determined by statistical methods based on information about states of the environment that have arisen for the operations of the control object in the previous time interval, or expert methods. When using expert methods, the index of a consistency of experts' thoughts and the indexes of a validity of the provided ratings should be defined to determine the possibility of using these ratings in further studies.

A creative part of the development of the game models is to construct a prize matrix of the first player and a functional definition of the elements of this matrix.

The first consciously acting player in this paper is the management body of a production enterprise. Strategies of the first player corresponding to the row of the prize matrix are the amount of funds that will be spent on an enterprise development in the forthcoming planning period, that is, the size of the development fund.

The possible size of the development fund $F_{k}$ is calculated in the percentage expression from the size of free means $(F M)$ on the enterprise's account at the 
beginning of the planned period: $F_{1}=10 \% \quad F M, \quad F_{2}=20 \% \quad F M, \quad F_{3}=30 \% \quad F M$, $F_{4}=40 \% \mathrm{FM}, F_{5}=50 \% \mathrm{FM}, F_{6}=60 \% \mathrm{FM}, F_{7}=70 \% \mathrm{FM}, F_{8}=80 \% \mathrm{FM}, F_{9}=90 \% \mathrm{FM}$, $F_{10}=100 \%$ FM.

Strategies of the nature (an unconsciously acting player), that is, the state of the environment, to which the columns of the matrix of winnings correspond, are the risky situations that were discovered in the course of the qualitative analysis of risks and identified as the most threatening when quantified by expert methods [3].

Thus, we get the matrix consisting of ten rows and five columns, at the intersection of which are the first player's winnings, which show the amount of means that he will receive, provided that he puts a certain amount into his own development, taking into account the losses in the case of an unfavourable event that corresponds to the implementation of the risk of the corresponding column. A negative value of winning will indicate an excess of losses due to the unfavourable event of the means received by the enterprise from the development and corresponding increase in market share.

The next step is to develop a functional, for which the elements of the described matrix of wins are calculated. To solve this problem, it is necessary to determine:

- a formula for determining the amount of free financial means of the enterprise;

- amount of financial means that the enterprise will receive from a consumption of a certain amount of the development fund;

- the size of losses that the enterprise will incur from the implementation of each of the five risks.

\subsection{The determination of a number of free enterprise means}

The size of free financial means of a production enterprise can be determined by the known values of gross profit and expenses. The amount of gross profit for the planned period is determined by the product of the price of a product and the volume of sold for this period of production. For example, for a stained glass manufacturing company, the last value may be determined by square meters of products, and a price may consist of a base for one-meter square, further taking into account the coefficient determined by a complexity or non-standard of a product.

Sources of information on the costs of a production enterprise are as follows: "The report on costs of a production and selling of products (works, services) of the enterprise (organization)", planned and cost estimates of production costs, data on a synthetic and analytical accounting of costs for the major and auxiliary industries, etc.

A planning and accounting of cost at enterprises lead by elements of expenses and cost items of expenses.

Elements of expenses: material expenses (raw materials and materials, purchased component and semi-finished products, fuel, electricity, heat energy, etc.), labour costs, deductions for social needs, a depreciation of fixed assets, other expenses (a depreciation of intangible assets, rent, obligatory insurance payments, percentages on bank loans, taxes included in the cost of production, deductions in extrabudgetary funds, etc.)

Basic costing articles: raw materials and materials, wastes (deducted), purchased products and semi-finished products, fuel and energy for technological purposes, basic and additional wages of production workers, deductions for social and medical insurance of production workers, maintenance of machinery and equipment, generic 
production costs, general expenses, losses from marriage, other production costs, commercial expenses.

Depending on the volume of production, all costs of the enterprise can be divided into constants and variables.

Constant costs do not depend on the dynamics of the volume of production and product sales. One part of them is connected with a production capacity of the enterprise (depreciation, rent, salaries of managerial and service personnel on hourly payment and general expenses), the other - with management and organization of production and sale of products, the cost of research work, advertising, increase of qualifications of employees, etc.) [4].

In the economic theory, there are concepts of accounting and economic gains [5].

An accounting profit is the company's total revenue, excluding external costs.

An economic profit is total revenue, excluding all expenses (external and internal, including the last normal profit of an entrepreneur).

Economic costs are those payments that the firm is obliged to make or those revenues that the firm is obliged to provide to the supplier of resources in order to divert these resources from the use of alternative productions. These payments may be external or internal. Cash payments are the monetary costs that a firm pays "with its own pocket" to economic agents supplying labour services, raw materials, fuel, transport services, energy, etc.

The costs of the self-resource that are self-used are internal or non-paid costs. From the firm's point of view, these internal costs are equal to the cash payments that could be received for a resource that is used independently for the best possible use of it.

If the amount of cash receipts exceeds the company's economic costs, then this balance is accumulated in the entrepreneur's account. This remainder is called an economic or net profit (Figure 1).

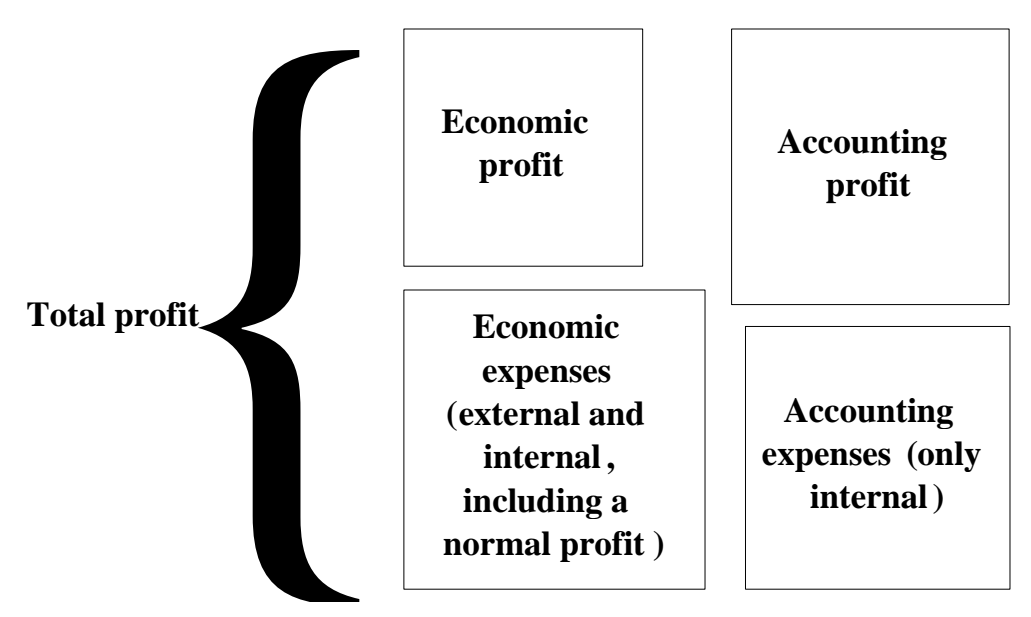

Figure 1. Economic and accounting profit

Economic profit equals total revenue excluding economic costs, and is calculated by the formula:

$$
E P=T P-E E
$$

where $E P$ - economic profit

$T P$ - total profit

$E E-$ economic expenses for all types of resources. 
In this paper, it is appropriate to determine free means of the enterprise as the difference between gross income and external costs.

A product of the price and the corresponding quantity of products that a firm can realize determines gross profit. In turn, its share of the total market of these products determines the quantity of products that the firm can realize for a certain period (the planning period).

According to the results of the research of the subject area, the following costs can be determined for a stained-glass manufacturing company:

- constant costs: a rent of premises, salaries of engineering staff,

- variable costs: payment of materials (a glass, a paint, etc.); Salaries of employees with a part-time wage (a designer, a colourist, etc.).

Taking into the account the variability of domestic fiscal policy, the costs of the input parameter in the process of setting the model.

Then, the formula for determining the size of free financial means of an enterprise acquires the following form:

$$
\mathrm{FM}=\mathrm{GP}-\mathrm{CE}-\mathrm{VE}-\mathrm{T},
$$

where $F M$ - free enterprise means;

$G P$ - gross profit;

$C E-$ amount of constant expenses;

$V E$ - amount of variable expenses;

$T$ - taxes in percentage terms.

Then the size of the development fund, corresponding to a certain solution, is determined by the formula:

$$
F_{k}=\Delta B 3 * \xi
$$

The coefficient $\xi$ determines the percentage of free means that is planned to be spent on the development of an enterprise. In this model, it is proposed to adopt $\xi=$ $[0,1 ; 1], \Delta \xi=0,1$, but this scheme can be changed during the setting of the model.

\section{Development of the functional of assessment of solutions}

\subsection{The determination of the amount of financial means that an enterprise will receive from a consumption of a certain amount of the development fund}

An increase in the development fund means better financing of activities related to increasing the competitiveness of a company in the market. The growth of the competitiveness of the company implies an increase in its market share, which in the financial sense means an increase in the gross profit of an enterprise $(\Delta G P)$.

It is possible to determine the following measures to increase a competitiveness of a production enterprise:

1) improving the quality of materials;

2) introduction of new technologies for manufacturing stained-glass windows;

3 ) raising the level of professionalism of employees;

4) application of new, more advanced equipment;

5) opening of new, more accessible sales points or accepting orders.

In [6], there is the model of the dependence of growth of a market share of an enterprise on the size of the development fund. This task includes solving two 
optimization tasks and decision-making tasks under conditions of risk and uncertainty.

The solutions, in this case, are different values of the size of the development fund (see Table 1).

Table 1

Matrix of payments

\begin{tabular}{|c|c|c|c|c|}
\hline$F_{p}$ & $\theta_{1}$ & $\theta_{2}$ & $\ldots$ & $\theta_{\mathrm{H}}$ \\
\hline$F_{1}$ & $\mathrm{D}_{11}(\mathrm{t}+\mathrm{T})$ & $\mathrm{D}_{12}(\mathrm{t}+\mathrm{T})$ & $\ldots$ & $\mathrm{D}_{1 \mathrm{H}}(\mathrm{t}+\mathrm{T})$ \\
\hline $\mathrm{F}_{2}$ & $\mathrm{D}_{21}(\mathrm{t}+\mathrm{T})$ & $\mathrm{D}_{22}(\mathrm{t}+\mathrm{T})$ & $\ldots$ & $\mathrm{D}_{2 \mathrm{H}}(\mathrm{t}+\mathrm{T})$ \\
\hline & . & & $\ldots$ & \\
\hline $\mathrm{F}_{\mathrm{P}}$ & $\mathrm{DP}_{\mathrm{P}}(\mathrm{t}+\mathrm{T})$ & $\mathrm{DP}_{2}(\mathrm{t}+\mathrm{T})$ & $\ldots$ & $D_{P H}(t+T)$ \\
\hline
\end{tabular}

Here $F_{p}-p$-e is the decision on the size of the development fund, expressed as a percentage of the company's free means; $\theta_{h}-h$ state of the environment (total fund of the development of competitors, expressed as a percentage of the total free funds of competitors); $D_{p h}(t+T)$ - a market share, which is controlled by an enterprise under consideration in the future planning period after the enterprise implements $p$ strategy in case of occurrence of $h$ situation in the market.

To determine the wins of an enterprise, it is necessary to solve the following tasks: to calculate the value of a generalized parameter of attractiveness, which corresponds to the $p$ decision; find the sum of the parameters of the attractiveness of competitors, which corresponds to the $h$ market situation.

The coefficient $\eta_{p}$ is a generalized multicriteria estimation of the set of characteristics (their list for all enterprises is the same), which determines the attractiveness of the enterprise's products for the consumer. It is necessary to decide on the distribution of the $F_{p}$ development fund among the parameters of attractiveness in such a way as to maximize the relative attractiveness factor, i.e. $\eta_{p} \rightarrow \max$. This is the task of a multi-criteria optimization: the local parameters of the enterprise's the attractiveness are the single criteria. The optimized function is formed on the basis of the additive utility theory:

$$
\eta_{j}=\sum_{i=1}^{n} \mu_{i j}, 0 \leq \mu_{i j} \leq 1,
$$

where $\mu_{i j}-$ a local parameter of the attractiveness of $j$ enterprise;

$n-$ a number of local parameters.

The production functions of the local parameters will look like:

$$
\mu_{i j}=b_{i j} *\left(\frac{r_{i j}}{d_{i j \max }-d_{i j \min }}\right)^{\alpha_{i j}},
$$


where $b_{i j}$ - a weight factor $i$ characteristics of the attractiveness;

$r_{i j}$ - an amount of development resource, allocated by the planning body on the $i$ characteristic of attractiveness;

$d_{\max i j}$ - the maximum amount of a resource that it is expedient to invest in the implementation of the $i$ characteristic;

$d_{\min i j}$ - the minimum amount of a resource required for the implementation of the $i$ characteristic;

$\alpha_{i j}-$ a coefficient of a nonlinearity of the production function of $i$ characteristic.

In determining the optimal strategy, the following conditions must be fulfilled:

$$
\sum_{i=1}^{n} d_{j i \min }<d_{i j}<\sum_{i=1}^{n} d_{j i \max }, d_{i j}=d_{i j \min }+r_{i j}, \sum_{i=1}^{n} r_{j i} \leq F_{p} .
$$

As a result, we obtain the task of a conditional optimization under deterministic conditions. It is solved by the method of a dynamic programming.

It is more difficult to determine the optimal strategy for allocating development funds for competitive enterprises since the planning body does not know the value of the parameters of the production functions of competitors. Proceeding from the fact that a technology of production for all enterprises is similar, mathematical model (6) - (8) can be used to determine the values of competitors' attractiveness indicators. In order to determine the generalized parameters of the attractiveness of competitors, it is necessary to solve (M-1) task of optimal allocation of the development fund in the task parameters of production functions in the form of intervals $b_{s i} \in\left[b_{s i \text { min }} ; b_{s i \max }\right]$; $\alpha_{s i} \in\left[\alpha_{s i \min } ; \alpha_{s i \max }\right]$. There is no information about the predominance of this or that parameter value at the specified intervals. The task is to determine on the hyperplane $F_{s h}=\sum_{i=1}^{n} r_{s i h}$ (where $r_{s i h}$ - the number of resources allocated by the management body of the $s$ enterprise to the $i$ local parameter of attractiveness in the conditions of the $h$ situation), the sub-domain of the admissible set of solutions corresponding to the variations of the parameters $b_{s i}, \alpha_{s i}$, and then a single decision is taken based on the minimax criterion from this area. As a result, we obtain the optimal solution for the distribution of the development fund in terms of increasing the effect of the whole

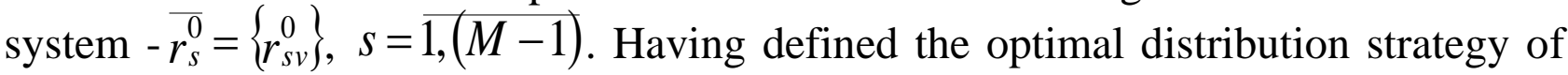
the development fund in an above-mentioned way, we calculate the value of the generalized parameters of the attractiveness of competitors $\eta_{s}, s=\overline{1,(M-1)}$.

To avoid overloading the paper by mathematical models, we consider the dependence of the growth of the market share of an enterprise $\Delta D_{k}$ on attracting the development fund $F_{k}$ directly proportional and linear:

$$
\Delta \mathrm{D}_{\mathrm{k}}=\varepsilon^{*} \mathrm{~F}_{\mathrm{k}},
$$

where $\varepsilon-$ the coefficient of proportionality that can be defined as a percentage and introduced as a parameter when setting up the model.

Then the increase in gross income of the enterprise $\Delta G I k$ is determined by the formula: 


$$
\Delta \mathrm{GI}_{\mathrm{k}}=\Delta \mathrm{D}_{\mathrm{k}} * \mathrm{P}=\varepsilon * \mathrm{~F}_{\mathrm{k}} * \mathrm{P},
$$

where $P-$ a price per square meter of a product.

The parameter $\mathrm{P}$ is entered during the model setting and is determined by the average arithmetic mean of the products over the previous planned period.

\subsection{Determining the amount of losses that the enterprise will incur from the implementation of each of the risks}

The amount of financial losses that the enterprise will incur from the implementation of a particular adverse situation can be found statistically, as the average arithmetic value of past periods:

$$
E_{j}^{c}=\frac{1}{n_{j}} \sum_{t=1}^{n_{j}} g_{j t},
$$

where $E_{j}^{c}$ - the average arithmetic value of the losses that an enterprise will incur from the occurrence of an adverse situation that corresponds to the risk $j$;

$g_{j t}$-the specific value of expenses incurred by an enterprise during the time $t$ of expenses for the occurrence of the $j$ adverse situation;

$n_{j}-$ the number of periods in which an adverse situation arose $j$.

Such a method can be used if the enterprise has been operating for quite a long time, for which there are relevant statistics on the costs of the enterprise and the occurrence of past adverse situations that meet the described risks. Otherwise, to define the size of losses, one should turn to experts who, on the basis of an analysis of the enterprise's activities and the activities of similar enterprises, may provide the possible amounts of expenses and the probability values, with which these expenses may occur.

Otherwise, by definition of the size of losses, one should turn to experts who, on the basis of an analysis of the enterprise's activities and the activities of similar enterprises, may provide the possible size of costs and the probability values with which these costs may occur.

Then the amount of financial losses that an enterprise will incur from the implementation of a particular adverse situation can be found as average weighted by the probability of values of past periods:

$$
E_{j}^{e}=M\left(Y_{j}\right)=\sum_{t=1}^{n_{j}} y_{j t} p_{j t},
$$

where $E_{j}^{e}$ - the average weighted to the probability of the amount of losses that the enterprise will incur from the occurrence of an adverse situation that corresponds to the risk $j$;

$Y_{j}$ - a random variable indicating the possible cost of the occurrence of the $j$ adverse situation;

$y_{j t}$ - the specific value of expenses incurred by the enterprise during the time $t$ of expenses for the occurrence of an $j$ adverse situation;

$p_{j t}$ - the probability, with which the random variable $Y_{j}$ will be of the value $y_{j t}$;

$n_{j}-$ the number of periods that have been investigated by an expert. 
The weight of an expert can also be taken into account that can be determined on the basis of: his previous activity (the ratio of the evaluations that came true), selfesteem, qualifications, position, rank, the term of work in the investigated area, etc. Then the formula, with which to determine the size of the loss, takes the form:

$$
E_{j}=\frac{\sum_{i=1}^{m} E_{j t}^{e} h_{i}}{\sum_{i=1}^{m} h_{i}},
$$

where $h_{i}$ - the weight of $i$ expert;

$m-$ a number of experts that take part in research.

\subsection{Construction of the matrix of winnings and the matrix of missed opportunities}

The matrix of winnings in this paper consists of the measurements of financial means that an enterprise will receive for investing a certain percentage of free funds into its development and provided that there is an adverse situation that will lead to certain financial losses. Elements of the matrix of wins are determined by the formula:

$$
\phi_{k j}=\Delta B Д_{k}-E_{j},
$$

Functional of the evaluation of the elements of the matrix can be graphically depicted in the following diagram in Fig. 2.

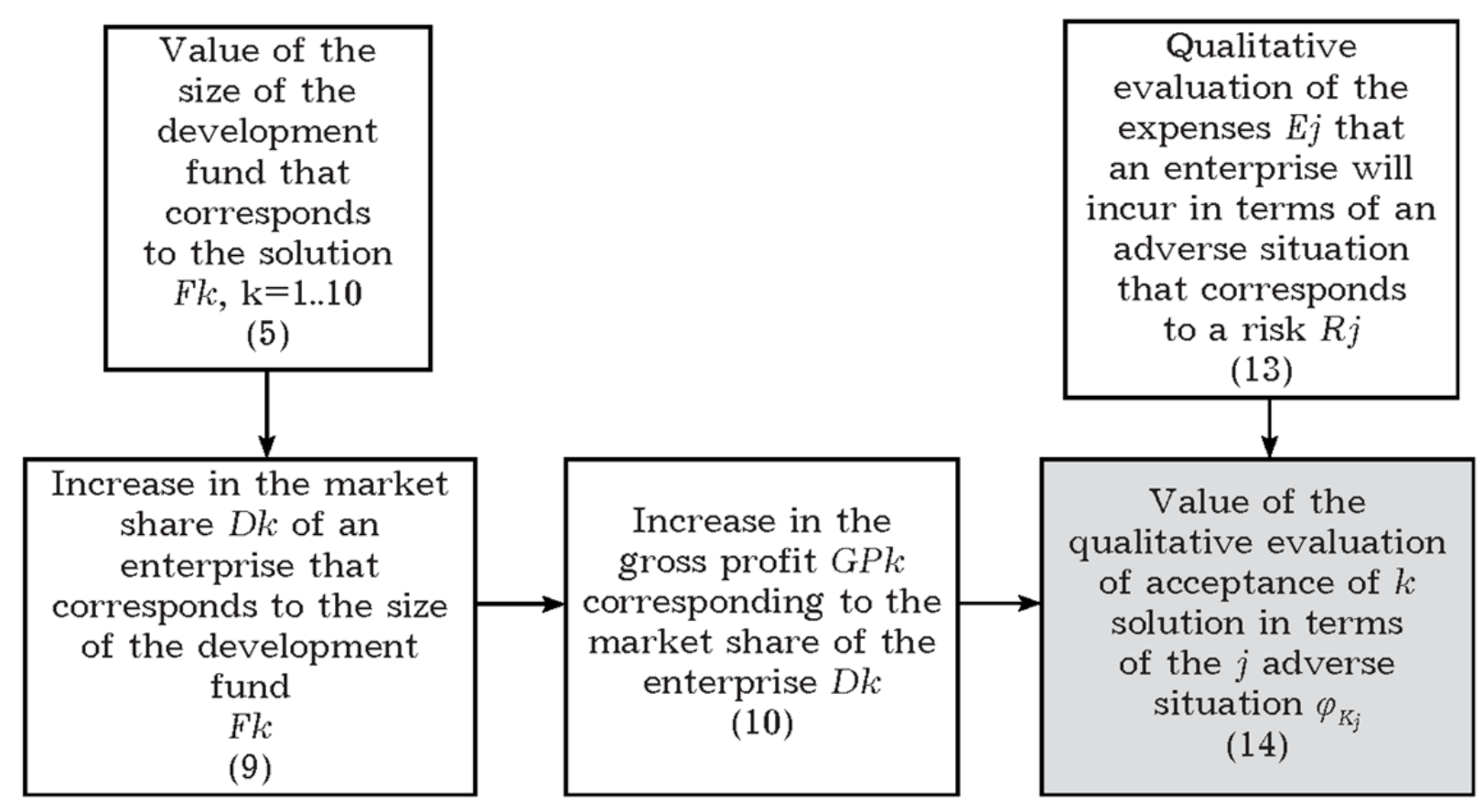

Figure 2. Scheme of the finding of a quantitative assessment of the effectiveness of the solution

In order to use the decision-making criteria under conditions of the uncertainty, a risk matrix or matrix of missed opportunities should also be constructed. 
The elements of this matrix determine the size of the losses of the first player because of the ignorance of many of its states nature chooses. After constructing the matrix of winnings, this matrix can be constructed by Formula (1).

\section{Model for the selection of the rational size of the development fund}

\subsection{The overview of decision-making criteria in terms of risk and uncertainty}

In cases where uncertainty relates to the complete lack of information about the probability of environmental states (nature), the following criteria are used to determine the best solutions: Maximax, Wald, Savage, Hurwicz, and Laplace. In the case of decision-making in the conditions of the first information situation, that is, when a given distribution of priori probabilities on the elements of the set of states of the environment, the Bayesian criterion can be used.

The essence of the Bayesian criterion is the maximization (minimization) of the mathematical expectation of the evaluation vector [1]. According to the Bayesian criterion, in the case when $\Phi=\Phi^{+}$the optimal solution $x_{k 0}$ is considered to be the one, for which the mathematical expectation of the evaluation vector reaches the maximum possible value that is, based on the condition:

$$
x_{k 0}: B^{+}\left(x_{k 0}, P\right)=\max _{x_{k} \in X} \sum_{j=1}^{n} p_{j} \phi_{k j}^{+}=M\left(\Phi_{k}^{+}\right) .
$$

If $\Phi=\Phi^{-}$, then, the optimal solution is determined, based on the condition:

$$
x_{k 0}: B^{-}\left(x_{k 0}, P\right)=\min _{x_{k} \in X} \sum_{j=1}^{n} p_{j} \phi_{k j}^{-}=M\left(\Phi_{k}^{-}\right) .
$$

There is another approach to solving the problem [7]. It consists of the development of a universal scheme for finding the optimal solution, which, when assigning the parameters of the model of the solution of various values, allows us to assess the player's strategies for behaviour according to such decision criteria: Bayesian, Laplace, Wald, Hodges-Lehman, Germire, Hurwicz's pessimismoptimism, the maximax criterion. As a result of the decision, a strategy that is better than other criteria is chosen.

After constructing the matrix of winnings according to the scheme in Fig. 2, the best solution for choosing the rational size of the $F_{k}$ development fund can be determined for each of the following criteria. The final decision is determined by most of the criteria that have determined it to be the best.

\subsection{Description of software complex modules}

To describe the module for constructing the first-player winning matrix, we will use the "black box" principle to determine the endogenous and exogenous variables of the model.

In the model of finding the rational size of the development fund for the endogenous enterprise, the following variables are adopted:

- nature strategies, more precisely, risky situations that have been identified during the qualitative risk analysis and identified as the most threatening when quantified by expert methods; 
- $E_{j}^{e}$ - the average weighted, according to the probability, amount of losses that the enterprise will incur from the occurrence of an adverse situation that corresponds to the risk $j$;

- $Y_{j}$ - a random variable indicating the possible cost of the occurrence of the $j$ adverse situation;

$-y_{j t}$ - the specific value of expenses incurred by the enterprise during the time $t$ of expenses for the occurrence of the $j$ adverse situation;

$-p_{j t}$ - the probability, with which the random variable $Y_{j}$ will accept the value $\mathrm{y}$ $y_{j t}$;

$-n_{j}$ - the number of periods that have been investigated by an expert.

In a model developed in this paper, exogenous variables are free enterprise means that will be spent on the development of an enterprise in the future planning period and the amount, by which they are calculated: $G P$ - gross profit; $C E$ - amount of constant expenses; $V E$ - amount of variable expenses; $T$ - taxes in percentage terms.

The coefficient $\xi$, which determines the percentage of free means that is planned to be spent on the enterprise development, can be taken $\xi=[0,1 ; 1], \Delta \xi=0,1$, but this scheme can be changed during the model setting.

After entering the initial data and refining the parameters of the model, the calculations take place by the formulas (5) - (14) according to the scheme in Fig. 2, that is, the size of the development fund that can be introduced into the winning matrix in percentage terms and the winnings of the first player are determined.

The result of the model's work is the value of the rational size of the development fund, taking into account possible losses associated with the implementation of adverse events. The final value of this value is determined by decision criteria in terms of risk and uncertainty.

Conclusions. The result of the research is the model for determining the rational fund for the development of a medium-sized enterprise, taking into account the losses that may arise during the implementation of adverse events that meet the most significant risks to the sector of stained glass manufacturing.

During the research, the following tasks were solved:

1. the qualitative analysis and classification of risks in the field of a stained glass production is carried out;

2. risks are monitored by the method of expert estimation to determine the most influential risks;

3. a game with nature is formed, namely:

- a set of environmental conditions, which are formed as a result of the implementation of adverse situations associated with the most influential risks is formed;

- a set of possible sizes of the enterprise development fund as a percentage of the number of free financial assets of an enterprise at the beginning of a planning period is defined (without the use of loans);

- wins of the enterprise for the occurrence of certain risky situations and for a certain amount of the development fund are defined;

- a rational, from the point of view of possible realizations of an adverse risky situation, in conditions of a risk and uncertainty, size of the enterprise development fund is chosen with the help of the decision criteria. 
The developed model received a partial program implementation by means of spreadsheets. The model and its program realization were applied to Manufacturing \& Trading Company "Diapazon" LLC, which is engaged in the production of a stained glass and can be applied to other firms of small- and medium-sized business.

\section{References:}

1. Вітлінський В.В., Верченко П.Г. Аналіз, моделювання та управління економічним ризиком. - К.: КНЕУ, 2000. -292 с.

2. Новожилова М.В., Солодовник Г.В. Моделювання управління комерційним ризиком: Навчально-методичний посібник. - Харків: ХНУБА, 2016 р. - 81 с.

3. Sizova N.D., Solodovnik G.V., Perun M.U. Analysis of the methods of assessment of investment appeal of construction objects in term of uncertainty and risk// Science magazine "Young Scientist" №10 (37) october, 2016 p. Part 3 P. 417-420.

4. Цены и ценообразование // Под ред. В.Е. Есипова. - СПб: Питер, 2001. - 464c.

5. Савицкая Г.В. Анализ хозяйственной деятельности предприятия: 4-е изд., перераб. И доп. - Минск: ООО «Новое издание», 2010. - 688 с.

6. Солодовник Г.В. Моделі та інструментальні засоби управління розвитком підприємства: Автореферат дисертації канд. тех. наук: 01.05.02 / Харківський національний університет радіоелектроніки. - Харків: 2004 р. - 21 с.

7. Лабскер Л.Г., Яновская Е.В. Общая методика конструирования критериев оптимальности решений в условиях риска и неопределенности // Финансовый менеджмент. 2002. - № 5. - C. 58-74. 


\section{INTEGRATION OF BUSINESS STRUCTURES \\ OF COUNTRIES OF THE VISEGRÁD GROUP AND UKRAINE}

Германюк Н.В.

кандидат економічних наук, дочент кафедри аграрного менеджменту Віннииького національного аграрного університету

\section{ТРУДОВІ РЕСУРСИ АГРОСФЕРИ В УМОВАХ ІНТЕГРАЦИЙНОГО РОЗВИТКУ}

Анотація. У монографії досліджено сучасний стан кадрів підприємств у трансформаційних умовах сочіально-економічного розвитку. Визначено, щзо в прочесі інтеграчії бізнес-структур країн Вишеградської четвірки та Украӥни актуальною є проблема матеріальної мотивації персоналу в цілому. Розроблено підхід стосовно поліпшення рівня зайнятості сільського населення, зацікавленості робітників в ефективній праці, що реалізується шляхом ефективного стимулювання. Виявлено необхідність формування здорової конкуренції між працівниками у внутрішньому середовищі. Розглянуто деякі інновачійні напрями та відповідний механізм реалізації сучасної кадрової політики підприємств аграрної галузі. Запропонована методика розрахунків матеріального заохочення людських ресурсів на прикладі СТОВ «Промінь» за рівнем освіти, стажем роботи, фактично відпрацьованим часом і складністю роботи, яка висвітлює рейтинг окремого працівника та обсяг винагороди. 3'ясовано, що пошук ефективних способів управління стимулюванням за прозорими принципами є найбільш оптимальним напрямом забезпечення активізації використання трудового потениіалу. Поряд із изим доцільними $\epsilon$ застосування досвіду успішних європейських держав, а також подальша співпрачя між крайнами Вишеградської четвірки та Україною.

Вступ. Національна аграрна галузь успадкувала досить могутній професійнокваліфікаційний потенціал трудових ресурсів, що протягом тривалого періоду характеризувався потужною здатністю вирішувати складні виробничі та соціальні питання. Проте входження України в ринкові відносини та перехід на приватні принципи функціонування призвели до скорочення обсягів виробництва і масового відчуження робочої сили. Звільнення працівників, у т. ч. високопрофесійних спеціалістів сільського господарства, призвело до суцільної руйнації мотиваційних чинників стосовно ефективного використання кадрового потенціалу, що, своєю чергою, зумовило зниження ефективності галузевого виробництва. Останнім часом під впливом трансформаційних інтеграційних процесів в Україні спостерігається суттєвий відтік трудових ресурсів - робоча міграція за кордон, насамперед до сусідніх європейських країн Вишеградської четвірки (Польщі, Чехії, Словаччини та Угорщини). Поліпшення рівня зайнятості сільського населення останніх, а також 
зацікавленість того або іншого робітника в ефективній праці відбуваються шляхом соціально-економічної мотивації та ефективного стимулювання. У даному ключі під час виробничої діяльності функціонує механізм відносин між керівництвом і працівниками підприємства.

У цілому мотивація трудової активності в будь-якому колективі базується на раціональній системі матеріального і морального заохочення та в результаті має бути пов'язана 3 формуванням і збереженням трудового потенціалу на всіх етапах виробничого процесу. Саме тому під час удосконалення вітчизняної системи стимулювання праці доцільно застосовувати концепцію, яка сприяє підвищенню інтересів керівників аграрних підприємств стосовно збереження робочих місць, забезпечує відповідну професійну кваліфікацію працівників 3 урахуванням ступеня складності та якості робіт, що виконуються. Зауважимо, що, за оцінкою багатьох вітчизняних і закордонних науковців, формування та створення нових робочих місць вимагають значно більших витрат, аніж підтримка наявних.

\section{1. Місце мотивації та стимулювання у підвищенні продуктивності праці}

Сьогодні розвиток мотиваційного механізму на основі збереження та створення нових робочих місць з урахуванням гідного рівня оплати праці й матеріального стимулювання надає можливість вирішення суттєвої проблеми оптимального використання трудових ресурсів у сільській місцевості. Зацікавленість кожного працівника у власних результатах повинна базуватися на мотиваційних засадах якісного виконання роботи в установлені терміни та одержанні належної винагороди (рис. 1).

У цьому разі формується здорова конкуренція між інтересами працівників у внутрішньому середовищі, що забезпечує ефективність виробництва та отримання прогнозованого мотиву кожного робітника та колективу взагалі. Поряд із визначеним украй необхідно застосовувати принцип справедливості, який особливо стосується оплати праці. Остання повинна грунтуватися на здатності людини якісно виконувати роботу заданої складності з урахуванням технологічно-організаційних термінів, а також на відповідних результатах діяльності. Виходячи 3 даної гіпотези, основним завданням органів державної влади $є$ приведення системи оплати праці у відповідність до професійного рівня працівників, їх справжніх потреб, використовуючи досвід провідних європейських країн. Водночас доцільно враховувати той факт, що людина, яка працює, зобов'язана одержувати заробітну плату не нижче мінімального гарантованого рівня. Фінансова різниця між можливими реальним та мінімальним рівнями оплати праці завжди слугуватиме певним стимулом для підвищення ефективності витрачання зусиль кожним робітником, поліпшення його професійно-кваліфікаційних характеристик за допомогою мотиваційних заходів.

Слід зауважити, що категорії «мотивація», «інтерес», «потреба», «стимулювання» дещо відрізняються змістом. Так, «мотив» (лат. movere приводити в рух) трудової поведінки формує у працівника бажання до праці передусім для максимального задоволення власних потреб та прагнень. 


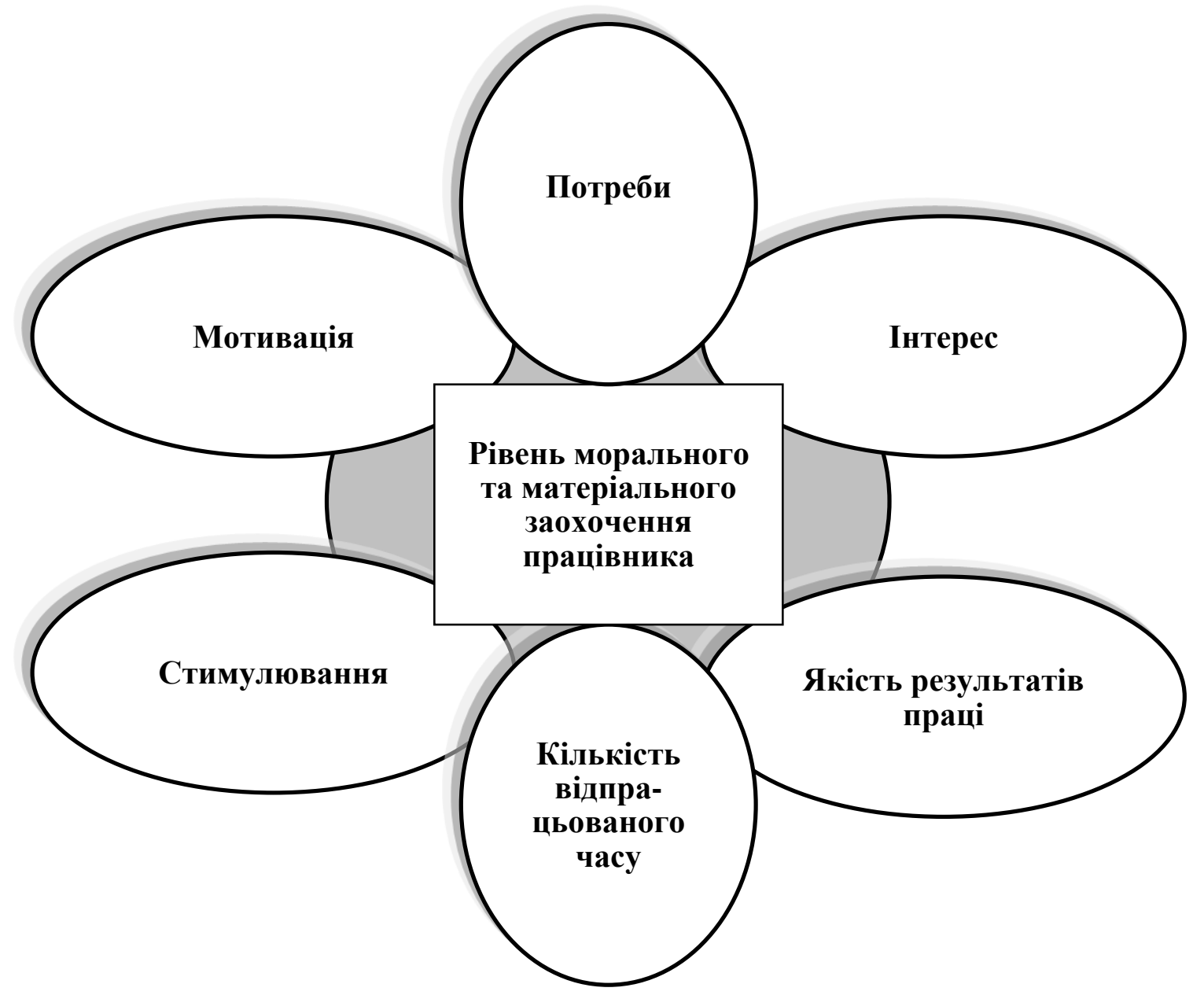

Рис. 1. Механізм формування мотивації та матеріального заохочення діяльності в аграрній галузі

Джерело: розроблено автором

«Потреба» (англ. need - запит) - це необхідність особистості у забезпеченні певних результатів і умов життя та праці.

«Інтерес» (англ. interest - цікавість) зумовлює цільову поведінку працівника відповідно до мотивів. Це можуть бути окремі духовно-пізнавальні, матеріально-житлові, побутові зручності, соціально-суспільні, культурні та інші інтереси.

«Стимулювання» (лат. stimulus - поштовх) - це категорія додатковоспонукальної дії, за допомогою якої відбувається прискорення мотиваційного здійснення трудової діяльності взагалі [3, с. 440-442].

Відповідно, можна зробити висновок, що основою мотиву є запрошення до дії, отримання від неї належної винагороди 3 подальшим просуванням по службі, а інтерес являє собою конкретно-цільову причину, яка спонукає працівника до певних вчинків стосовно прагнення задовольнити власні потреби. Моральне і матеріальне стимулювання будь-якої діяльності доцільно розглядати як прискорене бажання до певної активності для реалізації очікувань виробника та робітника щодо відтворення конкретної дії, спрямованої на отримання ефекту. Отже, мотив є суб'єктивним явищем, яке у кінцевому підсумку 3 урахуванням внутрішніх i зовнішніх факторів впливу перетворюється у визначення стратегічної цілі у напрямі вирішення потреб (інтересів). 
Спонукальні фактори заведено класифікувати за матеріальними, моральними, ідейно-політичними, колективними та іншими ознаками, що діють у суспільстві та впливають як на індивідуальні, так і на колективні, товариські взаємовідносини.

Факторами внутрішнього характеру, які стимулюють трудовий процес, $\epsilon$ психологічне задоволення робітника від творчої самореалізації та якісно зробленої справи, відчуття особистої належності до успіхів підприємства, визнання керівництвом його професійності та відповідне ставлення. Зазначене можна віднести до дій морально-особистого та морально-колективного характеру.

Певне зовнішнє підштовхування до трудової активності забезпечується безпосередньо управлінцями підприємства, а саме: рівнем оплати, можливістю просування по службі, додатковою відпусткою, іншими пільгами тощо.

Звичайно, матеріальні стимули повинні підтримувати бажання працювати краще, якісніше, надавати допомогу іншим і т. п. Але досить часто, на жаль, трапляється і прояв негативних наслідків: кар'єризм, користолюбство тощо. Ось чому дуже важливо, щоб i моральне, i матеріальне стимулювання максимально спрямовувалися не лише на інтерес окремої особистості, а й на результат колективної праці. Отже, в трансформаційний період розвитку нашої держави, в процесі інтеграції бізнес-структур країн Вишеградської четвірки та України достатньо актуальною проблемою $є$ питання матеріальної мотивації.

У цілому мотивація як індивідуальної, так і колективної активності не може функціонувати за відсутності матеріальної зацікавленості працівників. Провідне місце у мотиваційному механізмі має належати мотивації окремої людини, що в загальному вигляді розглядається нижче (рис. 2).

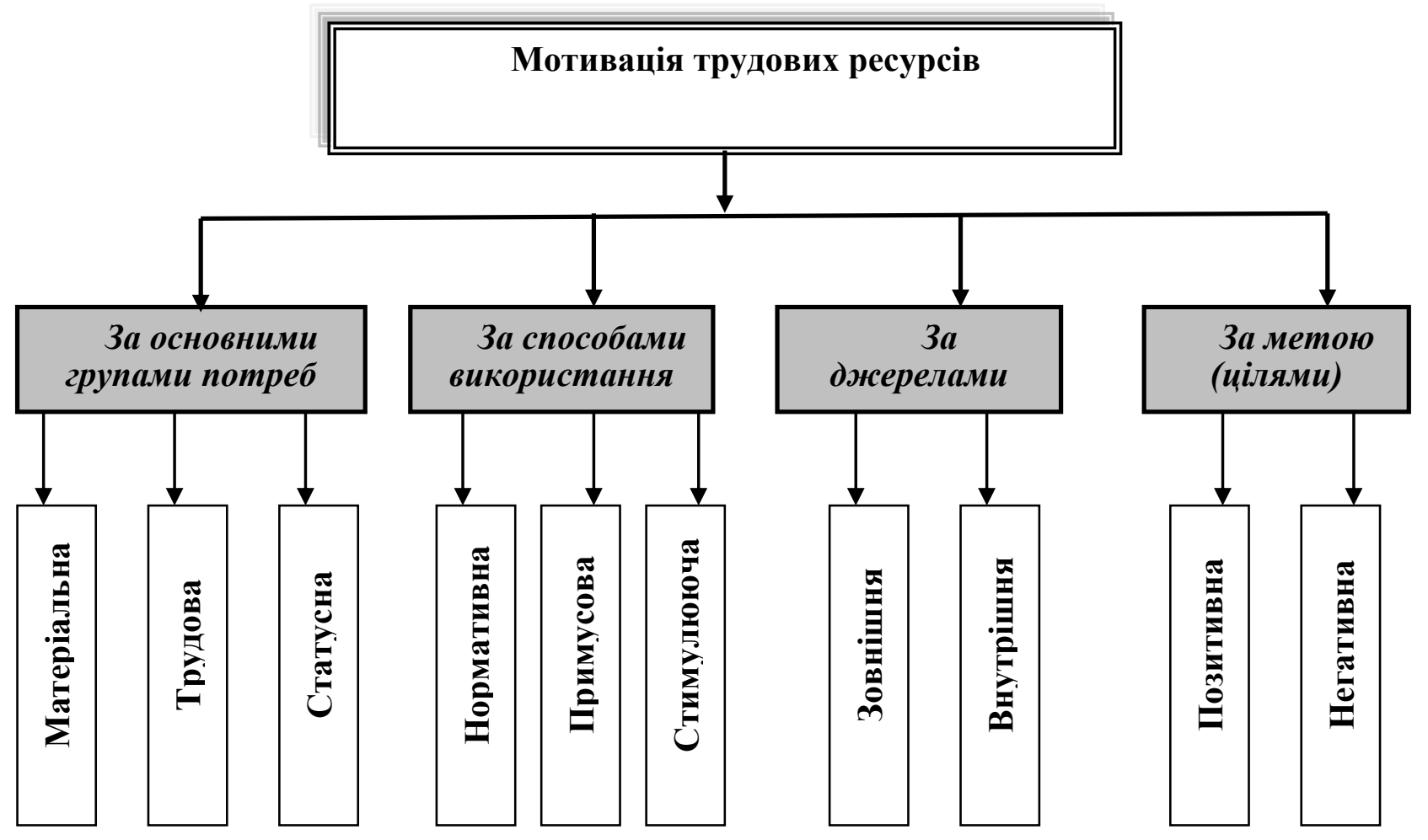

Рис. 2. Класифікація видів мотивації трудових ресурсів 
Під матеріальною мотивацією у цілому розуміють бажання окремого працівника (колективу) досягати рівня добробуту і достатку, що відповідатиме науково обгрунтованим стандартам і нормам життя. Прагнення людини до розвитку часто зумовлюється необхідністю збільшення трудового внеску в сім'ю, колектив, суспільство.

3 даного ракурсу матеріальну мотивацію активності праці в колективі, перш за все, бажано розглядати як похідну від обсягів отриманого кожним робітником доходу, який безпосередньо пов'язаний із рівнем заробітної плати. При цьому мотиваційну спрямованість людини доцільно орієнтувати на рівень оплати праці, яка $\epsilon$ основною формою статків сім ї. Під впливом сучасних фінансових змін суспільство змушене визнати необхідність зростання, насамперед, частки заробітної плати у загальних прибутках населення. Підвищення оплати праці повинно стати визначальною умовою державної соціально-економічної збалансованості, посилення зацікавленості працівників у результатах своєї роботи, що сприятиме збільшенню сукупної продуктивності.

Фактично помітна роль у стимулюванні належить статусній мотивації, яка (поряд iз трудовою) більше належить до внутрішніх імпульсів людської поведінки. Идеться про прагнення обіймати вищу, більш престижну i відповідальну посаду, набути лідерського статусу в колективі, користуватися пошаною та авторитетом.

Для усвідомлення внутрішніх мотиваційних алгоритмів трудової діяльності суттєвим є виявлення факторів, що впливають на рівень матеріальної мотивації, функціональність відповідних стимулів та з'ясування їх сутності. Зазначене представлено у вигляді тарифної системи оплати праці, за допомогою якої регулюються основні вимоги (нормативи) до праці та кваліфікаційні ознаки діяльності трудових ресурсів. Остання містить у собі тарифну сітку (шкалу) оплати праці, тарифну ставку (оклад) та штатний розпис.

Належна оцінка керівництвом роботи працівника за тарифною системою обов’язково призводить до позитивної мотивації останнього. Але на практиці це відбувається не завжди, що, як правило, знеохочує активність працівників. Недостатня самовіддача трудових кадрів часто спонукає керівництво до примусового впливу та специфічних мотиваційних заходів для отримання запланованого ефекту. Таку активність управлінців можна назвати зовнішньою, оскільки відбувається вона за бажанням керівника, ніби зовні. I, навпаки, якщо людина отримує справедливу оцінку своєї діяльності, то відчуває моральне задоволення, яке надає їй бажання працювати на тому ж рівні або навіть більш досконало. Позитивна (справедлива) мотивація викликає особливе бажання проникнути в сутність власної справи, облагороджує внутрішній стан особистості, згідно з чим формується подальша поведінка.

\section{2. Інноваційний напрям щодо реалізації кадрової політики}

В умовах інтеграції бізнес-структур Вишеградської четвірки та України розглянемо деякі інноваційні напрями та відповідний механізм реалізації сучасної кадрової політики на сільськогосподарських підприємствах для підвищення ефективності використання трудового потенціалу.

По-перше, необхідно визначити головну мету, пріоритетні завдання та дії, стосовно яких доцільно спрямовувати кадрову політику на будь-якому підприємстві. Остання передбачає залучення мобільних спеціалістів до процесу 
господарської діяльності, впровадження модернових технологій менеджменту персоналу, формування реального кадрового запасу, посилення вимог до моральних, психологічних та етичних рис працівників, створення умов для всебічного зростання людини, а також інвестування у професійний розвиток управлінців.

Сьогодні під час консолідованих господарських стосунків між Україною та державами Вишеградської четвірки провідним напрямом розвитку вітчизняних підприємств $\epsilon$ формування кадрової політики, відповідної положенням Стратегії державної кадрової політики на 2012-2020 pp. та стандартам Європейського Союзу.

Щодо країн Вишеградської четвірки, вони достатньо зацікавлені у співпраці 3 Україною як із близькою сусідкою та економічним партнером (з урахуванням рівня конкуренції на іншому європейському просторі), а також для поліпшення свого впливу в політиці СС. Зазначені держави технічно підтримують нашу країну в здійсненні політичних, соціально-економічних та секторальних реформ щодо: децентралізації влади й змін в адміністративно-територіальному складі; забезпечення й збереження енергії; сприяння розвитку малого і середнього підприємництва; збалансування режиму вільної торгівлі з СС; підтримки громадянських заходів тощо [4]. Використання формату інтеграції бізнесструктур Вишеградської четвірки та України на даному етапі є додатковим чинником у збереженні групи як функціонального просторового об'єднання із загальними інтересами.

Отже, головними завданнями кадрової політики на вітчизняних підприємствах аграрної сфери у трансформаційних умовах функціонування є:

1) формування нового покоління кваліфікованих працівників аграрної сфери, що володіють новітніми схемами праці;

2) підвищення результативності менеджменту трудових ресурсів на сільськогосподарських підприємствах;

3) розвиток внутрішніх зв'язків (між управлінцями й працівниками) та відносин між колегами, своєчасне забезпечення службовою інформацією;

4) поліпшення організаційної етики співробітників, популяризація роботи в аграрній сфері, введення високих культурних засад;

5) удосконалення алгоритму пошуку, підбирання та збалансування кадрів;

6) забезпечення переконливого управління професійним зростанням, підготовка та розвиток кадрів;

7) сприяння побудові віртуального середовища для навчання 3 метою самовдосконалення на базі передових комунікаційних засобів;

8) розроблення та втілення механізму прозорих кадрових показників, норм та чинників (за компетентністю, ефективністю);

9) побудова системи мотивацій та стимулювання, спрямованих на якісні результати;

10) залучення прийомів менеджменту щодо управління досвідом для накопичення, застосування відповідних знань, керування та обміну інтелектуальними можливостями.

Ці орієнтири спрямовані на досягнення гармонійності в процесах модернізації та збереження кількісного й якісного складу працівників на підприємствах, а також забезпечення висококваліфікованими кадрами [5]. 
Визначимо, що 3 погляду працівників кадрова політика має створювати комфортні умови для роботи, які надаватимуть можливості кар'єрного зростання та впевненість у майбутньому.

Важливим є те, що все більшого значення набувають стратегічні тенденції у роботі 3 персоналом, які домінують над традиційними управлінськими завданнями: плануванням, залученням, адмініструванням кадрів та підвищенням кваліфікації тощо.

Активна кадрова політика в аграрному секторі, насамперед, спрямовується на стратегічні фактори розвитку, а саме: 1) наближення до ринків шляхом моніторингу сфери діяльності та зосередження на попиті споживачів; 2) добірний сервіс із застосуванням відповідних технічних засобів; 3) високу якість продукції; 4) використання інноваційних досягнень; 5) економічну відповідальність та збалансованість; 6) кваліфікований кадровий потенціал; 7) адаптовані та мобільні організаційні установи.

Особисті завдання кадрової політики фірми створюються 3 урахуванням цілей, пов'язаних із зовнішніми умовами іiі діяльності та зумовлених внутрішніми вимогами, реалізація яких спрямована на вдосконалення відносин усередині колективу. Отже, на формування кадрової політики мають вплив зовнішні та внутрішні чинники.

Підприємство не в змозі уникнути зовнішніх чинників, тому для оптимального визначення потреб у трудових ресурсах та знаходження джерел їх покриття зобов' язано їх ураховувати. Серед таких факторів можна виділити:

1) ситуацію на ринку праці (демографічні чинники, освітня політика);

2) тенденції до економічного зростання;

3) науково-технічний розвиток (характер та сутність праці, що визначає попит фірми на конкретних фахівців, можливість перепідготовки кадрів);

4) нормативно-правове забезпечення (правила, встановлені урядом; законодавство про охорону праці, зайнятість, соціальну політику).

Своєю чергою, внутрішні чинники підлягають управлінському тиску з боку фірми, до них належать: 1) цілі підприємства; 2) модель керування (централізована або децентралізована, що потребує різних спеціалістів); 3) рівень фінансування (можливість інвестувати у заходи з менеджменту персоналом); 4) кадровий потенціал (оцінка здібностей працівників 3 оптимальним розгалуженням обов' язків).

Управління трудовими ресурсами підприємства $є$ важливим засобом щодо втілення кадрової політики, адже ефективно розвиватися та втримувати конкурентні позиції на ринку може та фірма, кадрова політика якої побудована на демократичних засадах i поглибленому моніторингу зовнішнього середовища. Одним із найбільш важливих завдань менеджменту на великих підприємствах є допомога керівництву різних рівнів під час виконання функцій, пов’язаних з управлінням.

У процесі визначення кадрової стратегії вкрай важливим є уявлення моделі своєї фірми відносно змістовності комунікаційних зв'язків та управління ними як сьогодні, так і в перспективі [6].

Тенденції кадрової політики безпосередньо перетинаються 3 функціями системи менеджменту персоналу даного підприємства. Представимо їх особливості поетапно: 
1) аналіз ситуації, прогнозування стану розвитку фірми, виявлення стратегічної мети;

2) уявлення головних засад кадрової політики та визначення пріоритетів;

3) офіційне затвердження кадрової політики на підприємстві;

4) впровадження необхідної інформації у колектив та збір думок;

5) оцінка обсягу інвестицій щодо втілення обраної стратегії - принцип розподілу коштів та сприяння стимулюванню праці;

6) побудова плану стосовно потреби у працівниках, прогнозів відносно штатної чисельності та складу, створення резервів;

7) здійснення кадрових засад: програма розвитку, відбір персоналу, побудова команди, відповідна підготовка та підвищення кваліфікації;

8) оцінка фінансових результатів підприємства - моніторинг щодо відповідності кадровій політиці, стратегії фірми, виокремлення складних питань, характеристика персоналу.

Види кадрової політики доцільно розрізняти за двома напрямами:

1) масштабами кадровик заходів;

2) ступенем відкритості.

Перший напрям пов'язаний зі сприйняттям правил та норм, які $\epsilon$ фундаментальними для основних кадрових заходів, а також шляхом прямого впливу керівництва на взаємовідносини з працівниками. Заведено виокремлювати певні види політики управління: пасивну, реактивну, превентивну, активну.

У ситуації, коли адміністрація не обізнана щодо чітких кадрових дій, а сутність взаємодії з працівниками виявляється лише в усуненні критичних наслідків, на підприємстві відбувається пасивна кадрова політика. Характерним для такої фірми є відсутність: прогнозів щодо необхідної чисельності кадрів, механізмів оцінювання штату та його роботи, моніторингу кадрового положення у цілому. Саме тут управлінці діють шляхом раптової реакції на складні обставини, намагаючись вирішити проблемні питання будь-яким методом, як правило, без спроби розібратися у причинах та можливих наслідках.

Під час реактивної політики кадрів адміністрація контролює ознаки ймовірного проблемного положення (у процесі роботи з людьми), передумови та розвиток кризи: появу поточних конфліктів, нестачу достатньо професійних працівників для вирішення актуальних завдань, відсутність мотивації. Управлінці роблять певні кроки у напрямі передбачення кризи з одночасним аналізом обставин, які забезпечили іiі формування. Відділи кадрів таких фірм зазвичай володіють механізмами визначення ситуації, що склалася, та мобільної результативної допомоги. У процесі розроблення програм із розвитку персоналу найбільші складності виникають протягом складання середньострокових прогнозів.

Відділи кадрів підприємств із превентивною політикою управління володіють не тільки способом тестування працівників, а й прогнозами на середньостроковий період. Програма розвитку такої фірми передбачає прогнозування на короткий та середньостроковий час щодо структурної та кількісної необхідності у трудових ресурсах, а також раціонально обгрунтовані напрями 3 поліпшення ситуації. Головна складність даної стратегії проектування цільових кадрових заходів на підприємстві. 
Щодо активної кадрової політики фірми, то мають місце ефективне адміністративне прогнозування, методика впливу на події, спостерігається розроблення антикризової програми 3 управління трудовими ресурсами, безперервний аналіз діяльності, а також корегування у виконанні програм, ураховуючи зовнішні та внутрішні обставини. При цьому виділяють раціональну та авантюристичну стратегії.

Під час утілення раціональної політики кадрів адміністрація фірми володіє як якісним діагнозом, так i обгрунтованим очікуваним розвитком подій та відповідними засобами впливу. Програми підприємства містять прогнози на короткий, середній та довгостроковий період відносно якісної та кількісної потреби у працівниках із різними шляхами реалізації трудових взаємостосунків iз персоналом.

Сутність ведення авантюристичної політики кадрів полягає у тому, що керівництво фірми не володіє якісним прогнозованим розвитком ситуації, але намагається впливати на останній. При цьому до програми дій включено планування трудових відносин із працівниками, яке зазвичай зорієнтоване на досягнення важливих цілей без урахування та дослідження ймовірних відхилень. При цьому уявлення стосовно напряму діяльності можуть бути правильними, але емоційними й не зовсім аргументованими. Під час суттєвих ринкових трансформацій, появи нового, більш якісного та слушного товару можуть виникнути значні проблеми щодо впровадження даного типу стратегіï.

Іншим напрямом у виокремленні видів політики кадрів може слугувати послідовне орієнтування на власний або зовнішній трудовий потенціал, рівень відкритості щодо навколишнього простору під час формування штату підприємства. У ракурсі визначеного кадрову політику фірми поділяють на: 1) відкритого типу; 2) закритого типу.

Особливість першого типу: підприємство $є$ прозорим для потенційних працівників будь-якого рівня, отже, кваліфікованому спеціалісту можна прийти та працювати на посаді свого статусу. Такий кадровий напрям властивий насамперед більшості сучасних телекомунікаційних компаній, автомобільних концернів, де не вимагають стажу роботи в аналогічних структурах. Відкритий тип також притаманний для нових підприємств різних напрямів діяльності (у т. ч. сільськогосподарських), які пропонують дещо агресивну політику завоювання конкурентних позицій на ринку та орієнтуються на стрімке зростання й швидкий розвиток у відповідній галузі.

Закрита кадрова політика передбачає залучення нових трудових ресурсів починаючи з низької посади, а заміщення вакантних посад відбувається лише працівниками фірми. Даний тип $є$ характерним для компаній із розвинутою корпоративною культурою, формуванням духу команди, а також для підприємств з обмеженою кількістю робітничого потенціалу тощо [7].

\section{3. Перспективи розвитку трудових ресурсів \\ та підвищення результатів праці}

У цілому з урахуванням інтеграційних напрямів ведення ефективної кадрової політики сучасна практика господарювання, безперечно, відтворює той факт, що роль мотивів і стимулів до якісної праці постійно зростає. Зазначені фактори все більше впливають на вибір поведінки працівника під час 
виробничої активності, формуючи його трудову мотивацію. Вони зумовлюються, як правило, сутністю роботи, розпорядком та умовами праці, структурною побудовою трудового процесу. У такому разі йдеться про комплексну систему рушійних сил щодо спрямування поведінки самої людини, відповідну мотивацію праці.

Отже, за визначеності перспектив розвитку кожної особистості виникає потреба в суттєвій і цікавій роботі, якісних умовах праці та оцінці керівництвом результатів роботи за оптимально високою шкалою. 3 одного боку, працівник пов'язує власну трудову мотивацію з корисністю самої справи, а з іншого - із самовираженням, самореалізацією та самоствердженням.

Стосовно ситуації в аграрному секторі, можна говорити про те, що всі форми мотиваційного стимулювання трудових кадрів у сільській місцевості $є$ життєво необхідними для відтворення робочої сили. Водночас провідне місце має належати матеріальній мотивації, насамперед рівню заробітної плати, яка $є$ основною формою доходів сільських родин.

Ступінь впливу факторів (їх похідних), який безпосередньо відзначається на результативних показниках та характеризує рівень матеріального заохочення працівника, можна проаналізувати на основі схеми, представленої нижче (рис. 3).

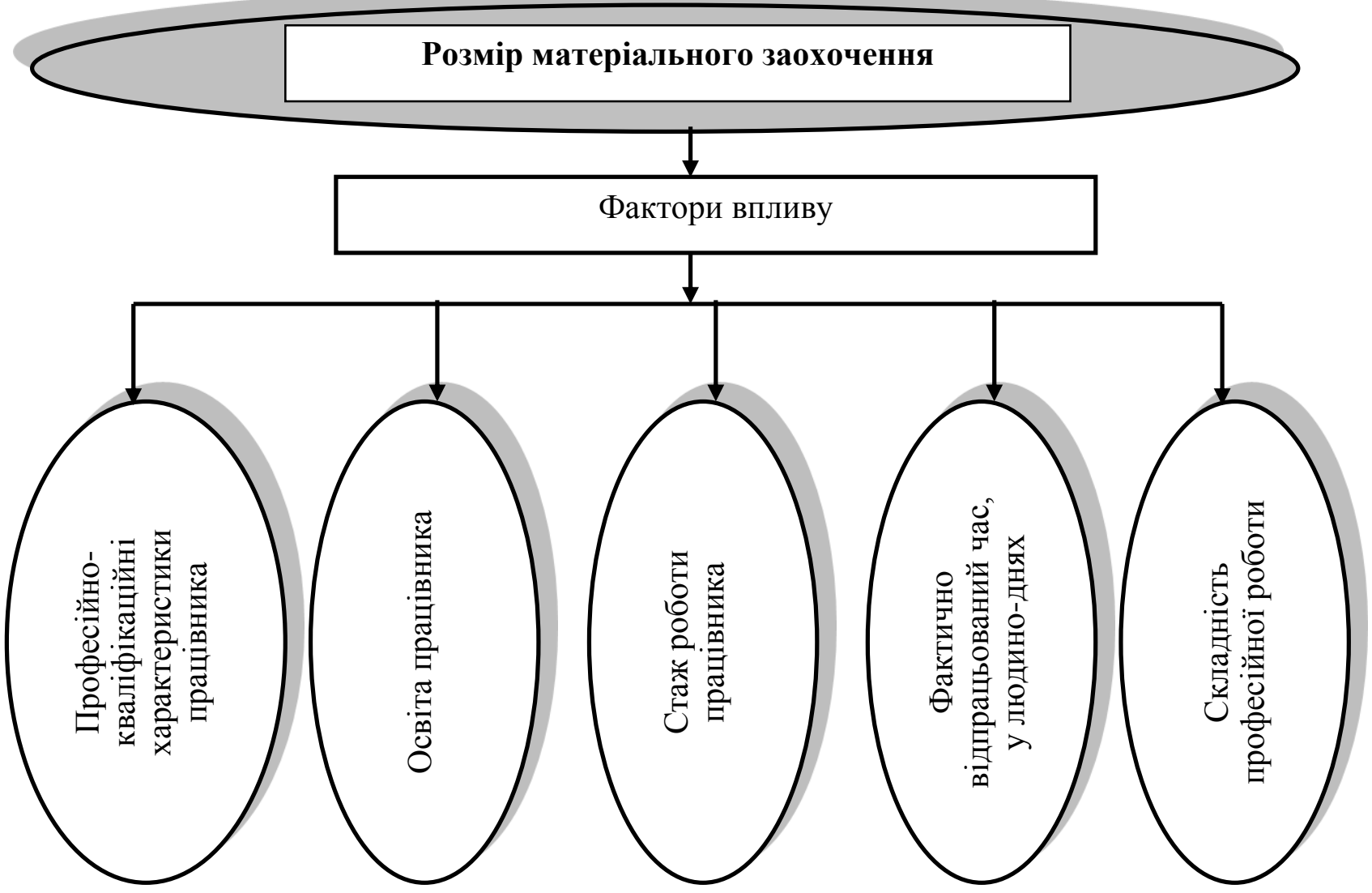

Рис. 3. Схема впливу системи факторів на розмір матеріального заохочення працівника

Джерело: розроблено автором 
Наведена далі комплексна порівняльна оцінка результатів праці будь-якого працівника може відбуватися за підсумками періодичного короткострокового (квартал, рік) та більш тривалого періодів.

Iїі можна виразити через багатофакторну модель (формула 1):

$$
M 3_{n+\infty}=O+C_{p .}+\Phi_{\text {в.ч. }}+C_{n p .},
$$

де:

M3 - розмір матеріального заохочення працівника, балів;

$O$ - освіта працівника, балів;

$C_{p .}$ - стаж роботи працівника підприємства, балів;

$\Phi_{\text {в.ч. }}-$ фактично відпрацьований час в людино-днях, балів;

$C_{n p}$ - складність професійної роботи, балів;

$n+\infty-$ кількість працівників.

Для прикладу оцінки результативного показника матеріального стимулювання нами обране СТОВ «Промінь» Калинівського району Вінницької області (табл. 1). Під час дослідження застосовано єдиний найбільш універсальний набір об'єктивних ознак 3 їх різним питомим значенням у сукупності. Кожна властивість, що впливає на мотивацію працівника, має коефіцієнт вагомості, загальна сума останніх повинна дорівнювати одиниці. Відповідно, для кожної ознаки розробляється шкала п'ятибальної оцінки, яка використовується для визначення індивідуального рангу вагомості працівників щодо матеріального стимулювання. У нашому випадку пофакторний коефіцієнт вагомості визначено експертним методом та становить: за освітою - 0,20; за стажем роботи - 0,30; за відпрацьованим часом - 0,35; за складністю роботи 0,15 . Всі наведені компоненти оцінювалися у п'ятибальному виразі.

Так, аналіз проведеної оцінки на експериментальному підприємстві показує, що найбільш вираженими діловими якостями для матеріального спонукання наділені: 1) у рослинництві -М.А. Січка, комбайнер, у якого сумарний інтегральний показник становить 4,775; К.В. Трачук, тракторист $-3,79$; О.А. Грицюк, агроном - 3,745 і В.О. Партека, насіннєвод - 2,95; 2) у тваринництві: В.Я. Борейко, телятниця - 4,39; А.О. Щерба, ветеринар - 4,11; Н.П. Джура, доярка - 3,79 і О.В. Ткач, зоотехнік - 3,13.

Впровадження системи стимулювання праці персоналу за даною схемою, насамперед, спрямоване на збереження та ефективне використання трудового потенціалу, поліпшення результатів виробничо-господарської діяльності підприємства загалом та налагодження потенційних інтеграційних зв'язків.

Висновки. Таким чином, залежно від фінансових можливостей фірми, а також змістовності іiі конкретних цілей у виробництві продукції можуть використовувати різні комбінаційні оцінки факторів щодо матеріального заохочення.

На підприємствах агросфери під час визначення ефективності застосування трудових ресурсів доцільним є втілення комплексної системи мотиваційної характеристики персоналу, яка дасть змогу найбільш раціонально реалізувати сукупність зовнішніх і внутрішніх якостей останнього у процесі бізнесдіяльності. 


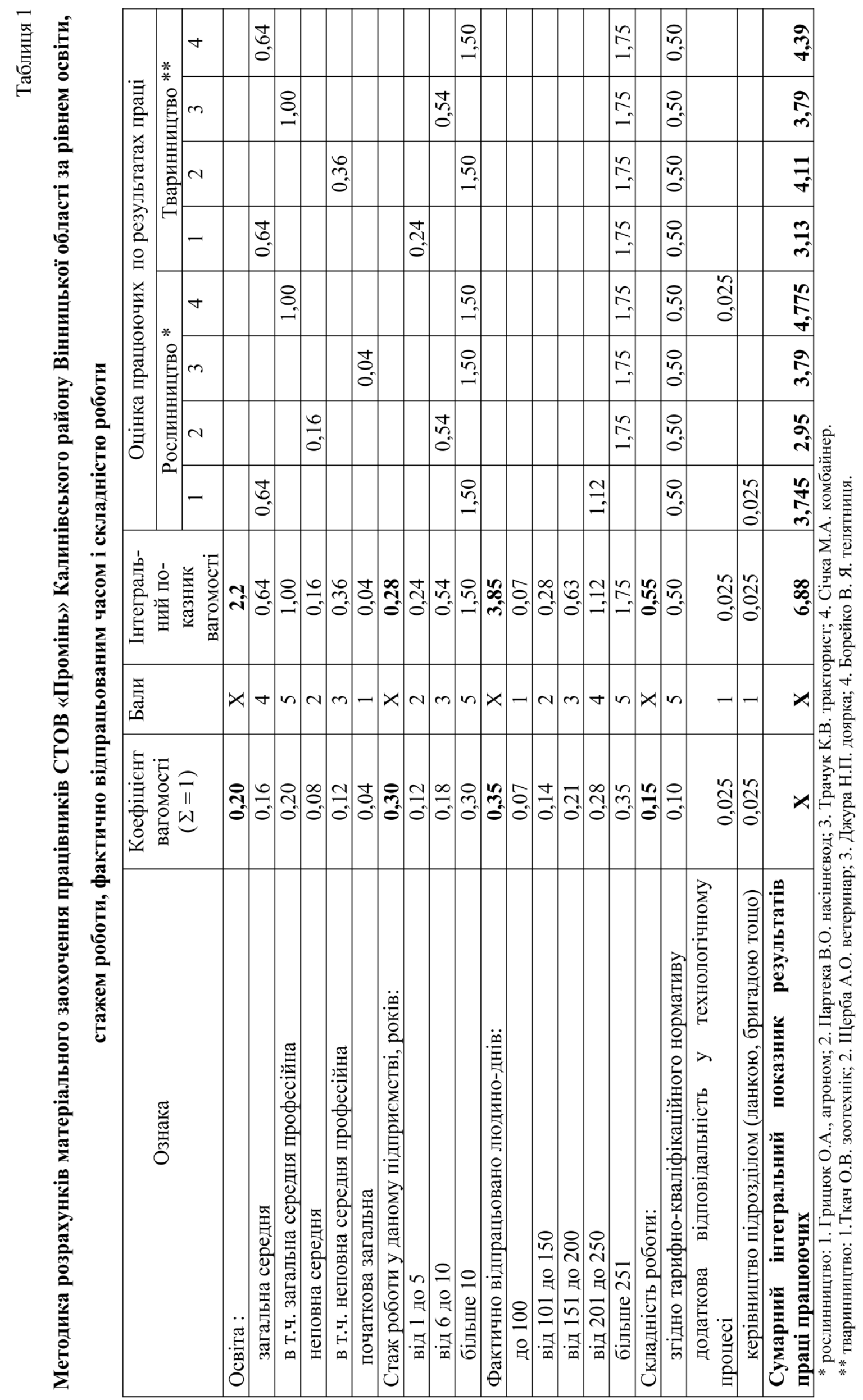


На нашу думку, найбільш ефективною моделлю управління кадрами підприємства $\epsilon$ така, де провідна роль людини розглядається не лише у виробничому, а й у соціальному спрямуванні. У зв'язку із цим особливого значення набуває поліпшення умов життя та праці людей, які мотивуватимуть робітників до якісної трудової діяльності. При цьому необхідним є оптимальне співвідношення між основною i додатковою заробітними платами. Слід зазначити, що останнім часом у процесі реформування галузевих відносин спостерігалися негативні зміни у структурі основної та додаткової заробітної плати. Як наслідок, їх заохочувальна роль утрачалася. Все це призвело до неефективного використання трудових ресурсів та зниження продуктивності праці в аграрному секторі у цілому.

Отже, запропонована нами концептуальна модель дає змогу визначити не лише рейтинг окремого працівника, а й обсяг його грошової винагороди, зацікавлюючи кожну людину в ефективній реалізації власного трудового потенціалу. Зазначене, своєю чергою, сприяє збереженню наявного кадрового потенціалу та забезпеченню підвищення рівня життя сімей усіх робітників аграрної сфери. Водночас одним із головних завдань $\epsilon$ інформування та обізнаність кожної людини стосовно результативної оцінки праці. Саме тому пошук ефективних способів управління матеріальним стимулюванням за прозорими принципами є найбільш оптимальним напрямом у забезпеченні активізації використання трудових ресурсів із застосуванням досвіду передових європейських держав та підтримки інтеграційної співпраці країн Вишеградської четвірки та України.

\section{Список використаних джерел:}

1. Андрійчук В.Г. Ефективність діяльності аграрних підприємств: теорія, методика, аналіз / В.Г. Андрійчук. - К. : КНЕУ, 2005. - 202 с.

2. Булавка О.Г. Оцінка ефективності використання трудових ресурсів сільського господарства / О.Г. Булавка, Н.В. Германюк // Сталий розвиток економіки. - 2011. - № 1. C. 64-69.

3. Завадський Й.С. Менеджмент : [підручник для студ. екон. спец. вищ. навч. закл.] : у 2-х т. Т. 2 / Й.С. Завадський. - К. : Європ. ун-т, 2003. - 640 с.

4. Національний інститут стратегічних досліджень [Електронний ресурс]. - Режим доступу : http://www.niss.gov.ua/articles/1861/.

5. Вісник: офіційно про податки [Електронний ресурс]. - Режим доступу: http://www.visnuk.com.ua/ru/pubs/id/6484?issue=151.

6. Кадровая политика [Електронний ресурс]. - Режим доступу: http://dps.smrtlc.ru/ Od_PM/Od_03_2.htm.

7. Кадровая политика организации [Електронний ресурс]. - Режим доступу: http://www.grandars.ru/college/biznes/kadrovaya-politika-organizacii.html.

8. Егоршин А.П. Управление персоналом : [учебник для вузов] / А.П. Егоршин. Н. Новгород : НИМБ, 2008. - 346 с.

9. Кибанова А.Я. Управление персоналом организации : [учебник] / А.Я. Кибанова. - М. : ИНФРА-М, 2002. - 638 с.

10. Шакирова Ф.К. Организация производства на предприятиях АПК : [учебник] / Ф.К. Шакирова. - М. : КолосС, 2007. - 520 с.

11. Хміль Ф.І. Управління персоналом : [підручник для студ. вищ. навч. закл.] / Ф.І. Хміль. - К. : Академвидав, 2006. - 488 с. 


\section{MODERN DETERMINANTS OF INVESTING AND PRODUCTION-FINANCIAL TNCS' ACTIVITIES}

Summary. The purpose of the work is an exposure of modern tendencies of investment policy of TNC. The methodological base of research is Ukrainian scientific works and foreign scientists and leading specialists, statistical and analytical materials of international organizations. There is no any direct dependence between of a particular branch interests in bringing in of DFI and real tendencies of their bringing in. It is analysed, in what industries of the economy of Ukraine direct foreign investments bring the most considerable contribution in the process of investing in the fixed assets. For estimation, the indexes of correlation of DFI in industry and investments in the fixed assets (FDI/FCI) are used. It is possible to draw a conclusion that without bringing foreign capital into the Ukrainian economy it is sufficiently difficult to attain high values of the economy growing and development. The possibility of activation of the attraction of foreign direct investments to Ukraine is fully real, as a result of economic and political changes, here is created a more favourable situation, than before reforms for the introduction in its economy of great foreign economic entities. At the same time, own large economic structures were formed in Ukraine: business concerns, consortia, associations, integrated associations, financial-industrial groups (FIG). It is important to mark that Ukraine falls behind in the lead through of market reforms from the countries of Central and East Europe (CEE), from China. However, tendencies, which showed up in afore-mentioned countries, in relation to attraction and use of direct foreign investments, come to light and in Ukraine.

Introduction. The beginning of relations between Ukraine and the TNCs of industrialized countries is often considered to be the external economic reform of 1987 aimed at creating an open economy, expanding the country's participation in the international division of labour, and developing production cooperation forms.

At the first stage, foreign capital was most actively invested in the processing and food industries of Ukraine, as well as in the construction of railways, oil production, and smelting of cast iron, and other (at that time) promising sectors. This contributed to the accelerated development of industry in the country. The largest foreign investors of the period under review were the financial and industrial groups of Germany and France. The peculiarity of this stage of investing in the Ukrainian economy is that it coincided with the trends in the development of the world economy as a whole.

At the second stage, Ukraine withdrew from the system of the world capitalist economy; its economy was isolated from the world economy. However, the solution of problems of economic development of the economy required significant financial and technical resources, which the country had not enough. To attract private foreign capital, the government allowed concluding concessions, by which private foreign 
capital was attracted to such industries and regions that the state could not develop on its own.

At the third stage, the foreign investment policy of the USSR was built, first of all, with an orientation toward the economy of countries with a similar political and economic system. During this period, the Council for Mutual Economic Assistance (CMEA) is being created and strengthened; various forms of economic cooperation with its participants are successfully developing. The main form of such cooperation was the coordination of the long-term and current national economic plans of the CMEA member states. However, there were also forms of direct investment and production cooperation (the "Druzhba" oil pipeline, the International Investment Bank for Economic Cooperation, the International Institute of Problems of the World Socialist System, the single currency - the transferable ruble, the unified energy system, etc.).

At the fourth stage, the gradual liberalization of domestic and foreign economic policies began, stemming from the beginning of economic and political reforms in the USSR, which continue to the present day in Ukraine. As a result of the liberalization of the economy, Ukrainian enterprises were given the right not only to carry out trade operations in the world market but also to act as investors. At the same time, favourable conditions were created for attracting foreign capital in a variety of forms - from completely foreign to joint ventures, including international joint ventures (associations, consortiums, etc.), concessions. Only for the 1990s, the number of enterprises with foreign investments increased more than 5.8 times $[2 ; 3 ; 13]$.

\section{TNCs' investment policy}

One cannot fail to note the special role of banks with the participation of foreign capital in the transnationalization of the economy of Ukraine. First of all, we emphasize that they serve related TNCs, and also often specialize in servicing other non-residents, their affiliated structures in Ukraine on transactions with the National Bank of Ukraine. This largely determines their sustainable and dynamic development. According to the NBU, the majority of banks controlled by foreign capital are included in the group of 200 largest banks, wholly owned by non-residents and the bank, the authorized capital of which is more than half formed by means of foreign investors. As NBU experts note, on the part of banks controlled by foreign participants, the struggle for leading positions in the banking system as a whole is intensifying. Thus, in the group of the largest banks, all banks controlled by foreign participants improve their positions every year $[2 ; 3 ; 15]$.

In addition, these banks often act as initiators for attracting other forms of capital. Such functions of banks with the participation of foreign capital allow Russian specialists to rightly assert that all negative phenomena in the field of financial relations, national currencies from the level of national economies are almost completely transferred to the international level. This observation was made with reference to the economic entities of the CIS countries, whose mutual calculations gave rise to such a phenomenon as the international crisis of non-payments. But it is also quite true for the banks of industrially developed countries. The mechanism of non-payments, launched at the national level, reproduces itself on an ever-expanding basis at the international level, threatening to curtail the trade and economic ties, restraining the integration processes and impeding the restoration of effective cooperative ties. This observation is also true in the reverse order: international 
financial crises, due to the involvement of Russian banks in the international financial system, generate a financial crisis already at the national level and cause the same negative consequences in the development of its economy.

The methods and forms of introducing foreign TNCs into the Ukrainian economy, in principle, do not differ from the methods of introducing these economic entities into the economy of others. However, in Ukraine, they have an unquestionable specificity. In the expansion of foreign TNCs in Ukraine, a large place belongs to the reimbursement on its territory of completely foreign enterprises (branches and subsidiaries of TNCs). In the late 1980s, a qualitatively new, promising form of transnationalization of the economy appeared in the USSR-consortiums involving large-scale trade between the USSR and Western partners.

In the writings of Western researchers, there is an opinion that attracting foreign TNCs to the country's economy may entail an increase in its openness and competitiveness in the world market. Consider, for example, the branches of the Ukrainian economy, the peculiarities of the impact of foreign TNCs on the efficiency and stability of their development, and try to test the hypothesis of the positive influence of the capital of foreign TNCs on the development of the economy of the host country $[5,6,7,11,12]$.

Based on the study of the theoretical approaches to the study of TNC formation issues, the forms and features of their transnationalization (expansion of activities abroad), the assessment of the effect of TNCs on the host economy, as the main indicator characterizing the level of transnationalization of the industry (or the country's economy as a whole) volumes of imported and exported foreign direct investment.

To date, virtually all FDI in the world economy is being carried out by transnational corporations. Extensive statistics on foreign direct investment greatly facilitate the task of assessing the potential and prospects for the transnationalization of the national economy (in particular, the transitive economy of Ukraine).

As for the so-called new forms of expanding the activities of TNCs abroad, in official statistics, they practically do not reflect, since the transnational corporations themselves are trying to veil the new technologies, with which they are expanding in the global economy.

In order to assess the appropriateness of attracting the capital of foreign TNCs to various sectors of the Ukrainian economy, as well as the prospects for the creation of Ukrainian transnational corporations, it is necessary to trace the relationship of foreign direct investment with the efficiency of the country's economy and efficiency indicators of a corporation focused on expansion abroad from a firm focused on the national economy. There are several aspects of the impact of FDI on the host economy (socio-economic, territorial, sectorial, etc.). In the study, we will identify the sectorial aspect of the impact of FDI of transnational corporations on the Ukrainian economy.

Let us analyse the situation in the field of foreign direct investment in Ukraine. The activation of FDI inflow to Ukraine was observed from the late 80's - early 90's of the XX century. It should be noted that in the early 90's of the XX century, in the Ukrainian economy, there was a deep crisis, and consequently there was a growing need to attract additional capital, especially in the form of FDI, which are investments by foreign investors (the main of which are TNCs) directly into the real sector of the 
economy. The dynamics of import of foreign investment in Ukraine by types and countries for the period from 2011 to 2016 is presented in Table 1, in Fig. 1.

Table 1

Dynamics of foreign investments in Ukraine, 2011-2016 [1]

\begin{tabular}{|l|c|c|c|c|c|c|}
\hline Type of investments & 2011 & 2012 & 2013 & 2014 & 2015 & 2016 \\
\hline FI, million dollars. & 11773 & 9560 & 10958 & 14258 & 19780 & 29699 \\
\hline FDI, mln. dollars & 3361 & 4260 & 4429 & 3980 & 4002 & 6781 \\
\hline Portfolio FI, mln. dollars & 191 & 31 & 145 & 451 & 472 & 401 \\
\hline Other FI, mln. dollars & 8221 & 5269 & 6384 & 9827 & 15306 & 22517 \\
\hline FDI,\% of FI & 28,6 & 44,6 & 40,4 & 27,9 & 20,2 & 22,8 \\
\hline
\end{tabular}

It should be noted that despite the growth of absolute FDI, their share in the total volume of foreign investments for the period under review decreased by $20.3 \%$, which reflects a decrease in the propensity of investors to invest in the real sector of the economy.

\section{Fig. 1. Dynamics of foreign investments in Ukraine, 2011-2016 [1]}

According to the Derzhkomstat of Ukraine, FDI in various spheres of the economy to the national economy in 2016 reached about 6.8 billion dollars (increased by $101.8 \%$ compared to 2007). In hryvnia equivalent, the growth in FDI was $213.3 \%$ for the period from 2011 to 2010. In accordance with the forecast of the Ukrainian economy developed by the specialists of the Ministry of Economic Development, FDI in Ukraine will increase by $5-7 \%$ annually $[1 ; 2 ; 15]$.

Indicative is the fact that in the rating of the investment potential index calculated by UNCTAD experts for 140 countries on the basis of 12 parameters, Ukraine rose from 48 positions to 41 (in terms of exporting FDI) and from 95th to 78th place (in terms of FDI imports) for the period from 2001 to 2011. This trend can be seen as leading to improving the investment climate for foreign capital, which increases the 
attractiveness of the Ukrainian economy for the largest suppliers of capital in the global economy - transnational corporations. Nevertheless, in the ranking of countries (2016) on the actual import of FDI, Ukraine occupies the 128th position, and on the actual export of FDI - 41st place. The current situation indicates the incomplete use of the Ukrainian economy's capacity to import foreign direct investment, which is mainly due to the continued high risk of investing in Ukraine $[2 ; 3]$.

The growing interest of transnational corporations in the Ukrainian economy may be due to a number of factors:

- emergence in Ukraine of an extremely capacious and unsaturated market;

- availability of natural resources in Ukraine and simplification of access of foreign capital to these resources;

- institutional reforms aimed at the nationalization of the economy, the privatization of numerous enterprises, the desire to reduce the state impact on the functioning of market mechanisms;

- liberalization of regimes for attracting foreign investment and the emergence of opportunities for the creation of joint ventures;

- closer relations of Ukraine with international economic organizations.

To determine the degree of transnationalization of the Ukrainian economy (the importance of transnational capital for them), as well as the degree of influence of TNCs on the indicators of profitability of the functioning of industries, the following indicators should be used.

The main indicator of the importance of foreign direct investment for the functioning of the country's economy is the share of accumulated foreign direct investment in GDP, calculated by the formula $1[2,3,13]$ :

$$
F D I^{G D P}=\frac{F D I_{\text {stock }}}{G D P}
$$

where $F D I^{G D P}$ - share of accumulated FDI in GDP;

$F D I_{\text {stock }} \sim$ the value of accumulated FDI;

GDP is the gross domestic product.

The degree of participation of foreign capital in the formation of the fixed capital of enterprises in the industry is characterized by the ratio of FDI and investments in fixed assets (both in the industry and in the economy as a whole). This indicator is calculated by the formula $2[2,3,13]$ :

$$
\mathrm{FDI}^{\mathrm{FCI}}=\frac{\mathrm{FDI}_{\text {inward }}}{\mathrm{FCI}}
$$

Where $F D I^{F C I}$ is the share of FDI in investments in fixed assets;

$F D I_{\text {inward }}$ - value volume of imported FDI;

FCI - investment in fixed assets.

Next, consider the dynamics of the above indicators for the period from 2011 to 2016. Based on the analysis of changes in GDP and FDI, it can be noted that foreign direct investment in the economy of Ukraine increased throughout the period under review, but at a slower pace than the country's gross domestic product. For example, GDP continued to grow throughout the period under review, increasing by $405.2 \%$ compared to 2011), and FDI amounted to the 2016 year to 1610.73 billion hryvnia (increased by $213.3 \%$ compared to 2011) [15].

In this regard, the share of FDI in GDP (Figure 2) from 2012 to 2013 and from 2015 to 2016 (by 9 and 20\%, respectively), however, for the entire period under 
review, there was a trend towards an increase in the absolute value of FDI, and in 2009 its value was 0.12 units (i.e., it increased by $100 \%$ compared with 2004). It should be noted that the share of FDI in GDP, despite its gradual increase, is still rather insignificant. Consequently, one can make a statement about the low degree of participation of foreign direct investment in the creation of the GDP of Ukraine.

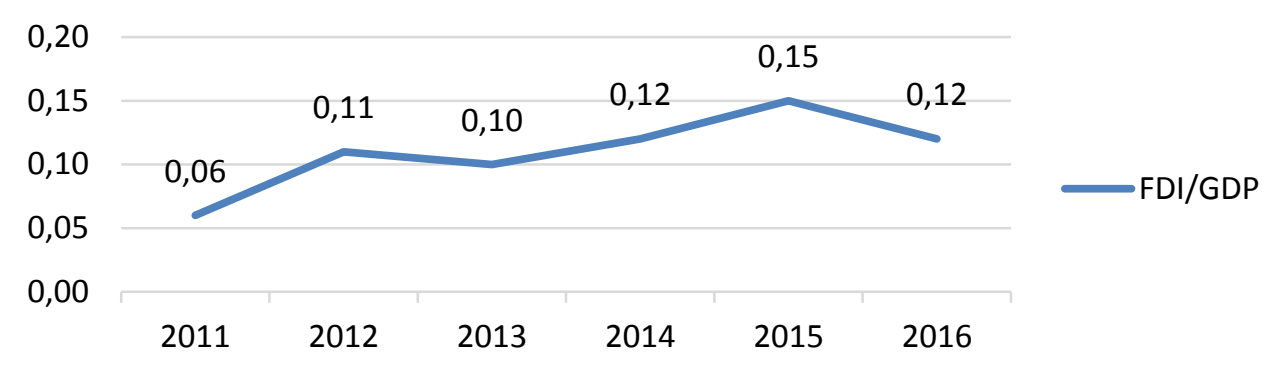

Fig. 2. Change in the share of accumulated FDI in the GDP of Ukraine [1]

Further, it is necessary to determine sectors of the economy of Ukraine that are in the greatest need of investments and to track whether FDI is directed to the sectors experiencing the greatest investment hunger. The basic index characterizing the need to attract investment in the industry will be considered the depreciation index of the fixed assets of the industry. Based on the data of the Derzhkomstat of Ukraine (see Appendix, Table 29), we will compile a rating of branches by the average depreciation of fixed assets (in descending order) for the period from 2011 to 2016 (Table 2).

Table 2

\section{Rating of economic branches by the average degree of depreciation of fixed assets in Ukraine [15]}

\begin{tabular}{|c|l|c|}
\hline $\begin{array}{c}\text { Place in } \\
\text { the rating }\end{array}$ & \multicolumn{1}{|c|}{ The sector } & $\begin{array}{c}\text { Average depreciation } \\
\text { of fixed assets (in \%) }\end{array}$ \\
\hline 1 & Chemical and petrochemical & 58,75 \\
\hline 2 & Mechanical engineering and metal working & 53,95 \\
\hline 3 & Oil producing & 53,18 \\
\hline 4 & Oil refining & 53,03 \\
\hline 5 & Ferrous metallurgy & 52,25 \\
\hline 6 & Building materials industry & 52,17 \\
\hline 7 & Agricultural production & 48,20 \\
\hline 8 & Non-ferrous metallurgy & 46,42 \\
\hline 9 & Foodstuffs & 37,97 \\
\hline
\end{tabular}

We will analyse, in which of the branches of the economy of Ukraine direct foreign investments make the most significant contribution to the process of investing in fixed capital. For estimation, we will use the ratio of FDI to industry and fixed capital investments (FDI/FCI). 
The dynamics of the FDI/FCI indicator for the oil-producing, oil refining, chemical and petrochemical industries looks as follows. It is characteristic that for the oilproducing, chemical and petrochemical branches in general, during the period under review, an increase in the indicator occurred (by $15.4 \%$ and $450 \%$ respectively). At the same time, in the chemical and petrochemical industry, the maximum FDI/FCI was reached in 2013 (0,15 units), after which there was a slight decrease for two years and, in 2016, the value of the indicator was 0,12 units. (increased by $450 \%$ compared to 2011). In the oil industry in the period from 2004 to 2005, there were a sharp increase in the FDI/FCI (130.8\%) and a further sharp decline from 2012 to 2013 (by 833.3\%), however, since 2014 there was a steady tendency towards the growth of the indicator, and its value at the end of the period under consideration amounted to 0.15 units, which is $15.4 \%$ higher than the value of 2011 . In the oil refining industry during the period from 2011 to 2015, there was a sharp decline in the FDI/FCI (from 0.32 to 0.01 or $968.7 \%$ ), and only between 2015 and 2016, the value of the considered indicator increased by $20 \%$ and amounted to 0.05 units at the end of the period under consideration. Next, consider the FDI/FCI dynamics for the sectors of black, nonferrous metallurgy, and machine building (Figure 3) [1; 13; 14].

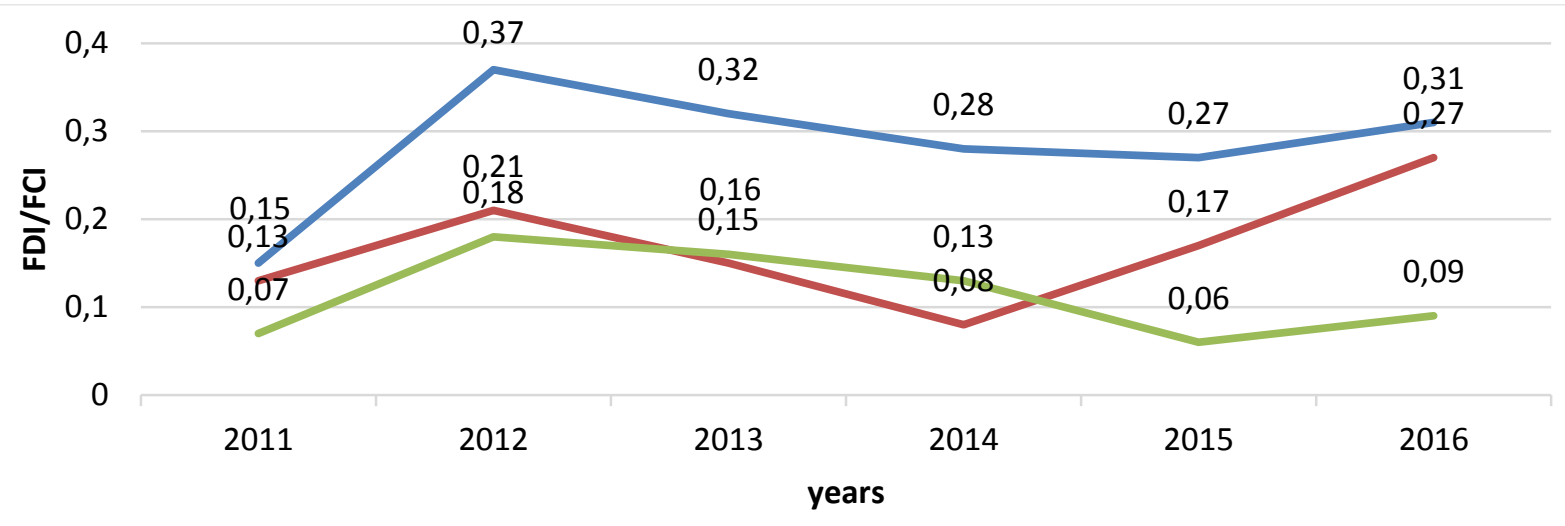

Ferrous metallurgy $\longrightarrow$ Non-ferrous metallurgy $\longrightarrow$ Mechanical engineering and metal working

\section{Fig. 3. Change in the FDI/FCI (sector of ferrous, nonferrous metallurgy, machine building, and metalworking)}

Based on the analysis of graphic data, it can be noted that for all the industries under consideration as a whole for the period from 2011 to 2016, there was a tendency to increase the FDI/FCI. However, within the period under review, the change in the indicator for the three branches was not the same. So, for ferrous metallurgy from 2011 to 2012, a sharp increase in the value of FDI/FCI (by $146.7 \%$ ), followed by $2012-2015$, there was a gradual decrease (by 27\%), and only in the period from 2015 to 2016 , the indicator grew by $14.8 \%$ and, it was 0.31 units in 2016 (i.e., it increased by $106.7 \%$ as compared to 2011 ).

For non-ferrous metallurgy from 2011 to 2012, then from 2012 to 2014, an increase in the FDI/FCI (61.5\%), was observed. There was a significant reduction (by 61.9\%) and, in the period from 2014 to 2016, the tendency towards its increase (but more intense - by 237.5\%) renewed. In general, for the whole period under review, the value of the indicator increased by $107.7 \%$ and amounted to 0.27 units in 2016. In the industry of mechanical engineering and metalworking in the period from 
2011 to 2012 , the FDI/FCI increased by $157.1 \%$, then it was reduced by $66.7 \%$ until 2015, and only between 2015 and 2016 the tendency towards the growth of the indicator has renewed (by 50\%). By the end of the period under review, it was 0.09 units, i.e. increased by $28.6 \%$ compared to 2011 . The dynamics of the FDI/FCI indicator for the food industry, trade, and agricultural production is illustrated in Fig. $4[1 ; 13 ; 14]$.

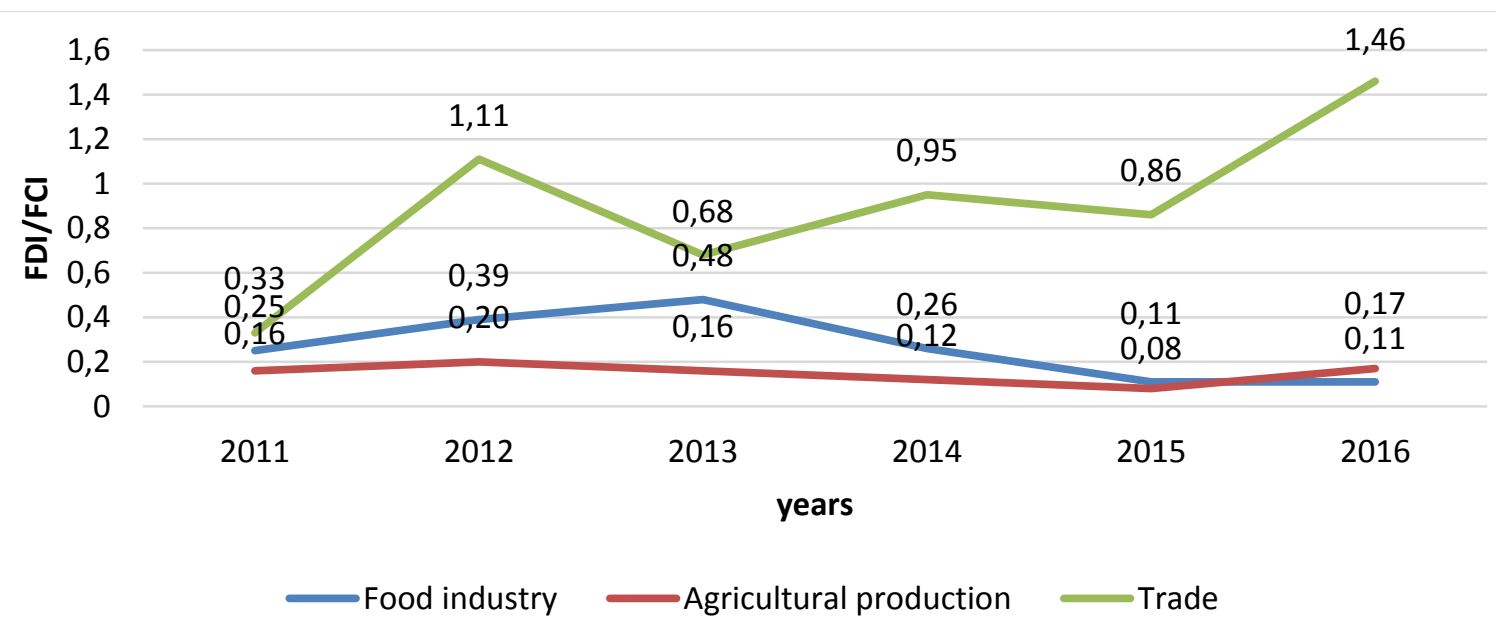

\section{Fig. 4. Dynamics of the FDI/FCI indicator for the food industry, trade, and agricultural production}

In the field of agricultural production, during the entire period under review, a slight increase (by 6.25\%) was observed. However, during the period, there were significant changes. From 2011 to 2012, the FDI/FCI increased by 25\%, then it was reduced by $60 \%$ by 2015 , and in 2016 it was quite intense (by $112.5 \%$ ). Trends in this indicator for the industries under consideration are fundamentally different.

For trade and catering, a sharp increase in the indicator is observed (by 348.5\%), and for the food industry, there was a significant (by 56\%) decrease in FDI/FCI over the period from 2011 to 2016 as a whole. Nevertheless, in the food industry, the indicator for 2011-2013 retained a tendency for the growth (by 92\%), then from 2013 to 2016 decreased by $77.1 \%$. In trade and public catering, on the contrary, each year, during the period under review, the trend of the indicator varied to the opposite, however, due to a sharp increase in the indicator in 2011-2012 and 2015-2016 (on 236 and 720,9\% respectively), there was an intensive growth for the period from 2011 to 2016. We now turn to the analysis of trends in the FDI/FCI indicator in the transport and telecommunication sectors of the economy (Figure 5) $[1 ; 13 ; 14]$.

For the transport industry, during the period under review, there was a tendency for the growth of FDI/FCI from 2011 to 2012 (from 0,02 to 0,05 units or by 150\%), then stagnation followed by a decrease in the indicator to zero in 2015. However, from 2015 to 2016, the value of the indicator increased and amounted to 0.01 units at the end of the period under review (decreased by 50\% compared to 2004). It should be noted that the transport industry has the lowest minimum FDI/FCI indicator of all industries under consideration. In the telecommunications sector, there was a sharp (by 600\%) jump in the indicator from 2011 to 2013, then its sharp decline (by 74.3\%) in 2013-2014, followed by a more flattening (by 44.4\%) decline in 2014-2016. At 
the end of the period under review, the value of the indicator was 0.05 units, i.e. did not change compared to $2011[1 ; 13 ; 14]$.

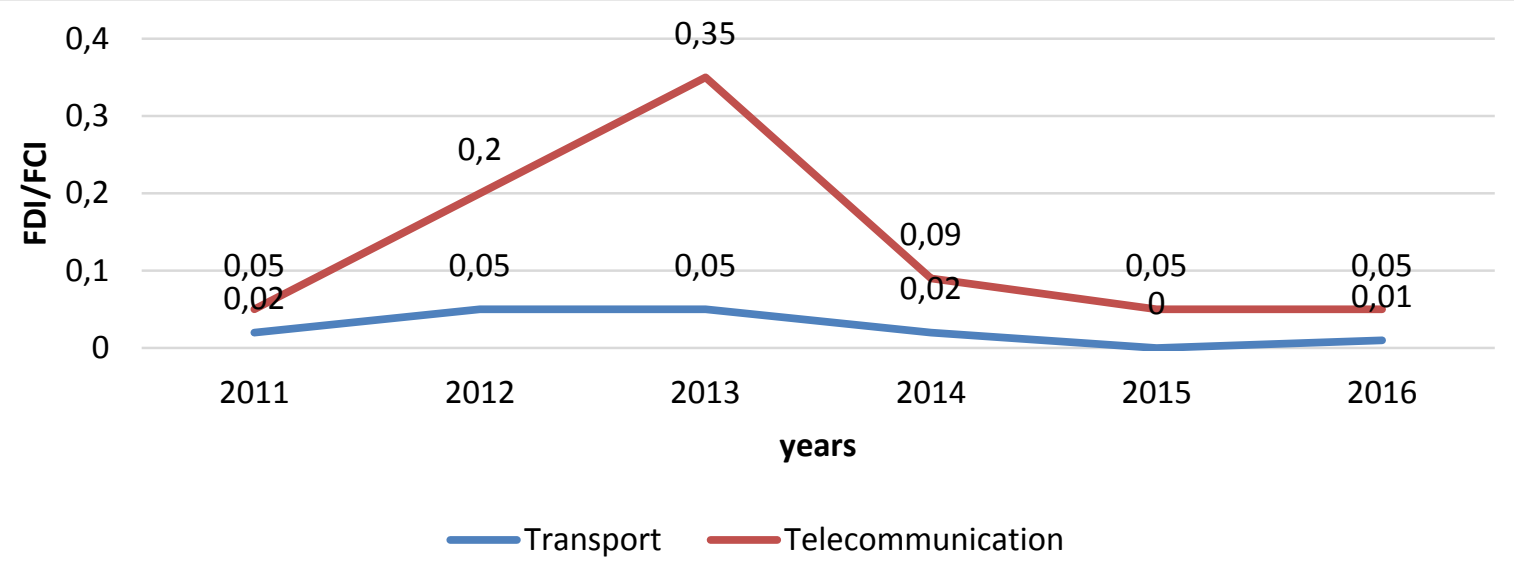

Fig. 5. Dynamics of the FDI/FCI indicator in the transport and telecommunication sectors of the economy

Table 5

The rating of industries by the average value of FDI/FCI [1]

\begin{tabular}{|c|l|c|}
\hline $\begin{array}{c}\text { Place in the } \\
\text { rating }\end{array}$ & \multicolumn{1}{|c|}{ The sector } & $\begin{array}{c}\text { Average value of } \\
\text { FDI/FCI (in units) }\end{array}$ \\
\hline 1 & Trade and catering & 0,90 \\
\hline 2 & Ferrous metallurgy & 0,28 \\
\hline 3 & Food & 0,27 \\
\hline 4 & Non-ferrous metallurgy & 0,17 \\
\hline 5 & Agricultural production & 0,15 \\
\hline 6 & Telecommunications & 0,13 \\
\hline 8 & Machine-building and metal working & 0,11 \\
\hline 9 & Oil refining & 0,10 \\
\hline 10 & Chemical and petrochemical & 0,09 \\
\hline 11 & Construction materials industry & 0,06 \\
\hline 12 & Transport & 0,02 \\
\hline
\end{tabular}

\section{Analysis of data of the correlation coefficient}

Next, we will try to establish a close link between direct foreign investments in the industry with the basic indicators of the industry. As an estimator, we will consider the correlation coefficient between the volume of FDI in the industry and the financial sector's financial result, as well as between the volume of FDI in the industry and the profitability of the products of this industry. We calculate the correlation coefficient by Formula 3:

$$
r_{x y}=\frac{n \sum_{i=1}^{n} y_{i} x_{i}-\sum_{i=1}^{n} x_{i} \sum_{i=1}^{n} y_{i}}{\sqrt{\left(n \sum_{i=1}^{n} x_{i}^{2}-\left(\sum_{i=1}^{n} x\right)\right.}}
$$


As a result of the comparison of a number of values for the selected period, we obtain the value of the correlation coefficient, which is in the range from -1 to +1 . Moreover, the closer the value to unity, the closer the connection (reverse or straight, respectively) between the parameters.

The data obtained as a result of calculations will be presented as Tab. 5. Based on the calculations, it was revealed that direct foreign investments have a significant effect on the financial result (the correlation coefficient exceeds the critical value of 0.7079 with a significance level of $99 \%)$ for ferrous metallurgy $(\%=0.84)$, machine building and metalworking $(\%=0.89)$ and the building materials industry $(\%=0.82)$. As for the impact of FDI on the profitability of industry products, there is a close relationship found only in the construction materials industry $(\%=0.78)($ Table 6$)$.

Table 6

Analysis of data of the correlation coefficient

\begin{tabular}{|l|c|c|}
\hline \multicolumn{1}{|c|}{ Correlation coefficient } & $\begin{array}{c}\text { FDI, UAH billions UAH; } \\
\text { SFR, million UAH }\end{array}$ & $\begin{array}{c}\text { FDI, billion } \\
\text { UAH R sales \% }\end{array}$ \\
\hline Oil refining industry & $-0,51$ & $-0,32$ \\
\hline Chemical and petrochemical industry & 0,45 & $-0,29$ \\
\hline Ferrous metallurgy & 0,84 & 0,27 \\
\hline Non-ferrous metallurgy & 0,41 & $-0,26$ \\
\hline Machine-building and metal working & 0,89 & 0,04 \\
\hline Construction materials industry & 0,82 & 0,78 \\
\hline Agricultural production & 0,52 & 0,11 \\
\hline Food industry & 0,31 & $-0,09$ \\
\hline
\end{tabular}

Nevertheless, from the sectors, in which there is a close relationship between FDI and the results of the industry, only in the ferrous metallurgy foreign direct investment occupies a significant share in fixed capital investments. Therefore, on the basis of the revealed features of the investment of capital of foreign TNCs in the sector of the Ukrainian economy, it can be concluded that divergences in direct foreign investment and development needs of the Ukrainian economy sectors. Only in some cases, foreign direct investment can be considered as an incentive for the successful functioning and development of the industry. It should be emphasized that the admission of foreign capital to the Ukrainian economy and the creation of various types of enterprises in its territory with its participation can be regarded as one of the important steps towards the introduction of international production into the practice of economic relations of Ukraine with foreign partners, i.e. as the transnationalization of the subjects of its economy.

In Ukraine, as a result of economic and political reforms of the late 80 's and early 90 's, irreversible geopolitical changes took place. This has led in all countries to a deep economic crisis, which continues in some of them to this day. The main features of the crisis were: the fall in GDP and gross industrial output (GDP), hyperinflation, unemployment, the negative balance of payment and trade balances, etc. Only by 1997, Ukraine was able to reach the positive growth rates of GDP and runway and somewhat reduce inflation, with the actual increase in unemployment and a 
significant decrease in the positive balance of foreign trade balance. However, even this insignificant economic growth prevailed in 1998 and replaced by a sharp decline in production in all sectors and the deterioration of other macroeconomic indicators. However, from the 2000 year, the positive dynamics of the main macroeconomic indicators of the country was observed. The global financial crisis of 2008 has had a similar impact on Ukraine's national economic system.

\section{Results}

We emphasize that without attracting foreign capital to the Ukrainian economy, it is rather difficult to achieve high values of economic growth and development. Given the difficult economic and debt situation, private foreign direct investment is the most preferable for the country, the main source of which, as was illustrated earlier, are transnational corporations.

The possibility of activating the inflows of foreign direct investment into Ukraine is quite real because as a result of economic and political changes, a situation has been created that is more favourable than before reforms for the introduction of large foreign economic entities into its economy. Simultaneously, Ukraine formed its own large economic structures: concerns, consortiums, associations, inter-industry associations, financial-industrial groups (FIGs).

It should be noted that Ukraine lags behind the implementation of market reforms from the countries of Central and Eastern Europe (CEE), from China. Nevertheless, the trends in attracting and using foreign direct investment in the aforementioned countries are also found in Ukraine. First of all, it concerns the creation of a favourable investment climate, the presence and degree of favourability of which characterize the state of the economy of the host country as a whole, and also are an indicator of the effectiveness of market reforms.

It is possible to identify a trend towards an increase in the total volume of FDI imports into the Ukrainian economy. However, one cannot help noticing the decline in the share of FDI in the total volume of foreign investment in Ukraine and the slowing of their annual growth rates. Obviously, this is due to the policy of the government that switched the demand of foreign investors from the real sector to speculative.

A significant negative impact on the objects of foreign investment entering Ukraine is due to the significance of volumes of the "shadow" economy, low solvent demand in the domestic market, and the growing external debt of Ukraine. For the same reasons, there is a slowdown in the growth rate of foreign investment in general, with a faster growth in portfolio investment. Foreign investors direct financial resources to industries that provide the highest profit and quick payback. The structure of the industry distribution of FDI in Ukraine corresponds to the distribution of gross accumulated foreign investment.

The distribution of foreign investment in general and FDI, in particular, by regions of Ukraine, is characterized by extreme unevenness. The overwhelming mass of them is concentrated in the Central and North-Eastern regions, distinguished by a relatively developed infrastructure and skilled labour. Together, these regions account for more than $85 \%$ of all investments in the national economy of Ukraine.

As noted earlier, about $90 \%$ of all FDI in the world is made by TNCs. In turn, the bulk of TNCs belongs to the industrialized countries. That is why the most developed of them occupy the first places among the largest investors in Ukraine. The first in 
the economy of Ukraine in the late 80's transnational corporations included in the rating of the world's 100 largest TNCs began to be introduced: Chevron, Eastman Kodak, Siemens, Salamander, Thompson, L'Oréal, Mitsubishi, Nestle, Danone, and other major corporations, attracted by the huge natural and economic potential of the country, the capacity of its domestic market, and the opportunity to extract high profits from economic reform.

The scale of foreign investment in Ukraine can be assessed as very limited. In global volumes, its share is from several tenths of a percent to several percents. The main cause of the current situation is a high degree of financial risk, which, in turn, is due to economic and political instability in the country. This is noted by both Russian and foreign specialists. It is this reason that determines not only the volume of FDI but also their sectorial distribution.

The overwhelming majority of FDI is directed to the industry with quick payback, minimal financial risk, which does not require highly qualified specialists (tourism, hotel business) and the creation of small joint ventures in services (engineering, advertising, consulting, etc.). In industry, only about $4 \%$ of the total number of joint ventures was created. Some of them contribute to the technological development of the country but the overwhelming majority is focused on the production of goods for the consumer market. In addition, the low absolute and relative volumes of direct foreign investment in the economy of the country cause their insignificant influence on its macroeconomic indicators.

Further transnationalization of the domestic economy is an objective necessity. Its development is associated with the evolution of forms of introduction and activity of transnational capital into Ukrainian markets according to the general pattern characteristic of the world economy as a whole: from the placement of its own subsidiaries in Ukraine to establish branches and international joint ventures. However, when joint ventures in countries with developed market economies are most often involved, partners with comparable potential, which are international in the field of activity, and each of which can make the same rather than complementary contribution, in Ukraine the situation is different. It, as a partner, most often makes an additional contribution. And this means the need for the Russian economy to develop its own economic entities adequate to large foreign transnational corporations.

Conclusions. In general, based on the analysis of the situation in the field of foreign direct investment (most of which is carried out by transnational corporations), a number of fundamental conclusions can be drawn about assumptions about the nature of the impact of transnational corporations on the economy of the host country.

Further transnationalization of the domestic economy is an objective necessity. Its development is associated with the evolution of the forms of introduction and activity of transnational capital into the Ukrainian markets according to the general pattern of the characteristic of the world economy as a whole: from the placement of its own subsidiaries in Ukraine to establish branches and international joint ventures. However, when joint ventures in countries with developed market economies are the most often involved, partners with comparable potential, which are in the field of activity, and each of which can be the same rather than complementary contribution. Ukraine, as a partner, most often makes an additional contribution to developing its own economic entities. In general, based on the analysis of the situation in the field of 
foreign direct investment (most of which is carried out by transnational corporations), and a number of fundamental conclusions can be drawn about assumptions about the nature of the impact of transnational corporations on the economy of the host country.

First, throughout the period under review, there was an intensive growth of foreign investment in the Ukrainian economy. But at the same time, the increase in foreign direct investment was less intensive (their share in the total volume of foreign investments was somewhat reduced), which illustrates the insufficient attractiveness of the real sector of the Ukrainian economy for the capital of foreign transnational corporations. Secondly, the share of accumulated FDI in Ukraine's GDP, despite the tendency to increase, remains insignificant, which allows us to speak about a low degree of participation of foreign capital in the process of creating the country's GDP. Third, industries most in the need for direct investment are engineering and metalworking, chemical and petrochemical, oil refining, ferrous metallurgy, construction materials industry, and agricultural production. In the listed branches, the average level of depreciation of fixed assets (for the period of 2011-2016) is more than $50 \%$. Fourth, the ratio of foreign direct investment to fixed investment is the lowest in the following sectors: chemical and petrochemical, construction materials and transport (less than 10\%). Consequently, in the above industries, the capital of foreign TNCs plays an insignificant role. Fifth, trade and public catering, ferrous metallurgy, food industry and non-ferrous metallurgy can be identified as sectors of the Ukrainian economy, in which the maximum values of the ratio of FDI to gross fixed capital formation are observed. Consequently, it can be concluded that foreign direct investment is mainly directed to commodity-producing industries, as well as to industries, in which the rate of return is the highest and the payback period is minimal.

Thus, expansion of foreign TNCs into the Ukrainian economy is observed, which did not become a tool for positive changes and a mechanism that ensures the attraction of sufficient economic resources required by the national economy for sustainable development. Directions of capital investments of foreign transnational corporations practically do not stimulate a deep modernization of the basic structures of the national economy of Ukraine but are aimed only at obtaining the maximum rate of profit and achieving the shortest payback periods, irrespective of the impact on the branches of the economy of the host country.

\section{References:}

1. Government statistic (2016). Retrieved from www.ukrstat.gov.ua (in Ukr.).

2. Monetary Fund - IMF Country Report (2016). Ukraine: First review under the extended arrangement. Retrieved from https://www.imf.org/external/pubs/ft/scr/2016/cr15218.pdf3 (in Eng.).

3. United Nations Conference on Trade and Development (UNCTAD) (2013). World Investment Report 2013. Global value Chains: Investment and Trade for Development, Geneva: United Nations. 12. Retrieved from http://vasilievaa.narod.ru/ptpu/10_4_99.htm (in Eng.).

4. Bolgarova, N.K. \& Panevnyk, T.M. (2013). Transnational process in Ukrainian economics. Bussinesinform, 12, 33-38 (in Ukr.).

5. Fournier, J.-M. (2013). The negative effect of regulatory divergence on foreign direct investment. OECD Economics Department Working Papers No. 1268. Retrieved from http://dx.doi.org/10.1787/5jrqgvg0dw27-en (in Eng.).

6. Wood, S. \& Reynolds, J. (2014). Establishing Territorial Embeddedness within Retail Transnational Corporation (TNC) Expansion: The Contribution of Store Development Departments. Regional Studies, 48 (8), pp. 1371-1390 (in Eng.). 
7. Ietto-Gillies, G. (2014). The Theory of the Transnational Corporation at 50+'. Economic Thought, 3.2, pp. 38-57. Retrieved from http://www.worldeconomicsassociation.org/files/ journals/economicthought/WEA-ET-3-2-Ietto-Gillies.pdf (in Eng.).

8. Hudym K.M. (2014). Priority forms and directions of functioning of the modern international business. Economy of Ukraine, 6, 77-85 (in Ukr.).

9. Hudym K.M. (2014). Transnationalization as a factor of globalization. Visnik KNTEU, 4, 33-44 (in Ukr.).

10. Hudym K.M. (2015). Modern models of integration of TNC into the agrarian market of the Eastern regions of the world. Materials of the International science and practice conference "Strategy of countries' economic development in globalization". Dnepropetrovsk, 1, 45-46 (in Ukr.).

11. Williams, C. \& Soo Hee, L. (2016). Knowledge flows in the emerging market MNC: Therole of subsidiary HRM practices in Korean MNCs. International Business Review, 233-243pp. Retrieved from: http://www.sciencedirect.com/science/article/pii/S0969593114001486 (in Eng.).

12. Hammoud, Mohamad S. \& Nash, Douglas P. (2014). What corporations do with foresight European Journal of Futures Research. Retrieved from: http://link.springer.com/article/ 10.1007/s40309-014-0042-9 (in Eng.).

13. UNCTAD World Investment Report 2016. Retrieved from: www.unctad.org/wir2016.

14. UNCTAD World Investment Report 2010. Retrieved from: www.unctad.org/wir2010.

15. Official site of the NBU. Retrieved from: https://www.bank.gov.ua/

Kovalenko S.I.

Candidate of Economic Sciences, Associate Professor, Danube Institute of National University "Odessa Maritime Academy"

\section{GAINING MESO-COMPETITIVE ADVANTAGES BASED ON NETWORK FORMS OF INTERNATIONAL QUASI-INTEGRATION}

Summary. This work is dedicated to the exploration of the main features inherent to meso-level of international integration formations representing network structures in intra-branch and inter-branch cooperation in the form of cross-border cluster systems encompassing macro-levels and micro-level of integration of the national economy of multiple states. Possibilities of theory synthesis of international economic integration and cluster concept in economic area virtualization environment are revealed. Cluster approach is proved to be the most efficient mechanism to develop cross-border economic relations and represents, finally, a meso-level of competitive international integration systems and mandatory condition of quality advance for Ukrainian European integration. The major objective of the proposed work consists in the exploration of economic development priorities of Euroregions where Ukraine is involved in terms of expanding EU by means of cross-border cluster systems generation being the institutions of networked industrial integrations becoming poles of economic growth and competitiveness for depressive peripheral territories in the European market.

Introduction. Industrial corporate networks become a major object of efficient economic management in the post-modern economic system. Being influenced by 
globalization and internationalization processes, they take a form of "hybrid" institutions of horizontal integration - the network clusters as agents of technological alterations, since they incorporate scientific research institution along with entities dealing with the commercialization of their discoveries and implementation of the latter into mass production.

Capability to adapt promptly to international competition becomes an important condition of steady and stable progress in the modern world rapidly and inevitably proceeding towards globalization. Demand for developing newer theoretical approaches to find solutions for problems of meso-competition formation and development has urged long ago and requires to studying a worldwide experience.

Competitiveness begins to occupy priority positions in outlining objectives for business entities' management. Steady competitiveness advance is stated to be a key aid to achieve strategic aims, improvement of political and economic part of Ukraine in the worldwide community. A major part of home manufacturers remains uncompetitive in the global market. This problem is accompanied by lack of positive structural and innovative dynamics of the economy in general, orientation towards raw materials export share increases as well, as dependence on foreign economic conjuncture. Such a tendency requires not only the improvement of already applicable tools, but also the development of their variety enabling to provide competition in structural alteration forms and methods and growth rate acceleration. Nowadays neither branch, nor territorial, nor corporative management principles succeeded to become dominating. A substantial number of researchers see one of the modern efficient instruments of competitiveness improvement in a policy of clusters stimulation as a network form of their integration [1, p. 118].

Research subject urgency is caused by an urgent need to improve mesocompetitiveness of the home industry by means of clusters formation within competitive branches and lack of scientifically supported organizational and economic approaches, methodological tools, and strategy of implementation of the above-mentioned necessity in modern economic conditions.

To date, meso-level of competitiveness is the least explored. This comparatively new aspect of economic analysis encompasses medium hierarchic level systems, such as branches of industry, quasi-integration formations within branches and/or a region, complexes and groups of enterprises. Increasing in competition field level makes it complicated to review comparative competitiveness of individual objects introducing newer factors and sources of competitive advantages.

Reviewing manufacturer's level as micro-economic one, the distinct line should be applied to separate enterprises themselves as atoms of economic life and their various groupings forming a meso-level of competitive relations.

\section{The fundamental problem lying in meso-competitiveness improvement for industrial enterprises of Ukraine}

Development of postmodern economy results from a transfer from the centralized control system in economic sphere to pluralism with the further transformation from vertical hierarchies towards horizontal networks. This process is identified by Western scientists and classified as "quasi-integration". Such conditions cause a necessity in searching for new sources of economic advance, in the formation of flexible business structures enabling to react promptly to changes in economic conjunctures and to generate competitive advantages of higher level, as may be 
demanded by growing degree of economy virtualization. The research aim consists in finding a solution to a fundamental problem lying in meso-competitiveness improvement for industrial enterprises of Ukraine basing upon cluster approach to outlining sources of competitive advantages and their application mechanism. Formation of meso-competitive clusters attains special importance for our State in view of increasing involvement of Ukraine into global processes running in the worldwide economy.

Only efficiently operating business entities may be considered as competitive, i.e. those, whose competitiveness represents efficiency category, but of a higher level. Such entities are capable of supplying competitive production to consumers, i.e. competitiveness of enterprises is finally displayed in a process of manufactured production sales. Two evaluation categories are proposed as the main competitiveness criteria, (1) value of goods or services produced by an enterprise, and (2) value of an enterprise as a business entity. Competitiveness is a dynamical category with its dynamics being determined, primarily, by external factors with their substantial part to be regarded as uncontrollable parameters.

There is a number of differing points of view to an enterprise, with each of them generating a different classification including that of kinds and factors of competitive advantages. An enterprise may be considered either as a combination of functional activities, or as a system of processes (opportunities, technologies), or "competencies portfolio". Functional approach specifies traditionally typical spheres of activities, such as manufacturing, sales, and marketing, finances, purchases, personnel. It is this approach that is nowadays applied for assessing competitiveness potential of an enterprise and is displayed in its indicators system.

A source of competitive advantages preservation lies in continuous upgrade of manufacturing and other kinds of activities. As stated by Mr. M. Porter, a corporation should generate newer advantages, at least, at such a rate, as competitors are capable of copying advantages already existing. Relying on the failure of newer technology applied by a competitor, ignoring a new market segment or sales canal are obvious signs of fading competitive advantage. Innovations become an essential factor in preserving competitive advantages and competitiveness guarantees [2, p. 62]. Factors regulating the formation of modern value generation sequences underline innovations importance not only for internal but also for external logistic links of an enterprise.

In terms of "newer" economy links between individual levels of competitiveness formation get tighter, especially within macro-levels and meso-levels. High competitiveness of an enterprise should not be expected once a state has got unregulated essential balances in political, economic, and social spheres. Competitive branch or state is impossible and unimaginable without competitive enterprises.

If competitiveness of a product is calculated on the basis of an enterprise, mesocompetitiveness factors of the latter should be identified on the adjacent mesoeconomic level (close surroundings as a part of the enterprise operational environment. In this view, macro-environment affects the enterprise competitiveness level only indirectly. Most of the experts share a common opinion, that "even the best management of macro-economy is unable to produce positive influence upon the situation" ("The Economist") [3]. The collapse in meso-economy became a key factor affecting the national economy of our State and current situation cannot be clearly understood without reviewing other levels of processes. The existing essential problem lies not at the macro-level. Neither it lies even at the micro level. It lies at 
the meso-level and requires meso-economic adjustment. Further ignoring an exceptionally important problem in home economic science and practice, such as the problem of inter-branches economic relations defined as meso-economy is impermissible anymore.

The meso-economic level is a cornerstone of the economy provided it combines rationally the territorial and branch aspects. Many important processes run within the branch, regional, and quasi-corporate levels. Ignoring them makes impossible coordination establishment and achieving a high technical level in manufacturing. Regrettably, these processes are the least applied in the national economy.

Economists are unanimous in their admitting the importance of the meso-economy intermediate mission, demand for newer quality management not only for macro- and micro-levels, by at the meso-level, too. Researches in economics should be focused not so much on industrial enterprises as they should be concentrated on their adaptation problems to changing operational conditions, which only may be solved on higher meso-level. Meso-economics encompasses areas between enterprises and over them and construes a link between microeconomic and macroeconomic levels. Gaining this level supposes consolidated efforts of individual enterprises in their struggle for the market, resources concentration, excluding competition at intermediate stages of manufacturing goods, and saving internal expenditures.

Distinguishing features of modern economic competition in view of globalization tendency include its destructive nature, dynamism, multi-aspects nature, mutual relations aggravation offensive aggressive nature, scope expansion, and its subjects' enlargement. It is proved already that various integrated formations of supercorporation level become key subjects of competitive relations in industrial areas. They are represented by oligopolistic vertically-integrated structures and globally operating industrial clusters.

Changing subjects of competitive relations affect the existing market theory being originally based on mutual relations between atomized economic units (manufacturers and consumers) within the framework of public governed labour division, specialization, and multi-faceted complicated mutual dependence of essential economic units. All these provisions alter substantially with globalization. A number and part of monopolized or oligopolistic sectors grow rapidly. They, using the most various means and techniques, subordinate multiple minor and medium business entities and govern their markets.

Critical significance of external factors of an enterprise competitiveness contributes substantially to cooperative behaviour development and inter-corporative network links formation, leaving bulky vertical integration schemes for more mobile and flexible links, awareness of critical role of key corporate features in its error-free positioning in common manufacturing and trading scheme, increasing interest in comparative analysis of competitors activity, and studying expenditures in the context of chain and system of value formation.

The most important key competence of an enterprise is now being its coordination capability, achieving stable arrangements with other market participants.

\section{The meso-level of development network forms of cross-border cooperation}

A certain number of authors classify enterprise (business entity) competitiveness as meso-economy defining meso-level as a sphere of summarized goods microcompetitiveness formation. G. B. Kleiner and a number of other authors regard 
manufacturer's level as micro-economic one, seeing a principal difference between enterprises as atoms of economic life and their various associations [4, p. 27]. Furthermore, territorial aspects are often omitted in research of competitiveness category vertical structure, where micro-, meso-, and macro-levels may be identified as municipal, regional, and national economy, respectively.

System solution of industrial enterprises competitiveness problems means that search for sources and factors of competitive advantages should encompass not so much their internal environment than their external environment being displayed at meso-level. From the point of view of industrial enterprises competitiveness management attention should be paid to the question of extent and sequence, in which competitive advantages factors should be used at each individual level and, at the first turn, at adjacent meso-economic level.

Knowledge and information become key sources of productiveness and competitiveness being two decisive factors for any economy. Newer network economy is being organized around data networks free of a centre and bases upon the continuous interaction between the knots of such networks, whether local or global.

Network organization forms provide substantial flexibility of business entities, individuals, and states enabling them to adapt continuously to rapid conjuncture changes in funding, demand, and technologies. The single existing rule consists in the total absence of any rules. Even if they still exist, they may be bypassed easily by means of the usage of a number of networks.

Virtual development resources are required for the postmodern economy. They are information, innovations, infrastructure (communications), knowledge, proficiency, skills and post-industrial public institutions. Competitive advantages' preservation techniques may include the establishment of post-industrial development institutions similar to networked institutions for adopting decisions (clusters, holdings, associations, etc.) and increase in scientific component share in manufacturing and consummation. Newer level of institutional development should be achieved in modern conditions of the economic growth - networked institutions for adopting decisions [5]. What formerly considered the same everywhere and might be ignored becomes a source of competitive advantage at the newer economy age. From the evolution point of view, such a cluster may be regarded as an agents' population. Each of them may be described applying three variables: (1) volume of production; (2) amount of expenses, and (3) innovation and technology component. These parameters, being summarized determine agents' current efficiency and competitiveness. An innovative component represents multi-dimensional characteristic displaying technologies available with an agent and capable of changing in the course of innovative search and/or simulation. Agents consume resources and generate production with differing efficiency and in different quantities. Agents of the system are autonomous (independent in taking a decision about production assortment and quantity) and semi-rational (don't possess complete and exhaustive information about the situation in the market) [5].

A meso-competitive cluster is a group of enterprises localized within a certain branch, or territory, supplying results of joint activities beyond their location. Cluster's offer formed endogenously together with exogenous demand determines the intensity of competition in the products market. Once competitiveness intensity changes in the market, agents, expenditures change in opposite direction, resulting, 
finally to efficiency decrease, total production decrease in the cluster and consequent fall of a competitive struggle for resources.

Otherwise, increased competitive struggle motivates agents to active innovations search. Cooperation among agents represents dependence on competition (in general, it is a feedback). Simulation of the most preferable technologies and economic activities techniques occurs during cooperative interactions affecting innovative and technological components available among agents. Describing cooperation process, agents' proximity and mutual influence should be taken into account since they are located in common innovative and technological environment.

Clusters may be described as groups of independent companies and associated organizations, which meet the following criteria: (1) they are geographically concentrated within a certain region; (2) they cooperate and compete; (3) they specialize in different branches; (4) they are linked with common technologies and practices and mutually supplement each other, which, finally, enables to obtain synergic and networked effects, knowledge and skills mutual exchange. The additional economic effect produced within the cluster framework benefits to competitive advantages.

Enterprises involved into cluster obtain additional synergic effect due to common resources usage (technologies and expenditures strategy), market infrastructure (joint sales) and activity spheres (planning and management synergy). Synergy strategy significance consists in enabling to achieve higher efficiency with cooperating enterprises involved in a cluster in comparison with enterprises that are run separately.

Synergic effect - advanced efficiency as a result of incorporation, integration, merging of individual components into a common system due to so-called positive system effect (emergence effect), where participants' cooperation effect within integrated system exceeds the summary effect of the individual activity of each participant.

M. Porter in his research of competitiveness problems revealed three major advantages of clusters [6].

Firstly, they increase productivity providing access to specialized resources and labour, making access to data, institutions, and social benefits easier.

Secondly, clusters encourage higher generation rates for new business formation transforming employees with existing companies into new businessmen.

Thirdly, they increase opportunities for corporations to implement innovations due to quicker and prompter spreading of technological knowledge. Unique capacity of clusters to boost innovations enables to define them as innovatively active economic agglomeration or an area of innovative activeness. Any cluster represents a network structure with competitive cooperation ideology (or co-competition) with development stimulations encouraged by competition among network participants are combined with cooperation intensification in mutually profitable directions. Network national economy organization model is seen as more perspective for modern conditions. This model formed an organization basis in regions who successfully found their place in global production, finances, labour technologies, and information exchange system. They are representing a network of autonomous and yet interchangeable enterprises [6].

Enterprises specialized in manufacturing of a certain production are concentrated within the same territory linking the branch with this region but not leading to its centralization. Enterprises cooperate basing upon provisions of cooperation 
agreements and sub-contractual relations. A part of enterprises promotes the final production in the market while the others operate subject to orders placed by a group, which initiated manufacturing of the specific product. In general, all the enterprises located in a certain territory of a certain state form a cooperative network or a network cluster.

The basic component of clusters theory is a group of institutional theories, which define economy as a system of cooperating institutions. In this aspect, the cluster may be regarded as a modern institution combining in different ratio a system of formalized and non-formalized relations both among the participants and between cluster and external surroundings. Furthermore, synergic effect generated as a result of cooperation between the enterprises forming the cluster is explainable as saving transaction expenses in the course of obtaining information, property titles specification, exchange costs saving, etc. [7].

Thus, R. Coase's transaction expenses theory, further to neoclassic theory, is the most applicable to synergy effect explanation and its assessment of cluster development efficiency. Global network theory in narrow speaking is defined in EC report as "an environment where any corporation or individual, located in any place of economic system may contact easily and at minimum cost with any other corporation, or individual on matters of joint work, trading, ideas, and know-how exchange or for mere pleasure." In a more expanded sense, generation of network economy is connected with IT development, leading to an evolution in modern economic systems, development of non-market regulation mechanism and network organizational structures. In total, a certain kind of branchless network economy based primarily on horizontal links is generated. Network clusters represent geographical concentrations of interlinked enterprises (suppliers) of one or more innovative branches (including venturing companies, universities, researching and implementing organizations, marketing and information agencies) and related institutions competing and yet cooperating with each other gaining benefits from specific local assets, neighbouring location and being built-in with economic and social space.

From the network concept point of view, clusters may be described as networks of mutually dependent corporations (including specialized suppliers) linked into a chain of added value formation and spreading newer knowledge, products, and technologies at a certain region territory, mutually facilitating growth of innovative competitiveness by means of simplifying access to newer technologies, risks distribution, and reducing transportation costs. Network cluster is a self-organizing system in the economy with its mutually dependent on institutional environment structure being one of the essential parameters of its order.

Cluster approach combines smoothly interests of business and territory since such an organization form enables mutual strengthening of their competition. Cluster approach is directly connected with territory competitiveness increase not only due to producing a simultaneous effect on competitiveness mainstays (productivity and employment). It relieves confrontation between them. Level of labour productivity within a cluster grows by means of specialization and outsourcing non-profile activities, whereas the level of employment grows by means of encouragement of newer subjects of economic activities in associated and supporting branches.

Competition occupies a very important place among the factors encouraging cluster formation due to its role as economic competition and the struggle between business entities (manufacturing) including brokers for most beneficial conditions of 
production (both goods and services) manufacturing and sales, particularly for gaining maximum profit from business activities (economic and financial).

Competition in the cluster, from one side, facilitates incorporation of parties interested in successful business development in a certain region within one branch with divided influence spheres and distribution of market shares of appropriate production among the cluster participants. It contributes to the development of intrasectoral competition intensifying struggle between manufacturers of the similar production for cost saving, prices reduction, production quality improvement, market expansion. At the other side, gaining higher production quality manufactured by cluster participants with reduced expenditures competition produces a positive effect on competitiveness in foreign markets both for cluster formations themselves and for the region in general.

A new approach to competitiveness improvement of industrial enterprises and selection of priorities in modern industrial policy is based on the encouragement of clusters formation and development as territorially localized networks encompassing independent manufacturing, servicing, and institutional corporations and bodies, linked with each other within a framework of uniform value generating chain. The content of cluster category includes inherent aspects of internal competition and cooperation unity, territorial localization and branch specialization, vertical and horizontal quasi-integration [8].

Industrial clusters construe a distinctive feature of any well-developed economy and their formation is a substantial component of economic development. Prevailing clusters instead of isolated companies or branches shows the importance of awareness of competition dialectic nature and the part played by geographical position in competitive advantages.

Search for solutions to any branch problems, or, even better, interbranch problems, in Ukraine inevitably takes the regional character. Therefore, a new image of competitive national industry compulsory includes a presence of competitive clusters, which become a new structure-forming element and an original investments magnet. All the required alterations in industry development management from the corporation to governmental levels are direct consequences from the above provision $[9$, p. 61].

To date clusters concept is applied as a key element in elaborating economic development strategy at various levels in advanced states. Therefore, the main idea lies in the necessity to clusterize industry. Once regional enterprises, remaining independent and striving to earn own profit get aware that they should implement a number of initiatives together with other corporations and institutions to improve competitiveness of their own business and entire region, they will commence not only to compete but to seek cooperation with each other and thus increase their own revenues in long-term prospect. As international experience showed, nowadays not individual corporations, but clusters are involved in competition. Business leaders who get aware of this fact earlier than others obtain unexpected competitive advantages.

General methodological approach to competitiveness improvement for industrial enterprises may be formulated, as follows:

1. Referring the analysis of hierarchic nature of competition category, system approach implementation as a cornerstone principle of scientific research supposes actions development at all three levels, i.e. microeconomic, meso-economic and 
macroeconomic. A higher level of competition field generates benefits for actions at a lower level, efficiency of which, in its turn, construes a way enabling to achieve competitiveness aims at a higher level. Achieving vertical unity in competitiveness gaining determines logical aspects for developing management tools.

2. Competitive advantages formation for Ukrainian enterprises should be built, first of all, applying meso-economic mechanism rather than macro-economic ones. Plenty important processes occur at branch, regional, and quasi-corporate levels, without which competitive advantages are impossible to be achieved by means of reconstruction and improvement of value generation chains. These processes are the least applied in industry.

3. In view of Ukrainian regional patchiness, a variety of regional "comparative advantages", meso-competitiveness of national industry should apply competitive advantages generated and kept in close connection with territorial conditions. Objective demand for the blurring of branch borders and dismantling of industrial branch management bring to the first place territorial localization of manufacturing industry and encourage generation of modern competition subjects on meso-level in regional aspect.

4. Despite globalization local business landscape should generate the architecture of value creation chains within newer "cultural and economic regions". Ukrainian business advance to scales comparable with global market don't mean its compulsory vertical or diversification integration. Consolidation processes may run within the framework of newer "cultural and economic" regions basing on network principle as some kind of meta-corporation involving suppliers, subcontractors and competitors.

\section{Cluster approach to increasing the competitiveness of Euroregions}

The proposed cluster approach to industrial enterprises competitiveness improvement represents a specific combination of territorial and management principles enabling to encourage integration processes at meso-level of the economy.

Clusters are represented in the global market as agents of both network and competition, which enables them to play equally and withstand disastrous tendencies in global competition. Such an approach is capable of changing in the most radical manner priorities of government industrial policy. In this case, efforts applied by the government should be focused on the development of mutual relations between suppliers and customers, between final consumers and manufacturers, between manufacturers themselves and public institutions, etc., rather than on supporting individual enterprises and branches. Traditional industrial policy instruments should be supplemented with newer specific measures encouraging cluster in its implementation of cluster initiatives, partnership development, and activities' coordination. Cluster concept brings substantial changes to the industrial policy development mechanism. Mode of interesting dialogue (partnership) between public bodies and business community becomes a mandatory condition with the business community being treated as a policy subject along with the state. Methods of industrial policy grounding experience changes, too. Clusters encourage substantial productivity growth and innovations implementation. Corporations gain from getting an opportunity to share a positive experience and reduce expenditures using jointly same services and suppliers. It is a unique combination of these companies with specific technological links, knowledge flows, and social relations that determine cluster's competitiveness. A complicated combination of cooperation and 
competition is formed within clusters. These components lie as if in different dimensions and supplement each other, especially in innovation processes. Relations with the internal consumer are based on competition, those with external customer on cooperation involving suppliers' apparatus and sharing a common logistic canal.

Clusters' current and potential competitiveness assessment considered as the growth points enables to reveal priorities of another degree and revealing, so to say, "bottlenecks" in their structure and competitive advantages construes a basis for propositions in cluster stimulation measures system. Such an approach enables, from one side, to preserve the active role of a state in regulating rates and quality of economic development and, from another side, to provide the necessary level of internal competition as a guarantee of Ukrainian industrial competitiveness in view of globalization tendencies.

Traditional power resources supply and cooperative relations between business entities of individual states will be supplemented by the formation of transnational economic structures in various organizational and legal formats, such as financial and industrial groups, conglomerates, corporations, syndicates, joint ventures.

Regions adjacent to national borders and developing cross-border activities deserved their title of "European integration locomotives". They represent one of the ways integrating a state in the global economy. The territories adjacent to the border are the most reasonable to deploy free (special) economic zones, common innovations centres, technopolices and technoparks, business hubs involving foreign funding.

Specific conditions of a newer economic system generation, determined by the dual process of globalization and regionalization of the worldwide economy, demand the creation of more economically efficient territorial international formations, matching the modern productive forces development level. It leads to the emergence of regional integrating reproduction complexes, encompassing significantly reproductive process within their own framework. In this view, the enhanced attention is being paid to the item of clusters formation representing a group of business entities specializing in adjacent or associated branches closely cooperating with each other in the form of stable partnership on manufacturing, technological, scientific, and innovative basis and, therefore, forming vertical and horizontal links at higher aggregation level to improve own competitiveness. Nowadays, clusters are extending their activity scales running beyond frames of individual states. State administration bodies and business entities encourage foreign business entities involvement and exchange with foreign clusters to improve the attractiveness of a certain region or branch of economy. A growing number of public figures and business entities get aware that cluster strengthening and improvement of its feasibility and survivability in global competition between regions requires the establishment of cross-border and transnational clusters with the involvement of foreign corporations and universities as partners.

Special significance is being attained by cross-border and transnational clusters in innovations sphere. Their formation contributes favourably to:

- Development of close cooperation not only between business entities of various states, their suppliers, and consumers of their production but with knowledge institutions, including large research centres and universities working on international level; 
- Creating competitive scientific and technological production capable of occupying and keeping positions in international market;

- Mastering certain skills in market researches enabling to estimate demand for newer products and relate it to global level;

- Establishing joint scientific centres to implement scientific developments;

- Encouraging scientific contacts, exchange, training, and practicing;

- Joint working on international projects and programs.

In general, more opportunities (financial, administrative, etc.) appear to build up entire technological chain running from joint researches to production commercialization including its promotion in the market. Cross-border clusters formation in Common Economic Space (CES) is an urging objective since it is cooperation of business entities within the cluster, which enables to use jointly accumulated experience, survive in competition, meet global market demands for new products and technologies, and solve problems of technological uncertainty.

The CES framework succeeded to preserve common transport, communications, power-generating and some other systems, which may work efficiently only if operated in joint mode. Preconditions of cross-border formation within the CES are caused by multiple factors, which may be grouped into categories, as follow:

- Political factors: customs union establishment and adopting a solution to implement "four freedoms" (free circulation of goods, services, funding and labour); mutually agreed policy in macroeconomic and currency spheres; unified trading policy; cancellation of anti-dumping and other protective measures; developed international relations and membership in international organizations;

- Institutional factors: establishment of supra-national governing institutions; legal base formation facilitating favourable conditions for investments and preserving access to existing sales market, using advantages of opened borders and common transport network, harmonizing technical and governing standards and regulations and other non-tariff barriers; providing non-discriminated equal access to natural resources, including power-generating, as productive factors;

- Economic factors: positive dynamic of CES states economic development; increase in gross internal product (GIP); high demand level; available labour resources, raw materials and assembly parts; favourable investments climate; preferential taxation in innovations; developed transport infrastructure;

- Technological factors: available new technologies in industrial sphere; law governing spheres of technological and innovative development; increased potential demand for technologies and innovations; experience in cooperation and joint funding of scientific researches;

- Social and cultural factors: generation of standard databases and stimulation of data exchange; shared basic values and tendencies in lifestyle.

Potential possibilities to generate transnational clusters within the CES are available with various branches of economy, such as biotechnologies, pharmacy, chemical industry, machinery building, IT. Cluster formation requires system generation with prompt cooperation between government bodies, business entities, science, and education. Coordination of fundamental scientific research, the formation of common scientific and educational infrastructure within the CES states, mutual validity admittance of documents issuable in scientific and educational 
spheres, implementation of the joint initiative in breakout sectors are also of utmost significance.

As defined, cross-border clusters encompass adjacent territories of neighbouring states with institutions and business entities residing at both sides of the border. Therefore, cross-border clusters may be defined as groups of independent corporations and associated institutions, which are:

1) Geographically concentrated in cross-border region;

2) Cooperate and compete;

3) Specialize in various branches;

4) Linked with common technologies and skills and supplement each other, finally, enabling them to obtain synergy and network effects, knowledge and skills exchange.

A specific feature of cross-border cluster consists in their participants' habitation in different taxation, customs, legal environments. Yet they are able to have joint ventures and organizations, use common infrastructure and operate, primarily, in cross-border markets. At the same time, Ukrainian economy may get benefits not only from the creation of cross-border clusters to strengthen the competitiveness of territories adjacent to borders due to intense resources, technologies (both manufacturing and administrative), "know how" exchange, unique business models implementation, common data space establishment, etc. Participation in such structures underlies a foundation for a prospect for Ukraine to gain deserved positions in the global economic system. Logistical network operation within the framework of the cross-border maritime cluster may contribute to the optimum organization of transport and manufacturing complex on a territorial basis. Sphere of economic activities in ports expanded beyond territorial borders and was transferred to auxiliary objects beyond them according to complex supply system due to fundamental alterations in the global economy, technology, and society. Such an approach leads to port logistical networks formation encompassing various transport nodes, such as specialized ports, terminals, storages and workshops, industrial objects with their activities sensitive to cargo operations in large ports. A special attention should be paid to developing an innovative model of cross-border cooperation, which provides for resources concentration in regions adjacent to borders to carry on fundamental and applicable researches to increase their scientific, technological, and productive potential and application of programmed targeted approach to innovative projects aimed at the development of the Black Sea coastal Euroregion [8, p. 129].

Creation and operation of the cross-border maritime cluster in the Black Sea coastal region may contribute beneficially to economic cooperation between the involved states. As for Ukraine, the creation of such a cluster may influence ports' integration into the regional logistical network and Ukrainian industry may integrate into existing international manufacturing chains, improving business activity level, its innovative and competitive capabilities. Newer post-modern reality consists in the combination of post-industrial manufacturing with the networked structure of economic space. It supposes institutions' transplantation by means of hybrid network clusters self-organization at both sides of national borders becoming a factor for the integration and free funds circulation in Euroregions. Competitiveness with such a newer mode is determined by innovations implementation rate and capability to continuous renovation. Modern theoretical economics supplements an "integration/disintegration" dichotomy with one another "quasi-integration" category, and "corporation - market" dichotomy is expanded with "hybrid" category. Applying 
the assets control criterion quasi-integration may be defined as a process of establishing control over the behaviour of formally independent corporations without taking their assets under control [9]. A number of experts regard clusters as a practically sole real source of investments and innovations. Yet clusters still remain a kind of theoretical construction with none practical sensible features and positive externalities. However, these quasi-integration forms may become a main driving force of innovation in forthcoming future. Industrial corporate networks become major objects of economic management in the post-industrial economic system. They transform into transnational cluster system under the influence of globalization and internationalization processes. Network clusters are the agents of technological alterations, as they incorporate organizations carrying on scientific and research works as well, as their commercialization and implementation into manufacturing activities within the framework of a particular cluster. Nowadays a persistent demand is to develop and implement cross-border development strategy for Euroregions in view of European experience in generating trans-regional strategies. It should be noted that an object of such a strategy is a steady social and economic development of Euroregional system encompassing its human, natural, resources potential and institutional environment.

Ukrainian striving into the EU requires consolidating cross-border cooperation experience as a preliminary and supplementing stage of integration in regional dimension. The theoretical and methodological foundation of cooperation and newer forms and mechanism for its implementation in view of transnational cluster systems should be developed to form an integrated, consistent and efficient policy of crossborder cooperation development in Ukraine.

Conclusions. Steady social and economic development of the state and maintaining its competitiveness in foreign markets is provided, first of all, by available well-developed knowledge generation environment based on the substantial sector of fundamental research in combination with the efficient education system, developed national innovation scheme, integrated and consistent policy and regulatory and legal support of innovation activities.

Intense cluster systems development in Ukraine supposes concept adoption and development of a national program of cluster formations development based on the implementation of models of territorial clusters' development composed of a number of sequential coordinated organizational and economic measures, aggregated into a systematized mechanism. Cluster technologies implementation results into a generation of both external and internal competitive advantages for subjects of the economy, strengthening competitive environment support, which produces a positive effect on improving national economy's competitiveness in integration processes.

Development of international competition resulted in the creation of newer theories of competitive advantages formation, within which achievement of international advantages, competitiveness development bases upon determinants of national "golden section" and operates in the form of competitive clusters established within national economy branches. Taking into account that modern competitive advantages are practically totally achieved by means of advantages in manufacturing technologies, management technologies, production promotion organization, successful meso-competitiveness development is possible for the economic system 
with complex application of cluster mechanism theories and modern concepts of innovative development.

To date, decisive steps should be taken not only to achieve national manufacturing competitiveness, reviving innovation activeness but to gain a breakthrough in this sphere. This problem may be solved by means of competitive clusters establishment in national industry. A solution of this problem is capable to provide building structures enabling to improve the competitiveness of the entire economy by means of its reorientation towards the creation and development of newer high-tech manufacturing based on the latest scientific and technical discoveries with high intelligence component ratio. It might enable to keep for Ukraine a deserved respectable part in the scientific and technological sphere and increase substantially the meso-competitiveness of the national economy in conditions associated with European integration.

\section{References:}

1. Porter M. E. Clusters and competition: new agendas for companies, governments, and institutions // Porter M. E. On Competition. Boston, MA: Harvard Business School Press, 1998.

2. North D. Institutions, Institutional Change and Economic Performance, 1990.

3. Krugman P. The Self-Organizing Economy. - Cambridge: Blackwell Publishers, 1996.

4. Klejner G.B. Evolyuciya institucional'nyh sistem. - M.: Nauka, 2004. - 240 pages.

5. Andersson T., Schwaag-Serger S., Sorvik J., Hansson E.W. The Cluster Policies Whitebook. [Electronic resource] // Malmo, Sweden: International organization for knowledge economy and enterprise development. -2004 . $-250 \mathrm{p}$.

6. Porter M. The Competitiveness Advantage of Nations. - London: Macmillan, 1990.

7. Armstrong H.W. The Role and Evolution of European Community Regional Policy / B. Jones, M. Keating (Eds.) // The European Union and the Regions. - Oxford: Clarindon Press, 1995. - P. 23-62.

8. Mikula N.A. Strategiya formuvannya ta pidtrimki rozvitku transkordonnih klasteriv / N.A. Mikula // Sotsialno-ekonomichni problemi suchasnogo periodu Ukrayini. Klasteri ta konkurentospromozhnist prikordonnih regioniv: Zbirnik naukovih prats. Vip.3 (71) / NAN Ukrayini. In-t regionalnih doslidzhen; Redkol.: Vidp. red. E.I. Boyko. - Lviv, 2008. - Pp. 129-141.

9. Rekord S.I. Metodologiya razvitiya klasternyh sistem kak mezourovnya mezhdunarodnoj ehkonomicheskoj integracii / S.I. Rekord. - SPb. : Izd-vo SPb GUEHF, 2012. - $211 \mathrm{~s}$. 
Krutova A.S.

Doctor of Economic Sciences, Professor, Head of Department of Finance, Analysis and Insurance, Kharkiv State University of Food Technology and Trade

Tarasova T.O.

Doctor of Economic Sciences, Associate Professor, Professor at Department of Finance, Analysis and Insurance, Kharkiv State University of Food Technology and Trade

Yanchev A.V.

Doctor of Economic Sciences, Associate Professor, Professor at Department of Accounting, Audit and Taxation, Kharkiv State University of Food Technology and Trade

\section{ACCOUNTING SYSTEM AS A BASIS FOR UKRAINIAN BUSINESS INTEGRATION IN THE EUROPEAN ECONOMIC ENVIRONMENT}

Summary. Informational substantiation in the accounting system for the integration of Ukrainian business structures into the European Economic Area is formalized in the article. The theoretical postulates of accounting and analytical support for the trade enterprises sustainable development management are substantiated. It is proved that the accounting and analytical support for the sustainable development management is multifunctional and consists of two hierarchical levels: system-target and technological. Proposed functional model of accounting and analytical support, within the information structure of the administrative business-process, creates communication channels for the knowledge's accumulation. The structural and logical scheme of information communications of the trade enterprise's main business-processes (supply of goods, pre-sale services and after-sales service of customers) with auxiliary businessprocesses (human resources management, information resources, IT technologies, financial flows, research and development) is developed.

Introduction. The countries of the Visegrád Four play a significant role in European values creation. They make a great contribution to the construction of the European architecture of economic security and cooperation based on effective cooperation within the European institutions. All four countries in the Visegrád Group are high-income countries and are characterized by a sustained economic growth and high human development index.

Due to the pro-European implementation of reforms in Ukraine, we see the transformation of the Visegrád Association into a format of five states with the participation of Ukraine, which will allow our country to implement effective economic policies, intensify small and medium businesses' activity, and introduce free trade zones between Ukraine and the EU. In this context, in July 2016, the Ministry of Economic Development and Trade of Ukraine launched a national consultation on the implementation of Section IV "Trade and Trade-Related Issues" of the Association 
Agreement between Ukraine and the European Union, the European Atomic Energy Community, and their member states for 2016-2019, and in particular Section 13 of the Agreement on Trade and Sustainable Development. According to the regulations, the effectiveness of management is based on the well-known doctrine of sustainable development, which proceeds from the main assumption that managerial decisions and their consequences must be based on the economic, social, and environmental responsibility of business-units. Such an approach determines the overall vector of business-entities ontogenesis, which is based on four common research areas: industrial ecology and economics, cyclic business models and product designs, environmentally friendly technologies and resource efficiency. Thus requires changing in theoretical and methodological approaches to accounting process, which is capable to create an informational background for the integration of Ukrainian business into the European Economic Area.

Analysis of modern scientific sources proves that research on the formation of information support of business entities' sustainable development has traditionally been carried out in two areas - economic (managerial) and accounting. The study of the economic aspect was taken by M. Belousenko, M. Van Breda, R. Anthony, I. Kalinska, E. Leote, I. Lizan, A. Mazaraki, N. Mazur, K. Marenich, M. Munitz, V. Paton, P. Sabluk, G. Simon, E. Hendriksen, T. Ustimenko, N. Tsopa, V. Shevchuk, A. Shulha, whose works focus on information support as a tool of the management system. At the same time, the urgency of the issue was conditioned by the necessity in unification and standardization of sustainable development management processes, as well as the implementation of international standards ISO 9000 "Quality Management Systems".

The decisive the role of management information support was actualized by M. Benko, O. Vysochan, L. Hnylytska, T. Gogol, Y. Grinchishin, D. Grytsishen, T. Davydiuk, S. Dipiase, T. Efimenko, V. Evdokimov, R. Eccles, V. Zhuk, M. Koryagin, L. Lovinskaya, K. Nazarova, O. Orlova, O. Petruk, A. Pylypenko, O. Stoliarenko, and other scientists. They investigated the structural and functional regulation of accounting and analytical processes, organization tools of accounting in the context of sustainable development indexed disclosure, instruments of long-term planning of the economic growth, human resource development, and ecology protection. Undoubtedly, both approaches are interconnected, so it is expediently to carry out a scientific search for directions for expanding information capabilities of the information system for the sustainable development management, which will provide information support to manage business-processes coordination.

\section{Theoretical and methodological principles of business processes re-engineering}

Informatisation significantly influences management systems. Timely received information can provide substantial cost savings and, consequently, prevents the emergence of a crisis. The system of management information support, depending on the specifics of the particular business unit activities, may have different configurations, determined by a set of the information needs required by the management system. On the other hand, in order to understand information needs of the management system, it is necessary to analyse the complex of information flows that arise during the implementation of the basic and supporting business processes. 
Management system's information needs are determined by the structure of its goals and objectives, which are to be solved in different economic situations. Within the framework of pre-crisis management, the tasks of optimal cost management, ensuring the stable customer loyalty, establishing effective relationships in creating value, monitoring the current financial situation, assessing the probability of a crisis situation, strategic control, and strategic restructuration are completed. At the same time, the most important task for the creation of an early warning information system, capable to detect environmental changes, which are to be quickly responded, often remains unattained. For the purpose of emergency crisis management, the tasks of improving the business financial situation are to be solved based on the strategic controlling and business re-engineering.

The development of modern market society puts forward high demands concerning management system enforcing it to continuous improvement of production and financial processes technology, implementation of adapted information technologies, development of organizational complexes of methodical solutions and searching the reserves for business activation. A global computer network, electronic catalogues of goods, and the possibility of purchasing them directly from suppliers regardless of their location gave consumers the opportunity to put forward high demands concerning producers and stimulate competition. The process of market economy development makes it necessary to search for new directions for the improvement of modern management system in accordance with the organizational, scientific and technological potential of the enterprise. In such conditions, the creation of a sound crisis management information support system is the most important task for the business unit sustainable development. From the standpoint of modern economic research, such an approach is interpreted as the theoretical basis for business processes re-engineering or as a set of methods and tools designed for the fundamental improvement of key performance indicators of the enterprise activities by modelling, analysing, and designing of business processes [1, p. 7].

Today, the need for information about business processes has grown due to the transition from a functional to a process approach in management and prevalence of the business-processes reengineering concept in the theory and practice of management. According to that concept, management turns into a set of continuous interconnected business processes, the ultimate goal of which is the creation of an added value for external or internal users of finished products or services [2, p. 46]. Generated information resources are aimed at the improvement of enterprises' financial and economic activities and competitiveness enhancing, which is the main advantage of such an approach [3, p. 15]. The concept of process management is based on the National Accounting Principles (Standards), Quality Management Standards ISO 9000, and cost management concept. Economic literature sources do not provide a clear definition of a business process that leads to the incorrect use of this concept in the context of obtaining information support of the enterprises' economic and financial activities diversification and management decision-making.

Analysis of literary sources proves that according to the generally accepted interpretation, a business process is an algorithm of cyclicality executed functional operations of a business unit, results of which is the creation of a product (service) that is necessary to satisfy through cost, quality, and level of service. The most important direction of transition to process-oriented management is identification and classification performed by the enterprise processes. The Standard DSTU ISO 9000: 
2007 stipulates that "activities within each process must be defined and adapted to the size and characteristics of the organization" $[4$, p. 8]. It means that a manager, selecting the enterprise's business-processes, should rely on the existing organizational structure and consider actual activities carried out by a specific business unit. Consequently, one of the most commonly used in practice businessprocesses classification divides them into basic, auxiliary, and managerial (Figure 1).

Examination of standardized business processes classification allows making a conclusion that the process of generating anti-crisis management information support is assigned to a secondary position among the auxiliary business processes, unacceptable for the understanding of the role and importance of information resources generated by the accounting system in the conditions of constant informatisation and virtualization of socio-economic relations. That is why L. Hnylytska considers managerial accounting and analytical support as a holistic information system combining methods and technologies of all types of accounting, analysis, and control. Their task is to provide managerial decisions on the enterprise sustainable development and counteraction of security internal and external threats [5, p. 44].

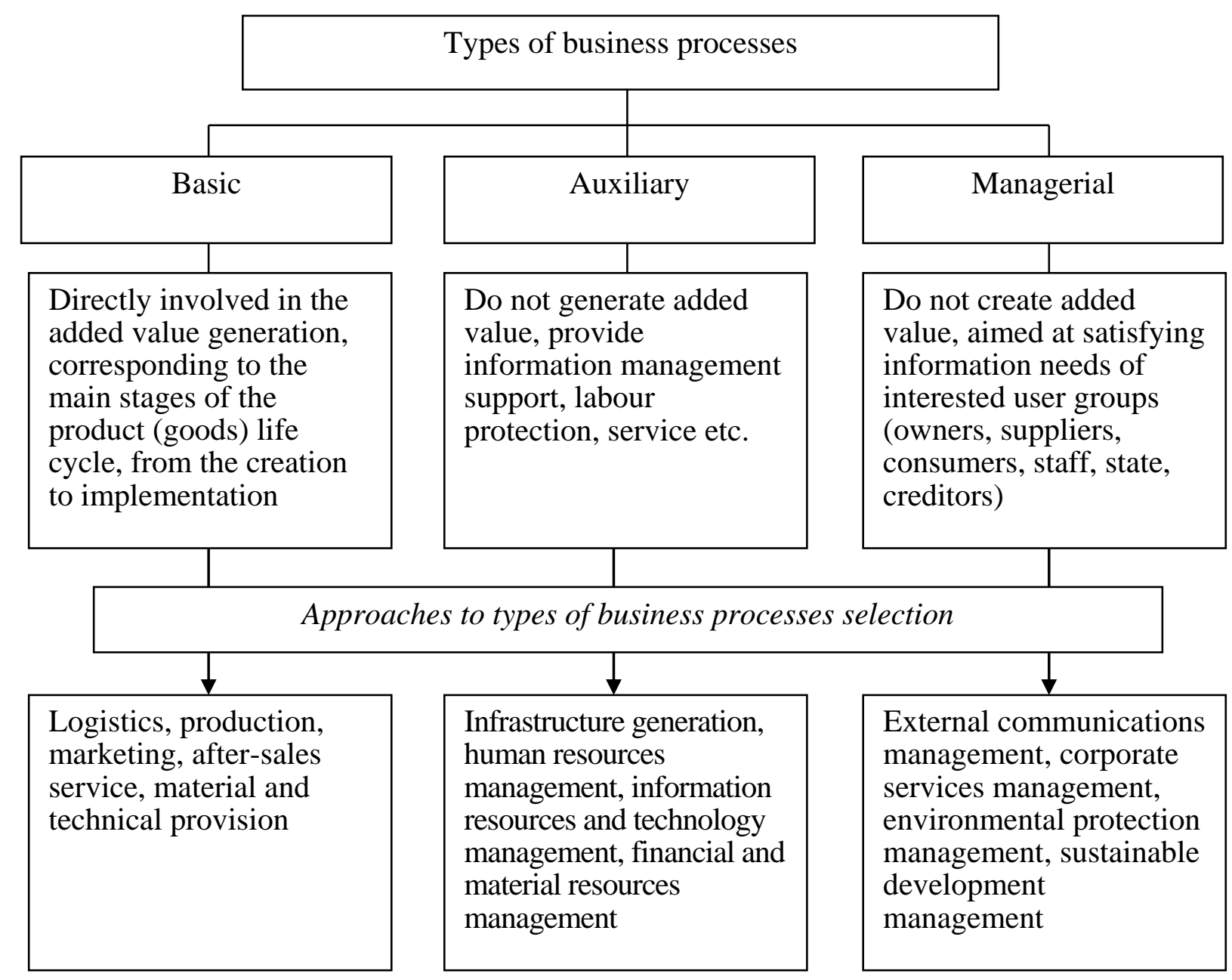

Figure 1. Business process classification according to ISO 9000: 2007

In this definition, we can clearly trace technical requirements concerning information on the part of economic security. Therefore, in the further presentation of the material, we will make an attempt to combine purely economic postulates of the 
economic security theory and methodological principles of the enterprise management system information support generation.

\section{Modelling administrative business process for generating crisis management information support}

Studying theoretical foundations of management decisions information support and methodological requirements, focused on the needs of crisis management system, allowed defining "business processes information support" as a management information system design, which, due to the application of certain tools for collecting, generalizing, processing, and analysing information on enterprise business processes, will generate the information basis for making sound managerial decisions. The process of the generation of management information support is an administrative business process, which has a priority among the others and combines their information flows, communication channels, and accumulated knowledge. Such a methodological approach coincides with the International Benchmarking Chamber (International Benchmarking Clearinghouse) model, which is universal for enterprises of any organizational structure and classifies business-processes in the following areas: marketing and customers support, strategy development, product (services) development, sales and services support, customer management, human resources management, information support, financial and material security, ecology, external connections, improvement, and changes [6]. This classification does not include a hierarchical ranking of business-processes because all of them are equally important for the management system.

From the point of the further improvement of management information support, emphasis should be made on developing tools for interacting accounting functions with the functions of financial management, the success of which depends on the combination of accounting and management standards within the framework of the global qualitative management system. That is why the whole management information support system was divided into two components - accounting and analytical. Accounting support starts at the operational level of the management system that is subject to obligatory documentation during the formation of the informational entropy zone at the tactical level. Further, it allows combining the accounting process and analytical procedures into a single information flow, which supports modelling of managerial decisions at the strategic level of the management system. As far as all functional units and business processes use the results of the administrative business process, it is necessary to prove the cyclicality of the causeeffect relationships between the process of information support generation and other business processes at the enterprise (Figure 2).

Accounting component of the administrative business-process model includes the process of financial indicators (cost, sales price, profit, transport and procurement costs, sales costs etc.) documenting and evaluation. Analytical component gives quantitative and qualitative characteristics of changes occurring within a particular business-process and provides an opportunity to analyse trends in the development of economic phenomena (identification of economic trends, identification of social changes, analysis of purchases motivation, monitoring of the market segmentation and buyers' typology). 


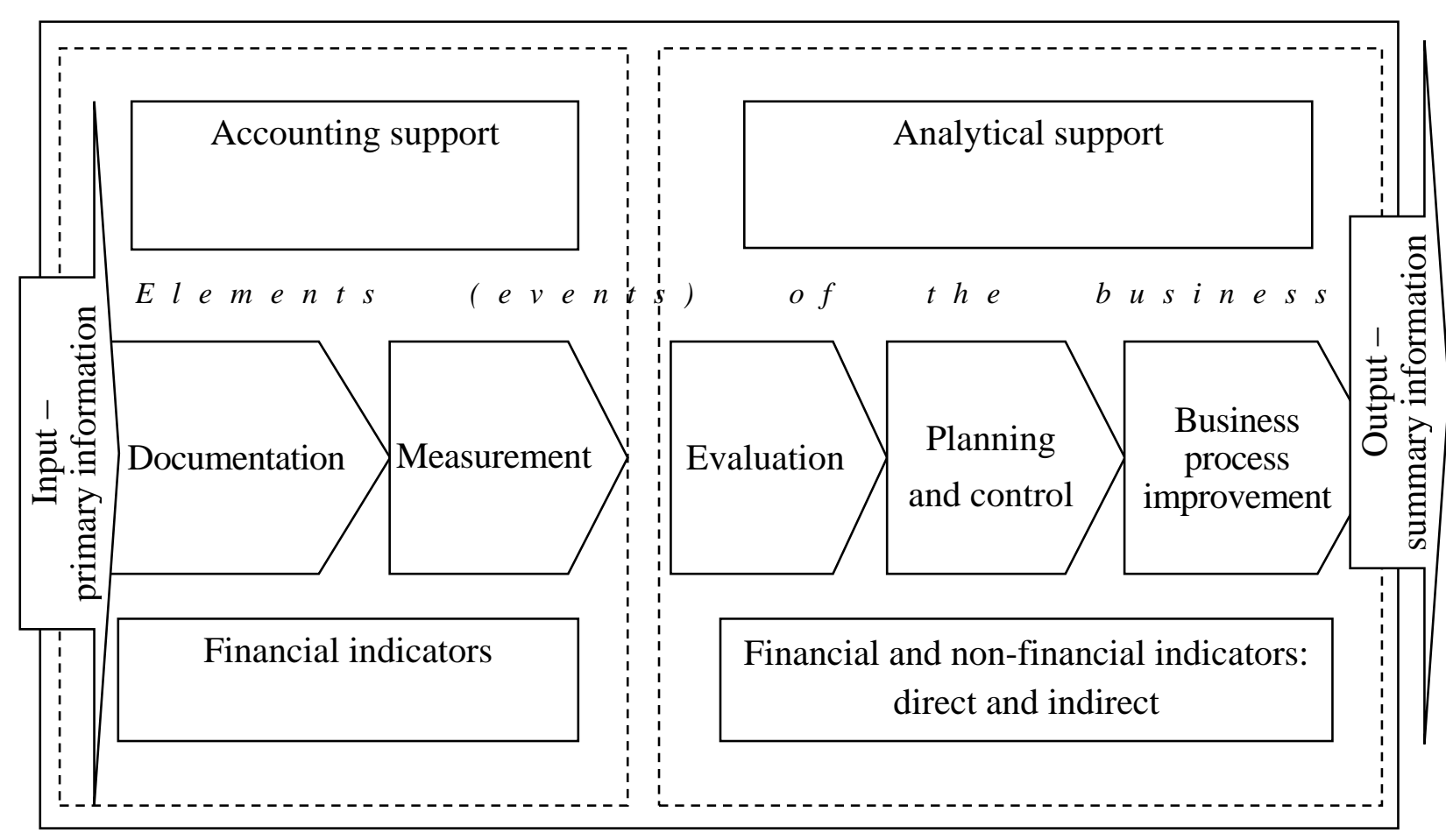

Figure 2. Model of the administrative business process of crisis management information support generation

Accounting information is a source for the analysis of coefficients, based on the costs concept and it is far from being the best source for the solution of forecasting problems and assessment of the feasibility of investing into the firm [7, p. 9]. Nonfinancial indicators are measured through the subjective expert judgments by monitoring of business processes and their results that include relative competitive position of the enterprise, customer satisfaction index, staff satisfaction index, labour and executive discipline level, documentation process quality and timeliness, compliance with standards and regulations, execution of the management system orders. The compromise and cyclical nature of business processes in trade require application of predictive non-financial indicators that directly affect results and warnings concerning possible deviations of quantitative indicators. For example, the decrease in employee satisfaction index leads to the reduction in labour productivity and increase in staff turnover. The decrease in customer satisfaction index inevitably reflects sales volume and financial performance of the enterprise, etc.

In the course of the study, it was inquired that the distinctive feature of business processes' management information support is the diversity of previous ideas, theories, and methodologies that are quite controversial. Thus, business processes' management information support is based on two scientific aspects - development of recommendations for the use of information and communication technologies capable of generating reliable information resources with high speed of information flows and reorientation of the management system to business processes re-engineering.

Formation of the field of management system information is aimed at the determination of functional subordination of the basic and auxiliary business processes components. In the process of financial and economic activity of the enterprise, a significant number of the expedients to perform functions as efficiently as possible are implemented. Information and communication technologies that have become widespread in accounting, logistics, production, and outsourcing can increase 
productivity. Therefore, an approval of various business-processes within a company as an economic system is of great importance. This, in its turn, requires clear identification of business processes within the economic system in general.

Business processes identification will help to determine the need for information about them, as well as form an adequate control system based on accounting and analysis data [8]. One of the main priorities of a trade company sustainable development is the definition of the main and auxiliary business-processes that create benefit in trade turnover. Each business-process has its input - definition of consumer needs, search for relevant markets, determining the demand for goods, procurement organization, commodities supply, goods quantity and quality control, paying for goods or issuing making claims, etc. Financial and non-financial indicators are generated by accounting and analytical system as an output of each business process. Therefore, to generate the system of management information support for trade companies, it is necessary to reveal their technological processes in terms of inputs, outputs, and information flows interconnection.

\section{Generation of technological processes \\ for the management information support at trade companies}

The emergence of innovations in trade is accompanied by the restructuration of the commodity circulation, changes in trade organization formats, implementation of electronic communication and marketing. This contributes to the fact that trade has turned from a conventional means of goods flow from the sphere of manufacture to the sphere of consumption into a complex technological industry with extensive sales processes, customer service, and technological innovations. Modern trade should be considered as the industry creating a comprehensive proposal with the commodity and process components. Ensuring the direct bringing of goods to consumers, trade process involves research of the demand, assortment formation, advertising, providing customers with additional services, insurance stock formation. The technological process is responsible for the processing or production of commodity stocks by the stages of commodity circulation starting from procurements and finishing with preparation for sale. Technological process includes such operations as acceptance of goods by quantity and quality, storage, packing, merchandising, and own brand goods production. Service functions can be performed without the buyers' participation. Therefore, it is reasonable to consider business-processes of a commercial enterprise as a set of trade and technological functions, consistently interrelated, serving commodity flows, determining the range of inventories and bringing them into proper quality for customers in a process of benefit creation taking into account specifics of its commercial activities (Figure 3).

The block of basic business processes characterizes the operations of retail customer service in three main directions: commodity supply, pre-sales, and aftersales services. Auxiliary business processes block performs service functions that are responsible for the quality of trade process, and provide management functions for the professional development, information resources, IT technologies, financial flows, improvements, and changes. This made it possible to determine the logic of the generation of managerial system information support for business processes in trade, which involves the continuous integration of information resources from the accounting data into the database of analytical support. 


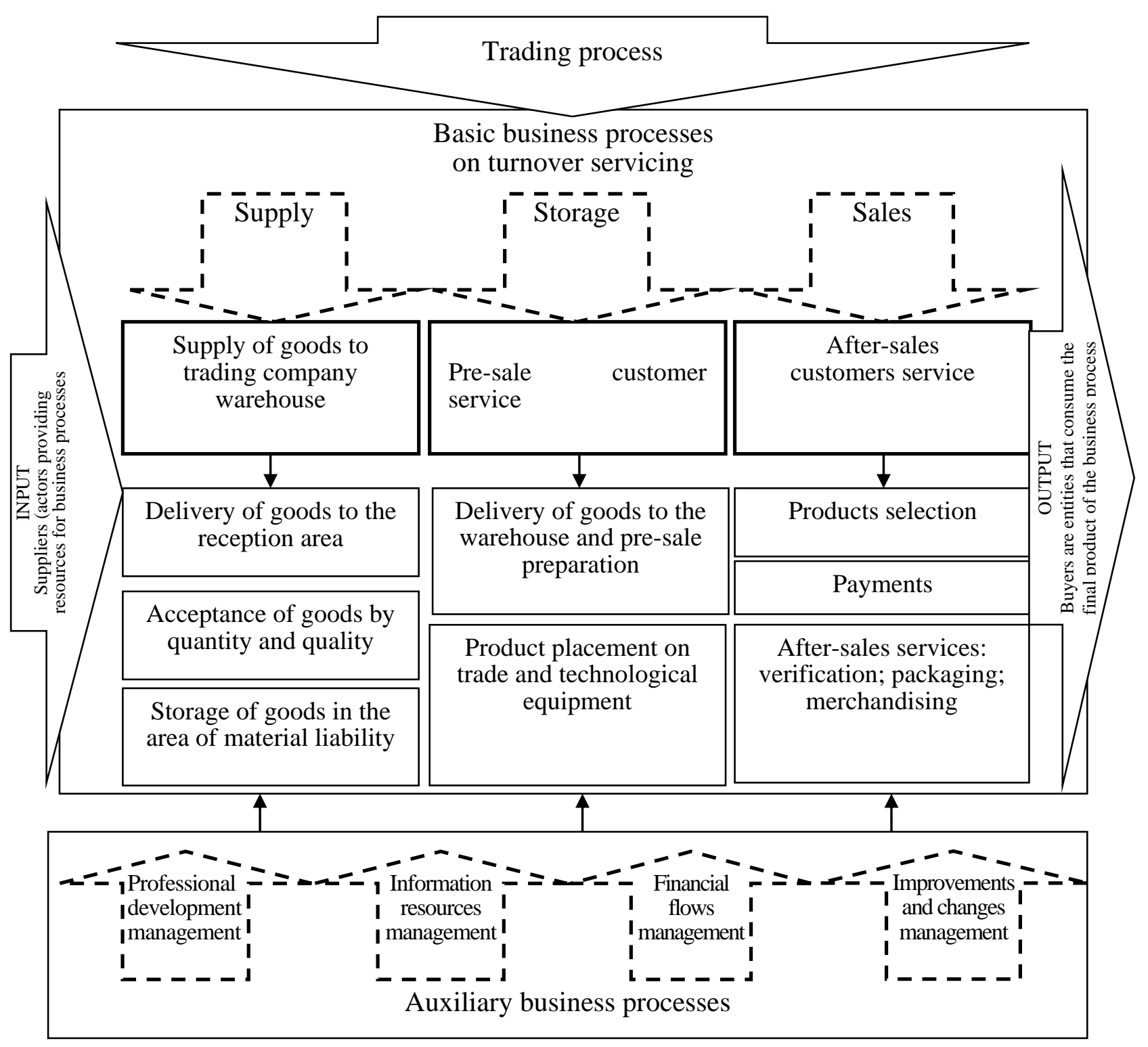

Figure 3. Commercial and technological processes of trade enterprises

To support decision-making at different levels of management, primary accounting data, databases, knowledge bases, and data warehouses are accumulated. Figure four shows that the process of generating information field of accounting and analytical support should be considered as a unified system, within which the information logic of the database creation is formed based on the accounting indicators - primary data and analytic indicators - knowledge base (Figure 4).

Considering the system of accounting and analytical support as a single integrated system, O. Kundria-Vysotskaya insists that information support should take the main place in the information system of the enterprise, and not only provide generation of all financial and non-financial indicators of internal processes within the environment of the organization but also coordinate information flows, link different levels of information, and present them in the integrated reporting form for all groups of external users [9, p. 57]. 


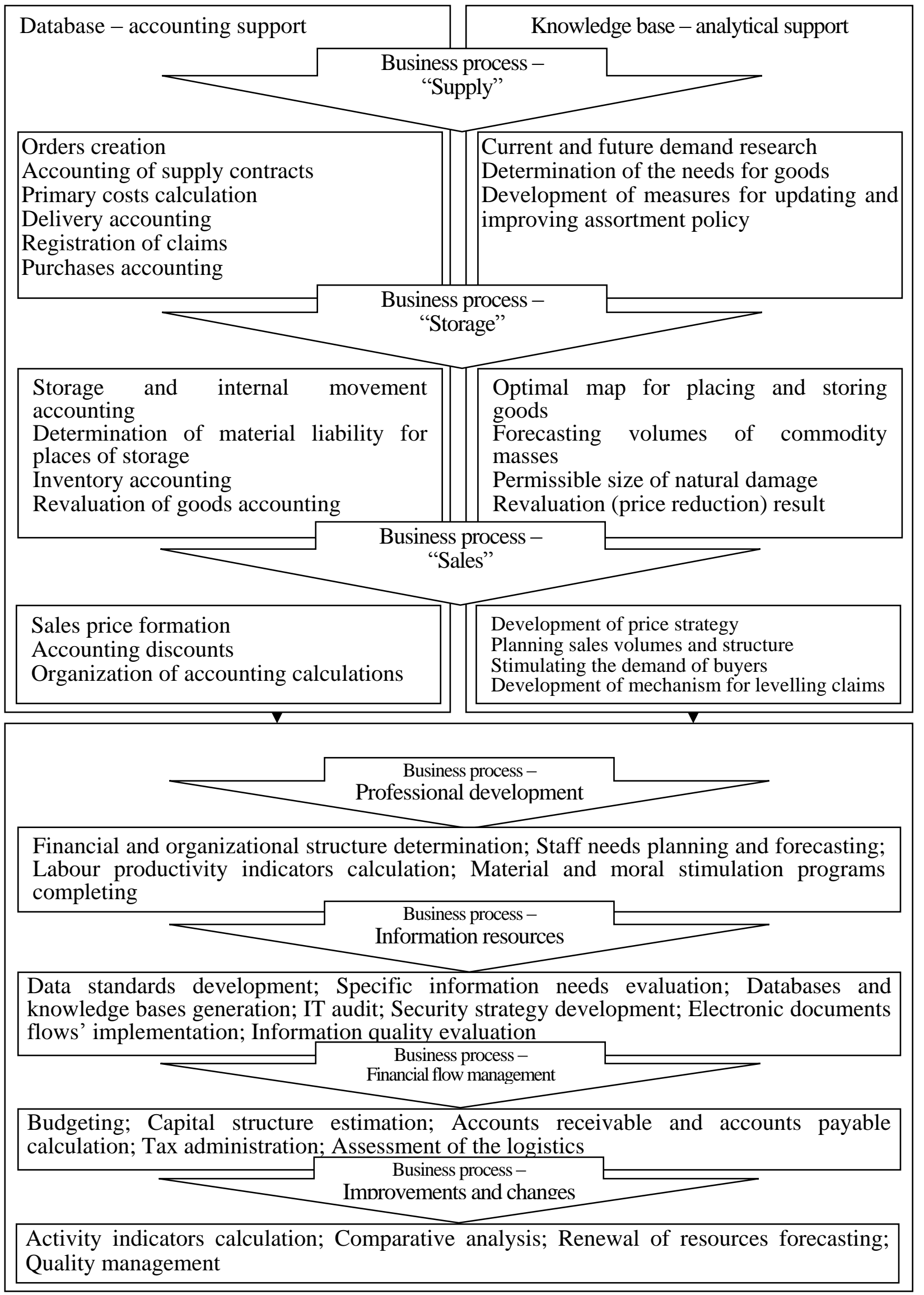

Figure 4. Hierarchy logic of information support system for trade business processes 
Information support involves the complex of accounting, analysis, and audit systems that form a consolidated information flow for managing economic processes when choosing or implementing directions of an enterprise operation and development [10, p. 47]. Agreeing with the given definitions, we consider that it is necessary to state that the information support system under the influence of causal links generates information flows about economic phenomena and economic processes characterizing economic activity, satisfying the requirements to analysis, planning, and control of management decisions implementation.

Allocation of business processes within the framework of trade-technological processes allows differentiating informational properties of management information support system and coordinating the responsibilities. Information support should meet the needs of operational, tactical, and strategic management. Thus, in transition to the standards of the trading company, sustainable development of an adequate information support system allows providing a comprehensive solution of the main problems connected with the commodity turnover within the framework of a unified information system, which requires the development of crisis management functional mechanism.

In practice, business functions are usually associated with business objectives, duties or execution processes. In the modern economy, two terminological approaches are singled out; in particular, R. Evdokymenko interprets the function of management system as a model containing the organization objectives tree, which ensures achieving the ultimate goal and reflects the business-processes hierarchy [11]. Supporters of another approach put in the forefront description of the process as a sequence of logically related procedures that have several inputs and outputs and intend to produce a specific final outcome [12, p. 5-8].

In the accounting system, scientific and methodological approach to the definition of information support functions is traditional and tends to associate them with management functions. In the process of these functions' performance, information resources about business activities of the enterprise are created, results of business processes are registered, and information flows are transmitted, processed, and stored in the information system [13]. In practice, it means that the organization of the accounting process and accounting policy model should create information conditions for the effective implementation of management process functions - planning, control, analysis, and regulation [14, p. 212].

Information revolution allowed storing, replacing and transmitting huge amounts of information resources, which contributed to the reorientation of the information system from the resources of the system on their functions [15, p. 90]. Therefore, in our opinion, the list of information support functions should be expanded in accordance with the current requirements to reflect the real state of business, adequate response to changes in business processes and search for the most effective interaction of financial, material, and intellectual resources of the business. Information management system is multifunctional and performs various functions that are the objective components of management, combines a set of homogeneous processes with a clearly expressed content, implementation procedure, and structure. Therefore, it is appropriate to distinguish two hierarchical levels: system-specific and technological (Figure 5) between the functions of management information system. 


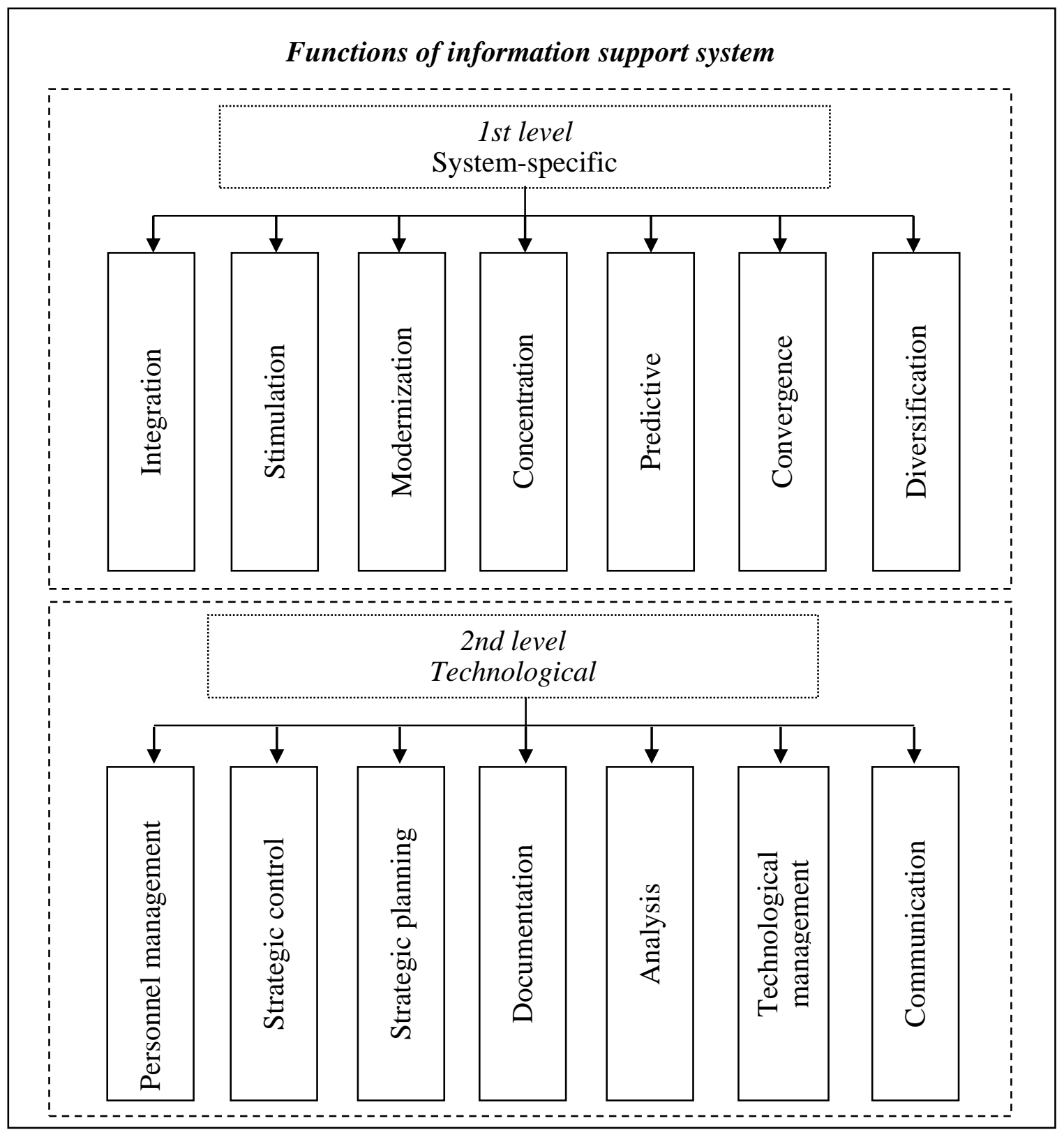

\section{Figure 5. Hierarchy model of functions of the management information support system}

The integration function is implemented through interactive dialogue between the user and the generator of accounting and analytical resources. It creates the basis for implementing business processes in a virtual environment, changes management capabilities due to business forecasting expectations, synchronizes information flows between partners, clients, and investors - value-added chain parties. It creates conditions for a consistent going out of the business beyond the frame of one enterprise, creating new forms of cooperation - from usual periodic data exchange to collaborative processes based on the coherent use of information resources.

Implementation of the activation function is aimed at substantiating the main directions and proportions of innovation work in accordance with the adopted strategic goals of development, resources, innovation potential of the enterprise and the existing market demand on the formation of government bodies, the relevant organizational structure of managerial, organizational forms, information sharing; on motivation and stimulation of employees to the interest of results of innovation work 
[16, p. 119]. Therefore, the activation function is aimed at visualizing the development strategy in accordance with external changes, consolidating factual data, and tracking key success factors based on benchmarks, building business performance indicators, finding new innovative offers, and ways to increase profits.

The function of modernization involves streamlining and optimization of organizational processes and technological procedures for the comprehensive protection of information resources, which consists of the introduction of measures aimed at the achievement of the appropriate level of the information system protection from accidental and targeted effects of natural or artificial nature.

Distribution function corresponds to the concept of distribution of powers and allows forming a personalized working environment that involves the development of personalization options, provides clear functional distribution, transparency of information, protects excess information, creates effective motivational mechanisms, etc.

Implementation of the forecast function involves information provision for the evaluation of the development prospects, identifying investment needs for strategic objectives, based on widespread use of forecasting techniques, and development of the investment strategy aimed at increasing value added and market values $[17$, p. 89]. The forecasting function provides an opportunity to evaluate the maximum possible amount of resources necessary for the solution of economic, scientific, and technical problems and foreseeing possible distribution of resources in different directions.

Convergence as a function is fundamentally new. Modern changes, which are enshrined in Ukraine's statutory acts regarding the definition of IFRS status, determine a new role of business [18]. Accordingly, there is a necessity to expand both economic and social initiatives of business, which in practice are implemented through the specific instrumental mechanism for regulating economic relations. Its full potential can be realized through the introduction of international standards of financial reporting. In such circumstances, one can agree with the opinion of N.V. Porokhniak, who believes that the convergence function is responsible for the development of tools for accounting standardization of information to overcome differences and reduce investment risk [19, p. 34]. The convergence function allows you to combine the capabilities of information technology and process modelling, and also implements the intermediary capabilities of information provision between business and information technology, as it is an ideal ground for deploying cloud infrastructures, working with intelligence and based on open standards.

Enterprises of different industries in the conditions of the world economy globalization, characterized by continuous penetration of technologies and capital, are interested in the diversification of their own economic and financial activity, aimed at the expansion of markets for goods, works or services that are in demand and/or are approaching the world level of competitiveness. Clear division of the responsibility for individual components of the diversification process requires well-functioning and efficiently functioning accounting and analytical support system. In this connection, new requirements for credentials become applicable only when their form allows a particular manager to use them for the purpose of making managerial decisions on the way of fulfilling certain functions [20, p. 90]. This gives reason to assert that the process of information support formation acquires a new function of diversification. 
The process of the information support formation is associated with a number of functions of the second level, the implementation of which provides information resources of users (professional experts, investors, stakeholders) on the state of material, labor and monetary resources, and effectiveness of the investment and credit policy, cost and production efficiency. While developing promising directions for the enterprise development, these functions play a role of feedback in the management system.

Organizational and personnel functions provide the process of transforming intellectual capital into financial capital. It provides identification of priorities in the formation of organizational structure, management procedures, information structure and frequency of its circulation; development of electronic accounting of personnel; coordination of the activities of structural units and personnel; stimulation of labour activity of personnel.

Traditional functions, that serve the process of the formation of management information support include documentary, analytical, transformational, and control. In the context of management system reorientation from organizational model to the functional documentary function of information provision, the information process of the collection, registration, processing, and transmission of information is based on the principle of information unity, rational organization of the primary registration and documentation of economic operations by the centres of financial responsibility. Due to analytical function, analysis of the problem situation, the formation of goals and limitations of economic resources, and assessment of the effectiveness of management decisions are generated. The transformational function of accounting and analytical support are realized within the information processing from the modification of primary data into the resulting information as a set of interrelated technological operations that are executed in a certain sequence through their formal description. The control function is realized by the continuous monitoring of objects and processes, systematization of information resources for further analysis, diagnostics, revealing trends of development and forecasting at different levels of management (integral control, monitoring tactical plans implementation, operational control) in order to detect deviations.

The planning-strategic function is realized through the determination of the priority of the tasks, which are to be solved by means of statistical estimation of performance indicators based on the use of modern tools - budgeting, business planning, controlling. The planned-strategic function is aimed at the formation of information security of the enterprise sustainable development; assessment of crisis development factors; identification of trends and patterns of the enterprise development; prevention of negative influence of internal and external factors on financial result and market situation.

In uncertainty and variability of the environmental conditions, communication function serves the process of the information resources generation that is the subject of exchange and ensures optimization of the information flows through the links of the organizational management structure.

Implementation of certain functions for multifunctional levels of management is regarded as a transfer of information resources from one function to another where the functions themselves are the processes of information resources transformation through documentation, decisions making, and new information generation. In this case, the flow of information generated in the process of performing the functions of 
the system-target level ensures the influence of the control system on the managed one, i.e., the control apparatus influence on the organizational and functional divisions of the enterprise. Information resources produced at the technological level provide the control apparatus with information on the effectiveness of these influences. The presented functional model of information provision is a design that provides information support for optimal managerial decisions and allows us to assess the information potential of modern business sustainable development.

Conclusion. The exigency of intensifying the national economy's development and increasing social standards in the framework of European integration of Ukraine requires the improvement of economic instruments for managing business-processes to ensure compliance with the principle of continuity and sustainable development of business structures. According to the World Economic Forum, Ukraine's rating in the global competitiveness index has tended to increase over the last 5 years. However, Ukraine is still in a group of countries that have not reached the average competitiveness indicators, and far behind the Visegrád countries.

The Visegrád countries, like Ukraine, pay great attention to regional cooperation development based on the effective interaction of business structures. However, our country is still facing information constraints and, consequently, distrust of relations concerning the development of a strategy for successful cooperation that prevents business from establishing economic relations. This problem can be solved by expanding information capabilities of the accounting system as the main information communicator for management of the basic and auxiliary business-processes.

It is proved that information support process holds a secondary position among the auxiliary business-processes, which is unacceptable for the awareness of the role and importance of information resources generated by the accounting system in the conditions of continuous informatisation and virtualization of social relations. After examining modern requirements for business focused on the needs of process management, it is proposed to understand the design of the information management system as the information support of business-processes in trade, which, due to the application of certain tools for collecting, summarizing, processing, and analysing information about business-processes, will allow creating database for making sound managerial decisions. It is proved that the process of information support generation is an administrative business-process, which has a priority among others and combines information flows, communication channels, and accumulated knowledge. Therefore, taking into account specifics of trading activities, it is expedient to consider business-processes at a trade enterprise as a set of commercial and technological functions, consistently interrelated, serving commodity flows, determining the range of inventories and bringing them into proper quality for customers in a process of added value creation. Allocation of business processes within the framework of trade and technological processes allows differentiating informational properties of management information support system and coordinating responsibilities. It is proved that the information system for supporting sustainable development management is multifunctional and consists of two hierarchical levels system-specific and technological. System-specific level characterizes the influence of a control system on the operational structure of a business entity, and technologically evaluates the effectiveness of that influence. 


\section{References:}

1. Shubin, A. A. Sovershenstvovanye byznes-protsessov v roznychnom torhovom predpryiatyy: monohrafyia / pod red. A. A. Shubyna, A. A. Sadekova. Donetsk: DonHUЭT ym. TuhanBaranovskoho, 2006. $197 \mathrm{~s}$.

2. Bazhyn, Y. Y., Sysoev, V. V. (2005) Proektno-lohystycheskoe upravlenye resursnym obespechenyem : monohrafyia. N. Novhorod. $222 \mathrm{~s}$.

3. Ustymenko, T. O., Marenych, K. M., Lizan, I. Ia. (2011) Avtomatyzatsiia biznes-protsesiv: navch. posibnyk / Pid zah. red. kand. tekhn. nauk T. O. Ustymenko. Donetsk: DonNTU, Drukarskyi dvir,. $156 \mathrm{~s}$.

4. DSTU ISO 9000:2007. Natsionalnyi Standart Ukrainy Derzhspozhyvstandart Ukrainy. 2008. Osnovni polozhennia ta slovnyk terminiv (ISO 9000:2005, IDT) Systemy upravlinnia yakistiu. Available at: http://dbn.at.ua/_ld/11/1128_432_iso9000-1-.pdf.

5. Hnylytska L. V. (2012) Oblikovo-analitychne zabezpechennia ekonomichnoi bezpeky pidpryiemstva: monohrafiia. K.: KNEU. 305 s.

6. Repyn, V. V., Elyferov, V. H. (2013) Protsessnyi podkhod k upravlenyiu. Modelyrovanye byznes-protsessov: monohrafyia. M.: Mann, Yvanov y Ferber. 544 s.

7. Babaev, Iu. A. (2005) Bukhhalterskyi uchet: ucheb. dlia vuzov. M.: Velby Prospekt. 392 s.

8. Ponomareva, N. Y. (2008) Osobennosty formyrovanyia bloka ynformatsyy o byznesprotsessakh. Uspekhy sovremennoho estestvoznanyia: nauchnyi zhurnal. № 7. S. 70-72.

9. Kundria-Vysotska O. P., Vahner I. M., Klius M. I. (2013) Bukhhalterskyi oblik v umovakh intehratsiinykh protsesiv: suchasnyi stan ta napriamy rozvytku: monohrafiia. Kyiv: UBS NBU. $286 \mathrm{~s}$.

10. Mekhanizm zabezpechennia rozvytku Ukrainy: humanitarni ta ekonomichni aspekty (2013). Monohrafiia / za red. d-ra ekon. nauk N. S. Riznyk, kand. ekon. nauk A. T. Moskovchuk. Lutsk: SPD Hadiak Zh. V., 722 s.

11. Evdokymenko, R. A. (2004) Byznes-protsessy, protsessnoe upravlenye i effektivnost. Menedzhment v Rossii y za rubezhom. № 5. S. 23-32.

12. Repyn, V. V., Elyferov, V. H. (2013) Protsessnyi podkhod k upravlenyiu. Modelyrovanye byznes-protsessov: monohrafyia. M.: Mann, Yvanov y Ferber. 544 s.

13. Zadorozhnyi, Z.-M. V., Krupka, Ia. D., Ometsinska, I. Ia. (2013) Stan i perspektyvy rozvytku vitchyznianoi systemy obliku: monohrafiia/za nauk. red. Z.-M. V. Zadorozhnoho, Ia. D. Krupky. Ternopil: TNEU, 293 s.

14. Lokhanova N. O. (2012) Intehratsiini protsesy $\mathrm{v}$ obilku $\mathrm{v}$ umovakh instytutsionalnykh peretvoren: monohrafiia. Kherson. $400 \mathrm{~s}$.

15. Melnyk, L. H., Yliashenko, S. N., Kasianenko, V. A. (2004) Ekonomyka ynformatsyy y ynformatsyonnыe systemy predpryiatyia: ucheb. posobye dlia vuzov. Sumy: Unyversytetskaia knyha. $399 \mathrm{~s}$.

16. Tverdushka, T. B. (2012) Aktyvizatsii innovatsiinoi pratsi u konteksti konkurentnykh zmin na promyslovomu pidpryiemstvi. Sotsialno-trudovi vidnosyny: teoriia ta praktyka: zb. nauk. prats. № 2(4). S. 118-122.

17. Fedorovich, T. V. (2012) Bazovyie polozheniya kontseptsii transformatsii informatsionnoanaliticheskogo obespecheniya $\mathrm{v}$ sisteme strategicheskogo upravlencheskogo ucheta. Vestnik Tomskogo gosudarstvennogo universiteta. Seriya: Ekonomika. № 3. S. 86-94.

18. Pro stratehiiu staloho rozvytku «Ukraina - 2020»: Ukaz Prezydenta Ukrainy vid 12.01.2015 r. № 5/2015. Available at: http://zakon4.rada. gov.ua/laws/show/5/2015.

19. Porokhniak, N. V. MSFZ yak bazova oblikovo-analitychna model dlia biznesu Ukrainy. MSFZ: doslidzhennia, nauka, praktyka, implementatsiia: materialy vidkrytoi mizhnar. int.-konf., Kharkiv. X.: Ahentstvo z MSFZ, 2014. S. 33-35.

20. Mekhanizm oblikovo-analitychnoho zabezpechennia pryiniattia upravlinskykh rishen u haluziakh ekonomiky (2011). Monohrafiia. Pid red. k.e.n., dots. Sh. M. Akaieva. Makiivka: Noulidzh. 409 s. 
Prymostka O.O.

Doctor of Economic Sciences, Professor,

Kyiv National Economic University named after Vadym Hetman

\section{UKRAINE PARTNERSHIP OF THE VISEGRÁD GROUP IN THE GLOBAL WORLD}

Summary. The peculiarities of the partnership between Ukraine and the Visegrád Group at the present stage of development of the international system are analysed. The necessity of rethinking the functions of Visegrád is substantiated. It is concluded that the Visegrád Four, despite the disagreement over the Ukrainian-Russian conflict at the official level, still supports Ukraine's position, is interested in cooperation with Kyiv in order to form a zone of security, stability and democratic political regime. Specifics of the activities and prospects of the Visegrád Four have been the subject of scientific research of both domestic and foreign scientists. Quite often, this topic is discussed at international forums, which promotes not only the theoretical understanding of the role of Central European countries in the modern system of international relations but also plays an important practical role for the implementation of regional integration projects, the democratization of social processes and the mastering of mechanisms for the realization of national interests in the conditions of globalization. In the current circumstances, it is also extremely important for Kyiv to continue and build military cooperation with the Visegrád Group countries. Primarily cooperation should be through engagement in the formation of a joint EU combat tactical group, which is an important contribution to the development of the European defence system and an adequate response to the current challenges of security and defence policy.

Introduction. In the context of globalization and the development of integration processes, the geographical expansion of the European Union, the new actors of the system of international relations, in particular, regional associations are becoming more and more important. In this regard, Ukraine not only declared its intention to join the European Union but also identified as one of the priorities of its foreign policy course of increasing cooperation with the countries of the Visegrád Group (VG), which, with the help of EU tools, form a new architecture of international relations. For the Ukrainian community, both the transformational experience of Central European countries and the search for allies that have real levers of influence on the intensification of Kyiv's relations with Brussels and NATO are important.

International regional integration of Central European countries is due to a number of reasons: their common historical past and regional interests, geographic location, as well as political and economic ties, similar opportunities, and aspirations.

The founding of the regional association "Visegrád Four", which included the Czech Republic, Slovakia, Hungary, and Poland, took place on February 15, 1991, in the city of Visegrád in Hungary.

The name of this city was called the "Visegrád Triangle", and after the collapse of Czechoslovakia into two independent states, the Visegrád Four. 


\section{Visegrád Association - cooperation with Ukraine}

The five main points clearly defined the purpose of the Visegrád Association of Central European countries:

- restoration of state independence, democracy, and freedom;

- elimination of remnants of the totalitarian regime in all spheres of life of the economy of the economy;

- formation of parliamentary democracy and a modern state of law along with observance of basic human rights and freedoms;

- creation of a modern market economy;

- full integration into European political, economic, security and legal systems [1].

Cooperation with Ukraine has evolved both bilaterally and in the Visegrád Four plus format. However, in some areas, cooperation started after the Visegrád Group's re-establishment in 1998, the accession of the V4 countries to the European Union, and later backed up by promising political changes in Ukraine in winter 2004, can be considered an impetus for more substantial cooperation.

The question of rethinking key areas of cooperation between Ukraine and the countries of the Visegrád Four (V4) has been updated due to a number of reasons: the signing of the Association Agreement between Ukraine and the European Union, which allows the transition from partnership and cooperation to political association and economic integration, as well as a result of aggravation of Russian-Ukrainian relations through the annexation by Russia of Crimea, support of terrorist groups and separatist actions in the territory of Eastern Ukraine. Obviously, Western countries underestimated, on the one hand, the Euro-integration aspirations of Ukrainians, and, on the other hand, the geopolitical ambitions of Moscow, giving a security issue of a secondary importance compared with economic ones. However, the restoration of territorial integrity and the preservation of state sovereignty of Ukraine to a large extent depend on the position of the West, the support of their democratic transformations in Ukrainian society and the realization of the real threats posed by the anti-democratic regime of the President of the Russian Federation, V. Putin. In this situation, the Visegrád countries can become reliable partners of Kyiv in solving their tasks, because they are directly influencing the development of a modern system of international relations as members of the EU.

Relations with the countries of the Visegrád Four (V4) for Ukraine have always been of fundamental importance. First, three out of four Visegrád countries are neighbouring states, with which Ukraine had historically friendly relations. And, secondly, all four countries have become an example of a successful accession to the $\mathrm{EU}$ and, therefore, the support and authority of the association for the promotion of Ukraine's European aspirations have become a valuable source of borrowing of useful experience.

Taking into account the practice of cooperation of the Visegrád countries in Ukraine, Euroregional cooperation is intensifying in many areas. It is accepted to define four levels of implementation of Euroregional cooperation: the international level, which implements a policy of pan-European interests, coordinates national regional policies to participate in the balanced development of the European space; the state level concentrates on the development of a national policy for the development of Euroregional cooperation and the harmonization of national interests with pan-European ones, as well as the harmonization of national and regional goals; 
regional level: the policy of Euroregional cooperation is implemented taking into account the interests of the state and local authorities, coordination is carried out between regions of neighbouring countries; local level: the coordination of local government development plans is carried out, with a significant attention to regional and national interests, and concrete cooperation is taking place between the subjects of the border territories.

The specifics of the activities and prospects of the VisegrádFour have been the subject of scientific research both domestic and foreign scientists. Quite often, this topic is discussed at international forums, which promotes not only the theoretical understanding of the role of Central European countries in the modern system of international relations, but also plays an important practical role for the implementation of regional integration projects, the democratization of social processes and the mastering of mechanisms for the realization of national interests in the conditions of globalization. Today, the issues of relations in the format of "V4 + Ukraine" are sufficiently researched. A particular attention in the development of this issue requires a collection of scientific works on the results of the conference "Ukraine and the Visegrád Four: on the path to mutually beneficial relations" [2], Monograph of Kish E. B. "Central Europe in the modern system of Euroregional integration" [1], and the analytical report of the National Institute for Strategic Studies "Cooperation with the Visegrád Countries as an Instrument for European Integration and Modernization of Ukraine" [3].

At the same time, beyond the attention of scientists, the question remains about the prospects for the development of V4 in connection with new geopolitical challenges, first of all, the aggravation of Ukrainian-Russian relations, foreign policy aggression of the Russian Federation, which is a real threat to the modern world order. The actual rethinking of the functions of the Visegrád Four, the identification of the most beneficial mechanisms for cooperation with Ukraine in the face of intensification of separatist movements, terrorist groups, and Russian foreign aggression, is the purpose of the proposed study.

The Visegrád Four is an informal political association of Poland, Hungary, the Czech Republic, and Slovakia, which was established in 1991. The prerequisite for its foundation was the desire of Central European countries to withdraw from the control of the Soviet Union, prevent the restoration of the previous political regime, and co-ordinate cross-border cooperation and foreign policy towards integration into European and Euro-Atlantic structures. The activities of the Central European Society made it possible to effectively solve many of the political and economic problems that arose in the early 90's of the twentieth century in front of the Visegrád countries as a result of radical transformational transformations that at that time captured the postSoviet countries of Central Europe. The basis for cooperation between the countries of the Visegrád Group was the geographical proximity of the member states, the commonality of history and the mental similarity of their citizens, the similarity of socio-economic models of development, and the coincidence of interests on many issues that are debated at the EU level. The equally important unifying role was played by the significant potential of the European Parliament, which allowed the Visegrád countries to adjust the decision-making process within the European Union.

Today, the Visegrád Four is a powerful regional entity within the EU, which has a constructive impact on the process of European integration. Cooperation between members of V4 is carried out through regular contacts and coordination of common 
positions on various issues, which are subsequently presented at the EU forums [4]. Its active activities are aimed at the development of Central Europe both at the level of regional co-operation and the EU as a whole, defending the common interests of states in Brussels and maintaining the identity of the region within the EU and NATO [5, p. 40]. Thus, the association of Central European countries primarily serves as an institution whose purpose is to protect and promote their own national or common interests of the Visegrád countries. According to expert estimates, if during the first five years of its membership in the EU the countries of the V4 group did not significantly influence its development strategy, during the revision of the budget of the European Union for 2007-2013, they have achieved a significant increase in the share of structural funds aimed at the needs of post-socialist countries [6]. Priority in the Visegrád Group is the question of the volume and distribution of subsidies from the European budget, which determines the development of EU member states [7]. However, from the second half of 2000, Central European countries began to actively use the instrument of national programs of international assistance to support the development of democracy, especially in Ukraine, Belarus, and the Balkan countries.

The practice of international relations confirms that Ukraine is an important Eastern European partner for the Visegrád countries. Official relations with it began in December 1999 during a meeting in Gerlach, when the presidents of four Central European countries expressed their desire to support pro-European forces in Ukraine [7, p. 39]. Cooperation with Kyiv evolved both bilaterally and in the "VisegrádFour Plus" format, where priority was given to cross-border cooperation. The political leaders of Central European countries have consistently emphasized their commitment to Ukraine and the need to help them in transforming and modernizing social processes. In the political sense, they strongly supported the European integration course of Kyiv within the framework of the so-called "Group of friends", directly contributed to the implementation of the EU-Ukraine Action Plan through the strengthening of intergovernmental contacts, the diversification of activities in the political, military, security, energy, socio-cultural spheres [7, p. 40]. The issue of Ukraine's membership in the Visegrád Association has also been discussed repeatedly.

Cooperation with Kyiv significantly intensified after the accession of the Visegrád countries to the EU, as well as the 2004 Orange Revolution. Actually, during this period, the leaders of Central European countries repeatedly demonstrated their support to Kyiv in implementing its integration ambitions aimed at EU and NATO membership [8, p. 13-14]. The all-round link between Ukraine and the Visegrád Four has uncertainty during the time of Yanukovych's presidency when the process of integration into the European Union was considered through the prism of geopolitical rapprochement with the Russian Federation. The proclamation of the non-aligned status of Ukraine has shown the uncertainty of the priorities of not only its internal but also foreign policy. The new political course envisaged the refusal of NATO membership, rapprochement with Russia in the form of an in-depth strategic partnership, and aimed at dismantling the democratic system in the state and building an authoritarian kleptocratic regime [9, p. 59]. Domestic analysts in 2010 warned that under such circumstances Ukraine's European integration would depend on Russia's position, which eventually was confirmed in the fall of 2013, the European integration prospects of Kyiv contradicted the interests of the Russian Federation, and the issue of a visa-free regime, the creation of a free trade zone or the signing of an association with the EU, needed a compulsory agreement with the Kremlin [10, pp. 97-98]. 
The beginning of the next wave of intensification of relations between Kyiv and the countries of the Visegrád Four is connected not only with the question of the European integration course of Ukraine but also the Ukrainian-Russian conflict, which was marked by the annexation of the Crimea, the support by the Russian Federation of separatist movements and terrorist groups operating in the territory of Eastern Ukraine. The aggravation of the confrontation between Kyiv and Moscow actualizes the problem of reorientation of the functional priorities of the Visegrád from economic to politico-security. Some analysts argue that V4 as a regional entity has no political perspectives, just like the CIS, GUAM, the Weimar Triangle or the Central European Initiative. The reason for such considerations is the fact that now there is no precondition (common interest) that would be a unifying element for the activity of the Visegrád community. Indeed, a number of tasks set by the V4 member states have already been implemented, in particular, the accession to the EU and NATO, others have not been implemented (internal integration) or have lost their relevance due to the divergent positions of certain states of Visegrád regarding the format of the implementation of Eastern policy, the attitude towards the Eurocurrency or priority of interests in the EU [11]. However, on the other hand, the conflict, which continues today in the east of Ukraine and confirms the total levelling of the international order and the norms of international law by the Russian Federation, may, in fact, be an impetus (unifying idea) for a new stage in the development of the Visegrád Four.

\section{Ukraine in the process of European integration}

The dominant here is the work on the settlement of armed confrontation with the help of EU instruments, providing Ukraine with comprehensive support in the process of European integration, strengthening its international image as a democratic and European state, and so on.

The appropriateness of this approach is grounded in several positions. First, all V4 countries belong to the so-called post-Soviet countries and, therefore, they are aware of the danger of the restoration of Soviet authoritarianism, which is largely reflected in the political regime of Putin. On the other hand, it is the historical experience that enables the Visegrád countries to propose the most effective instruments for countering the threats to European democratic values. Second, the mentality of the population of the Visegrád countries is much closer to Ukrainian than the life philosophy of the Germans, the French or the Italians. It is these states that are most "own" to Ukraine amongst other members of the European community and, therefore, have a significant impact on its domestic and foreign policy. This makes it possible for the Visegrád Four to apply Ukraine's soft-power policy instruments aimed at creating the attractiveness of its economic, political, social, etc. systems, establishing close contacts with local self-government bodies and civil society actors. Thirdly, Poland, Hungary, and Slovakia are territorially bordered by Ukraine, which greatly enhances regional integration. It should be noted that in the conditions of close interconnection of independent states, the violation of peaceful life in one region affects everyone else. As a result, the geographical neighbours are interested in the stability of Ukraine, its movement towards the EU and NATO, the development of democratic foundations in both domestic and foreign policy. Equally important is the fact that the economic progress of countries V4 depends on the expansion of markets and the development of new spheres of investment that Ukraine 
can provide. That is why the successful realization by Kyiv of the European foreign policy direction, coupled with effective internal reforms, is an important prerequisite for the full realization of national interests by the Visegrád countries in the international arena. Moreover, it is obvious that the "new" members of the European Union do not have sufficient resources to achieve the goals set for the Eastern Partnership and, therefore, attract the potential of other EU countries, which will generally contribute to the European integration course of Ukraine.

The Central European countries of the V4 group are undoubtedly interested in cooperation with Kyiv, and the priorities here are the formation of a zone of security, stability, democratic political regime (at least non-authoritarian). However, according to international experts, the potential of cooperation between Ukraine and the Visegrád Group is not fully utilized. Ukraine, for its part, considered the support of European partners to be insufficient, while Europeans criticized Kyiv for insignificant results in the integration progress and democratic transformations. This situation has led to mutual frustration after too much expectation on both sides [12, p. 11].

Consequently, Ukraine and the problems of its state-building process have always been at the centre of the attention of the Visegrád countries, which have not yet developed a coherent position on the events in eastern Ukraine, the intensification of relations with the Russian Federation. Although at the official level, the Visegrád members still support Ukraine and are in favour of preserving its territorial integrity, there are some inconsistencies in the positions of both political leaders and the public. Thus, Ipsos MORI, operating in the UK and Ireland, conducted a sociological survey in eleven European countries (Sweden, Poland, Germany, the United Kingdom, Spain, the Netherlands, Ireland, Belgium, France, Italy, and Hungary) regarding the imposition of EU and US sanctions on Russia In total, 8333 respondents aged 16 to 64 were polled, who answered the question: "Would you agree with the fact that your country imposed sanctions against Russia?" As it turned out, only in Hungary, the majority of the population did not support the idea of introducing sanctions against Russia caused by the crisis situation in Ukraine. If the Hungarian public expressed a pro-Russian position (31\% fully or partially supported sanctions, $37 \%$ did not fully or partially support sanctions, $30 \%$ did not answer the question), Poland demonstrated unequivocal support to Ukraine, categorically condemning Russia's actions (53\% or partially supported sanctions, $23 \%$ - completely or partially did not support sanctions, 24\% - did not answer the question) [13]. For many years of cooperation, Poland has undoubtedly gained the status of Ukrainian lawyer in Europe since it actively lobbies for the European integration of Ukrainians. Warsaw consistently supported the idea of signing an association between Ukraine and the EU in all conditions because, according to its officials, it is possible to solve the problem of adherence to democratic standards and selective justice. According to a sociological poll, $26 \%$ of Poles favour Ukraine's immediate accession to the EU, $47 \%$ also support such an initiative but consider it a challenge for the future, and only $11 \%$ of respondents declare the opposite. Most Poles (65\%) also believe that Ukraine's integration into the European Union corresponds to the national interests of Poland, while only $14 \%$ of respondents prefer to strengthen cooperation with the Russian Federation [14, p. 41]. So, Poland (RP) has taken an open position on categorical rejection of Russia's aggressive actions, consistently supports the policy of the Ukrainian government and insists on strengthening NATO's defence capabilities in the region of Central and Eastern Europe. 
Warsaw's position for the geopolitical prospects of Ukraine is extremely important, as this country is among the six largest economies in Europe and has the status of the largest recipient of EU assistance from all member states. Taking into account the lessons of political history, Warsaw builds relations with Kyiv in the form of a strategic partnership, because the confrontation of relations between the countries already led to the loss of statehood of both Poland and Ukraine. The Republic of Poland effectively used its membership in the EU to find the most effective mechanisms for introducing the Central European experience of reforms in Ukraine, in particular through the format of "V4 + Ukraine", initiated a program of support for regional cooperation and civil society within the framework of the Visegrád Fund [15, p. 26]. Poland also announced the possibility of involving Ukraine in the operation of the Visegrád Battlegroup. The parties also realize that the alliance of both states is a reliable obstacle for the expansion of Russian expansion into the territory of Central and Eastern Europe.

Instead, it does not show much activity in shaping the new priorities of the EU's foreign policy towards Russia, the Czech Republic. At the official level, it also supports the European integration prospects of Ukraine, although Ukrainian-Czech relations are sometimes controversial. The Czech government has repeatedly criticized the political situation in Ukraine, for example, in the case of Y. Tymoshenko, Y. Lutsenko or providing political asylum to representatives of the Ukrainian opposition during the presidency of Viktor Yanukovych [15, p.31]. The Czech president, M. Zeman, also criticized the EU's policy of imposing sanctions on the Russian Federation, while substantiating the expediency of intensifying cooperation with Moscow to address the threat of Islamic terrorism [16]. It should be noted that the fact that the Czech society also did not develop a clear position regarding the appropriateness of imposing sanctions against the Russian Federation. About $70 \%$ of the population disagreed with the scandalous statements of President M. Zeman concerning Ukraine and sanctions against Russia, who believe that such statements contradict Czech government policy, divide the society and significantly impair the image of the country on the international scene. According to a sociological survey carried out by the Czech company CVVM, only $2 \%$ of Czechs described as "very good" actions of Russia, another 9\% said "rather good" assessment of the Kremlin's position, while the separatists are supported by 7\% [17]. Despite the split in assessing the Ukrainian issue, citizens of the Czech Republic still see the threat of spreading Russian expansion to their country (65\% of respondents), and $73 \%$ of respondents believe that Ukrainian events are dangerous for Europe as a whole. Presumably, such social sentiment will allow the Czech authorities to continue to express ambiguity regarding sanctions against the Russian Federation [16]. The position and specificity of the Ukrainian-Czech relations can be explained by the absence of a common border. Therefore, unlike other countries of the Visegrád Group, the Czech Republic is more oriented not to the East but to the West.

On the contrary, the format of the Slovak-Ukrainian intergovernmental relations is intensified by the presence of the territorial neighbourhood, as well as the dependence of the Slovak Republic on Russian energy carriers coming through the territory of Ukraine. Bratislava conducts foreign policy towards Ukrainians in accordance with the "Strategy for the Development of Relations with Ukraine" (2001), which seeks to fulfil the national interests of Slovakia through the increased cooperation with the EU, NATO, and Ukraine as an important component of the pan-European system of 
stability. In general, Bratislava supports the Brussels policy towards Kyiv and Moscow, and the provision of gas reverse on its territory to Ukraine helped to resist Russia's "gas pressure". At the same time, there is a certain divergence in the position of the Slovak political leaders in the interpretation of contemporary events in Ukraine. So, the president of the country, A. Kiska, fully supports the EU sanctions regime against the Russian Federation, and Prime Minister R. Fico, referring to economic priorities, notes their ungroundedness and perceives Ukraine as a state that cannot resolve internal conflicts on its own. Although, according to international economists-analysts, sanctions against Russia do not pose serious threats to the national economy of Slovakia [17]. Despite these differences, Bratislava actively supports the European integration and modernization processes taking place in Ukraine, shows interest in establishing a free trade zone between the EU and Ukraine, and develops joint projects between non-governmental organizations [15, pp. 31-32].

Instead, Hungary considers the solution to the problems in the ethnopolitical sphere as the key to the European perspective of Ukraine, having specific relations with Kyiv on this particular plane [6]. The development of cooperation between Ukraine and Hungary took place in a confrontation between Budapest and Brussels, which was the result of Prime Minister V. Orbán's government policy, which contradicts the conceptual principles of the functioning of the European community. It is about adopting amendments to the Constitution that are not in line with the principle of freedom of speech, the weakening of the role of the Constitutional Court, support for anti-Semitic sentiments in society, etc. The tensions with the EU member states forced Hungary to strengthen its cooperation with other Eastern European countries, in particular, with Belarus, under the Eastern Partnership program, as well as with the Russian Federation in trade, economic and energy spheres [15, p. 28]. The Prime Minister of Hungary generally criticizes the liberal-democratic model of the social system and considers Turkey, Singapore, China, and Russia to be more effective. Regarding cooperation with Ukraine, in 2013, an agreement was reached on the reversal of natural gas from Hungary, as well as the support for Ukraine's conclusion of the Association Agreement with the EU. At the same time, differences in ethnic issues do not promote intensification of cooperation between the two countries. This is a latent conflict between Hungary and Ukraine through the policy of dual citizenship regarding Hungarians living in the Transcarpathian region. In view of the annexation by the Russian Federation, the statements of some Hungarian politicians about creating autonomy for ethnic Hungarians residing in the Transcarpathian region of Ukraine look inappropriate [8]. It is from the agreement of this discourse that the future format of Hungarian-Ukrainian cooperation depends.

Differences in the assessments of the Visegrád countries' four specific events of international life are shaped by various factors, mainly political, security, institutional, economic, historical, and ethnic. It is worth noting that GH has already experienced emerging crises because of the lack of a common position among the Member States on a number of issues. For the most part, distinguish two periods of development of the Visegrád Four. The first lasted from 1999 to 2004, in fact until the accession of Central European countries to the EU and NATO. The second started in 2004 and reflects the cooperation of V4 countries already in the European Union $[18$, p. 260]. The first crisis in the organization's activities was observed during 1993-1998 and was provoked by the collapse of Czechoslovakia and the orientation of the Mecchire Slovakia towards Russia. Since 1994, there have been signs of a 
confrontation of relations within the V4, reinforced by the ambitions of Poland regarding the status of a regional leader, as well as the self-isolation of the Slovak Republic. During the stagnation of the Visegrád Group, the number of meetings within the organization fell sharply, and the focus of the leaders of Central European countries was concentrated on the issue of NATO membership [18, pp. 261, 264]. The consolidation basis for the Visegrád countries then became CEFTA, which proved to be quite effective in solving many economic problems. The situation changed dramatically in 1998 when power in Bratislava was taken over by the proEuropean government of M. Zurindy. The second crisis began in January 2009, when Slovakia joined the Eurozone and tried to strengthen the informal alliance with Germany, Austria and other countries that manage largely consolidated finances [11]. There are also some differences in the positions of the Visegrád countries, but already in connection with the "Ukrainian question".

One of the reasons for the different vision of the development path of foreign policy relations is the imperfection of the institutional organization of the Visegrád Four, the lack of a focal point (secretariat) of the group's activities. The only VG institution remains the International Visegrád Fund, which mainly supports and administers joint projects in the field of culture, education, scholarship, and student exchanges, etc. On the one hand, the weak level of institutionalization of the Visegrád Four contributes to the effective use of financial resources, flexibility and openness to new ideas, and, on the other hand, has led to a lack of consistent development strategies, clear communication procedures and cooperation mechanisms, in particular, in the field of foreign policy [8, p. 16-17].

The peculiarities of foreign policy are also explained by the lack of integration at the level of society of the member countries of the Visegrád Four. There is a rather low activity of the Polish-Slovak or Polish-Czech cross-border cooperation, which significantly weakened after the accession of the V4 countries to the EU and the abolition of internal borders. If the Czech-Slovak and Slovak-Hungarian regional cooperation develop relatively intensely, due to the historical past and the presence of ethnically mixed territories, Poland greatly increases the integration activity in the direction of Ukraine and Belarus.

Undoubtedly, the position of Central European countries is also shaped by the influence of economic circumstances. Here it is necessary to take into account the fact that the introduction of sanctions against Russia also negatively affects the economic performance of the European Union, especially its new members. Since the development of the V4 countries depends to a large extent on European investment and capital, it is quite vulnerable. Therefore, the leaders of the Visegrád Group, while taking political decisions, always consider its economic consequences, which are not the same for all members of the group. Under such conditions, Ukraine, together with the V4 countries, needs to continually analyse the implementation of pre-signed agreements, deepen cross-border cooperation and support joint business associations, Euroregions, promote investment from the Visegrád countries and, on the other hand, create opportunities for the development of domestic business in the countriesmembers of the V4, to extend the experience of Central European countries on the modernization of industrial enterprises and the agrarian sector, etc. [10, p. 111]. The intensification of economic cooperation between Ukraine and the Visegrád countries will partially offset the negative impact of sanctions imposed on Russia. 
Historical past also makes adjustments to contemporary international politics. At the same time, events in Czechoslovakia and Hungary did not receive adequate response and support from Europe and the world, infuriated by the nuclear potential of the Soviet Union. Accordingly, today these countries are not ready to give way to national interests in order to save Ukraine, recalling its neutral attitude to their problem in the past. Rather, they are striving to increase their own strengths in order to have sufficient resources to counter external threats. Despite some differences regarding the adoption of certain decisions, open and latent conflicts, the Visegrád Four still has sufficient potential for influence on pan-European policy, in particular, with regard to the countries of Eastern Europe. For Ukraine, it is important both political support from the Visegrád countries and the use of their positive integration experience, which will enable to avoid false decisions during the modernization of the socio-economic system, an adaptation of legislation to European norms. Kyiv must constantly demonstrate and prove that economic interest, which involves the expansion of markets, the receipt of new technologies or investments, is not a priority in relations with the states of Central Europe. Instead, it is extremely important to master the experience of democratization and modernization, the perception of European values and standards, as well as the integration into the European security system.

Conclusions. After the signing of the Association Agreement between Ukraine and the EU, a central executive body should be set up to coordinate the practical process of European integration, adapt domestic legislation to the requirements of the EU, and so on. It is here that the experience of the Visegrád countries should be used, and some experts from Central European countries can be involved in this structure to transfer the skills of transforming the post-socialist model to the EU standards. At the same time, it is necessary to constantly disseminate through the media information on the results of cooperation between Ukraine and the V4 countries in various fields in order to create a positive image of both Ukraine in Europe and the countries of the Visegrád Four in Ukrainian society, as well as acquainting interested persons with the opportunities provided by such cooperation [19, p. 148-150]. Consequently, the particularities of the V4 countries and their partners in the implementation of relevant information policies can be the subject of further research.

At the same time, it is necessary to take measures aimed at mitigating the ethnic, historical or cultural contradictions that have developed between the countries of Central and Eastern Europe. In this case, the tool for using a variety of humanitarian and educational projects to form a certain Central European mentality, a part of which should be Ukraine [15, p. 3-4], is effective.

In the current circumstances, it is also extremely important for Kyiv to continue and build military cooperation with the Visegrád Group countries, primarily through engagement in the formation of a joint EU combat tactical group, which is an important contribution to the development of the European defence system and an adequate response to the current challenges of security and defence policy. Although the Kyiv-Balkan military-political dialogue is confirmed by a number of interagency agreements and annual meetings of defence ministry leaders, its further development depends on the sequence of policy, funding, and the effectiveness of the implementation of the previous stages of cooperation. Enhancing co-operation with V4 will enable Ukraine to integrate into Europe through its cultural, political, economic, and security components. At the same time, the political will and the 
coherence of the positions of both Kyiv and the member countries of the Visegrád Four are necessary for the realization of the set tasks.

\section{References:}

1. Kish Y.B. Central Europe in the modern system of Euroregional integration: Monograph. Uzhgorod: Lira, 2008. - 440 p.

2. Ukraine and the Visegrad Four: on the path to mutually beneficial relations: a collection of sciences. works / order. V. Pulishova, T. Sage. - Bratislava, 2010. - 166 pp.

3. Cooperation with the Visegrad Four countries as an instrument of European integration and modernization of Ukraine: analyst. add / S.I. Mitryayeva, M.O. Lundel, A.D. Stryapko, A.M. Krizhevsky [and others]. - K . : NISS, 2014. - 128 p.

4. 10 LatczlonkostwaPolski w UniiEuropejskiej [Electronic resource]. - Access mode: http://astana.msz.gov.pl/resource/dc2c1be8-a198-4246-a4e8-140bd7881ba5:JCR.

5. The theory of international relations: the terminology dictionary / MP Hetmanchuk, O. S. Ivachi, O. V. Kukartsev and others. - Lviv: Triad plus, 2011. - 318 p.

6. Lhendyel L.O. Modern potential of the Visegrad Group influence on the formation of the European Union policy towards Ukraine [Electronic resource] / L.O. - Access mode: http://www.niss.gov.ua/Articles /1127/

7. Kudryachenko I. Ukraine and the Visegrad Four: the state and prospects of cooperation [Electronic resource] / I. Kudryachenko // Ukraine and the Visegrad Four: towards mutually beneficial relations / emphasis. V. Pulishova, T. Sage. - Bratislava, 2010. - P. 37-54. - Access mode: http://www.sfpa.sk/surec/static/pdf/kniha-ua-shengen-ua.pdf.

8. Sargsha T. Towards a strengthened cooperation: assessment of partnership models between Ukraine and the Visegrad group [Electronic resource] / T. Strazhay, V. Pulishova // Ukraine and the Visegrad Four: towards mutually beneficial relations / emphasis. V. Pulishova, T. Sage. Bratislava, 2010. - P. 13-37. - Access mode: http://www.sfpa.sk/surec/static/pdf/kniha-uashengen-ua.pdf.

9. European integration: experience of the Visegrad countries and Ukrainian realities / ed. I. Kosse. - K .: Institute for Economic Research and Policy Consulting, 2014. - $87 \mathrm{~s}$.

10. Perepelitsa G. Opportunities of development tools of mutually beneficial relations in the format Ukraine - "Visegrad plus" [Electronic resource] / G. Perepelitsa // Ukraine and Visegrad Four: towards mutually beneficial relations / emphasis. V. Pulishova, T. Sage. - Bratislava, 2010. P. 96-112. - Access mode: http://www.sfpa.sk/surec/static/pdf/kniha-ua- shengen-ua.pdf.

11. Logins YaVsegradskaya four: the end of illusion [Electronic resource] / Ya. Login // Mirror of the week.Ukraine / Ya. Login. - 2014 - August 5th. - Mode of access: http://gazeta.dt.ua/ international/vishegradska-chetvirka-kinec-ilyuziy-_html.

12. Wagner P. Can the Visegrad Group serve as a model for developing cooperation among other countries? [Electronic resource] / P. Wagner // Ukraine and the Visegrad four: towards mutually beneficial relations / emphasis. V. Pulishova, T. Sage. - Bratislava, 2010. - Pp. 9-13. - Access mode: http://www.sfpa.sk/surec/static/pdf/kniha-ua-shengen-ua.pdf.

13. Grafikon: A magyaroktöbbségeazoroszokmellettáll [Electronic resource]. - Access mode: http://hvg.hu/vilag/20140429_Grafikon_A_magyarok_tobbsege_eliteli_az_o.

14. Orzechowski M. Polskawobecwydarzeńna Ukraine / M. Orzechowski // Activation of civil society in Ukraine. Events on EuroMaidan in Kiev. - Szczecin, 2014. - P. 31-43.

15. Cooperation with the Visegrad countries as an instrument of European integration and modernization of Ukraine: analyst. add / M.O. Lendiel, A.D. Stryapko, A. M. Krizhevsky and others. - K.: NISS, 2013. -49 p.

16. Messezhnikov G. Vyshegrad and Ukraine: peculiarities of national approaches [Electronic resource] / G. Mesjezhnikov. - Access mode: http://www.eurointegration.com.ua/news/ 2014/10/6/ $7026545 /$;

17. Only $11 \%$ of Czechs are on the Russian side, but there is also no sanctions support [Electronic resource]. - Access to the source: http://www.eurointegration.com.ua/news/ 2014/10/6/ $7026545 \%$. 
18. Kish Y.B. "European Map" of the Visegrad Four countries: the history of development and the format of cooperation / E. B. Kisch // Scientific Bulletin of the Nikolayev National University named after V.O. Sukhomlynsky. Sir: Historical Sciences. - 2012. - Exp. 3.33. - P. 259-267.

19. Surnina-Dalekoyra S. Ukraine and Visegrad: ways of interaction [Electronic resource] / O. Surnina-Dalekray, N. Gichka // Ukraine and the Visegrad Four: towards mutually beneficial relations / emphasis. V. Pulishova, T. Sage. - Bratislava, 2010. - P. 129-154. - Access mode: http://www.sfpa.sk/surec/ static / pdf / kniha-ua-shengen-ua.pdf. 

Izdevniecība "Baltija Publishing" Valdeķu iela 62 - 156, Rīga, LV-1058

Iespiests tipogrāfijā SIA "Izdevniecība "Baltija Publishing" Parakstīts iespiešanai: 2017. gada 25. decembris Tirāža 300 eks. 